UNIVERSIDADE DE SÃO PAULO

FACULDADE DE FILOSOFIA, LETRAS E CIÊNCIAS HUMANAS DEPARTAMENTO DE LETRAS MODERNAS

PROGRAMA DE PÓS-GRADUAÇÃO EM ESTUDOS LINGUÍSTICOS E LITERÁRIOS EM INGLÊS

SABRINA MATUDA

\title{
A fraseologia do futebol: um estudo bilíngue português-inglês direcionado pelo corpus
}


UNIVERSIDADE DE SÃO PAULO

FACULDADE DE FILOSOFIA, LETRAS E CIÊNCIAS HUMANAS

DEPARTAMENTO DE LETRAS MODERNAS

PROGRAMA DE PÓS-GRADUAÇÃO E EM ESTUDOS LINGUÍSTICOS E

LITERÁRIOS EM INGLÊS

\title{
A fraseologia do futebol: um estudo bilíngue português-inglês direcionado pelo corpus
}

\author{
Sabrina Matuda
}

Dissertação apresentada ao Programa de Pós-Graduação em Estudos Linguísticos e Literários em Inglês do Departamento de Letras Modernas da Faculdade de Filosofia, Letras e Ciências Humanas da Universidade de São Paulo, para a obtenção do título de Mestre em Letras.

Orientadora: Profa. Dra. Stella Esther Ortweiler Tagnin

São Paulo 
AUTORIZO A REPRODUÇÃO TOTAL OU PARCIAL DESTE TRABALHO, POR QUALQUER MEIO CONVENCIONAL OU ELETRÔNICO, PARA FINS DE ESTUDO OU PESQUISA, DESDE QUE CITADA A FONTE.

\author{
Catalogação na Publicação \\ Serviço de Biblioteca e Documentação
}

Faculdade de Filosofia, Letras e Ciências Humanas da Universidade de São Paulo

Matuda, Sabrina

A fraseologia do futebol: um estudo bilíngue português-inglês direcionado pelo corpus / Sabrina Matuda ; orientadora Stella Esther Ortweiler Tagnin. - São Paulo, 2011.

304 f. ; il.

Dissertação (Mestrado) - Faculdade de Filosofia, Letras e Ciências Humanas da Universidade de São Paulo. Departamento de Letras Modernas. Área de concentração: Estudos Linguísticos e Literários em Inglês.

1. Língua inglesa. 2. Futebol - terminologia. 3. Fraseologia. 4. Tradução. I. Título. II. Tagnin, Stella Esther Ortweiler. 


\section{FOLHA DE APROVAÇÃO}

Sabrina Matuda

A fraseologia do futebol: um estudo bilíngue português-inglês direcionado pelo corpus

Dissertação submetida ao Programa de Pós-Graduação da Faculdade de Filosofia, Letras e Ciências Humanas, Departamento de Letras Modernas, Área de Estudos Linguísticos e Literários em Inglês, da Universidade de São Paulo, como requisito parcial à obtenção do grau de Mestre em Letras.

Aprovada em: I

Banca Examinadora

Prof. Dr.:

Instituição:

Assinatura:

Prof. Dr.:

Instituição:

Assinatura:

Prof. Dr.:

Instituição: Assinatura: 
Aos meus pais, Hélio e Rita 


\section{AGRADECIMENTOS}

Aos meus pais, Hélio e Rita, que sempre torceram por mim.

À minha irmã, Carina, pela amizade e paciência em meus momentos de crise.

Um agradecimento especial à minha orientadora, Prof ${ }^{\mathrm{a}}$. Stella Tagnin, pelo incentivo constante, pela preciosa orientação e pela confiança em mim depositada.

Aos professores John Milton e Ieda Maria Alves, pelas contribuições no exame de qualificação.

Aos colegas do Grupo COMET: Cris, Elisa, Rozane, Sandra, Marlene A., Marlene D., Lu Carvalho, Lu Ginezi, Alva, Carla Nejm, Andrea, Helmara, Josi, Danilo e Sérgio pelas discussões sempre proveitosas e, é claro, pelos momentos de descontração.

À "Superwise", também conhecida como Carmen Dyrell, pela ajuda com os testes estatísticos, com o WordSmith Tools e tantas outras coisas.

À FAPESP (Fundação de Amparo à Pesquisa do Estado de São Paulo) pela concessão da bolsa de estudos.

Aos amigos, pelo incentivo permanente. 


\section{RESUMO}

Matuda, Sabrina. A fraseologia do futebol: um estudo bilíngue português-inglês direcionado pelo corpus. Dissertação (Mestrado). São Paulo: Faculdade de Filosofia, Letras e Ciências Humanas, Universidade de São Paulo, São Paulo, 2011.304 f. ; il.

O objetivo desta pesquisa é estudar a terminologia do futebol em inglês e português por meio do estabelecimento de equivalentes fraseológicos.

A escolha de trabalhar com unidades fraseológicas, e não apenas com termos isolados, deve-se ao fato de acreditarmos que um termo raramente ocorre sozinho. Em outras palavras, é muito provável que este venha acompanhado de um colocado, formando uma colocação e, muitas vezes, seja até parte de uma unidade de sentido maior. Para tanto, a fundamentação teórica embasa-se na Linguística de Corpus, na Terminologia Textual, na Tradução Técnica como ato comunicativo sujeito a condicionantes culturais e no conceito forma-representação.

O corpus de estudo possui, aproximadamente, um milhão de palavras em cada língua: 917.073 em português e 1.002 .897 em inglês. Cada corpus é dividido em quatro subcorpora: regras do jogo, textos jornalísticos sobre resultados de partidas, narrações minuto a minuto e "transmissões sociais".

A análise do corpus foi realizada de maneira semiautomática, utilizando o etiquetador Tree-Tagger para fazer a etiquetagem morfossintática dos textos e o programa WordSmith Tools para explorar o corpus.

O estudo nos mostrou que a extração de unidades fraseológicas é uma abordagem promissora para a compilação de um glossário que tenha como objetivo registrar o uso autêntico da terminologia técnica - em nosso caso, do futebol. Ao final do trabalho, apresentamos um modelo de glossário bilíngue português-inglês de fraseologias formadas a partir do termo "gol", com base na análise realizada.

PALAVRAS-CHAVE: Futebol. Linguística de Corpus. Terminologia. Unidade Fraseológica Especializada. Tradução 


\begin{abstract}
Matuda, Sabrina. Football Phraseology: A bilingual Portuguese-English corpus-driven study. Dissertation. São Paulo: Faculdade de Filosofia, Letras e Ciências Humanas, Universidade de São Paulo, São Paulo, 2011.304 f. ; il.
\end{abstract}

This study investigates football terminology both in English and in Portuguese and attempts to establish phraseological equivalents.

Phraseological units were chosen to the detriment of individual terms because these usually occur in a larger context rather than as isolated lexical items living a life of their own. We believe that a term tends to be accompanied by a collocate, making up a collocation, which is frequently part of an extended unit of meaning. Therefore, the study is based on the notions of Corpus Linguistics and Textual Terminology. To explain cultural differences, technical translation is viewed as a communicative act subject to cultural restraints and the concept of "form-representation" is called upon to elucidate such differences.

Our corpus consists of approximately two million words - 1.002.897 in English and 917.073 in Portuguese. Each corpus is divided into four subcorpora: laws of the game, newspaper reports on match results, live mi nute by mi nute commentaries and live commentaries by sports journalists and by football fans via social media like twitter and facebook.

The analysis was carried out semi-automatically on tagged corpora, for which we used Helmut Schmid's Tree-Tagger and Mike Scott's WordSmith Tools.

All in all, the study proved that the extraction of phraseological units is a promising approach to build a glossary which aims at registering the authentic use of specialized language, in this case, the language of football.

The study concludes with a model for a bilingual Portuguese-English phraseological glossary with entries made up of the term goal.

KEYWORDS: Football. Corpus Linguistics. Terminology. Specialized Phraseological Unit. Translation 


\section{LISTA DE FIGURAS}

Figura 1 - Interface do WordSmith Tools 5.0......................................................... 38 -

Figura 2 - Lista de palavras em ordem alfabética ................................................... 39 -

Figura 3 - Lista de palavras em ordem de frequência ................................................ 39 -

Figura 4 - Tela com as estatísticas do corpus ............................................................ 40 -

Figura 5 - Tela de confi guração do idioma ........................................................... 41 -

Figura 6 - Lista de palavras do corpus de estudo (PT) ............................................ 42 -

Figura 7 - Lista de palavras do corpus de referência.................................................. 42 -

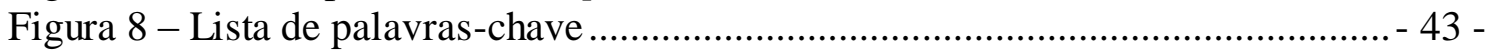

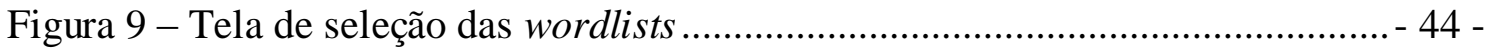

Figura 10 - Resultado de busca para "falta" na ferramenta Concord .......................... 45 -

Figura 11 - Tela que permite ordenar as linhas de concordância ............................... 46 -

Figura 12 - Resultado de busca para "falta" reordenado pela primeira palavra à esquerda

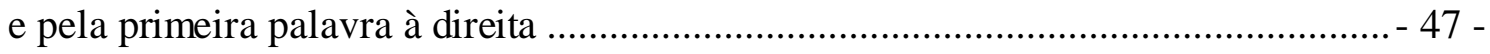

Figura 13 - Contexto expandido de uma das linhas de concordância de "falta" ........ 48 -

Figura 14 - Tela da ferramenta Concord .................................................................... 49 -

Figura 15 - Ajuste dos parâmetros para a extração dos clusters de falta ..................... 50 -

Figura 16 - página do jornal $O$ Estado de São Paulo e do Lancenet sobre o resultado da partida entre o Coritiba e o Palmeiras do jogo de ida pelas quartas de finais da Copa do

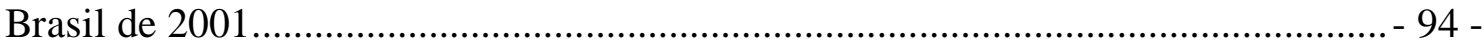
Figura 17 - página do site football.uk e do jornal The Guardian sobre o resultado da partida entre o Barcelona e o Real Madrid no segundo jogo das semifinais da Liga dos

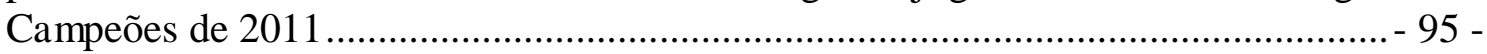

Figura 18 - Exemplo de cabeçalho de texto informativo....................................... 108 -

Figura 19 - Etiquetas discursivas criadas para os textos jornalísticos ...................... 111 -

Figura 20 - Etiquetas discursivas utilizadas nas transmissões minuto a minuto ...... - 111 -

Figura 21 - Etiquetas discursivas utilizadas nas "transmissões sociais" ................. - 112 -

Figura 22 - Página inicial do etiquetador Tree-Tagger .......................................... 114 -

Figura 23 - Texto etiquetado e salvo em formato ".txt" ....................................... 114 -

Figura 24 - Interface do Tree-Tagger ............................................................... 115 -

Figura 25 - Linhas de concordância da expressão de busca "were VBD be made" . - 118 Figura 26 - Seleção dos textos na ferramenta wordlist .......................................... 121 Figura 27 - Parte da lista de palavras do corpus em português organizada pela ordem de frequência ................................................................................................... 122 -

Figura 28 - Configurações da ferramenta keywords .............................................. 123 -

Figura 29 - Palavras-chave do corpus de português ................................................ - 124 -

Figura 30 - Linhas de concordância de gol ordenadas pela primeira palavra à direita e pelas duas palavras à esquerda do nódulo ......................................................... - 125 -

Figura 31 - Ajuste das configurações do dispositivo Cluster ................................... 126 -

Figura 32 - Seleção das linhas de concordância para por cima do gol ..................... 130 Figura 33 - Seleção de linhas de concordância para gol feito por ............................ - 131 Figura 34 - Linhas de concordância de goal* ordenadas pela primeira palavra à direita $\mathrm{e}$ pela primeira palavra à esquerda ...................................................................... 134 Figura 35 - Clusters de goal .......................................................................... 135 - 
Figura 36 - linhas de concordância para only ordenadas pelas três primeiras palavras à

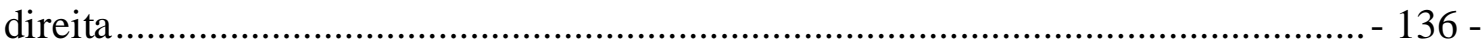

Figura 37 - Seleção das linhas de concordância para JJ * goal ............................... - 137 -

Figura 38 - Parte das linhas de concordância de after ordenadas pelas duas primeiras

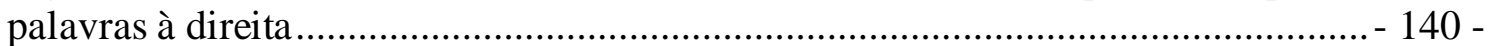

Figura 39 - Linhas de concordância de author .......................................................... - 141 -

Figura 40 - Linhas de concordância de autor do gol ............................................... 142 -

Figura 41 - Parte das linhas de concordância de who ordenadas pela primeira palavra à

esquerda e pelas duas primeiras palavras à direita ................................................. 143 -

Figura 42 - Parte das linhas de concordância de scorer ordenadas alfabeticamente pela

primeira palavra à direita e pelas duas primeiras palavras à esquerda do nódulo .... - 144 -

Figura 43 - Parte das linhas de concordância da expressão de busca " $J J$ * goal "... - 146 -

Figura 44 - Parte das linhas de concordância para a expressão "gol *ADJ".......... 147 -

Figura 45 - Parte das linhas de concordância para a expressão "ADJ * gol"........... 147 -

Figura 46 - Linhas de concordância de goalmouth .................................................... 149 -

Figura 47 - Parte das linhas de concordância de goal ordenadas pelas três primeiras

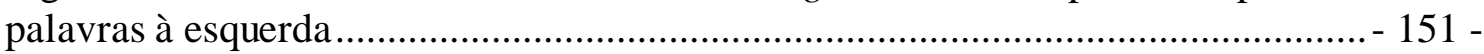

Figura 48 - Parte das linhas de concordância de "opportunit*” ordenadas pelas três

primeiras palavras à esquerda........................................................................... 151 -

Figura 49 - Linhas de concordância para chegar ao gol ordenadas pelas duas primeiras

palavras à esquerda e pela primeira palavra à direita

Figura 50 - Parte das linhas de concordância de close ordenadas pelas duas primeiras

palavras à esquerda e pela primeira palavra à direita ............................................. 155 -

Figura 51 - Parte das linhas de concordância para right/left ordenadas pelas três

primeiras palavras à direita............................................................................... 156 -

Figura 52 - Seleção de linhas de concordância de left-footed shot ordenadas pelas três

primeiras palavras à esquerda

Figura 53 - Parte das linhas de concordância de free-kick ordenadas pelas duas

primeiras palavras à esquerda............................................................................. 160 -

Figura 54 - Parte das linhas de concordância da expressão “ $V V Z$ * a DT a free-kick".... 161 -

Figura 55- Parte das linhas de concordância da expressão " $V V N *$ a DT a free-kick"..... 161 -

Figura 56 - Parte das linhas de concordância da busca "NP *'s POS 's goal" ....... - 163 -

Figura 57 - Seleção de linhas de concordância da UFE com um gol de .................... - 164 -

Figura 58 - Seleção de linhas para a expressão de busca "when * scored"............... 165 -

Figura 59 - Seleção das linhas de concordância de "to the right of the goal"......... - 166 -

Figura 60 - Parte das linhas de concordância de evitar/evitou o gol ........................ - 167 -

Figura 61 - Seleção de linhas de concordância de "block*”. ................................... 168 -

Figura 62 - Parte das linhas de concordância da etiqueta VVG ............................ 171 -

Figura 63 - Parte das linhas de concordância de "fire **"....................................... 172 -

Figura 64 - Parte do contexto expandido da linha de concordância 153 de fire *.... 172 -

Figura 65 - Linhas de concordância para a expressão " $J J *$ goal "........................... 196 -

Figura 66 - Parte das linhas de concordância de winner ordenadas pelas três primeiras

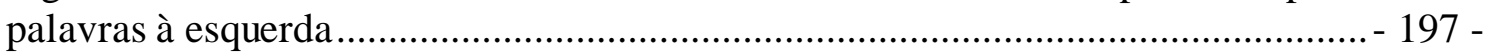

Figura 67 - Linhas de concordância para decisive goal .......................................... - 199 -

Figura 68 - Linhas de goal ordenadas pelas duas primeiras palavras à esquerda..... - 200 -

Figura 69 - Parte das linhas de concordância de ahead ordenadas pelas duas primeiras

palavras à esquerda e pela primeira palavra à direita $201-$ 
Figura 70 - Parte das linhas de concordância de lead ordenadas pelas duas primeiras

palavras à esquerda e pela primeira palavra à direita ............................................... 202 .

Figura 71 - Linhas de concordância de tying ......................................................... 203 -

Figura 72 - Seleção de linhas de concordância para equalis ${ }^{*}$................................. 204 -

Figura 73 - Linhas de concordância de penalty kick ................................................. - 205 -

Figura 74 - Linhas de concordância da expressão "POS * penalty"........................ 206 -

Figura 75 - Linhas de concordância de goalkeeper/keeper ordenadas pela primeira

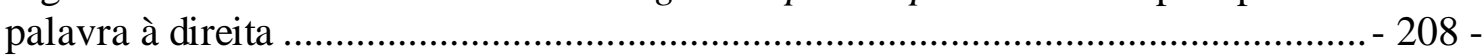

Figura 76 - Linhas de concordância de his first goal ordenadas pelas três primeiras

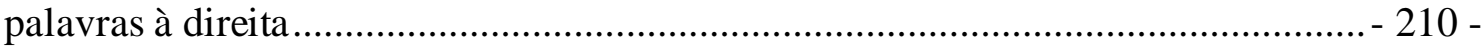

Figura 77 - Linhas de concordância para a expressão de busca "his * goal ".......... 211 -

Figura 78 - Clusters de wide ............................................................................... 213 -

Figura 79 - Parte das linhas de concordância de wide of ordenadas pelas três primeiras

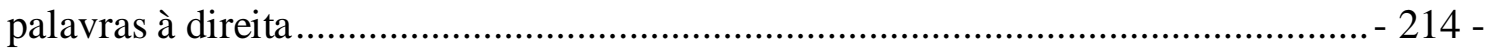

Figura 80 - Linhas de concordância para a expressão de busca "the middle/centre of"... 219 -

Figura 81 - Linhas de concordância de net ordenadas pelas três primeiras palavras à

esquerda

Figura 82- Parte das linhas de concordância de goalwards ordenadas pelas três

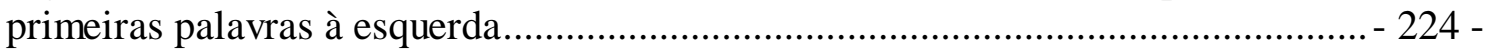

Figura 83 - Seleção de linhas de concordância de goalwards ordenadas pelas três

primeiras palavras à direita........................................................................... 225 -

Figura 84 - Parte das linhas de concordância para empty ordenadas pela primeira

palavra à direita e pelas duas primeiras palavras à esquerda................................... - 233 -

Figura 85 - Seleção das linhas de concordância de threat ordenadas pelas duas

primeiras palavras à esquerda e pela primeira palavra à direita .............................. 234 -

Figura 86 - Seleção das linhas de concordância da expressão de busca“bar / post /

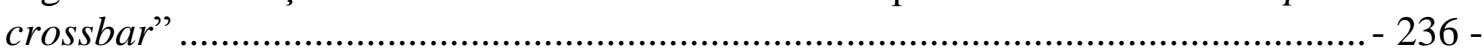

Figura 87 - Parte das linhas de concordância da expressão "'s POS 's first JJ first goal

NN goal ",

Figura 88 - Seleção das linhas de concordância da expressão de busca "NP ** VVD"... 244 -

Figura 89 - Linhas de concordâncias da expressão de busca " $J J$ * goal” $-246-$ 


\section{LISTA DOS QUADROS}

Quadro 1 - Resumo dos critérios de delimitação das UFEs

$-79-$

Quadro 2 - Critérios iniciais para a compilação do corpus

Quadro 3 - contraste de algumas características entre high-context cultures e lowcontext cultures.

Quadro 4 - Critérios de compilação redefinidos....

Quadro 5 - Legenda das etiquetas do cabeçalho

Quadro 6 - Etiquetas do Tree-Tagger (inglês)

Quadro 7 - Etiquetas do Tree-Tagger (português)

-117 -

Quadro 8 - Seleção dos cem primeiros clusters de gol ......................................... - 128 -

Quadro 9 - Agrupamento e elimi nação das UFs ................................................... 129 -

Quadro 10 - UFEs encontradas ....................................................................... 133 -

Quadro 11 - Verbos classificados por categoria semântica ..................................... 159 -

Quadro 12 - Verbos que antecedem a expressão de busca "shot * wide of" classificados

por categoria semântica

Quadro 13 - Verbos que ocorrem na estrutura "effort * wide of" classificados por categoria semântica

Quadro 14 - Verbos classificados por categoria semântica

Quadro 15 - Verbos classificados por categoria semântica

Quadro 16 - Verbos classificados por categoria semântica

Quadro 17 - Verbos classificados por categoria semântica

$237-$

Quadro 18 - Verbos classificados por categoria semântica

$240-$

Quadro 19 - Verbos classificados por categoria semântica

Quadro 20 - Verbos classificados por categoria semântica 


\section{LISTA DAS TABELAS}

Tabela 1 - Relação do número de palavras e de textos do subcorpus de notícias sobre resultados de partidas.

Tabela 2 - Características do corpus após o primeiro balanceamento........................... 98 -

Tabela 3 - Fontes utilizadas para a compilação do corpus jornalístico de inglês..... - 100 Tabela 4 - Fontes utilizadas para a compilação do corpus de transmissão minuto a minuto de inglês $-102-$ Tabela 5 - Fontes utilizadas para a compilação do corpus jornalístico de português. - 104

Tabela 6 - Fontes utilizadas para a compilação do corpus de transmissão minuto a

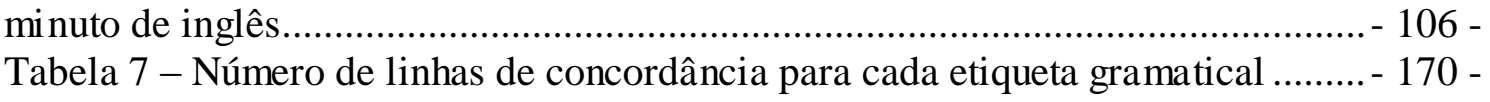
$106-$ 


\section{LISTA DOS GRÁFICOS}

Gráfico 1 - Tipos de fontes utilizadas na composição do corpus jornalístico de inglês... 102 -

Gráfico 2 - Tipos de fontes utilizadas na composição do corpus de transmissões minuto a minuto de inglês. $-103-$ Gráfico 3 - Tipos de fontes utilizadas na composição do corpus jornalístico de português $104-$ Gráfico 4 - Tipos de fontes utilizadas na composição do corpus de transmissões minuto a minuto de português $-106-$ 


\section{LISTA DE ABREVIATURAS}

\begin{tabular}{|l|l|}
\hline LC & Linguística de Corpus \\
\hline UF & Unidade Fraseológica \\
\hline UFE & Unidade Fraseológica Especializada \\
\hline VB & Lema do verbo (inglês) \\
\hline VBD & Verbo no passado (inglês) \\
\hline VBN & Particípio passado (inglês) \\
\hline VBP & Verbo no presente (inglês) \\
\hline VBZ & Verbo no presente - terceira pessoa do singular (inglês) \\
\hline JJ & Adjetivo (inglês) \\
\hline POS & Caso genitivo (inglês) \\
\hline ADJ & Adjetivo (português) \\
\hline V & Verbo (português) \\
\hline
\end{tabular}




\section{SUMÁRIO}

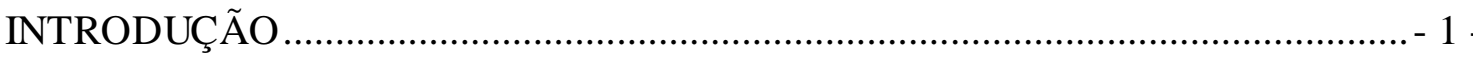

Capítulo 1 - Futebol .................................................................................... 7 -

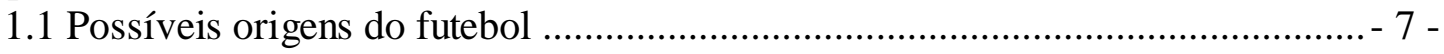

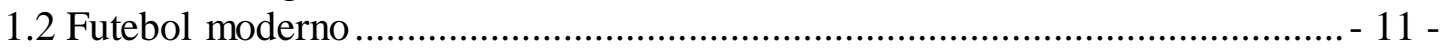

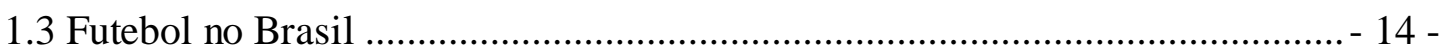

1.4 Forma-representação ............................................................................ 21 -

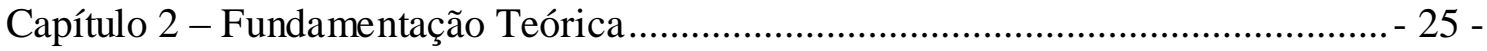

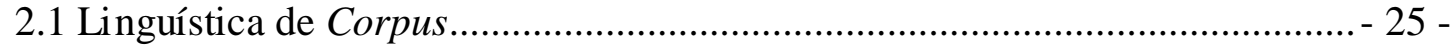

2.1.1 Tipologia de Corpus ......................................................................... 30 -

2.1.2 Abordagem baseada em corpus (corpus-based) e abordagem direcionada pelo corpus (corpus-driven) .................................................................................... 33 -

2.1.3 Tipos de pesquisas em Linguística de Corpus........................................... 34 -

2.1.3.1 Lingüística de Corpus e convencionalidade...................................... 35 -

2.1.4 Ferramentas de exploração de corpora ….............................................. 37 -

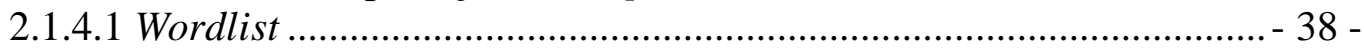

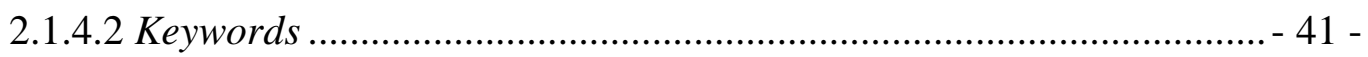

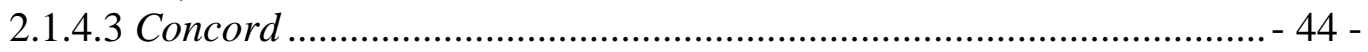

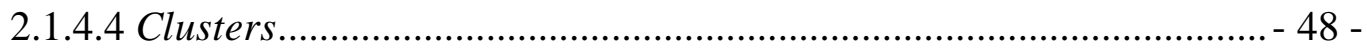

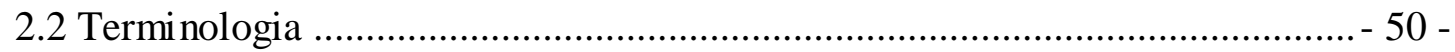

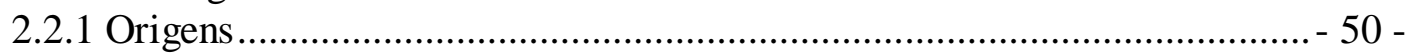

2.2.2 Desenvolvimento ................................................................................ 53 -

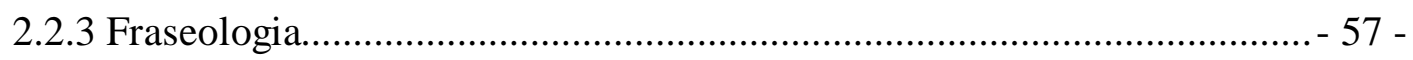

2.2.3.1 Texto Especializado................................................................. 57 -

2.2.3.2 Termi nologia te $x$ tual................................................................ 60 -

2.2.3.3 Unidades Fraseológicas Especializadas............................................. 62 -

2.2.3.3.1 Definições ........................................................................... 64 -

2.2.3.3.2 Critérios de identificação......................................................... 69 -

2.2.3.3.3 Definição e critérios adotados .................................................... 72 -

2.3 Tradução técnica e condicionantes culturais ...................................................... 80 -

Capítulo 3 - Materiais e Métodos.............................................................................. 85 -

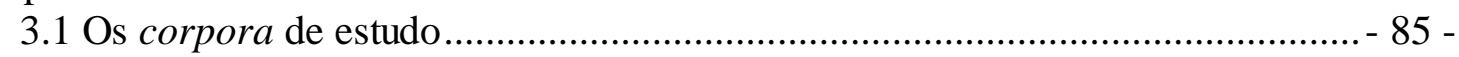

3.1.1 Construção do corpus ...................................................................... 85 -

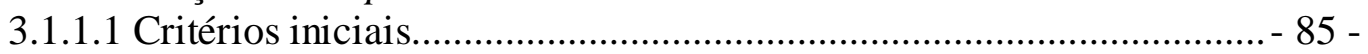

3.1.1.2 Critérios redefinidos .............................................................. 87 -

3.1.1.3 Limpeza do corpus ..................................................................... 97 -

3.1.1.4 Armazenamento dos textos ............................................................... 97 -

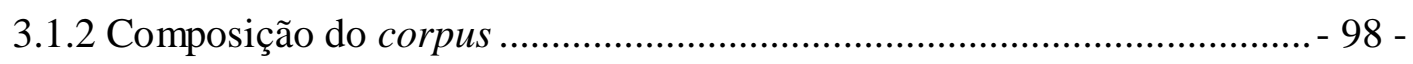

3.1.2.1 Caracterização das fontes utilizadas ................................................... 99 -

3.1.2.1.1 Corpus de inglês ..................................................................... 99 -

3.1.2.1.2 Corpus de português .............................................................. 103 -

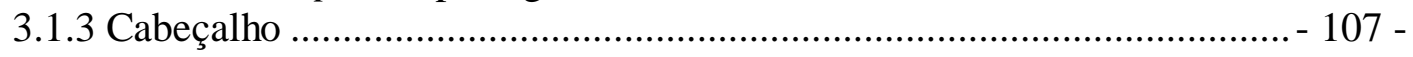

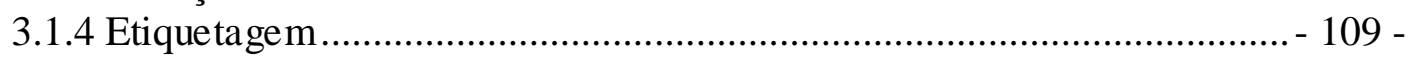

3.1.4.1 Etiquetagem discursiva ......................................................... 110 -

3.1.4.2 Etiquetagem morfossintática ...................................................... 112 - 
3.1.4.2.1 Etiquetador.......................................................................... 113 -

3.1.4.2.2 Etiquetas .......................................................................... 116 -

3.1.4.2.3 Expressões de busca ............................................................. - 117 -

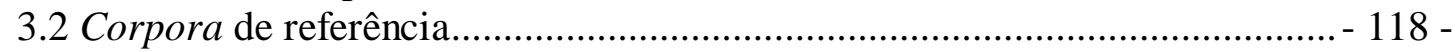

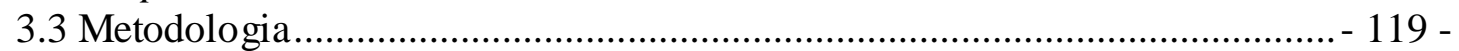

3.3.1 Procedimentos de análise.................................................................... 119 -

3.3.1.1 Extração dos candidatos a termo ................................................... 120 -

3.3.1.2 Levantamento das UFs ........................................................... 125 -

3.3.1.3 Validação das UFs .................................................................... - 128 -

3.3.1.4 Atribuição dos equivalentes das UFs encontradas .......................... 133 -

Capítulo 4 - Análise e Discussão dos Dados ............................................................ - 139 -

4.1 após o gol (55) / depois do gol (46) ............................................................... 139 -

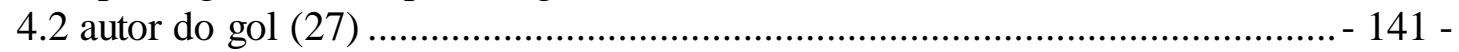

4.3 belo gol, um (31) / gol incrível, um (24) / bonito gol, um (10) ..................... 145 -

4.4 na cara do gol (90) / de frente para o gol (26) .............................................. 148 -

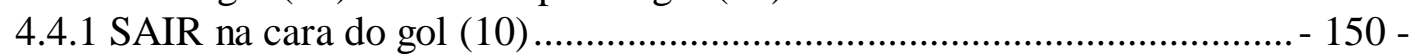

4.5 chance(s) de gol (118) / oportunidade(s) de gol (37) ................................... 150 -

4.5.1 boa(s) $\{$ chance(s) $\mid$ oportunidade(s) $\}$ de gol (10) .................................. 152 -

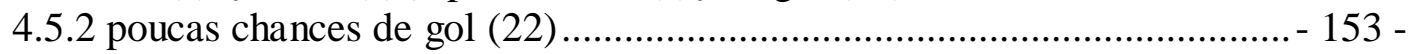

4.6 che gar ao gol (39) ............................................................................ 153 -

4.7 chute de $\{$ direita|esquerda\} no gol feito por [jogador] (180) ......................... 156 -

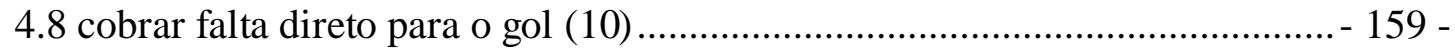

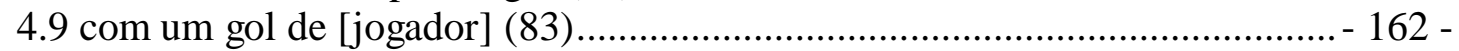

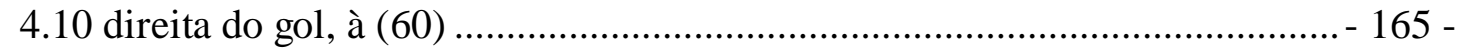

4.10.1 a bola \{PASSAR|SAIR\} à direita do gol........................................... 166 -

4.11 esquerda do gol, à (75) ............................................................................ 166 -

4.11.1 a bola \{PASSAR | SAIR \} à esquerda do gol ...................................... 166 -

4.12 EVITAR o gol (32) ............................................................................. 167 -

4.13 FAZER \{o | um\} gol (473) / MARCAR \{o|um\} gol (145)/ MARCAR o tento

(40) / FINALIZAR (35) / EMPATAR (50) ...................................................... 168 -

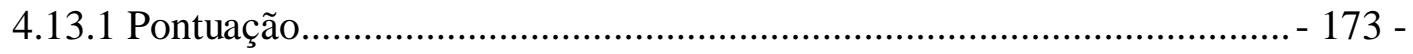

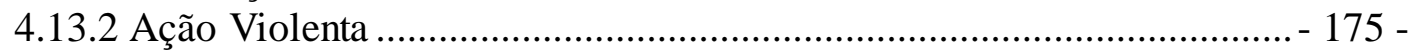

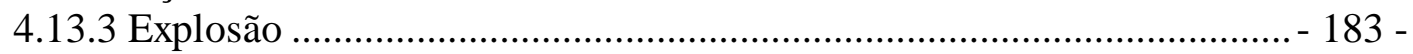

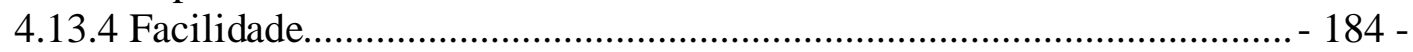

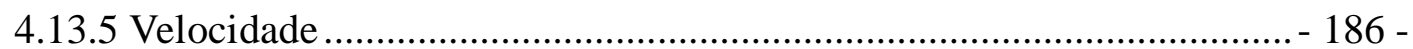

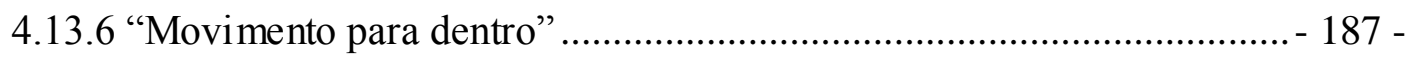

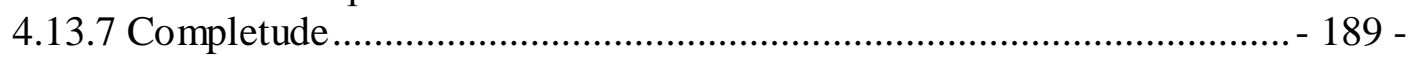

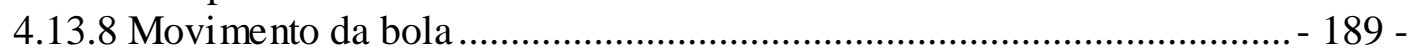

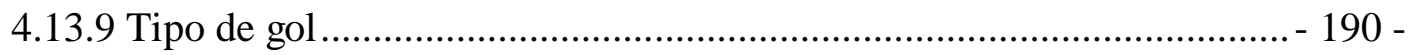

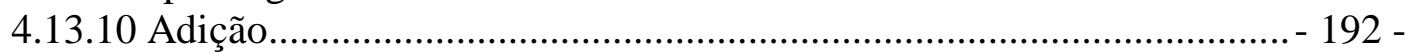

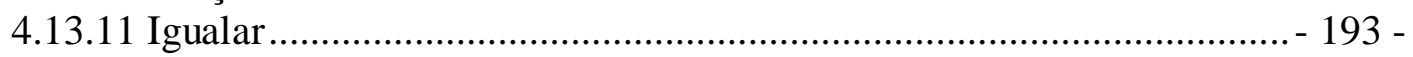

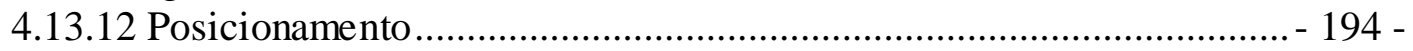

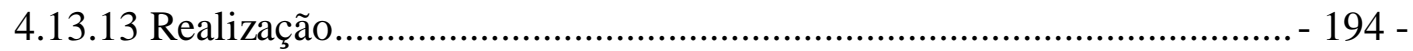

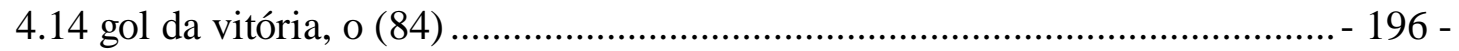

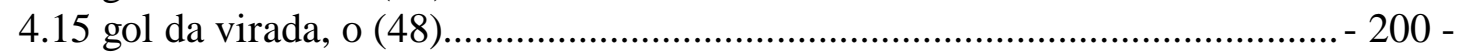

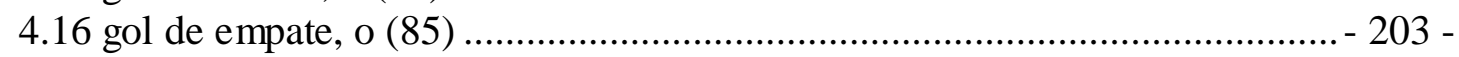

4.17 gol de pênalti, um (32) ................................................................... 204 -

4.17.1 com um gol de pênalti (5) ............................................................... 207 -

4.18 [goleiro] SAIR $\{\mathrm{mal} \mid$ bem $\}$ (do gol) (51) ............................................. 208 - 
4.19 ORDINAL gol \{do atacante | de [jogador]\} EM \{[torneio] | [competição] |

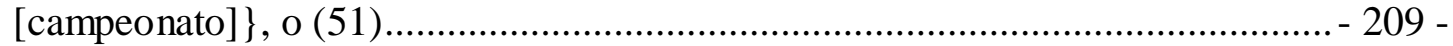

4.19.1 primeiro gol de [jogador] com a camisa ADJ ADN, o (10) .................. 211 -

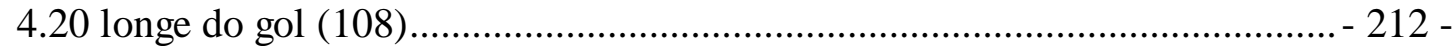

4.20.1 a bola PASSAR longe do gol (13) .................................................... 215 -

4.20.2 \{FINALIZAR|MANDAR\} para longe do gol (16) .............................. 217 -

4.21 meio do gol, no (77) ........................................................................... 219 -

4.21.1 [goleiro] segura no meio do gol (20) ............................................... 220 -

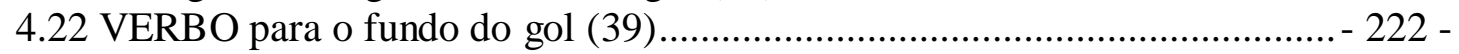

4.23 para o gol (318)........................................................................... 223 -

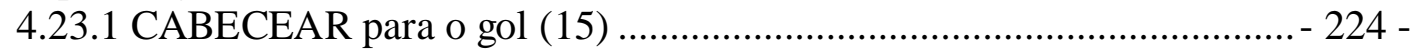

4.23.2 [jogador] DES VIAR para o gol (18) ................................................ 225 -

4.23.3 \{ARREMATAR | COMPLETAR | CONCLUIR |FINALIZAR \} para o gol

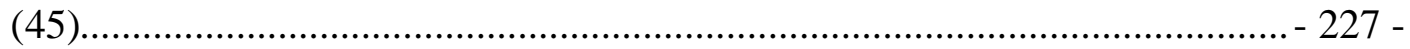

4.23.4 \{BATER | CHUTAR | EMPURRAR | MANDAR | TOCAR\} para o gol

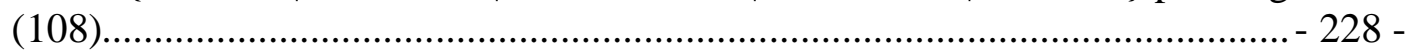

4.23.5 RECEBER de costas para o gol (10) .............................................. 232 -

4.24 VERBO para o gol vazio (33) ............................................................. 233 -

4.25 perigo ao gol de [goleiro] (36)............................................................. 234 -

4.26 (muito) perto do gol (79) …................................................................. 235 -

4.26.1 a bola PASSAR (muito) perto do gol (42) .......................................... 236 -

4.27 por cima do gol (230) …....................................................................... 237 -

4.27.1 a bola \{IR |PASSAR | SAIR \} por cima do gol (51) ........................... 237 -

4.27.2 CABECEAR por cima do gol (26) ................................................... 239 -

4.27.3 \{CHUTAR | MANDAR\} (a bola) por cima do gol (64) ....................... 240 -

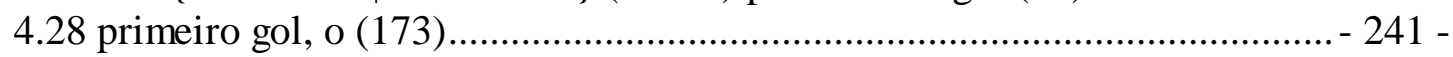

4.28.1 o primeiro gol do [time] (29) ......................................................... 241 -

4.28.2 o primeiro gol DE \{partida |jogo \} (23) ............................................ 242 -

4.29 sair do gol (35)................................................................................. 243 -

4.29.1 [goleiro] SAIR do gol e ficar com a bola (20) ..................................... 245 -

4.30 único gol da partida, o (22) .................................................................. 245 -

Capítulo 5 - Modelo de Verbete ......................................................................... 247 -

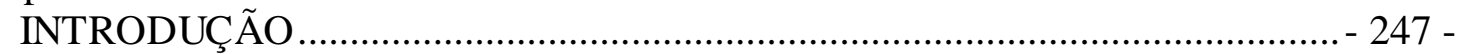

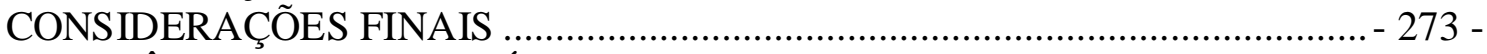

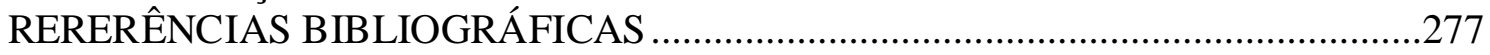

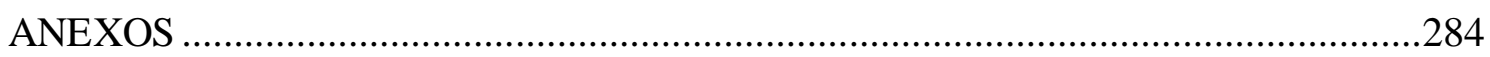

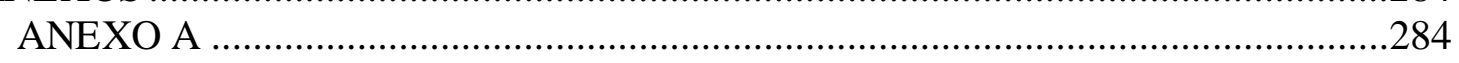

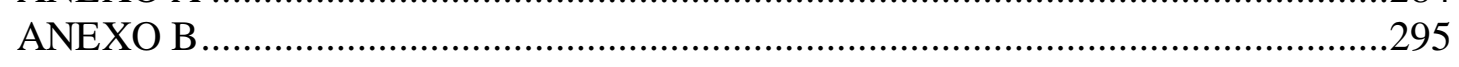

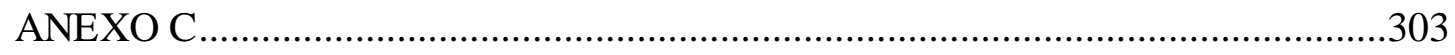

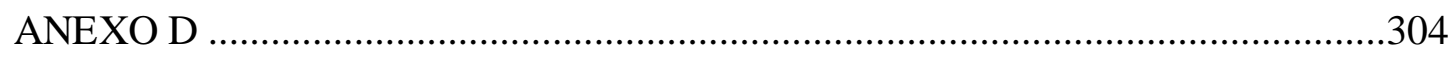

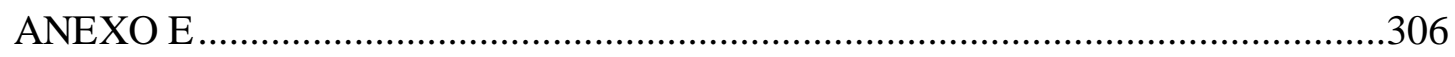

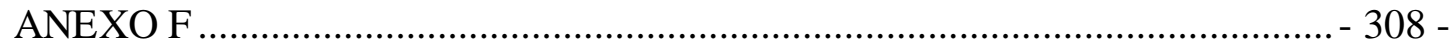




\section{INTRODUÇÃO}

O futebol tem muitas dimensões que se entrelaçam, formando um mosaico amplo, variado e global. Ele pode ser encarado como espetáculo, competição, ritual, metáfora, celebração, síntese, catarse. E tudo isso ao mesmo tempo. Mas não há apenas um futebol. Embora o conjunto de regras, o palco e a base do repertório sejam comuns, cada sociedade tem o seu modo próprio de jogar e de torcer, resultado de sua história e de sua cultura, e da interação de sua história e de sua cultura com as outras. $O$ futebol tem, portanto, uma dimensão que integra as demais: trata-se de uma construção cultural. (GIL, 2004).

O futebol é o esporte mais praticado no Brasil e no mundo. É reconhecido mundialmente enquanto competição, manifestação cultural e até mesmo como um mercado na ordem econômica. A FIFA (Federação Internacional de Futebol Associado) congrega mais de 140 milhões de jogadores de 300 mil clubes, em 207 países afiliados ${ }^{1}$. O Brasil, conhecido mundialmente como o "País do Futebol" ou "Pátria de Chuteiras", tem aproximadamente 40 milhões de praticantes, entre atletas profissionais e amadores, cerca de 11 mil jogadores federados, 800 clubes, mais de dois mil atletas atuando em outros países e 580 estádios. Isso, sem contar ao redor de 20 mil "campinhos" de pelada, nos bairros de classe mais baixa ${ }^{2}$, as escolinhas de futebol e os milhares de torcedores.

O esporte é praticado em todo o país por camadas sociais distintas e em diferentes espaços: campos de várzea, quadras, praias, ruas, escolas, clubes etc. Enfim, é parte do cotidiano de muitos brasileiros. DaMatta (1982, p. 21) destaca que "o futebol praticado, vivido, discutido e teorizado no Brasil seria um modo específico, entre tantos outros, pelo qual a sociedade brasileira fala, apresenta-se, revela-se, deixando-se, portanto, descobrir".

Essa popularidade, tanto no Brasil quanto em outros países, tem aumentado a participação da indústria do futebol na economia mundial, movimentando cerca de 250

\footnotetext{
${ }^{1}$ Disponível em: < http://www.papodebola.com.br/pernambucoaqui/20081001.htm>. Acesso em: 05 abr. 2011.

${ }^{2}$ Disponível em: < http://desafios2.ipea.gov.br/desafios/edicoes/24/artigo22656-2.php>. Acesso em: 08 abr. 2011.
} 
bilhões de dólares anuais, dos quais apenas $1 \%$ refere-se à participação brasileira (LEONCINI; SILVA, 2005).

Independentemente dessa participação reduzida, é fato que as relações futebolísticas entre o Brasil e os países da Europa crescem cada vez mais (CRUZ, 2005); seja pelo intercâmbio de contratos de jogadores e técnicos; pelos direitos de transmissão de campeonatos como a Copa do Mundo, a Liga dos Campeões, a Copa das Confederações e os campeonatos europeus em geral; pelo patrocínio de jogadores por grandes marcas e por qualquer outra negociação que envolva um produto relacionado ao futebol.

Para que todas essas relações se materializem, estabelecemos uma comunicação que, na grande maioria das vezes, se dá no uso da língua inglesa. No entanto, cada nação tem a sua maneira de jogar, torcer e narrar, maneira, esta, expressa por meio da nossa língua materna. $O$ problema surge quando queremos expressar essas particularidades em uma língua estrangeira.

Embora seja, muitas vezes, relacionado somente ao lazer, o futebol é uma área técnica, pois possui um vocabulário específico organizado em torno de uma temática. Constitui uma área técnica tanto no Brasil quanto em outros países. Sendo assim, possui uma linguagem específica utilizada para descrever acontecimentos a ele relacionados. Essa linguagem é padronizada e, justamente por esse motivo, não pode ser utilizada de qualquer forma. Ao falar em padronização, não pretendemos, de forma alguma, tentar normatizar o léxico do futebol para favorecer a eficácia das comunicações especializadas em torno dessa temática. Ao contrário, pretendemos favorecer as peculiaridades de cada texto dentro de seu discurso (FINATTO; KRIEGER, 2004).

Durante a pesquisa, analisamos algumas passagens do livro Brasil o Melhor Futebol do Mundo, uma edição trilíngue (português-inglês-espanhol) que retrata alguns marcos históricos do futebol brasileiro. Na breve análise que fizemos, constatamos a não padronização na tradução das unidades fraseológicas especializadas. Encontramos três ocorrências para a expressão "fazer linha de impedimento", que foram traduzidas de três maneiras diferentes:

- to pull an offside trap

- to play an offside trap 
- to play a restraining line

Realizamos também um levantamento dos glossários e obras bilíngües inglêsportuguês sobre futebol. Constatamos que tanto os dicionários on-line quanto os impressos disponibilizam, na maioria das vezes, somente equivalentes para os termos, raramente incluindo um colocado ou a frase em que o termo ocorre. Outra característica comum é a ausência de exemplos, ou seja, ao usuário é apresentado o termo equivalente, mas sem informações, quer das palavras que o acompanham, quer do contexto no qual é utilizado - informações que são de extrema importância para qualquer pessoa que escreva um texto técnico, seja na área do futebol ou em qualquer outra área. Em um dos glossários ${ }^{3}$ consultados, encontramos alguns equivalentes fraseológicos e algumas colocações. Porém, a utilização dessas expressões não era o uso convencionado, ou melhor, o uso de praxe na língua utilizada para falar de futebol (TAGNIN, 2005). Novamente, remetemos ao mesmo exemplo: encontramos to pull an offside trap para "fazer linha de impedimento", enquanto o uso mais frequente para esta expressão em inglês é to play an offside trap.

No que se refere aos estudos linguísticos do Futebol já existentes, podemos mencionar o livro The Linguistics of Football (2008), que contém uma série de artigos sobre terminologia ${ }^{4}$, expressões idiomáticas, metáforas, discurso, ensino de línguas e mídia do futebol. O livro é escrito em inglês, mas os artigos refletem estudos realizados em várias línguas, dentre elas: francês, inglês, alemão, croata, búlgaro, árabe, espanhol, polonês e malaio. Outra obra, o Kicktionary (SCHMIDT, 2008), dicionário online multilíngue (inglês - francês - alemão) de futebol, desenvolvido no FrameNet project da Universidade de Berkeley, explora a forma como as teorias de semântica lexical, linguística de corpus e processamento de línguas naturais contribuem para a elaboração de obras de referência destinadas à pesquisa lexical. Atualmente, o dicionário conta com 1900 unidades lexicais. No Brasil, temos várias obras que retratam aspectos da linguagem futebolística, dentre eles: Feijó (2006), D’Ambrosio (2006), Maranhão (1998) e Capinussú (1998), dicionários monolíngues e ainda trabalhos como o de Maria

\footnotetext{
${ }_{4}^{3}$ Disponível em: < http://br.geocities.com/helcio_englishteacher/soccer.html>. Acesso em: 14 nov. 2009.

4 Utilizamos terminologia com " $t$ " minúsculo para o conjuto de termos especializados próprios de uma área técnica e Terminologia com " $T$ " maiúsculo para fazer referência à disciplina linguística que estuda as linguagens especializadas.
} 
Cristina Andrade Santos, na área de Linguística da Universidade Federal de São Carlos, que propõe a construção de uma ontologia do domínio "futebol" (SANTOS; VALE, 2008). No entanto, todos esses trabalhos, realizados com rigor metodológico e que descrevem particularidades da linguagem específica que o futebol constitui, são monolíngues ou em português.

Em The Linguistics of Football, pesquisadores do Innsbruck Football Research Team apresentam um panorama do multilinguismo no futebol ressaltando a importância da terminologia para a eficácia da comunicação entre técnicos e jogadores de culturas diferentes. Ainda neste mesmo volume, Engelbert Thaler discorre sobre futebol e ensino de inglês como língua estrangeira e mostra como essas duas áreas, aparentemente tão distantes, podem estar atreladas.

Como trabalho de conclusão de curso para a disciplina "Panorama teórico da tradução", investigamos as diferenças que permeiam a produção de notícias sobre resultados de partida em inglês e português e as modificações que notícias escritas originalmente em inglês sofrem ao serem reescritas em português. Para tanto, entramos em contato com o editor esportivo de um jornal conceituado e perguntamos quem eram os responsáveis pela edição dessas notícias. Para nossa surpresa, a resposta foi: "um jornalista, um comentarista, um apaixonado por futebol bilíngue, menos um tradutor". Segundo o editor, os textos de tradutores profissionais soam artificiais, pois fraseologias, expressões idiomáticas e metáforas são deixadas de lado dando lugar a uma línguagem estranha que não representa o futebolês ${ }^{5}$ presente nas notícias.

Dada a escassez de obras terminográficas na área do futebol para o par de línguas português-inglês, a importância da eficácia na comunicação especializada e a falta de padronização na tradução das fraseologias, o objetivo principal desta pesquisa é fazer um estudo aprofundado da terminologia do futebol por meio do estabelecimento de equivalentes fraseológicos. Os objetivos específicos do estudo das unidades fraseológicas especializadas (UFEs) ${ }^{6}$ são:

1) a partir da compilação de um corpus comparável português-inglês de futebol, identificar as UFEs mais frequentes no corpus de português e seus equivalentes no corpus de inglês;

\footnotetext{
${ }^{5}$ Linguagem utilizada para falar de futebol.

${ }^{6}$ A definição de UFE é apresentada no item 2.2.3.3.3.
} 
2) criar um modelo de glossário bilíngue português-inglês de fraseologias do futebol;

3) elaborar um verbete do glossário tendo como base o modelo proposto.

A escolha de trabalhar com UFEs, e não apenas com termos isolados, se deve ao fato de acreditarmos que um termo raramente ocorre sozinho, ou seja, é muito provável que venha acompanhado de um colocado, formando uma colocação e, muitas vezes, seja até parte de uma unidade de sentido maior.

A fim de atingir os objetivos propostos, compilamos um corpus comparável português-inglês de futebol composto por notícias de resultados de partida, transmissões minuto a minuto, transmissões sociais ${ }^{7}$ e regras do jogo. Os textos foram coletados de jornais, tabloides, periódicos esportivos, periódicos sobre futebol, revistas e agências de notícias.

Para conduzir a análise, utilizamos quatro abordagens teóricas: a Linguística de Corpus (LC), a Terminologia Textual, a Tradução Técnica como ato comunicativo sujeito a condicionantes culturais e o conceito forma-representação.

A compilação e a exploração dos corpora foram realizadas utilizando os conceitos subjacentes à LC, que se ocupa da coleta e análise de corpus para a investigação de fenômenos prováveis na língua.

A Terminologia Textual nos deu o aporte teórico para o estabelecimento dos critérios de identificação bem como para a definição das UFEs.

As noções de equivalência de Azenha Jr. (1999) e Tagnin (2007), utilizadas na tradução técnica, contribuíram de forma significativa para nossa concepção de equivalente fraseológico.

O conceito forma-representação de Toledo (2002) foi fundamental para entendermos algumas discrepâncias na linguagem utilizada para falar de futebol em inglês e português.

O produto final do trabalho, o modelo de glossário bilíngue português-inglês de fraseologias do futebol, que será exemplificado com o termo "gol", tem como objetivo

\footnotetext{
7 Transmissões minuto a minuto em que os internautas interagem com o narrador por meio de
} comentários. 
disponibilizar informações necessárias para a consulta de tradutores em geral, estudantes de tradução, comentaristas, colunistas, jornalistas e clubes esportivos, do Ministério do Esporte, este responsável por construir a Política Nacional do Esporte bem como difundir os esportes praticados no Brasil para turistas, e da própria Confederação Brasileira de Futebol (CBF), que é associada à FIFA.

Quanto à divisão, o trabalho estruturou-se em cinco capítulos:

No "capítulo 1", apresentamos um breve histórico do futebol, com as possíveis origens do esporte, alguns pontos que marcaram o surgimento do futebol moderno e sua introdução no Brasil. Ao final, introduzimos o conceito de forma-representação proposto por Toledo (2002).

O "capítulo 2" aborda as três principais abordagens teóricas utilizadas na pesquisa: Linguística de Corpus, Terminologia Textual e Tradução Técnica como ato comunicativo sujeito a condicionantes culturais.

O "capítulo 3" introduz a metodologia adotada na pesquisa. Apresenta, inicialmente, o corpus de estudo e os corpora de referência e, ao final, descreve os passos seguidos para a análise dos dados.

O “capítulo 4" apresenta uma análise detalhada das UFEs formadas com o termo "gol".

O "capítulo 5" apresenta um modelo de verbete para um glossário bilíngue português-inglês de fraseologias do futebol.

Em "Considerações Finais", recapitulamos os resultados alcançados e tecemos alguns comentários sobre possibilidades futuras. 


\section{Capítulo 1 - Futebol}

A história do futebol não pode ser dissociada da história geral das civilizações. (FRANCO JÚNIOR, 2007).

O presente capítulo apresenta um breve histórico do futebol. Primeiramente, expomos algumas das possíveis origens do esporte. Em seguida, levantamos alguns pontos que marcaram o surgimento do futebol moderno e discorremos sobre a introdução do futebol no Brasil. Ao final, introduzimos o conceito de formarepresentação proposto por Toledo (2002).

\subsection{Possíveis origens do futebol}

O futebol é o esporte coletivo mais praticado no mundo. É o que atrai mais torcedores e um dos que movimentam mais recursos, tanto direta quanto indiretamente, desde bilheterias e direitos de transmissões de jogos até a venda de artigos esportivos. São 265 milhões de praticantes em todo o mundo, 270 se os árbitros, árbitros assistentes, também conhecidos como bandeirinhas, e os árbitros reservas forem levados em conta ${ }^{8}$. Mais significativo ainda é o número de envolvidos indiretamente com o esporte, como patrocinadores, grandes marcas, emissoras de TV, profissionais ligados aos grandes times, torcedores e telespectadores.

A relação do futebol com o povo manifesta-se em diferentes esferas. Segundo Gil (2004), o futebol pode ser encarado como espetáculo, competição, ritual, metáfora, celebração, síntese e catarse. Procuramos, neste trabalho, observar o futebol como fenômeno cultural sem fazer distinção entre os diferentes ângulos do qual pode ser abordado. Por outro lado, achamos importante a oposição feita por Franco Júnior (2007, p. 14):

De um lado, há quem veja nele atividade de espírito infantil praticada por homens adultos, desviados dessa maneira de tarefas produtivas e de ações

\footnotetext{
${ }^{8}$ Dados obtidos em FIFA Big Count 2006.
} 
sociais mais nobres. De outro lado, há parcela considerável da população mundial que atribui a ele papel importante, senão central, na sua vida.

O futebol como mercado de investimentos também tem importância significativa em alguns países. Na Espanha, por exemplo, a movimentação financeira dos dois principais clubes, o Real Madrid e o Barcelona, representou 0,062\% do PIB na temporada de 2007/2008 ${ }^{9}$. Em 2009, apesar da crise que abalou a economia mundial, bancos como o BBVA, o Santander, o Itaú e o BES mantiveram firme sua ligação com a indústria futebolística ${ }^{10}$. Atualmente a FIFA, entidade diretora do futebol mundial, possui mais de 200 federações associadas, reunindo politicamente mais países que a Organização das Nações Unidas, com 192 estados-membros.

Enfim, não se pode negar a posição de destaque que o futebol ocupa na sociedade contemporânea. Mas será que essa importância deu-se somente na contemporaneidade? Qual a origem do esporte que instiga milhões de pessoas em todo o mundo? Como surgiu o futebol moderno? Como o jogo foi implementado no Brasil? São inúmeros os questionamentos históricos, filosóficos, sociológicos, pedagógicos e antropológicos a serem levantados acerca do futebol. Para os propósitos deste estudo, apresentaremos um breve panorama histórico, se é que assim o podemos chamar. Tal panorama foi realizado sempre com vistas à justificativa e à execução da presente pesquisa já que, dentro da perspectiva de Terminologia em que nos ancoramos, seria impossível isolar o vocabulário técnico do futebol e investigá-lo à parte do contexto sócio-histórico-cultural em que o jogo está inserido.

Inúmeras são as especulações sobre as origens do esporte. A seguir algumas hipóteses são levantadas.

Na China antiga, entre 2000 e 1500 a.C., guerreiros criaram um passatempo que consistia em chutar o crânio dos inimigos para relaxar após as batalhas. A prática consistia em passar o crânio de pé em pé sem deixá-lo cair no chão, levando-o para dentro de duas varas fincadas no campo. No século III a.C., o passatempo deu origem a

\footnotetext{
${ }^{9}$ Artigo de Amir Somoggi sobre a relação do Real Madrid e do Barcelona com a economia Espanhola. Disponível em: <http://www.futebolfinance.com/real-madrid-barcelona-e-a-economia-da-espanha>. Acesso em: 14 abr. 2010.

10 Aanálise financeira sobre o investimento de bancos na indústria futebolística feita pelo Futebol Finance. Disponível em: <http://www.futebolfinance.com/bancos-as-instituicoes-financeiras-no-futebol>. Acesso em: 14 abr. 2010.
} 
uma prática militar chamada $t s u$-chu, literalmente "chutar a bola"11. No exercício, os participantes, doze ou oito em cada time, chutavam uma bola de couro recheada de crina para dentro de varas de bambu. No século II, o tsu-chu foi importado pelo Japão e teve seu nome traduzido para Kemari. A prática perdeu seu caráter de competição e passou a ser mais associada a um ritual. Os jogadores, posicionados em um círculo relativamente pequeno, tinham que passar a bola sem deixá-la tocar o chão.

Outro suposto antecessor do futebol é o tlachtli. Jogado na América Central por volta de 900 a.C., o tlachtli era praticado com uma bola de borracha e os jogadores das equipes, dessa vez com sete integrantes cada uma, tinham como objetivo arremessar a bola em aros de pedra no campo adversário por meio de toques feitos somente com os joelhos, cotovelos e bacia. Apesar de no fim de cada partida o capitão da equipe perdedora ser decapitado, o tlachtli era um jogo rito pois, como o próprio nome revela, “o que se dá a ver"12" ou, simplesmente, "espetáculo" 13, a atividade possuía uma relevância simbólica para seus praticantes. As quadras em que o jogo era praticado ainda são preservadas em sítios arqueológicos na região e são consideradas monumentos.

O espaço indo-europeu abriga outros dois possíveis antepassados do futebol: o Epyskiros grego e o Harpastum de Roma.

Na Grécia clássica, pelo menos desde IV a.C., o epyskiros, do qual poucos detalhes concretos foram encontrados, era jogado por nove homens que tentavam introduzir uma bola recheada de areia em um alvo determinado. Da prática grega, surgiu em Roma, por volta de III a.C., o harpastum, jogo inicialmente utilizado como exercício militar com o intuito de aperfeiçoar a capacidade atlética, desenvolver a tática, a lógica e a organização dos soldados, que se popularizou a partir do século I d.C.. A possível ligação com o futebol moderno se deve à sua introdução nas ilhas britânicas pelas tropas romanas, o que teria dado origem a diferentes jogos com bola, dentre eles o futebol.

Um jogo praticado com bola na Florença do século XVI também tem suas possíveis raízes no harpastum. Denominado calcio, termo até hoje utilizado para designar o futebol pelos italianos, o esporte era praticado em um campo retangular, no principal espaço público da cidade, Piazza Santa Croce. Era composto por dois times de

\footnotetext{
${ }^{11}$ Franco Júnior (2007, p. 15).

${ }^{12}$ Wisnik (2008, p. 71).

13 Tradução proposta por Franco Júnior (2007, p. 16).
} 
27 homens uniformizados, possuía um conjunto de regras e árbitro. Para Franco Júnior (2007, p. 17), o calcio marcou uma nova etapa na história do jogo devido às suas características e organização. A princípio era praticado por todos os segmentos sociais, no entanto, na segunda metade do século XVI tornou-se exclusividade da nobreza, sem nunca deixar de atrair grande público a suas partidas. Nesse período, o calcio contava com jogadores como Maquiavel e torcedores como Leonardo da Vinci. Devido ao seu caráter nobre, o esporte foi introduzido no treinamento da elite paramilitar local entre os séculos XV e XVIII ${ }^{14}$. Essa estreita ligação com a nobreza e sua aplicação no aperfeiçoamento militar levou ao seu desaparecimento durante mudanças políticosociais em 1739. Em 1930, o esporte ressurge atrelado ao estado fascista, em comemoração do quarto centenário de uma partida histórica jogada pelas tropas do imperador austríaco Carlos $\mathrm{V}^{15}$.

De acordo com Franco Júnior (2007, p. 17-18), dada a inegável origem inglesa do futebol moderno, é comum tentar encontrar suas origens em práticas com bolas realizadas no espaço anglo-normando medieval como na soule. Essa prática tinha um caráter mais ritual, se assemelhava mais a uma festa popular do que a um jogo propriamente dito. Era disputada por grupos muito grandes e descrita por Wisnik (2008, p. 77) como uma "espécie de vale-tudo pela pelota" em que se usavam as mãos, todo e qualquer tipo de choque e, até mesmo, golpes mais agressivos. A multidão de jogadores percorria campos, bosques e arredores de povoados na disputa pela bola. Ferimentos e fraturas faziam parte da prática e não raras eram as mortes. Os adversários tinham mais um caráter totêmico de clãs, como comunidades vizinhas, casados x solteiros, cidade $\mathrm{x}$ campo, do que de equipes esportivas ${ }^{16}$. O objetivo final era conduzir a bola ao território adversário ou subtraí-la do domínio do outro grupo até seu próprio território.

As hipóteses acima expostas contribuem, de alguma forma, para nossa reflexão de que o Kemari, o tlachtli, o epyskiros, o harpastum, o calcio, a soule e todos os outros possíveis antepassados estavam presentes em várias facetas da vida social: diversão, esporte, condicionamento físico, guerra e política, assim como ocorre com o futebol moderno. Além disso, todas as práticas acima citadas denotam condições culturais específicas de um determinado povo em uma determinada época, da mesma forma que o

\footnotetext{
${ }^{14}$ Franco Júnior (2007, p. 17).

${ }^{15}$ Franco Júnior (2007, p. 17).

${ }^{16}$ Wisnik (2008, p. 77).
} 
futebol contemporâneo é descrito, jogado e vivido de inúmeras maneiras em diferentes culturas.

\subsection{Futebol moderno}

Devido à amplitude dos estudos sobre o futebol moderno, seria inviável em um único capítulo, que tem como objetivo situar a prática do futebol moderno no quadro histórico-social-geográfico de seu surgimento, fazer uma revisão bibliográfica dos autores que tratam a questão. Optamos, por esse motivo, apresentar um breve panorama histórico tendo como fonte de referência a obra A dança dos Deuses. Futebol, Sociedade e Cultura do historiador Hilário Franco Júnior.

A escolha dessa obra e não de outras que também tratam da história do futebol se deu devido à proposta do livro em questão: demonstrar que o futebol é um "fenômeno cultural total", cujas relações com os mais variados campos do saber humano ajudam não apenas a iluminar a prática do esporte como a entender melhor a sociedade em que vivemos (FRANCO JÚNIOR, 2007). Sendo assim, saliente-se que a seção que se segue é muito mais uma revisão bibliográfica do primeiro capítulo da obra de Franco Júnior, intitulado "Síntese da Europa industrial e colonialista", do que uma historiografia do futebol.

Ao falar nas origens do futebol moderno somos levados a viajar para a Inglaterra do século XIX. Embora tenha sido praticado nas primeiras décadas do século XIX já com um formato bem parecido com o atual, o esporte só surgiu oficialmente em 1848 durante a Revolução Industrial. Segundo o professor Hilário Franco Júnior (2007, p. 25), é praticamente impossível não associar a propagação do futebol à ascensão da Inglaterra durante o Império Britânico já que os dois se baseiam, sobretudo, em competição, produtividade, quantificação de resultados e fixação de regras.

Após a derrota do imperialismo napoleônico na batalha de Waterloo, a Inglaterra passou por uma época de prosperidade política, econômica e social, em que o futebol foi utilizado como um dos instrumentos para moldar o caráter da elite inglesa e preparar futuros governantes por meio do chamado "cristianismo atlético", descrito por Franco Júnior (2007, p. 25) como "concepção pedagógica que pretendia desenvolver a fibra moral da elite britânica destinada a governar regiões longínquas e inóspitas, plenas de 
súditos hostis e pouco civilizados". Com esse intuito, o football, até então um jogo de bola sem regras, foi sendo, aos poucos, introduzido nas escolas particulares e nas universidades. No entanto, para que tal política funcionasse, fazia-se necessário um conjunto de regras capaz de organizar o esporte e, consequentemente, a sociedade. Por esse motivo, em 1848 houve a primeira tentativa de uniformização das regras. O conjunto de regras resultante não teve caráter definitivo e foi revisado e alterado inúmeras vezes por diversos motivos. Anos depois, já em 1863, foi fundada a Football Association juntamente com um comitê responsável pela revisão das regras (FRANCO JÚNIOR, 2007, p. 28).

Todas as regras e as mudanças que as sucederam se configuraram como resultado de decisões expressas por grande parte da população. Por esse motivo, o football era considerado, pelo ingleses, um jogo de caráter extremamente britânico. Presentes em diversos lugares do mundo devido ao imperialismo britânico, os ingleses sempre procuravam jogar football entre si, deixando de fora os habitantes locais.

Até o fim do século XIX, o futebol era um esporte praticado, quase que exclusivamente, pela burguesia inglesa entre times locais no esquema 1-10 (10 atacantes e um beque). Outra característica predominante era o dribbling game, em que o desempenho individual do jogador era mais importante do que o da equipe, prática que mudou por volta de 1876, quando o passing game, forma de jogar que priorizava a importância coletiva do esporte, passou a predominar nas partidas. Outras mudanças estariam por vir: em 1867, foi introduzida a regra do offside ${ }^{17}$; em 1868, a figura do árbitro; em 1869, o tiro de meta; em 1871, o goleiro; em 1872, definiu-se o tamanho e peso da bola.

As duas últimas décadas do século XIX foram marcadas por diversos acontecimentos no mundo do futebol. Surge, em 1863, a Federação Inglesa (Football Association), que inspirou associações similares como a irlandesa (1882), a escocesa (1873) e a galesa (1876), contribuindo significativamente para a divulgação do esporte por meio da organização de campeonatos. O público das partidas aumentou consideravelmente e, como consequência dessa difusão, o esporte foi, aos poucos, deixando de ser exclusividade da burguesia e passou a atrair as classes menos abastadas. Em 1870, surgiram clubes de empresas siderúrgicas e no início da década seguinte o

\footnotetext{
${ }^{17}$ Impedimento.
} 
futebol passou a ser praticado nas escolas públicas (FRANCO JÚNIOR, 2007, p. 34). Trabalhadores passaram a administrar clubes e os melhores jogadores eram convidados a trocar seu time por outro em troca de um emprego mais vantajoso (FRANCO JÚNIOR, 2007, p. 35).

A nobreza tentava combater esse "profissionalismo" a fim de que o futebol permanecesse como um lazer elitista. No entanto, mesmo com todos os esforços desta elite, em 1885 a Football Association reconheceu o futebol como atividade profissional.

Todas essas mudanças dentro da esfera futebolística, juntamente com a busca da identidade do esporte, que desde os primórdios passou por diversas mudanças, clamaram por uma revisão no conjunto de regras estabelecido em 1863.

Dessa vez, a revisão não aconteceu por meio de uma reunião em que membros da Football Association sugeriam e discutiam alterações. Ao contrário, foi um processo bastante demorado, que se estendeu até as primeiras décadas do século XX. A revisão das regras existentes e a implementação das novas deu-se por meio da aceitação das práticas futebolísticas consagradas nos anos anteriores, refletindo-se, dessa forma, o conjunto legal inglês, common law, que é resultante de práticas sociais reiteradas.

A identidade que o jogo acabara de adquirir - por meio da revisão das regras -, sua popularização, a criação de federações e a situação econômica durante a Revolução Industrial que, dentre inúmeros feitos, ampliou significativamente a rede de ferrovias e impulsionou a melhora nos outros meios de transporte, ligando várias regiões do país, foram essenciais para a difusão do esporte na própria Inglaterra.

A propagação pela Europa e América foi, acima de tudo, fruto do imperialismo inglês que exportava não só seus produtos industrializados como também suas práticas culturais (FRANCO JÚNIOR, 2007, p. 40). Em grande parte dos casos, o contato dos países com a bola dava-se de dois modos: por meio de ingleses que residiam no exterior ou de estrangeiros que, após estudarem na Inglaterra, voltavam para seu país de origem e introduziam o esporte.

Como podemos ver, o multiculturalismo é característica intrínseca ao futebol, esporte de origem inglesa que se disseminou em todo o mundo assumindo características distintas em diferentes culturas. Contudo, não nos cabe, neste trabalho, investigar a propagação do futebol moderno fora da Inglaterra. Para nossos propósitos, no item que segue, faremos apenas uma breve introdução de como o futebol chegou ao 
Brasil, destacando o papel que este esporte exerce na sociedade, sempre com vistas à comparação com o papel do futebol na sociedade inglesa, já que fatores como esse refletirão, de forma direta, na terminologia empregada nas duas línguas de estudo.

\subsection{Futebol no Brasil}

Nesta seção, assim como na anterior, faremos uma revisão bibliográfica de um capítulo da obra de Franco Júnior (2007). Desta vez, o capítulo selecionado foi "Síntese do Brasil agrícola e mestiço" que bem sintetiza a relação do futebol com a história brasileira. Por meio da seleção de alguns momentos importantes, tentamos estabelecer um diálogo com Toledo (2000) em O país do Futebol e com a coletânea de crônicas e contos sobre futebol de personagens da literatura brasileira compilada por Ramos (1990), a fim de abordar alguns pontos marcantes do futebol em nossa sociedade.

As origens do futebol no Brasil são frequentemente atribuídas a Charles Miller, filho de engenheiro escocês que veio ao Brasil para trabalhar na São Paulo Railway Company, e de mãe brasileira de ascendência inglesa. Charles foi enviado à Inglaterra em 1883, com apenas nove anos, para completar seus estudos. Em fevereiro de 1894, retorna ao Brasil e traz em sua bagagem os instrumentos necessários para a prática do que se tornaria o esporte das multidões. Funcionário da São Paulo Railway Company e sócio do São Paulo Athletic Club, Miller foi responsável pela primeira partida oficial no Brasil, realizada em 14 de abril de 1895 pelas duas entidades ${ }^{18}$.

No entanto, existem registros que comprovam que um esporte muito parecido com o futebol já era praticado no Brasil entre 1880 e 1890 quando jesuítas introduziram no colégio São Luís em Itu o "bate bolão". Também era praticado por jovens da elite em outros colégios confessionais e laicos de São Paulo, Rio de Janeiro e Rio Grande do Sul e por marinheiros ingleses no litoral brasileiro. Existe até mesmo registro de uma partida realizada, em 1878, em frente à residência da princesa Isabel, no Rio de Janeiro (FRANCO JÚNIOR, 2007, p. 62).

Para Franco Júnior (2007), atribuir paternidades quase heróicas e datas ofi ciais à introdução do esporte no Brasil não reflete a relação entre o futebol e a sociedade brasileira. Ao contrário, pode limitá-la, pois as significações mais profundas estão no

\footnotetext{
${ }^{18}$ Franco Júnior (2007, p. 60).
} 
processo de apropriação pelas diversas camadas sociais que transformaram o futebol em um fenômeno popular.

Nos primeiros anos, o esporte era símbolo da modernidade europeia e, portanto, não poderia estar ausente na elite brasileira. Começaram a surgir, então, ligas que representavam o verdadeiro futebol ${ }^{19}$, sempre formadas por jovens da elite, seguindo a lógica excludente da estrutura política nacional ${ }^{20}$.

Assim como na Inglaterra, o esporte foi sendo, aos poucos, apropriado pelas camadas sociais menos privilegiadas, que o transformaram em um "fenômeno de massas", quebrando as barreiras sociais, dentro e fora do campo, com a criação de times nos subúrbios.

A partir desse momento, evidencia-se uma dupla concepção do futebol dentro da sociedade brasileira. De um lado, o futebol lógico dos sportsmen ${ }^{21}$, reflexo da perspectiva pedagógica europeia empregada por meio do cristianismo pedagógico para preparar os futuros líderes do país. De outro, o futebol dos "canelas negras", praticado pela grande massa onde a ginga, as improvisações e as influências de danças populares encantavam o público.

Embora os objetivos deste trabalho não sejam de cunho histórico, sociológico ou antropológico, é praticamente impossível contar a história do futebol brasileiro, mesmo que brevemente, sem falar da história do Brasil. Cabe aqui uma importante ressalva de que não consideramos o futebol apenas como um "espelho" da sociedade brasileira. Observamos, também, o futebol de uma forma parecida com a proposta por Verdú ${ }^{22}$ : Futebol como mímese, ou seja, como uma das inúmeras representações possíveis do jogo social, onde o jogo incorpora alguns elementos indicativos de mudança histórica. Dentro dessa concepção, nas primeiras duas décadas do século XX, inicia-se o fenômeno de incorporação das grandes massas à elite na sociedade brasileira e, consequentemente, no futebol, ou vice-versa.

\footnotetext{
${ }^{19}$ Durante muito tempo houve uma divisão entre o futebol da elite e o futebol praticado pelas camadas mais pobres da população, pois a elite era a única classe com acesso aos meios necessários para praticar o esporte: uniformes, bola e conjunto de regras.

${ }^{20}$ Em seu livro A Dança dos Deuses, o professor Dr. Hilário Franco Júnior faz uma síntese do papel que o futebol desempenhou na sociedade brasileira e chama atenção para como a propagação do esporte refletiu o momento político-social em que o Brasil se encontrava entre 1885 e 1920.

${ }^{21}$ Termo utilizado para designar os praticantes de futebol da elite inglesa.

${ }^{22}$ Verdú, 1980, apud Wisnik, 2008, p. 47.
} 
A adesão, em 1912, do Corinthians, o mais popular dos times de várzea, à Associação Paulista de Sports Athléticos (APSA) ${ }^{23}$, foi um dos principais frutos dessa incorporação. Outro fator de suma importância para o afrouxamento das barreiras sociais dentro do esporte foi a decisão de cobrar ingressos para os jogos, tomada pela APSA, em 1913, que aumentou a competitividade entre os times incentivando a contratação de jogadores que, frequentemente, eram negros ou estrangeiros.

Mesmo já consagrado como esporte nacional e das massas, o futebol ainda enfrentava grande resistência por parte de alguns intelectuais. Em diferentes épocas, Rui Barbosa, Graciliano Ramos e Lima Barreto deixavam clara a antipatia pelo esporte. Graciliano Ramos declara:

\footnotetext{
'Não seria, porventura, melhor exercitar-se a mocidade em jogos nacionais, sem mescla de estrangeirismo, o murro, o cacete, a faca de ponta, por exemplo? (...)

Temos esportes em quantidade. Para que metermos o bedelho em coisas estrangeiras? (...)

Desenvolvam os músculos, rapazes, ganhem força, desempenem a coluna vertebral. Mas não é necessário ir longe, em procura de esquisitices que têm nomes que vocês nem sabem pronunciar." (RAMOS, G., 1990, p. 26-29).
}

Também contra a introdução do futebol, Lima Barreto atribuía a crescente rivalidade entre Rio e São Paulo, a violência e os atos de preconceito contra os negros ao football (RAMOS, 1990, p. 7-17). Rui Barbosa deixa clara sua antipatia pelo esporte, um "elemento estranho incorporado à cultura brasileira", e também pelos seus praticantes, “corja de malandros e vagabundos" (apud FRANCO JÚNIOR, 2007, p. 69).

Apesar dessa resistência em certos meios intelectuais, o futebol tornou-se o esporte mais praticado no país, tanto pela elite quanto pela massa, atingindo, dessa forma, todos os níveis sociais e refletindo, de forma direta, questões da sociedade brasileira.

As duas primeiras décadas do século $\mathrm{XX}$ foram marcadas pelo surgimento de ligas representantes do futebol brasileiro: Federação Brasileira de Sports (1914) e Federação Brasileira de Football (1915), unificadas em 1916, dando origem à Confederação Brasileira de Desportos (CBD) (FRANCO JÚNIOR, 2007, p. 73). As mesmas décadas também foram marcadas pelo profissionalismo dissimulado, ou mais vulgarmente conhecido como amadorismo marrom, prática em que os dirigentes dos

\footnotetext{
${ }^{23}$ Associação elitista fundada pelo Paulistano, pela A.A. Palmeiras e pelo Mackenzie.
} 
clubes recompensavam financeiramente os craques que não tinham contrato ou que recebiam "abaixo do merecido".

Nos anos que se seguem, ocorreram as primeiras partidas com times estrangeiros, como o Exeter City da Inglaterra, e a primeira Copa Roca na Argentina. Esses jogos despertaram nos brasileiros um sentimento de patriotismo e de unidade, pois pessoas de diferentes camadas sociais se reuniam em torno de um mesmo evento. Essa paixão pelo esporte colaborou, significativamente, para a construção de uma identidade nacional em torno do esporte (FRANCO JÚNIOR, 2007, p. 80).

Durante a década de 30, com o reflexo da queda da bolsa de Nova York em 1929 e o tumulto na economia e na política do país, os jogadores brasileiros começaram a migrar para times europeus, fugindo do amadorismo em busca de melhores condições.

Coincidentemente, em 1931, durante o governo Vargas, com essa migração e com o sonho de modernização do país, o futebol foi incluído entre as profissões que deveriam ser regulamentadas na legislação brasileira, refletindo um passo em direção à sua organização. Segundo Toledo (2002, p. 17), foi também na década de 30 que aconteceu o primeiro boom na publicação de manuais técnicos, movimento favorável à profissionalização, que coincidiu com o surgimento, no Rio de Janeiro, da Sport Ilustrado, primeira revista brasileira dedicada ao futebol.

A Copa de 1938 na França marcou uma nova fase do esporte. Além de a seleção ter sido símbolo de uma unidade nacional, inicia-se um fenômeno descrito por Franco Júnior (2007) como a "carnavalização do futebol”. Surgem as bandeiras, hinos, símbolos, mascotes e outras bugigangas para representar o fanatismo do torcedor. Apesar do terceiro lugar, os jogadores fora m reconhecidos como heróis do país, dentro e fora do jogo: dentro porque apesar de um esquema tático precário, conquistou o terceiro lugar, e fora porque a seleção era composta também por negros e membros da classe mais baixa da população, um fato que em si sugeria um discurso em torno de uma real possibilidade de ascensão e conquista de um lugar na sociedade pelos menos abastados, afirmando, em certa medida, uma vitória do próprio regime militar em curso (FRANCO JÚNIOR, 2007, p. 81).

Em 1942 é criada a primeira torcida organizada do Brasil: a charanga rubronegra $^{24}$. Nos anos seguintes, o profissionalismo avançou e os jogadores passaram, cada

\footnotetext{
${ }^{24}$ Torcida do Flamengo.
} 
vez mais, a trocar de clubes por ofertas melhores. O eixo Rio-São Paulo era, desde aquela época, polo atrativo para atletas que saíam de pequenas cidades e de outros estados. Apesar do avanço alcançado, as limitações do profissionalismo eram visíveis na forma como os jogadores eram tratados: frequentemente tinham que excursionar no período de férias e jogar lesionados.

Para Franco Júnior (2007, p. 83), a política desportiva de Vargas não se consolidou devido à eclosão da Segunda Guerra Mundial e a consagração da identidade nacional por meio do esporte direcionou-se para as disputas sul-americanas durante os anos sem Copa.

Para o autor, durante a guerra, o futebol foi utilizado como um instrumento de contestação tanto à política interna quanto à internacional por meio de manifestações, como a ocorrida na inauguração do Pacaembu em 1940. Na ocasião, a delegação do São Paulo foi ovacionada por todo o estádio que, voltado para a tribuna do ditador, gritava o nome do clube de forma provocativa, identificando-o com o estado em protesto ao sufocamento da Revolução Constitucionalista de 22, representando, de forma simbólica, o inconformismo de São Paulo em relação à ditadura Vargas (FRANCO JÚNIOR, 2007, p. 84). Ou ainda, com a hostilização a clubes vinculados à colônia italiana, como o Palestra Itália de São Paulo, após a entrada do Brasil na guerra.

Mesmo não tendo sido consolidada, a política esportiva de Vargas contribuiu para que o futebol evocasse um sentimento de identidade nacional. Quando Vargas perde a direção do processo de democratização do país e Dutra é escolhido como presidente, um novo jogo político se forma e o futebol, assim como nos anos anteriores, continua a ser elemento importante. Com os negros, reconhecidos como legítimos representantes da nação, os estádios tornaram-se espaço frequentado também pelas camadas menos abastadas (FRANCO JÚNIOR, 2007, p. 86).

$\mathrm{Na}$ copa de 50, a primeira realizada após a guerra, a seleção venceu o México por 4 a 0, empatou com a Suíça em 2 a 2, ganhou de 2 a 0 da Iugoslávia, e goleou a Suécia por 7 a 1 e a Espanha por 6 a 1, perdendo na final por 2 a 1 para o Uruguai, na partida que ficou conhecida como Maracanaço.

A derrota de 50 não se resumiu a uma derrota em campo, mas sim a uma derrota que se estende a outros dois setores. Primeiramente, no que se refere à igualdade racial, pois a derrota despertou um debate racista que questionava a habilidade dos atletas de 
origem negra. Sobre o Barbosa, o goleiro da seleção, recaiu grande parte da culpa da derrota (TOLEDO, 2000, p. 72). Além disso, 1950 era ano de eleições e os candidatos estavam utilizando o futebol como um dos principais instrumentos para aumentar sua popularidade ao lado das massas.

O mundial de 54 realizado na Suíça também não traz boas recordações aos brasileiros. Com um time desorganizado e perdido em campo, que refletia o governo de Vargas (FRANCO JÚNIOR, 2007, p. 93), a seleção perdeu para a Hungria por 4 a 2 e se envolveu na maior briga em campo na história das copas.

Finalmente, após golear a Suécia por 5 a 2, na final da Copa de 1958, os jogadores da seleção ficaram conhecidos como os heróis da pátria (FRANCO JÚNIOR, 2007, p. 135). Em 62, a vitória se repete, dessa vez, com vitória na final por 3 a 1 contra a Tchecoslováquia. Era época de prosperidade; os times nacionais faziam campanha pela Europa, auferindo lucros aos seus clubes e dirigentes. Dessa leva, sem dúvida, o Botafogo era o melhor representante.

Durante o regime militar (1964-1985), o futebol continuou a prosperar. Usado para desviar a atenção do povo das tensões políticas, simbolizar a identidade da nação e promover o amor à pátria, ficou conhecido como "ópio do povo".

Já em 1970, a seleção conquista o tri-campeonato no México no primeiro mundial transmitido pela televisão.

As décadas de 80 e 90 seguem marcadas por uma série de mudanças na organização do futebol brasileiro. Dentre as muitas modificações, destacam-se: a criação do clube dos treze em 1987, entidade organizada para defender os interesses políticos e comerciais dos grandes clubes; o desaparecimento das competições locais e menores, cedendo lugar às competições nacionais e internacionais; e a ampliação do processo de profissionalização tanto entre os jogadores, tendo como principal marco a regulamentação da Lei Pelée 25 que estabelece o fim da "lei do passe" ${ }^{\text {"26 }}$, quanto na forma

\footnotetext{
${ }^{25}$ Lei que entrou em vigor no dia 24 de março de 1998, substituía e tentava aperfeiçoar a Lei Zico. Determinou o fim da lei do passe. Em dois anos, os jogadores deixam de ser propriedade dos clubes. A lei também estimula a transformação dos clubes em empresas, incentiva a criação de associações para árbitros e determina que os tribunais de justiça esportiva tenham representantes indicados pela sociedade civil. A lei determina ainda a fiscalização das atividades de clubes e federações pelo Ministério Público. O dinheiro do esporte não pode mais ser usado sem que sejam dadas explicações. Disponível em: <http://www.nominuto.com/esporte/esporte/vinte-perguntas-lei-pele/16997/>. Acesso em: 18 nov. 2010.

${ }^{26}$ Lei no 6.354 , de 2 de setembro de 1976, que dispõe sobre as relações de trabalho do jogador de futebol e dá outras providências. A lei trata da forma, do conteúdo e dos requisitos do contrato de trabalho do atleta, bem como de suas obrigações para com o clube empregador (arts. $1^{\circ}$ a $10^{\circ}$ ); reserva quatro anos à
} 
de administração dos clubes, federações e confederações com participação cada vez maior de empresas privadas (TOLEDO, 2000, p. 10).

No século XXI, a aceleração do impacto televisivo, a revolução digital, o sistema pay-per view e o crescente número de jornais on-line colaboraram para que as dimensões de espaço e tempo diminuíssem, de forma a quase deixarem de existir. À medida que várias partidas são transmitidas simultaneamente em países de línguas diferentes, surge uma crescente necessidade de tradução, reescritura, adaptação ou transmissão de um fenômeno mundial que é, ao mesmo tempo, muito particular a cada cultura.

Dentro dessa perspectiva cultural do futebol, o ensaísta-cineasta Pier Paolo Pasolini (WISNIK, 2008) descreve o esporte como "linguagem", fazendo uma analogia entre discurso e estilo de jogo ao comparar o futebol prosa europeu ao futebol poesia do Brasil. O primeiro é linear, esquematizado e centrado em um fim: vencer a partida. $\mathrm{O}$ segundo é caracterizado pela não-linearidade e improviso, visando um espetáculo. A concepção de que o "Brasil reinventou o futebol" 27 não é estranha aos apaixonados e envolvidos pelo esporte, assim como os jargões "futebol arte", "Brazilian football", que são usados e discutidos mundialmente a exemplo do teor do artigo "The riddle of Brazilian Soccer: Reflection on the Emancipatory Dimension of Culture".

Diante desses diferentes “jeitos de jogar", nos encontramos frente ao desafio de descrever, para uma cultura, uma partida ou campeonato que acontece u em outra cultura que possui sua própria história, sua visão do esporte e um estilo completamente diferentes. É dentro dessa perspectiva terminológica cultural que nosso trabalho pretende se inserir.

preparação técnica e atlética do jogador $\left(\operatorname{art.~} 5^{\circ}\right)$; regula a cessão temporária e definitiva do atleta por um clube a outro (arts. $11^{\circ}$ a $14^{\circ}$ ); dispõe sobre as penas que podem ser aplicadas ao atleta pelas entidades (art. $15^{\circ}$ ) e pela Justiça Desportiva (art. $19^{\circ}$ ); cuida dos direitos dos trabalhadores da bola, tais como garantia de salário, férias, duração do trabalho, condições de trabalho (arts. $16^{\circ}, 17^{\circ}, 18^{\circ}$ e $20^{\circ}$ a $27^{\circ}$ ); fixa penas para as entidades desportivas que desconsiderarem os direitos de seus atletas (arts. $30^{\circ}$ e $32^{\circ}$ ), define a competência e abrangência da Justiça Desportiva em matéria de litígios trabalhistas. Disponível em: <http://www2.camara.gov.br/documentos-e-pesquisa/publicacoes/estnottec/tema11/pdf/200500.pdf>. Acesso em: 18 nov. 2010.

${ }^{27}$ Tema de uma entrevista realizada com o poeta e antropólogo Antonio Risério pela Terra Magazine em novembro de 2007. Disponível em: <http://terramagazine.terra.com.br/interna/0,OI2056760-EI6608,00Uma+entrevista+parte+II.html>. Acesso em: 15 abr. 2011. 


\subsection{Forma-representação}

Em Lógicas no futebol (2002), Toledo aborda o futebol como fenômeno cultural de um ponto de vista bastante amplo e extremamente interessante para os propósitos de nossa pesquisa. Nessa abordagem, são analisados diversos atores, como profissionais, especialistas e torcedores, entre os quais se estabelece um sistema de relações. O esporte não deixa de ser tratado como uma questão nacional; no entanto, o autor toma os devidos cuidados para não vinculá-lo única e exclusivamente a um suposto ethos brasileiro.

Toledo parte de três realidades no campo:

- profissionais: jogadores, técnicos, dirigentes, juízes, preparadores, médicos etc.;

- especialistas: a crônica esportiva, que é composta por comentaristas, locutores e repórteres;

- torcedores.

Segundo o autor (2002, p. 27), cada um dos grupos sociais viabiliza uma partida de maneira distinta. Os profissionais são os responsáveis por viabilizar a partida; os especialistas por decodificar e ordenar a circularidade e emoção em uma narrativa linear, estabelecendo uma relação entre profissionais e torcedores; e os torcedores por articular a magia e emoção que são transmitidas tanto de forma direta, pelos profissionais, quanto de forma indireta, pelos especialistas.

Em uma pesquisa em que o objeto de estudo é o léxico especializado, é de se esperar que o recorte realizado envolva apenas o segundo grupo de atores sociais, os especialistas, uma vez que são eles os responsáveis pela criação das notícias. Entretanto, tal recorte não será feito, pois, seguindo a lógica de Toledo, acreditamos que os três grupos desempenham, cada um de sua forma, papel importante para a produção do jornalismo esportivo.

Sendo assim, embora não sejam tratados de forma direta, o primeiro e o terceiro grupo permeiam toda a análise. O primeiro porque sem seus membros - jogadores, técnicos, dirigentes, etc. - nosso objeto de estudo não existiria, sem contar o fato de que o jornalismo usa expressões e chavões cunhados por atores desse grupo. Ao grupo dos 
torcedores que, a princípio tem uma participação menos representativa na produção das notícias, atribuímos duas participações relevantes para a pesquisa. De acordo com a abordagem da Terminologia com a qual trabalhamos, o fazer terminológico está intrinsecamente ligado ao contexto sociocultural em que é produzido e, por isso, o público-alvo, em nosso caso os torcedores que leem os periódicos, tem papel ativo na reprodução do discurso. De forma menos significativa, temos a participação efetiva dos torcedores nas "transmissões sociais", por meio de comentários e interação com os narradores. Atribuímos essa grande importância ao terceiro grupo, pois, no futebol, diferentemente da maioria das áreas técnicas, uma pessoa que acompanhe jogos e mesas redondas e converse sobre o resultado de uma partida até mesmo na mesa de um bar é, muitas vezes, considerada especialista no assunto, pois, afinal, "entende" de futebol. Além disso, as expressões criadas pelos atores do primeiro e segundo grupos se tornam consagradas na língua quando aceitas e reproduzidas pelo terceiro grupo.

$\mathrm{Na}$ breve análise que segue, partiremos dos manuais técnicos para sua universalização e, consequentemente, para a fragmentação de estilos que refletem as formas de jogar e esquemas táticos, tendo como objetivo entender, mais profundamente, o jornalismo esportivo brasileiro e inglês. É importante ressaltar que ao declarar que objetivamos "entender, mais profundamente, o jornalismo esportivo brasileiro e inglês", não pretendemos analisar sistematicamente os parâmetros que norteiam a produção das notícias, mas sim entender e caracterizar o tipo de informação veiculada que refletirá, de forma direta, no léxico utilizado. Além disso, a opção de trabalhar com o conceito forma-representação de Toledo (2002), explicado nos parágrafos que seguem, revelouse como importante aporte teórico para explicar a diferença das palavras-chave dos corpora nas duas línguas.

Seria impossível falar de um jeito brasileiro de jogar ou de um futebol inglês sem fazer alusão às regras do jogo, que desempenham papel importante na difusão do futebol. No Brasil, desde sua introdução, há registros de empreendimentos editorais que tinham como objetivo divulgar e universalizar as regras e maneiras de jogar (TOLEDO, 2002, p. 31). Em 1912, já circulavam obras, como a série Guia de Football, para um público mais ampliado. Segundo Toledo (2002, p. 31), essas obras eram restritas de um ponto de vista social, mas preencheram uma lacuna esportiva na vida das cidades, já que os jornais da época pouca atenção davam aos jogos ocorridos. 
A década de 20 foi marcada pela produção de manuais para o público mais elitista, ao passo que a década de 30, devido ao caminho à profissionalização, à difusão do rádio, à imprensa esportiva e à prática do futebol de várzea, foi marcada pelo consumo de manuais por parte de um público que estava comprometido diretamente com o esporte. Esses manuais surgiram, sobretudo, como o objetivo de ampliar o conhecimento sobre a prática do futebol, de universalizar e de profissionalizar o esporte.

A manipulação da produção desses manuais técnicos, em diversas camadas da sociedade, gerou diferentes processos de internalização das regras. Estas passaram por interpretações e aclimatações distintas nos lugares em que o futebol se projetou como esporte popular, provocando, consequentemente, uma fragmentação no estilo de jogar. Fragmentação que, para Toledo (2002, p. 50),

\begin{abstract}
[está] condicionada às variabilidades locais impostas pelos interesses, percepções, leituras e entendimentos das mesmas regras, alterando as padronizações e conferindo plasticidades e emoções variadas à sua função, dentro e fora do jogo.
\end{abstract}

Cada interpretação, que favorece uma forma de jogar, resulta de "manejos culturais" 28 das regras e favorece o surgimento de estilos próprios.

Nesse sentido, segundo a proposta de Toledo (2002, p. 61), o conjunto de regras que define a atividade como esporte não delimita as maneiras de jogar. Na verdade, é a apropriação e a interpretação cultural que cada região faz das regras que determinam as "formas de jogo". Justapostas, as regras e as "formas de jogo" dão origem às "representações", ou seja, o ajustamento da observação empírica das "formas de jogo" em um plano simbólico que, por sua vez, consolidam as conhecidas "escolas", "jeitos" e "estilos" de se jogar.

As formas-representação estão inscritas e, não raras vezes, consolidadas no imaginário coletivo do torcedor e, por que não, da imprensa, que as trans mitem para o grande público?

O conceito aqui apresentado tem o propósito de dar aporte teórico à nossa premissa: a de que o "jogar à brasileira" ou o "futebol inglês" permeiam toda a produção jornalística nas duas culturas. No entanto, acreditamos que as noções de ginga, malícia, raça, virilidade não são fatores exclusivos na definição do futebol

\footnotetext{
${ }^{28}$ Termo cunhado por Toledo (2005, p. 55).
} 
praticado por uma cultura. Em nossa pesquisa, a análise do léxico do futebol, que nos dá uma primeira ideia das formas-representação dos dois futebóis, será realizada por meio da observação das palavras-chave dos dois corpora. 


\section{Capítulo 2 - Fundamentação Teórica}

Este capítulo, inicialmente, faz uma introdução à Linguística de Corpus; em seguida, apresenta um panorama geral da Terminologia e expõe a vertente aqui adotada bem como a definição das unidades fraseológicas. Depois, discorre sobre alguns conceitos da tradução técnica. Ao fím, mostra a relevância da Linguística de Corpus para esta pesquisa.

\subsection{Linguística de Corpus}

O uso de corpora não eletrônicos em pesquisas linguísticas data do século XVIII um estudo sobre o léxico da Bíblia. Na ocasião, foram geradas listas de concordâncias dos termos bíblicos para avaliar a uniformização e consistência das partes da Bíblia. Também existem registros de estudos lexicográficos, dialetais, de ensino e de gramática (BERBER SARDINHA, 2002).

Corpora não eletrônicos também foram utilizados durante um longo período do século XX com vistas ao ensino de língua. Esses corpora, assim como os dos séculos anteriores, eram coletados, organizados, mantidos e analisados manualmente por uma equipe de linguistas.

O corpus não eletrônico mais conhecido de que se tem registro é o SEU (Survey of English Usage), compilado por Randolf Quirk e composto por 200 textos de 500 palavras cada na primeira tentativa de composição de um corpus representativo (BERBER SARDINHA, 2004, p. 3).

Apesar da vantagem de estudar ocorrências naturais da língua, os problemas relacionados ao uso desses corpora eram inúmeros. Primeiramente, a própria compilação do corpus era problemática, uma vez que era necessária uma equipe muito grande para coletar e organizar os dados manualmente, fator que não contribuía muito para a uniformização do corpus. Além disso, a atividade em si demandava muito tempo. Outro problema era a não confiabilidade da extração de dados de grandes quantidades de textos realizada por humanos, suscetíveis a erros e distrações. 
O primeiro corpus eletrônico, o Brown University Standard Corpus of Presentday American English, foi lançado em 1964 e possui um milhão de palavras.

É fato que o desenvolvimento da Linguística de Corpus (LC) está intimamente relacionado à tecnologia. Foi com o surgimento dos microcomputadores na década de 80 e do acesso à internet na década de 90 que ocorreu a maior popularização dos corpora e das ferramentas computacionais. Inovações, como essas, provocaram, consequentemente, uma mudança na concepção de corpus, mudança que também ocorreu devido a dois fatores principais: 1) o reconhecimento da Linguística de Corpus como teoria linguística ${ }^{29}$ e 2) o desenvolvimento tecnológico.

Ainda hoje, é possível encontrar as mais diferentes definições de corpus que, vale ressaltar, na maioria das vezes, não são feitas dentro dos parâmetros da LC, pois antecedem seu surgimento ou o descrevem de uma maneira mais geral. O dicionário Aurélio $^{30}$ define corpus como "um conjunto de documentos, dados e informações sobre determinada matéria" e como "conjunto de materiais significantes (enunciados lingüísticos, capas de revistas) constituído com vistas à análise semiológica”. O dicionário Houaiss 31 , por sua vez, apresenta a seguinte definição: "conjunto de enunciados numa determinada língua, ger. colhidos de atos reais da fala, que servem como material para análise lingüística”.

Nenhuma das definições acima contempla os requisitos que um corpus deve ter de acordo com os princípios da LC. Não convém aqui, por falta de espaço e, principalmente, por não ser o objetivo de nossa pesquisa, apresentar todas as definições. Portanto, para nossos propósitos, adotamos a definição de Berber Sardinha (2004, p. 18):

Um conjunto de dados linguísticos (pertencentes ao uso oral ou escrito da língua, ou a ambos), sistematizados segundo determinados critérios, suficientemente extensos em amplitude e profundidade, de maneira que sejam representativos da totalidade do uso linguístico ou de algum de seus âmbitos, dispostos de tal modo que possam ser processados por computador, com a finalidade de propiciar resultados vários e úteis para a descrição e análise.

\footnotetext{
29 Discutiremos mais adiante a caracterização da Línguistica de Corpus como teoria linguística, metodologia, abordagem e disciplina.

${ }^{30}$ Aurélio Eletrônico.

${ }^{31}$ Houaiss Eletrônico.
} 
Dada a definição de corpus, perguntamos: quais as vantagens da pesquisa em corpus? A resposta imediata para qualquer linguista de corpus seria: inúmeras. Primeiramente, atentamos para o fato de que um corpus é somente uma forma de armazenar dados linguísticos. Como Hunston (2002, p. 3) afirma, um corpus não disponibiliza ao pesquisador informações novas e inéditas sobre a língua; no entanto, seu acesso por meio de programas destinados à análise linguística pode abrir um novo caminho para qualquer pesquisa à medida que o tratamento do texto torna-se mui to mais prático.

Um dos pontos da definição de corpus proposta por Berber Sardinha (2004) é que todo corpus é compilado com o objetivo de ser representativo da totalidade do uso linguístico ou de algum de seus âmbitos. Tendo esse princípio em mente, encontramos uma das principais vantagens dos corpora: a observação da língua natural, ou seja, da língua em uso. Em nossa pesquisa, observamos os usos do futebolês em contextos reais, prática que nos possibilita um distanciamento de teorias da Terminologia que tratam o léxico especializado como um construto teórico idealizado livre de contaminações contextuais.

Leech (1991, p. 107) postula as principais características da Linguística de Corpus:

a) foco no desempenho;

b) foco na descrição lingüística;

c) foco em modelos de língua quantitativos e qualitativos;

d) visão empírica de língua.

Seria praticamente impossível caracterizar a LC sem mencionar a dicotomia chomskyniana de competência linguística e desempenho linguístico. A primeira advoga que o principal objeto de estudo da linguística é a competência do falante ideal dominar um sistema abstrato de regras que governam a linguagem; a segunda pode ser descrita como a manifestação física da língua em uso.

Uma vez que a LC analisa o comportamento linguístico por meio da observação de discursos naturais, sejam escritos ou falados, seu foco está na performance e não na competência. Além disso, o estudo do desempenho se mostra mais útil para as 
aplicações da linguística como, por exemplo, na educação, na tradução e no processamento de linguagem natural (LEECH, 1991, p. 108).

Para Leech (1991), a distinção competência e desempenho sempre foi exagerada, pois a gramática de uma língua como construto mental e a gramática que é manifestada na performance, ou seja, no uso, estão muito próximas, já que a última nada mais é do que o produto da primeira, visão não compartilhada pela maioria dos linguistas de corpus.

O autor ainda chama atenção para o fato de que a performance pode ser estudada como processo ou como produto. Seu estudo como processo envolve a observação dos processos psicológicos envolvidos na produção e na interpretação de um texto. Já o estudo da performance como produto, caso da LC, foca na análise da manifestação física da língua e deixa de lado a caracterização do processo mental realizado para sua produção ou interpretação.

A segunda característica que Leech propõe é a descrição linguística em detrimento da elaboração de universais linguísticos. Antes de o uso do computador se popularizar em pesquisas linguísticas, era comum referir-se aos linguístas de corpus como linguistas descritivos. A referência tinha uma prosódia extremamente negativa e esses linguistas tinham como objeto de estudo um corpus de textos, normalmente de tamanho reduzido, dadas as limitações tecnológicas da época, e seu principal objetivo era descrever a linguagem presente no corpus. Essa prática foi, durante muito tempo, inferiorizada pelos "verdadeiros" teóricos que descreviam a linguagem como um todo para a identificação de universais linguísticos (LEECH, 1991, p. 109).

Com a introdução do computador nas pesquisas linguísticas e, consequentemente, a ampliação do tamanho dos corpora, os estudos descritivos ganharam mais credibilidade e passaram a caracterizar uma nova vertente, nem inferior nem superior, do modo de se observar a língua.

Assim como Leech (1991), acreditamos que os estudos descritivos, tanto os realizados em mini-corpora como os realizados em corpora gigantes, são tão "teóricos" quanto os universais de Chomsky, já que refletem uma maneira distinta de descrever, analisar e teorizar sobre a língua.

As noções de análise quantitativa e qualitativa são de extrema importância no que se refere à caracterização da LC. O fato de trabalhar com a manipulação de grande 
quantidade de textos por meio de software evidencia sua natureza quantitativa. No entanto, a LC é muitas vezes caracterizada erroneamente como abordagem nãoqualitativa (LEECH, 1991, p. 110) dada a importância que atribui à frequência e à probabilidade.

É fato que os estudos baseados em corpus partem de uma análise quantitativa, que constitui o primeiro de vários passos a caminho de uma descrição mais detalhada. Essa tendência de associar o quantitativo como oposto de qualitativo acaba, muitas vezes, ofuscando outras características da LC.

O último ponto aqui enfatizado é a visão empirista em detrimento da visão racionalista da linguagem. Em oposição à teoria racionalista de Chomsky de que uma criança adquire as estruturas linguísticas e, consequentemente, a gramática de uma língua geneticamente, a LC advoga que a observação contribui mais para a teoria do que a teoria para a observação (LEECH, 1991, p. 111).

Nesse sentido, Halliday (1991, p. 31) afirma que o sistema linguístico é probabilístico por natureza e que a frequência no texto representa a probabilidade na gramática, ou seja, parte do significado de uma palavra está embutido na probabilidade com a qual ela é escolhida. Essa visão pressupõe que, embora muitas combinações e arranjos sejam gramaticalmente possíveis, não são utilizados frequentemente.

Um aspecto muito debatido entre os teóricos da LC é sua caracterização como abordagem, metodologia e, mais recentemente, como teoria linguística. Alguns autores, como Berber Sardinha (2000), consideram a LC uma abordagem, e outros, como é o caso de Rocha (2001), uma metodologia. Existem ainda os estudiosos que preferem ser mais neutros em suas definições e não tomam nenhum partido como, por exemplo, Aijmer e Altenberg (1991, p. 2), que definem LC como "o estudo da língua por meio de corpora". Há ainda os que adotam as duas definições como Bowker e Pearson (2002, p. 20): "uma abordagem ou metodologia para o estudo da língua em uso".

Berber Sardinha chama atenção para o fato de que a LC não constitui somente um metodologia, um instrumental, do qual outras áreas podem se valer para o estudo da linguagem. Para o autor, a LC apresenta também uma nova perspectiva de se chegar à linguagem possibilitando aos seus seguidores produzirem conhecimento novo que muitas vezes colocam teorias linguísticas tradicionais em questão. Sendo assim, neste trabalho, a LC é vista como uma abordagem empirista que toma a visão de linguagem 
como sistema probabilístico, refletindo uma nova maneira de enxergar a linguagem e, consequentemente e futuramente, em uma nova teoria linguística (BERBER SARDINHA, 2004, p. 32).

\subsubsection{Tipologia de Corpus}

Os resultados de uma pesquisa dependem essencialmente do conteúdo e da tipologia do corpus de estudo. A literatura distingue vários tipos de corpora e, para os fins dessa pesquisa, adotamos a tipologia proposta por Berber Sardinha (2004, p. 20), que os agrupa de acordo com alguns critérios:

\section{modo:}

- falado: composto por textos transcritos de fala;

- escrito: composto por textos escritos.

\section{tempo:}

- sincrônico: compreende um período no tempo;

- diacrônico: compreende vários períodos no tempo;

- contemporâneo: composto por textos de um período de tempo corrente;

- histórico: composto por textos de um período de tempo passado.

\section{seleção:}

- de amostragem: representa uma amostra finita da linguagem; é composto por porções de textos ou variedades textuais;

- monitor: "a composição é [atualizada] para refletir o estado atual de uma língua. Opõe-se a corpora de amostragem" (2004, p. 20)

- dinâmico e orgânico: caracteriza o corpus monitor, sofre acréscimos e decréscimos;

- estático: caracteriza o corpus de amostragem, é oposto ao dinâmico; não sofre acréscimos nem decréscimos;

- equilibrado: os gêneros textuais, tipos textuais, fontes e número de palavras dos textos são distribuídos uniformemente. 


\section{conteúdo:}

- especializado: composto por textos de tipos específicos;

- regional ou dialetal: textos de uma ou mais variedades sociolinguísticas específicas;

- multilíngue: textos de idiomas diferentes.

Adotamos, também, a classificação de corpora quanto à língua proposta por Susan Hunston (2002, p. 15), ou seja, os corpora podem ser:

- comparáveis: compostos por textos originalmente escritos em uma ou mais línguas e compilados de acordo com os mesmos critérios;

- paralelos: compostos por textos originais e suas traduções em uma ou mais línguas.

Hunston (2002) discute, ainda, outros três aspectos que devem ser considerados para a compilação de um corpus, são eles: tamanho, conteúdo e balanceamento.

\section{tamanho}

Assim como outros aspectos da LC, discussões teóricas acerca do tamanho ideal de um corpus tendem a ser controversas. Há quem advogue que quanto maior o corpus melhores serão os resultados. No entanto, existe uma tendência cada vez maior para a compilação de mini corpora especializados para a extração terminológica e produção de glossários (MAIA, 2000). Esses corpora são formados por textos de uma área de especialidade em que o léxico não apresenta muita variação como, por exemplo, as áreas técnicas de hipertensão e de insuficiência renal. Em 2004, Berber Sardinha sugere uma classificação de tamanho para os corpora baseada na observação de corpora utilizados durante quatro anos do congresso de Linguística de Corpus $^{32}$ :

- pequeno: menos de 80 mil palavras;

- pequeno-médio: de 80 a 250 mil;

- médio: de 250 mil a um milhão;

- médio-grande: de um milhão a dez milhões;

\footnotetext{
${ }^{32}$ Corpus Linguistics Conference.
} 
- grande: mais de dez milhões.

A classificação, que reflete o tamanho dos corpora existentes na época, está ultrapassada se tomarmos o tamanho dos corpora atuais:

- The Corpus of Contemporary American English (COCA): 425 milhões de palavras;

- Bank of English: 650 milhões de palavras;

- Collins Corpus: 2,5 bilhões de palavras;

- Corpus do Português: 45 milhões de palavras;

- Banco de Português: 240 milhões de palavras;

- Corpus Brasileiro: um bilhão de palavras.

\section{Conteúdo}

Como já mencionado anteriormente, o conteúdo de um corpus é definido com base nos resultados que uma pesquisa pretende alcançar. Sendo assim, nenhum corpus deve ser considerado ruim ou bom em sua essência, mas sim tendo em vista determinado estudo linguístico.

representatividade e balanceamento

Não existem critérios pré-definidos para a determinação da representatividade de um corpus. "Na sua essência, um corpus, seja de que tipo for, é tido como representativo da linguagem, de um idioma, ou de uma variedade dele." (BERBER SARDINHA, 2004, p. 22). Normalmente, o tamanho do corpus é associado à sua representatividade. Se tomarmos a língua como um sistema probabilístico e o corpus como uma amostra desse sistema, um corpus representativo deve possuir o maior número de palavras possível de forma que possibilite a identificação tanto dos traços de sistematicidade mais frequentes quanto dos menos comuns.

Supondo não existir critérios para a determinação da representatividade de um corpus (BERBER SARDINHA, 2004, p. 23), duas perguntas, no entanto, podem ajudar o pesquisador a trabalhar a questão: "representativo do quê e para quem?" (2004, p. 23). 
Se o corpus a ser compilado tem como objetivo ser representativo de uma língua ou variedade linguística, deve-se estar sempre atento à questão do número de palavras, número de textos e número de gêneros, registros ou tipos textuais, já que delimitar a população total de uma língua ou de uma de suas variedades constitui tarefa impraticável. Representativo para quem? Uma vez que é impossível delimitar por completo a representatividade de um corpus, cabe ao pesquisador determinar os critérios de representatividade de acordo com os objetivos de seu estudo a fim de não generalizar os achados de uma amostra não representativa para a população inteira.

Assim como a representatividade, a noção de balanceamento também gera várias controvérsias. Em teoria, um corpus balanceado deve conter número aproximado de palavras em todas as categorias (registros, tipos, gêneros textuais etc.) que abrange, fato que nem sempre é possível devido às próprias características intrínsecas a cada gênero. Por esse motivo, os critérios de balanceamento são diferentes para cada pesquisa ${ }^{33}$.

Outro aspecto a ser considerado durante a compilação do corpus é a autenticidade dos textos. Se a Linguística de Corpus representa uma visão probabilística da linguagem que tem raízes na linguística Hallidayana - teoria que descreve a probabilidade dos sistemas linguísticos, dados os contextos em que os falantes os empregam (BERBER SARDINHA, 2004, p. 30) -, os textos que compõem um corpus devem ser autênticos, ou seja, representações reais da língua ou linguagem que se pretende estudar e não textos produzidos com vistas à análise linguística.

Em nosso estudo, trabalhamos com representações reais da linguagem futebolística ao selecionar textos jornalísticos, transmissões minuto a minuto, regras do jogo e transmissão social para a composição do nosso corpus.

2.1.2 Abordagem baseada em corpus (corpus-based) e abordagem direcionada pelo corpus (corpus-driven)

Um corpus pode ser utilizado de diferentes maneiras para validar, exemplificar, contestar ou formular teorias linguísticas. Tognini-Bonelli (2001) distingue duas

\footnotetext{
${ }^{33}$ Os critérios de balanceamento adotados para este estudo serão discutidos no capítulo 4.
} 
abordagens principais de pesquisa realizadas em corpora: abordagem baseada em corpus (corpus-based) e abordagem direcionada pelo corpus (corpus-driven).

$\mathrm{Na}$ abordagem baseada em corpus, o linguista utiliza o corpus para explicitar, testar e exemplificar teorias e hipóteses pré-existentes e, principalmente, para extrair exemplos.

A vantagem dessa abordagem é que a extração de exemplos autênticos, seja para fins lexicográficos ou para a validação de hipóteses, confere mais autoridade à pesquisa. Por outro lado, utilizar o corpus somente para verificar dados limita a visão do linguista, que ignora novos fenômenos deixando de fazer novas descobertas e de desafiar teorias já existentes.

$\mathrm{Na}$ abordagem direcionada pelo corpus, o linguista analisa o corpus sem hipóteses pré-concebidas. O corpus mostra-lhe o caminho a ser percorrido. As descrições são feitas sempre com base nas evidências do corpus, possibilitando, assim, novas descobertas. Por isso, dizemos que nessa abordagem o linguista não busca evidências para classificá-las dentro de categorias pré-definidas. Ao contrário, se no decorrer da pesquisa não forem encontrados padrões linguísticos ou se os padrões encontrados não puderem ser encaixados em alguma categoria, os achados constituirão argumentos de extrema relevância para a descrição da linguagem ou para a descoberta de novos fenômenos.

Nessa abordagem, o caminho metodológico percorrido pelo linguista é claro: a observação dos dados conduz à formulação de hipóteses que, consequentemente, leva à generalização dos resultados possibilitando, assim, a formulação de novas teorias (TOGNINI-BONELLI, 2001, p. 85).

Apesar de as duas abordagens apresentarem características bem distintas, acreditamos que podem ser utilizadas em conjunto. Neste trabalho, utilizamos a abordagem direcionada pelo corpus para extrair as unidades fraseológicas a serem estudadas por meio das keywords e de seus clusters. Por outro lado, lançamos mão da abordagem baseada em corpus quando partimos de uma tradução prima facie para a busca dos equivalentes nas linhas de concordância.

2.1.3 Tipos de pesquisas em Linguística de Corpus 
A Linguística de Corpus não cons titui uma disciplina, pois não possui um objeto de pesquisa delimitado tal como outras áreas. Ao contrário, descreve vários fenômenos pertencentes a outras disciplinas (BERBER SARDINHA, 2004, p. 36) como a tradução, a Terminologia, a lexicografia, o ensino etc. São vários os tipos de pesquisas privilegiados pela LC, dentre os quais podemos citar: a pesquisa lexicográfica e terminográfica, com a compilação de dicionários e glossários; a tradução, tanto para seus estudos descritivos quanto para a formação de tradutores; o ensino e aprendizado de línguas estrangeiras, na descrição da linguagem e na elaboração de materiais didáticos; sem contar os centros dedicados à compilação de corpora, ao PLN (processamento de linguagem natural) e ao desenvolvimento de ferramentas computacionais.

Para os fins desta pesquisa, nos concentraremos em três dos aspectos acima mencionados: descrição da linguagem, com enfoque na convencionalidade; tradução, em nosso caso na busca de equivalentes em corpora comparáveis para tradução técnica ${ }^{34}$; e Termi nologia ${ }^{35}$.

\subsubsection{Lingüística de Corpus e convencionalidade}

O dicionário Houaiss descreve convencionalidade como aquilo "que é de uso ou de praxe; consolidado pelo uso ou pela prática" ou "que obedece a padrões aceitos; não original, comum.” (HOUAISS, 2001). Essa definição, bastante ampla, quando aplicada ao nível lingüístico, resulta em uma "forma peculiar de expressão de uma dada língua ou comunidade lingüística." (TAGNIN, 2005, p. 14).

Se a definição proposta por Houaiss refere-se ao nível social e reflete um comportamento esperado em determinada situação, a definição de Tagnin refere-se ao nível linguístico no que diz respeito a "como dizer" o esperado.

“Como dizer" exemplifica a questão da convencionalidade de forma muito clara. Professores e estudantes de línguas estrangeiras frequentemente se veem diante de uma situação em que sabem o que tem de ser dito mas não estão certos se o que têm em mente reflete a forma mais natural de dizê-lo.

\footnotetext{
${ }^{34}$ Tópico discutido no item 3.3.1.4.

${ }^{35}$ Tópico discutido no item 3.2 .
} 
A convencionalidade caminha lado a lado com a LC, pois partilham uma mesma visão de língua: embora muitas combinações e arranjos sejam gramaticalmente possíveis, não são utilizados com frequência.

A convencionalidade está presente em diversos níveis da língua. Apresentaremos aqui somente uma breve explanação dos níveis sintático e semântico.

"O nível sintático compreende a combinabilidade dos elementos, sua ordem e sua gramaticalidade." (TAGNIN, 2005, p. 17).

A combinabilidade refere-se à propriedade que os elementos linguísticos têm de se combinar entre si, ou seja, algumas palavras atraem a companhia de outras. Em português dizemos "gol contra" ao passo que em inglês não dizemos goal against e sim own goal.

A ordem dos elementos também pode ser resultado da convenção (TAGNIN, 2005, p. 18). Por exemplo, em inglês, quando um jogador tem participação decisiva em uma partida dizemos que ele foi o heart and soul da partida e na ordem inversa.

Sabe-se que tanto na língua geral quanto em línguas de especialidade existem construções e expressões que desafiam a gramática normativa, "mas cujo uso é consagrado" (TAGNIN, 2005, p. 18). Em nosso caso, um exemplo a ser elucidado é quando jogadores ingleses conversam entre si ou dão entrevistas a emissoras de TV falando em futebolês. "Os jogadores amam o particípio passado, mas nunca o usam na passiva e nem no present perfect" (LEITH, 1998, p. 18). É quase praxe ouvir frases como The boy done good, ao invés de the boy did well. Embora a frase esteja gramaticalmente incorreta, é de uso comum entre os jogadores.

É no nível semântico que observamos a relação não motivada de uma expressão e seu significado. Como explicaríamos, por exemplo, a origem da famosa "zona do agrião"? ${ }^{36}$

Tanto os exemplos no nível sintático quanto o exemplo do nível semântico reforçam a idéia de Sinclair (1984, p. 203) de que existe um grande número de frases gramaticamente corretas que não soam natural ao falante nativo. Essas frases ocorrem geralmente em textos produzidos em situações comunicativas específicas como, por exemplo, na produção oral e escrita de falantes não-nativos.

\footnotetext{
${ }^{36}$ Expressão antiga, criada por João Saldanha, para referir-se à grande área.
} 
Por fim, uma vez que a Linguística de Corpus se ocupa da investigação de uma língua ou variedade linguística por meio da análise de evidências empíricas extraídas de corpora por meio de um programa (BERBER SARDINHA, 2004, p. 3), ela se configura como uma abordagem que permite ao linguista descrever os fenômenos linguísticos de forma bem detalhada.

\subsubsection{Ferramentas de exploração de corpora}

Inúmeras são as vantagens do uso do computador e de software usados para a análise linguística. Primeiramente, como aponta Berber-Sardinha (2004, p. 85), os computadores não se cansam e realizam tarefas tediosas como contar palavras, identificar ocorrências e classificar a ordem dos itens listados com rapidez e eficácia. Além disso, os softwares nos permitem trabalhar com uma quantidade de textos muito grande. Fazer uma lista de palavras de um corpus, como o nosso, de um milhão de palavras em cada língua, seria uma tarefa árdua, quiçá quase impossível, sem uma ferramenta computacional.

Outra vantagem apontada pelo autor é a possibilidade da descoberta de novos dados, da contestação de crenças e teorias já estabelecidas e, porque não, do surgimento de novas teorias?

Em nossa pesquisa, utilizamos o software WordSmith Tools versão 5.0, desenvolvido por Mike Scott e publicado pela Oxford University Press. O programa possui três ferramentas principais WordList, KeyWords e Concord e uma série de aplicativos extremamente úteis para a análise linguística. Nos itens que seguem, faremos uma introdução às principais ferramentas do software bem como a alguns aplicativos. Ressaltamos que o WordSmith Tools 5 é um software riquíssimo para a análise linguística, sendo que cada uma de suas ferramentas possui vários instrumentos de análise. Contudo, descreveremos aqui somente as ferramentas e utilitários que foram utilizados em nossa pesquisa. A figura 1 mostra a interface do software: 


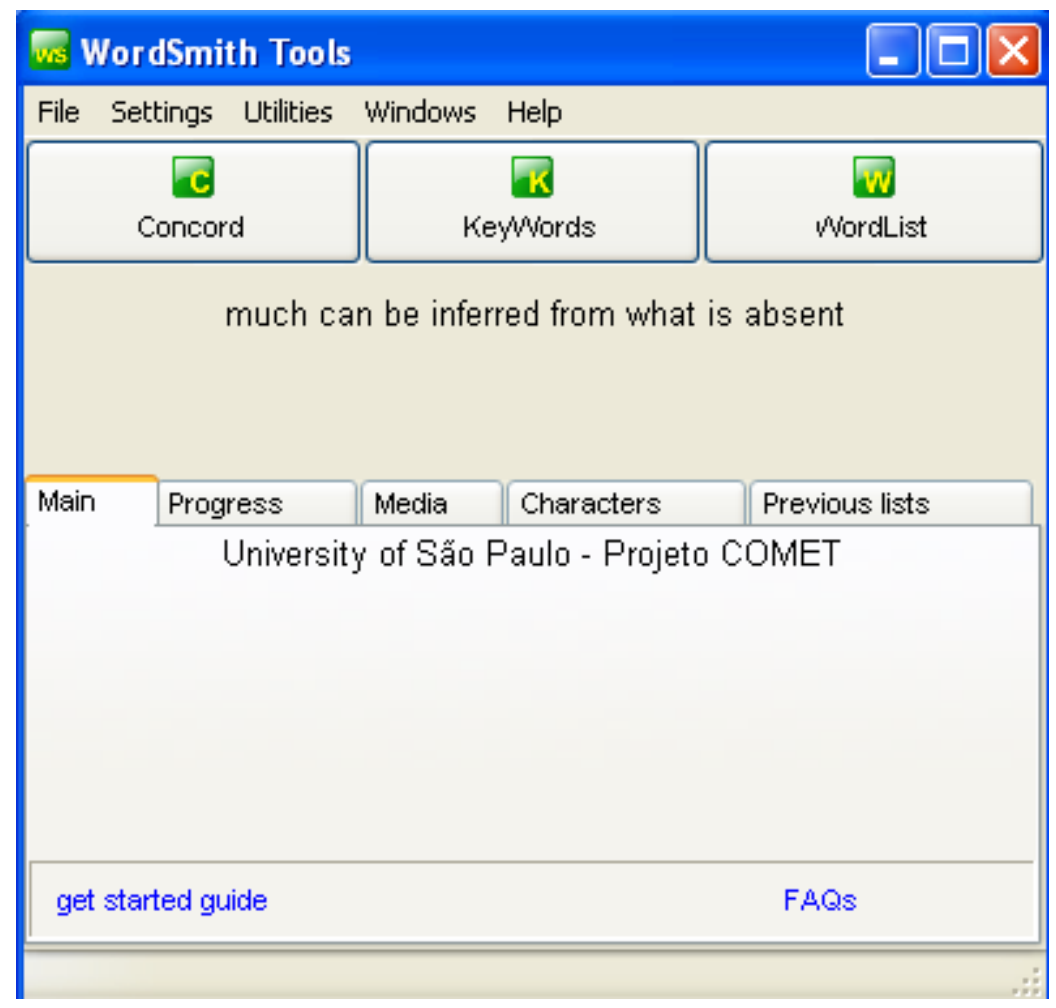

Figura 1 - Interface do WordSmith Tools 5.0

\subsubsection{Wordlist}

Possibilita a criação de listas de palavras. O programa exibe duas listas de palavras: uma em ordem alfabética, do A ao Z (vide Fig. 2), e que pode ser reordenada, e a outra em ordem de frequência, com a palavra mais frequente no início da lista (vide Fig. 3). Juntamente com as listas de palavras, o programa exibe, em outra janela, estatísticas do corpus (vide Fig. 4), tais como o número total de palavras (tokens); o número de palavras distintas (types); a razão forma/ocorrência ou, em inglês, type/token ratio; o número de sentenças; o número de parágrafos, entre outras. 


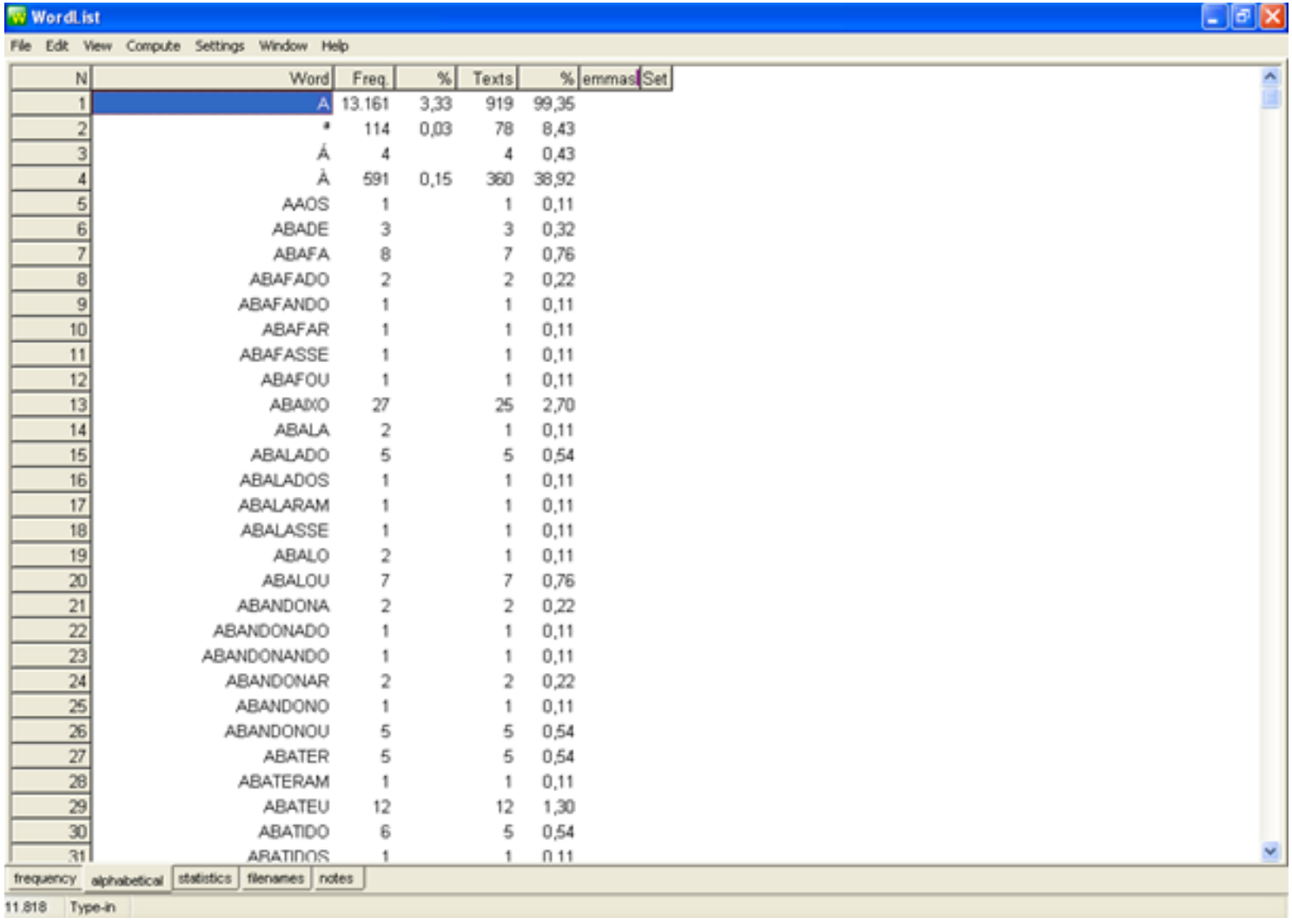

Figura 2 - Lista de palavras em ordem alfabética

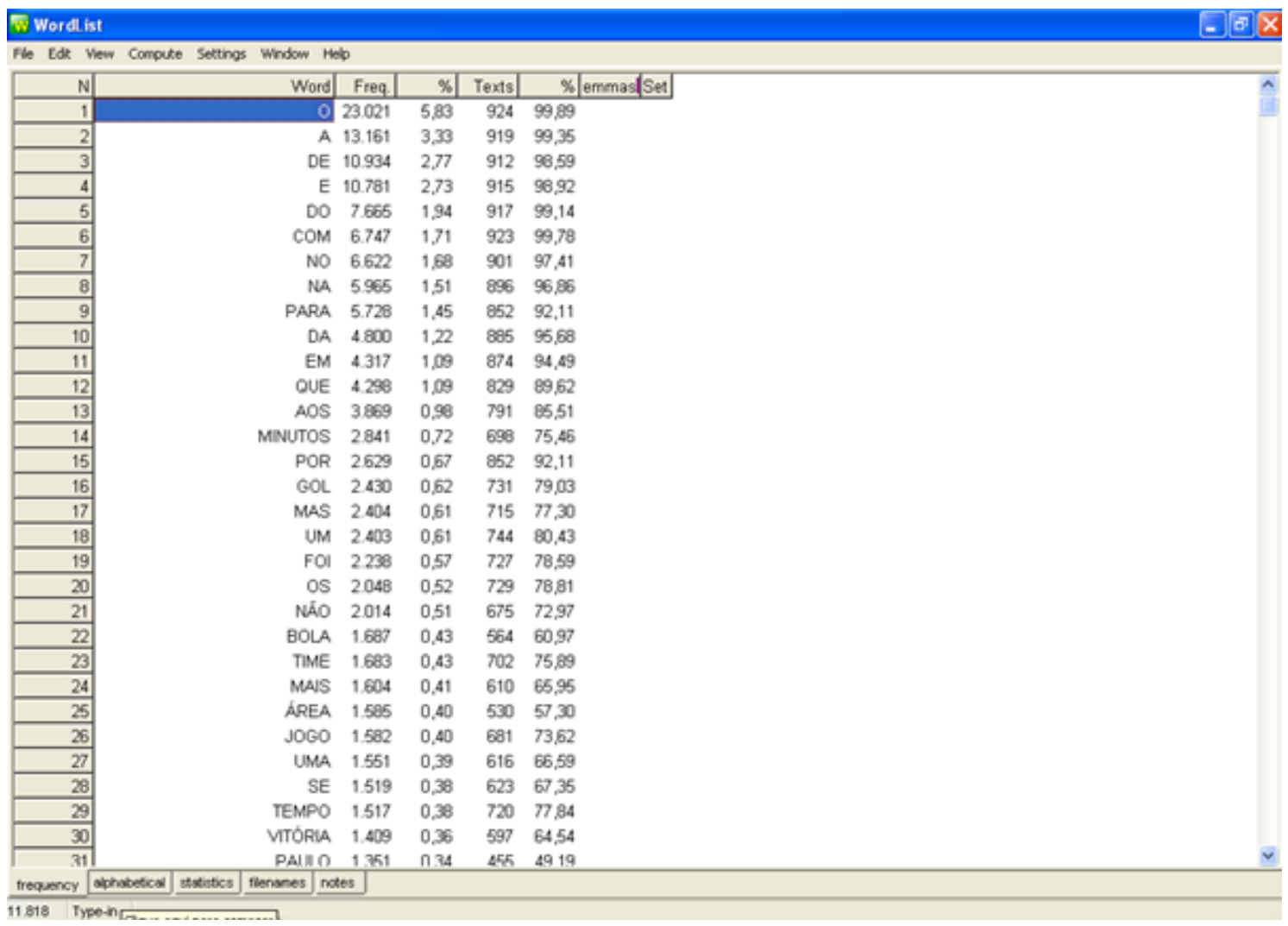

Figura 3 - Lista de palavras em ordem de frequência 


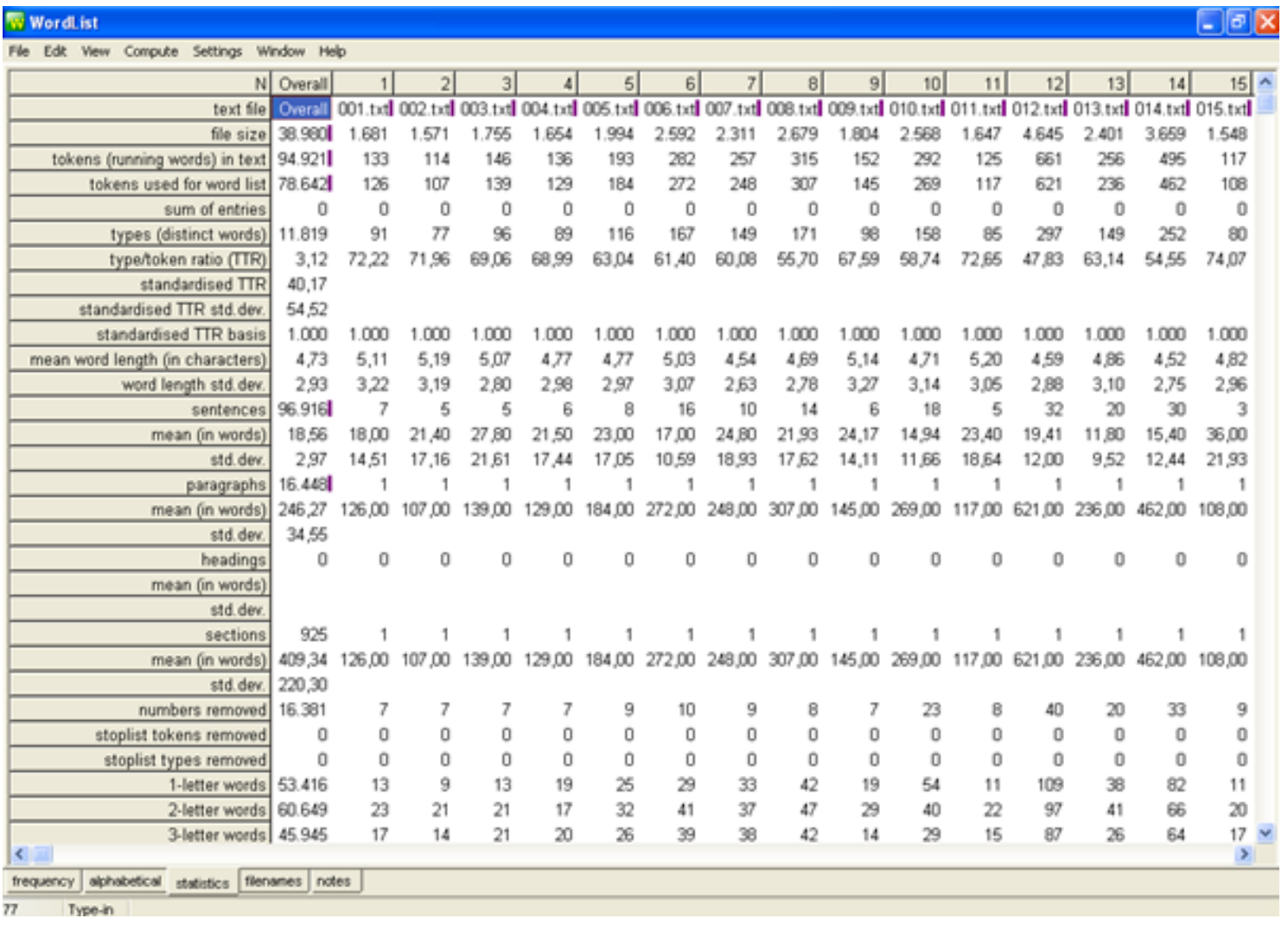

Figura 4 - Tela com as estatísticas do corpus

Para gerar uma wordlist, basta abrir a ferramenta na tela principal do WordSmith Tools, clicar em arquivo (file), novo (new), selecionar os textos por meio da opção "selecionar textos" (choose texts now) e clicar no botão "fazer lista de palavras" (make a wordlist now). O processo é bastante simples, todavia, o pesquisador deve configurar a opção do idioma (vide Fig. 5) antes de gerar qualquer wordlist, pois se uma lista de palavras em português for salva no idioma inglês não será possível gerar keywords, conforme descrito a seguir. Para configurar a língua da wordlist, deve-se clicar na opção configurações (settings) na tela principal e depois em ajustar configurações (adjust settings). O programa abrirá uma janela que exibe todas as configurações. $\mathrm{O}$ usuário deve clicar na aba idiomas (languages) e selecionar a língua em que a wordlist será salva. 


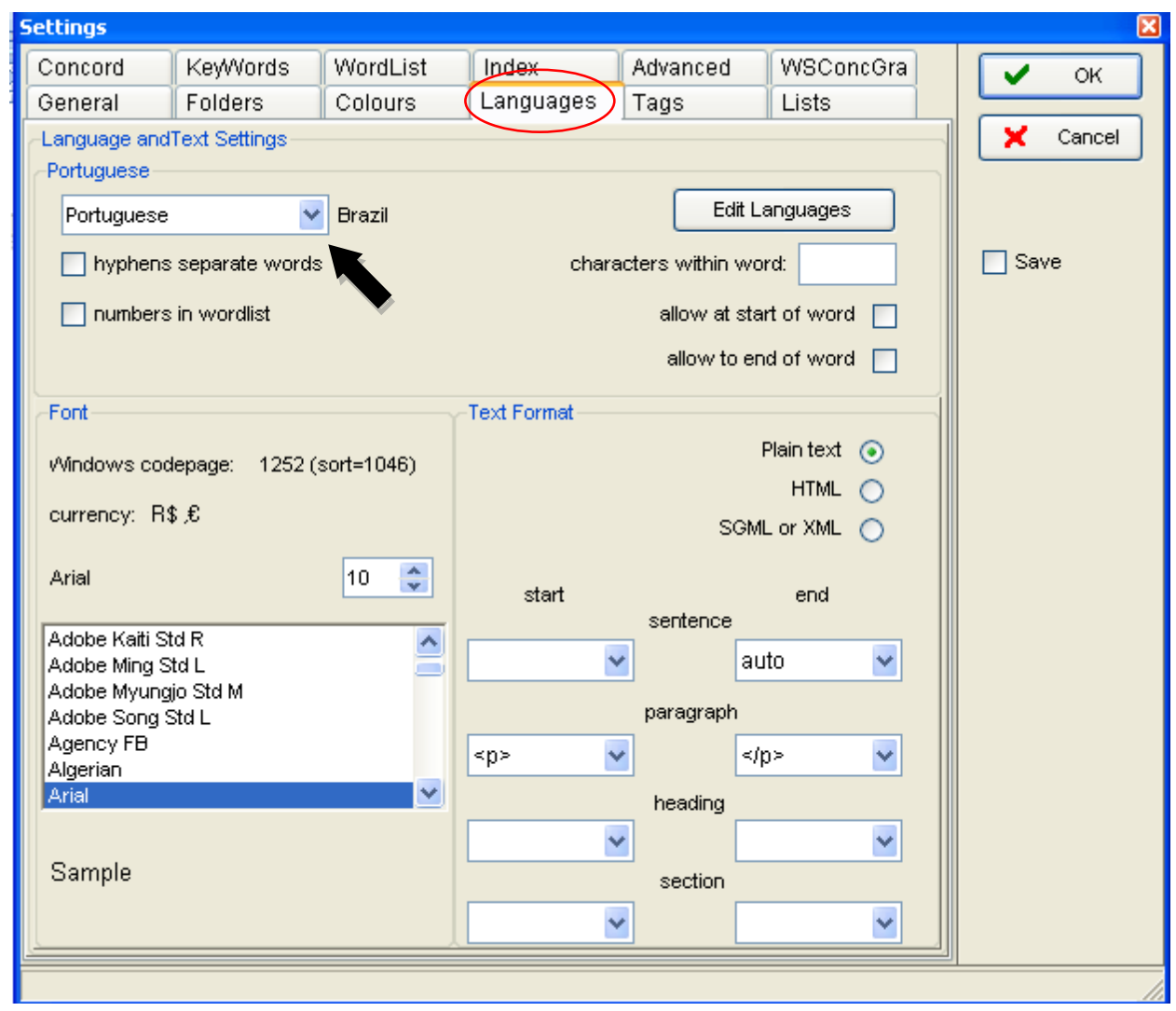

Figura 5 - Tela de configuração do idioma

\subsubsection{Keywords}

A ferramenta Keywords nos permite comparar nosso corpus de estudo (vide fig. 6) com um corpus de referência ${ }^{37}$ (vide Fig. 7) de modo a verificar as palavras estatisticamente mais frequentes no corpus de estudo. Estas palavras são consideradas palavras-chave (vide Fig. 8), pois possuem, em termos estatísticos, uma frequência relativa de maior importância no corpus de estudo do que no corpus de referência, e podem nos indicar a temática do corpus.

\footnotetext{
${ }^{37}$ A definição e características do corpus de referência serão apresentadas no item 3.2.
} 


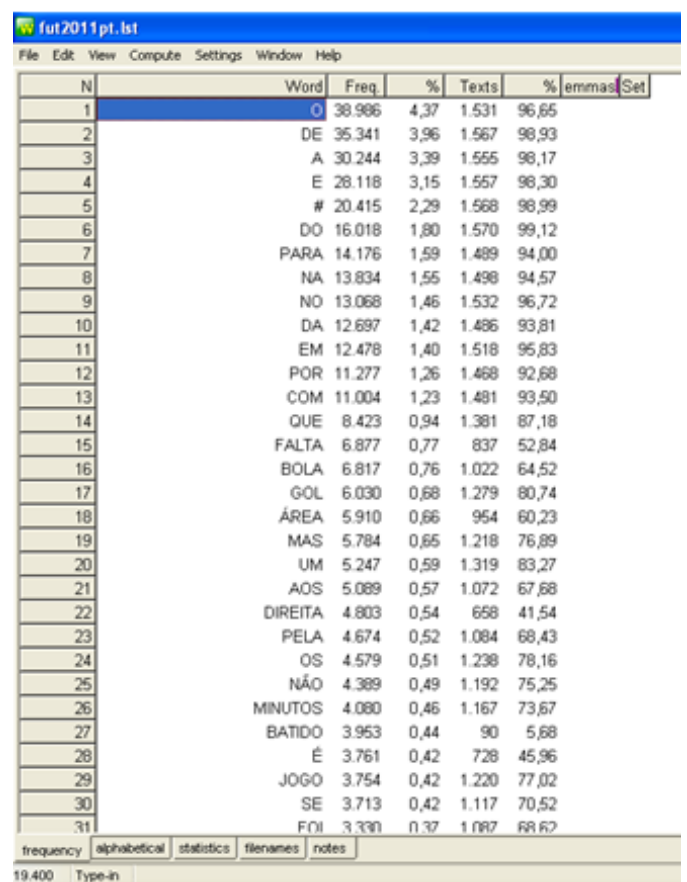

Figura 6 - Lista de palavras do corpus de estudo (PT)

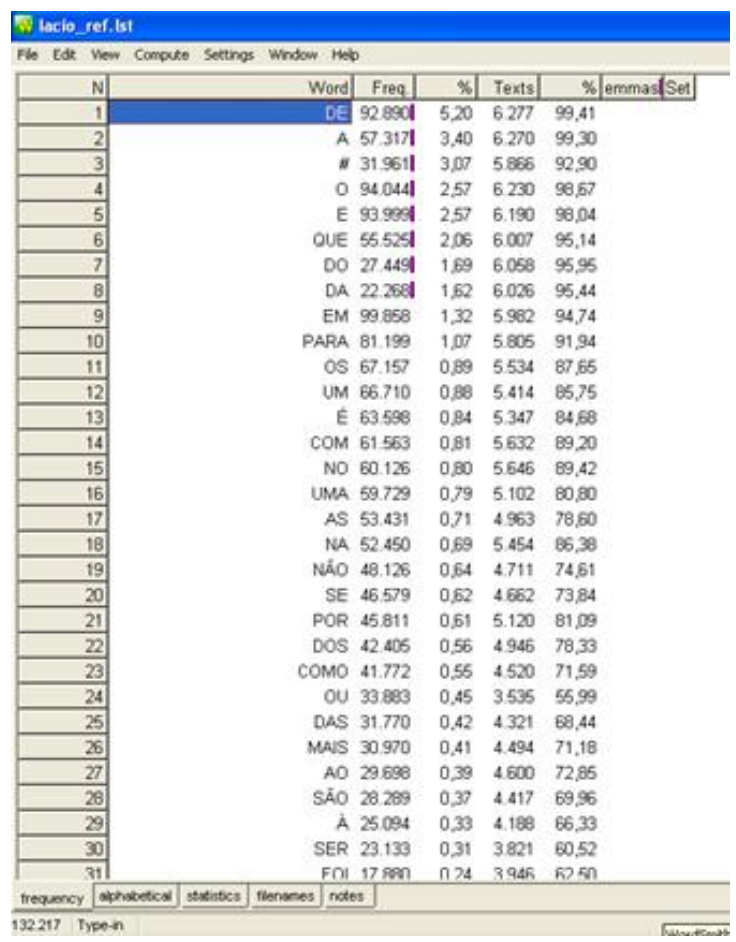

Figura 7 - Lista de palavras do corpus de referência 


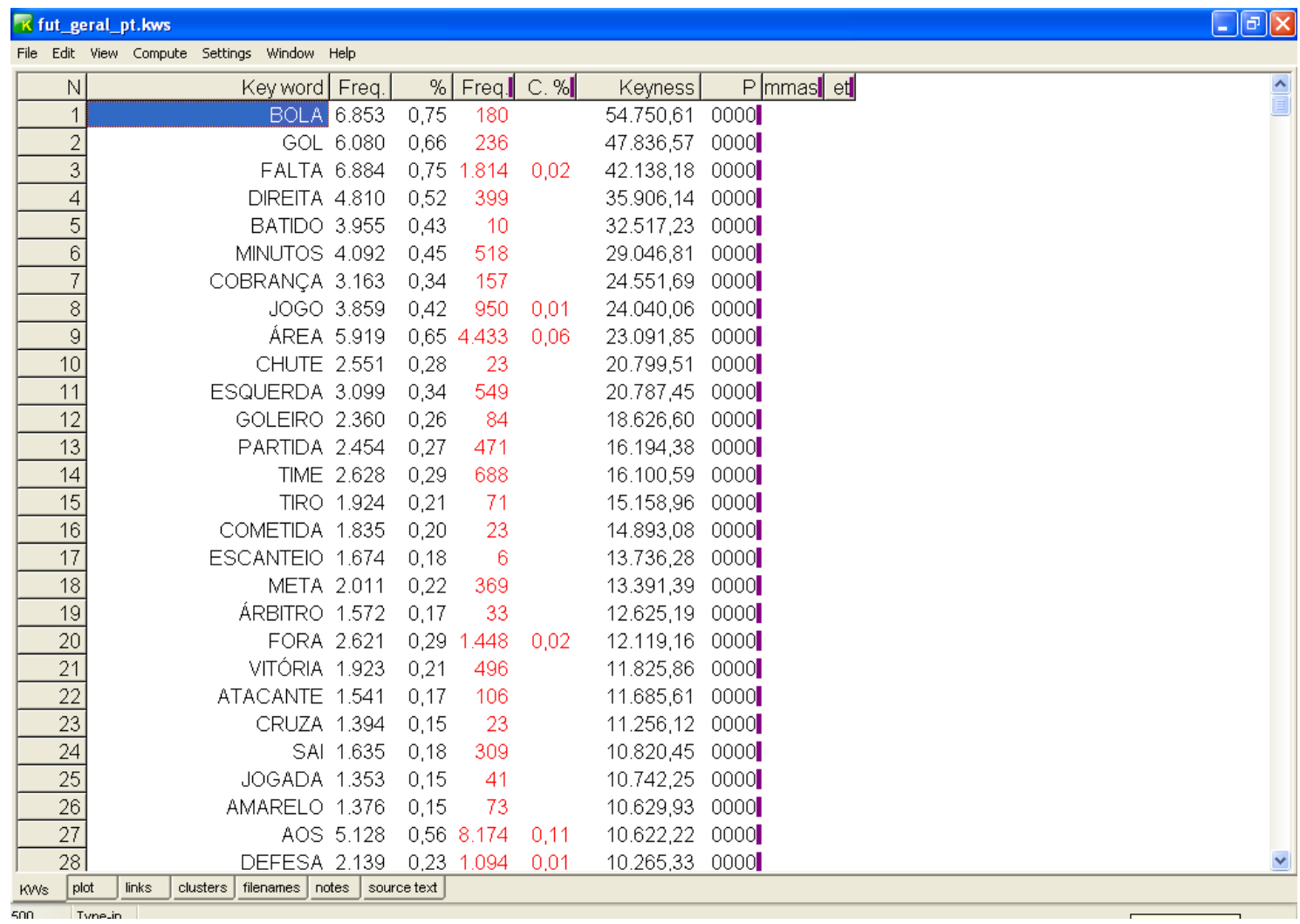

Figura 8 - Lista de palavras-chave

A tela de exibição das palavras-chave possui sete colunas: 1) palavras-chave do corpus de estudo por ordem de chavicidade; 2) frequência de cada palavra-chave no corpus de estudo; 3 ) porcentagem da palavra-chave em relação ao corpus de estudo; 4) frequência da palavra-chave no corpus de referência; 5) porcentagem da palavra-chave em relação ao total do corpus de referência; 6) chavicidade; que pode ser calculada usando tanto o log-likelihood quanto o qui-quadrado ${ }^{38}$; 7) o P, valor da significância estatística atingido pelo resultado do teste estatístico.

Ao observar, por exemplo, as duas primeiras palavras da figura 8, é possível perceber que embora a palavra gol (236) seja mais frequente que a palavra bola (180), a segunda apresenta uma chavicidade maior no corpus de estudo, pois sua frequência no corpus de referência é menor em relação à frequência de $g o l$.

O primeiro passo para gerar palavras-chave é abrir a ferramenta keywords na tela principal do WordSmith Tools e clicar em "arquivo" (file) e depois em "novo"

\footnotetext{
${ }^{38}$ A escolha do teste estatístico é justificada no item 3.3.1.1.
} 
(new). O programa abrirá uma tela em que o usuário deve escolher as wordlists a serem comparadas, como mostra a figura 9:

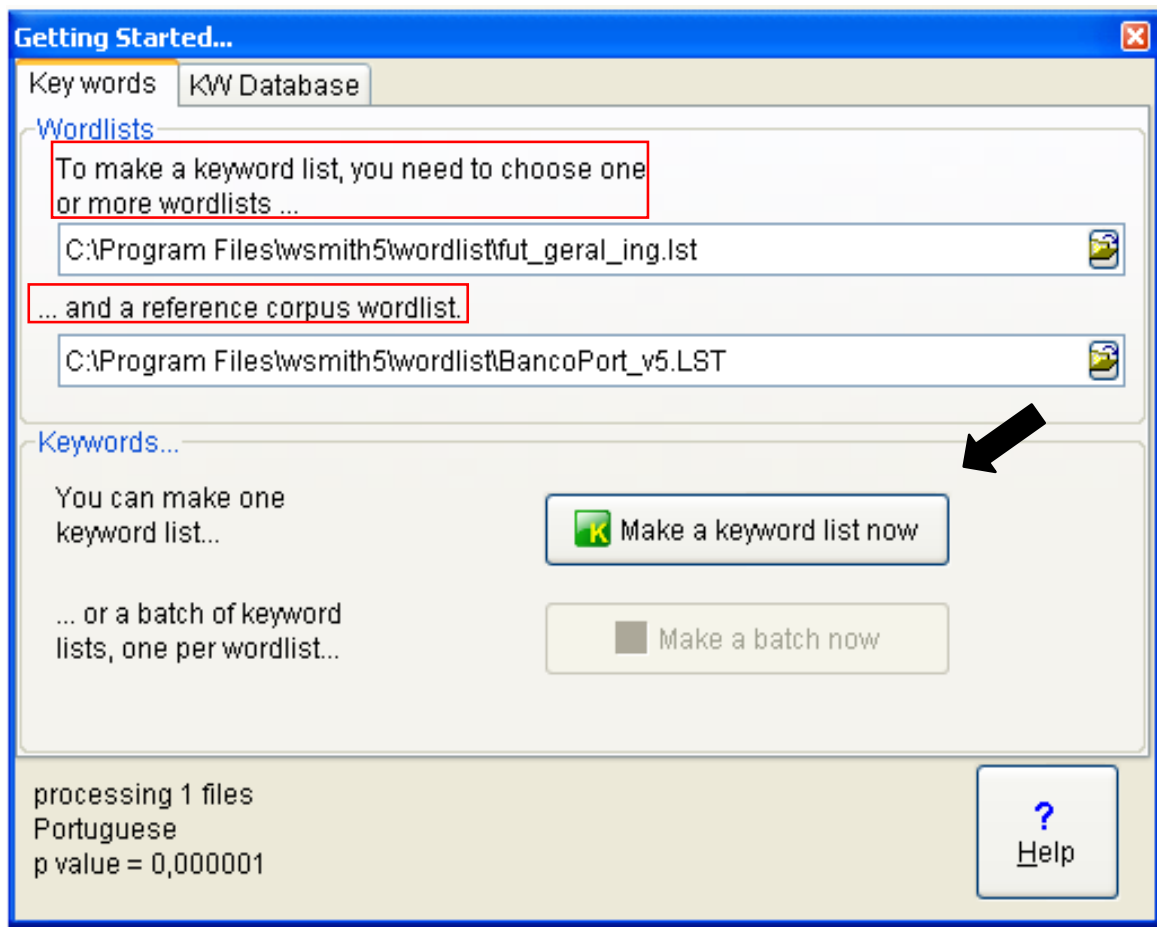

Figura 9 - Tela de seleção das wordlists

Selecionadas as listas, o passo final é clicar no botão "gerar lista de palavraschave" (make a keyword list now).

\subsubsection{Concord}

A ferramenta Concord gera linhas de concordância, ou seja, listagens das ocorrências de um item específico, chamado de palavra de busca ou nódulo. Esse ite m pode ser formado por uma ou mais palavras e é apresentado com o cotexto ao seu redor.

Para gerar linhas de concordância, o usuário deve abrir a ferramenta Concord na tela principal e clicar em arquivo (file) e em novo (new). O programa abrirá uma janela com a opção "escolher textos" (choose texts now). Clicando na opção, abre-se uma nova janela onde o usuário pode selecionar a(s) pasta(s) em que os textos estão armazenados. Selecionados os textos, basta escolher uma palavra de busca e clicar no botão $O K$. 


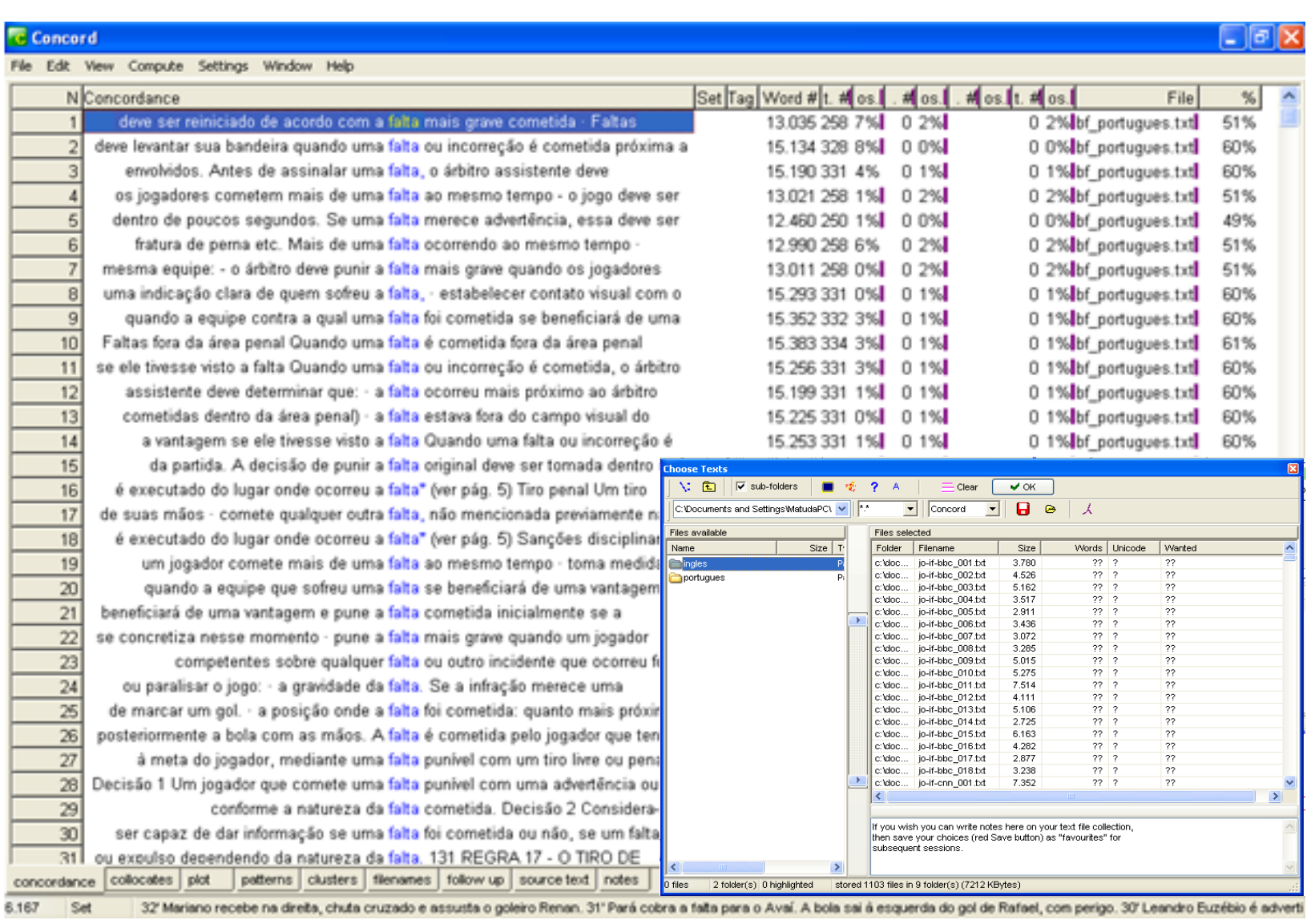

Figura 10 - Resultado de busca para "falta" na ferramenta Concord

A observação das linhas facilita a identificação de padrões linguísticos, como colocações e unidades fraseológicas. No entanto, quando o número de linhas disponibilizadas pela ferramenta é muito alto, como no caso de falta (6.167), torna-se difícil, para não dizer impossível, estabelecer algum padrão somente observando as concordâncias. Para a identificação de padrões em casos como esse, é possível reordenar as linhas de diversas maneiras. Em pesquisas terminológicas ou lexicográficas, o mais comum é ordenar o resultado pelos colocados à direita ou à esquerda do nódulo. Para tanto, o usuário deve clicar no menu "editar" (edit) e na opção "reordenar" (resort). A seguinte tela aparecerá: 


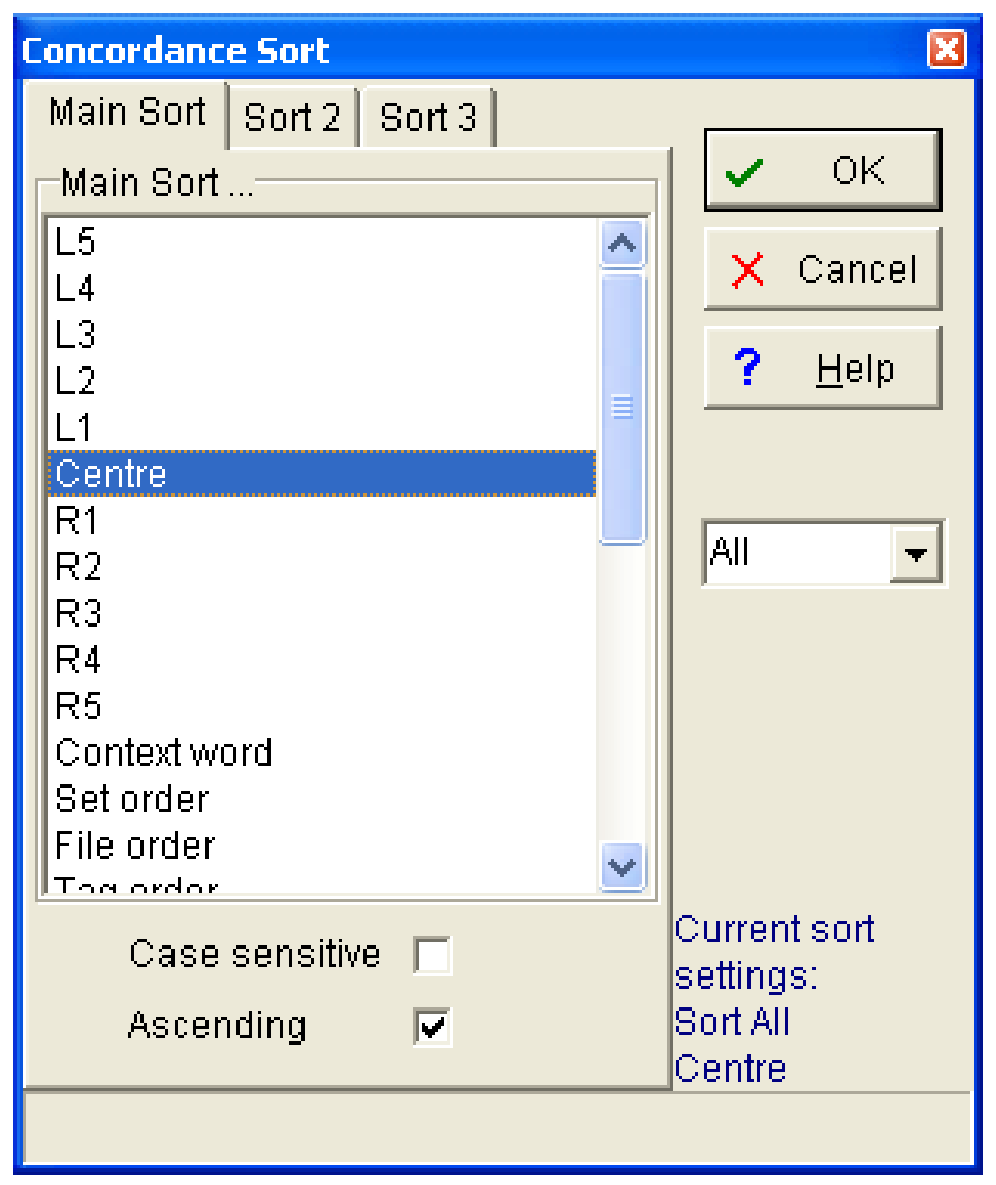

Figura 11 - Tela que permite ordenar as linhas de concordância

Como podemos observar na figura acima, utilizando o resort, o pesquisador pode reordenar o resultado das linhas de concordância da maneira mais conveniente para sua pesquisa. A ordenação pode ser feita em três níveis: main sort, sort 2 e sort 3. Na figura 12, mostramos o resultado das linhas de concordância de falta reordenadas tendo como main sort o nódulo, como sort 2 a primeira palavra à esquerda e como sort 3 a primeira palavra à direita. 
Fhe Edk New Compute Settings Whow How

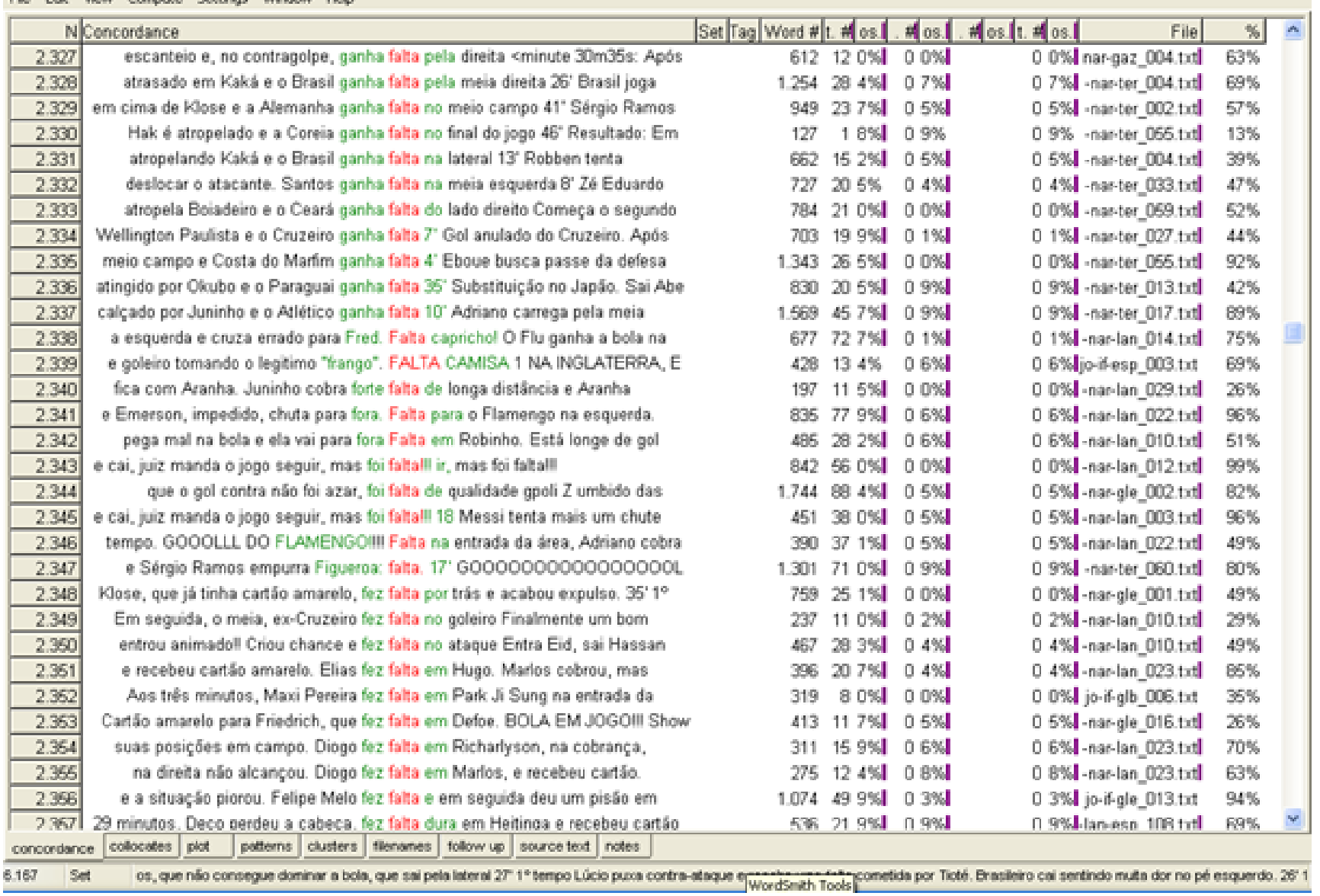

Figura 12 - Resultado de busca para "falta" reordenado pela primeira palavra à esquerda e pela primeira palavra à direita

Também é possível clicar duas vezes em cima de uma linha de concordância e acessar o texto integral, que aparece com a palavra de busca iluminada, para analisar, de forma mais detalhada, o contexto em que o item ocorreu (Fig. 13). 
Figura 13 - Contexto expandido de uma das linhas de concordância de "falta"

\subsubsection{Clusters}

O dispositivo Clusters, acoplado à ferramenta Concord, permite a identificação de clusters, também conhecidos como N-Gramas, que podem ser descritos como associações de palavras que coocorrerem com uma determinada frequência dentro de uma janela de $x$ palavras à esquerda e à direita de um nódulo, ou palavra de busca.

Os clusters são computados automaticamente e não refletem, necessariamente, unidades fraseológicas. Contudo, podem ser um primeiro passo para a identificação dessas unidades, pelo menos assim o foi em nossa pesquisa. Para obter uma lista de clusters, clicamos na aba clusters que aparece no fim da tela da ferramenta Concord, como mostra a figura abaixo: 


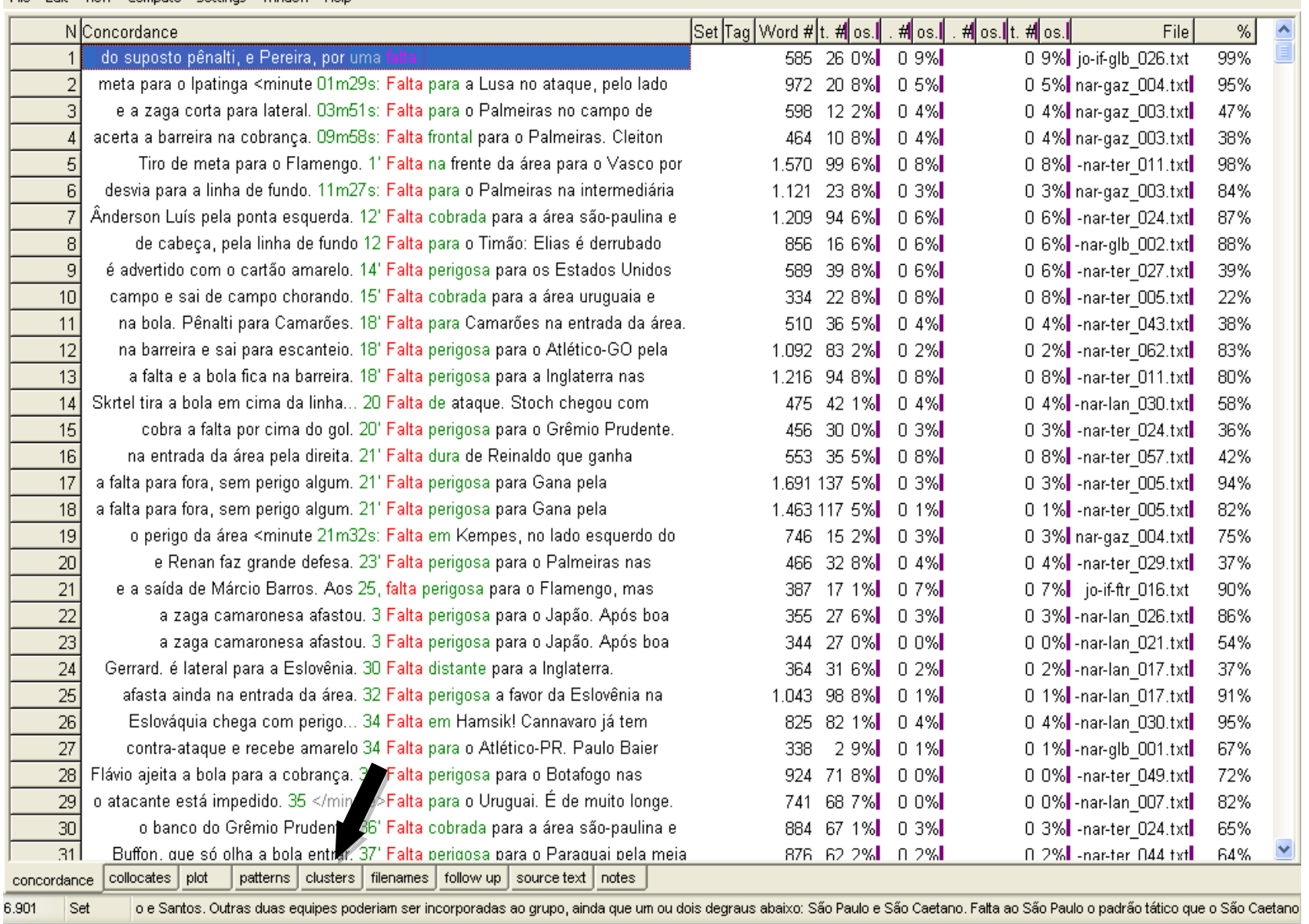

Figura 14 - Tela da ferramenta Concord

O dispositivo, que já vem com ajuste padrão, pode ter suas configurações modificadas de acordo com cada pesquisa. Para tanto, basta acessar a tela de configurações (settings) do programa, como mostra a figura 15. 


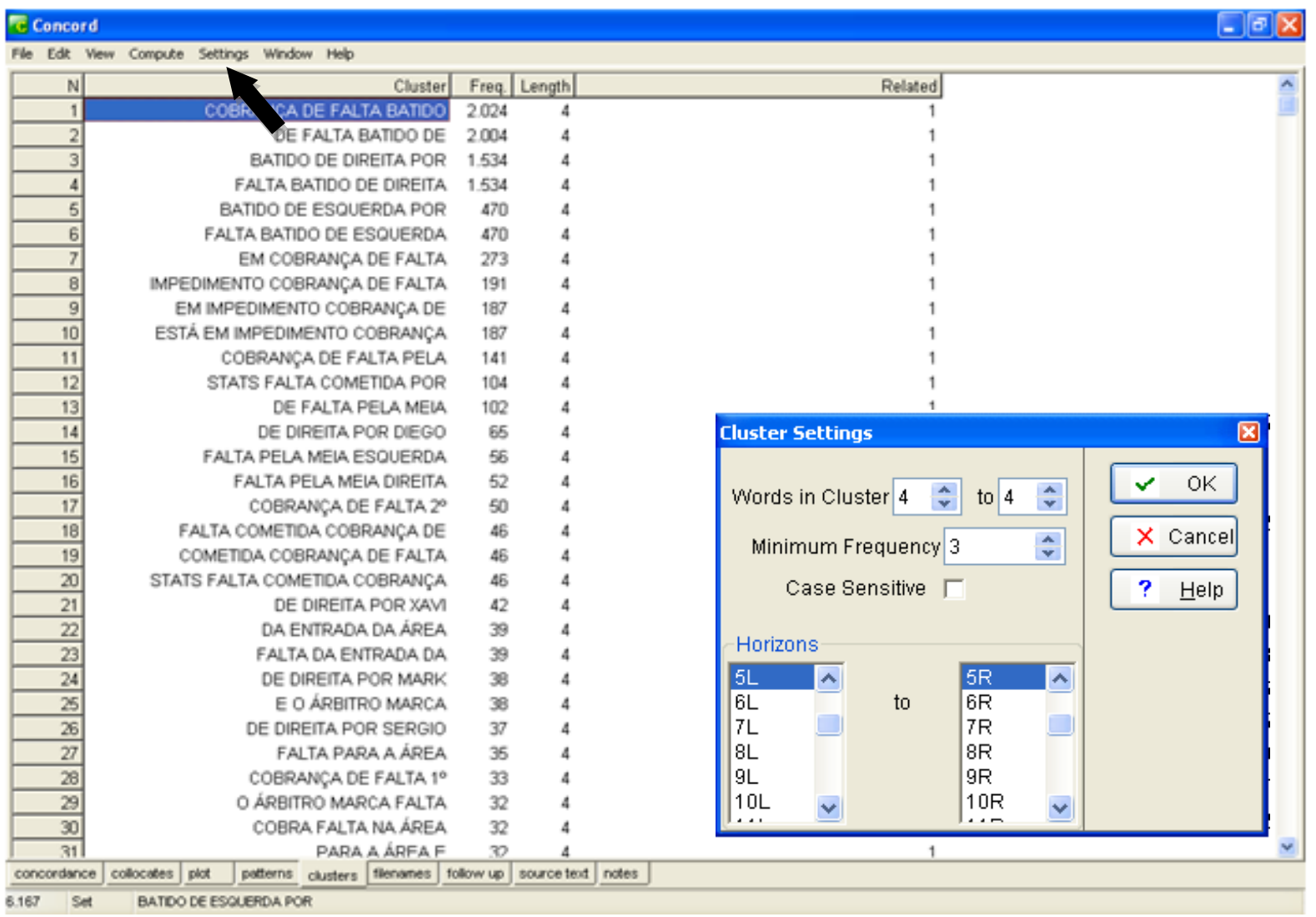

Figura 15 - Ajuste dos parâmetros para a extração dos clusters de falta

No ajuste realizado acima para a palavra falta, o programa foi preparado para encontrar clusters de quatro palavras, com frequência mínima de três e em uma janela de cinco palavras à direita e cinco à esquerda.

Enfim, os princípios da Linguística de Corpus e o programa WordSmith Tools desempenharam papel fundamental no direcionamento de nossa pesquisa.

\subsection{Terminologia}

\subsubsection{Origens}

Sabe-se que a prática terminológica não é um fenômeno recente; data do século XVII com trabalhos na área da química, botânica e zoologia (ALMEIDA, 2003, p. 211). 
O interesse pela Terminologia surgiu, primeiramente, da parte de especialistas de áreas distintas diante da necessidade de relacionar denominações a conceitos científicos com o objetivo de assegurar a univocidade da comunicação científica. Durante o século XIX, esse interesse pela denominação de conceitos aumentou significativamente devido ao crescimento progressivo das ciências (ALMEIDA, 2003, p. 213).

Até a primeira metade do século XX, a terminologia era feita por especialistas de cada área; já os linguistas mostraram um interesse tardio pela Terminologia, que se manifestou só na segunda metade do século passado.

Diante da amplitude de situar as bases teóricas da Terminologia, apresentaremos um breve panorama teórico da disciplina que tem como único objetivo contrastar alguns pontos das principais correntes com vistas a justificar a abordagem escolhida para este trabalho.

A primeira metade do século $\mathrm{XX}$ foi marcada pelo trabalho do engenheiro austríaco E. Wüster, que justificou a criação da disciplina pela necessidade de estabelecer comunicação em línguas de especialidade. Em razão dessa natureza, a disciplina que acabara de surgir deveria abranger três âmbitos principais: sociopolítico, acadêmico e científico.

Nos primeiros 50 anos de existência, não havia terminólogos ou técnicos em fazer terminologia. O trabalho era realizado por especialistas de cada área, uma vez que eram os únicos que detinham o conhecimento necessário para encontrar os termos mais adequados.

A atividade era onomasiológica, o conhecimento sobre uma determinada matéria precedia a seleção de dominações, ou seja, partia-se do conceito para a denominação. Sendo assim, o trabalho resultante era quase sempre uma compilação de formas normatizadas para cada conceito (CABRÉ, 2005, p. 3).

Wüster alegava que o funcionamento da língua geral era diferente do funcionamento das línguas de especialidade. No primeiro caso, a língua se desenvolve de forma espontânea, sem nenhum tipo de orientação. No segundo caso, as regras e a normatização são elementos fundamentais, pois, devido à grande produtividade de novos conceitos, os termos estariam à mercê de sofrerem variação (WÜSTER, 1998, p. 23). 
Foi seguindo essas premissas, partindo de um conceito e identificando a nomenclatura mais adequada, que Wüster compilou seu dicionário sobre máquinas e ferramentas, que, por sua vez, serviria como base para a elaboração de sua teoria da Termi nologia.

Os esforços para o reconhecimento da terminologia como necessidade comunicativa entre os especialistas resultou na criação do comitê técnico 37 do ISO (International Organization for Standardization) e também na criação do INFOTERM (Centro Internacional de Documentação sobre a Terminologia), resultado da aprovação de um programa da UNESCO dedicado à Terminologia.

O reconhecimento da Terminologia no âmbito acadêmico foi mais difícil devido à resistência, por parte dos acadêmicos, da inclusão de uma nova disciplina. Os linguistas mais "puros" reduziam a Terminologia à produção de dicionários técnicos e defendiam que para a realização de tal tarefa não eram necessários grandes conhecimentos linguísticos. Como consequência dessa visão, a Terminologia sempre foi inserida em programas de tradução e documentação e não em programas de filologia e linguística, à exceção fica por conta do curso de Terminologia Geral da Universidade de Viena (CABRÉ, 2005, p. 3).

Para consolidar e justificar a Terminologia como disciplina no âmbito acadêmico, Wüster adotou uma teoria que tinha como base a metodologia utilizada para a elaboração de seu dicionário, e que foi denominada por seus seguidores de Teoria Geral da Terminologia (TGT).

A TGT dava prioridade ao conceito em detrimento da designação. A forma escrita dos termos destacava-se perante a forma oral e o objetivo final da disciplina era a produção de glossários plurilíngues, que permitissem ao especialista consultar a forma normatizada $^{39}$ de um termo em sua língua materna e seus equivalentes normatizados em outras línguas.

As prioridades descritas acima configuraram a TGT como uma Terminologia representativa, já que era fundamental denominar e etiquetar a informação, e prescritiva,

\footnotetext{
${ }^{39}$ Utilizamos o termo normatizado em lugar do termo normalizado com base na distinção realizada por Krieger e Finatto (2004, p. 39): Normalizar compreende aparelhar as línguas para todas as formas de expressão, sobretudo a expressão técnico-científica. Normatizar diz respeito à fixação de uma determinada expressão como a mais adequada.
} 
pois as terminologias precisavam ser controladas para que a comunicação fosse eficaz (ALMEIDA, 2003, p. 14).

Paralelas e com bases teóricas bem similares à teoria de Wüster, surgem outras duas escolas: a de Praga e a Russa. Ambas também tiveram papel fundamental no desenvolvimento das teorias da Terminologia.

As três escolas possuíam características comuns. Dentre elas, citamos o delineamento de diretrizes para a sistematização do fazer terminológico, a valorização da dimensão cognitiva dos termos bem como sua padronização.

Embora frequentemente criticada por teóricos de outras linhas devido a suas características prescritiva e normalizadora (FINATTO; KRIEGER, 2004, p. 33), não podemos negar que a TGT é o pilar referencial dos estudos terminológicos e a teoria que impulsionou grandes avanços na disciplina.

\subsubsection{Desenvolvimento}

Durante o século $\mathrm{XX}$, mais precisamente na segunda metade, fatores sociais colocaram em questão muitos valores presentes na teoria de Wüster que até então eram considerados absolutos.

Cabré (2005, p. 4) destaca os cinco aspectos mais relevantes que influenciaram a concepção teórica e prática da Terminologia: 1) a multiplicação dos intercâmbios plurilíngues entre línguas de status sociopolítico e tipo linguístico distintos, com destaque para os países com culturas muito distantes; 2) diversas necessidades de transmissão do conhecimento especializado; 3) a multiplicação dos temas de intercâmbio internacional devido ao crescimento acelerado do conhecimento e à diversificação dos conteúdos especializados; 4) a difusão do conhecimento especializado e a extensão da formação especializada; 5) a ampla implantação de tecnologias em todo o espectro profissional.

Cabré (2005) ainda destaca a importância dada às línguas próprias pelos governos como símbolo de afirmação nacional. Ao tratar de terminologia do futebol, tal fato evidencia-se quando todo o vocabulário técnico do jogo, escrito originalmente em inglês, passa a ser traduzido para o português. A série Guia de Football, publicada por Mário Cardin, um dos primeiros tradutores das regras do futebol em português é um 
bom exemplo da iniciativa de transmitir o conhecimento especializado do futebol ao grande público, ainda que restrita a um grupo social, se levarmos em conta que era destinada ao público oriundo das camadas mais favorecidas (TOLEDO, 2002, p. 32). Outro exemplo é o volume Regras Officiaes de Todos os Sports, publicado em 1916 pela Casa Sportman, que, apesar do título, dedica dois terços de suas páginas ao futebol (TOLEDO, 2002, p. 34). Esse aumento na publicação de manuais técnicos evidenciou um movimento em direção à extensão da formação especializada, o quarto aspecto que influenciou a concepção da Termi nologia, segundo Cabré.

Dentro dessa nova perspectiva, ocorre um desenvolvimento da Terminologia como campo de conhecimento capaz de promover o intercâmbio científico, tecnológico e cultural entre culturas distintas. Daí começam a surgir investi gações terminológicas de base linguístico-comunicativa que levam em conta o funcionamento das unidades terminológicas (UTs) no âmbito das comunicações especializadas (FINATTO; KRIEGER, 2004, p. 34). Como consequência dessas mudanças, os termos passam a ser tratados de maneira descritiva a fim de expressar a realidade dos usos terminológicos.

Começam a surgir, então, teorias interessadas no funcionamento das terminologias. Dentre elas, a socioterminologia, proposta por François Gaudin.

Inspirada na socioliguística, essa teoria tem a variação como objeto essencial para a existência de uma terminologia. A variação é levada em conta e é descrita na terminologia, e não eliminada a fim de favorecer uma comunicação unívoca.

Essa perspectiva teórica nos permite descrever a diversidade da linguagem das comunicações especializadas. No que se refere ao futebolês, a teoria nos dá suporte para explicar a variação terminológica existente nos periódicos analisados, variações que ocorrem por inúmeras razões como, por exemplo, a cultura, o contexto, o público-alvo e a época em que a notícia foi produzida. De acordo com Gaudin (1993, p. 120, tradução nossa):

A variação linguística está no cerne do dilema terminológico que reside na coexistência de sistemas de noções de caráter translinguístico e da necessidade de expressá-las no interior da tradição de uma língua e no respeito de suas coerções de formação. Este elo entre a linguagem e o conhecimento obriga que se preste atenção às especificidades das línguas: a terminologia deve respeitar as identidades culturais porque as línguas têm 
estruturas diferentes que correspondem a maneiras de pensamento e expressão. $^{40}$

A Socioterminologia situa a comunicação especializada em seu lugar social e analisa a terminologia como prática linguística social dos homens que a emprega (GAUDIN, 1993, p. 121). Gaudin acredita que, com esses princípios, a disciplina evoluirá tanto em termos teóricos como em termos práticos.

Com os avanços da linguística, surgem outras teorias que questionam o caráter monossêmico dos termos e o "louvor" ao conceito em detrimento da forma. Essas novas teorias descrevem o termo com base em seu comportamento em dado cenário linguístico. Representante dessa nova visão, a Teoria Sociocognitiva da Terminologia (TST) de Rita Temmerman, de enfoque hermenêutico, advoga que os termos não possuem significado objetivo, ao contrário, constituem unidades de compreensão e de representação que funcionam em modelos cognitivos e culturais (FINATTO; KRIEGER, 2004, p. 37). Estes últimos são estruturados prototipicamente e descrevem seus significados tal como aparecem nos textos.

A principal característica dessa teoria é a adoção de uma unidade de compreensão em detrimento do "conceito", aspecto privilegiado na TGT (TEMMERMAN, 2000, p. 223). Para a TST, a visão de conceito em sua definição tradicional, "unidade de pensamento formada pela abstração com base em propriedades de um conjunto de um ou mais objetos" ${ }^{41}$, é muito restrita. Pois entendemos o mundo por meio de frames cognitivos ou de modelos cognitivos idealizados (Idealised Cognive Models $)^{42}$, nos quais as diferentes unidades de compreensão estruturadas prototicamente se relacionam. Em outras palavras, a TST parte da premissa de que para estudar uma terminologia se deve partir das unidades de conhecimento e não de conceitos.

Dentro dos princípios da TST, a polissemia é fenômeno inerente no processo de entendimento dos termos, pois os modelos cognitivos estão em contínua transformação. Os conceitos e os termos não são vistos como construtos teóricos idealizados

\footnotetext{
${ }^{40}$ La variété des langues est au coeur du dilemme termiologique qui réside dans la coexistence de systèmes de notions à caractère translinguistique et de la nécessité de les exprimer à l'intérieur de la tradition d'une langue et dans le respect de ses contraintes de formation de la langue. Ce lien entre langage et connaissance oblige à prêter attention aux spécificités des langues: la terminologie doit-elle faire respecter les identités culturelles parce que les langues ont des structures différentes qui correspondent à des habitudes de pensée et d'expression différentes.

${ }^{41}$ Unit of thought constituted through abstraction on the basis of properties of a set of one or more objects.

${ }^{42}$ Estruturas de arquivamento de experiências que são acionadas para compor os significados linguísticos.
} 
independentes do contexto em que estão inseridos. Ao contrário, a descrição dos termos acontece a partir do conteúdo do domínio de especialidade em questão e do perfil do us uário potencial do trabalho terminográfico. Sendo assim, a descrição dos termos não é estática, sempre varia.

No quadro de teorias que questionam os postulados da TGT e apontam inconsistências das escolas Russa e de Praga, a Teoria Comunicativa da Terminologia (TCT) desempenha papel fundamental. A TCT, que tem como principal representante Maria Teresa Cabré e o grupo de pesquisadores do Instituto de Linguística Aplicada, da Universidade Pompeu Fabra, em Barcelona, assim como a TGT e as outras teorias, tem o termo como pilar central da investigação termi nológica:

\footnotetext{
"A terminologia foca unicamente nos termos, ou palavras próprias de um campo de especialidade (como a física, a química, a antropologia e o desenho artístico) ou de uma área profissional (como o comércio, a indústria, os esportes etc. $^{43}$
}

No entanto, diferentemente da TGT, parte do princípio de que não existem termos per se, mas sim unidades lexicais que adquirem status de termo quando inseridas em uma comunicação especializada. Consequentemente, seu conteúdo não é fixo, e os termos assumem caráter diferente de acordo com a situação comunicativa em que estão inseridos, ou seja, a especialização de um conceito é estabelecida por critérios pragmáticos.

Outra característica da TCT é a interdisciplinaridade. A Terminologia é vista como uma matéria interdisciplinar que integra fundamentos das ciências da língua, das ciências da cognição e das ciências sociais. Sendo assim, a unidade terminológica é, ao mesmo tempo, uma unidade linguística, cognitiva e sociocultural (CABRÉ, 1999, p. 70). Dentro dessa visão, o pesquisador pode adotar uma posição mais integradora ou limitar-se ao estudo da terminologia tendo apenas um dos fenômenos acima descritos como elemento norteador.

Ainda para a autora, toda unidade terminológica tem uma finalidade comunicativa, que pode ser imediata, ao se materializar em uma comunicação direta (comunicação entre especialistas, discurso didático ou de divulgação científica etc.) ou

43 La terminología se centra únicamente em los términos, o palavras propias de um campo de especialidade (como la física, la química, la antropologia o el dibujo artístico) o de uma área profesional (como el comercio, la industria, los deportes, etc.). (CABRÉ, 1999, p. 25). 
não-imediata (tradução e interpretação). Pode ainda ser menos imediata como, por exemplo, na compilação de glossários, atividade que utiliza as unidades terminológicas para a representação do conhecimento, etiquetando conceitos especializados (CABRÉ, 1999, p. 85).

A sinonímia e a polissemia são características inerentes às unidades terminológicas. Por esse motivo, a Terminologia não deve ser feita da mesma maneira em países diferentes, pois os contextos, as finalidades, os recursos e o grau de especialização da termi nologia em questão sempre variam. De acordo com Cabré (1999, p. 71), é essa especificidade que confere à TCT seu caráter pragmático.

Partindo do pressuposto de que os termos são utilizados em situação de comunicação, existe uma tendência em direção a uma Terminologia textual (FINATTO; KRIEGER, 2004, p. 38), pois as UTs devem ser analisadas em seus contextos reais de comunicação e o texto, seja ele escrito ou falado, constitui o habitat natural dessas unidades.

\subsubsection{Fraseologia}

Apresentamos, nos itens que seguem, o percurso que realizamos para um melhor entendimento das UFEs. Primeiramente, discorremos sobre a noção de texto especializado; em seguida discutimos algumas características da Terminologia textual, seguidas de um panorama de definições e critérios de identificação existentes na literatura; ao final, apresentamos nossa visão de UF.

\subsubsection{Texto Especializado}

Seria impossível falar sobre uma Terminologia textual sem caracterizar o texto especializado, uma vez que o texto representa a materialização das linguagens especializadas.

Visto que o texto especializado constitui o principal objeto de estudo da Terminologia textual, alguns teóricos passaram a delinear critérios classificatórios para sua identificação. 
Segundo Hoffmann (1998 apud FINATTO; KRIEGER, 2004, p. 113), dois eixos básicos de classificação podem ser estabelecidos: um horizontal, relacionado ao critério temático, englobando diferentes disciplinas e suas eventuais subdivisões, e um vertical, relacionado ao grau de especialização do texto, ou seja, à densidade terminológica. A classificação de Hoffmann ressalta o fator pragmático no âmbito das comunicações especializadas e enfatiza o papel que as unidades lexicais assumem em diferentes contextos de comunicação especializados.

Alguns tipos de texto possuem maior densidade terminológica do que outros: em nosso caso, as notícias de resultados de partidas possuem densidade terminológica bem menor do que os relatos de partida minuto a minuto. Por outro lado, seria ingenuidade de nossa parte analisar a densidade terminológica de nosso corpus somente pela divisão de gêneros textuais. Por esse motivo, optamos por adotar um caráter gradual para observar a densidade terminológica dos textos, pois, por exemplo, um texto sobre resultado de partida publicado pela Placar pode apresentar uma terminologia bem distinta daquela expressa em um texto do mesmo gênero publicado pelo LanceNet. Essa variação terminológica não se refere apenas à densidade terminológica de um texto, mas também às diferentes terminologias encontradas em periódicos distintos. Por esse motivo, mais do que o tema, o grau de densidade informativa, a forma de se comunicar, a situação em que se comunica e para quem se comunica constituem fatores determinantes do grau de especialização de um texto.

Finatto e Krieger (2004, p. 116) propõem que a variação tipológica no âmbito da comunicação especializada se reflete, por exemplo, na distinção entre uma tese, um artigo de periódico altamente especializado em determinada área do conhecimento e um texto de jornal ou de revista informativa redigido com a finalidade de divulgar ao grande público um acontecimento científico. Essa distinção não pode ser aplicada ao nosso caso por vários motivos. Primeiramente, devido à grande repercussão que o futebol tem na sociedade moderna, a delimitação de "grande público" e de especialistas se torna um pouco controversa. Em um primeiro momento, tenderíamos a caracterizar os jornalistas esportivos, jogadores, técnicos e membros da comissão técnica como especialistas e os leitores e fãs de futebol em geral como "grande público". No entanto, o que acontece é que, em se tratando de futebol, todo torcedor pode ser considerado um especialista na área. 
Devido a essa grande dificuldade de delimitação de "grande público" e de especialistas, adotamos, aqui, a classificação de atores sociais do futebol proposta por Toledo (2002, p. 15):

Parto de três [atores sociais] dentro do campo esportivo: os profissionais (jogadores, técnicos, dirigentes, juízes, preparadores, médicos, etc.), os especialistas (a crônica esportiva) e o conjunto genérico de torcedores, "comuns" ou nomeados e reunidos em certas coletividades específicas.

Essa classificação é utilizada por Toledo para uma análise das lógicas do futebol, com o propósito de caracterizar os grupos sociais que se expressam por meio do futebolês. Dentro dessa ordem, os profissionais são todos aqueles que interferem diretamente no jogo, quer dentro do campo, como os jogadores, quer fora do campo, como os dirigentes e instituições como federações. Os especialistas são representados pela crônica esportiva e pelo jornalismo esportivo ${ }^{44}$ e, segundo Toledo, ocupam um lugar simbólico equidistante entre os profissionais e os torcedores, pois não participam efetivamente da partida, mas também não se comprometem em um nível de emoção partidária, pelo menos em teoria. Por fim, o "grande público" é caracterizado pelos torcedores.

É a classe dos especialistas que mais nos interessa neste trabalho, pois é através do produto do fazer jornalístico que observamos o futebol fora de seu locus de ritualização máxima, que é a partida. Ademais, é também por meio dos textos jornalísticos que o futebol alcança o "grande público".

Deve-se somar, ainda, à classificação de Toledo, o grau de densidade informativa da notícia, a forma de se comunicar, os traços de impessoalidade do jornalista, o contexto em que a notícia foi produzida ${ }^{45}$, o propósito da comunicação, que pode ser mais informativo, mais descritivo, mais técnico, para que, assim, seja possível caracterizar o texto técnico propriamente.

\footnotetext{
${ }^{44}$ Embora a crônica esportiva faça parte do grupo de especialistas dentro da classificação com a qual optamos por trabalhar, é importante ressaltar que não coletamos textos do gênero para a compilação do corpus de estudo. Ademais, há no fazer jornalístico um reivindicado distanciamento entre o jornalista e o fato, que se opõe à condição dos cronistas. Esses narram e descrevem uma partida expressando opinião pessoal e de forma mais literária, fugindo à linguagem meramente descritiva que é o objeto de estudo desta pesquisa.

${ }^{45}$ Uma notícia sobre o resultado de partida de um jogo do campeonato brasileiro provavelmente é produzida em um contexto mais específico e, portanto, voltada para um público mais específico do que uma notícia sobre uma partida de Copa do Mundo, pois durante esse acontecimento mais pessoas torcem, inclusive torcedores não habituais.
} 
Diante da caracterização de texto especializado proposta, a presença de termos deixa de ser o elemento primordial que configura o caráter de uma comunicação especializada (FINATTO; KRIEGER, 2004, p. 118). Ao contrário, os mecanismos linguísticos, textuais e pragmáticos dos quais um texto especializado faz uso também constituem elementos caracterizadores de uma dada língua de especialidade. $\mathrm{O}$ uso de todos esses elementos em conjunto nos permite enxergar a complexidade do texto especializado.

\subsubsection{Terminologia textual}

A mudança de paradigmas prescritivos para descritivos acarretou uma série de modificações na concepção da Terminologia como disciplina, na definição e no tratamento das UTs e, consequentemente, na compilação de obras de referência especializadas.

Tanto a consciência de que a investigação terminológica não pode ignorar os contextos de ocorrência como o reconhecimento da importância do texto especializado direcionam os estudos terminológicos para uma Terminologia de caráter textual, que está diretamente vinculada ao contexto sociodiscursivos. Por esse motivo, chamamos a atenção do leitor para o fato de que o termo é um dos aspectos a serem considerados em uma investigação termi nológica e não o único ou o mais importante.

Nos parágrafos que seguem, descreveremos e discutiremos algumas características dessa nova trajetória da Terminologia que ainda está dando seus primeiros passos ${ }^{46}$ e que, portanto, está longe de constituir uma teoria finalizada.

O primeiro problema com que deparamos é a nomenclatura adotada para designar a vertente da Terminologia à qual nos filiamos: Terminologia textual. $\mathrm{O}$ nome parece um pouco controverso. Pois, de um lado temos o termo terminologia que, como exposto anteriormente, trata de uma ciência do termo, e do outro temos o termo texto, definido por Bakhtin (1986, p. 113) como:

Manifestação verbal constituída de elementos linguísticos selecionados e ordenados pelos falantes durante a atividade verbal, de modo a permitir aos parceiros, na interação, não apenas a depreensão de conteúdos semânticos,

${ }^{46}$ Temos ciência da existência de trabalhos como os de L. Hoffmann (1998) que já salientavam alguns aspectos que aqui são descritos como características da Terminologia textual. 
em decorrência da ativação de processos e estratégias de ordem cognitiva, como também a interação (ou atuação) de acordo com práticas socioculturais.

Zílio (2009) chama atenção para o conflito ontológico que pode aparecer quando o objeto de uma pesquisa terminológica deixa de ser o termo. Para solucionar o problema, o autor propõe que pesquisadores, ao optarem trabalhar com esse novo modo de fazer terminologia, não deixem de dizer que estão fazendo terminologia simplesmente por um conflito ontológico, mas que enfatizem, em seus percursos, a existência de uma nova perspectiva terminológica que se propõe a estudar mais do que o termo.

Para Finatto e Krieger (2004, p. 119), essa Terminologia, na qual o objeto termo dá lugar ao objeto texto, possui duas características principais. A primeira refere-se ao reconhecimento do papel do cenário comunicativo e, consequentemente, do texto especializado para a descrição de uma terminologia. A segunda está relacionada ao estudo e caracterização do texto especializado, discutida na seção anterior.

Ao reconhecer o papel do cenário comunicativo, a Terminologia textual parte do pressuposto de que os termos são utilizados em situação de comunicação e que, portanto, não devem, ou melhor, não podem ser estudados à parte do contexto sociocultural em que ocorrem.

Os termos passaram a ser analisados em funcionamento, ou seja, em textos especializados, permitindo, assim, a verificação de fenômenos até então ignorados, ou deixados em segundo plano pelos terminólogos. O contexto discursivo, antes considerado insignificante, passa a representar uma das principais características da Terminologia, contribuindo para um novo tratamento das UTs, deixando de lado a ideia de que os termos constituem construtos teóricos idealizados em um sistema linguístico independente.

Conforme já exposto, embora não fosse um fenômeno tão recente, o novo enfoque sobre o texto direciona os estudos terminológicos para a descrição de variações, neologismos, sintagmas terminológicos, colocações, coligações e fraseologias de um dado cenário de comunicação, levando em conta não somente os aspectos linguísticos, mas também os comunicativos, cognitivos e pragmáticos.

Nessa perspectiva, nosso objetivo é, pura e simplesmente, a observação de unidades fraseológicas especializadas (UFEs) na linguagem do futebol em inglês e 
português. Unidades, estas, que podem constituir colocações, sejam verbais, adjetivas ou adverbiais, ou que, muitas vezes, podem ir além dos limites convencionais das fraseologias. Ao delimitar as UFEs como objeto de estudo, esperamos contribuir para o entendimento do texto especializado de futebol.

Tendo estabelecido a perspectiva de Terminologia com a qual trabalhamos, discutiremos, no próximo item, algumas definições de UFs e, ao final, apresentaremos a definição que elegemos para nossa pesquisa.

\subsubsection{Unidades Fraseológicas Especializadas}

A definição e a delimitação das UFEs são objeto de grande complexidade. A problemática inicia-se na própria terminologia utilizada para nomear essas estruturas:

- expressão terminológica terminological phrase;

- expressão de linguaguem para fins específicos LSP phrase;

- expressão técnica technical phrase;

- frasema ou unidade fraseológica;

- termo fraseológico;

- profissionalismo ou jargão;

- item lexical multi-palavra ${ }^{47}$

e, ainda,

- colocação (HEID, 1992, 1994, 1998; MARTIN, 1992; SCHAETZEN, 1993; DESMET, 1996);

- colocação de linguagens de especialidade (L'HOMME, 1998, 2000);

• coocorrência (LAINÉ; PAVEL; BOILEAU, 1992; PESANT; THIBAULT, 1993);

- entidade fraseológica (GOUADEC, 1994);

- frasema (GRÉCIANO, 1993);

- fraseologismo (BLAIS, 1993; PAVEL, 1993);

${ }^{47}$ Termos apresentados por Giuseppe Palumbo (2003, p. 202), em The use of phraseology for training and research in the translation of LSP texts, ao discorrer sobre a problemática da definição e da nomenclatura de unidades fraseológicas em linguagens especializadas. Tradução nossa. 
- unidade fraseológica (GOUADEC, 1994; BEVILACQUA, 1996);

- unidade fraseológica especializada (CABRÉ; LORENTE; ESTOPÀ, 1996) ${ }^{48}$.

Essa variedade terminológica não corresponde, necessariamente, a uma mesma variedade conceitual. Ou seja, vários termos podem ter a mesma definição.

No que se refere às definições, Bevilacqua $(2004$, p. 25) destaca três tendências principais. Uma primeira tendência que parte de uma perspectiva da lexicologia e define as UFEs como colocações, ou seja, combinações de duas unidades léxicas, semiacabadas, de caráter semi-fixo e de uso comum entre um grupo de especialistas. São formadas por estruturas como, por exemplo, tratamento de dados (substantivo + substantivo) e tratar uma doença (verbo + substantivo), revelando, dessa forma, o estabelecimento de padrões morfossintáticos. A segunda tendência parte da perspectiva terminológica, pois define as UFEs como combinações sintagmáticas entre duas unidades léxicas, cujo núcleo é uma unidade terminológica. Comparada com a tendência anterior, observa-se que o ponto de partida é o termo e não as estruturas morfossintáticas pré-estabelecidas, embora, muitas vezes, as estruturas identificadas coincidam com sintagmas verbais, nominais, adjetivos e preposicionais. A terceira tendência parte de uma perspectiva dos estudos contrastivos da tradução ao considerar como UFE não só sintagmas, mas também expressões formuláicas e orações particulares de um domínio discursivo, uma vez que a identificação de equivalentes desses três elementos se mostra relevante para a tradução.

Ainda segundo a autora (2004, p. 26-27), no que se refere à tipologia morfossintática, as duas primeiras tendências seguem caminhos parecidos, pois embora adotem critérios de identificação distintos - a primeira a partir de estruturas morfossintáticas pré-estabelecidas e a segunda a partir do termo -, as UFEs são formadas por sintagmas verbais, nominais, preposicionais e adjetivos. A terceira tendência, ao contrário das outras duas, não estabelece uma tipologia morfossintática e, muitas vezes, nem um critério de identificação, uma vez que considera como UFE qualquer unidade que seja relevante para a produção de um texto especializado, sem levar em conta sua tipologia.

\footnotetext{
${ }^{48}$ Termos apresentados por Bevilacqua (2004, p. 24) em sua tese de doutorado. Tradução nossa.
} 
Diante da dificuldade de eleger uma definição para UFEs, expomos, nas seções que seguem, definições e critérios de identificação das UFEs adotados por teóricos representantes da segunda e da terceira tendências supracitadas. Optamos por não abordar autores da primeira tendência, pois acreditamos que as abordagens que descrevem as UFEs da perspectiva da Terminologia e da tradução se mostram mais úteis para os propósitos desta pesquisa do que abordagens que têm como base um ponto de vista lexicográfico e que investigam UFs em língua geral. É importante ressaltar que, devido à variação termi nológica, elegemos, aqui, para esta discussão, o termo UFE para unidade fraseológica especializada e o termo UF para unidade fraseológica não especializada, independente do termo adotado pelo autor em questão.

\subsection{Definições}

Nesta seção, discutiremos algumas definições de UFs e UFEs da perspectiva da Terminologia e da tradução. Tentaremos, sempre que possível, estabelecer pontos comuns entre as definições de modo a agrupá-las dentro de uma mesma tendência.

L'Homme (2000), Knowles e Thomas (1996), Finatto e Krieger (2004) e Bevilacqua (2004) representam o grupo que define as UFEs tendo como base uma perspectiva terminológica.

L’Homme (2000 apud ZÍLIO, 2009) as define como combinações binárias entre um termo e um outro lexema. Knowles e Thomas (1996) compartilham uma visão bastante parecida com a de L'Homme ao adotar a definição de Arntz e Picht (1989, p. 34, apud KNOWLES; THOMAS, 1996, p. 2):

uma unidade fraseológica especializada resulta de uma ligação sintática entre dois ou mais elementos de uma linguagem especializada para formar uma frase ou uma expressão que possua conteúdo especializado, cuja coerência interna é baseada na possibilidade de combinação conceitual dos elementos ${ }^{49}$.

A definição acima parte de uma base terminológica ao assumir que uma UFE é formada por dois ou mais elementos de uma LSP (linguagem para propósitos

\footnotetext{
${ }^{49}$ An LSP phrase results from the syntactic linking of at least two LSP elements to form a phrase or expression which has an LSP content, the inner coherence of which is based on the ability of the elements to combine conceptually. A obra original está escrita em alemão; a tradução foi feita a partir da citação em inglês do estudo de Knowles e Thomas (1996).
} 
específicos). Os autores não deixam claro, no entanto, o que consideram como elementos de uma LSP.

Uma das propostas mais significativas no âmbito da fraseologia especializada e que também parte de uma perspectiva terminológica é a de Finatto e Krieger (2004, p. 91), autoras que definem UFE como:

formulação prototípica de cada tipo de comunicação especializada e ainda as estruturas sintagmáticas pluriverbais que comportam um termo, unidade lexical semanticamente representativa da área temática em foco.

As autoras acreditam que os enfoques que se ocupam em mostrar somente as regularidades estruturais das UFEs são limitadas por restringirem a identificação das UFEs à constituição morfossintática; uma vez que não consideram a presença de um termo como critério de identificação, nem sempre essas estruturas constituem UFEs.

Para integrar o grupo de definições que partem de uma perspectiva terminológica, apresentamos a proposta de Bevilacqua (2004, p. 29, tradução nossa) que define as UFEs como:

Unidades de significação especializada sintagmáticas, formadas por um [Núcleo Terminológico] (unidade terminológica simples ou sintagmática) e por um NE (verbo, substantivo de verbal ou particípio derivado de verbo), que representam as atividades e processos específicos de um âmbito. São, dessa forma, dependentes de uma área temática, apresentam um determinado grau de fixação interna e frequência relevante em textos de um âmbito especializado $^{50}$.

A tipologia morfossintática das quatro tendências difere, pois, para L'Homme, UFEs são combinações binárias entre um termo e outro lexema; para Knowles e Thomas, são formadas por uma ligação sintática entre dois ou mais elementos de uma linguagem de especialidade; para Finatto e Krieger, são caracterizadas por estruturas sintagmáticas pluriverbais que comportam um termo; e, para Bevilacqua, são formadas por uma base que possui uma estrutura subjacente formada por um núcleo eventivo (NE) e um núcleo terminológico. No entanto, todas consideram o termo elemento

\footnotetext{
${ }^{50}$ Unidades de significación especializada sintagmáticas, que están formadas por un NT (UT simple o sintagmática) y por un NE (verbo, nombre deverbal o participio derivado del verbo), que representan las actividades y procesos específicos de un ámbito. Son, pues, dependientes de un área temática, poseen un determinado grado de fijación interna y tienen una frecuencia relevante en los textos de un ámbito especializado.
} 
essencial para a caracterização de uma UFE. Nessas tendências, qualquer combinação que possua frequência relativa significativamente maior em uma dada língua de especialidade em comparação com a língua geral, mas que não possua um termo, não é considerada uma UFE.

Como representantes da tendência que define as UFEs a partir de uma perspectiva dos estudos contrastivos da tradução temos Gouadec (1994), Marco (2000), Stubss (2001), Frérot, Rigou e Lacombe (2001), Palumbo (2003) e Tognini-Bonelli (2002).

Gouadec (1994 apud BEVILACQUA, 1996) considera UFEs cadeias de caracteres especializados, utilizadas sistematicamente em um domínio conceptual próprio ou ainda em determinadas situações comunicativas. Podem compreender uma colocação, uma expressão formulaica, locuções, frases e, até mesmo, um conjunto de frases (BEVILACQUA, 1996, p. 41).

O autor não dá muita importância para a delimitação da fronteira entre termo, colocação e fraseologia, já que tal distinção vai depender da perspectiva e dos critérios de identificação adotados. Ainda para Gouadec (1994), esses fatores não têm importância primordial para o tradutor, que precisa traduzir um texto especializado da língua A para a língua $\mathrm{B}$ de modo que o texto de chegada reflita os padrões convencionais da língua de especialidade A na língua B. Em nosso caso, o tradutor deve traduzir a linguagem utilizada para falar de futebol em inglês para português, ou viceversa.

Com uma visão semelhante à de Gouadec, no sentido de que não define as UFEs a partir de combinações binárias em que uma palavra lexical representa o núcleo, Marco (2000) defende a idéia de que o idiom principle ${ }^{51}$ é essencial para entender o funcionamento de um texto e das unidades linguísticas que o compõem; por esse motivo, esta estudiosa considera a língua como um sistema fraseológico em oposição à tradicional distinção entre léxico e gramática (open-choice principle), em que as escolhas são regidas apenas pelas regras gramaticais.

Assim como Marco, Stubbs (2001) advoga que uma unidade de sentido da língua raramente é formada por uma única palavra, mas sim por uma unidade maior, composta de, pelo menos, duas palavras. Essas unidades de sentido podem ser

${ }^{51}$ Semi-preconstructed phrases that constitute single choices, even though they might appear to be analysable into segments. (SINCLAIR, 1991, p. 110). 
consideradas UFs. Como se nota no período anterior, julgamos apropriada a forma condicional por meio do verbo "poder" na medida em que o próprio estudioso Stubbs, assim como Gouadec, opta por não traçar uma clara distinção entre colocação e UF. Sendo assim, unidades de sentido formadas por duas palavras também podem constituir colocações. A dúvida permanece ao se ler a definição de colocação proposta pelo autor: "relação lexical entre duas ou mais palavras que apresentam tendência de coocorrerem dentro de uma determinada janela em um texto corrido ${ }^{52 \%}$.

A definição de Frérot, Rigou e Lacombe (2001) compartilha um aspecto da definição de Stubbs. Os autores definem as UFEs como

expressões multipalavras mais ou menos fixas - mais conhecidas como colocações - que causam graves problemas para tradutores e escritores técnicos uma vez que a tradução desses textos para outras línguas apresenta grande dificuldade devido às características sintáticas e lexicais de cada língua de especialidade ${ }^{53}$.

Outra característica da abordagem dos autores é o envolvimento com a tradução, que é explicitado no próprio objetivo final do trabalho deles: desenvolver uma ferramenta de escrita e tradução técnica (inglês-francês) com ênfase nas UFEs.

Também motivado pela tradução, Palumbo (2003) advoga que "tanto padrões colocacionais quanto gramaticais/coligacionais devem ser considerados parte do domínio da fraseologia especializada." 54 .

O principal objetivo da proposta é a identificação de equivalentes para unidades "úteis" para a produção de textos especializados, interesse que compartilha com Gouadec. Esse interesse surge, em parte, da experiência de Palumbo como tradutor profissional e, em parte, de sua atuação como pesquisador no Departamento de Estudos da Língua, Texto e Tradução, da Universidade Modena e Reggio Emilia, na Itália.

A motivação do tradutor surgiu diante da dificuldade de lidar com as palavras que "estão ao redor dos termos", ou seja, seus colocados, ao traduzir um texto técnico. A motivação do pesquisador surgiu da necessidade de preparar os futuros tradutores

\footnotetext{
${ }^{52}$ A lexical relation between two or more words which have a tendency to co-occur within a few words of each other in running text.

${ }^{53}$ More or less fixed multiword expressions - often called collocations - which cause serious problems for translators and technical writers, since translating them into the target language is rendered difficult by the syntactic and lexical characteristics of each Language for Specific Purposes.

54 Both collocational and grammatical/colligational patterns could then be considered as part of the domain's special phraseology
} 
para produzirem textos que estejam em conformidade com as convenções da língua de especialidade com a qual trabalham.

O estudo de Palumbo parte do pressuposto de que a tendência fraseológica desempenha papel fundamental nas línguas de especialidade e que o princípio da cosseleção é fundamental para qualquer investigação de cunho terminológico, uma vez que os padrões gramaticais e lexicais são interdependentes.

O conceito de interdependência léxico-gramatical investigado por Palumbo também é compartilhado por Tognini-Bonelli, que, diferente dos outros teóricos, não apresenta uma definição própria para as UFEs, sequer apresenta alguma outra definição. A autora utiliza o conceito de "unidades de sentido estendidas" 55 de Sinclair (1996). De acordo com Sinclair, a escolha lexical é regida por limitações léxico-gramaticais em que as palavras assimilam os traços de repetição de uso, possibilitando, assim, o surgimento de colocações e fraseologias, as quais o autor denomina "itens lexicais multipalavras"

Tognini-Bonelli também aproxima sua teoria à de Gouadec e Stubbs no que se refere ao significado dos termos, já que o objetivo principal de seu trabalho é verificar se o termo possui o status privilegiado que lhe é atribuído pelas principais vertentes da Terminologia ou se o contexto no qual está inserido afeta esse status, influenciando, assim, o significado.

Antes de caracterizar fraseologia, a autora apresenta algumas premissas que adota para seu estudo. Primeiramente, posiciona-se quanto à distinção entre termo e palavra feita pelos terminólogos. Nessa distinção, o termo "vive uma vida à parte, independente do contexto em que ocorre ${ }^{57 \text { " }}$ (PEARSON, 1998), ao passo que o significado de uma palavra não só pode, como deve, ser definido pelo seu uso. Seguindo essa linha, o termo possui um significado estático definido em relação ao conceito ao qual se refere e a palavra tem seu significado inferido a partir da situação comunicativa empregada. Tognini-Bonelli adota a "teoria contextual do significado" de Firth para se posicionar diante da questão. Segundo a autora, os termos não estão imunes às relações que travam com o contexto; ao contrário, o significado é sempre resultante da dependência contextual, revelando, assim, a indeterminação como uma das principais características do significado terminológico.

\footnotetext{
${ }^{55}$ Extended units of meaning.

${ }^{56}$ Multi-word lexical items.

${ }^{57}$ Lives a life of its own quite separate from its environment.
} 
A consciência de que um termo não pode ser utilizado de qualquer maneira em um texto reflete uma visão probabilística da linguagem. Dentro dessa perspectiva, Sinclair (1991) chama a atenção para a tendência terminológica e para a tendência fraseológica, ou seja, a tendência de um termo ocorrer sozinho, sem estabelecer relações com outros itens, e a tendência de um termo ocorrer acompanhado de outros itens e, consequentemente, ser parte integrante de uma unidade de sentido maior.

Para Sinclair (1991), toda unidade lexical (UL) tem um lugar na tendência terminológica e na tendência fraseológica, ou seja, ora a UL possui um status privilegiado e não tem seu significado "contaminado" pelos seus colocados, ora é apenas um componente de uma unidade de sentido maior.

Ao adotar o conceito de "unidades de sentido estendidas" e defender a idéia de que as palavras, ou termos de uma língua de especialidade, assimilam traços de repetição de uso devido às limitações léxico-gramaticais, que acontecem de forma distinta em duas línguas, Tognini-Bonelli (2002) mostra certa preocupação com o tratamento das UFEs na tradução.

Os autores que compõem esse grupo compartilham três características: não consideram a coocorrência de estruturas morfossintáticas pré-estabelecidas em suas definições; não estabelecem uma divisão clara entre colocação e UF; e demonstram preocupação com o problema que essas estruturas podem causar na tradução.

\subsection{Critérios de identificação}

Assim como na seção anterior, em que dividimos as definições entre os seguidores da tendência terminológica e os da perspectiva da tradução, iniciaremos a apresentação dos critérios de identificação das UFEs pelos autores que seguem a primeira tendência e, em seguida, apresentaremos os critérios dos autores vinculados à segunda tendência.

Para L'Homme (2000), a identificação das UFEs é feita por meio da observação coocorrente de estruturas sintáticas como, por exemplo, subst. (termo) + verbo, subst. (termo) + adj., subst. (termo) + subst.

Knowles e Thomas (1996) adotam um critério similar no que se refere à forma sintática: para os autores, uma UFE é identificada pela combinação entre dois ou mais 
elementos de uma linguagem especializada. O que difere entre as duas propostas é que na de L'Homme as UFEs são formadas por apenas dois elementos, ao passo que na de Knowles e Tomas as UFEs podem ser formadas por apenas dois elementos ou mesmo por uma frase inteira.

Krieger e Finatto (2004) apresentam critérios de definição mais específicos. Para as autoras, as UFEs são formadas basicamente por duas partes: uma matriz e constituintes variáveis. A matriz é a parte estável da UFE, enquanto as constituintes variáveis apresentam possibilidades combinatórias que dependem semântica e gramaticalmente da base matricial. A estereotipia é fator considerado na identificação das UFEs, porém não é elemento excludente, pois para as autoras as UFEs apresentam um caráter de fixação variável.

Mais específicos ainda são os critérios adotados por Bevilacqua (2004) que, ao revisar a literatura, apresenta oito critérios identificadores para as UFEs: caráter sintagmático, estabilidade semântica, estabilidade sintática ${ }^{58}$, grau de fixação ${ }^{59}$, inclusão de uma unidade terminológica, semicomposicionalidade ou composicionalidade, uso em uma comunicação especializada e frequência relevante.

A autora observa que alguns dos critérios são obrigatórios e outros facultativos, sendo assim, adota para sua pesquisa os seguintes critérios:

- presença de uma unidade terminológica;

- estabilidade sintática: as UFEs devem apresentar um certo grau de fixação nas estruturas morfossintáticas;

- estabilidade semântica: determinada pela relação estabelecida entre os elementos que compõem a UFE;

- frequência relevante em textos de um domínio especializado;

- uso em um domínio especializado.

Para a autora, as UFEs restringem-se a sintagmas verbais ou derivados do verbo. São, em sua maioria, constituídas por uma base que possui uma estrutura subjacente formada por um núcleo eventivo (NE) e um núcleo termi nológico (NT), a partir do qual

\footnotetext{
${ }^{58}$ Refere-se à identificação das UFEs a partir de padrões morfossintáticos pré-estabelecidos e à possibilidade de inserir outros elementos no interior da unidade.

${ }^{59}$ Determinado pelo caráter sintagmático e pela estabilidade semântica.
} 
é possível o surgimento de três estruturas superficiais: $[[\mathrm{NE}] \mathrm{v}+[\mathrm{NT}] \mathrm{N}]$; $[[\mathrm{NE}] \mathrm{Ndev}+$ $[\mathrm{NT}] \mathrm{Sp} ;[[\mathrm{NT}] \mathrm{N}+[\mathrm{NE}] \text { PartAdj }]^{60}$. No entanto, vale ressaltar que, devido aos critérios estabelecidos, tanto o NT quanto o NE possuem valor especializado e, consequentemente, a unidade como um todo adquire esse valor. Por esse motivo, os fatores que determinam a estabilidade e o grau de fixação são mais de caráter semântico e pragmático-discursivo do que sintático (BEVILACQUA, 2002, p. 138).

Apesar das especificidades adotadas por cada autor, fica claro que as quatro propostas compartilham um mesmo critério: a presença de uma unidade terminológica como elemento obrigatório para a identificação de uma UFE.

No que se refere aos autores da segunda tendência, optamos por dividi-los em dois grupos. Um primeiro grupo que, apesar de ter a tradução como pano de fundo para o estudo das UFs, adota critérios morfossintáticos e, um segundo grupo que adota critérios utilizados na Linguística de Corpus.

Como representantes do primeiro grupo temos Marco (2000) e Frérot, Rigou e Lacombe (2001). Marco propõe a identificação das UFEs por meio de collocational frameworks, que podem ser definidas como matrizes compostas por palavras gramaticais como, por exemplo, a matriz the...of. Nessa visão, o significado dos termos não é estável, muda de acordo com as palavras com que coocorre. Frérot, Rigou e Lacombe não explicitam os critérios adotados; no entanto, deixam clara uma preocupação com padrões morfossintáticos, já que a identificação das UFEs é realizada por meio da extração de estruturas sintáticas recorrentes.

Representante do segundo grupo, Gouadec (1994) adota dois critérios para a identificação das UFEs: a estereotipia e a repetição. $O$ primeiro se refere ao comportamento linguístico das UFEs e o segundo à frequência com que uma UFE ocorre em um domínio especializado. Ao considerar esses dois critérios, o autor aborda as UFEs de uma forma mais abrangente, que trata desde colocações até um conjunto de frases.

Também preocupada com a frequência, Tognini-Bonelli (2002) delimita as UFEs por meio da observação da coocorrência e defende a idéia de que os termos são, em sua grande maioria, vinculados a expressões maiores que caracterizam um modo de

${ }^{60}$ Em que NT= núcleo terminológico; V=verbo; Ndev =substantivo deverbal; $\mathrm{Sp}=$ sintagma preposicional; PartAdj = particípio adjetivo . 
expressão específico de uma dada linguagem especializada, sem deixar clara a extensão que essas expressões podem ter.

Também adepto do critério da frequência, Stubbs (2001) não estabelece distinção entre colocação e UF e se mostra vinculado a uma abordagem mais direcionada pelo corpus, pois, para o autor, é a partir do corpus que o pesquisador consegue identificar as UFs ${ }^{61}$.

Último representante desse grupo, Palumbo (2003) não estabelece padrões de identificação ${ }^{62}$; no entanto, frisa a importância da construção de um corpus como ponto de partida para a extração fraseológica, sejam os critérios eleitos os de frequência ou os sintáticos.

Assim como no primeiro grupo, fica claro o compartilhamento de um mesmo critério pelos autores desse segundo grupo: a frequência, critério que, além de revelar uma preocupação com a tradução, explicita uma forte ligação com a Linguística de Corpus, uma vez que é a partir da observação de corpora que se estabelece uma frequência significativa para a identificação das UFs e, no caso dos autores citados, para o estabelecimento de equivalentes tradutórios. Além disso, nenhum dos pesquisadores demonstra preocupação em distinguir colocação de UF, fato que não apresenta grande relevância para a tradução, uma vez que os tradutores necessitam traduzir segmentos de um texto especializado de uma língua A para uma língua B, sejam eles formados por duas ou mais palavras.

\subsection{Definição e critérios adotados}

Nos parágrafos que seguem, partiremos do que foi apresentado para tentar estabelecer alguns parâmetros de identificação e uma definição de UFE a fim de mostrar nosso posicionamento diante das diferentes abordagens existentes. Dada a amplitude dos estudos fraseológicos, os critérios apresentados e a definição que propomos não têm como pretensão alguma serem absolutos. Ao contrário, o objetivo em questão é fazer um recorte das diferentes abordagens de modo a estabelecer critérios de identificação

\footnotetext{
${ }^{61}$ É importante ressaltar que, na obra consultada, Stubbs (2001) reflete tanto sobre UFs em língua geral como em línguas de especialidade. No entanto, em sua teoria, não faz distinção na definição e tampouco na identificação das UFs nos dois âmbitos distintos.

${ }^{62}$ Embora o autor não explicite os critérios de identificação que segue, é visível, em seu trabalho, um comprometimento com a frequência.
} 
que permitam a extração de UFEs relevantes ao nosso trabalho. A definição resultante é provisória e tem como fator delineador os objetivos gerais da pesquisa.

Tognini-Bonelli (2001, p. 104) resume, de forma muito clara, a problemática diante da delimitação de UFEs:

onde está a fronteira entre um item relativamente independente, como uma palavra ou um termo técnico, e um onde o contexto se torna parte de uma expressão, a qual, Sinclair defende, é, na realidade, um item lexical multipalavra $^{63}$.

Diante dos critérios propostos, selecionamos os que melhor se enquadram dentro do objetivo de nossa pesquisa: entender o texto especializado de futebol por meio do levantamento, análise e identificação de equivalentes de UFEs. Como exposto na introdução, um dos objetivos finais da pesquisa é auxiliar qualquer pessoa que necessite produzir um texto sobre futebol em português ou inglês. Tendo em vista este objetivo, consideramos importante tudo o que é de uso convencional no futebolês, pois, assim como Gouadec (1994), Palumbo (2003) e outros teóricos que tratam as UFEs tendo a tradução como pano de fundo, toda e qualquer informação que auxilie o consulente da obra final a utilizar as UFEs de forma convencional será considerada relevante.

Partindo dessa idéia, justifica-se que a frequência seja nosso primeiro critério de identificação. Além disso, em um primeiro momento, eleger a frequência como critério parece essencial em qualquer pesquisa direcionada pelo corpus. No entanto, no decorrer da análise, nos ocorreram algumas dúvidas cruciais que, aos poucos, transformaram a delimitação de um "simples" critério como a frequência em uma escolha extremamente complexa.

Primeiramente, pensamos em estabelecer um número de corte alto com o objetivo de não pegar muito ruído ${ }^{64}$. O problema é que se o número de corte é muito alto, os neologismos e os hapax legomena ${ }^{65}$ que formam UFEs passam despercebidos. Por outro lado, quando estabelecemos um número muito baixo, qualquer sequência de palavras pode ser considerada uma UFE.

\footnotetext{
${ }^{63}$.Where is the boundary between a relatively independent item, such as the word as a technical term, and one where the environment becomes part of a phrase, which, Sinclair argues, is effectively a multiword lexical item.

${ }^{64}$ Ruído aqui é entendido como associações de palavras que não configuram UFEs, mas que possuem frequência alta no corpus.

${ }^{65}$ Palavras que ocorrem uma única vez em um corpus.
} 
Outra questão central à identificação das UFEs, senão a mais importante é: frequência do que?

Seria quase impossível não cair em contradição ao responder essa pergunta trabalhando com extração semiautomática de UFEs e com uma abordagem textual da Terminologia. Uma vez que nossa proposta é tirar o foco de atenção do termo e o direcionar para o texto como um todo, seria um tanto quanto estranho ter o termo como ponto de partida para a identificação das UFEs. No entanto, nossas tentativas de gerar WordLists com mais de uma palavra não foram bem sucedidas. Por esse motivo, optamos por adotar a definição de termo proposta por Pearson (1998). De acordo com essa definição existem três categorias de termos: subject specific vocabulary, non subject-specific specialized vocabulary e general vocabulary. O primeiro grupo é composto por itens lexicais que fazem parte de um único domínio; em nosso caso, itens lexicais que ocorram exclusivamente no futebolês. O segundo é composto por itens lexicais que fazem parte de mais de um domínio especializado como os itens lexicais que ocorrem em mais de um domínio esportivo (ex.: falta, gol, etc.). O terceiro é composto por itens lexicais de língua geral que adquirem status de termo simplesmente por serem utilizados em uma determinada língua de especialidade. Neste último caso, consideramos termos preposições, conjunções, enfim, palavras gramaticais que apresentem frequência relevante nos textos ${ }^{66}$. Ao fazer essa distinção, Pearson propõe um novo paradigma para a Terminologia, pois não inclui em sua definição a característica principal das definições de correntes mais tradicionais: denominação para um determinado conceito.

Ao adotar a definição de Pearson, refutamos a idéia de que um termo deve estar relacionado a um único conceito e de que seu significado é sempre estável.

Neste trabalho, os termos serão identificados por meio do cruzamento da wordlist do nosso corpus com a wordlist de um corpus de referência com o objetivo de gerar keywords, que são palavras-chave do domínio do futebol. Partiremos, então, dessas palavras-chave para realizar a identificação das UFEs.

Reconhecemos a validade da adoção de critérios morfológicos para a identificação das UFEs, como propõem Bevilacqua (2004) e Zílio (2009). Contudo,

\footnotetext{
${ }^{66}$ Importante ressaltar que, embora a visão de termo adotada permita o reconhecimento de palavras gramaticais como termo, nossos critérios de identificação nos direcionam para a identificação de sequências de palavras coocorrentes.
} 
para nossos objetivos, estaríamos limitando os achados, pois estaríamos preocupados com a produção de texto e, em se tratando de uma situação real de uso da língua, cabe salientar que o autor não realiza suas escolhas lexicais por meio de padrões morfossintáticos.

Ainda no que se refere à frequência, estabelecemos o número de corte maior ou igual a três ocorrências de uma associação de, pelo menos, três palavras; sendo uma obrigatoriamente palavra-chave como, por exemplo, bola.

Definidas as palavras-chave como nosso ponto de partida, deparamos com outras questões inerentes ao processo de identificação de UFEs: o grau de fixação, a comutabilidade, a extensão e a indecomponibilidade, que discutimos a seguir.

O grau de fixação também foi adotado como critério de identificação. Consideramos UFEs desde estruturas completamente fixas até estruturas que admitem um certo grau de variação. No futebolês, são comuns os casos em que arti gos, pronomes e preposições que fazem parte da unidade fraseológica sofram variação. Em português, a UFE $F A Z E R^{67}\{a \mid u m\}$ gol pode ocorrer tanto com o artigo definido quanto com o artigo indefinido; em inglês, um de seus possíveis equivalentes, NOD \{home (into an empty goal) | in | into the net\} apresenta um grau de variação bem flexível. O verbo $N O D$, palavra-chave da UFE, pode ocorrer seguido de home, in ou into the net. Além disso, quando seguido de home, ainda existe a opção de se utilizar into an empty goal.

a) It came from the head of Sneijder who profited from slack marking in the sixyard box to nod home his third goal of the finals after Kuyt had flicked on Robben's corner.

b) Hull just couldn't withstand the pressure though and when Myhill failed to claim a Van Persie free-kick into the area, the ball looped up nicely for Gallas who nodded home into an empty goal although Hull looked to have a case in their claims for offside against the Frenchman.

c) Barry helps to calm England's early nerves and sloppiness to nod in the opener.

\footnotetext{
${ }^{67}$ Maiúsculas representam o lema do verbo.
} 
d) A free-kick floated into the Uruguay box is headed up in the air by Maurico Victorino and it lands about six yards out - where Bolton's Lee Chung-Yong is on hand to get there before Fernando Muslera and nod into the net, with Jorge Fucile failing to hack it off the line.

O grau de fixação nos remete, quase que automaticamente, a um outro critério: a comutabilidade, ou seja, a propriedade da substituição de elementos sinonímicos na unidade. Adotamos, para nossos propósitos, os níveis de comutabilidade propostos por Pavel (1993): combinações fixas, que não admitem comutabilidade; combinações semifixas, que admitem substituição de um elemento da combinação; e combinações mais livres. Como exemplo de combinação fixa, temos a UFE longe do gol, em que não utilizamos a palavra distante ou algum outro sinônimo no lugar de longe. Como exemplo de combinação semifixa, remetemos à UFE NET [a goal], em que a segunda parte pode ser substituída por um gol específico, por exemplo:

a) Garcia netted a goal in each half to help Liverpool to victory.

b) Substitute Stefan Maierhofer netted a late consolation for Wolves.

No primeiro exemplo, temos NET a goal, enquanto no segundo [a goal] foi substituído por [a late consolation], que se refere a um gol de honra que foi marcado nos últimos minutos da partida. A UFE SLAM (the ball) \{in | past [goalkeeper] |home / SLAM \{in | home $\}$ [a kick] exemplifica os casos de combinações mais livres. Tomemos os seguintes exemplos:

a) Grosso slammed in the decisive kick.

b) Lukas Podolski celebrates after slamming the ball past David James for the Germans second.

c) Spurs' keeper Gomes needlessly hauled down Johnson as he dashed from his goal and Gerrard slammed home the spot-kick.

No primeiro exemplo, a UF é formada por SLAM in; no segundo, the ball, elemento opcional, está presente e é seguido de past David James, goleiro do Bristol City; no último, a UF é composta por SLAM home e é seguida por the spot-kick, chute que caracteriza uma cobrança de pênalti. 
O grau de fixação está intrinsicamente ligado à comutabilidade, pois é a partir desta última que uma unidade se encaixa nos graus de fixação propostos por Pavel (1993). Teoricamente, quanto maior a possibilidade de comutabilidade, menos fixa é a combinação e, consequentemente, menor a possibilidade de a associação constituir uma fraseologia. Em nosso trabalho, a comutabilidade não é utilizada como fator excludente, pois nosso propósito é conscientizar o consulente da obra final sobre as mais prováveis variações da UFE.

Outro critério que costuma ser adotado para a delimitação de UFs é a extensão. Como pudemos observar durante a breve revisão bibliográfica sobre o assunto, há autores que delimitam as fraseologias tendo como um dos critérios o número de palavras. No entanto, não acreditamos que o número de palavras de uma associação seja um fator a ser considerado para validar uma UF. Explicitamos, desde o início, que nossa compilação de dados tem como objetivo ajudar produtores de texto, sendo assim, não temos motivos para privilegiar associações de duas, três ou quatro palavras, já que, uma vez frequentes em um texto especializado, todas associações passam a ser relevantes.

Já em relação à indecomponibilidade semântica, que ocorre quando o sentido de uma fraseologia não deriva da soma do significado de seus componentes, seria contraditório não considerá-la um dos critérios em nossa investigação uma vez que advogamos em prol de uma Terminologia textual cujo o foco de estudo não é o termo isolado, mas o fato de que seu significado só é alcançado por meio da análise de seus colocados dentro de um contexto sociocultural específico. Tomemos como exemplo a UFE “cricket score" em inglês, que ocorre quando um time vence o outro com uma diferença de gols grande:

At 2-0 I thought it was going to be a cricket score.

O significado da UFE é claro para qualquer inglês que conhece pelo menos um pouco de críquete e sabe que um placar como 517 x 1 é comum no jogo. No entanto, para o brasileiro comum, que pouco ou nada entende de críquete, a UF não tem o menor sentido, já que seu significado só é alcançado por meio da análise do contexto sociocultural em que está inserida. Em português, um dos possíveis equivalentes para "cricket score" é o termo "chocolate", também utilizado para descrever uma goleada: 
Desta vez, a Alemanha não precisou de pênaltis e nem de sofrimento, como em 2006: sem dar chances ao time de Diego Maradona, os alemães aplicaram um chocolate inapelável por 4 a 0 na Cidade do Cabo e estão classificados para a semifinal da Copa do Mundo, contra a Espanha.

A origem da expressão é incerta, no entanto, a idéia de que tenha surgido em uma partida do Campeonato Brasileiro, em 1981, em que o Vasco goleou o Internacional por 4-0 é compartilhada por muitos. $\mathrm{O}$ resultado foi, na época, considerado uma vingança pela derrota da final do Campeonato Brasileiro de 1979, em que o Internacional tinha derrotado o Vasco. Na final de 1981, durante a derrota do Internacional, o narrador Washington Rodrigues teria colocado no ar a música " $E l$ bodeguero" do cubano Richard Egües, cujo refrão é "Toma chocolate / Paga lo que debes".

Se o cenário acima descreve o surgimento do termo "chocolate", podemos afirmar que seu significado está atrelado a um contexto sociocultural específico. Da mesma forma que a UF "cricket score" soa estranha para o brasileiro, o significado do termo "chocolate" provavelmente será desconhecido para o inglês.

A presença de um ou mais termos costuma ser elemento fundamental na identificação de uma UFE. No entanto, em nossa pesquisa, não consideraremos a presença de termos, e sim a presença de palavras-chave. Estas, é importante ressaltar, são tratadas como elementos essenciais na formação de UFEs. Sendo assim, toda e qualquer associação de palavras que apresente ocorrência significativa no corpus constituirá potencial objeto de estudo.

Apresentamos, no quadro abaixo, um resumo dos critérios adotados em nosso trabalho para a delimitação das UFEs: 


\begin{tabular}{|l|l|}
\hline Frequência & $\begin{array}{l}\text { maior ou igual a duas ocorrências de uma associação de, pelo } \\
\text { menos, duas palavras; sendo uma delas obrigatoriamente uma } \\
\text { palavra-chave. }\end{array}$ \\
\hline $\begin{array}{l}\text { Presença de uma ou mais palavras- } \\
\text { chave }\end{array}$ & a unidade de ve conter uma ou mais palavras-chave. \\
\hline $\begin{array}{l}\text { Grau de fixação / comutabilidade / } \\
\text { extensão }\end{array}$ & $\begin{array}{l}\text { desde estruturas fixas, como expressões idiomáticas, até } \\
\text { estruturas com grau de fixação mais baixo; não delimitamos o } \\
\text { número de palavras a priori. }\end{array}$ \\
\hline Comutabilidade & combinações fixas, semifixas e mais livres. \\
\hline Indecomponibilidade semântica & $\begin{array}{l}\text { Embora apresentemos significados em nosso modelo de glossário } \\
\text { somente para as expressões idiomáticas, partimos do pressuposto } \\
\text { que o sentido de uma UFE pode ou não ser composto pela soma } \\
\text { dos significados de seus elementos. Sendo assim, não } \\
\text { consideramos a indecomponibilidade semântica critério } \\
\text { obrigatório para a delimitação de uma UFE. }\end{array}$ \\
\hline
\end{tabular}

Quadro 1 - Resumo dos critérios de delimitação das UFEs

Em resumo, propomos que associações de, no mínimo, duas palavras, sendo uma delas obrigatoriamente uma palavra-chave, apresentem frequência maior ou igual a três sejam reconhecidas como unidades fraseológicas especializadas.

Ao analisar os critérios adotados, fica evidente que trabalhamos com uma concepção bastante ampla de UFE. Tal escolha se deve ao fato de o trabalho, além de ocupar seu lugar nos estudos terminológicos, estar ligado a outras duas áreas: Tradução e Linguística de Corpus.

A concepção adotada nos permite o estudo tanto de associações que contenham um termo ${ }^{68}$ em sua definição mais tradicional, quanto de associações que não comportem um termo, mas sejam formadas por elementos que apresentem frequência relevante no corpus. Pretendemos, dessa forma, tirar do termo o status que lhe é atribuído e direcionar o estudo para a compreensão de UFEs que reflitam o uso convencionado de associações de palavras, levando em consideração as particularidades de seus significados, usos e prosódia semântica. Parte desse objetivo deve-se ao fato de acreditarmos que as unidades fraseológicas não são formadas apenas por associações entre termo e colocado, mas também por unidades lexicais convencionais em uma determinada Língua de Especialidade que não contenham um termo como a UFE pela $\{$ direita|esquerda\} e seu equivalente em inglês down the \{right|left\}.

\footnotetext{
${ }^{68}$ Palavra à qual se atribui um conceito como seu significado.
} 
O fato de não delimitarmos o número de palavras a priori nos possibilita considerar como UF desde colocações, formadas por uma base e um colocado, até expressões idiomáticas ou convencionais mais extensas.

O grau de fixação e a comutabilidade dos elementos também são considerados de forma bastante abrangente. Contudo, é importante que se destaque que a adoção de critérios quase nada restritivos se deu diante da necessidade de tratar de todas as associações compostas por mais de um elemento que provaram ser de uso convencional no futebolês.

Por fim, cremos que todas essas associações exercem papel fundamental na representação do conhecimento especializado e, por esse motivo, devem ser identificadas e descritas de forma que possam ser utilizadas adequadamente, de forma convencional, ou seja, de forma natural e fluente, em uma comunicação especializada.

\subsection{Tradução técnica e condicionantes culturais}

Embora em um primeiro momento nossa pesquisa se enquadre no âmbito terminológico, julgamos por bem tecer algumas considerações acerca da tradução. Considerações que não tem como objetivo discutir teorias da tradução, muito menos discorrer exaustivamente sobre os conceitos da disciplina. Nosso objetivo é definir e discutir alguns pontos essenciais com o objetivo de proporcionar um melhor entendimento do produto final do trabalho: um modelo de glossário fraseológico bilíngue inglês-português sobre futebol.

Entendemos tradução técnica como um ramo da tradução que se ocupa da tradução de textos de línguas de especialidade. Para caracterizar as linguagens de especialidade, tomamos a definição proposta por Zanatta (2004, p. 12):

[...] a língua especializada - ou linguagem técnica - compõe-se de vocabulário específico e ao mesmo tempo obedece a normas próprias de sua área, caracterizando, assim, uma terminologia e uma padronização, cujo uso leva à estratificação no meio em que é empregada. 
A estratificação dessas linguagens está intrinsecamente ligada ao tipo textual do texto especializado ${ }^{69}$ que apresentará maior ou menor grau de especialização.

Visto que a tradução técnica se realiza a partir de um texto técnico - "habitat natural" das terminologias -, o interesse dos tradutores por um bom manejo terminológico a fim de estabelecer equivalentes adequados entre duas línguas de especialidade é quase óbvio.

Os tradutores, assim como os intérpretes, os redatores técnicos, os jornalistas e os documentalistas são usuários indiretos das terminologias, pois a eles interessa o uso adequado dos termos, fraseologias e expressões idiomáticas para que o texto esteja de acordo com as normas de convencionalidade que regem a produção do tipo e do gênero textual em questão na cultura em que é produzido.

Muito comum é a idéia de que a tradução técnica, diferente da literária, constitui um universo à parte, pois, para alguns, sua terminologia não se deixa contaminar por relações contextuais e pragmáticas, possuindo uma certa estabilidade que favorece e facilita o processo tradutório. Com base nesses preceitos, a tradução técnica é, muitas vezes, definida como uma operação de transcodificação em que os conceitos "constituem uma (sic) amálgama indissolúvel e imune aos efeitos do tempo e do espaço, a fim de poderem resistir a uma série de condicionantes a que estão expostos." (AZENHA, 1999, p. 10).

Nesta pesquisa, adotamos a proposta de Azenha (1999, p. 60), a de uma tradução técnica que vai além dos limites do texto. Uma tradução que define o ato tradutório tendo como ponto de partida o ato de comunicação. Em virtude disso, o texto técnico, assim como qualquer outra forma de comunicação, está atrelado a uma realidade sóciohistórico-cultural.

Para o autor, não podemos deixar de lado as relações que o texto técnico trava com o contexto em que é produzido durante a tradução. Ao contrário, os termos, as fraseologias, as definições, os equivalentes e as expressões devem ser empregados de maneira convencional no texto de chegada, respeitando as variáveis ligadas ao emissor, receptor, situação e objetivo de comunicação.

Em nossa pesquisa, consideramos o gênero textual, o periódico ou site em que a notícia foi publicada, o jogo e o campeonato reportado na notícia, o autor da notícia e

\footnotetext{
${ }^{69}$ Tópico discutido no item 2.2.3.2.
} 
toda e qualquer variável que influencie a escolha terminológica. Também não podemos deixar de levar em consideração, mesmo sem entrar em detalhes, as formasrepresentações que caracterizam o futebol inglês e o futebol brasileiro. Os jeitos de jogar são diferentes e, consequentemente, as jogadas, têm reflexo direto na terminologia usada nas duas línguas. Esses diferentes jeitos de jogar podem causar dificuldade ao tradutor durante a busca de equivalentes, pois, muitas vezes, um termo comumente utilizado em uma língua simplesmente não ocorre na outra, pois caracteriza uma prática não comum.

Neste estudo, consideramos "equivalente" uma unidade fraseológica que funcione no texto de chegada como funciona no texto de partida (TAGNIN, 2007, p. 1). O conceito, bastante amplo, nos permite identificar equivalentes não só no nível da palavra, do texto ou da frase, mas também equivalentes pragmáticos, ou seja, equivalentes que embora não reflitam uma tradução para a língua de chegada, são utilizados no mesmo contexto e com o mesmo objetivo comunicativo como a UFE primeiro gol de [jogador] com a camisa $A D J A D N$, que tem como equivalente [footballer]'s first goal for [club $]^{70}$.

Outro ponto a ser ponderado em se tratando de tradução é a definição de unidade de tradução (UT). Inúmeras são as discussões a respeito da delimitação das UTs. No entanto, para os objetivos de nosso trabalho, não adentraremos nenhuma das definições já propostas e consideraremos como UTs, em nosso caso UTEs (Unidades de Tradução Especializadas), as unidades fraseológicas especializadas.

Estabelecidas as conexões entre tradução e terminologia, discutiremos, nos parágrafos a seguir, a relação entre Linguística de Corpus e tradução.

É fato que a LC muito tem a contribuir aos estudos da tradução e à formação de tradutores. Cabe salientar, no entanto, que essa relação é um fenômeno novo que está presente somente em estudos mais recentes de LC (OLOHAN, 2004, p. 14). Segundo Berber Sardinha (2004, p. 235), o estudo da tradução por meio da LC tem se tornado, nos últimos anos, uma das linhas de pesquisa mais privilegiadas da Linguística de Corpus.

Estudos de tradução e corpora tendem a dividir-se em duas áreas: teórica e prática (HUNSTON, 2002, p. 123). Em termos teóricos, as teorias da tradução podem se

\footnotetext{
${ }^{70} \mathrm{O}$ estabelecimento da equivalência entre as UFEs é explicado no item 3.3.1.4.
} 
beneficiar de corpora paralelos para investigar o processo, as metodologias, abordagens, preferências e normas de tradução. Já em termos práticos, o tradutor pode se beneficiar dos softwares que podem ser aplicados aos corpora, de corpora monolíngues disponíveis on-line para a busca e verificação de padrões linguísticos e expressões convencionais em determinada língua, de corpora paralelos para a busca de equivalentes tradutórios, de corpora comparáveis, principalmente os da língua de especialidade, para a busca e confirmação de equivalentes tradutórios. Enfim, a contribuição da LC para a tradução pode ser bastante relevante e variada.

Uma vez que a presente pesquisa tem fins terminológicos, enfatizamos aqui a importância de corpora comparáveis para a busca de equivalentes tradutórios adequados, ou melhor ainda, consagrados.

Laviosa (2002, p. 18) cita a contribuição do uso de corpora na tradução para a substituição da noção estática de equivalência, por muito tempo entendida como correspondência formal de estruturas semânticas e sintáticas, pelo conceito dinâmico de equivalência funcional entre o texto de partida e o de chegada.

A identificação de equivalentes tradutórios em corpora pode ser realizada por meio de corpora paralelos e comparáveis, ambos com suas vantagens e desvantagens. Os corpora paralelos fornecem, de forma rápida e prática, equivalentes utilizados por tradutores que, muitas vezes, são possíveis, mas não prováveis. Além disso, a escassez de corpora paralelos em áreas técnicas contribui para que tradutores optem por outras alternativas, como os corpora comparáveis e a própria web. Por outro lado, corpora comparáveis constituem fontes riquíssimas para a busca de equivalentes tradutórios uma vez que fornecerão o equivalente mais provável em contexto real de uso, pois são formados somente por textos originais. Deve-se considerar que a identificação do equivalente pode ser um pouco mais demorada, já que nem sempre é possível estabelecer uma tradução prima facie entre os termos ${ }^{71}$.

Por fim, ao considerarmos que os termos são empregados em um dado cenário histórico-cultural e, portanto, condicionados por normas sociais e linguísticas sempre sujeitas a alterações (AZENHA, 1999, p. 22), não vemos outra possibilidade senão o uso de corpora comparáveis para a identificação dos equivalentes fraseológicos ${ }^{72}$.

\footnotetext{
${ }^{71}$ Explicamos a metodologia adotada na identificação dos equivalentes das unidades fraseológicas em que não conseguimos estabelecer uma tradução prima facie no capítulo 4.

${ }^{72}$ Vide capítulo 4 para o detalhamento.
} 
Neste capítulo, apresentamos a fundamentação teórica do trabalho. Primeiro, introduzimos a Linguística de Corpus bem como a definição e as tipologias de corpus presentes na literatura; em seguida, discutimos a abordagem baseada em corpus e a abordagem direcionada pelo corpus. Na segunda seção, apresentamos um breve panorama histórico da Terminologia, descrevendo as origens e o desenvolvimento da disciplina. Introduzimos a questão do texto especializado; em seguida, discorremos sobre a Terminologia Textual e, ao final, definimos UFEs como associações de duas palavras, sendo uma obrigatoriamente uma palavra-chave, em que ambas apresentem frequência maior ou igual a três. Por fim, na terceira seção, apresentamos nossa visão de tradução técnica. No próximo capítulo, será exposta a metodologia utilizada na pesquisa. 


\section{Capítulo 3 - Materiais e Métodos}

Neste capítulo apresentamos, inicialmente, o corpus de estudo e os corpora de referência. Ao final, expomos a metodologia utilizada na pesquisa e descrevemos os passos seguidos para a análise dos dados.

\subsection{Os corpora de estudo}

Nesta seção do capítulo, apresentamos os corpora de estudo utilizados para a extração terminológica. Primeiro, descrevemos os critérios utilizados para a compi lação do corpus; para, em seguida, expormos o cabeçalho criado para facilitar o manuseio do corpus; , por fim, mostramos o etiquetador utilizado.

\subsubsection{Cons trução do corpus}

O design e a qualidade do corpus de estudo constituem o pilar de qualquer pesquisa em corpus. Há um número significativo de trabalhos dedicados a delimitar critérios para a compilação de corpus. Em nossa pesquisa, utilizamos alguns dos critéiros propostos por Atkins e Clear (1992), Hunston (2002), Sinclair (1991), Bowker e Pearson (2002), Berber Sardinha (2004) e Maia (2000).

\subsubsection{Critérios iniciais}

Um corpus pode ser definido como um conjunto de dados linguísticos sistematizados segundo determinados critérios de modo que sejam representativos de uma língua ou variedade linguística (BERBER SARDINHA, 2004, p. 18). Tendo em vista essa definição, adotamos os seguintes critérios para compilar um corpus representativo da linguagem do futebol: 


\begin{tabular}{|l|l|}
\hline Conteúdo & Especializado \\
\hline Assunto & Futebol \\
\hline Autoria & De língua nativa \\
\hline Língua & Português (BR) e inglês (ING); comparável \\
\hline Meio & Eletrônico \\
\hline Modo & Escrito \\
\hline Tipo de texto & Resultados de partidas e regras do jogo \\
\hline Período & Últimos quatro anos \\
\hline Tamanho & 250 mil palavras em cada língua \\
\hline
\end{tabular}

Quadro 2 - Critérios iniciais para a compilação do corpus

O conteúdo do corpus é especializado, pois coletamos somente textos sobre um único assunto: futebol. O corpus é de língua nativa, ou seja, todos os textos são escritos originalmente, pelo menos na teoria ${ }^{73}$, em inglês e em português, configurando, dessa forma, um corpus comparável. As variedades escolhidas foram português do Brasil e inglês britânico.

Para facilitar a construção, optamos por trabalhar somente com textos escritos e em formato eletrônico. Em se tratando de futebol, acreditamos que os gêneros textuais que melhor se aplicam à extração terminológica são as regras do jogo e notícias sobre resultados de partidas.

Escolhemos trabalhar com um corpus de amostragem estático que compreende os últimos quatro anos, visto que, no início do projeto, tínhamos à nossa disposição um corpus comparável inglês-português da Copa do Mundo de 2006. Sendo assim, a idéia foi acoplar esse corpus, já compilado, aos textos que ainda seriam coletados. Com o objetivo de caracterizar uma amostra finita da linguagem como um todo, em um dado período no tempo, achamos por bem finalizar a coleta no ano de 2010, após a Copa do Mundo. Saliente-se que a amostra coletada não caracteriza todo o período 2006-2010, pois, como já mencionado, tínhamos o corpus da copa de 2006 à nossa disposição no início da pesquisa, no entanto, só retomamos a coleta dos textos no início de 2009. O corpus final, portanto, é composto por textos dos anos de 2006, 2009 e 2010.

\footnotetext{
${ }^{73} \mathrm{Em}$ grande parte dos casos não encontramos dificuldade para afirmar que a notícia foi escrita por um falante nativo, pois se espera que uma notícia sobre o resultado de uma partida entre, por exemplo, Palmeiras e Santos, tenha sido escrita por um brasileiro para um jornal brasileiro. No entanto, algumas notícias internacionais, como a de um jogo entre o Manchester United e o Chelsea, tanto podem ter sido escritas por um brasileiro que faz parte da equipe de futebol internacional de um jornal, quanto por um inglês que escreveu para um periódico inglês e que teve sua notícia reescrita em português.
} 
Um dos critérios para uma pesquisa bem sucedida é construir um corpus balanceado e, uma vez que optamos por trabalhar somente com dois gêneros textuais, regras do jogo e notícias sobre resultados de partidas, e que as regras, independente do meio em que sejam coletadas, sempre serão as mesmas, acreditamos que o balanceamento do corpus não apresentaria grandes problemas. Coletaríamos somente a versão oficial das regras dos sites da FIFA e da CBF e a outra porção de textos que comporia o corpus seriam as notícias coletadas de periódicos e jornais esportivos online.

Optamos por trabalhar com textos jornalísticos de resultados de partidas devido à alta concentração termi nológica nesse tipo de notícias. Além disso, muitas das notícias sobre futebol, sejam elas publicadas em jornais ou em periódicos esportivos, tratam de temas os quais não pretendemos nos ocupar, como, por exemplo, contratação de jogadores, organização de campeonatos, eleição dos melhores jogadores etc. Já o subcorpus de regras do jogo foi compilado para que pudéssemos identificar a terminologia utilizada pelas associações internacionais.

Após leituras exaustivas sobre a representatividade do corpus, decidimos compilar um corpus de 250 mil palavras em cada língua. A escolha deu-se por dois motivos principais. Primeiramente, porque optamos por seguir a tipologia de corpus adotada pelo projeto $\operatorname{CorTec}^{74}$ que atualmente possui 14 corpora técnicos comparáveis inglês-português de aproximadamente 200 mil palavras cada e também por alguns projetos bem sucedidos que adotaram minicorpora ${ }^{75}$ para a extração terminológica, dentre eles: Varantola (2000), Maia (2000) e Zanettin (2002).

\subsubsection{Critérios redefinidos}

Após as primeiras buscas no corpus, não obtivemos resultados satisfatórios, pois não encontramos algumas colocações e fraseologias esperadas, tais como, gol da vitória, gol de pênalti, cometer uma falta e cavar uma falta. Os motivos para essa não incidência de fraseologias repetidas podem ser devidos à própria tipologia textual dos

\footnotetext{
${ }^{74}$ Disponível em: 〈http://www.fflch.usp.br/dlm/comet/consulta_cortec.html〉.

75 Maia (2000) descreve minicorpora como corpora compilados por estudantes para servirem a um propósito específico. São, sobretudo, formados por textos extraídos da web e não são disponibilizados para o uso público.
} 
textos que compõem o corpus. Sabe-se que a linguagem do futebol é muito criativa, cheia de desvios e marcas culturais (CAPINUSSÚ, 1998, p. 15). Por esse motivo, decidimos alterar alguns critérios e incluir em nosso corpus outros dois gêneros textuais: narrações minuto a minuto e "transmissão social". A idéia inicial seria incluir no corpus de inglês e no de português um subcorpus com a transcrição de um jogo. No entanto, o trabalho de transcrição demanda muito tempo e os softwares de transcrição disponíveis no mercado muitas vezes não conseguem reconhecer mais de uma voz ao mesmo tempo, algo que acontece em uma narração onde geralmente temos o narrador principal e os comentaristas. Decidimos, então, procurar por narrações on-line, mas não conseguimos nenhuma integral. Durante essa busca, encontramos alguns sites que disponibilizam narrações em tempo real, sempre realizadas por um comentarista ou jornalista esportivo. Localizamos também alguns sites que disponibilizam, geralmente no fim da notícia ou em um link, o relato por escrito da partida, relato este muito parecido com as narrações minuto a minuto, embora não possua, por assim dizer, a impressão pessoal que um comentarista exprime ao relatar oralmente e ao descrever os acontecimentos de uma partida ${ }^{76}$. Contudo, infelizmente, esse gênero textual foi encontrado somente nos sites ingleses e, por esse motivo, não faz parte de nosso corpus $^{77}$.

Durante a Copa do Mundo de 2010, o Globo Esporte, em parceria com duas grandes redes sociais, o Facebook e o Twitter, realizou uma "transmissão social" dos jogos. A transmissão foi feita por meio de uma ferramenta que vai ao ar alguns minutos antes do jogo no site do Globo Esporte. A ferramenta disponibiliza na web a transmissão de um jogo aliada a um bate-papo simultâneo com participantes das duas redes sociais que atuam como comentaristas do início ao fim do jogo. Coletamos todas as transmissões que estavam disponíveis, pois a princípio pensamos que os textos poderiam constituir material rico para a investigação terminológica, visto que são marcados pela oralidade, característica que ainda não tínhamos conseguido incorporar à análise.

\footnotetext{
${ }^{76}$ Os relatos de partida constituem, basicamente, a descrição dos acontecimentos de um jogo. Diferenciam-se dos excertos de narrações, pois nesses, o narrador, mesmo que por escrito, imprime sua opinião sobre a partida. Há ocorrências de adjetivos, advérbios e a linguagem é bastante criativa.

${ }^{77}$ Compilamos um corpus de aproximadamente 100 mil palavras de relato de partidas em inglês e guardamos para uma futura análise.
} 
Para compor a parte em inglês do corpus da "transmissão social", coletamos textos com as mesmas características, ou seja, narrados por um especialista e comentado por fãs de futebol usuários do Facebook e do Twitter.

O interesse por esse gênero textual surgiu ainda no início da pesquisa, ao coletarmos notícias de resultados de partidas nos periódicos ingleses e constatar a diversidade de opções de notícias que são disponibilizadas ao fã de futebol inglês. Tanto os jornais - sejam os tabloides ou os veículos mais tradicionais - como os sites esportivos apresentam uma divisão muito bem detalhada no que se refere ao tipo de notícia. Para quase todas as partidas, os sites apresentam uma notícia principal, uma narração minuto a minuto, com comentários dos usuários das redes sociais já aqui mencionadas, um link para um relato com os principais acontecimentos da partida, informações estatísticas e também uma página só com comentários de pessoas que se cadastram como usuários dos sites.

Como em português encontramos somente um site que disponibiliza a "transmissão social", optamos por coletar o mesmo gênero textual em inglês de um único site com o objetivo de balancear o corpus.

Durante uma análise prévia dos textos da transmissão social em português, observamos que, muitas vezes, as pessoas que deveriam interagir como comentaristas usavam o espaço disponível para fazer piadas e falar de outros assuntos que não a dinâmica da partida. Encontramos comentários como: "vocês viram que um vendedor se acorrenta em SP 'pelo Brasil'? \#CABAÇO” ou então "Alguma gatinha que gosta de futebol quer sair comigo?". Devido à grande ocorrência de comentários como esses, coletamos apenas 21 transmissões sociais. Poderíamos ter seguido adiante e coletado as transmissões de todos os outros jogos, mas dado o trabalho que a coleta demanda e a inapropriação de uma grande quantidade de comentários extra-partida nas transmissões sociais, achamos melhor focar na coleta de transmissões minuto a minuto e de notícias sobre resultados de partidas.

O recorte em inglês foi realizado com base no recorte em português. Sendo assim, quando atingimos número aproximado de palavras no corpus de "transmissão social" de inglês paramos a coleta.

Embora os textos da transmissão social não tenham contribuído muito para a extração terminológica, a coleta e compilação do subcorpus, este ainda que pequeno, 
nos fez observar o público que lê sobre futebol no Brasil e na Inglaterra, assim como o tipo de notícia que é consumida. Não temos dados suficientes para generalizar, mas a constatação de que os "comentaristas" brasileiros falam mais de assuntos alheios ao futebol do que sobre a partida em seus comentários sugere que o fã de futebol brasileiro se interessa menos pela interação por meio das redes sociais do que os ingleses.

Independentemente da relevância dos comentários dos fãs na "transmissão social", a composição dos tipos de texto que compõem o corpus mudou significativamente.

Os textos jornalísticos foram coletados de jornais on-line e de sites esportivos. $\mathrm{O}$ corpus de inglês é composto por textos dos seguintes sites: Football 365, eyefootball, Daily Mail, ESPN ${ }^{78}$, FourFourTwo, Football.uk, The Guardian, The Independent, Daily Mirror, FIFA, Reuters, 90 soccer, Sporting Life, The Sun, Telegraph, The FA, The Times e UEFA. Para o corpus de português, coletamos textos dos sites: Arena Esportiva, CBF, O Estado de São Paulo, Futebol Interior, Folha Online, Futebol na Rede, Gazeta Esportiva, Globo Esporte, O Globo, Jornal de Santa Catarina, Lancenet, blog do Milton Neves, Placar, Trivela e UOL Esporte.

As transmissões minuto a minuto em inglês foram coletadas dos jornais $B B C$, The Guardian, The Telegraph e Daily Mail e dos sites esportivos Footaball.uk, SkySports.uk e The FA. As transmissões em português foram coletadas dos seguintes sites esportivos: Gazeta Esportiva, Globo Esporte, LanceNet, Terra Esportes e Yahoo Sports.

A "transmissão social” foi coletada do site do Globo Esporte em português e do $B B C$ sports em inglês.

A ideia inicial, e que estaria de acordo com os princípios da LC, seria coletar a mesma quantidade de textos de jornais e periódicos com características similares, ideia que não conseguimos levar adiante, pois a disponibilidade de textos de um mesmo gênero textual em veículos informativos semelhantes em duas línguas diferentes nem sempre era correspondente. Por exemplo, para o subcorpus "transmissão social" em português, coletamos textos de um periódico esportivo. No entanto, para compor o mesmo subcorpus em inglês coletamos textos da $\mathrm{BBC}$, emissora de rádio, televisão e internet. A escolha deu-se devido à disponibilidade e, principalmente, à facilidade de

78 Embora a ESPN seja uma emissora americana e a 90 soccer uma revista também americana, os jornalistas e colaboradores são de diferentes países, em sua maioria da Europa. 
coleta, pois, embora existam periódicos esportivos ingleses que realizem esse tipo de transmissão, o site da $\mathrm{BBC}$ era o mais amigável, pois quase nunca apresentava problemas técnicos ${ }^{79}$.

Os critérios de seleção, que inicialmente classificavam o corpus como de amostragem, estático e balanceado, também foram alterados parcialmente. Ao passo que no início o balanceamento do corpus era uma tarefa simples, com a inclusão de outros dois gêneros textuais, esse processo tornou-se uma das partes mais laboriosas da pesquisa.

Para que nosso corpus fosse representativo da linguagem utilizada para descrever acontecimentos de uma partida, fizemos a divisão de gêneros textuais descrita acima. Tal divisão pressupõe que todas as partes possuam número igual ou aproximado de palavras ou de textos. Esse tipo de balanceamento não foi possível em nosso trabalho uma vez que as notícias de resultados de partidas são abundantes e estão disponíveis diariamente, enquanto as transmissões minuto a minuto e a "transmissão social" são menos recorrentes, pois os sites que possuem esses tipos de texto não os disponibilizam regularmente ${ }^{80}$. Deparamos ainda com a questão das regras: a FIFA é responsável pelas regras do jogo e as associações representantes dos países, em nosso caso a CBF, têm que utilizar as regras estabelecidas pela FIFA. Em outras palavras, não existe um conjunto de regras da $\mathrm{CBF}$ ou de qualquer outra associação que tenha sido escrito originalmente em português; o que existe é o conjunto de regras da FIFA traduzido para o português. Uma vez que as regras da CBF representam uma tradução "consagrada" e são utilizadas para a criação de regras de associações menores, estas serão aqui consideradas como texto original.

Enfrentamos ainda o problema da grande diferença no número de palavras de um texto jornalístico sobre resultados de partidas em inglês em relação ao mesmo tipo textual em português. Os textos em inglês tendem a ser mais explicativos e, consequentemente, possuem um número maior de palavras. Já os textos em português tendem a ser mais sucintos e menores:

\footnotetext{
${ }^{79}$ É muito comum esses sites travarem quando o pesquisador está selecionando o texto para copiá-lo, pois a transmissão é atualizada a cada minuto juntamente com os comentários dos internautas. A coleta tem que ser feita durante a partida, porque, muitas vezes, os primeiros comentários saem do ar ainda durante a transmissão do jogo.

${ }^{80}$ As transmissões minuto a minuto são disponibilizadas com maior frequência que as transmissões sociais, que, em português, só aconteceram regularmente durante a Copa do Mundo.
} 


\begin{tabular}{|l|l|l|l|}
\hline & \multicolumn{1}{|c|}{ número de textos } & \multicolumn{1}{|c|}{ número de palavras } & $\begin{array}{c}\text { média do número de } \\
\text { palavras por texto }\end{array}$ \\
\hline Inglês & 947 & 584.931 & 570 \\
\hline Português & 1.335 & 544.002 & 308 \\
\hline
\end{tabular}

Tabela 1 - Relação do número de palavras e de textos do subcorpus de notícias sobre resultados de partidas

O subcorpus em português possui número menor de palavras; no entanto, o número de textos é bem maior. A média do número de palavras por texto nas notícias em português é 308, ao passo que em inglês a média sobe para 570 .

Para explicar essa grande diferença, utilizamos os conceitos de high-context culture e low-context culture do antropólogo Edward Hall (1976). A teoria de Hall parte do pressuposto de que a quantidade de informação linguística e contextual necessária para trans mitir o significado varia de acordo com a cultura e, para descrever as culturas, o autor cria dois grupos: high-context culture, formado por países como Brasil, Itália, Grécia e países da África, Asia e América Latina; e low-context culture, formado por países como Estados Unidos, Alemanha, Suíça e outros países da Europa ocidental e do Reino Unido.

As culturas que pertencem ao primeiro grupo são caracterizadas por utilizarem grande quantidade de elementos contextuais, os quais auxiliam seus integrantes a entenderem as regras, ou seja, o modo como a cultura funciona. Por esse motivo, parte da informação aparece de forma implícita, é o dito pelo não dito, informações que estão subentendidas na fala ou, em nosso caso, em um texto podem contribuir muito mais para a transmissão do significado do que aparentam. Essas culturas possuem um forte senso de comunidade, fator que implica em diferentes estilos comportamentais (MANCA, 2010, p. 373), que são dados como subtendidos e, raramente, aparecem de forma explícita.

As culturas que se enquadram no segundo grupo, low-context, são caracterizadas por explicitar os elementos contextuais. Quase nada é subentendido, os assuntos são debatidos exaustivamente de modo que não restem dúvidas ou margem para uma interpretação equivocada. A comunicação é feita da forma mais explícita possível e é realizada por meio da transmissão de fatos, sem a expressão de sentimentos.

A teoria de Hall é bastante complexa e detalhada. Contudo, para nossa pesquisa, selecionamos apenas três elementos que acreditamos desempenharem papel 
fundamental na produção dos textos sobre futebol. São eles: clareza das mensagens, uso da comunicação não verbal e flexibilidade de tempo. O quadro a seguiir ${ }^{81}$ mostra como esses três elementos se realizam nos dois tipos de cultura:

\begin{tabular}{|c|c|c|}
\hline & high-context cultures & low-context cultures \\
\hline Clareza das mensagens & $\begin{array}{l}\text { informação implícita; o significado } \\
\text { entre linhas é tão importante quanto } \\
\text { o que está explícito. }\end{array}$ & $\begin{array}{l}\text { informação explícita; transmitida } \\
\text { de forma clara e simples de } \\
\text { modo a não deixar nada } \\
\text { subentendido. }\end{array}$ \\
\hline $\begin{array}{l}\text { Uso da comunicação não- } \\
\text { verbal }\end{array}$ & muita informação não verbal; & $\begin{array}{l}\text { ausência de informação não } \\
\text { verbal; todo o significado deve } \\
\text { estar explícito em forma de } \\
\text { texto. }\end{array}$ \\
\hline Flexibilidade de tempo & $\begin{array}{l}\text { tempo policromático; a noção de } \\
\text { tempo é aberta e flexível; pouca } \\
\text { importância é atribuída a horários } \\
\text { marcados; agendar uma atividade é } \\
\text { tarefa quase impossível, a menos } \\
\text { que o indivíduo tenha aprendido a } \\
\text { se organizar de acordo com o } \\
\text { tempo monocromático (HALL, } \\
\text { 1976, p. 22) }\end{array}$ & $\begin{array}{l}\text { tempo monocromático; horários } \\
\text { marcados, segmentação das } \\
\text { atividades } \\
\text { funcionam como prontidão } \\
\text { organização da noção de tempo. }\end{array}$ \\
\hline
\end{tabular}

Quadro 3 - contraste de algumas características entre high-context cultures e lowcontext cultures

O quadro, a partir da visão de Hall, mostra alguns pontos em que a cultura brasileira (high-context culture) e a cultura inglesa (low-context cultute) diferem no que se refere à produção de textos. Em nosso caso, a clareza das mensagens fica evidente nos textos jornalísticos sobre o resultado de uma partida em inglês. As informações são apresentadas de forma linear e simples. A própria divisão das páginas das notícias reflete essa organização. Tomemos, por exemplo, a estrutura da notícia de dois jornais brasileiros e de dois jornais ingleses transmitindo o resultado de uma partida.

\footnotetext{
${ }^{81}$ Quadro completo disponível em:

<http://www.changingminds.org/explanations/culture/hall_culture.htm>. Acesso em: 05 mai. 2011.

${ }^{82}$ Para Hall, embora a noção de tempo seja cultural, é possível para uma pessoa de high-context culture aprender a lidar com o tempo monocromático.
} 


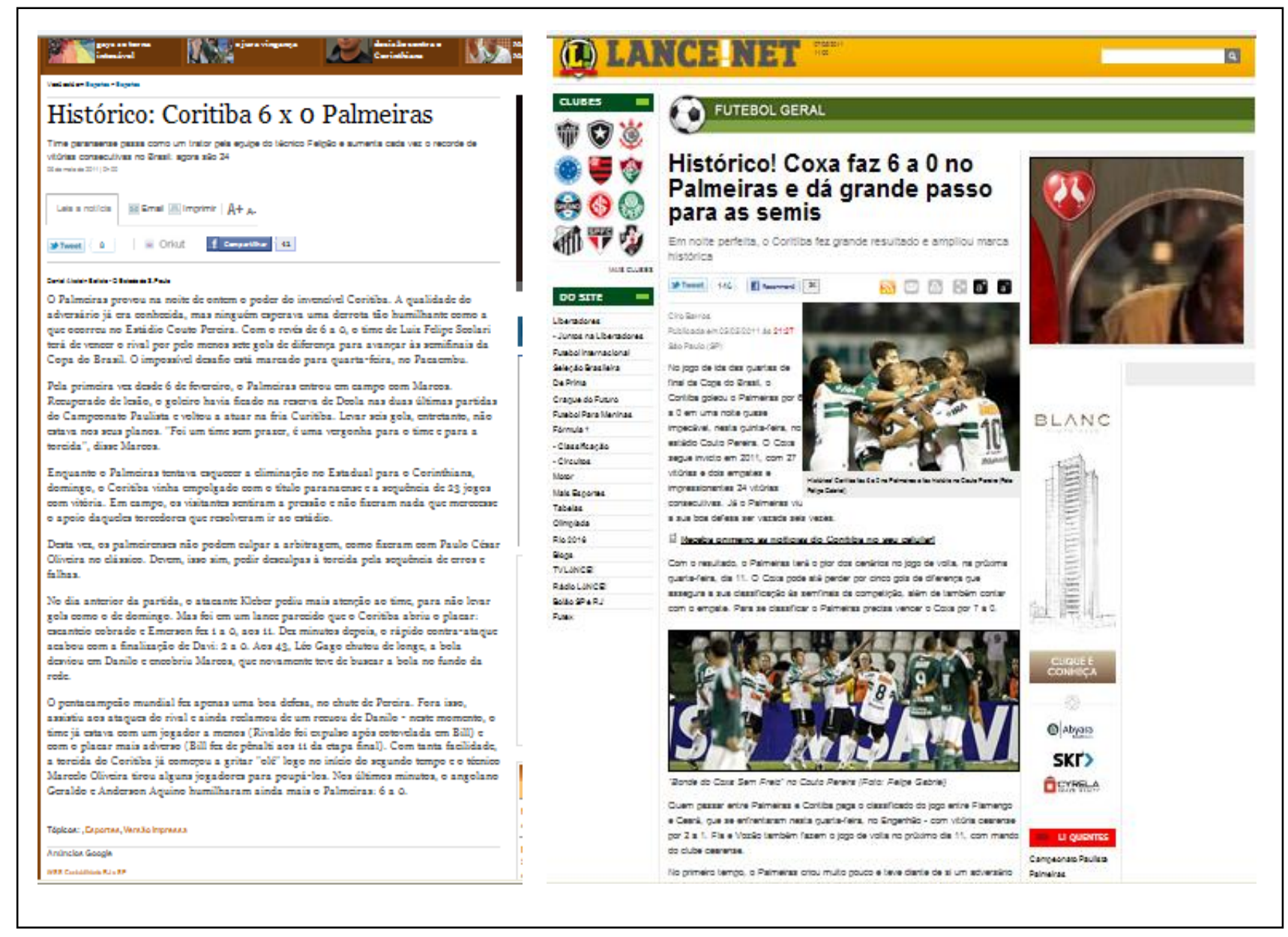

Figura 16 - página do jornal $O$ Estado de São Paulo e do Lancenet sobre o resultado da partida entre o Coritiba e o Palmeiras do jogo de ida pelas quartas de finais da Copa do Brasil de 2001 


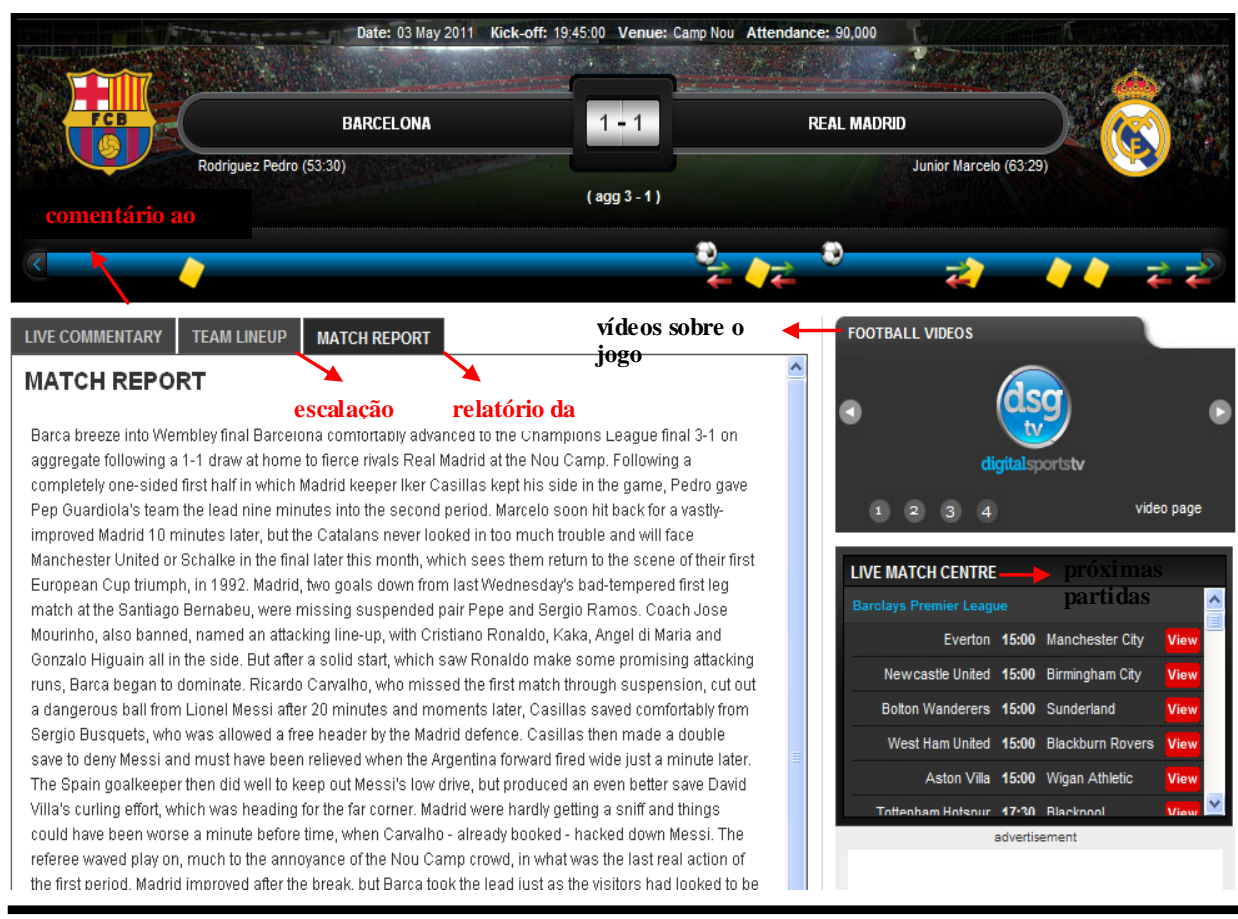

guardian.co.uk

News | Sport |Comment Culture | Business |Money $\mid$ Life \& sty] Jobs

\section{Sport > Football > Champions League}

Champions League semi-final, second leg

Barcelona hold off Real Madrid threat to reach Champions League final transmissãominuto a números da minuto Min-by-min Guardian report

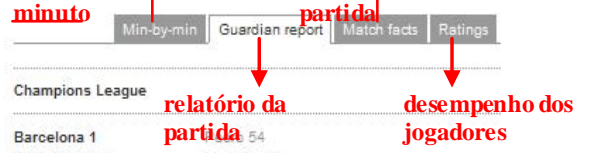

Barcelona 1 partida 54 jogadores

Real Madrid 1
Paul Hayward at Camp Nou
guardian. 00 .uk, Tuesday 3 May 201121.54 BST
Anticle history

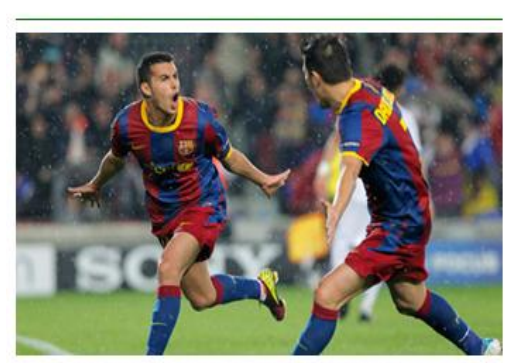

Garcelon's's Pedro, left, with David Vilia a atter scoring against Real Mastid in the Champions League semi-final second leg. Photograph: Andres Kudacki/A

The last instalment of a four-match, 18-day scorpion danos that became nastier by the hour was a proper contest in which Real Madrid recovered Manchester United in the Champions League final at Wembley. "This has been one of the most besutiful nights I have ever lived," said Pep. Guardiols, the Barç cosch.

The last act was the sweetest the bumps, on the pitch, for Eric Abidg the Barcelona defender who undenvent an eoeration teremove. a tumour
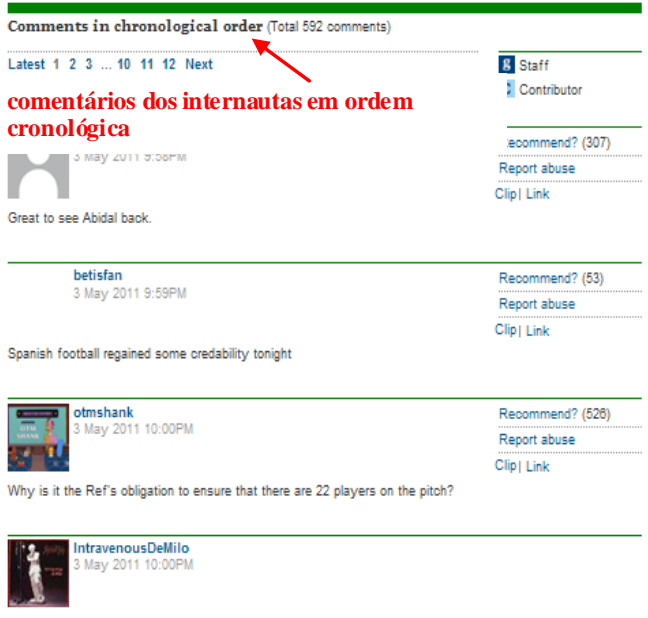

This comment was removed by a moderator because it dijn't abide by our
community standards. Replies may also be deleteded. For more detall see our
FAQS.

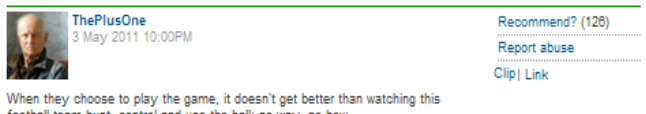

I can't imagine there is a composite of XI plyyers anywhere in the world - a club
side, a national team, a Playstation World XI - that can beast this team right now

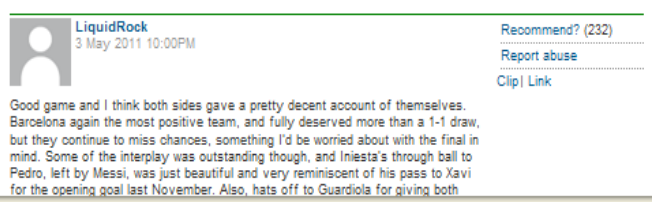

Figura 17 - página do site football.uk e do jornal The Guardian sobre o resultado da partida entre o Barcelona e o Real Madrid no segundo jogo das semifinais da Liga dos Campeões de 2011 
Como podemos notar, as páginas dos sites brasileiros, tanto a do jornal $O$ Estado de São Paulo como a do LanceNet, apresentam uma notícia principal sobre a partida e nada mais. Por outro lado, ao observarmos a página do football.uk e do The Guardian, notamos uma quantidade considerável de links na página da notícia principal. O site football.uk apresenta o relatório da partida, que corresponde à notícia principal dos jornais brasileiros, um link para os comentários ao vivo e outro link para a escalação dos times. O jornal The Guadian apresenta o relatório da partida, a transmissão minuto a minuto, os números da partida (faltas cometidas, posse de bola de cada time, impedimentos etc.), o desempenho atribuído aos jogadores por usuários do site e ainda comentários feitos pelos internautas sobre a partida, estes publicados em ordem cronológica. Além dessa diferença na estrutura, o texto é rico em detalhes e os seus relatos são feitos de forma precisa, impossibilitando, dessa forma, uma interpretação equivocada dos lances da partida. Por outro lado, nos textos em português, as informações nem sempre são apresentadas de forma linear e há muita informação implícita no texto como, por exemplo, a omissão das jogadas que resultaram em um gol, fator que não compromete, de forma alguma, o significado do texto para um leitor inserido em nossa cultura.

Quanto ao uso da informação não verbal nos textos jornalísticos, podemos afirmar que da mesma forma que os textos em inglês apresentam maior número de palavras do que os textos em português, as notícias em português normalmente são ilustradas com mais fotos do que as notícias em inglês.

Quanto à flexibilidade de tempo, observamos que durante as transmissões sociais, nas quais os internautas interagem com os narradores, o público inglês tende a comentar lance por lance, ao passo que o público brasileiro, ao opinar, geralmente tece um comentário geral sobre um período da partida, por exemplo, sobre a atuação de um time no início do primeiro tempo, e não sobre lances individuais.

Embora não tenhamos nos aprofundado na teoria de Hall, cremos que ela foi extremamente relevante para o nosso entendimento do funcionamento dos textos no Brasil e na Inglaterra, além de nos fornecer subsídios para o estabelecimento das decisões sobre os critérios de compilação do corpus.

Por fim, o tamanho do corpus também mudou bastante desde a concepção da ideia até sua finalização. Inicialmente, planejamos compilar um corpus de 250 mil 
palavras em cada língua. Contudo, após revisitar nossos critérios aumentamos sua extensão para, aproximadamente, um milhão de palavras em cada língua. Tal mudança trilhava um objetivo: encontrar mais repetições e validar os sintagmas encontrados como fraseologias, sem precisar recorrer a fontes externas, como, por exemplo, o Google. O quadro 4 mostra os critérios de compilação redefinidos:

\begin{tabular}{|l|l|}
\hline Conteúdo & Especializado \\
\hline Assunto & Futebol \\
\hline Autoria & De língua nativa \\
\hline Língua & Português (BR) e inglês (ING); comparável \\
\hline Finalidade & De estudo \\
\hline Meio & Eletrônico \\
\hline Modo & Escrito e falado (porções de falas transcritas) \\
\hline Tipo de texto & $\begin{array}{l}\text { Resultados de partidas, regras do jogo, narrações } \\
\text { minuto a minuto e "transmissão social". }\end{array}$ \\
\hline Período & Últimos quatro anos \\
\hline Seleção & De amostragem; estático; equilibrado \\
\hline Tamanho & $\begin{array}{l}\text { Aproximadamente um milhão de palavras em cada } \\
\text { língua }\end{array}$ \\
\hline
\end{tabular}

Quadro 4 - Critérios de compilação redefinidos

\subsubsection{Limpeza do corpus}

Nessa etapa eliminamos figuras, anúncios publicitários e outras informações que não são relevantes para nossa análise ${ }^{83}$.

\subsubsection{Armazenamento dos textos}

Os textos foram gravados em extensão ".txt" no programa Bloco de Notas e armazenados em subpastas para facilitar sua manipulação pelo Wordsmith Tools, software que utilizamos para processar o corpus.

Também para facilitar essa manipulação, optamos por nomeá-los de acordo com a nomenclatura utilizada no Cortec (Corpus Técnico-Científico) disponível no Projeto Comet. Exemplo:

\section{JO-IF-GUA_016}

em que, $\mathrm{JO}=$ texto jornalístico, $\mathrm{IF}=$ informativo, $\mathrm{GUA}=$ The Guardian, e 016= número do arquivo.

\footnotetext{
${ }^{83}$ Guardamos os textos em Word com todas essas informações para futuras pesquisas e referências
} 


\subsubsection{Composição do corpus}

Após redefinir os critérios de compilação e realizar um primeiro balanceamento construímos um corpus com as seguintes características:

\begin{tabular}{|c|c|c|c|c|c|c|c|c|c|c|}
\hline & \multicolumn{2}{|c|}{ Total } & \multicolumn{2}{|c|}{ Jornalístico } & \multicolumn{2}{|c|}{ Regras } & \multicolumn{2}{|c|}{$\begin{array}{c}\text { Transmissão } \\
\text { mi nuto a minuto }\end{array}$} & \multicolumn{2}{|c|}{$\begin{array}{c}\text { Transmissão } \\
\text { social }\end{array}$} \\
\hline & tokens & $\begin{array}{l}\mathrm{n}^{\circ} \mathrm{de} \\
\text { textos }\end{array}$ & Tokens & $\begin{array}{l}\mathrm{n}^{\circ} \mathrm{de} \\
\text { textos }\end{array}$ & tokens & $\begin{array}{l}\mathrm{n}^{\circ} \mathrm{de} \\
\text { textos }\end{array}$ & tokens & $\begin{array}{l}\mathrm{n}^{\circ} \mathrm{de} \\
\text { textos }\end{array}$ & tokens & $\begin{array}{l}\mathrm{n}^{\circ} \mathrm{de} \\
\text { textos }\end{array}$ \\
\hline Inglês & 1.002 .897 & 1.103 & 584.931 & 947 & 22.583 & 1 & 322.895 & 138 & 72.488 & 17 \\
\hline português & 917.073 & 1.641 & 544.002 & 1.335 & 24.593 & 1 & 311.147 & 284 & 37.331 & 21 \\
\hline
\end{tabular}

Tabela 2 - Características do corpus após o primeiro balanceamento

O número de palavras não difere muito entre os dois corpora, 1.002 .897 em inglês e 917.073 em português. Tentamos, na medida do possível, fazer o balanceamento pelo número de palavras em cada categoria e não pelo número de textos. Ao observar a tabela 2, podemos perceber que em todas as categorias os corpora de português possuem número maior de textos, fato que, em nenhum dos casos, coincidiu com número maior de palavras ${ }^{84}$. Embora o balanceamento tenha sido realizado pelo número de palavras, encerramos a coleta no segundo semestre de 2010, quando atingimos o maior número possível de transmissões minuto a minuto em português. Como já possuíamos uma quantidade superior de textos da mesma categoria em inglês, realizamos o corte desse subcorpus pelo número de textos e não pelo número de palavras.

O subcorpus que apresenta maior diferença no número de palavras é o da “transmissão social". Tal diferença pode ser justificada por dois motivos principais. Primeiramente, é característica intrínseca aos textos em inglês apresentarem mais informações e serem mais detalhados. Além disso, fazer comentários em um site sobre os lances do jogo parece ser prática comum ao torcedor inglês, que interage durante toda a partida com os comentaristas, ao passo que o torcedor brasileiro parece não se

\footnotetext{
${ }^{84}$ Exceto em Regras, em que o número de palavras é maior em português e número de textos é idêntico, um pra cada língua.
} 
interessar pela prática e, quando participa das narrações, aborda outros tópicos que não a partida ${ }^{85}$.

Outro fator que contribuiu para esse tipo de divisão foi a relação type/token ratio $^{86}$ dos quatro subcorpora. Em inglês o type/token ratio continuava a subir à medida que inserimos mais textos, indicando a incidência de palavras novas (types), já em português essa relação não sofre alteração, ou seja, não há aumento significativo no número de formas novas com a inserção de novos textos.

Uma vez que nossa pesquisa possui fins terminológicos e não discursivos ou de análise de gêneros textuais, realizamos o balanceamento "final" do corpus pelo número de palavras. A alternativa encontrada foi coletar mais textos jornalísticos em português do que em inglês para compensar a diferença nos outros gêneros.

\subsubsection{Caracterização das fontes utilizadas}

Neste item apresentaremos, de forma mais detalhada, as fontes dos textos que compõem os corpora de estudo. A caracterização será dividida por língua e feita em forma de gráficos para melhor visualização. Primeiramente, mostraremos as fontes utilizadas para a composição do corpus jornalístico; em seguida, as fontes que compõem o corpus de transmissão minuto a minuto e, ao final, as que compõem o corpus de "transmissão social".

\subsection{Corpus de inglês}

A tabela 3 contém as fontes que configuram o corpus jornalístico, composto por textos sobre resultados de partidas da Premier League ${ }^{87}$, da Football League Championship $^{88}$, da Football League One ${ }^{89}$, da Champions League ${ }^{90}$, da Confederations Cup $^{91}$ e também por textos coletados durante as copas do mundo de 2006 e de 2010.

\footnotetext{
${ }^{85}$ Não eliminamos nenhum dos comentários realizados pelos internautas, nem mesmo os que fogem à partida.

${ }^{86}$ Relação entre o número de palavras corridas e palavras distintas. Na frase "O goleiro defendeu o gol", temos 5 types (palavras corridas) e 4 tokens (palavras distintas), pois o artigo "o" ocorre duas vezes.

${ }^{87}$ Liga profissional de futebol da Inglaterra que está no topo da pirâmide do futebol inglês.

${ }^{88}$ Mais alta di visão da Football League inglesa, e a segunda mais alta di visão no sistema de ligas inglesas de futebol, depois da Premier League.

${ }^{89}$ Segunda competição mais importante da Football League.
} 


\begin{tabular}{|l|l|}
\hline \multicolumn{1}{|c|}{ Fonte } & \multicolumn{1}{c|}{ sigla } \\
\hline Football365.com & 365 \\
\hline BBC Sport & BBC \\
\hline sportsillustrated.cnn & CNN \\
\hline Daily Mail & DAY \\
\hline ESPN & ESPN \\
\hline Eyefootball & EYE \\
\hline FourFourTwo & FFT \\
\hline FIFA News & FIF \\
\hline Football.co.uk & FOO \\
\hline The Guardian & GUA \\
\hline The Independent & IND \\
\hline Los Angeles Times & LAT \\
\hline Mercury news & MER \\
\hline Daily Mirror & MIR \\
\hline News Week & NW \\
\hline The New York Times & NYT \\
\hline Reuters & REU \\
\hline Sky Sports & SKY \\
\hline Soccer Magazine & SOC \\
\hline sportingLife.com & SPL \\
\hline The Sun & SUN \\
\hline Telegraph & TEL \\
\hline The FA & TFA \\
\hline The Times & TIM \\
\hline UEFA & UEF \\
\hline The World Cup Blog & WCB \\
\hline The Washington Post & WP \\
\hline Tabela 3 Fons & \\
\hline
\end{tabular}

Tabela 3 - Fontes utilizadas para a compilação do corpus jornalístico de inglês

Como explicado anteriormente, por razões óbvias escolhemos trabalhar com a variante britânica do inglês. No entanto, ainda assim, possuímos algumas fontes que refletem, a princípio, o inglês americano: os jornais The New York Times, The Washington Post e LA Times, o site da rede de programação de esportes e entretenimento ESPN e a revista semanal Newsweek.

No início da pesquisa já tínhamos à disposição um corpus com textos sobre a Copa do Mundo de 2006 e, na época em que o corpus foi compilado, o recorte para o inglês britânico ainda não tinha sido feito, por esse motivo o corpus contém textos tanto de fontes inglesas quanto americanas. Na verdade, a maior parte do corpus é composta por textos do The New York Times, do The Washington Post e da revista Newsweek. Ao optar por não excluir esses textos do corpus, estamos colocando em prática um dos

\footnotetext{
${ }^{90}$ Competição organizada pela UEFA para os clubes de futebol mais prestigiados da Europa.

${ }^{91}$ Torneio organizado pela FIFA entre os os seis campeões continentais mais o país-sede e o campeão mundial. Ocorre a cada quatro anos.
} 
princípios da LC: a reusabilidade. Se existe à nossa disposição um corpus sobre a temática com que trabalhamos, por que não usá-lo? Além disso, a Copa do Mundo é um evento de repercussão mundial, maior nos países em que o esporte é mais praticado, mas também acompanhado em países em que o futebol representa um papel secundário. No entanto, qualquer expressão diferente entre as duas variantes poderá ser identificada pela etiqueta $\left\langle\right.$ language $>^{92}$ presente no cabeçalho.

Outra parte do corpus jornalístico foi compilada para a realização do trabalho final da disciplina "Panorama Teórico da Tradução" (de mar. 2009 à jul. 2009). O trabalho tinha como propósito estudar as adaptações que notícias sobre resultados de partidas de futebol escritas originalmente em inglês sofrem quando são reescritas em jornais brasileiros. Para tanto, compilamos dois corpora: um com textos escritos originalmente em inglês e outro com textos escritos em português a partir de notícias em inglês. Em relação à tradução jornalística, não existe uma definição clara de texto original. Contudo, esse não é um problema relacionado somente à tradução, é uma característica intrínseca ao texto jornalístico. Muitas notícias dos jornais que lemos são adaptações intra ou interlinguais de despachos de agências de notícias ou de notícias de outros jornais. Desse modo, uma única notícia pode ser o recorte de dois ou três despachos feitos por uma ou mais agências. Por exemplo, a revista Placar frequentemente trabalha com a Gazeta Press, assim como o jornal The Guardian com a agência Reuters.

Por esse motivo, para a referida disciplina, nosso critério de coleta foi selecionar textos que retratassem a mesma partida, oriundos das mesmas agências de notícias e, sempre que possível, coletados no mesmo período do dia. Dada a complexidade da compilação dessa parte do corpus, acreditamos justificar a presença de sete textos da ESPN, dois do Los Angeles Times e seis do The New York Times, já que muitas vezes não encontrávamos uma notícia que tivesse como origem um despacho, por exemplo, da Reuters, e que tivesse sido publicada em um jornal brasileiro tendo como origem o mesmo despacho.

Para encerrar a parte americana do corpus jornalístico, durante a copa de 2010 coletamos dez textos da ESPN e, assim como nos outros casos, também temos uma justificativa plausível. Chegamos a esses textos por meio de um link no nome do autor

\footnotetext{
${ }^{92}$ Vide figura 1
} 
de outras notícias em um jornal inglês. Ou seja, o veículo de informação é americano, mas como o jornalista que escreveu a notícia é inglês e escreve regularmente para um periódico inglês, não vimos problemas eminserir os textos no corpus.

Utilizamos 27 fontes distintas. Dentre elas, jornais, tabloides, periódicos esportivos, periódicos especializados em futebol, uma revista e uma agência de notícias. O gráfico 1 mostra a porcentagem de cada tipo de veículo informativo na composição do corpus:

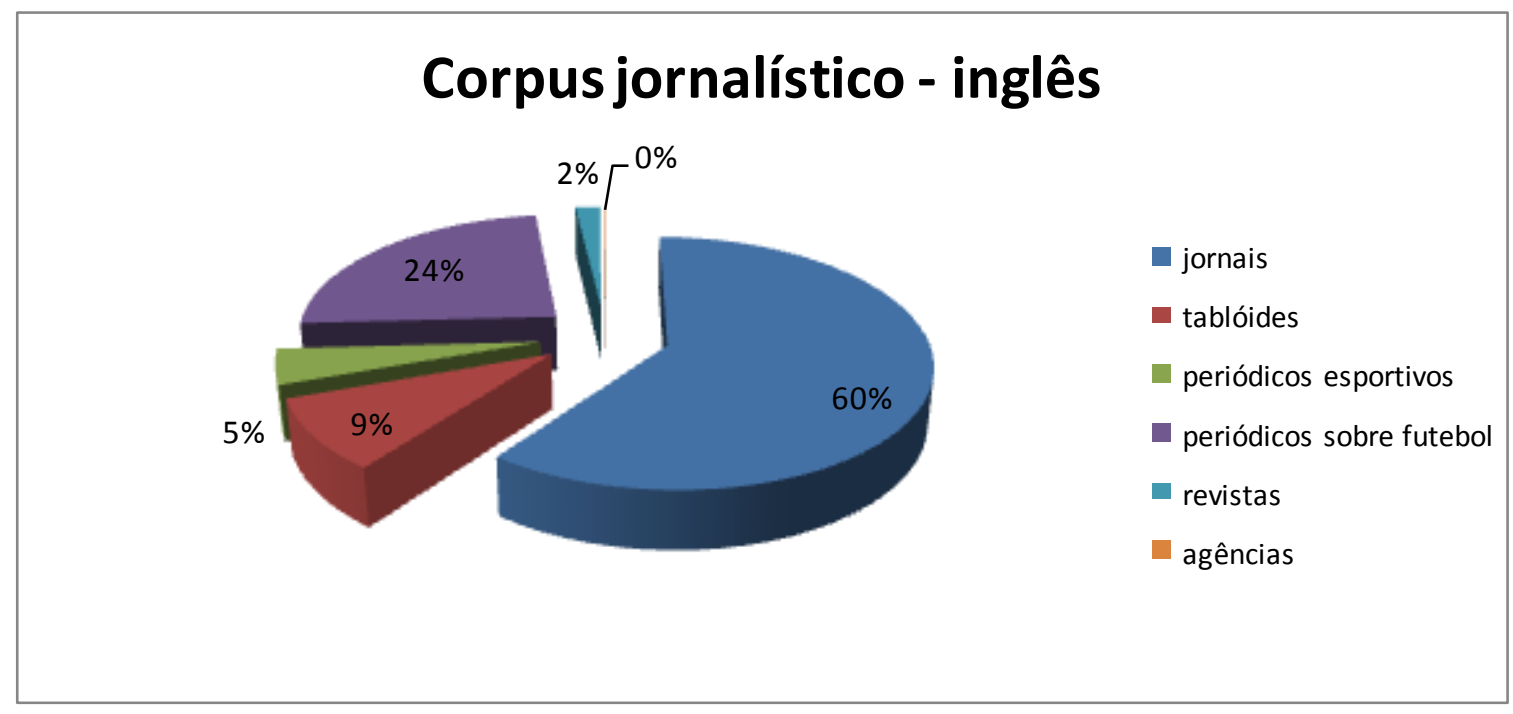

Gráfico 1 - Tipos de fontes utilizadas na composição do corpus jornalístico de inglês

Para a composição do corpus de transmissões minuto a minuto, coletamos textos das seguintes fontes:

\begin{tabular}{|l|l|}
\hline \multicolumn{1}{|c|}{ Fonte } & \multicolumn{1}{c|}{ sigla } \\
\hline BBC Sport & BBC \\
\hline Daily Mail & DAY \\
\hline Football.co.uk & FOO \\
\hline The Guardian & GUA \\
\hline Telegraph & TEL \\
\hline Sky Sports & SKY \\
\hline The FA & TFA \\
\hline
\end{tabular}

Tabela 4 - Fontes utilizadas para a compilação do corpus de transmissão minuto a minuto de inglês 
O gráfico a seguir mostra a porcentagem de cada tipo de veículo informativo na composição do corpus:

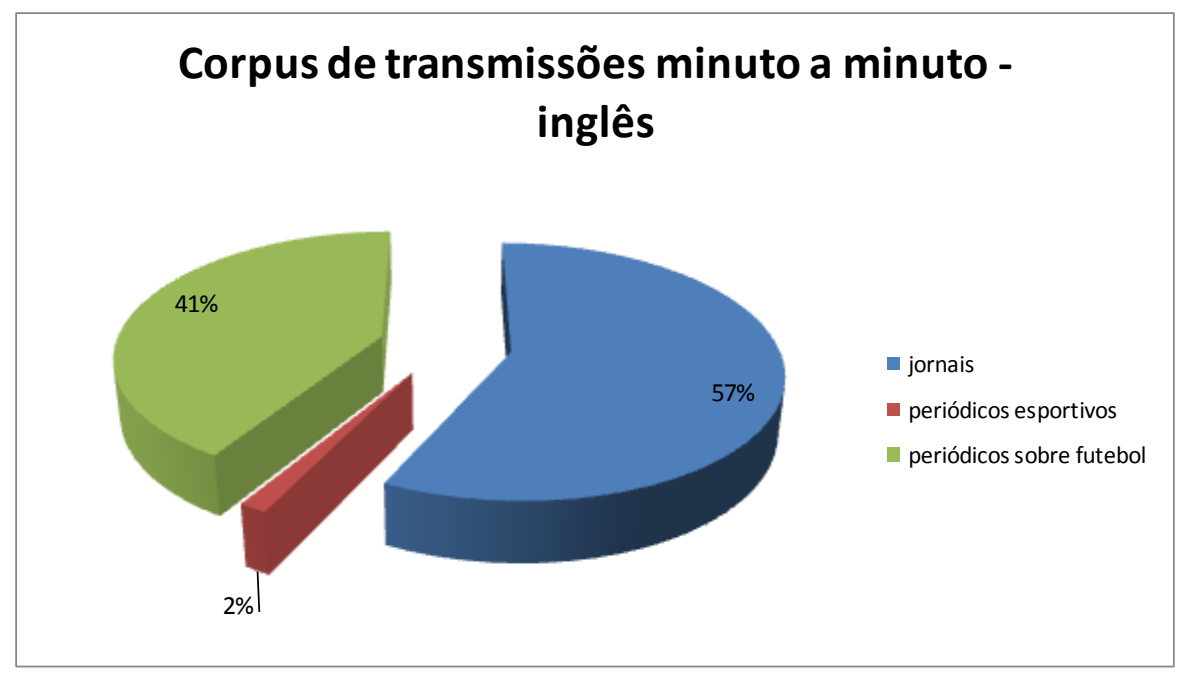

Gráfico 2 - Tipos de fontes utilizadas na composição do corpus de transmissões minuto a minuto de inglês

A caracterização do corpus de "transmissão social" não demanda apresentação de tabela ou gráfico uma vez que todos os textos, 17 no total, foram coletados de uma única fonte: BBC.

\subsection{Corpus de português}

A tabela 5 contém as fontes que compõem o corpus jornalístico. É formado por textos sobre resultados de partidas do Campeonato Brasileiro, do Campeonato Paulista, do Campeonato Carioca, da Libertadores da América, da Copa das Confederações e também por textos coletados durante as Copas do Mundo de 2006 e de 2010. 


\begin{tabular}{|l|l|}
\hline \multicolumn{1}{|c|}{ Fonte } & \multicolumn{1}{c|}{ sigla } \\
\hline Arena FC & ARE \\
\hline CBF news & CFB \\
\hline Diário do Pará & DPA \\
\hline O Estado de São Paulo & ESP \\
\hline ESPN & ESPN \\
\hline Futebol Interior & FIN \\
\hline Folha Online & FSP \\
\hline Futebol na Rede & FTR \\
\hline Gazeta Esportiva & GAZ \\
\hline O Globo & GLB \\
\hline Globo Esporte & GLE \\
\hline Jornal de Santa Catarina & JSC \\
\hline LanceNet & LAN \\
\hline Blog do Milton Neves & MIL \\
\hline Placar & PLA \\
\hline Trivela & TRI \\
\hline Esporte UOL & UOL \\
\hline Yahoo esportes & YAH \\
\hline Tabola 5- Fondes
\end{tabular}

Tabela 5 - Fontes utilizadas para a compilação do corpus jornalístico de português

Utilizamos 18 fontes distintas, dentre elas, jornais, periódicos esportivos, periódicos especializados em futebol e sites. O gráfico abaixo mostra a porcentagem de cada tipo de veículo informativo na composição do corpus:

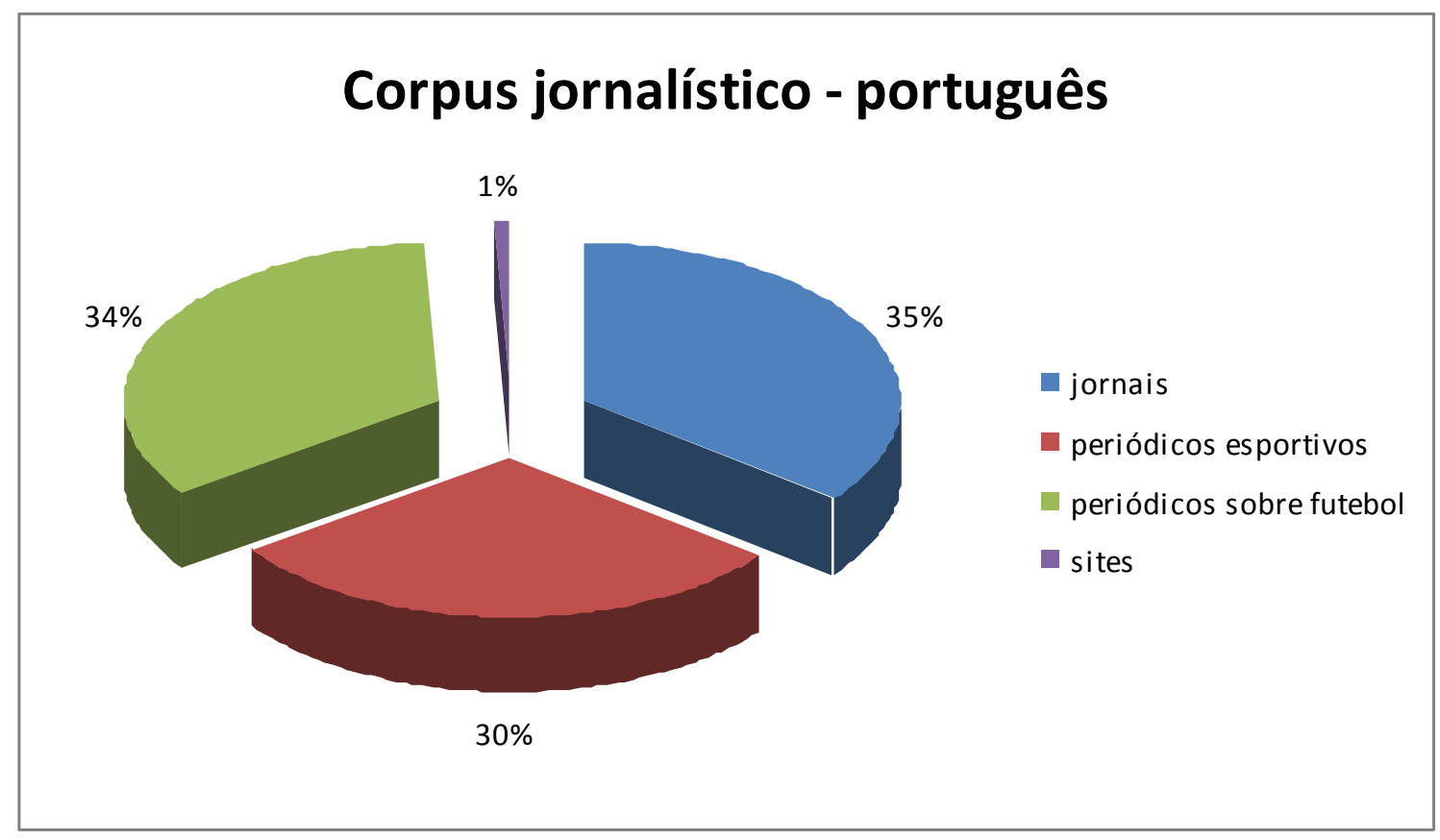

Gráfico 3 - Tipos de fontes utilizadas na composição do corpus jornalístico de português 
A seleção das fontes que compõem o corpus de português deu-se de forma distinta da realizada no corpus de inglês. Primeiramente, a diversidade do tipo de fontes em inglês é maior do que em português. Em inglês incluímos uma revista unicamente porque o corpus disponível no início do trabalho abrigava textos da revista Newsweek. Como o mesmo corpus em português não possuía textos de nenhuma revista, optamos por não acrescentar, mesmo porque a Newsweek é uma revista semanal que aborda diversos tópicos, dentre eles o futebol durante a época de Copa do Mundo. Em português, não havia uma revista que abordasse o futebol da mesma forma que o semanário americano. As revistas semanais brasileiras que falam de futebol durante a Copa não possuem artigos sobre partidas específicas, mas sim sobre o evento Copa do Mundo como um todo.

No corpus de inglês coletamos somente um texto publicado no site da Reuters, agência de notícias. Tal coleta foi realizada para compor a parte do corpus que foi utilizado no trabalho final de uma disciplina de tradução, como explicado antes. À ocasião, não estávamos encontrando em jornais e periódicos esportivos dois textos, um em inglês e outro em português, sobre a mesma partida e, durante a coleta, encontramos um texto em português que tinha como fonte um despacho da Reuters e o próprio despacho no site da Reuters.

No corpus em inglês coletamos textos de tabloides, onde as notícias são tratadas de forma mais superficial e o número de ilustrações é normalmente superior ao dos diários mais tradicionais, pois mesmo nesse tipo de mídia as notícias sobre resultados de partidas possuíam uma extensão razoável, normalmente a mesma dos jornais mais tradicionais em português. Por outro lado, os textos de tabloides brasileiros como o Correio do Povo, Zero Hora, Série Aqui, Diário Popular, entre outros, são tão pequenos que demandariam muito tempo de coleta, armazenamento, etiquetagem discursiva e etiquetagem morfossintática e, mesmo assim, não aumentariam significativamente o número de palavras do corpus. Estamos cientes da importância do registro da variedade linguística utilizada nesses veículos, contudo, durante o processo de compilação do corpus, julgamos que a inserção de textos dessas fontes não apresentava um bom "custo benefício" para a pesquisa.

Para a composição do corpus de transmissões minuto a minuto, coletamos textos das seguintes fontes: 


\begin{tabular}{|l|l|}
\hline \multicolumn{1}{|c|}{ Fonte } & \multicolumn{1}{c|}{ sigla } \\
\hline Gazeta Esportiva & GAZ \\
\hline O Globo & GLB \\
\hline Globo Esporte & GLE \\
\hline LanceNet & LAN \\
\hline Terra Esportes & TER \\
\hline Yahoo Esportes & YAH \\
\hline
\end{tabular}

Tabela 6 - Fontes utilizadas para a compilação do corpus de transmissão minuto a minuto de inglês

O gráfico 5 mostra a porcentagem de cada tipo de veículo informativo na composição do corpus:

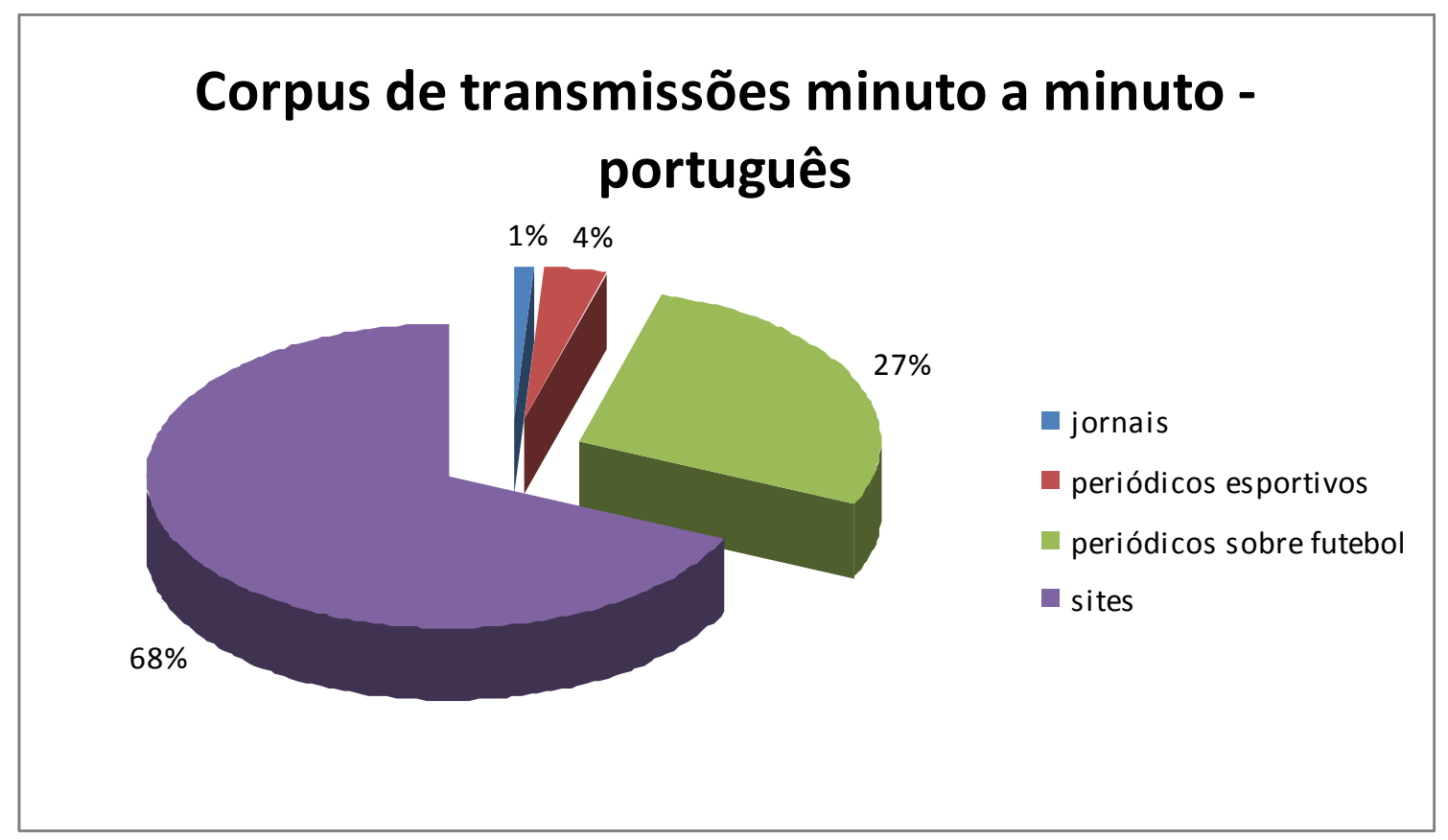

Gráfico 4 - Tipos de fontes utilizadas na composição do corpus de transmissões minuto a minuto de português

Como podemos observar nos últimos itens, a seleção das fontes que compõem o corpus sempre acontece de forma distinta nas duas línguas. O recorte de fontes utilizadas aqui foi realizado unicamente pela disponibilidade regular e pelo "bom funcionamento" do site. Não é comum nos jornais e sites brasileiros, pelo menos não até meados de 2010, a disponibilização regular desse tipo de transmissão. Muitas vezes o site do jornal anuncia, na página inicial, que a transmissão acontecerá, mas o link 
disponibilizado não funciona. Também é bastante comum a tela do computador congelar enquanto o pesquisador copia o texto e, em seguida, aparecer uma mensage m de erro. Em nossa coleta, o número de transmissões coletadas do Yahoo Esportes e do Terra Esportes totaliza quase $70 \%$ do corpus, pois esse sites exibiam as transmissões regularmente e suas páginas não apresentavam problemas técnicos. Ao contrário do site do LanceNet, por exemplo, que exibia links para as transmissões esporadicamente.

Assim como no corpus de inglês, a caracterização do corpus de "transmissão social" não demanda apresentação de tabela ou gráfico uma vez que todos os textos, 21 no total, foram coletados de uma única fonte: Globo Esporte.

\subsubsection{Cabeçalho}

Cabeçalhos são trechos demarcados com informação não veiculada verbalmente no ato comunicativo e são utilizados para auxiliar a extração de informações importantes para a pesquisa (BERBER SARDINHA, 2004, p. 145). Para nossos propósitos, criamos o cabeçalho apresentado na figura 18.

O cabeçalho foi compilado com o objetivo de organizar informações sobre a coleta dos textos que julgamos importantes para a análise terminológica como, por exemplo, a data de publicação, a fonte do texto, o local em que a notícia foi produzida, $\mathrm{o}(\mathrm{s})$ autor(es) etc. 


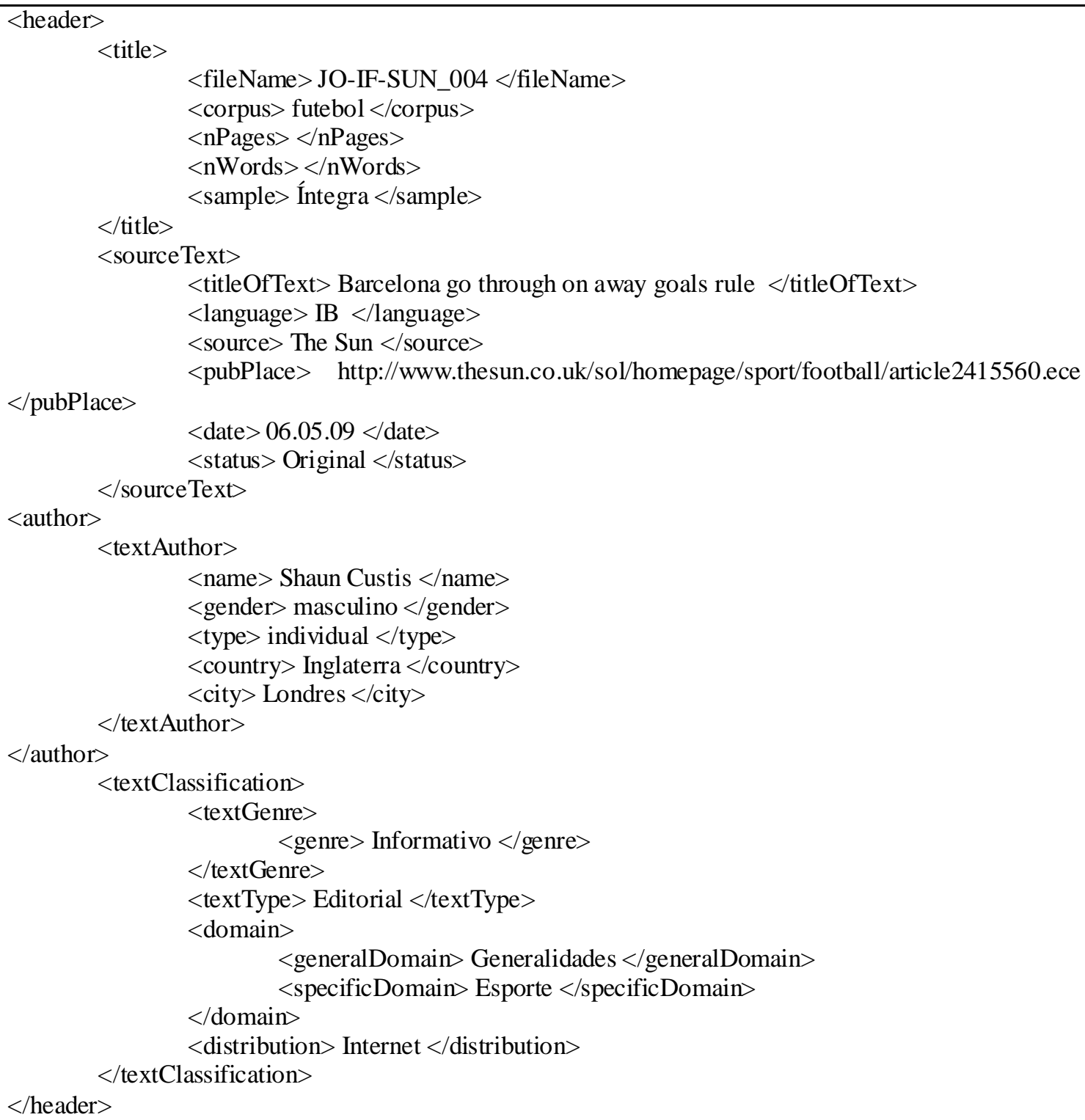

Figura 18 - Exemplo de cabeçalho de texto informativo

Explicamos as etiquetas criadas no quadro abaixo: 


\begin{tabular}{|c|c|c|c|c|}
\hline \multirow{5}{*}{$\begin{array}{l}\text { Title } \\
\text { Título }\end{array}$} & \multicolumn{2}{|l|}{ Filename } & \multicolumn{2}{|c|}{ nomenclatura do arquivo } \\
\hline & \multicolumn{2}{|l|}{ Corpus } & \multicolumn{2}{|l|}{ nome do corpus } \\
\hline & \multicolumn{2}{|l|}{ NPages } & \multicolumn{2}{|c|}{ número de páginas } \\
\hline & \multicolumn{2}{|l|}{ NWords } & \multicolumn{2}{|c|}{ número de palavras } \\
\hline & \multicolumn{2}{|l|}{ Sample } & \multicolumn{2}{|c|}{ íntegra ou parte do texto } \\
\hline \multirow{6}{*}{$\begin{array}{c}\text { source Text } \\
\text { Informações sobre o texto }\end{array}$} & \multicolumn{2}{|l|}{ TitleOfText } & \multicolumn{2}{|l|}{ título do texto } \\
\hline & \multicolumn{2}{|l|}{ Language } & \multicolumn{2}{|l|}{ Lingual } \\
\hline & \multicolumn{2}{|l|}{ Source } & \multicolumn{2}{|l|}{ nome do site } \\
\hline & \multicolumn{2}{|l|}{ Pubplace } & \multicolumn{2}{|l|}{ endereço do site } \\
\hline & \multicolumn{2}{|l|}{ Date } & \multicolumn{2}{|l|}{ data de coleta } \\
\hline & \multicolumn{2}{|l|}{ Status } & \multicolumn{2}{|c|}{ original ou tradução } \\
\hline \multirow{5}{*}{$\begin{array}{c}\text { textAuthor } \\
\text { Informações sobre o autor }\end{array}$} & \multicolumn{2}{|l|}{ Name } & \multicolumn{2}{|l|}{ Nome } \\
\hline & \multicolumn{2}{|l|}{ Gender } & \multicolumn{2}{|l|}{ Sexo } \\
\hline & \multicolumn{2}{|l|}{ Type } & \multicolumn{2}{|c|}{ individual/ parceria/ grupo } \\
\hline & \multicolumn{2}{|l|}{ Country } & \multicolumn{2}{|l|}{ País } \\
\hline & \multicolumn{2}{|l|}{ City } & \multicolumn{2}{|l|}{ Cidade } \\
\hline \multirow{5}{*}{$\begin{array}{c}\text { textClassification } \\
\text { Classificação do texto }\end{array}$} & textGenre & gênero textual & Genre & gênero textual \\
\hline & TextType & & tipo textual & \\
\hline & textDomain & & generalDomain & domínio geral \\
\hline & textDomain & dominio & specificDomain & domínio específico \\
\hline & Distribution & & meio de distribui & \\
\hline
\end{tabular}

Quadro 5 - Legenda das etiquetas do cabeçalho

Optamos por trabalhar com etiquetas SGML. Nesse formato, utilizamos uma etiqueta de abertura, inserimos a informação e, logo após, uma etiqueta de fechamento como, por exemplo: <titleOfText> Barcelona go through on away goals rule $</$ titleOfText $>$.

As etiquetas são hierárquicas, ou seja, estão subordinadas umas às outras. A etiqueta <header> abre o cabeçalho e a $</$ header $>$ o fecha.

Berber Sardinha (2004, p. 76) chama atenção para o fato de que os cabeçalhos geralmente representam um obstáculo para os usuários de corpus, pois aumentam o tamanho do arquivo, ocupando mais espaço no computador, dificultam o proces samento do corpus e, além disso, demandam tempo para serem inseridos no texto. Por esse motivo, todo cabeçalho deve ser preparado tendo em vista as necessidades da pesquisa a ser realizada.

\subsubsection{Etiquetagem}

A etiquetagem pode ser descrita como a adição de informação a um corpus com o objetivo de facilitar a análise linguística (HUSTON, 2002, p. 79). Há diversas formas 
de $\operatorname{anotação~}^{93}$ : a morfossintática, a sintática, a semântica e a discursiva. Em nosso estudo, utilizamos a discursiva e a morfossintática.

\subsubsection{Etiquetagem discursiva}

A etiquetagem discursiva é descrita por Berber Sardinha (2004, p. 114) como a anotação de características como marcadores anafóricos, tópicos ou marcadores discursivos. Para nosso corpus, criamos três modelos de anotação discursiva: um para os textos jornalísticos (vide Fig. 19), outro para as transmissões minuto a minuto (vide Fig. 20) e um último para os textos da "transmissão social" (vide Fig. 21), cada um de acordo com as partes os compõem.

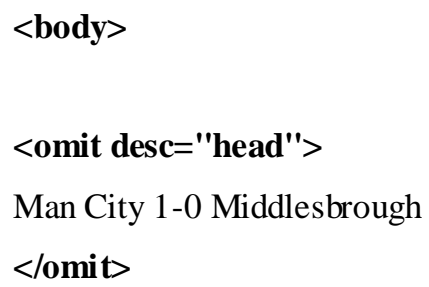

<standfirst> Manchester City secured a slender win against Middlesbrough, thanks to the first half goal by Craig Bellamy. But, the real hero of the day was debutante goal keeper Shay Given. </standfirst>

A man of the match performance from new signing Shay Given helped Man City to secure a home win against the relegation battling Middlesbrough.

Bellamy's pace and "eye for the goal" disturbed the Boro defense, and he scored in the 18th minute. Stephen Ireland came close to scoring, he hit the woodwork.

Boro never looked threatening, their strategy was to defend, block and clear any ball, a four centre-back defense was placed just to do this. Southgate had been under pressure and this match will not help him either.

Afonso Alves was the only Boro player who tried something "adventurous" and had four shots on goal, all cleared by the impressive Shay Given. Given was rock solid at the back and deserved the clean sheet;

$</$ body $>$

${ }^{93}$ Utilizamos os termos "etiquetagem" e "anotação" como sinônimos. 
Figura 19 - Etiquetas discursivas criadas para os textos jornalísticos

A etiqueta <omit desc="head" > </omit> é utilizada para marcar o título do texto, a <standfirst $></$ standfirst $>$ é para marcar a linha fina, também conhecida como olho ou subtítulo da notícia, e a $<$ body $></$ body $>$ para marcar o corpo do texto.

Nas transmissões minuto a minuto, as etiquetas que marcam o título e o corpo do texto são as mesmas dos textos jornalísticos. A única etiqueta que tivemos que criar especificamente para as transmissões é a $<$ minute $></$ minute $>$, que marca o minuto da narração. Dessa forma, temos a opção de pedir que o programa WordSmith Tools ignore a etiqueta $<$ minute $><$ /minute $>$ no momento em que gera uma lista de palavras. Se não fizéssemos dessa forma, nossas wordlists estariam repletas de números.

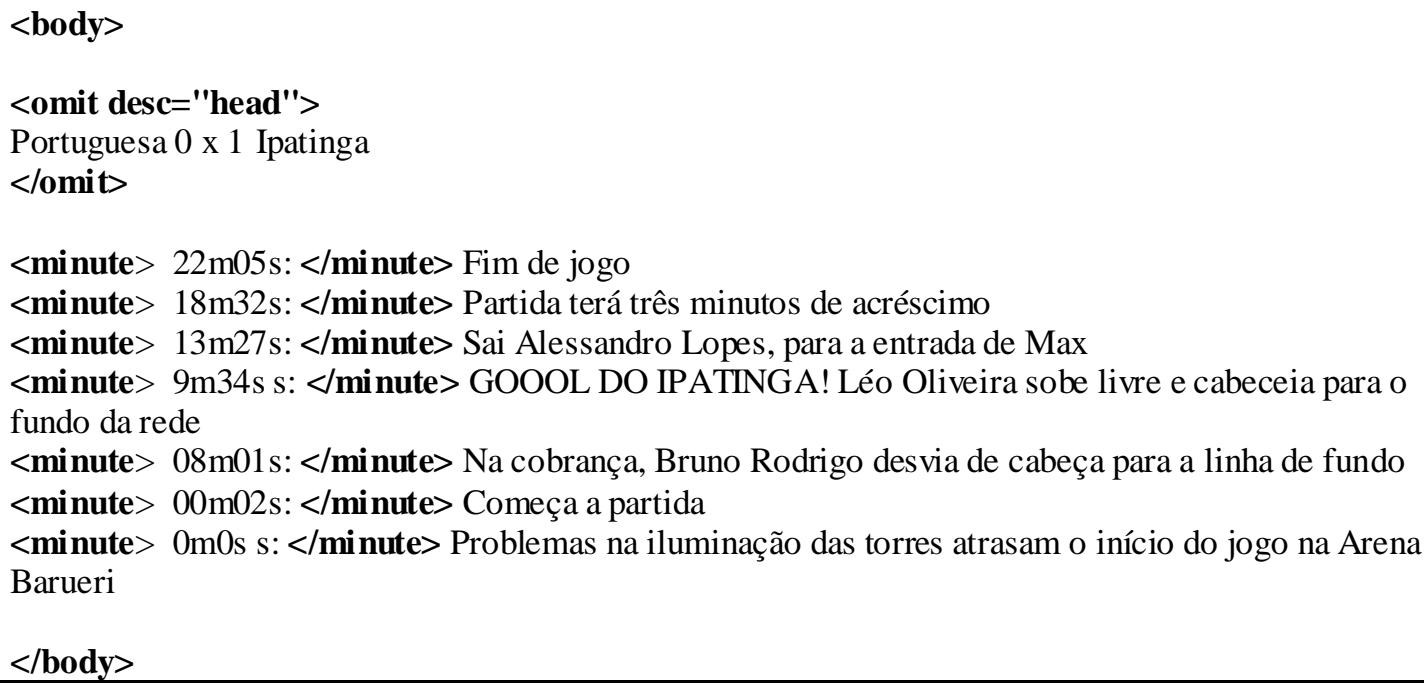

Figura 20 - Etiquetas discursivas utilizadas nas transmissões minuto a minuto

Para os textos da "transmissão social" utilizamos as mesmas etiquetas das transmissões minuto a minuto e criamos duas novas: <commentary> </commentary> e <commentator> </commentator>, em que a primeira é utilizada para marcar o comentário e a segunda para marcar o autor do comentário. 


\section{$\langle$ body $>$ \\ <omit desc="head"> \\ Australia 2-1 Serbia \\ $</$ omit $>$}

<commentary > <commentator > Paul Fletcher </commentator >

"I'm going to try to kick start this game into life by suggesting that although Australia have improved since the break, the match has deteriorated as a contest." </commentary $>$

$<$ minute $>20: 50</$ minute $>$

Drilled effort from Marco Bresciano, good save by Vladimir Stojkovic. More ambition being shown by Australia in this half.

$<$ minute $>20: 49</$ minute $>$

Germany's goal means they now top the group as it stands (and are in line to face England), but Ghana still edge second spot (and a last 16 tie with USA) from Serbia on goals scored.

$<$ commentary $><$ commentator $>$ Twitter

From 337ee: </commentator> "Typical. Germany score just as I tweet that the Ghana central defenders have been immensah... sorry." $</$ commentary $>$

$<$ minute $>20: 48<$ minute $>$

Ghana almost level immediately, but Prince Tagoe's header at the far post ricochets off Jerome Boateng's leg and behind for a corner.

$</$ body $>$

Figura 21 - Etiquetas discursivas utilizadas nas "transmissões sociais"

\subsubsection{Etiquetagem morfossintática}

A etiquetagem morfossintática, ou part of speech tagging (POS), consiste em colocar em cada palavra do corpus uma etiqueta que indique sua classe gramatical.

Não convém, neste trabalho, apresentar os etiquetadores disponíveis nem a forma como funcionam. Contudo, acreditamos ser importante deixar claro que nenhum procedimento automático possui $100 \%$ de acerto, embora a porcentagem de acerto alcançada pelos etiquetadores automáticos seja de cerca de 97\% (BERBER SARDINHA, 2004, p. 156), revelando-se, desse modo, um alto grau de confiabilidade.

São várias as razões para etiquetar um corpus morfossintaticamente. Hunston (2004, p. 80) afirma que é muito mais simples fazer buscas mais complexas em um corpus etiquetado. Além disso, as possibilidades de investigação aumentam, visto que o pesquisador pode fazer generalizações sobre, por exemplo, uma classe gramatical e não somente sobre uma palavra de busca.

Em nossa análise, utilizamos tanto a versão do corpus etiquetado, quanto a versão crua, sem etiquetas. 
A versão crua foi utilizada para gerar as listas de palavras e as palavras-chave e para identificar e validar as UFEs. Poderíamos ter usado o corpus etiquetado para essas etapas, mas não o utilizamos porque nos interessa identificar as UFs mais comuns na linguagem do futebol independentemente da classe gramatical das palavras que as compõem.

A versão etiquetada foi utilizada para aprimorar o processo de identificação dos equivalentes tradutórios. Quando o corpus ainda não estava etiquetado, partíamos de uma tradução prima facie ou de possíveis colocados para encontrar equivalentes para as UFEs em português no corpus de inglês. Após a etiquetagem do corpus, passamos a realizar buscas por classes gramaticais, fato que enriqueceu os achados e ampliou a possibilidade de equivalentes e, muito frequentemente, de equivalentes mais apropriados.

\subsection{Etiquetador}

A etiquetagem foi realizada com o etiquetador Tree-Tagger, disponibilizado pelo professor Tony Berber Sardinha, da Pontifica Universidade Católica de São Paulo (PUC-SP) no site do LAEL (Programa de Linguística Aplicada e Estudos da Linguagem) ${ }^{94}$ e também no link Ferramentas do site do VIII Encontro de Linguística de Corpus $^{95}$.

O Tree-Tagger é um etiquetador automático que apresenta a anotação morfossintática e o lema de cada ocorrência no corpus. Foi desenvolvido por Helmut Schmid no projeto TC (Textual Corpora and tools for their exploration) no Instituto de Linguística Computacional da Universidade de Stuttgart. O Tree Tagger pode ser utilizado para etiquetar textos em alemão, inglês, francês, italiano, holandês, espanhol, búlgaro, russo, grego, português, chinês, suaíli, latim, estoniano e francês antigo.

\footnotetext{
${ }^{94}$ Disponível em: <http://www2.lael.pucsp.br/corpora/etiquetagem/>.

${ }^{95}$ Disponível em: <http://corpuslg.org/tools/etiquetagem/>.
} 


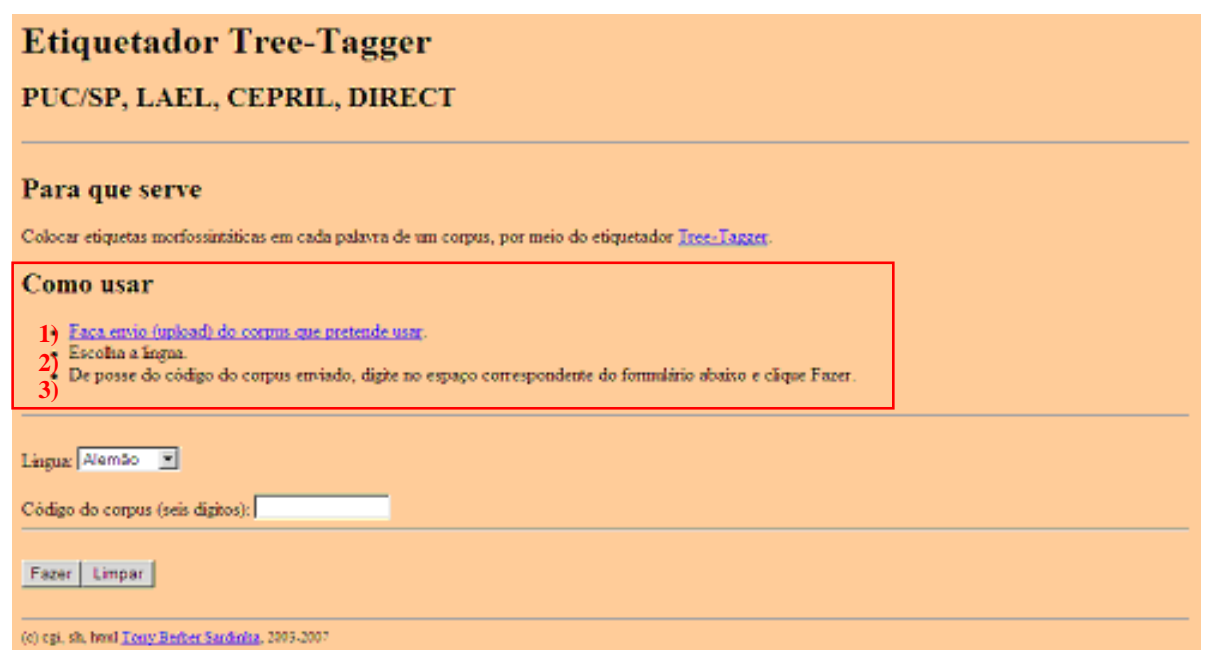

Figura 22 - Página inicial do etiquetador Tree-Tagger

Basta seguir os procedimentos acima que o texto é etiquetado. Para o manuseio, o pesquisador deve salvá-lo em formato “.txt”.

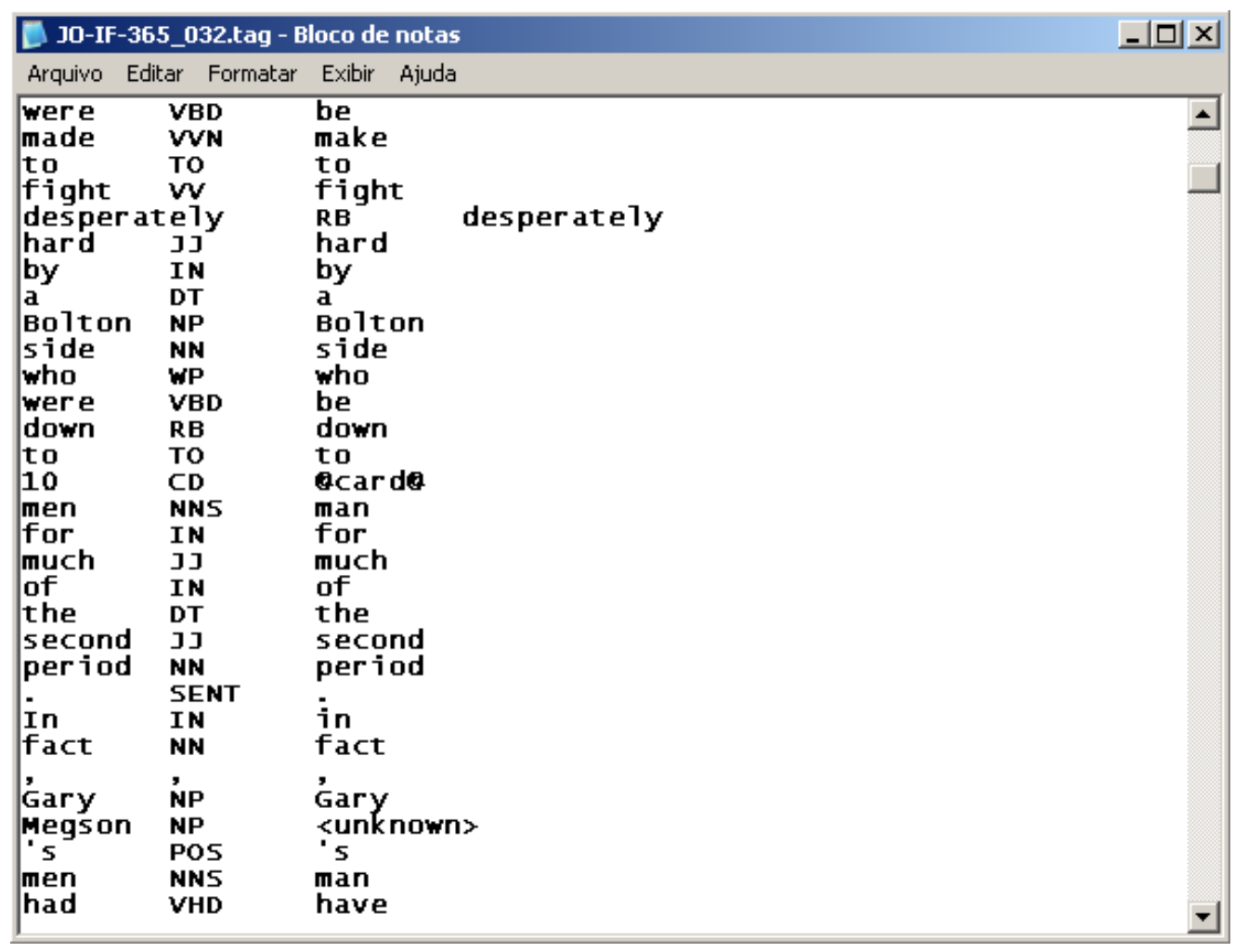

Figura 23 - Texto etiquetado e salvo em formato ".txt" 
Todavia, não foi possível realizar esse procedimento para a etiquetagem dos textos de nosso corpus, pois o Tree-Tagger não estava funcionando em nenhum dos links disponíveis. A solução encontrada foi baixar o programa direto para nosso computador $^{96}$. Tarefa que, vale ressaltar, foi uma das mais laboriosas da pesquisa, visto que baixamos os arquivos necessários para a instalação, sem, no entanto, possuir um manual do usuário com os passos a serem seguidos. Após auxílio via email do professor Berber Sardinha, conseguimos, finalmente, instalar o Tree-Tagger. Realizamos um teste com o etiquetador para as duas línguas e o Tree-Tagger funcionou perfeitamente para a etiquetagem em inglês. Porém, quando tentávamos etiquetar qualquer texto em português, recebíamos a mensagem de que o português não era uma língua disponível. Entramos novamente em contato com o professor Berber Sardinha e um de seus orientandos nos passou um novo link ${ }^{97}$, dessa vez com a opção de etiquetagem em português.

A figura 24 mostra a interface do etiquetador:

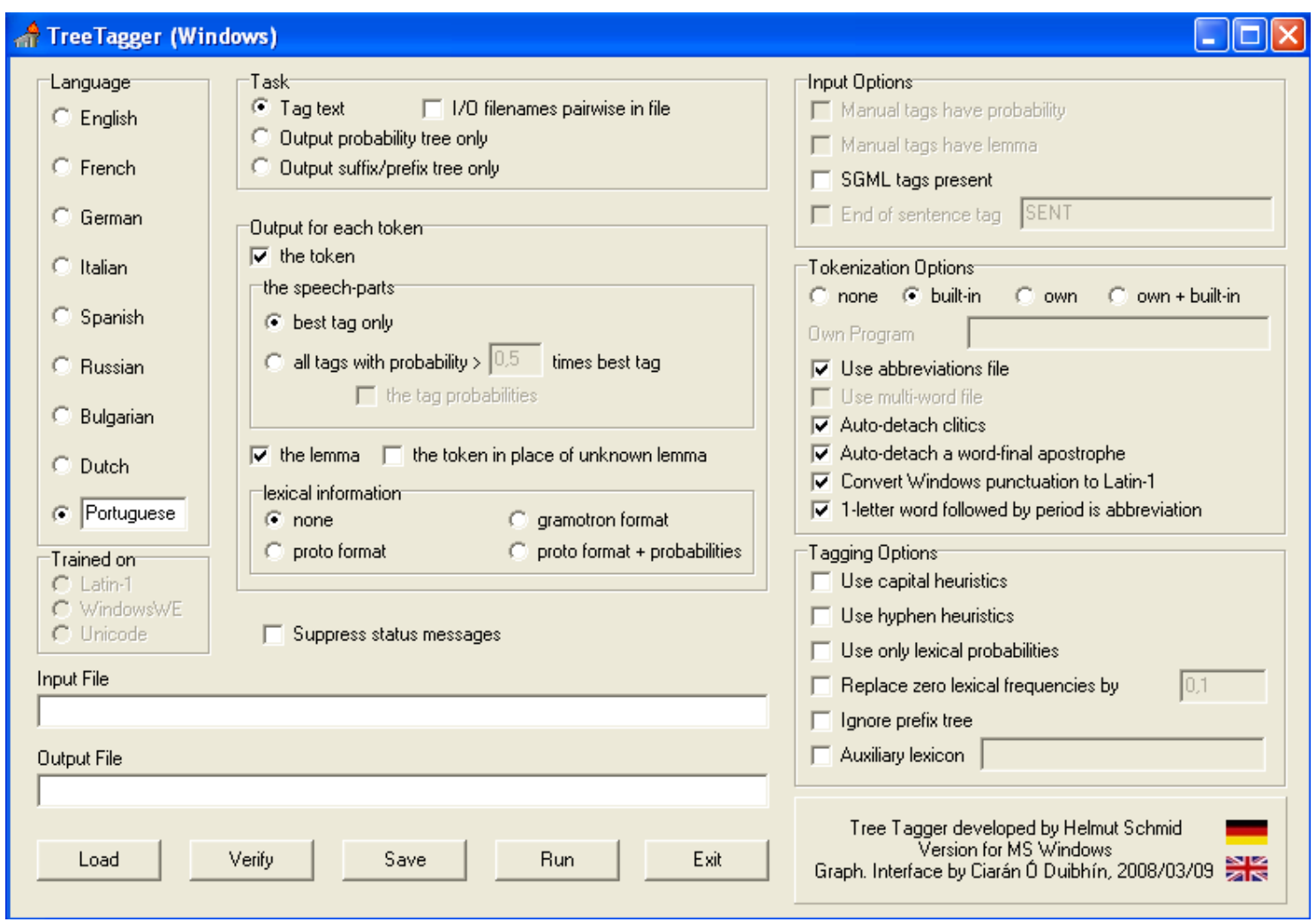

Figura 24 - Interface do Tree-Tagger

96 O programa está disponível para ser baixado no site: <http://corpuslg.org/courses/tree-taggerwindows.zip> .

${ }^{97}$ Disponível em: <http://corpuslg.org/users/crismayer>. 
O processo de etiquetagem, embora simples, é bastante laborioso, pois o programa etiqueta somente um texto de cada vez. O primeiro passo é selecionar a língua do texto a ser etiquetado. Na figura acima, selecionamos a opção em branco e digitamos "Portuguese". Após essa seleção, clicamos em "Input File" para selecionar o arquivo a ser etiquetado. Selecionado o arquivo, clicamos em "Output file" e o programa abre uma caixa de diálogo "Salvar Como" onde escolhemos a pasta de destino em que o arquivo seria armazenado. Por fim, nomeamos o arquivo, sempre acrescentando a terminação ".tag” para que o Tree-Tagger funcionasse corretamente.

\subsection{Etiquetas}

O Tree-Tagger utiliza um conjunto de etiquetas diferentes para cada língua. Para o inglês são 36 etiquetas (SANTORINI, 1991, p. 6-7):

\begin{tabular}{|l|l|}
\hline \multicolumn{1}{|c|}{ Etiqueta } & \\
\hline CC & coordinating conjunction \\
\hline CD & Cardinal Number \\
\hline DT & Determiner \\
\hline EX & Existentião \\
\hline FW & Foreign Word \\
\hline IN & Preposition or subordinating conjunction \\
\hline JJ & Adjective \\
\hline JJR & Adjective, comparative \\
\hline JJS & Adjective, superlative \\
\hline LS & List item marker \\
\hline MD & Modal \\
\hline NN & Noun, singular or mass \\
\hline NNS & Noun, plural \\
\hline NP & Proper noun, singular \\
\hline NPS & Porper noun, plura \\
\hline PDT & Predeterminer \\
\hline POS & Possessive ending \\
\hline PP & Personal pronoun \\
\hline PP\$ & Possessive pronoun \\
\hline RB & Adverb \\
\hline RBR & Adverb, comparative \\
\hline RBS & Adverb, superlative \\
\hline RP & Particle \\
\hline SYM & Symbol \\
\hline TO & To \\
\hline UH & Interjection \\
\hline VB & Verb, base form \\
\hline VBD & Verb, past tense \\
\hline VBG & Verb, gerund or present participle \\
\hline & \\
\hline
\end{tabular}




\begin{tabular}{|l|l|}
\hline VBN & Verb, past participle \\
\hline VBP & Verb, non-3rd person singular present \\
\hline VBZ & Verb, 3rd person singular present \\
\hline WDT & Wh-determiner \\
\hline WP & Wh-pronoun \\
\hline WP\$ & Possessive pronoun \\
\hline WRB & Wh-adverb \\
\hline
\end{tabular}

Quadro 6 - Etiquetas do Tree-Tagger (inglês)

Para o português, o conjunto de etiquetas é menos detalhado, são apenas 11, conforme o quadro abaixo:

\begin{tabular}{|l|l|}
\hline \multicolumn{1}{|c|}{ Etiqueta } & \multicolumn{1}{c|}{ Descrição } \\
\hline ADJ & Adjectivo \\
\hline ADV & Advérbio \\
\hline DET & Determinante \\
\hline CARD & Número Cardinal / Ordinal \\
\hline NON & Nome Comum / Próprio \\
\hline P & Pronome \\
\hline PREP & Preposição \\
\hline V & Verbo \\
\hline I & Interjeição \\
\hline VIRG & Separadores dentro da oraçao \\
\hline SENT & Separadores de orações \\
\hline
\end{tabular}

Quadro 7 - Etiquetas do Tree-Tagger (português)

Apesar do tempo consumido, a etiquetagem morfossintática se mostrou de extrema importância para a atribuição dos equivalentes tradutórios, que será descrita no item 3.3.1.4 e, mais detalhadamente, na análise de dados.

\subsection{Expressões de busca}

Explicaremos detalhadamente cada busca realizada no corpus etiquetado no “capítulo 4 - Análise e Discussão dos Dados”. Nesta seção, apresentaremos, brevemente, como devemos conduzir as buscas pelas etiquetas.

Se observarmos a figura 23 , veremos que o texto etiquetado é apresentado em um arquivo ".txt", dividido em três colunas. A exemplo da primeira linha da figura, na primeira coluna, temos a ocorrência do corpus, o verbo were; na segunda, temos a etiqueta gramatical VBD, que indica um verbo no passado; na terceira, temos a forma lematizada do verbo, $b e$. 
Dada a forma como o Tree-Tagger apresenta o texto etiquetado, temos que digitar a expressão de busca tal qual aparece no arquivo. Nesse caso, se quiséssemos ter acesso às concordâncias do verbo were seguido de made, teríamos que digitar a expressão de busca "were VBD be made". Observemos a figura a seguir:

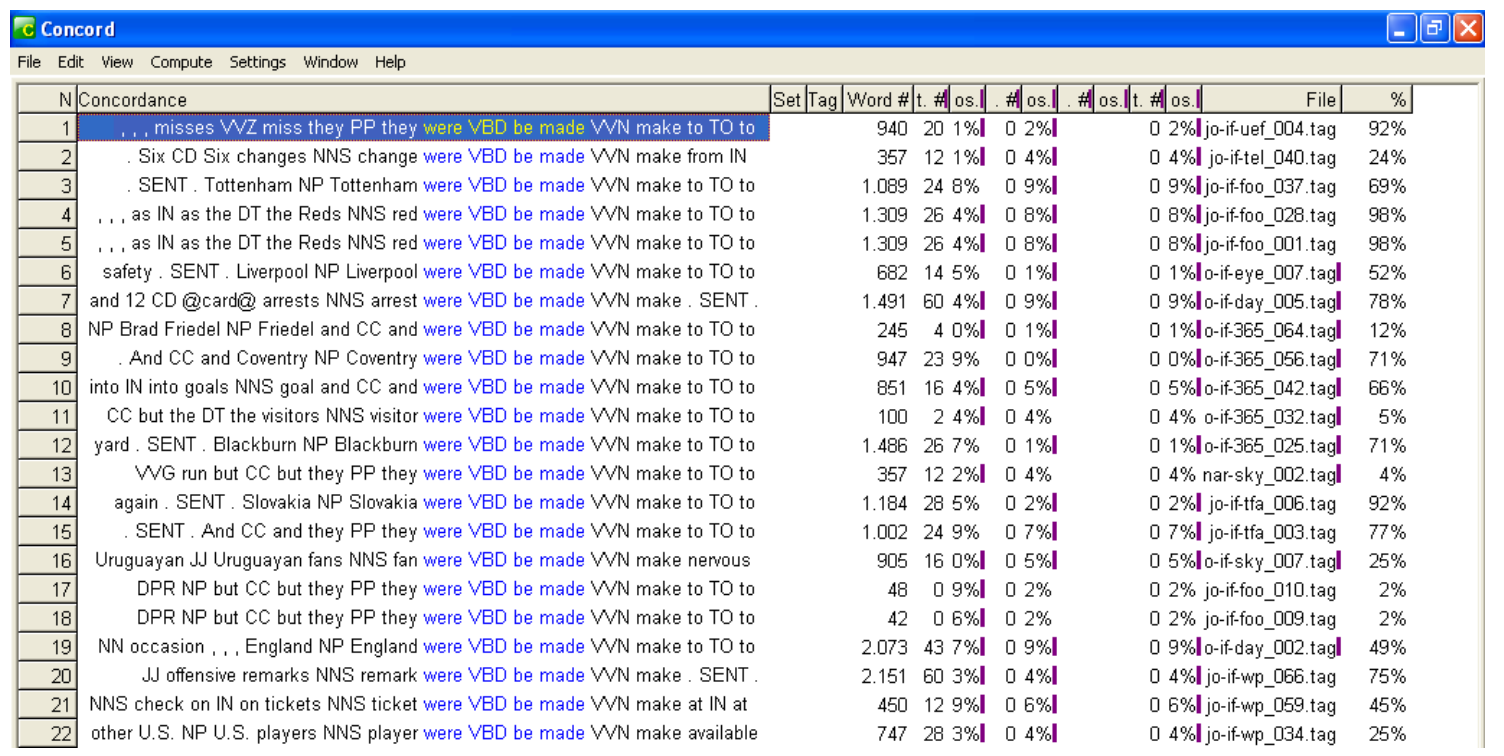

Figura 25 - Linhas de concordância da expressão de busca "were VBD be made"

Se digitássemos apenas "were made" o programa identificaria a presença da etiqueta e da forma lematizada entre were e made e não retornaria nenhum resultado.

\subsection{Corpora de referência}

O corpus de referência é utilizado para contrastar com o corpus de estudo com o objetivo de evidenciar as formas mais frequentes no corpus de estudo, filtrando os elementos mais genéricos. Em geral, devem-se incluir vários gêneros de modo que proporcione uma escolha não-marcada das palavras-chave, pois suas características influenciam de forma direta os tipos de palavra que podem se tornar chave (BERBER SARDINHA, 2004, p. 100).

O tamanho do corpus de referência influencia o número de palavras-chave obtidas. Berber Sardinha (2004, p. 102) recomenda que o corpus de referência seja entre três e cinco vezes maior que o corpus de estudo. 
Compilar um corpus muito maior do que o recomendado não retornará, necessariamente, maior número de palavras-chave (BERBER SARDINHA, 2004, p. 103). No entanto, não existem restrições que limitem o tamanho do corpus de referência.

Em nossa pesquisa utilizamos dois corpora de referência: o BNC (British National Corpus $)^{98}$ e o Banco de Português ${ }^{99}$. Ambos são muito maiores que o de estudo. Contudo, foram os que nos retornaram melhores resultados.

O BNC, corpus fechado (1990-1994), possui 100 milhões de palavras e foi desenvolvido com o objetivo de ser representativo das variantes escrita e falada do inglês britânico.

O Banco do Português é um corpus monitor do português do Brasil, ou seja, está aberto e é constantemente atualizado. Na época da pesquisa, agosto de 2010, contava com 240 milhões de palavras.

\subsection{Metodologia}

Nesta seção, descrevemos a metodologia utilizada em nossa pesquisa. Primeiramente, mostramos os procedimentos adotados para o levantamento dos candidatos a termo; em seguida; explicitamos o caminho percorrido para a extração e validação das UFEs; e, ao final, descrevemos os passos seguidos para o estabelecimento dos equivalentes fraseológicos entre o par de línguas português-inglês. Ressaltamos que, para esta pesquisa, trabalhamos somente com as UFEs do termo gol, palavra-chave mais frequente do corpus de português.

\subsubsection{Procedimentos de análise}

Dividimos o procedimento de análise em três partes: extração dos candidatos a termo, identificação e validação das UFEs e estabelecimento dos equivalentes:

\footnotetext{
${ }^{98}$ Disponível em: <http://www.natcorp.ox.ac.uk/>. Acesso em: 14 abr. 2010.

${ }^{99}$ Disponível em: <http://www2.lael.pucsp.br/corpora/bp/conc/index.html>. Acesso em: 14 abr. 2010. 
a) Extração dos candidatos a termo:

- gerar palavras-chave (keywords) do corpus em português ${ }^{100}$.

b) Identificação e validação das UFEs:

- gerar linhas de concordância para gol e examinar os clusters para extrair os candidatos a fraseologias;

- unificar os clusters que fazem parte de uma mesma unidade de sentido;

- gerar linhas de concordância para os clusters em busca de padrões maiores;

- eliminar os clusters que não constituem UFEs e os que ocorrem somente em um único veículo de informação.

c) Estabelecimento dos equivalentes

- gerar linhas de concordância para goal;

- examinar os clusters de goal;

- gerar linhas de concordância da tradução prima facie dos colocados de goal quando não é possível identificar um equivalente pela análise de suas concordâncias;

- gerar linhas de concordância das etiquetas gramaticais para procurar sinônimos e UFEs que não comportam o termo goal.

Descreveremos cada um dos passos nos itens que seguem.

\subsubsection{Extração dos candidatos a termo}

Para extrair os candidatos a termo, geramos uma lista palavras-chave para o corpus de português, já que a extração terminológica foi realizada do português para o inglês. Para tanto, primeiramente, abrimos a ferramenta wordlist do programa WordSmith Tools, clicamos em "arquivo" (file) e em "novo" (new) para gerar uma lista

${ }^{100}$ Vide anexo A 
de palavras do corpus de futebol em português, e selecionamos a pasta em que os textos estão salvos, como mostra a figura a seguir:

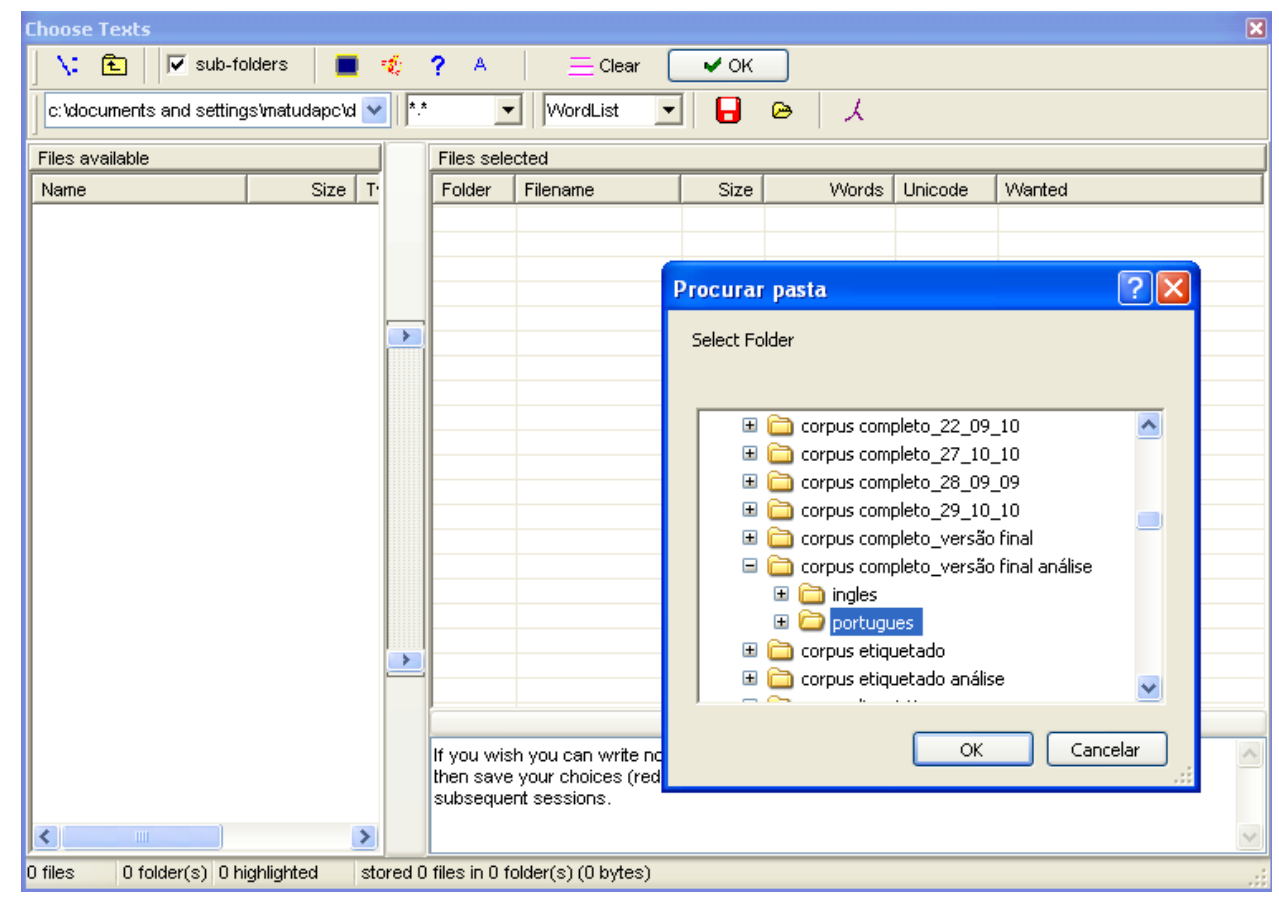

Figura 26 - Seleção dos textos na ferramenta wordlist

Selecionados os textos, clicamos em "fazer lista de palavras" (make a wordlist now) e o programa gerou a wordlist para os textos selecionados: 


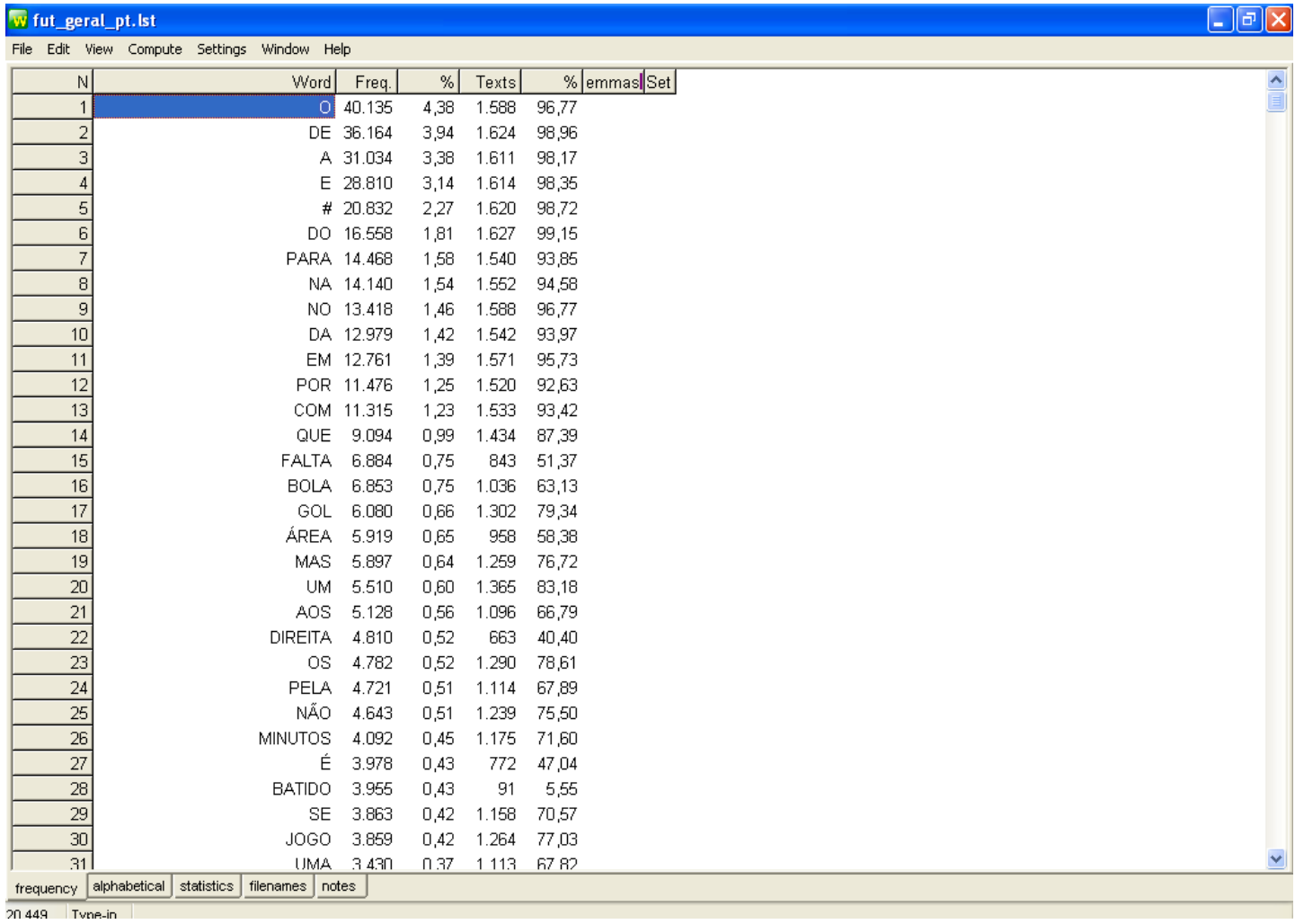

Figura 27 - Parte da lista de palavras do corpus em português organizada pela ordem de frequência

Salvamos a lista na pasta wordlist, subpasta da pasta WordSmith Tools, que está localizada em "arquivos de programas" no diretório C:/ de nosso computador.

O passo seguinte foi comparar a lista de palavras de nosso corpus com a lista de palavras do corpus de referência utilizando a ferramenta keywords, que compara automaticamente as duas listas e elimina as palavras com frequências relativas similares nos dois corpora, evidenciando, dessa forma, as palavras que caracterizam o léxico do futebol. Essa eliminação, no entanto, não é feita a esmo. Por isso, ao iniciar o processo, ajustamos as configurações da ferramenta para alcançar os resultados esperados, já que cada pesquisa necessita de uma configuração específica. A figura 28 mostra os ajustes realizados: 


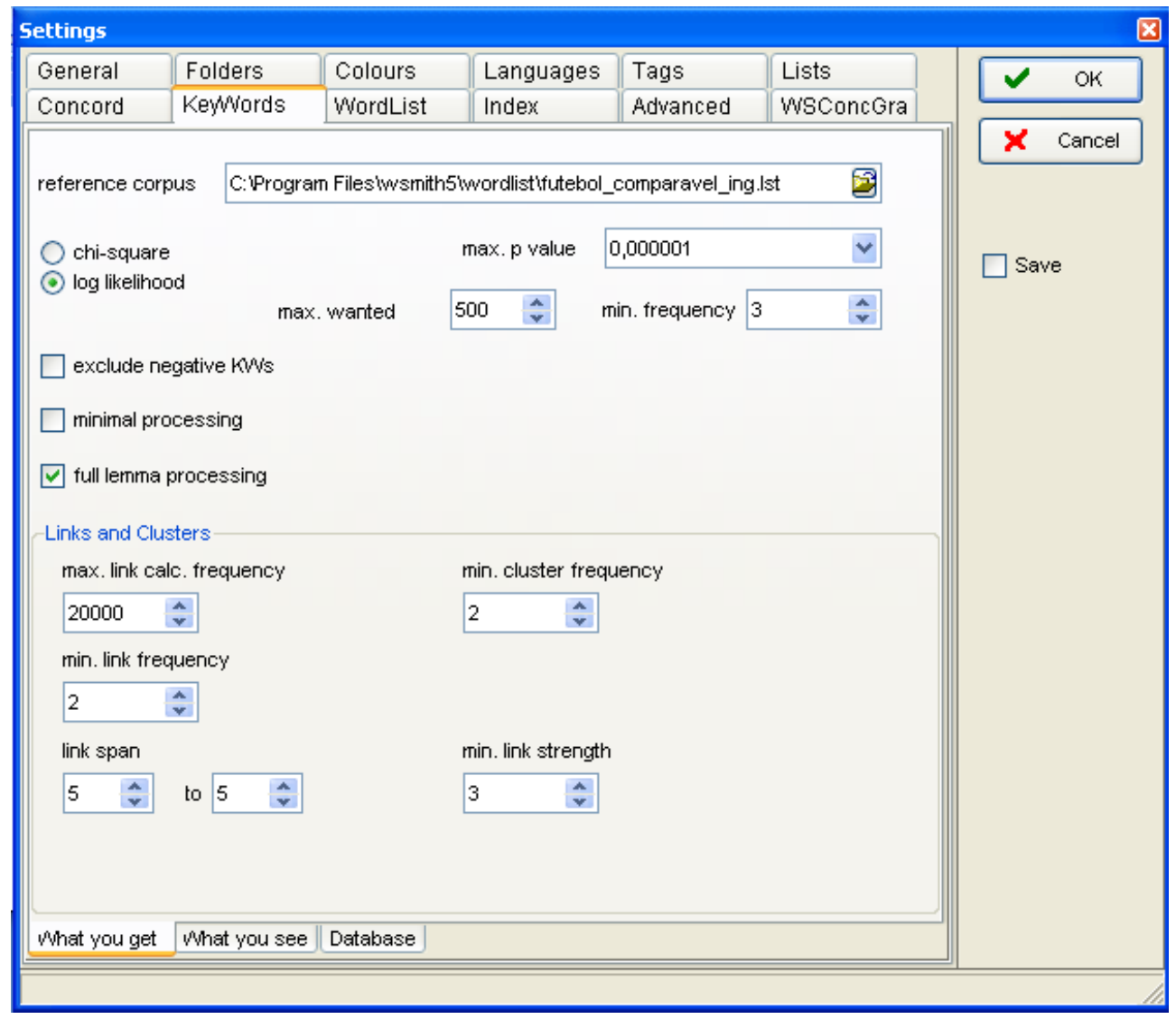

Figura 28 - Configurações da ferramenta keywords

Utilizamos a medida estatística log likelihood ${ }^{101}$ e ajustamos o $p$-value ${ }^{102}$ para 0,000001. Essa medida varia de 0,1 a 0,0000001 e, quanto maior o valor, maior número de keywords é disponibilizado. Para restringir ainda mais o número de keywords, optamos por ter acesso a somente 500 palavras, com frequência mínima de 3. Realizados os ajustes, abrimos a keywords, clicamos no menu "arquivo" (file) e na opção "novo" (new). O programa abriu uma nova janela onde selecionamos a wordlist do corpus de estudo e a wordlist do corpus de referência para que a comparação fosse realizada. Selecionadas as listas, clicamos no botão "gerar lista de palavras-chave" (make keyword list now) e obtivemos:

101 Segundo Gerber (2007) a medida estatística log-likelihood é indicada quando o pesquisador tem a intenção de comparar listas de grandes dimensões entre si, enquanto o chi-square, a outra medida disponível no programa, tem maior eficácia quando usada para comparar uma amostra da população. Em nosso caso, a segunda medida seria adotada se quiséssemos comparar os diferentes gêneros textuais que compõem o corpus.

$102 \mathrm{O}$ p-value é o resultado de um teste de significância, em nosso caso o log-likelyhood, que é aplicado para verificar a hipótese nula de que não existe diferença significativa entre dois grupos de dados e as diferenças entre eles ocorrem puramente por acaso (DAYRELL, 2011, p. 147). 


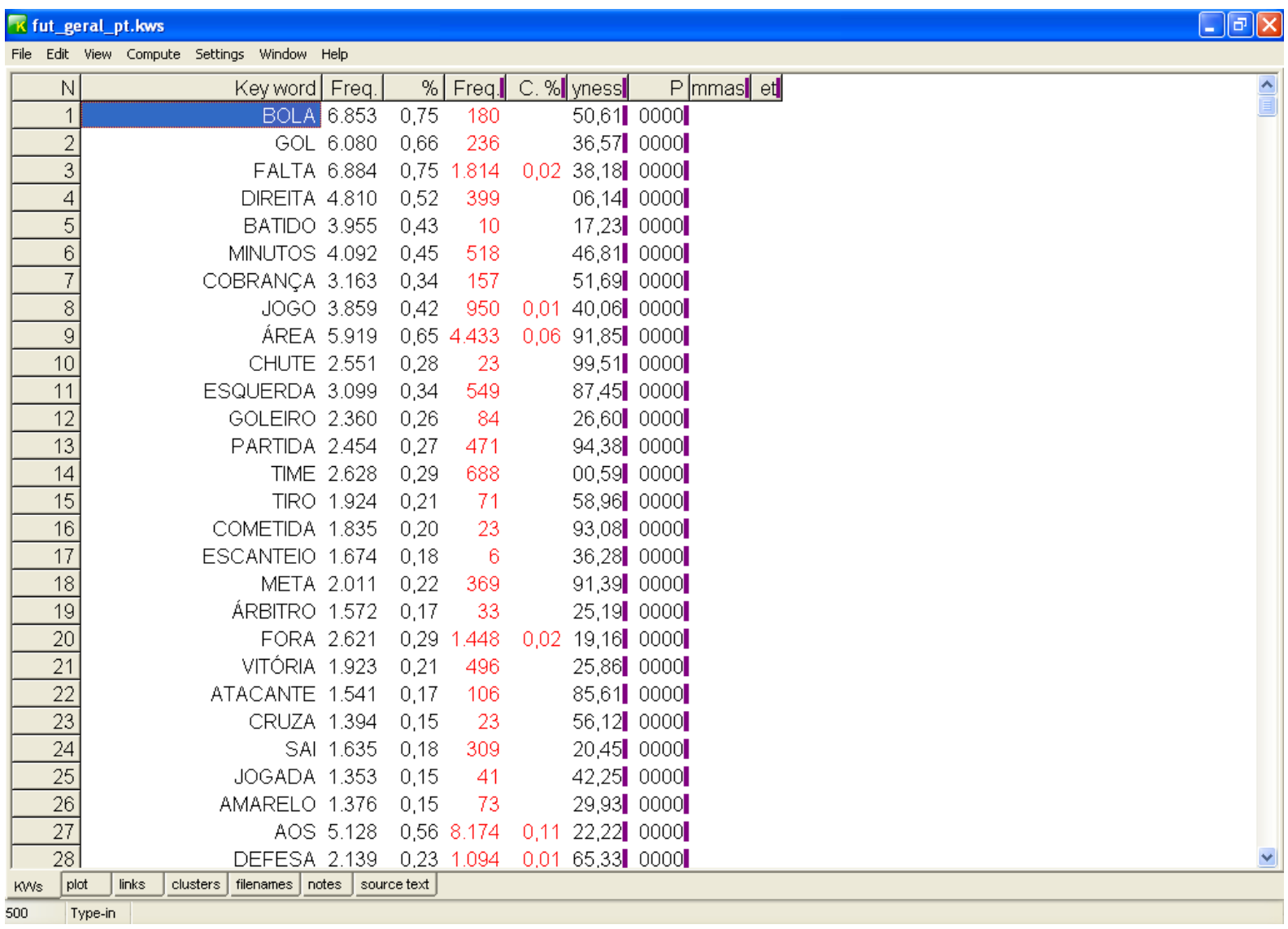

Figura 29 - Palavras-chave do corpus de português

A palavra gol aparece como segundo item lexical mais frequente no corpus, com 6080 ocorrências, logo após bola, com 6853. No entanto, vale lembrar que a lista resultante não é lematizada, já que as diferentes formas de um mesmo item não aparecem agrupadas. Assim, como nos guiamos por uma abordagem direcionada pelo corpus e queremos trabalhar com os itens mais frequentes, optamos por lematizar parte do corpus, ou seja, os itens lexicais que analisamos: gol e seus colocados. Após a lematização, o número de ocorrências de gol subiu para 7357 ultrapassando bola, pois o corpus possui 1277 ocorrências de gols.

Selecionado o item mais frequente do corpus, descreveremos, nos itens que seguem, os passos realizados para o levantamento das UFEs em que o termo gol está inserido e os procedimentos adotados para o estabelecimento de equivalentes fraseológicos entre o par de línguas inglês- português. Ressaltamos, aqui, que como o 
objetivo final de nossa pesquisa é compilar um modelo de glossário bilíngue inglêsportuguês de fraseologias do futebol, selecionamos o termo gol para a elaboração do modelo de glossário.

\subsubsection{Levantamento das UFs}

Inicialmente, geramos as linhas de concordância da palavra gol na ferramenta Concord. Em seguida, aplicamos o dispositivo Re-sort que nos permite ordenar as linhas de concordância de acordo com as palavras próximas à palavra de busca. No entanto, devido ao grande número de ocorrências de gol (7.357), julgamos impossível identificar as possíveis fraseologias somente pela observação das linhas de concordâncias, mesmo que reordenadas.

A figura 30 mostra as linhas de concordância de gol ordenadas pela primeira palavra à esquerda e pelas duas primeiras palavras à direita:

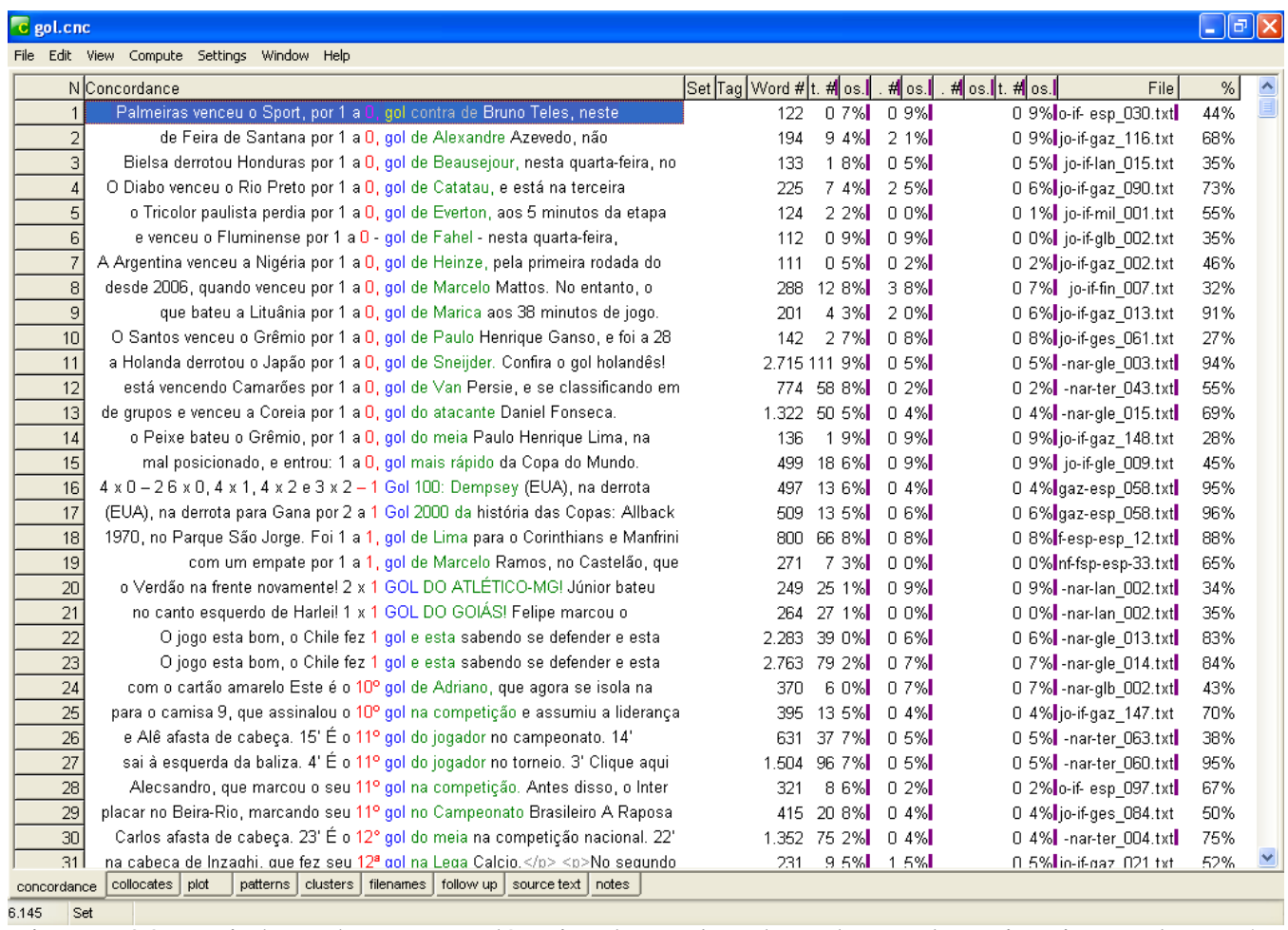

Figura 30 - Linhas de concordância de gol ordenadas pela primeira palavra à direita e pelas duas palavras à esquerda do nódulo 
Resolvemos, então, utilizar o dispositivo Cluster, que disponibiliza sequências de palavras que ocorrem com determinada frequência. Assim como as outras ferramentas do programa, o dispositivo permite ao usuário ajustar as configurações para que retorne melhores resultados. Ajustamos as configurações para encontrar clusters de três palavras, com a frequência mínima de cinco, em uma janela de cinco palavras à direita e cinco à esquerda, como mostra a figura 31 .

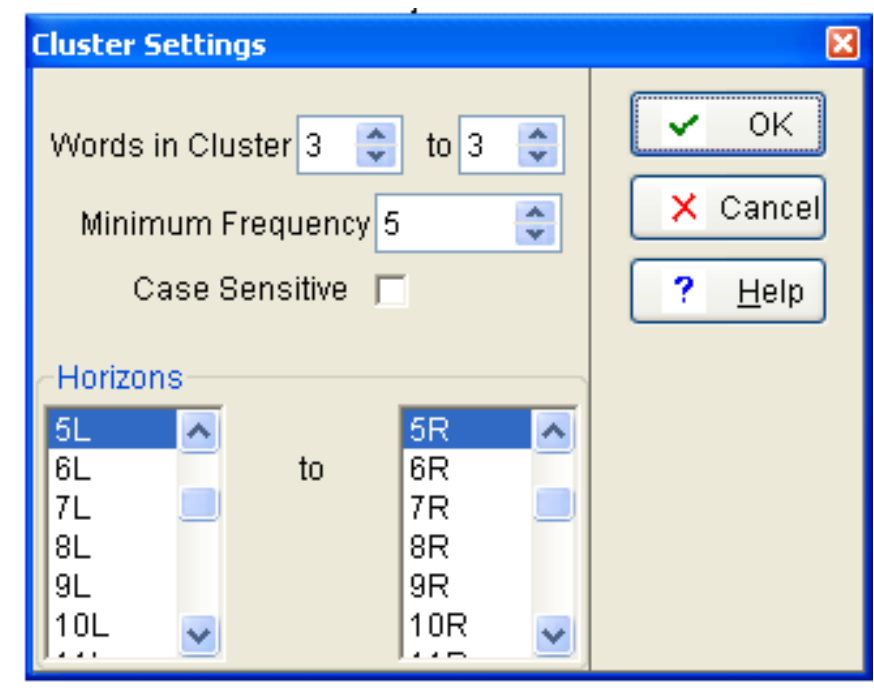

Figura 31 - Ajuste das configurações do dispositivo Cluster

Realizados os ajustes, obtivemos 1.572 clusters, dos quais selecionamos os cem primeiros para análise:

\begin{tabular}{rrr}
$\mathbf{N}$ & Cluster & Freq. \\
\hline 1 & GOL FEITO POR & 561 \\
2 & NO GOL FEITO & 561 \\
3 & DIREITA NO GOL & 391 \\
4 & DE DIREITA NO & 391 \\
5 & PARA O GOL & 318 \\
6 & POR CIMA DO & 230 \\
7 & CIMA DO GOL & 221 \\
8 & DO GOL DE & 196 \\
9 & OPRIMEIRO GOL & 173 \\
10 & O GOL DE & 173 \\
11 & ESQUERDA NO GOL & 169 \\
12 & DE ESQUERDA NO & 169 \\
13 & DO GOL E & 165 \\
14 & OSEGUNDO GOL & 149 \\
15 & DEPOIS DO GOL & 146 \\
16 & O GOL DA & 126 \\
17 & SAÍDA DEPOIS DO & 123 \\
18 & COM GOL DE & 109
\end{tabular}


LONGE DO GOL $\quad 108$ SAIDO GOL $\quad 106$ COM UM GOL $\quad 102$ NA CARA DO $\quad 92$ 


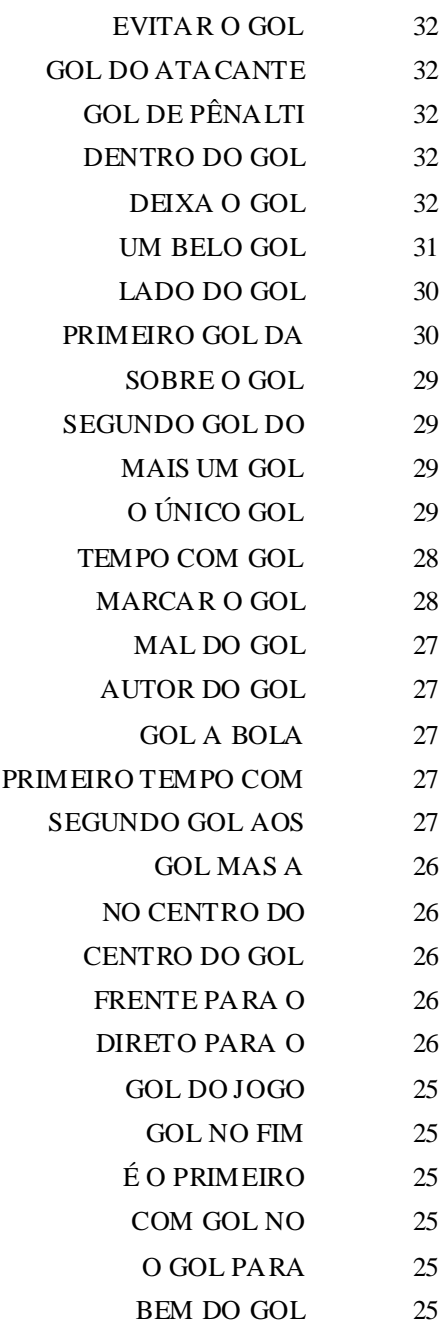

Quadro 8 - Seleção dos cem primeiros clusters de gol

Como podemos observar, o fato de algumas palavras serem encontradas repetidamente em uma mesma sequência não lhes garante o status de UFE, pois não constituem unidades de sentido como, por exemplo, bem do gol (100) e o gol para (99).

\subsubsection{Validação das UFs}

Para validar as fraseologias, agrupamos os clusters que pareciam expressar uma mesma unidade de sentido, estendemos os que pertenciam a uma unidade de sentido maior e eliminamos os que não constituíam UFs e os que ocorriam somente em um único veículo de informação ${ }^{103}$. O quadro 9 mostra como o agrupamento foi realizado:

${ }^{103}$ Um dos critérios para a validação de uma fraseologia é que seu uso não seja restrito a um único veículo ou autor. 


\begin{tabular}{|c|c|c|c|c|c|}
\hline $\mathbf{N}$ & Cluster & Freq. & Length & Related & \\
\hline 1 & GOL FEITO POR & 561 & 3 & 4 & $\begin{array}{l}\text { 2: mesma UFE / ocorre somente na transmissão minuto a } \\
\text { minuto realizada pelo YahooSports }\end{array}$ \\
\hline$z$ & NOGOLFEITO & 561 & 3 & 4 & \\
\hline 3 & DIREITA NO GOL & 394 & 3 & 4 & 4: mesma UFE \\
\hline 4 & DEDIREITANO & 394 & 3 & 4 & \\
\hline 5 & PARAOGOL & 318 & 3 & 4 & \\
\hline 6 & POR CIMA DO & 230 & 3 & 4 & 7: mesma UFE \\
\hline 7 & EIMADOGOL & 221 & 3 & 4 & \\
\hline 8 & DO GOL DE & 196 & 3 & 1 & é sempre parte de outra UFE \\
\hline 9 & O PRIMEIRO GOL & 173 & 3 & 1 & 39, 70, 78 e 97: mesma UFE \\
\hline 10 & O GOL DE & 173 & 3 & 1 & é sempre parte de outra UFE \\
\hline 11 & ESQUERDA NO GOL & 169 & 3 & 4 & 12: mesma UF \\
\hline 12 & DE ESQUERDANO & 169 & 3 & 4 & \\
\hline 13 & DO GOL E & 165 & 3 & 1 & é sempre parte de outra UFE \\
\hline 14 & O SEGUNDO GOL & 149 & 3 & 1 & 65, 80 e 89: mesma UFE \\
\hline 15 & DEPOIS DO GOL & 146 & 3 & 1 & apenas 46 são UFE \\
\hline 16 & OGOLDA & 126 & 3 & 4 & 394, 143, 60, 27: mesma UFE \\
\hline 17 & SAIIDA DEPOIS DO & 123 & 3 & 1 & $\begin{array}{l}\text { Ocorre somente durante a transmissão da copa realiada pelo } \\
\text { YahooSports }\end{array}$ \\
\hline 18 & COMGOL DE & 109 & 3 & 4 & 21,26: mesma UFE \\
\hline 19 & LONGE DO GOL & 108 & 3 & 1 & \\
\hline 20 & SAI DO GOL & 106 & 3 & 1 & \\
\hline
\end{tabular}

Quadro 9 - Agrupamento e elimi nação das UFs

O primeiro passo foi agrupar os clusters que faziam parte de uma mesma unidade fraseológica. Por exemplo, o cluster número 6, por cima do, e o número 7, cima do gol, foram agrupados e deram origem à UF por cima do gol.

Apesar do agrupamento, a UF ainda parecia estar "quebrada", ou seja, incompleta. Para verificar seu comportamento, observamos as linhas de concordância de por cima do gol onde pudemos constatar que a UF era, muitas vezes, parte integrante de unidades maiores. A figura 32 mostra uma seleção de linhas de concordância para por cima do gol: 


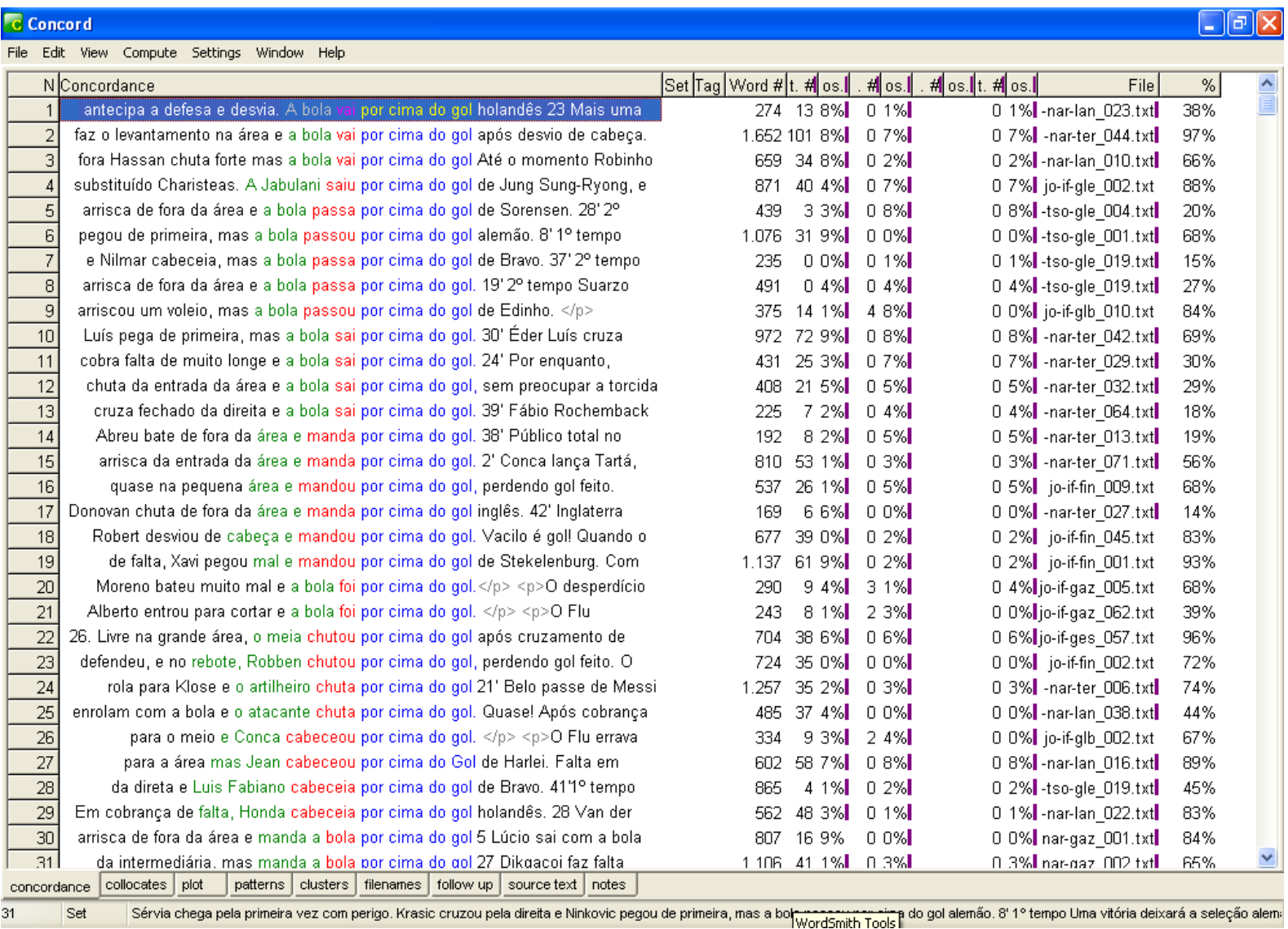

Figura 32 - Seleção das linhas de concordância para por cima do gol

Por questão de espaço, não seria possível mostrar as 230 linhas de concordância que o programa nos retornou ${ }^{104}$. Sendo assim, fizemos uma seleção de modo a representar todas as estruturas em que por cima do gol ocorre.

Ao analisar as linhas, podemos observar que a UF ocorre sempre como parte integrante de três estruturas maiores:

a) a bola $\{$ IR/PASSAR|SAIR] por cima do gol; linhas 1-13

b) \{CHUTAR|MANDAR $\}$ (a bola) por cima do gol; linhas 14-19, 22-25 e 30-31

c) CABECEAR por cima do gol; linhas 26-29

Todas as estruturas acima possuem frequência superior a dez em nosso corpus, frequencia relativamente alta dada à extensão que possuem. Durante a observação das linhas, também encontramos outras estruturas que ocorreram menos de dez vezes e que

${ }^{104}$ Vide anexo B para observar todas as linhas de concordância. 
optamos por não incluir no modelo de glossário por questão de espaço. Temos ciência de que o corte realizado foi alto, entretanto, foi a alternativa mais viável para a compilação de um verbete que auxilie o produtor de texto de forma detalhada, mas não exaustiva. Dessa forma, UFEs como SOLTAR uma bomba por cima do gol (3) não entram para o modelo de glossário.

Voltando aos clusters, o passo seguinte foi eliminar os clusters que não constituíam UFEs. Por exemplo, o cluster número oito, do gol de, é sempre parte de alguma outra UFE como, por exemplo, a bola $\{P A S S A R \mid S A I R\}$ à direita do gol de [goalkeeper], ou ocorre no texto, mas sem o status de UFE como nos exemplos abaixo:

a) Logo aos 13 minutos, Roger apresentou o cartão de visitas ao Verdão e carimbou o travessão do gol de Marcos.

b) O tira-teima do gol de Robinho.

c) A alegria santista, no entanto, durou apenas 10 minutos, já que o goleiro Felipe saiu do gol de maneira atrapalhada e cometeu pênalti em Gilmar, que cobrou e deixou tudo igual nos Aflitos.

O último passo foi eliminar os clusters que só ocorriam em um único veículo de informação como o caso do cluster mais frequente de nossa lista: gol feito por:

\begin{tabular}{|c|c|c|c|c|c|c|c|c|}
\hline \multicolumn{7}{|c|}{ c Concord } & \multicolumn{2}{|c|}{ E回 $x$} \\
\hline File Edit $\mathrm{v}$ & niew Compute & Settings Window Help & & & & & & \\
\hline $\mathrm{N} / \mathrm{Co}_{0}$ & incordance & & Set Tag Word \# & t. 湅 os. $\mid$. & An os & 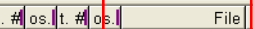 & $\%$ & \\
\hline 1 & intl_soccer & gol feito por Dominic Adiyiah (GHA) 2nd & 300 & $67 \%$ & $09 \%$ & $09 \%$ nar-yah_054.txt| & $11 \%$ & \\
\hline 2 & & Chute de direita no gol feito por Aruna Dindane (CIV) $1^{\circ}$ & 1.324 & $255 \%$ & $07 \%$ & $07 \%$ n naryah_025.txtI & $68 \%$ & \\
\hline 3 & & Chute de direita no gol feito por Vincent Aboubakar (CMR) & 320 & $32 \% \mathbf{I}$ & $07 \% \mathbf{I}$ & $07 \%$ Inar-yah_024.txtI & $19 \%$ & \\
\hline 4 & & Chute de direita no gol feito por Dani Alves (BRA) $1^{\circ}$ & 958 & $122 \%$ & $03 \%$ & $03 \%$ nar-yah_041.txtI & $55 \%$ & \\
\hline 5 & & Chute de direita no gol feito por Emmanuel Eboué (CIV) $1^{\circ}$ & 1.245 & $244 \%$ & $03 \%$ & $03 \%$ nar-yah_025.txtI & $64 \%$ & \\
\hline 6 & & Chute de direita no gol feito por Park Chu-Young (KOR) $2^{\circ}$ & 717 & $137 \%$ & $06 \% \mathbf{I}$ & $06 \%$ nar-yah_031.txtI & $38 \%$ & \\
\hline 7 & & Chute de direita no gol feito por Lee Young-Pyo (KOR) $2^{\circ}$ & 743 & $133 \%$ & $07 \%$ & $07 \%$ nar-yah_031.txt] & $39 \%$ & \\
\hline 8 & & Chute de direita no gol feito por Juan Sebastián Verón & 1.223 & $159 \%$ & $04 \%$ & $04 \%$ nar-yah_032.txt] & $74 \%$ & \\
\hline 9 & & Chute de direita no gol feito por Asamoah Gyan (GHA) $1^{\circ}$ & 1.781 & $313 \% \mathbf{I}$ & $09 \%$ & 0 9\%/ nar-yah_023.txt] & $79 \%$ & \\
\hline 10 & & Chute de direita no gol feito por Achille Emana (CMR) $2^{\circ}$ & 418 & $47 \%$ & $03 \%$ & 0 3\% nar-yah_024.txtI & $25 \%$ & \\
\hline 11 & & Chute de direita no gol feito por Stéphane MBia (CMR) $2^{\circ}$ & 621 & $68 \%$ & $03 \%$ & $03 \%$ Inar-yah_024.txtI & $35 \%$ & \\
\hline 12 & & Chute de direita no gol feito por Pierre Webó (CMR) $2^{\circ}$ & 722 & $86 \%$ & $09 \%$ & 0 9\%ol nar-yah_024.txtI & $41 \%$ & \\
\hline 13 & & Chute de direita no gol feito por Kevin-Prince Boateng (GHA) & 1.361 & $225 \%$ & $00 \%$ & 0 o\% I nar-yah_023.txtI & $61 \%$ & \\
\hline 14 & & Chute de direita no gol feito por Ramires (BRA) $2^{\circ}$ tempo $45^{\prime}$ & 203 & $27 \%$ & $01 \%$ & $01 \%$ Inar-yah_041.txt] & $13 \%$ & \\
\hline 15 & & Chute de direita no gol feito por Jonathan Mensah (GHA) $1^{\circ}$ & 1.729 & $302 \%$ & $07 \%$ & $07 \%$ n naryah_023.txtI & $77 \%$ & \\
\hline 16 & & Chute de direita no gol feito por Ibrahim Afellay (NED) $2^{\circ}$ & 325 & $22 \%$ & $08 \% \mathbf{l}$ & $08 \%$ I nar-yah_022.txt] & $21 \%$ & \\
\hline 17 & & Chute de esquerda no gol feito por Andraz Kirm (SVN) $2^{\circ}$ & 713 & $104 \%$ & $06 \%$ & 0 6\% I nar-yah_033.txtI & $36 \%$ & \\
\hline 18 & & Chute de esquerda no gol feito por Victor Caceres (PAR) $1^{\circ}$ & 1.443 & $229 \%$ & $00 \%$ & $00 \%$ n nar-yah_038.txtl & $80 \%$ & \\
\hline 19 & & Chute de esquerda no gol feito por Lionel Messi (ARG) 2nd & 909 & $05 \%$ & $01 \% \mathbf{I}$ & 0 1\% I nar-yah_002.txt] & $52 \%$ & \\
\hline 20 & & Chute de esquerda no gol feito por Giovani Dos Santos (MEX) & 2.026 & $27 \% \mathbf{I}$ & $08 \% \mathbf{I}$ & $08 \%$ nar-yah_001.txt] & $98 \%$ & \\
\hline 21 & & Chute de esquerda no gol feito por Hakan Yakin (SUI) $2^{\circ}$ & 226 & $19 \% \mathbf{I}$ & $02 \%$ & $02 \%$ Inar-yah_043.txtI & $14 \%$ & \\
\hline 22 & & Chute de esquerda no gol feito por Rafael van der Vaart (NED) & 645 & $118 \% \mathbf{l}$ & $03 \%$ & 0 3\% I nar-yah_040.txtI & $35 \%$ & \\
\hline 23 & & Chute de esquerda no gol feito por Mark González $(\mathrm{CHI}) 1^{\circ}$ & 1.059 & $199 \%$ & $03 \%$ & $03 \%$ nar-yah_044.txtl & $64 \%$ & \\
\hline 24 & & Chute de esquerda no gol feito por Mesut Özil (GER) $1^{\circ}$ & 1.318 & $167 \%$ & $03 \%$ & 0 3\% n nar-yah_035.txtl & $84 \%$ & \\
\hline 25 & & Chute de esquerda no gol feito por Lionel Messi (ARG) 1st & 1.247 & $06 \% \mathbf{l}$ & $00 \%$ & $00 \%$ Inar-yah_002.txt] & $71 \%$ & \\
\hline 26 & & Chute de esquerda no gol feito por Lionel Messi (ARG) 1 st & 1.519 & $03 \%$ & $06 \%$ & $06 \%$ nar-yah_002.tx+1 & $86 \%$ & \\
\hline 27 & & Chute de esquerda no gol feito por Giovani Dos Santos (MEX) & 1.298 & $23 \%$ & $03 \%$ & 0 3\% n nar-yah_001.txt] & $63 \%$ & \\
\hline 28 & & Chute de esquerda no gol feito por Giovani Dos Santos (MEX) & 835 & $13 \% \mathbf{I}$ & $00 \%$ & 0 o\%l nar-yah_001.txtl & $40 \%$ & \\
\hline 29 & & Chute de esquerda no gol feito por Benoit Assou-Ekotto (CMR) & 1.840 & $267 \%$ & $09 \%$ & 0 9\%/ nar-yah_024.txtl & $99 \%$ & \\
\hline 30 & & Chute de esquerda no gol feito por Hong Young Jo (PRK) $2^{\circ}$ & 1.128 & $239 \%$ & $06 \%$ & $06 \%$ Inar-yah_026.txtI & $57 \%$ & \\
\hline 31 & & Chute de esauerda no aol feito por Tave Taiwo (NGA) 1st & 1.351 & $\pi .3 \%$ & $n 7 \%$ & ก 7 \% I nar-vah $n$ nก $+x+1$ & $77 \%$ & $\underline{\underline{v}}$ \\
\hline cordanc & cates & 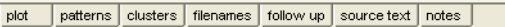 & & & & & & \\
\hline
\end{tabular}

Figura 33 - Seleção de linhas de concordância para gol feito por 
Ao observar a coluna de número 13, podemos concluir que o cluster ocorre somente nos textos de uma única fonte, o site YahooSports.

Após a validação dos clusters como UFEs, criamos uma outra planilha no Excel para organizar as UFEs encontradas:

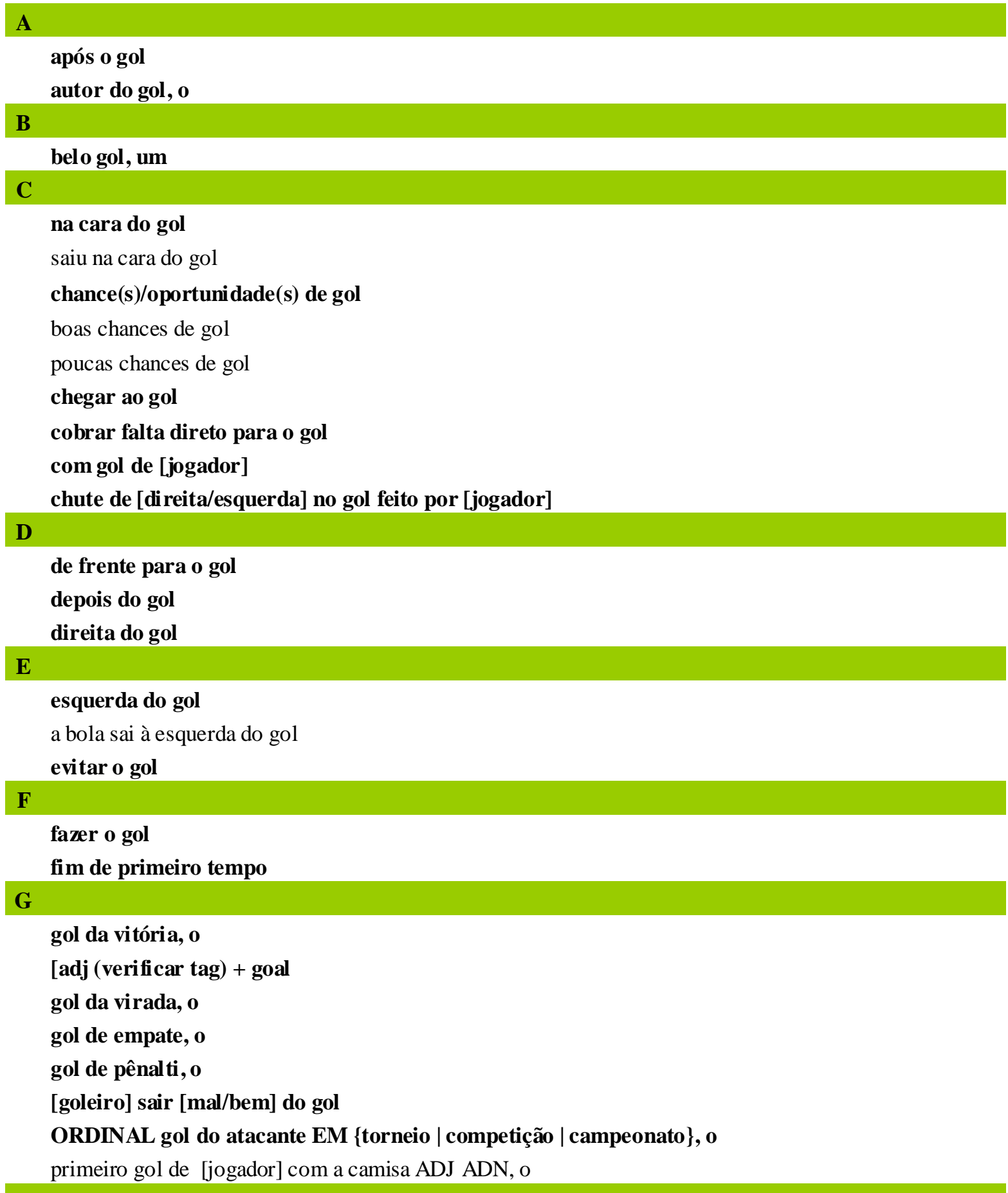




\section{longe do gol}

a bola [passar] longe do gol

[finalizar|mandar] para longe do gol

M

[marcou(45)/marcar] (28) o gol

meio do gol, no

[goleiro] segura no meio do gol

O

oportunidades de gol

$\mathbf{P}$

para o gol

CABECEAR para o gol

[jogador] DESVIAR para o gol

\{ARREMATAR | COMPLETAR | CONCLUIR | FINALISAR \} para o gol

\{BATER | CHUTAR | EMPURRAR | MANDAR | TOCAR\} para o gol

RECEBER de costas para o gol

VERBO para o gol vazio

perigo ao gol de [goleiro]

perto do gol

a bola [passa*/passou] (muito) perto do gol

por cima do gol

a bola \{ir|passar|sair] por cima do gol

cabecear por cima do gol

chutar/mandar (a bola) por cima do gol

S

sair do gol

[goleiro] SAIR do gol e ficar com a bola

U

único gol da partida, o

Quadro 10 - UFEs encontradas

Após a validação das UFEs em português, a etapa seguinte foi estabelecer seus equivalentes eminglês, passo que será detalhado no próximo item.

\subsubsection{Atribuição dos equivalentes das UFs encontradas}

O primeiro passo para o estabelecimento de equivalentes eminglês para as UFEs em português foi gerar linhas de concordância para goal* ${ }^{105}$ :

\footnotetext{
${ }^{105}$ Opatmos pelo nódulo de busca goal* para obter tanto as ocorrências de goal quanto de goals.
} 


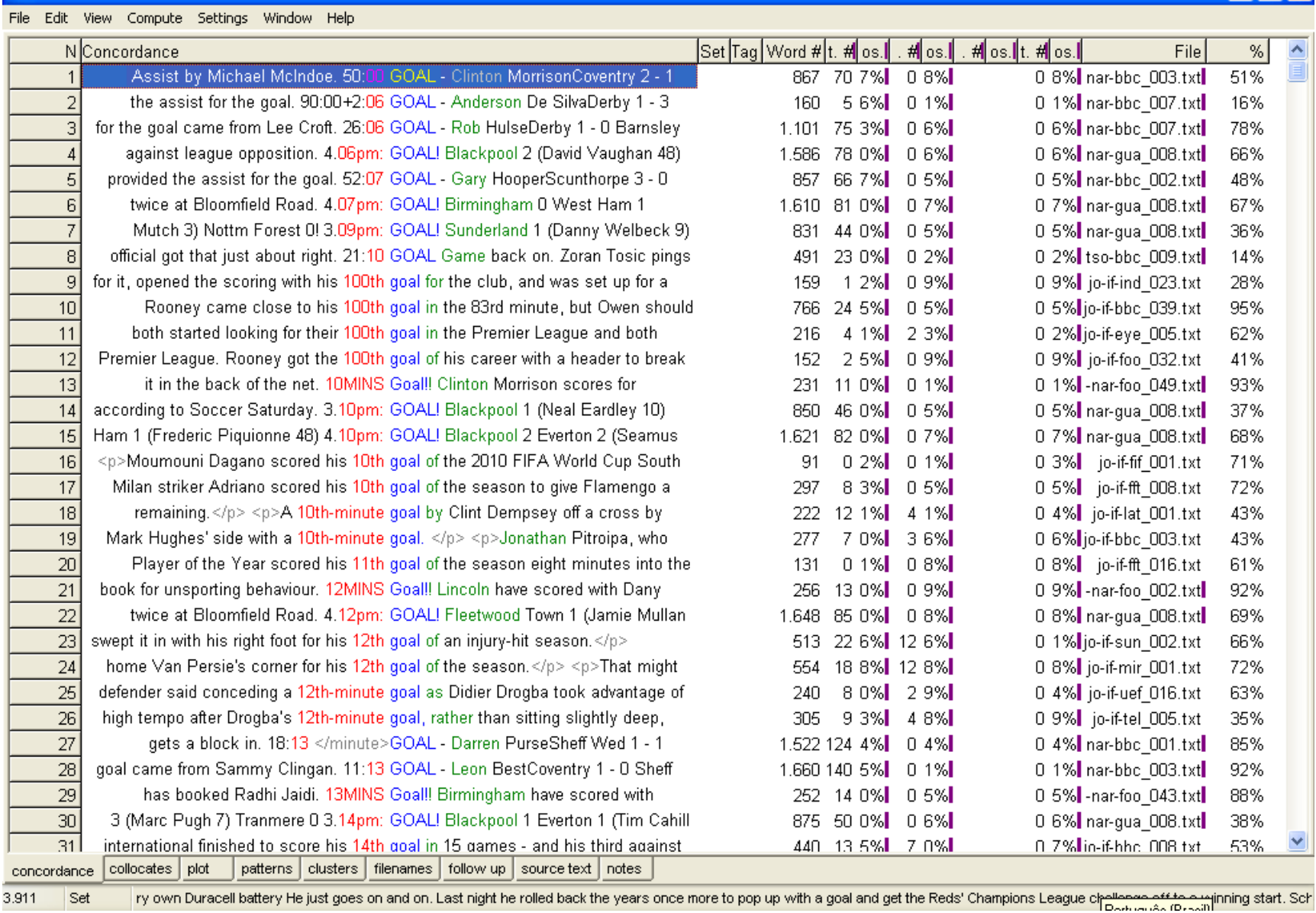

Figura 34 - Linhas de concordância de goal* ordenadas pela primeira palavra à direita e pela primeira palavra à esquerda

Como podemos observar, seria quase impossível estabelecer padrões para as estruturas em que goal ocorre somente pela análise das linhas de concordância, pois teríamos que analisar as 7.357 concordâncias em busca dos equivalentes. Por esse motivo, resolvemos gerar clusters de goal para verificar se poderiam ser possíveis equivalentes dos clusters de gol: 


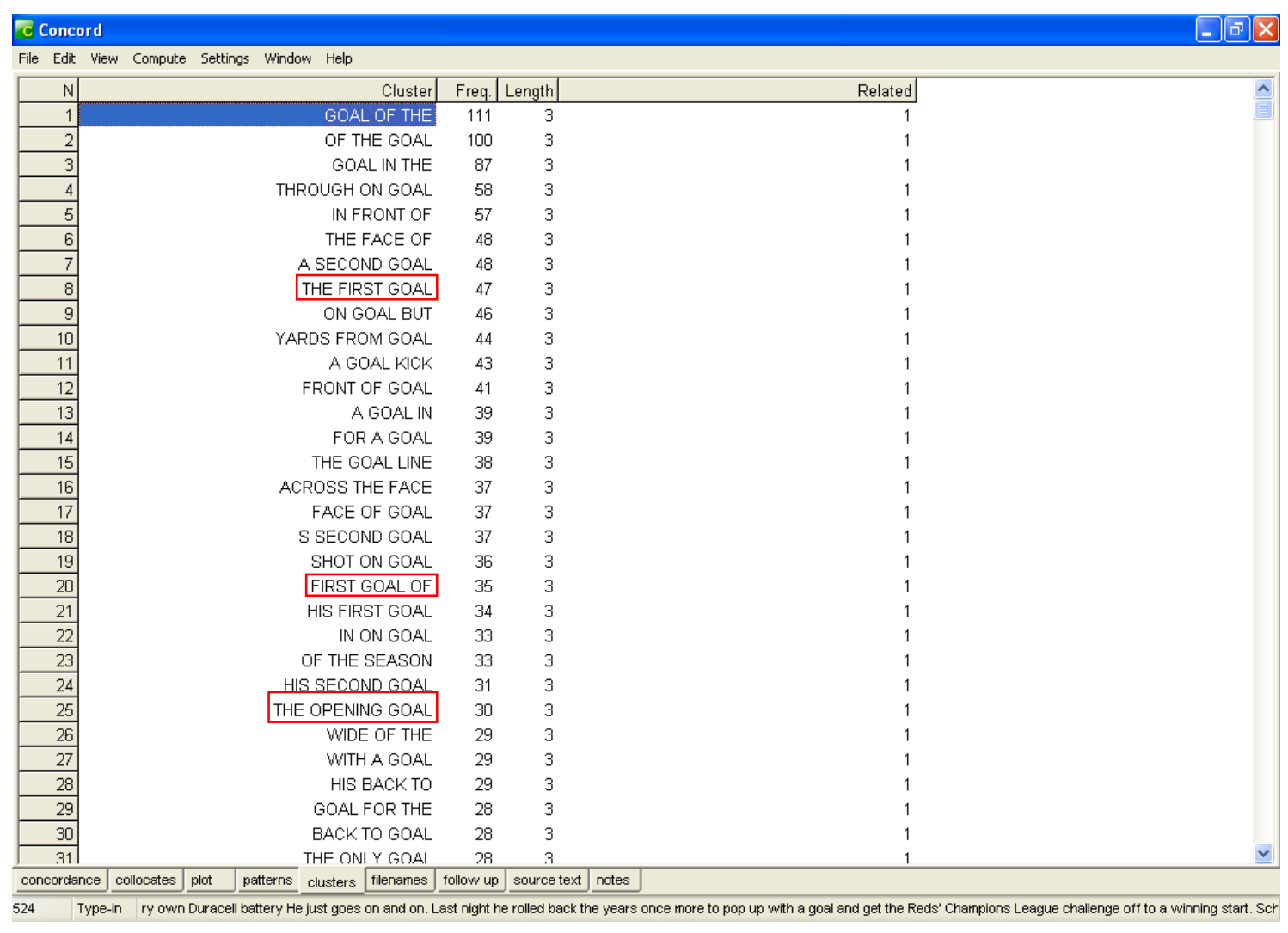

Figura 35 - Clusters de goal

Com o objetivo de facilitar a análise, ajustamos as configurações do dispositivo para encontrar clusters de três palavras, com a frequência mínima de três em uma janela de cinco palavras à direita e cinco à esquerda de goal. Para a extração em português utilizamos a frequência cinco, número que optamos por reduzir para a extração em inglês devido à menor ocorrência da palavra GOAL (4843) comparada ao seu equivalente em português GOL (7357).

Ao observar a lista, fica evidente que alguns clusters de goal como, por exemplo os clusters 8, 20 e 25, the first goal, first goal of e the opening goal, são equivalentes dos clusters o primeiro gol, primeiro gol do, primeiro gol de e primeiro gol da, em português. No entanto, não encontramos equivalentes para a maior parte das UFEs. Por esse motivo, realizamos outros dois tipos de busca: 1) para os possíveis colocados de goal; 2) para algumas etiquetas gramaticais.

Vale ressaltar que, apesar de muitas vezes um mesmo tipo de busca ser utilizado para UFEs diferentes, a forma de analisar o resultado foi diferente para cada UFE. 
Sendo assim, nesta seção apresentaremos os dois outros tipos de buscas realizadas e, no próximo capítulo, descreveremos detalhadamente o caminho percorrido para $\mathrm{o}$ estabelecimento do(s) equivalente(s) de cada UFE.

Para ilustrar o primeiro tipo de busca, utilizaremos a fraseologia o único gol da partida. Como analisar todos os colocados à esquerda de gol em busca de um equivalente para único demandaria muito tempo, mesmo com as linhas ordenadas alfabeticamente pela primeira palavra à esquerda, geramos linhas de concordância para only e chegamos à UF the only goal of the game|match:

\begin{tabular}{|c|c|c|c|c|c|c|c|}
\hline \multicolumn{6}{|l|}{ C Concord } & \multicolumn{2}{|c|}{ - 0 a } \\
\hline \multicolumn{8}{|c|}{ File Edit View Compute Settings Window Help } \\
\hline & Concordance & \begin{tabular}{|l|l|l|} 
Set & Tag & Word \# \\
\end{tabular} & t. 刑 0 os.| & H. 0 os. $\mid$ & $H \mid$ os. $\mid$ t. $\# \mid$ os.|| & $\%$ & $\underline{\underline{\Lambda}}$ \\
\hline 646 & \multirow{3}{*}{$\begin{array}{l}\text { against Benfica Gareth Bale scored the only goal as Tottenham beat Benfica 1-0 } \\
\text { Fernando Torres scored Liverpool's only goal but this season they will need } \\
\text { substitutes before Stoyanov scored the only goal. Ciaran Martyn came on as a }\end{array}$} & 91 & $01 \%$ & $03 \%$ & 0 3\%ljo-if-365_082.txt & $61 \%$ & \\
\hline 647 & & 321 & $83 \% \mathbf{I}$ & $03 \% \mathbf{I}$ & 0 3\%l jo-if-ind_011.txt & $41 \%$ & \\
\hline 648 & & 259 & $84 \% \mathbf{I}$ & $07 \%$ & 0 7\%ljo-if-bbc_009.txt & $90 \%$ & \\
\hline 649 & American group on 30 points, with only goal difference separating them from & 161 & $17 \% \mathbf{I}$ & $06 \%$ & 0 6\%l jo-iffft_022.txt & $36 \%$ & \\
\hline 650 & \multirow{2}{*}{$\begin{array}{l}\text { back, but with nine games left it's still only goal difference that's keeping them } \\
\text { Íntegra David Villa scores only goal for record-breaking Spain IB }\end{array}$} & 454 & $165 \% \mathbf{I}$ & $52 \% \mathbf{I}$ & 0 1\%ljo-if-gua_020.txt & $46 \%$ & \\
\hline 651 & & 22 & $07 \%$ & $07 \% \mathbf{I}$ & $04 \%$ jo-if-gua_009.txt & $6 \%$ & \\
\hline 652 & Internet David Villa scores only goal for record-breaking Spain & 95 & $05 \% \mathbf{l}$ & $05 \%$ & 0 7\%ljo-if-gua_009.txt & $29 \%$ & \\
\hline 653 & of unity after slotting home the game's only goal from six yards. $\langle p\rangle\langle p\rangle$ & 304 & $60 \%$ & $33 \% \mathbf{I}$ & 0 2\%ljo-if-gua_012.txt & $48 \%$ & \\
\hline 654 & \multirow{2}{*}{$\begin{array}{l}\text { The fact remains, however, that their only goal has come courtesy of a rush of } \\
\text { Moment of the match: It has to be the only goal. Holland had repelled Spain - }\end{array}$} & 215 & $44 \% \mathbf{l}$ & $05 \% \mathbf{l}$ & 0 5\%l jo-if-ind_025.txt & $44 \%$ & \\
\hline 655 & & 1.561 & $722 \% \mathbf{I}$ & $09 \% \mathbf{I}$ & 0 9\%ljo-if-sky_004.txt & $90 \%$ & \\
\hline 656 & Zidane converted a penalty kick for the only goal in a defeat of Portugal, and in & 435 & $110 \% \mathbf{I}$ & $41 \% \mathbf{I}$ & 0 5\%l jo-if-wp_066.txt & $49 \%$ & \\
\hline 657 & \multirow{2}{*}{$\begin{array}{l}\text { Not since Carlos Tevez scored the only goal in a defeat to Manchester } \\
\text { relied on the speed of Robben for the only goal in an opening 1-0 win over }\end{array}$} & 148 & $20 \% \mathbf{l}$ & $05 \% \mathbf{I}$ & 0 5\%l jo-if-ind_011.txt & $25 \%$ & \\
\hline 658 & & 128 & $12 \% \mid$ & $17 \% \mathbf{I}$ & 0 5\%l jo-if-wp_076.txt & $48 \%$ & \\
\hline 659 & $\begin{array}{l}\text { relied on the speed of Robben for the only goal in an opening 1-0 win over } \\
\text { relied on the speed of Robben for the only goal in an opening 1-0 win over }\end{array}$ & 124 & $12 \% \mid$ & $17 \% \mathbf{I}$ & $04 \%$ jo-if-wp_ $070 . t \times t$ & $47 \%$ & \\
\hline 660 & \multirow{2}{*}{ the Caribbean camp. $\langle/ p\rangle\langle p\rangle$ The only goal in the first two games Saturday } & 153 & $32 \% \mathbf{I}$ & $16 \%$ & $00 \% \mathbf{l}$ jo-if-wp_060.txt & $28 \%$ & \\
\hline 661 & & 342 & $110 \% \mathbf{I}$ & $49 \% \mathbf{I}$ & 0 3\%l jo-if-wp_007.txt & $38 \%$ & \\
\hline 662 & $\begin{array}{l}\text { suggestion considering their only goal in the first two games was } \\
\text { to leave his mark. The Americans' only goal in the tournament was knocked }\end{array}$ & 828 & $412 \%$ I & $146 \% \mathbf{I}$ & $02 \%$ jo-if-wp_017.txt & $93 \%$ & \\
\hline 663 & Preamble: Algeria have scored only goal in their last seven matches and & 148 & $21 \% \mathbf{I}$ & $04 \%$ & $04 \%$ nar-gua_ $036 . t x t \mid$ & $7 \%$ & \\
\hline 664 & \multirow{2}{*}{$\begin{array}{l}\text { in six games - from } 10 \text { scorers. And the only goal it conceded was through a } \\
\text { to keep out a header from Sidwell. The only goal occurred after Stuart Parnaby }\end{array}$} & 851 & $355 \% \mathbf{l}$ & $131 \% \mathbf{l}$ & $04 \%$ l jo-if-ny_011.txt & $76 \%$ & \\
\hline 665 & & 484 & $167 \% \mathbf{I}$ & $04 \%$ & $04 \%$ jo-ifffoo_007.txt & $95 \%$ & \\
\hline 666 & \multirow{2}{*}{$\begin{array}{l}\text { his full debut in perfect fashion with the only goal of a poor game just after the } \\
\text { show, but Gabriel Heinze scored the only goal of an excellent match that }\end{array}$} & 177 & $16 \%$ & $03 \% \mathbf{I}$ & 0 3\%l jo-if-ind_024.txt & $45 \%$ & \\
\hline 667 & & 108 & $14 \% \mathbf{I}$ & $01 \% \mathbf{I}$ & 0 $1 \%$ l jo-if-tfa_001.txt & $34 \%$ & \\
\hline 668 & & 104 & $15 \% \mid$ & $04 \%$ I & $04 \%$ ljo-if-gua_063.txt & $27 \%$ & \\
\hline 669 & \multirow{3}{*}{$\begin{array}{l}\text { minute strike which proved to be the only goal of the game. Blake took centre } \\
\langle p\rangle \text { Thembinkosi Fanteni scored the only goal of the game after six minutes, } \\
\text { week of his club's season with the only goal of the game. }\langle p\rangle\langle p\rangle \text { More }\end{array}$} & 149 & $23 \% \mathbf{I}$ & $05 \% \mathbf{I}$ & 0 5\% jo-iffoo_035.txt & $48 \%$ & \\
\hline 670 & & 118 & $15 \% \mathbf{I}$ & $06 \%$ & 0 9\%ljo-if-bbc_016.txt & $30 \%$ & \\
\hline 671 & & 163 & $12 \% \mathbf{I}$ & $08 \% \mathbf{I}$ & 0 2\%ljo-if-gua_012.txt & $31 \%$ & \\
\hline 672 & \multirow{2}{*}{$\begin{array}{l}\text { Marshall in the 18th minute for the only goal of the game. Cardiff went on to } \\
\text { of endeavour but West Ham scored the only goal of the first half, a curling Mark }\end{array}$} & 136 & $17 \% \mathbf{I}$ & $06 \% \mathbf{I}$ & 0 6\%ljo-if-365_054.txt & $38 \%$ & \\
\hline 673 & & 127 & $18 \% \mathbf{I}$ & $08 \% \mathbf{I}$ & $08 \%$ ljo-if-bbc_032.txt & $27 \%$ & \\
\hline 674 & marauder was at his finest, scoring the only goal of the game and setting up a & 162 & $41 \% \mathbf{I}$ & $06 \% \mathbf{I}$ & 0 6\%ljo-if-sun_031.txt & $23 \%$ & \\
\hline 675 & & 172 & $39 \% \mathbf{l}$ & $07 \% \mathbf{l}$ & $07 \%$ jo-iffoo_038.txt & $48 \%$ & \\
\hline ค7ต - & $\begin{array}{l}\text { form. The England striker scored the only goal of the game and could easily } \\
\text { Moscow midfielder Honda scored the only aoal of the aame seven minutes }\end{array}$ & 177 & $27 \%$ & $n 8 \% \mathbf{l}$ & $\Pi 8 \%$ in-if-tfa $\Pi 1 \Pi$ txt & $4 \Pi \%$ & $\underline{\underline{v}}$ \\
\hline cordance & \begin{tabular}{|l|l|l|l|l} 
patterns & clusters & filenames & follow up & source text \\
notes
\end{tabular} & & & & & & \\
\hline
\end{tabular}

Figura 36 - linhas de concordância para only ordenadas pelas três primeiras palavras à direita

Para verificar se havia algum outro equivalente possível, geramos concordâncias para goal of the game, as ordenamos pela primeira palavra à esquerda e encontramos algumas ocorrências de the lone goal of the game.

Como exemplo do segundo tipo de busca, por etiquetas gramaticais, podemos utilizar UFEs como um belo gol, um gol incrível, um bonito gol e o gol da vitória. De acordo com a sintaxe da língua inglesa, os adjetivos que possivelmente antecedem o 
termo goal ocorrem imediatamente à sua esquerda. Sendo assim, geramos linhas de concordância para $J J *$ goal, em que a etiqueta $J J$ corresponde a um adjetivo:

\begin{tabular}{|c|c|c|c|c|c|c|}
\hline \multicolumn{2}{|c|}{ C Concord } & & & & \multicolumn{2}{|c|}{ - } \\
\hline \multicolumn{7}{|c|}{ File Edit View Compute Settings Window Help } \\
\hline \multicolumn{2}{|c|}{$\mathrm{N}$ Concordance } & Set $\mid$ Tag $\mid$ Word \#|t. \#| os.|| & \#| os.|| & 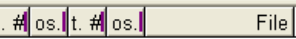 & $\%$ & $\hat{\underline{A}}$ \\
\hline 67 & \multirow{2}{*}{$\begin{array}{l}\text { through on } I N \text { on the DT the American } J J \text { American goal NN goal by IN by a DT } \\
\text { a disallowed } W D \text { disallow American } J J \text { American goal NN goal and } C C \text { and }\end{array}$} & $10.1693499 \%$ & $08 \% \mathbf{I}$ & $08 \%$ Inar-gua_031.tagl & $68 \%$ & \\
\hline 68 & & $159117 \% \mathbf{l}$ & $06 \%$ & $06 \%$ jo-if-wp_026.tag & $6 \%$ & \\
\hline 69 & NN start. SENT. The DT the American JJ American goal NN goal may MD may & $400 \quad 67 \%$ & $08 \%$ & $08 \%$ o-if-gua_002.tagl & $8 \%$ & \\
\hline 70 & \multirow{2}{*}{$\begin{array}{l}\ldots \text {, but } C C \text { but the } D T \text { the apparent } J J \text { apparent goal NN goal was VBD be } \\
\text { into IN into the } D T \text { the Argentine } J J \text { Argentine goal NN goal off IN off the }\end{array}$} & $1.660459 \%$ & $09 \%$ & 0 9\%l jo-if-wp_023.tag & $49 \%$ & \\
\hline 71 & & $1.208506 \% \mathbf{I}$ & $02 \% \mathbf{I}$ & $02 \%$ jo-if-tel_007.tag & $41 \%$ & \\
\hline 72 & WP threaten the DT the Austrian JJ Austrian goal NN goal. SENT & $1.245287 \% \mathbf{I}$ & $09 \% \mathbf{I}$ & 0 9\%lo-if-gua_063.tagl & $58 \%$ & \\
\hline 73 c & conceded WD concede an DT an awful JJ awful goal NN goal at IN at Stoke NP & $1.339426 \% \mathbf{I}$ & $03 \% \mathbf{I}$ & $03 \%$ o-if-sun_047.tagl & $64 \%$ & \\
\hline 74 & \multirow{2}{*}{$\begin{array}{l}\text { free-kick NN was VBD be a DT a bad JJ bad goal NN goal. SENT. At IN at } \\
\text { What WP What a DT a beautiful JJ beautiful goal NN goal. SENT. From }\end{array}$} & $806145 \% \mathbf{l}$ & $09 \% \mathbf{I}$ & 0 9\%lo-if-gua_095.tagl & $81 \%$ & \\
\hline 75 & & $3.0621119 \% \mathbf{I}$ & $06 \% \mathbf{I}$ & 0 6\%Inar-gua_011.tagl & $26 \%$ & \\
\hline 76 & with IN with a DT a big JJ big , , , big JJ big goal NN goal -running WG on IN & $5.1801822 \%$ I & $09 \% \mathbf{I}$ & $09 \%$ Inar- & $39 \%$ & \\
\hline 77 & \multirow{2}{*}{$\begin{array}{l}\text { with IN with another DT another bizarre JJ bizarre goal NN goal from IN from } \\
\text { followed } W D \text { follow a DT a bizarre JJ bizarre goal NN goal celebration NN }\end{array}$} & $951283 \% \mathbf{I}$ & $03 \% \mathbf{I}$ & $03 \% \mathbf{j o}$ & $73 \%$ & \\
\hline 78 & & $1.172277 \%$ & $06 \% \mathbf{I}$ & 0 6\%ljo- & $67 \%$ & \\
\hline 79 & and frankly RB frankly a DT a bizarre JJ bizarre goal NN goal , . , as IN as the & $3.3151511 \% \mathbf{I}$ & $05 \% \mathbf{I}$ & $05 \%$ Inar- & $25 \%$ & \\
\hline 80 & PP it was VBD be a DT a breathtaking JJ breathtaking goal NN goal . . . & $762235 \% \mathbf{l}$ & $01 \% \mathbf{I}$ & $\left.01 \%\right|_{0}-$ & $60 \%$ & \\
\hline 81 & NP Howard. SENT. BREATHTAKING JJ breathtaking GOAL NP It PP it was & $747 \quad 236 \%$ & $00 \% \mathbf{I}$ & $00 \% I_{0}$ & $59 \%$ & \\
\hline 82 & have scored WN score a DT a brilliant JJ brilliant goal NN goal ; : ; Gary NP & $3.1211064 \% \mathbf{I}$ & $01 \% \mathbf{I}$ & $01 \%$ Inar & $30 \%$ & \\
\hline 83 & and it PP it 's VBZ be a DT a brilliant JJ brilliant goal NN goal too RB too. & $2.8901009 \% \mathbf{I}$ & $08 \%$ & $08 \%$ Inar- & $28 \%$ & \\
\hline 84 & \multirow{2}{*}{$\begin{array}{l}\text { )) What WP What a DT a brilliant JJ brilliant goal NN goal from IN from } \\
\text { more but CC but a DT a calamitous } J J \text { calamitous goal NN goal that WDT }\end{array}$} & $7.9593028 \% \mathbf{I}$ & $08 \% \mathbf{I}$ & $08 \%$ Inar & $78 \%$ & \\
\hline 85 & & $37186 \% \mathbf{I}$ & $05 \% \mathbf{I}$ & $05 \% \mathbf{l} 0$ & $15 \%$ & \\
\hline 86 & robbed $W N$ rob of IN of a DT a certain JJ certain goal NN goal , , , calls $W Z$ & $497140 \% \mathbf{l}$ & $01 \% \mathbf{I}$ & $01 \% \mathbf{l}$ jo-if-tfa_005.tag & $42 \%$ & \\
\hline 87 & PP he saved WD save a DT a certain JJ certain goal NN goal there RB there & $2.6641573 \%$ & $01 \% \mathbf{I}$ & 0 1\%Inar-day_001.tagl & $61 \%$ & \\
\hline 88 & \multirow{2}{*}{ laid WN lay on IN on a DT a certain $J J$ certain goal NN goal , , , with IN with } & $479 \quad 81 \% \mathbf{l}$ & $02 \% \mathbf{I}$ & $02 \%$ jo-if-fif_005.tag & $33 \%$ & \\
\hline 89 & & $970246 \% \mathbf{l}$ & $07 \% \mathbf{I}$ & 0 7\%ljo-iffoo_016.tag & $57 \%$ & \\
\hline 90 & the DT the best RBS well competitive $J J$ competitive goal NN goal I PP I ever & $6.9722585 \% \mathbf{I}$ & $02 \% \mathbf{I}$ & $02 \%$ Inar-gua_009.tagl & $52 \%$ & \\
\hline 91 & \multirow{2}{*}{$\begin{array}{l}\text { hit the } D T \text { the first } J J \text { first competitive } J J \text { competitive goal } N N \text { goal in } I N \text { in } \\
\text { in his PP\$ his first } J \cdot J \text { first competitive } J J \text { competitive goal NN goal for IN for }\end{array}$} & $9528 \% \mathbf{I}$ & $06 \%$ & $06 \%$ o-if-bbc_023.tagl & $6 \%$ & \\
\hline 92 & & $666102 \%$ & $01 \% \mathbf{I}$ & 0 1\%lo-if-bbc_011.tagl & $21 \%$ & \\
\hline $93 \mathrm{t}$ & \multirow{2}{*}{$\begin{array}{l}\text { the first } J J \text { first ever RB ever competitive } J J \text { competitive goal NN goal at IN at } \\
\text { at his } \mathrm{PP} \$ \text { his first } J J \text { first competitive } J J \text { competitive goal NN goal since IN }\end{array}$} & $1.310328 \% \mathbf{I}$ & $03 \% \mathbf{I}$ & ay_042.tagl & $63 \%$ & \\
\hline 94 & & $1.152220 \% \mathbf{I}$ & $08 \% \mathbf{l}$ & $08 \% \mathrm{ljo}$ & $59 \%$ & \\
\hline 95 & 'POS ' highly RB highly controversial JJ controversial goal NN goal in IN in & $37982 \% \mathbf{I}$ & $05 \% \mathbf{I}$ & 0 5\%l-if-espn_003.tagl & $15 \%$ & \\
\hline 96 & have scored WN score a DT a critical JJ critical goal NN goal to TO to put $W$ & $418 \quad 61 \% \mathbf{I}$ & $02 \%$ & 0 2\%ljo-if-tim_038.tag & $12 \%$ & \\
\hline 97 & to TO to be VB be the DT the crucial JJ crucial aoal NN aoal as IN as Uruauav & $3.364 \quad 557 \%$ & $\Pi 4 \% \mathbf{l}$ & ก 4\%In-if-skv $\cap n+7$ tarl & $94 \%$ & $\underline{\underline{v}}$ \\
\hline concordane & \begin{tabular}{|l|l|l|l|l|l|l|l} 
patterns & clusters & filenames & follow up source text notes \\
\end{tabular} & & & & & \\
\hline
\end{tabular}

Figura 37 - Seleção das linhas de concordância para JJ * goal

A busca realizada nos retornou 988 ocorrências da palavra goal antecedida por um adjetivo, que reordenamos pelo nódulo, ou seja, pelo adjetivo entre a etiqueta $J J$ e a palavra goal, para facilitar a análise. Ao analisar as concordâncias, pudemos verificar que os adjetivos great, stunning, superb, wonderful, lovely, outstanding, brilliant, excellent e dazzling coocorrem com goal como equivalentes de um belo gol.

Nessa seção descrevemos a metodologia utilizada em nossa pesquisa. Primeiramente, mostramos os procedimentos adotados para o levantamento dos candidatos a termo; em seguida, explicitamos o caminho percorrido para a extração das possíveis fraseologias; depois, apresentamos os procedimentos utilizados para a validação das fraseologias encontradas e, ao final, descrevemos, por meio de alguns 
exemplos, os tipos de buscas realizadas para o estabelecimento dos equivalentes fraseológicos entre o par de línguas português-inglês. No próximo capítulo apresentaremos a análise e a discussão dos dados. 


\section{Capítulo 4 - Análise e Discussão dos Dados}

O objetivo do presente capítulo é apresentar a análise das UFEs em que o termo gol está inserido (vide quadro 10). Cada UFE será apresentada individualmente por ordem alfabética. Primeiramente, apresentamos os procedimentos adotados para o estabelecimento dos equivalentes fraseológicos e em seguida, as formas sinônimas, quando existentes; ao final, analisamos o contexto e a situação em que a UFE ocorre.

\section{1 após o gol (55) ${ }^{106} /$ depois do gol (46)}

Para encontrar o equivalente de após o gol e de seu sinônimo depois do gol, geramos linhas de concordância para a palavra after, aplicamos o dispositivo resort, ordenamos as linhas pelas duas primeiras palavras à direita e chegamos à after the goal (75):

${ }^{106}$ O número de ocorrências das UFEs será sempre apresentado entre parênteses. 


\begin{tabular}{|c|c|c|c|c|c|c|c|}
\hline \multicolumn{6}{|l|}{ C Concord } & \multicolumn{2}{|c|}{ 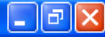 } \\
\hline File Edit Vie & View Compute Settings Window Help & & & & & & \\
\hline $\mathrm{N} / \mathrm{Co}_{0}$ & Concordance & Set Tag & Word \#|t. \#|los.|| & \#| os.l| & . $\#$ os.||t. 卅os.|| & $\%$ & ( \\
\hline 2.989 & by Giggs in several different interviews after the game, suggesting perhaps there & & $358133 \%$ & $06 \%$ & 0 6\%l jo-if-ind_036.txt & $52 \%$ & \\
\hline 2.990 & your talking on the pitch, not before or after the game. Tonight the players were & & $640341 \% \mathbf{I}$ & $40 \% \mathbf{I}$ & 0 9\% jo-if-uef_015.txt & $90 \%$ & \\
\hline $2.991 \mathrm{~d}$ & down when his contract expires in July. After the game, Iran's Physical & & $566 \quad 232 \% \mathbf{l}$ & $116 \% \mathbf{l}$ & 0 6\% jo-if-wp_012.txt & $77 \%$ & \\
\hline $2.992 \mathrm{~F}$ & French sport and to France." $\langle/ p\rangle\langle p\rangle$ After the game, thousands of people, & & $628335 \% \mathbf{I}$ & $126 \%$ & $06 \% \mathbf{l}$ jo-if-ny $025 . t x t$ & $78 \%$ & \\
\hline 2.993 & Stadium, although Pulis revealed after the game that talks are still & & $413 \quad 102 \% \mathbf{I}$ & $01 \% \mathbf{l}$ & 0 1\%ljo-if-365_022.txt & $57 \%$ & \\
\hline 2.994 & their winner, was booked for dissent after the game ended. Predictably and & & $2.407996 \% \mathbf{l}$ & $08 \% \mathbf{I}$ & $08 \%$ Inar-gua_012.txt| & $98 \%$ & \\
\hline $2.995 \mathrm{~b}$ & boos from the visiting section continued after the game had started, although that & & $32993 \% \mathbf{l}$ & $00 \% \mathbf{l}$ & 0 0\%ljo-if-365_058.txt & $45 \%$ & \\
\hline 2.996 & with it," U.S coach Bruce Arena said after the game in Kaiserslautern, home & & $33190 \% \mathbf{l}$ & $70 \% \mathbf{l}$ & 0 1\%l jo-if-wp_025.txt & $46 \%$ & \\
\hline 2.997 & game plan. We threw that page away after the game and we'll try to come up & & $950497 \% \mathbf{l}$ & $169 \% \mathbf{l}$ & 0 1\%l jo-if-wp_034.txt & $91 \%$ & \\
\hline 2.998 b & boos from the visiting section continued after the game had started, although that & & $32993 \% \mathbf{I}$ & $00 \% \mathbf{I}$ & 0 0\%ljo-if-365_068.txt & $45 \%$ & \\
\hline 2.999 & at something." $\langle/ p\rangle\langle p\rangle$ For hours after the game, fans tooting horns and & & $375132 \% \mathbf{I}$ & $58 \%$ & $00 \%$ jo-if-ny_026.txt & $45 \%$ & \\
\hline 3.000 & World Cup, with a mass brawl erupting after the Germans won on penalties. & & $31874 \% \mathbf{I}$ & $05 \% \mathbf{I}$ & 0 5\%ljo-if-sky_008.txt & $41 \%$ & \\
\hline 3.001 & out of this group. We got together after the Germany game and said we are & & $2.9191075 \% \mathbf{I}$ & $06 \% \mathbf{I}$ & 0 6\% tso-bbc_001.txt| & $87 \%$ & \\
\hline $3.002 \mathrm{cr}$ & couldn't guarantee a plentitude of goals. After the Germany-Costa Rica contest. & & $583269 \%$ & $07 \% \mathbf{I}$ & 0 7\%l-nw-esp_007.txt| & $40 \%$ & \\
\hline 3.003 le & leading up to the goal, then six minutes after the goal Etuhu caught the Everton & & $644219 \% \mathbf{I}$ & $06 \% \mathbf{l}$ & $06 \%$ jo-ifind $041 . t \times t$ & $87 \%$ & \\
\hline 3.004 & who offered any support to Green after the goal or at halftime?" asks Peter & & $3.2611498 \% \mathbf{I}$ & $00 \% \mathbf{l}$ & 0 0\%I nar-gua_031.txt| & $71 \%$ & \\
\hline 3.005 & who offered any support to Green after the goal or at halftime?" asks Peter & & $3.2901498 \% \mathbf{I}$ & 0 0\% & 0 0\%I nar-gua_008.txtl & $71 \%$ & \\
\hline 3.006 le & leading up to the goal, then six minutes after the goal Etuhu caught the Everton & & $636219 \% \mathbf{I}$ & $06 \% \mathbf{I}$ & 0 6\%ljo-if-365_053.txt & $87 \%$ & \\
\hline 3.007 le & leading up to the goal, then six minutes after the goal Etuhu caught the Everton & & $636219 \% \mathbf{l}$ & $06 \% \mathbf{l}$ & 0 6\%ljo-if-365_065.txt & $87 \%$ & \\
\hline 3.008 & Brazil began to show their class after the goal and it was no surprise & & $664253 \% \mathbf{I}$ & $00 \% \mathbf{l}$ & $00 \%$ jo-if-mir_003.txt & $91 \%$ & \\
\hline 3.009 & Nicky Shorey's cross inches wide. After the goal, Ashley Young grazed a & & $348 \quad 119 \%$ & $49 \%$ & 0 7\%ljo-if-gua_002.txt & $72 \%$ & \\
\hline 3.010 & comfort or criticism for him immediately after the goal or on the way off the pitch & & $3.3041542 \% \mathbf{I}$ & $01 \% \mathbf{I}$ & $01 \%$ Inar-gua_031.txt| & $72 \%$ & \\
\hline 3.011 & condition of Gerrard who was taken off after the goal suffering from & & $860438 \% \mathbf{l}$ & $286 \% \mathbf{l}$ & 0 2\%ljo-if-sun_008.txt & $83 \%$ & \\
\hline $3.012 \mathrm{cc}$ & comfort or criticism for him immediately after the goal or on the way off the pitch & & $3.3331542 \% \mathbf{I}$ & $01 \% \mathbf{I}$ & 0 1\%I nar-gua_008.txt| & $72 \%$ & \\
\hline $3.013 \mathrm{cc} c \mathrm{c}$ & comfort or criticism for him immediately after the goal or on the way off the pitch & & $3.3111522 \% \mathbf{I}$ & $01 \% \mathbf{l}$ & 0 1\%I nar-gua_003.txtl & $72 \%$ & \\
\hline 3.014 & Coincidence?" Argentinian anguish: "After the goal I wondered why do we & & $1.627880 \% \mathbf{I}$ & $04 \% \mathbf{I}$ & $04 \%$ Inar-gua_027.txtl & $55 \%$ & \\
\hline 3.015 & $\langle p\rangle$ Paraguay put Trinidad on its heels after the goal and nearly added to its & & $852407 \% \mathbf{I}$ & $188 \%$ & 0 6\%l jo-if-wp_014.txt & $88 \%$ & \\
\hline 3.016 & But the Tigers were a different team after the goal and debutant Altidore, & & $17331 \% \mathbf{I}$ & $01 \% \mathbf{l}$ & 0 1\%ljo-if-365_023.txt & $28 \%$ & \\
\hline 3.017 & rawness was demonstrated moments after the goal when he broke through & & $31582 \% \mathbf{l}$ & $09 \% \mathbf{I}$ & 0 9\% jo-if-ind_030.txt & $36 \%$ & \\
\hline 3.018 & but it was Villa who had the chances after the goal. First Agbonlahor and then & & $1.035414 \% \mathbf{I}$ & $06 \% \mathbf{I}$ & 0 6\%l jo-ifind_030.txt & $97 \%$ & \\
\hline $3 \cap 19$ & who offered anv sunport to Green after the coal or at halttime?" asks Peter & & $3>$ hR $147 \mathrm{~F} \% \mathrm{I}$ & ก $1 \% \mathbf{I}$ & ก 1\%I nar-rula กก:3 +x+l & $71 \%$ & $\underline{\underline{v}}$ \\
\hline concordance & 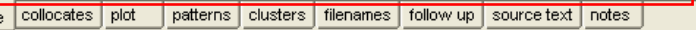 & & & & & & \\
\hline
\end{tabular}

Figura 38 - Parte das linhas de concordância de after ordenadas pelas duas primeiras palavras à direita

Ao ampliar as linhas de concordância, constatamos que a UFE em inglês ocorre no mesmo contexto que seus dois equivalentes em português, ou seja, para informar uma mudança no jogo após um gol:

a) Brazil began to show their class after the goal and it was no surprise when they went further ahead in the 72 nd minute.

b) Paraguay put Trinidad on its heels after the goal and nearly added to its lead in the 36th minute but an apparent score by Denis Caniza was waved off by a late offsides flag.

c) Após o gol, a Holanda esfriou o jogo e começou a tocar a bola administrando a partida.

d) Depois do gol, o São Paulo passou a administrar o placar, enquanto o Barueri não esboçou força suficiente para ameaçar os visitantes. 
Como podemos observar nos exemplos acima, embora possa ser utilizada para narrar uma ação após o gol como, por exemplo, um contra-ataque, a UFE sempre aparece para relatar o rumo que a partida tomou após o gol.

Tanto em português quanto em inglês, as UFEs ocorrem com mais frequência em textos jornalísticos de resultados de partidas do que em narrações minuto a minuto e estão presentes em textos de diferentes veículos de comunicação, desde tabloides até jornais e revistas esportivas.

\section{2 autor do gol (27)}

Para a UFE autor do gol a busca não foi tão simples quanto a anterior. Primeiramente geramos linhas de concordância para a palavra de busca author; no entanto, o programa nos retornou apenas quatro ocorrências, sendo que nenhuma fazia alusão ao autor de um gol:

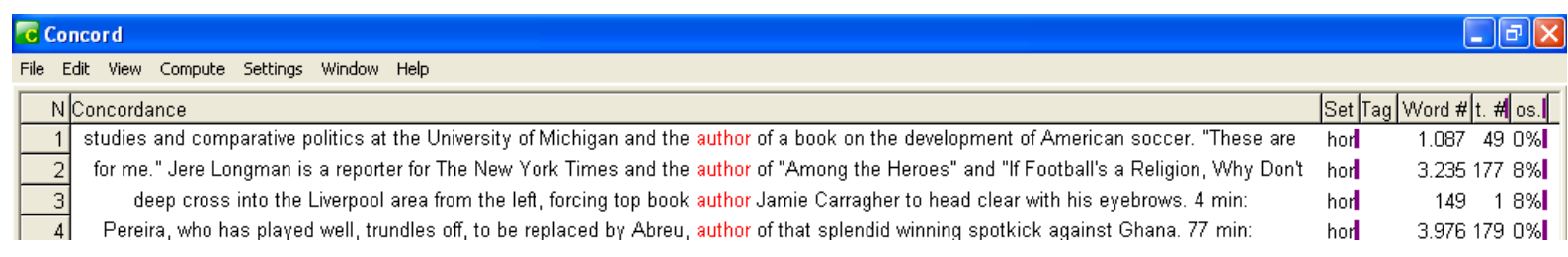

Figura 39 - Linhas de concordância de author

Decidimos, então, observar as linhas de concordância de autor do gol em português para verificar o contexto em que a UFE ocorre: 
ao escalar o time e manteve André Santos na lateral esquerda, com Daniel Alves, autor do gol da vitória sobre a África do Sul, no banco. $\langle/ p\rangle\langle p\rangle$ A seleção não Mandela Bay, em Porto Elizabeth. $25^{\prime} 2^{\circ}$ tempo PERDEU!!!! Lee Chung-Yong, autor do gol coreano, desperdiça a chance de colocar seu país em vantagem ao queiram, e eles não aceitaram, talvez porque beneficie o estilo de jogo deles. Autor do gol da vitória, o zagueiro Juanito disse que nẫo é todo dia que se estréia do Esmeraldino invadiu a área e chutou cruzado, para fora. Agência/Estado Autor do gol do Goiás, lateral Vitor disputa a bola com o meia Ewerton, do Barueri do técnico Mano Menezes, voltou a falhar. William fez pênalti bobo em Gilmar, autor do gol da vitória. Este foi o nono gol do camisa 11 do Náutico, artilheiro do não aproveita 23 Asanoah tenta jogada individual e se enrola com a bola Holman, autor do gol australiano, é substituido por Kennedy Na Austrália, Bresciano dá Internet Autor do gol da vitória, Kaká diz que já esperava dificuldade na estréia $\mathrm{O}$ I Íntegra Autor do gol da vitória, Kaká diz que já esperava dificuldade na estréia PB da vitória, Kaká diz que já esperava dificuldade na estréia 0 meio-campista Kaká, autor do gol do Brasil na vitória de 1 a 0 sobre a Croácia, que abriu a participação podiamos perder. Falhamos, nẫo podíamos falhar", lamentou 0 atacante Kieza, autor do gol de honra. Ao longo da semana, o time do Fluminense prometeu muita mas a preocupação da equipe agora é com a situação do atacante Magrão, autor do gol da equipe, que foi encaminhado para o hospital, com amnésia. As fez a sua parte fora de casa e venceu o Porto fora de casa, por 1 a 0 . Gilmar foi o autor do gol da vitória que deu uma sobrevida à equipe. 0 clássico será realizado Eliminatórias europeias da Copa do Mundo de 2010, com 16 pontos. $\langle p\rangle\langle p\rangle 0$ autor do gol dinamarquês, aos 22 do primeiro tempo, foi o meia Kahlenberg, Estádio do Barradão, pela 16. ${ }^{a}$ rodada do Campeonato Brasileiro. Dagoberto foi o autor do gol do atual tricampeẫo do torneio. 0 resultado deixou 0 São Paulo com entrou no lugar de Beto, com câimbras, no Bahia, e Rodrigo Broa substituiu o autor do gol do time da casa, Anderson Oliveira. O mesmo Broa quase empatou a com mais tranquilidade. E vem Nilmar por ai... Substituição27 No Brasil, sai o autor do gol Elano e entra Daniel Alves Gol25 GO0OOLLL!!! É do brasil! Elano por 5 a 3 nos pênaltis após um empate em 1 a 1 no tempo normal, Zidane foi o autor do gol francês, em uma cobrança de penalidade máxima na primeira etapa. que tocou na saída do goleiro adversário para virar o placar. Detalhe é que o autor do gol havia entrado em campo dois minutos antes, enquanto seu 0 Cruzeiro aproiveitou novamente e marcou o terceiro. Wellington Paulista foi 0 autor do gol. 0 mau momento do Coxa em campo acabou refletindo nas o Cruzeiro aproiveitou novamente e marcou o terceiro. Wellington Paulista foi o autor do gol. 0 mau momento do Coxa em campo acabou refletindo nas parte e venceram o Paulista por 1 a 0 neste sábado, no Pacaembu. Evandro foi o autor do gol, que garantiu ao time os 100\% de aproveitamento na temporada e a qualidade para Otacílio Neto, sozinho, colocar para dentro do gol de Vizzotto. $\mathrm{O}$ autor do gol também havia entrado na segunda etapa. Ronaldo nắo chegou a ver o Suarez arranca para o ataque, mas impedimento é assinalado pelo auxiliar. $\mathrm{O}$ autor do gol uruguaio fica na bronca com o assistente. $23^{\prime} 1^{\circ}$ tempo Chu Young jogada de Kuyt - e escora, na saída equivocada de Sorensen. Simon Poulsen, autor do gol contra, evita o terceiro tento holandês. $39^{\prime} 2^{\circ}$ tempo Gol de Kuyt!!! Van Fernando Prass fica com a bola. 39' O clima do jogo continua quente e Renato, autor do gol flamenguista, recebe amarelo. 38' Em andamento, Cruzeiro $3 \times 4$ i uma vitória merecida. Garamba RT @cintiabarlem: Suarez, autor do gol uruguaio, conhecido como el zorro. \#copa kibeloco

Figura 40 - Linhas de concordância de autor do gol

Ao observar as ocorrências, constatamos que o foco da UFE recai sobre o jogador e não sobre o gol marcado, seu uso está mui to mais relacionado à descrição de um jogador por meio de um gol por ele marcado do que ao próprio gol, como podemos observar no contexto expandido da linha de concordância 24:

a) Coreano é desarmado e Luis Suarez arranca para o ataque, mas impedimento é assinalado pelo auxiliar. $\boldsymbol{O}$ autor do gol uruguaio fica na bronca com o assistente.

Sem muitas opções de busca, geramos linhas de concordância para o pronome who: 
File Edit Yiew Compute Settings Window Help

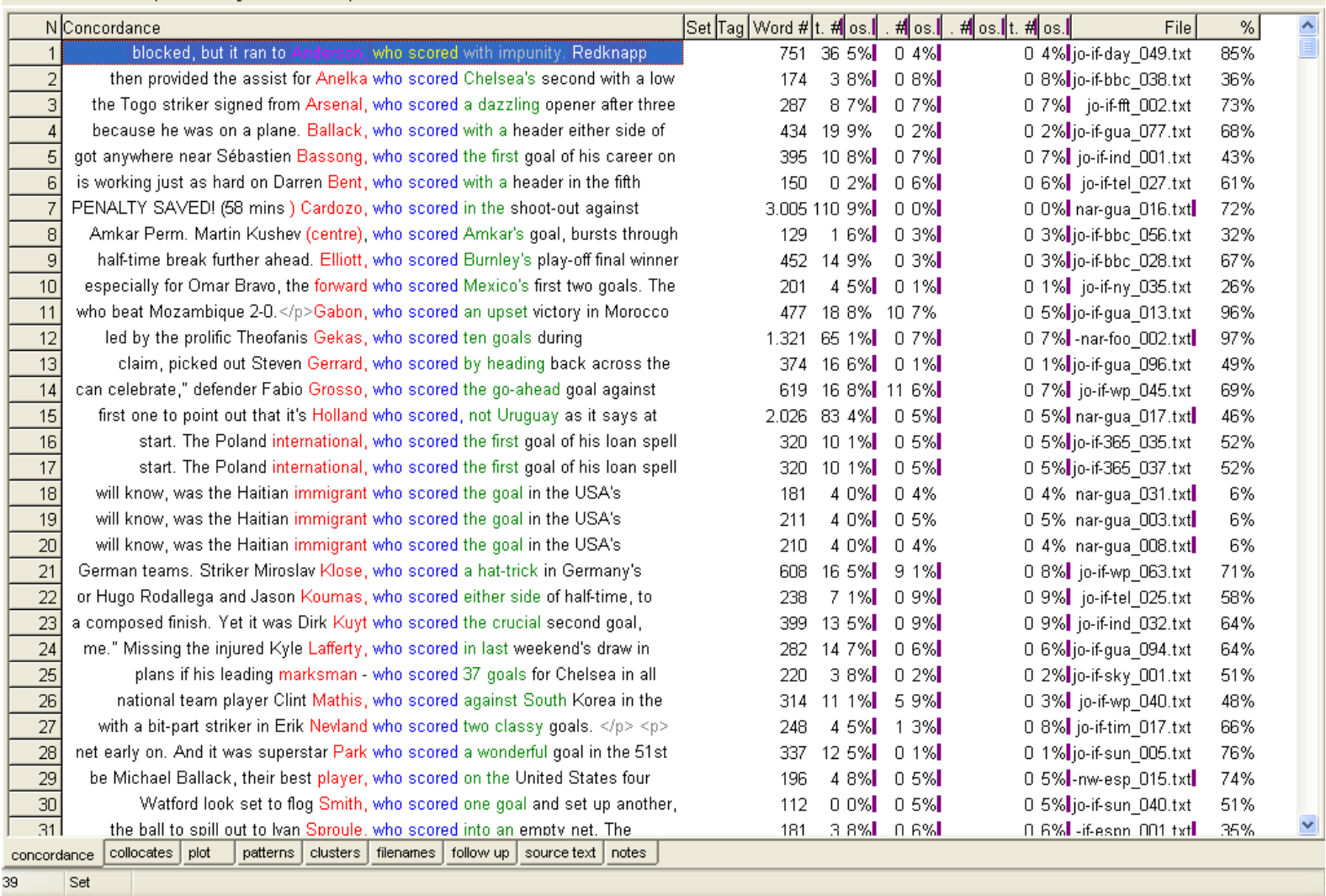

Figura 41 - Parte das linhas de concordância de who ordenadas pela primeira palavra à esquerda e pelas duas primeiras palavras à direita

A análise das linhas nos revela que a estrutura [footballer], who scored [the goal $^{107}$ (47) funciona da mesma maneira que a UFE autor do gol em português, ou seja, é utilizada para caracterizar um determinado jogador, como mostra o exemplo abaixo:

a) The Italians will hope Totti opens up space for Fiorentina's lanky striker Luca Toni, who scored 31 goals in the league this year.

Também geramos linhas de concordância para o termo scorer (79) a fim de verificar se a UFE poderia ter mais de um equivalente em inglês:

107 A palavra entre colchetes [] pode ser substituída por uma da mesma categoria. Neste exemplo, [footballer] pode ser substituído pelo nome de um jogador e [the goal] por um gol como, por exemplo, the s00000econd goal (o segundo gol). 


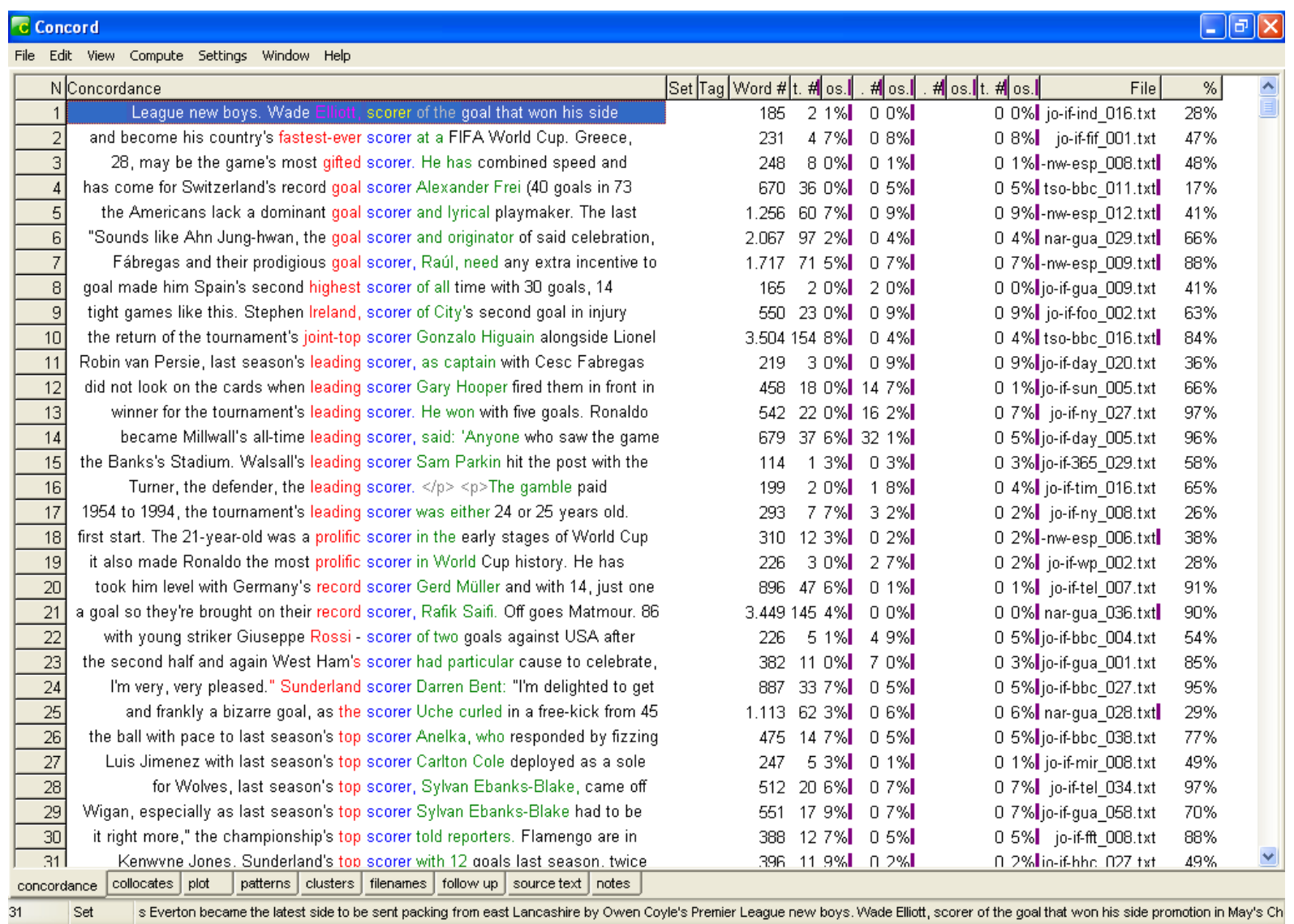

Figura 42 - Parte das linhas de concordância de scorer ordenadas alfabeticamente pela primeira palavra à direita e pelas duas primeiras palavras à esquerda do nódulo

Ao analisar as concordâncias, podemos perceber que somente as linhas 1, 5, 9, 11 e 14 funcionam da mesma maneira que autor do gol em português, como mostra o exemplo abaixo:

a) Wade Elliott, scorer of the goal that won his side promotion in May's Championship play-off final against Sheffield United, decided an entertaining contest with a strike just as valuable as the one he scored at Wembley.

Todas as outras ocorrências são parte de unidades de sentido maiores como, por exemplo, ${ }^{108}$ (all-time) leading scorer, (all-time) top scorer e (all-time) hightest scorer, que têm como função principal descrever ou eleger os maiores artilheiros de uma partida ou de um campeonato.

${ }^{108}$ As palavras entre parênteses () são opcionais. 
Tanto em português quanto em inglês as UFEs ocorrem em jornais, revistas e tabloides e são significativamente mais comuns em notícias de resultado de partidas do que em transmissões minuto a minuto. Tal fato pode ser explicado devido ao propósito da transmissão on-line, que seria informar $o$ internauta sobre os principais acontecimentos de uma partida, quase sempre de forma muita sucinta; objetivo que foge às descrições de um jogador.

\section{3 belo gol, um (31) / gol incrível, um (24) / bonito gol, um (10)}

Antes de iniciar a busca para um belo gol e seus sinônimos, verificamos no corpus de português se também é possível, ou melhor, comum, dizer um gol belo, um gol bonito e um incrível gol, já que em português a ordem do adjetivo é livre, e para nossa surpresa, não encontramos nenhuma ocorrência.

Para encontrar os equivalentes das UFEs no corpus de inglês, realizamos dois tipos de buscas. Primeiramente, geramos linhas de concordância para um dos possíveis colocados de goal em inglês, great, e o programa nos retornou sete linhas concordâncias, número relativamente baixo quando comparado com as 45 de belo gol. Realizamos a mesma busca para wonderful e o programa nos retornou quatro ocorrências da UFE. Neste momento, deparamos com a seguinte dúvida: se tanto great quanto wonderful podem ser colocados de gol para relatar um belo gol, quais outros adjetivos também podem exercer essa função? Por esse motivo, realizamos uma busca para a expressão “ $J J$ * goal”, em que a etiqueta $\mathrm{JJ}$ corresponde a um adjetivo: 


\begin{tabular}{|c|c|c|c|c|c|c|}
\hline \multicolumn{2}{|c|}{ C Concord } & & & & \multicolumn{2}{|c|}{ - } \\
\hline File Edit & View Compute Settings Window Help & & & & & \\
\hline \multicolumn{2}{|c|}{ N Concordance } & Set $|\operatorname{Tag}|$ Word \#|t. \#| os.|| & . & \#| os.||t. $\#$ os.|| & $\%$ & $\hat{\underline{\Lambda}}$ \\
\hline 855 & WG smash his PP\$ his sixth $J J$ sixth goal NN goal in IN in $12 \mathrm{CD}$ & $930226 \% \mathbf{I}$ & $06 \%$ & 0 6\%lo-if-gua_083.tagl & $37 \%$ & \\
\hline 856 & Defoe NP Defoe 's POS 's sixth JJ sixth goal NN goal of IN of the DT the & $1.667 \quad 449 \% \mathbf{I}$ & $01 \% \mathbf{l}$ & 0 1\%ljo-if-ind_013.tag & $71 \%$ & \\
\hline 857 & Rhodes NP Rhodes ' POS ' sixth JJ sixth goal NN goal of IN of the DT the & $25241 \% \mathbf{I}$ & $06 \% \mathbf{l}$ & 0 6\%lo-if-365_046.tagl & $16 \%$ & \\
\hline 858 & notched WD notch his PP\$ his sixth JJ sixth goal NN goal in IN in his PP\$ his & $11329 \% \mathbf{I}$ & $08 \%$ & $08 \%$ o-if-365_056.tagl & $9 \%$ & \\
\hline 859 & \multirow{2}{*}{$\begin{array}{l}\text { fire home } N N \text { home his PP\$ his sixth } J J \text { sixth goal NN goal this DT this term } \\
\text { NP Cup with IN with a DT a sizzling } J J \text { sizzling goal NN goal as IN as Holland }\end{array}$} & $1.548 \quad 402 \% \mathbf{I}$ & $02 \% \mathbf{l}$ & 0 2\%lo-if-sun_049.tagl & $92 \%$ & \\
\hline 860 & & $55 \quad 01 \% \mathbf{l}$ & $03 \%$ & 0 3\% o-if-sun_004.tagl & $2 \%$ & \\
\hline 861 & quarter-final. SENT . a DT a sizzling JJ sizzling goal NN goal as IN as Holland & $84 \quad 17 \% \mathbf{I}$ & $04 \%$ & $04 \%$ o-if-sun_004.tagl & $4 \%$ & \\
\hline 862 & , . , a DT a typically RB typically skillful JJ skillful goal NN goal which WDT which & $2.338728 \% \mathbf{I}$ & $09 \% \mathbf{I}$ & 0 9\%/ jo-if-wp_053.tag & $88 \%$ & \\
\hline 863 & conceding WG concede a DT a sloppy $J J$ sloppy goal NN goal less RBR less & $1.030248 \% \mathbf{I}$ & $09 \% \mathbf{I}$ & 0 9\% jo-if-tel_048.tag & $39 \%$ & \\
\hline 864 & \multirow{2}{*}{$\begin{array}{l}\text { WG look at IN at this DT this smart } J J \text { smart goal NN goal , , I I PP I think } \\
\text { scoring } W G \text { score a DT a solitary } J J \text { solitary goal NN goal against IN }\end{array}$} & $746 \quad 209 \% \mathbf{I}$ & $09 \%$ & 0 9\% nar-gua_032.tagl & $9 \%$ & \\
\hline 865 & & $2.647 \quad 746 \% \mathbf{I}$ & $07 \% \mathbf{I}$ & $07 \% \mathbf{l}$ jo-if-ny_011.tag & $77 \%$ & \\
\hline 866 & NP City. SENT. The DT the solitary JJ solitary goal NN goal came WD & $140 \quad 27 \%$ & $05 \%$ & 0 5\% jo-if-foo_003.tag & $5 \%$ & \\
\hline 867 & \multirow{2}{*}{$\begin{array}{l}\text { the DT the most RBS most spectacular } J J \text { spectacular goal NN goal of IN of the } \\
\text { campaign - : - his PP\$ his spectacular } J J \text { spectacular goal NN goal after IN after }\end{array}$} & $10129 \% \mathbf{I}$ & $09 \%$ & 0 9\% o-if-sun_006.tagl & $9 \%$ & \\
\hline 868 & & $692143 \% \mathbf{I}$ & $09 \% \mathbf{I}$ & 0 9\%ljo-if-ind_005.tag & $29 \%$ & \\
\hline 869 & campaign - : - his PP\$ his spectacular $J J$ spectacular goal NN goal after IN after & $629143 \% \mathbf{I}$ & $07 \% \mathbf{I}$ & $07 \%$ lo-if-365_072.tagl & $27 \%$ & \\
\hline 870 & NP scored WD score a DT a stunning JJ stunning goal NN goal from IN from an & $15229 \% \mathbf{I}$ & $08 \%$ & $08 \%$ jo-if-foo_o09.tag & $9 \%$ & \\
\hline 871 & NP scored WD score a DT a stunning JJ stunning goal NN goal to TO to help & $110 \quad 29 \% \mathbf{I}$ & $05 \%$ & $05 \%$ o-if-bbc_024.tagl & $5 \%$ & \\
\hline 872 & NP scored WD score a DT a stunning $J J$ stunning goal NN goal to TO to help & $3103 \% \mathbf{I}$ & $01 \%$ & 0 1\% o-if-bbc_024.tagl & $1 \%$ & \\
\hline 873 & NN with IN with a DT a stunning $J J$ stunning goal NN goal from IN from & $8022 \% \mathbf{l}$ & $02 \%$ & 00_016.tagl & $3 \%$ & \\
\hline 874 & scores NNS score a DT a stunning $J J$ stunning goal NN goal. SENT & $5.1631741 \% \mathbf{I}$ & $09 \% \mathbf{I}$ & a_009.tagl & $38 \%$ & \\
\hline 875 & $W$ give away RP away a DT a stupid $J J$ stupid goal NN goal in IN in games & $1.335344 \% \mathbf{I}$ & $00 \% \mathbf{I}$ & 0 0\%lo-if-365_024.tagl & $60 \%$ & \\
\hline 876 & \multirow{3}{*}{$\begin{array}{l}\text { NNS thank to TO to a DT a super JJ super goal NN goal from IN from } \\
\text { followed } W D \text { follow that DT that super } J J \text { super goal NN goal against IN against } \\
\mathbb{I N} \text { behind to To to a DT a superb } J J \text { superb goal NN goal from IN from }\end{array}$} & $499128 \% \mathbf{I}$ & $07 \%$ & $07 \%$ lo-if-day_008.tagl & $17 \%$ & \\
\hline 877 & & $1.761460 \% \mathbf{I}$ & $01 \% \mathbf{I}$ & 0 1\%lo-if-day_002.tagl & $61 \%$ & \\
\hline 878 & & $4.9331720 \% \mathbf{I}$ & $08 \% \mathbf{I}$ & 0 8\%Inar-gua_001.tagl & $48 \%$ & \\
\hline 879 & NN talent with IN with a DT a superb $J J$ superb goal NN goal against IN & $2.782986 \% \mathbf{I}$ & $09 \% \mathbf{I}$ & 0 9\%lo-if-gua_017.tagl & $88 \%$ & \\
\hline 880 & \multirow{2}{*}{$\begin{array}{l}\text { NP , , , Italy NP Italy 's POS 's superb JJ superb goal NN goal keeper NN } \\
\text { the net NN net. SENT. A DT a superb. JJ superb goal NN goal. SENT. " " " At }\end{array}$} & $4.2801320 \% \mathbf{I}$ & $07 \%$ & $07 \%$ jo-if-ny_024.tag & $88 \%$ & \\
\hline 881 & & $4.1041570 \% \mathbf{I}$ & $03 \% \mathbf{I}$ & 0 3\%Inar-bbc_003.tagl & $34 \%$ & \\
\hline 882 & \multirow{2}{*}{$\begin{array}{l}\text { WD score another DT another superb } J J \text { superb goal NN goal in IN in a DT a } \\
\text { have scored } W N \text { score a DT a superb } J J \text { superb goal NN goal - : - helped } W D\end{array}$} & $1.86346 \quad 1 \% \mathbf{I}$ & $02 \% \mathbf{I}$ & $02 \%$ l jo-if-wp_084.tag & $82 \%$ & \\
\hline 883 & & $5809 \% \mathbf{l}$ & $03 \%$ & 0 3\% o-if-365_020.tagl & $2 \%$ & \\
\hline 884 & \multirow{2}{*}{$\begin{array}{l}\text { scored WD score a DT a superb } J J \text { superb goal NN goal in IN in a DT a } \\
\text { of IN of their PP\$ their sunerior } J J \text { sunerior aoal NN aoal difference NN }\end{array}$} & $1.524383 \% \mathbf{I}$ & $08 \% \mathbf{l}$ & 0 8\%l jo-if-wp_073.tag & $57 \%$ & \\
\hline RiR5 & & $1.37 n \geqslant 4 \%$ & $\Pi 9 \%$ & П .9\% nar-rnla $\Pi 11$ tarl & $9 \%$ & $\underline{\underline{v}}$ \\
\hline concordan & patterns clusters filenames follow up source text notes & & & & & \\
\hline
\end{tabular}

Figura 43 - Parte das linhas de concordância da expressão de busca “ $J J$ * goal”

Com a busca, tivemos acesso a todos os adjetivos que antecedem a palavra goal, sem ter que observar as quase cinco mil linhas de concordância, e chegamos à UFE $a$ \{great | stunning | superb | wonderful | lovely | outstanding | brilliant $\mid$ excellent |

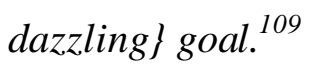

Como podemos observar, devido à maior variedade de adjetivos utilizados pela língua inglesa, a frequência de cada adjetivo é menor quando comparada ao português. Após encontrar os equivalentes em inglês, deparamos com outra dúvida: será que existem outros adjetivos que são utilizados com frequência ao lado de gol em português?

Para averiguar a questão, geramos linhas de concordância para as expressões de busca "gol * $A D J "$ (Fig. 44) e para " $A D J *$ gol" (Fig. 45), em que a etiqueta ADJ corresponde a um adjetivo:

${ }^{109}$ As chaves \{\} indicam o elenco de opções, ou seja, as palavras que podem completar a UFE, e a barra vertical ( | ) indica expressões sinônimas, que são apresentadas por ordem de frequência. 


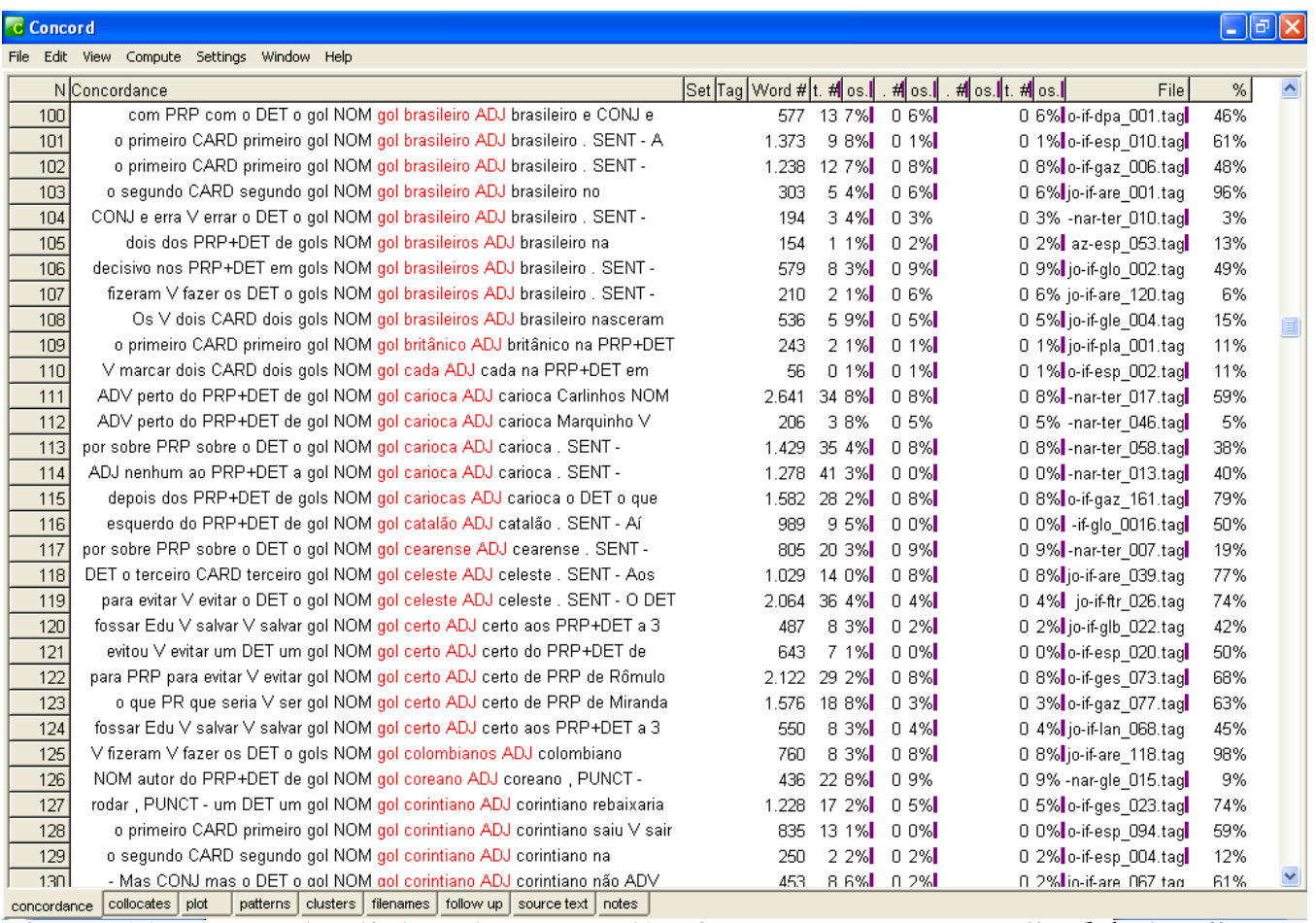

Figura 44 - Parte das linhas de concordância para a expressão "gol *ADJ"

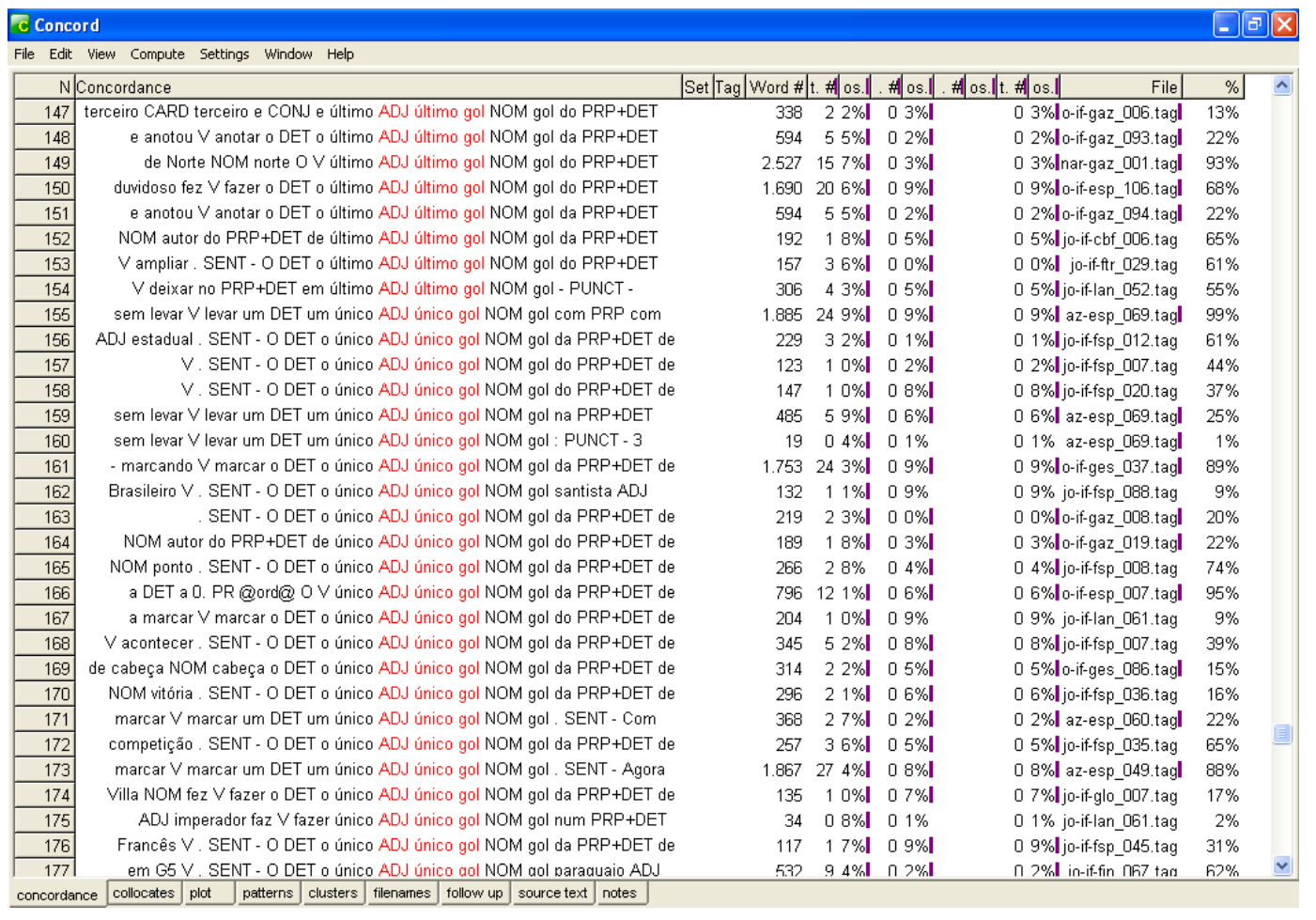

Figura 45 - Parte das linhas de concordância para a expressão " $A D J$ * gol"

Não encontramos nenhum outro adjetivo que coocorra com gol e que possa ser considerado sinônimo de um belo gol, tirando uma única ocorrência do adjetivo lindo. 
No que se refere ao tipo de mídia, tanto um belo gol, quanto um bonito gol e um gol incrível ocorrem quase que exclusivamente em jornais e revistas de esportes ou especializados em futebol. Somente 12, das 79 ocorrências das UFEs, foram encontradas em jornais, sempre na Folha de São Paulo ou no O Estado de São Paulo. Quanto ao gênero, podemos afirmar que a UFE ocorre predominantemente em textos jornalísticos, mas que apresenta algumas ocorrências nas transmissões minuto a minuto.

Diferentemente das UFEs em português, os equivalentes em inglês ocorrem em jornais e em periódicos esportivos com a mesma frequência, o que só difere nos tabloides, onde encontramos apenas uma única ocorrência (dazzling goal). Ademais, em inglês, as UFEs apresentam frequência muito parecida nas transmissões minuto a minuto e nas notícias de resultado de partidas, característica que pode estar relacionada ao detalhamento das transmissões on-line em inglês.

Um fator que nos chamou a atenção, no que se refere ao uso das UFEs nas duas culturas, é que embora a língua portuguesa utilize menos adjetivos para qualificar um gol, apenas três, comparada ao inglês (8), o número total de ocorrências de adjetivos em português (79) é mais que o dobro em inglês (39), aspecto que parece encontrar respaldo na teoria de Hall (1976) de high e low context culture ${ }^{110}$.

\section{4 na cara do gol (90) / de frente para o gol (26)}

Encontrar o equivalente para a UFE na cara do gol, e seu sinônimo de frente para o gol, demandou pouco trabalho já que in front of e front of goal aparecem no topo da lista de clusters (vide Fig. 35). Agrupamos os dois clusters e chegamos à UFE in front of goal (42). Os clusters the face of e face of goal também aparecem entre os 30 primeiros da lista. No entanto, após a análise das linhas de concordância da UFE the face of goal, esta foi descartada como equivalente já que a situação em que ocorre é diferente de na cara do gol e in front of goal. Tomemos os seguintes exemplos:

a) Lucas Barrios faz grande jogada e coloca Vera na cara do gol. O camisa 13 paraguaio mete de três dedos e abre o placar.

\footnotetext{
${ }^{110}$ Conceito abordado no item 3.1.1.2
} 
b) Roger passa para Leandro Domingues, que ganha da defesa e sai de frente para o gol, mas finaliza perto da trave

c) Klose, who also won his 100th cap for Germany, should have made it 2-0 when Mueller broke into the area down the right and squared for him in front of goal. But he fired wastefully over, not that it appeared to matter much at that point.

d) Aguero and Messi exchanged a one-two before the latter fired in a low shot that came back off the post and rolled across the face of goal, inviting Higuian to tap it into the empty net.

e) Good play by Chelsea as Florent Malouda drags a shot across the face of goal just past Mark Schwarzer's far post.

Nos três primeiros exemplos, na cara do gol e in front of goal são utilizadas para designar a posição de um jogador, enquanto, nos dois últimos, the face of goal descreve o percurso da bola e o resultado de uma finalização.

Após a eliminação de the face of goal, geramos linhas de concordância para um termo que já conhecíamos: goalmouth (pequena área):

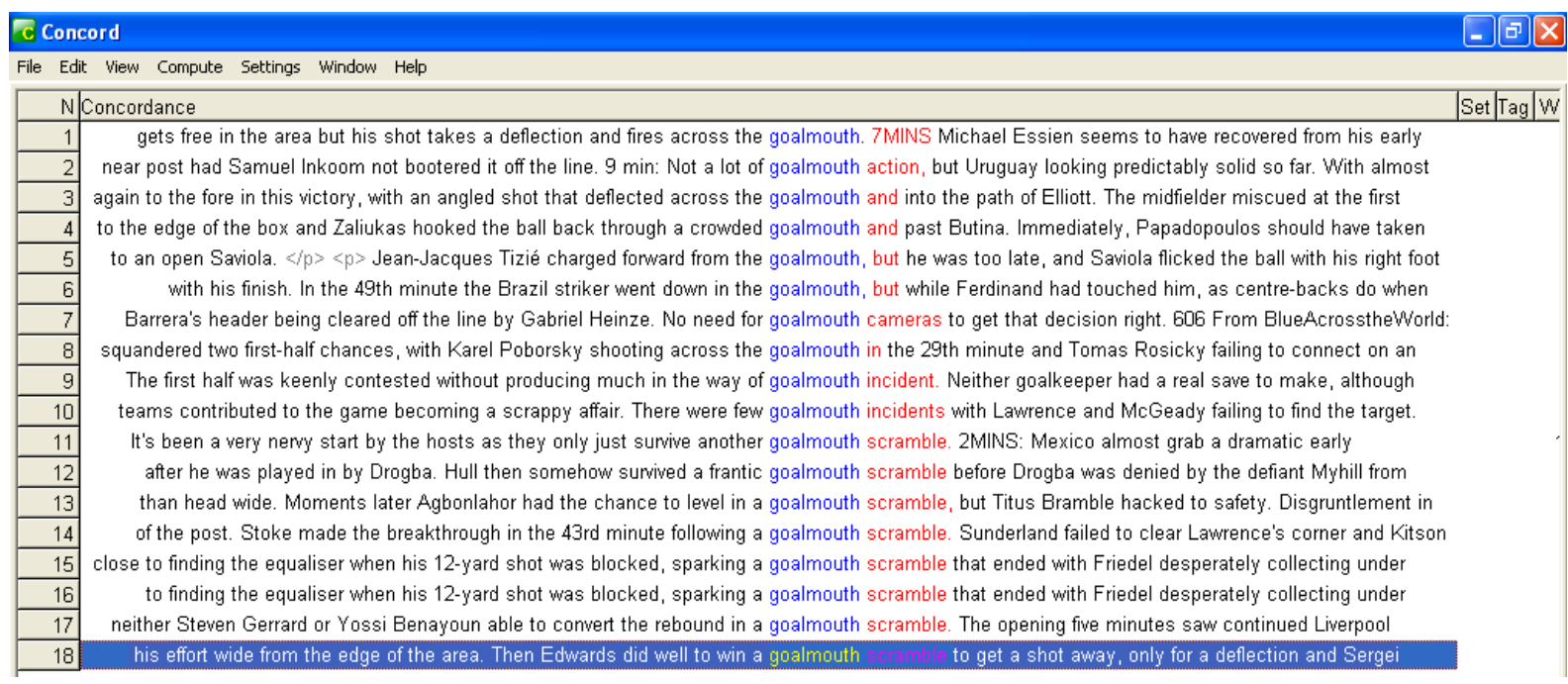

Figura 46 - Linhas de concordância de goalmouth

O termo ocorre somente 18 vezes no corpus, sendo que oito vezes é parte da UFE goalmouth scramble, utilizada, esta, quando um jogador tenta realizar um passe para a pequena área, mas não consegue devido ao grande número de jogadores concentrados no lugar. 
Tanto em inglês quanto em português, a UFE é utilizada em notícias de resultado de partidas e em transmissões minuto a minuto, sendo mais frequente no primeiro tipo de texto. No que se refere ao veículo de informação, aparece em jornais e em periódicos esportivos, em inglês e português, com a frequência bem distribuída.

4.4.1 SAIR na cara do gol (10)

Para encontrar o equivalente de SAIR na cara do gol, analisamos as linhas de concordância de in front of goal ordenadas pelos três primeiros colocados à esquerda e encontramos a UFE [footballer] FIND himself in front of goal (8). A estrutura da UFE é diferente nas duas línguas, no entanto, a situação de uso é a mesma. Observemos os exemplos:

a) Ghana handles the ball just outside the box. On the free kick Italy tries for trickery, and Totti finds himself in front of goal, but he knocks it over harmlessly.

b) A melhor chance alemã foi aos 23min, quando Özil saiu na cara do gol, $\underline{\text { mas }}$ chutou em cima do goleiro de Gana.

Além de serem utilizadas para descrever que um jogador se encontra em frente ao gol, as UFEs normalmente são seguidas de uma oração que descreve uma tentativa frustrada em que a bola foi para fora.

O uso da UFE, tanto em português quanto em inglês, aparece bem distribuído entre todos os gêneros textuais do corpus e também entre os veículos de comunicação.

\section{5 chance(s) de gol (118) / oportunidade(s) de gol (37)}

Para encontrar os equivalentes de chance(s) de gol e oportunidade(s) de gol, geramos linhas de concordância para "chance*",l11, um dos possíveis colocados de goal, e obtivemos:

${ }^{111} \mathrm{O}$ asterisco $(*)$ permite que a busca retorne tanto as ocorrências de chance quanto de chances. 
get out of this we need to get scoring chances for Michael. We'll be working on ces and Michael Bradley flubbed scoring chances, but Rossi did not. $\langle p\rangle \quad$ cesl attack effortlessly and finishes scoring chances with thunderous accuracy. $\langle p\rangle$ cesI Saha set up France's final scoring chance, using his chest to drop the ball ncel we had four, five excellent scoring chances," said midfielder Kim Kallstrom, cesl teams that rarely concede scoring chances, it is certainly possible another cesl side create many clear-cut scoring chances. At least Stoke had a bit of cesl the finesse to carve out clean scoring chances, however. They were, perhaps, cesl had the Soca Warriors' best scoring chance, a well-struck shot from the right ncel superbly in denying Brazil a scoring chance. Howard later was named goal. It is far easier to build a scoring chance from 40 yards away than from ncel goal. It is far easier to build a scoring chance from 40 yards away than from ncel

$1.632598 \%|09 \%|$ $549250 \% \mathbf{l} 01 \%$

$25436 \% \mathbf{I} \quad 09 \%$

$22536 \% \mathbf{l} \quad 08 \%$

$464 \quad 190 \%$ | $98 \%$

$517 \quad 204 \%$ | $04 \%$

$505 \quad 17 \quad 1 \% \mathbf{I} \quad 0 \quad 7 \% \mathbf{I}$

$17430 \%$ । $2 \%$

$21520 \%$ | $0 \%$ I

$443 \quad 160 \% \mathbf{l} \quad 7 \%$

$634318 \%$ | $89 \%$

$645337 \% 140 \%$

$\begin{array}{llllll}460 & 13 & 0 \% \mathbf{I} & 6 & 2 \% \mathbf{I}\end{array}$

$646 \quad 189 \%$ | $82 \%$ |

$636 \quad 273 \% \mathbf{I} 143 \%$

$339 \quad 65 \%$ | $30 \%$ I

$414 \quad 90 \%$ I $02 \%$ I

$654332 \%$ | $04 \%$

$860276 \%$ | $106 \%$

$443250 \%$ | $103 \%$ I

$1.9651009 \% \quad 00 \%$

$1.9661009 \%$ | $00 \%$

0 9\% nar-gua_001.txt $50 \%$

0 1\%I tso-bbc_012.txt| $13 \%$

0 9\% nar-gua_005.txtl $11 \%$

$08 \%$ nar-gua_045.txtl $11 \%$

0 9\% -if-espn 007.txtl $55 \%$

0 4\% jo-if-gua_055.txt $68 \%$

0 7\%ljo-if-day_023.txt $80 \%$

$02 \%$ jo-if-ny_033.txt $68 \%$

0 $6 \%$ I jo-if-fft_023.txt $56 \%$

0 9\% jo-if-wp_012.txt $62 \%$

0 7\% jo-if-tel 001.txt $61 \%$

$02 \%$ jo-if-nyt_002.txt $66 \%$

0 3\%l jo-if-wp_028.txt 66\%

0 3\%l jo-if-wp_035.txt $74 \%$

$03 \%$ l jo-if-wp_060.txt $84 \%$

0 8\%l jo-if-wp_057.txt $33 \%$

$02 \%$ ljo-if-gua $087 . t x t \quad 77 \%$

$04 \%$ ljo-if-gua_052.txt $85 \%$

0 6\% jo-if-wp_064.txt $87 \%$

$07 \%$ l jo-if-lat 001 txt $72 \%$

$00 \% \mathbf{l}$-nw-esp_010.txtl $62 \%$

0 0\%l-nw-esp_012.txt| $62 \%$

Figura 47 - Parte das linhas de concordância de goal ordenadas pelas três primeiras palavras à esquerda

A busca retornou quatro ocorrências de goalscoring chance(s) e 18 de scoring chance(s), das quais, 12 ocorrências são de periódicos americanos. Isso nos chamou a atenção, uma vez que a parte de inglês americano do nosso corpus é muito pequena. Resolvemos, então, gerar concordâncias para outro possível colocado, “opportunit*”:

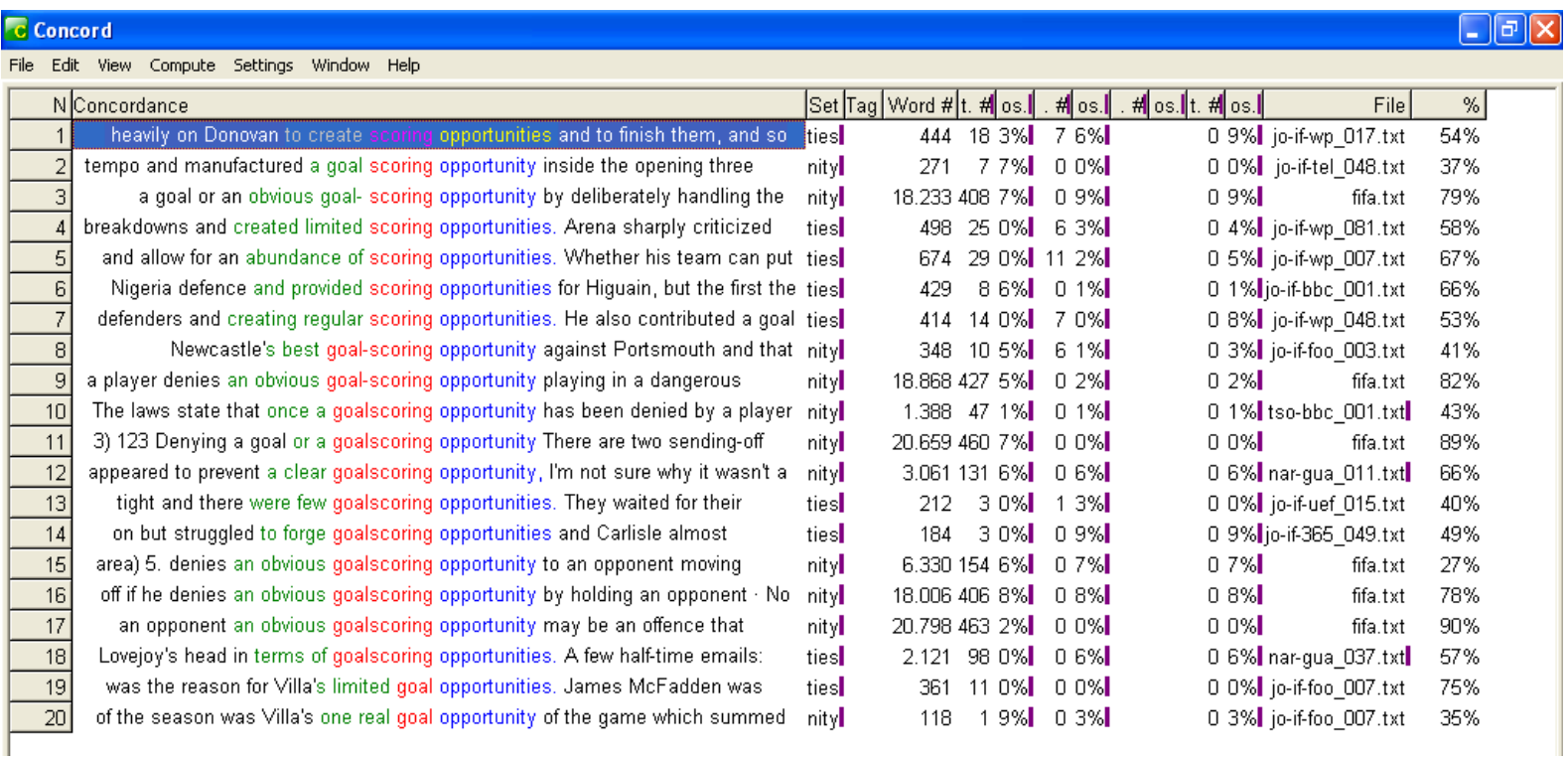

Figura 48 - Parte das linhas de concordância de "opportunit*" ordenadas pelas três primeiras palavras à esquerda

A busca retornou sete ocorrências de scoring opportunity(ies), 11 de goalscoring opportunity(ies) e duas de goal opportunity(ies). Desta vez, com a maior parte das 
ocorrências em periódicos britânicos. Sendo assim, validamos as duas UFEs como equivalentes, mas chamamos atenção para o fato que opportunity prevalece nos periódicos ingleses, ao passo que chance é mais comum nos americanos.

Tanto em inglês quanto em português, as UFEs ocorrem em textos jornalísticos, em transmissões minuto a minuto e nas regras do jogo; achado interessante, pois em quase todos os casos as UFEs que ocorrem nas regras do jogo não ocorrem em outros gêneros textuais.

\subsection{1 boa(s) \{chance(s) $\mid$ oportunidade(s)\} de gol (10)}

Para encontrar os equivalentes da UFE, analisamos os colocados à direita de goalscoring chance(s), de scoring chance(s), de scoring opportunity(ies), e de goalscoring opportunity(ies) e chegamos à UFE \{good | excellent\} scoring opportunity(ies). Contudo, ficamos receosos de validar a UFE encontrada, pois a pesquisa no corpus nos mostrou somente três ocorrências, duas com o adjetivo good e uma com excellent. Neste caso, resolvemos pesquisar pelas expressões "good scoring chance*" e "excellent scoring chance*" seguidas da palavra football no Google.uk. A busca retornou 129.000 ocorrências para a primeira expressão e 5.360 para a segunda, diferença que pode ser justificada pela qualidade da oportunidade, já que uma boa oportunidade de gol (good scoring chance) é mais fácil de ocorrer do que uma excelente oportunidade de gol (excellent scoring chance), ou seja, coisas "excelentes" são menos comuns que coisas "boas".

Nosso corpus foi compilado para ser representativo da linguagem do futebol, de modo que não fosse necessário recorrer, regularmente, às fontes de buscas externas, como o Google, para validar os resultados das pesquisas conduzidas no corpus. Entretanto, estamos cientes de que nenhum corpus apresenta ocorrências de todos os termos de uma língua de especialidade, por isso recorremos ao Google algumas vezes para validar nossos achados, sem prejudicar, de forma alguma, a compilação e importância do corpus. 
4.5.2 poucas chances de gol (22)

Analisamos os colocados à direita de goalscoring chance(s), de scoring chance(s) (vide Fig. 47), de scoring opportunity(ies), e de goalscoring opportunity(ies) (vide Fig. 48) para encontrar o equivalente da UFE e chegamos a few scoring chance $(s)$.

No entanto, assim como na UFE anterior, tivemos que recorrer ao Google para validar o resultado. Pesquisamos pelas expressões "few scoring chances" e "few scoring opportunities", seguidas da palavra football e obtivemos 39500 e 64700 ocorrências respectivamente, que nos permitiram validar as UFEs como equivalentes de poucas chances de gol.

A grande desvantagem de pesquisar no Google é que não podemos analisar o gênero textual e nem os tipos de periódicos em que a UFE ocorre de forma simples. Para isso, teríamos de realizar buscas individuais com a expressão seguida do nome de um periódico como, por exemplo, "few scoring opportunities" "the guardian", para verificar se a UFE ocorre no jornal The Guardian. Procedimento, este, que não realizamos.

\section{6 chegar ao gol (39)}

Encontrar um equivalente para a UFE chegar ao gol demandou um pouco mais de trabalho do que para as outras UFEs. Primeiramente, geramos linhas de concordância para approach, um dos equivalentes de chegar em inglês, mas a busca não retornou nenhum possível equivalente. Também tentamos observar as linhas de come procurando pelo colocado close, em busca de come close e, novamente, a busca não foi bem sucedida.

Para entender o funcionamento da UFE em português, geramos linhas de concordâncias para a expressão "chegar ao gol”: 


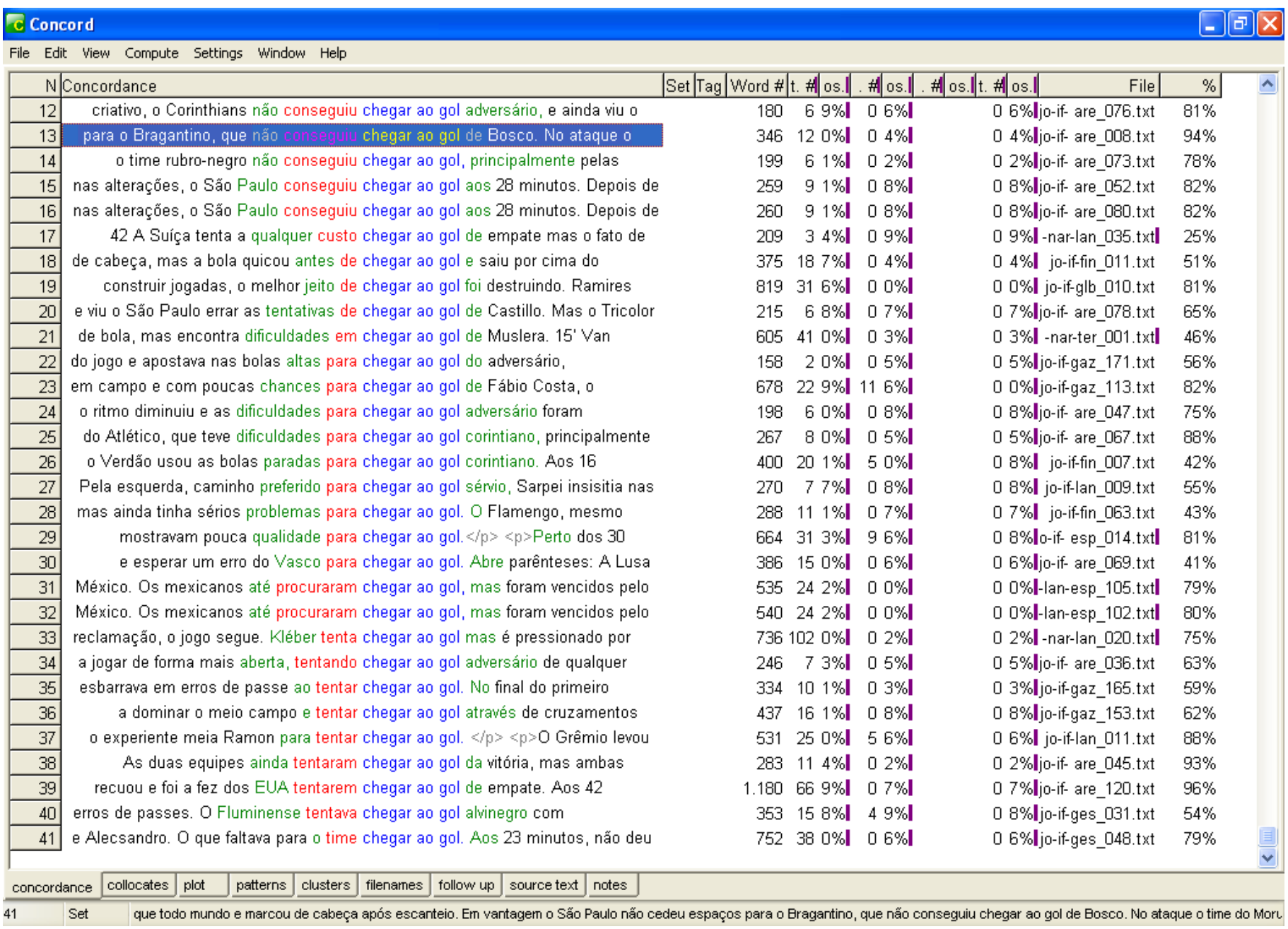

Figura 49 - Linhas de concordância para chegar ao gol ordenadas pelas duas primeiras palavras à esquerda e pela primeira palavra à direita

Ao observar a figura 49, percebemos que a UFE ocorre para relatar a tentativa de um time ou de um jogador de fazer um gol, raras vezes ocorre para falar de um gol que já foi feito. Sem muitas alternativas de buscas, geramos linhas de concordância para close e obtivemos: 


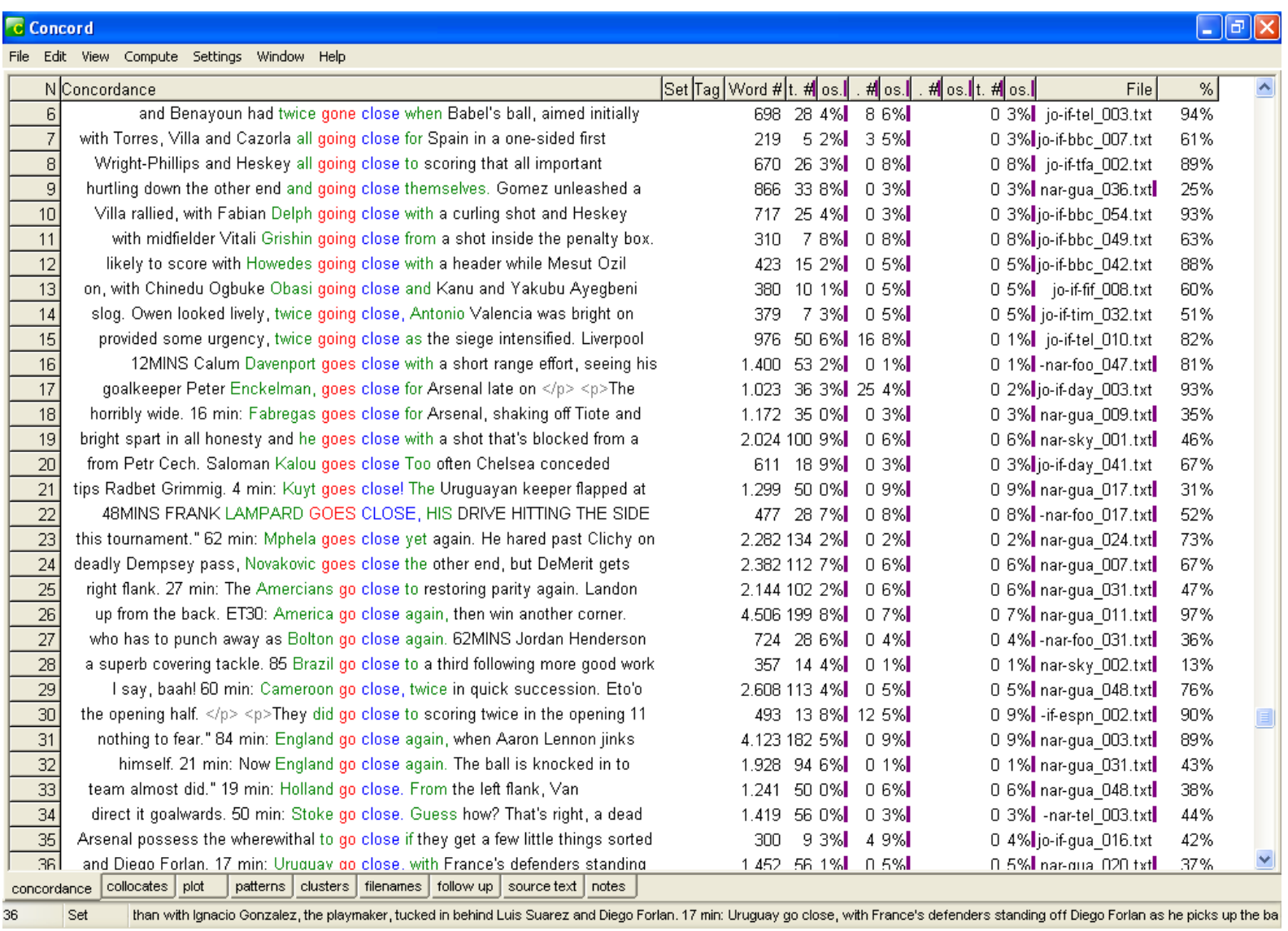

Figura 50 - Parte das linhas de concordância de close ordenadas pelas duas primeiras palavras à esquerda e pela primeira palavra à direita

Ao analisarmos as ocorrências de $G O$ close (46), percebemos que a UFE ocorre no mesmo contexto que chegar ao gol em português:

a) Villa rallied, with Fabian Delph going close with a curling shot and Heskey narrowly stabbing over after a clever near-post run, but the final clear opening of the tie fell to Vienna.

b) Gervinho has been the only bright spart in all honesty and he goes close with a shot that's blocked from a tight angle on the left.

c) England go close again, when Aaron Lennon jinks his way down the right side of the USA penalty area and pulls the ball back to Frank Lampard. 
A diferença de uso das UFEs nas duas línguas é que em português a UFE normalmente é seguida de um adjetivo que se refere a um time como, por exemplo, chegar ao gol corinthiano, e em inglês, a UFE é seguida da ação que descreve a tentativa do gol, como as partes sublinhadas nos exemplos acima.

Em português a UFE ocorre quase exclusivamente em notícias de resultados de partidas de periódicos esportivos, apresentando somente uma ocorrência no jornal $O$ Globo, ao passo que em inglês ocorre tanto em notícias como em transmissões minuto a minuto de jornais e de periódicos esportivos, não manifestando-se nenhuma vez em tabloides.

\section{7 chute de $\{$ direita|esquerda\} no gol feito por [jogador] (180)}

O primeiro passo para encontrar os equivalentes de chute de \{direita|esquerda\} no gol feito por [jogador] foi gerar linhas de concordância para os possíveis colocados de chute em inglês: right e left:

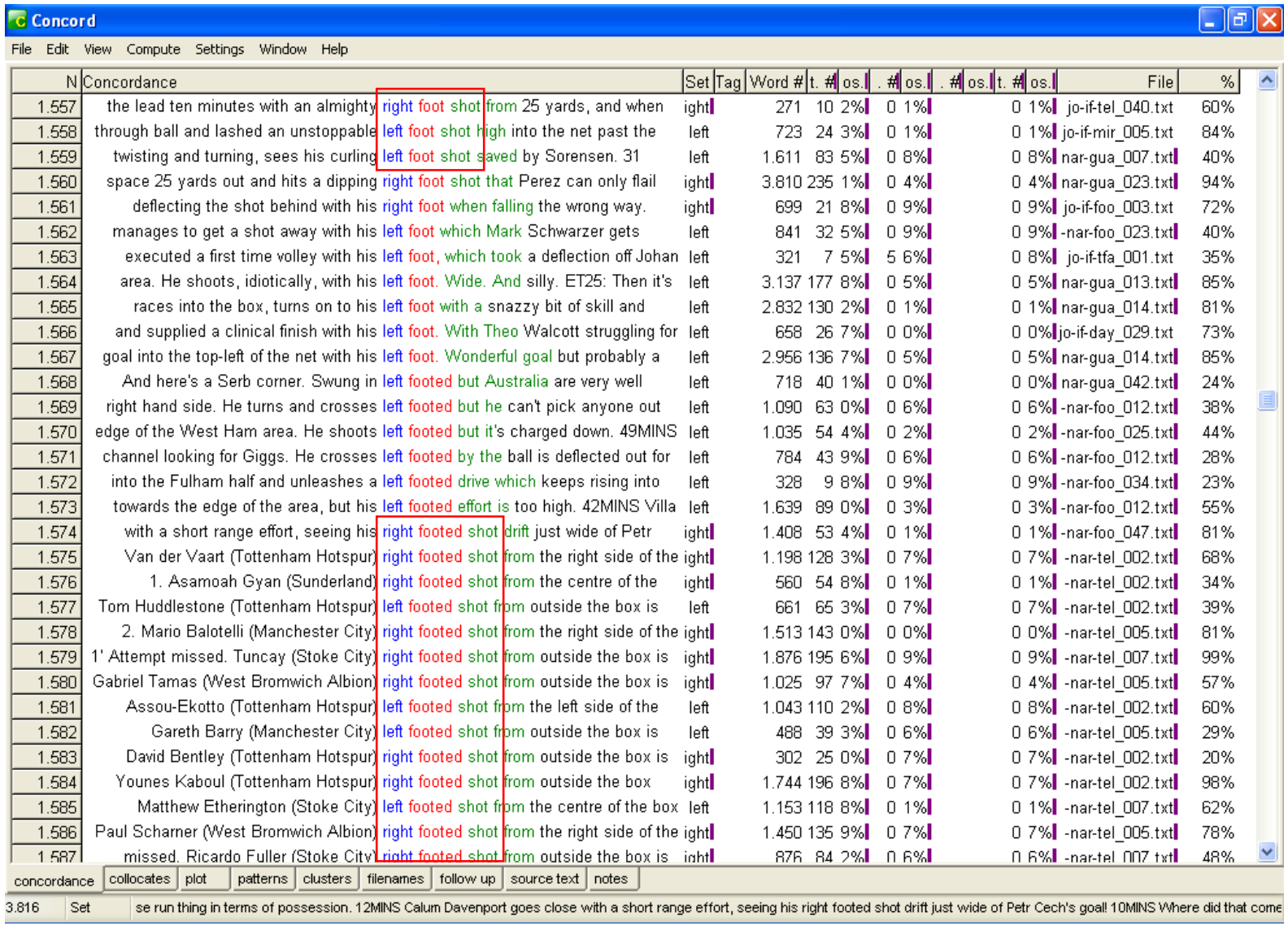

Figura 51 - Parte das linhas de concordância para right/left ordenadas pelas três primeiras palavras à direita 
A busca realizada nos permitiu identificar \{right|left $\}$-footed shot e $\{$ right $\mid$ left $\}$ foot shot como equivalentes para chute de \{direita|esquerda\}. O próximo passo foi gerar linhas de concordância para as quatro UFEs e ordená-las pelas três primeiras palavras à esquerda com o objetivo de descobrir os verbos que antecedem a expressão:

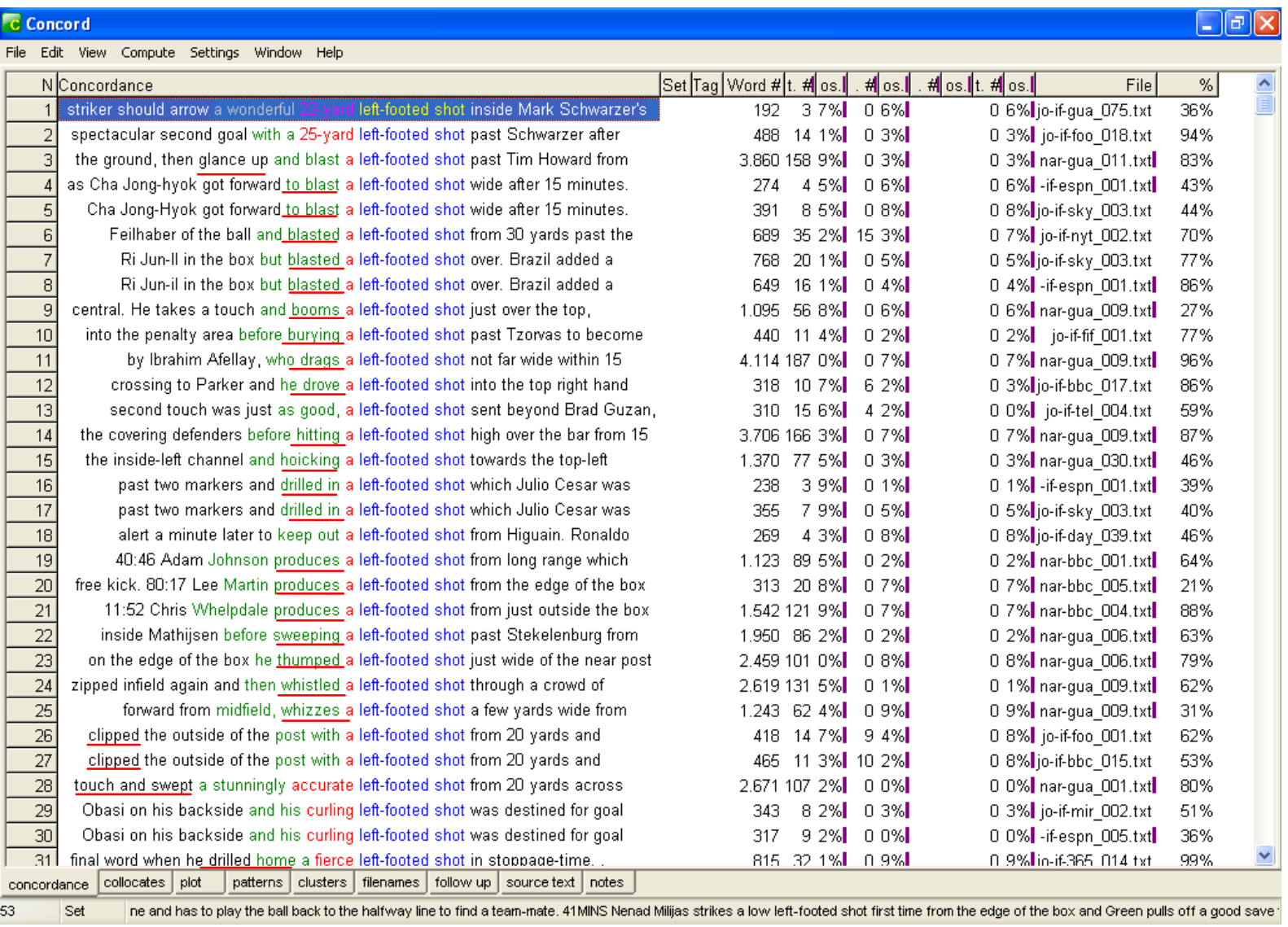

Figura 52 - Seleção de linhas de concordância de left-footed shot ordenadas pelas três primeiras palavras à esquerda

A figura acima mostra concordâncias para left-footed shot. Os verbos que aparecem sublinhados são os possíveis equivalentes de "feito" em português. Realizamos o mesmo procedimento para right-footed shot, right-foot shot e left-foot shot a fim de verificar todas as variantes possíveis ${ }^{112}$.

112 vide anexos $\mathrm{C}, \mathrm{D}$ e $\mathrm{E}$. 
Ao observar as linhas de concordância, percebemos que os colocados de $\{$ right $\mid$ left $\}$-footed shot são diferentes dos colocados de $\{$ right|left $\}$-foot shot. Por esse motivo, fizemos duas análises, uma para cada expressão de busca.

Analisadas as linhas de concordância, observamos que os verbos curl, produce, drive, smash, cannon, dispatch, fire, send, unleash, blast, boom, bury, drag, hit e hoick antecedem a expressão \{right | left $\}$-footed shot que é, algumas vezes, seguida do termo goalwards, que indica um chute ao gol.

A expressão \{right | left\}-foot shot é precedida dos verbos laze, drag, poke (in), hit, send, slam, slide, lash, smash, balloon, blast, bend, hammer, fire (in), slice, spank, curl, drive, unleash, scuff, slam, strike, direct, thump, blaze, drag, fizz, poke(in), send, chip, drill (in), crack in, dispatch, guide e leather. Tal expressão não é, em nenhuma das ocorrências, seguida do termo goalwards.

As UFEs encontradas ocorrem em todos os gêneros textuais que compõem nosso corpus. No que se refere ao tipo de veículo de informação, ocorrem, sobretudo, em jornais e periódicos esportivos, sendo que somente três das 175 ocorrências aparecem no tabloide Daily Mail. A princípio, a idéia era verificar quais verbos ocorrem em cada jornal, para, dessa forma, fazer uma distinção entre os usos. Contudo, não conseguimos conduzir a análise dada a baixa frequência individual dos verbos, ou seja, a língua inglesa apresenta um leque de opções muito amplo no que se refere ao verbo que precede a expressão \{right $\mid$ left $\}$-\{foot $\mid$ footed $)$ shot $\mathrm{e}$, justamente, devido a essa grande variedade, a frequência de cada um dos verbos é muito baixa. Alguns ocorrem somente uma vez no corpus e cremos que se relacionássemos determinados verbos a algum periódico, poderíamos fazer generalizações infundadas. Tomemos como exemplo o verbo cannon que, em nosso corpus, ocorreu quatro vezes no jornal The Guardian. Se em nossa análise afirmássemos que o verbo é característico das transmissões minuto a minuto do jornal em questão, estaríamos fazendo uma generalização falsa, uma vez que o verbo também ocorre em outros jornais e em outros gêneros textuais.

Com o objetivo de realizar uma distinção entre os verbos encontrados, em vez de agrupá-los por periódicos, optamos por classificá-los de acordo com o campo semântico a que pertencem, utilizando para esta classificação o Roget's International Thesaurus. Em uma primeira análise, observamos que os verbos podem ser agrupados na categoria 
de verbos de movimento. O quadro 11, a seguir, mostra uma classificação mais detalhada para todos os verbos:

\begin{tabular}{|l|l|}
\hline Categoria semântica & Verbos \\
\hline trajetória & curl, bend, balloon \\
\hline velocidade & Fizz \\
\hline transporte & send, dispatch, drive \\
\hline ação violenta & $\begin{array}{l}\text { fire, blast, boom, smash, hammer, spank, chip, lash, smash, knock, poke, } \\
\text { thump, strike, cannon, crack (in), hit, scuff, hoick }\end{array}$ \\
\hline liberação & unleash \\
\hline explosão & blast, boom \\
\hline lentidão & laze, drag \\
\hline facilidade & slide, sweep \\
\hline movimento para dentro & drill (in), bury \\
\hline fogo & blaze \\
\hline direção & direct, guide, slice \\
\hline realização & produce \\
\hline
\end{tabular}

Quadro 11 - Verbos classificados por categoria semântica

Como podemos observar, cada verbo carrega uma carga semântica própria, sendo que alguns como, por exemplo, o verbo boom, podem ser classificados em mais de uma categoria. Em português, a carga semântica poderia aparecer por meio do uso de um adjetivo ou de um advérbio. No entanto, dado o mínimo detalhamento das notícias nos jornais brasileiros, o modo com o qual o jogador chutou a bola em direção ao gol parece não ser muito relevante e, por esse motivo, não é explicitado.

\section{8 cobrar falta direto para o gol (10)}

Para encontrar o equivalente de cobrar falta direto para o gol, primeiramente, geramos concordâncias do termo foul (falta). Todavia, após observar as primeiras linhas, constatamos que o termo era quase sempre precedido de um adjetivo como, por exemplo, bad foul (falta dura). Para poupar tempo, realizamos a busca $V V N *$ foul. Em que a etiqueta VVN corresponde a um verbo no pretérito simples, para verificar os verbos que poderiam anteceder foul, mas o programa não retornou nenhuma ocorrência. 
Em buscas realizadas anteriormente, deparamos com o termo free-kick, que na ocasião foi utilizado para narrar uma falta que seria cobrada, e decidimos gerar linhas de concordância para entender seu significado:

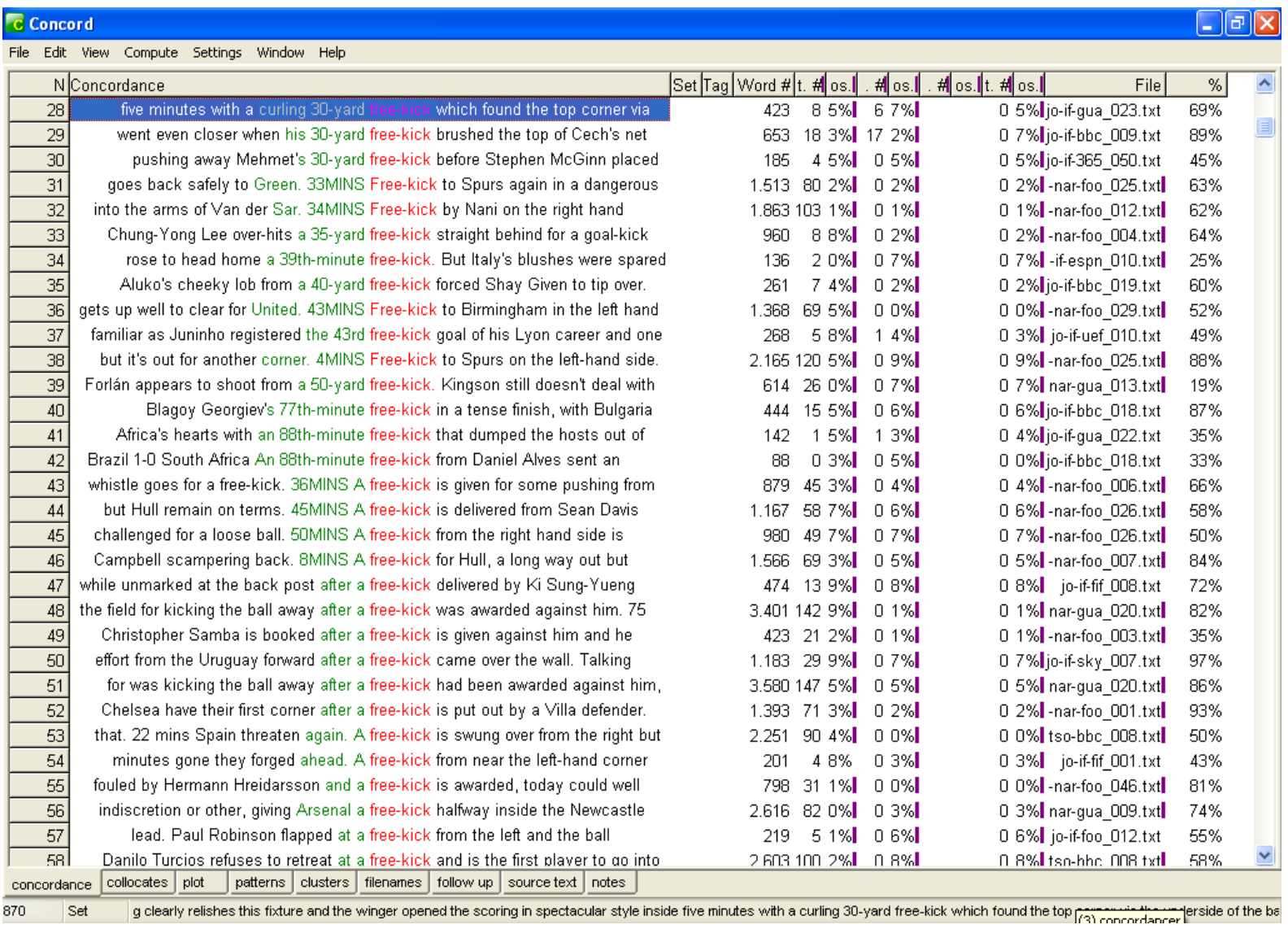

Figura 53 - Parte das linhas de concordância de free-kick ordenadas pelas duas primeiras palavras à esquerda

Assim como quando o encontramos, por acaso, durante uma das buscas, o termo é utilizado para designar a cobrança de uma falta. Entretanto, ainda nos faltava o verbo que antecede a cobrança. Para identificá-lo, realizamos duas buscas: "VVZ * a DT a free-kick" e "VVN * a DT a free-kick", em que a etiqueta VVZ corresponde a um verbo no presente na terceira pessoa do singular e VVN corresponde a um verbo no passado. A expressão "a DT a" foi incluída porque nas buscas com o corpus etiquetado temos que digitar a expressão tal qual aparece no arquivo etiquetado. Sendo assim, não poderíamos simplesmente procurar por $V V Z *$ a free-kick, pois o programa identificaria 
a existência de etiquetas entre o artigo $a$ e o substantivo free-kick e não retornaria nenhuma ocorrência. As buscas realizadas retornaram 53 ocorrências:

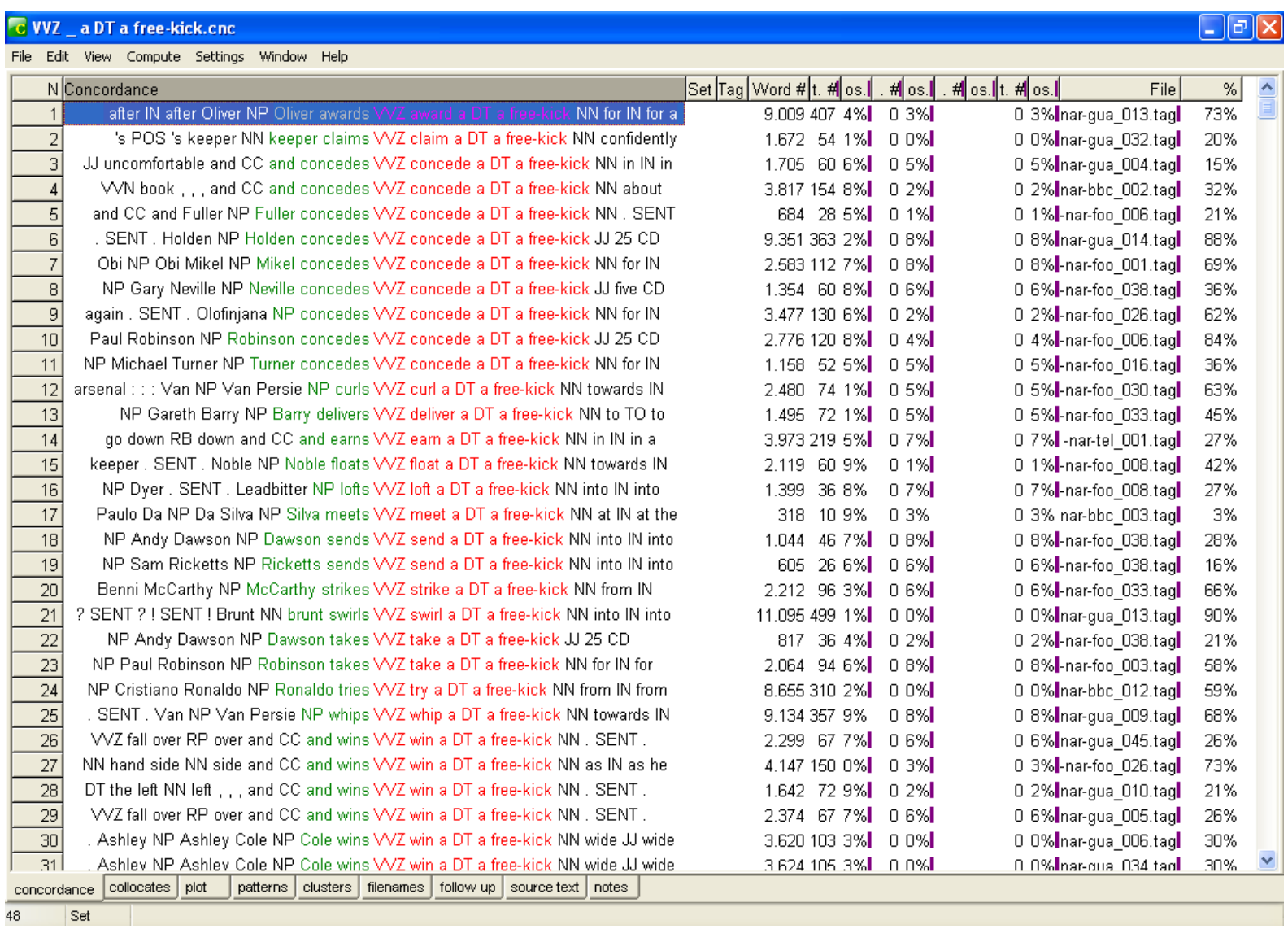

Figura 54 - Parte das linhas de concordância da expressão "VVZ * a DT a free-kick"

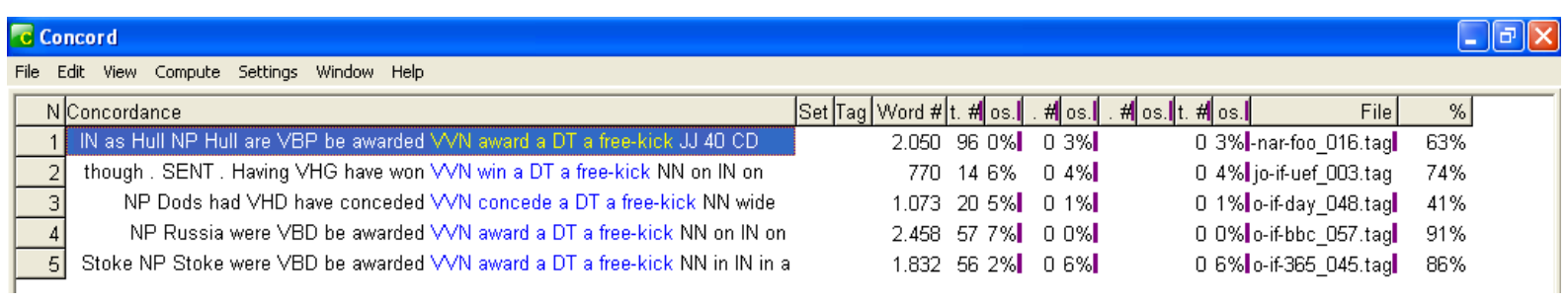

Figura 55- Parte das linhas de concordância da expressão "VVN * a DT a free-kick"

Ao observar as linhas, identificamos os verbos take, whip e deliver como equivalentes do verbo cobrar em português. Para encontrar, em inglês, um termo correspondente de para direto para o gol em português, ampliamos os contextos das linhas e encontramos algumas ocorrências de towards goal.

Um fato interessante é que a expressão direto para o gol é parte integrante da UFE em português para designar uma falta que foi cobrada direto para o gol sem que o 
cobrador toque para outro jogador, ao passo que, em inglês, o uso de towards goal é opcional. Observemos os exemplos que seguem:

a) Van Persie whips a free-kick towards goal from the right corner of the box, and Mucha does really well to punch clear under pressure from Kuyt, who flew in knee-first at him.

b) Steven Gerrard takes a free kick from the left but Friedel punches his effort away strongly.

Embora somente o primeiro exemplo o explicite, as duas cobranças foram realizadas direto para o gol. Na segunda, o fato evidencia-se quando lemos que o goleiro defendeu a cobrança feita pelo jogador que cobrou a falta.

Quanto ao gênero textual, podemos afirmar que a UFE ocorre com mais frequência em narrações do que em resultados de partida. Para tanto, nem foi preciso analisar a coluna da linha de concordância em que o nome do arquivo aparece, onde podemos verificar se o mesmo possui a sigla IF (jornalístico), (NAR) narração ou TSO (transmissão social); basta comparar o número de concordâncias para a busca com o verbo no presente (VVZ) com o número de concordâncias para a busca com o verbo no passado (VVN). Nas narrações minuto a minuto e na transmissão social, que são realizadas em tempo real, os verbos quase sempre ocorrem no presente, enquanto nas notícias, que são publicadas após o término da partida, mesmo que somente alguns minutos depois, os verbos são quase sempre utilizados no passado.

Por fim, assim como as outras UFEs, \{TAKE | WHIP | DELIVER] a free-kick (towards goal) ocorre com frequência muito similar em jornais e em periódicos esportivos, apresentando somente uma ocorrência em tabloide (Daily Mail).

\section{9 com um gol de [jogador] (83)}

Para identificar a UFE equivalente a com um gol de [jogador] geramos linhas de concordância para a expressão "NP * 's POS 's goal", em que NP corresponde a um substantivo próprio, o símbolo (*) designa um nome próprio que pode preencher a 
expressão, 's refere ao caso genitivo e POS à etiqueta do caso genitivo, a fim de encontrar nomes de jogadores seguidos do caso genitivo e da palavra gol. A figura 56 mostra as ocorrências que o programa retornou:

\begin{tabular}{|c|c|c|c|c|c|c|}
\hline \multicolumn{2}{|c|}{ C Concord } & & & & \multicolumn{2}{|c|}{ - } \\
\hline \multicolumn{7}{|c|}{ File Edit View Compute Settings Window Help } \\
\hline \multicolumn{2}{|c|}{ N Concordance } & Set $\mid$ Tag $\mid$ Word \# & \#nll| 0 . & \# & $\%$ & $\hat{\Lambda}$ \\
\hline 62 & 's delivery NN delivery. SENT. Friedel NP Friedel 's POS 's goal NN goal was & $2.176544 \%$ & $04 \%$ & $04 \%$ |o-if-gua_082.tagl & $94 \%$ & \\
\hline 63 & 's delivery NN delivery. SENT. Friedel NP Friedel 's POS 's goal NN goal was & $2.176 \quad 54 \quad 4 \%$ & $04 \% \mathbf{I}$ & $04 \%$ lo-if-gua_070.tagl & $94 \%$ & \\
\hline 64 & leave corner NN corner of IN of Friedel NP Friedel 's POS 's goal NN goal. & $1.209460 \% \mathbf{I}$ & $04 \% \mathbf{I}$ & $04 \%$-nar-foo_012.tagl & $14 \%$ & \\
\hline 65 & JJ wide of IN of Brad NP Brad Friedel NP Friedel 's POS 's goal NN goal. & $578260 \% \mathbf{I}$ & $05 \% \mathbf{I}$ & 0 5\%l-nar-f0o_001.tagl & $15 \%$ & \\
\hline 66 & narrowly wide JJ wide of IN of Foster NP Foster 's POS 's goal NN goal. & $1.067565 \% \mathbf{I}$ & $05 \%$ & 0 5\%l-nar-f0o_015.tagl & $36 \%$ & \\
\hline 67 . & pressure NN pressure on IN on Everton NP Everton 's POS 's goal NN goal was & $1.195424 \% \mathbf{I}$ & $00 \% \mathbf{I}$ & $\left.00 \%\right|_{0-i}$ & $50 \%$ & \\
\hline 68 & NP Pienaar scored WD score Everton NP Everton 's POS 's goal NN goal and & $116 \quad 28 \%$ & $05 \%$ & $05 \% 0-$ & $5 \%$ & \\
\hline 69 & TO to make W make in IN in England NP England 's POS 's goal NN goal all & $1.260295 \% \mathbf{I}$ & $09 \% \mathbf{I}$ & $09 \% \mathbf{j}$ & $89 \%$ & \\
\hline 70 b & by sealing WG seal up RP up England NP England 's POS 's goal NN goal & $411109 \% \mathbf{I}$ & $00 \% \mathbf{I}$ & $00 \% \mathbf{I}_{0}$ & $30 \%$ & \\
\hline 71 & \multirow{2}{*}{$\begin{array}{l}\text { of goalkeeper NN goalkeeper Eduardo NP Eduardo 's POS 's goal NN goal. } \\
\text { WG play Clint NP Clint Dempsey NP Dempsey 's POS 's goal NN goal }\end{array}$} & $984 \quad 227 \% \mathbf{I}$ & $02 \%$ & $\left.02 \%\right|_{0}$ & $34 \%$ & \\
\hline 72 & & $1.061292 \% \mathbf{I}$ & $02 \% \mathbf{I}$ & $02 \% I_{0}$ & $92 \%$ & \\
\hline 73 & \multirow{2}{*}{$\begin{array}{l}\text { DT the third JJ third. SENT. Dempsey NP Dempsey 's POS 's goal NN goal } \\
\text { moments NNS moment. } . \text { Crouch NP Crouch 's POS 's goal NN goal }\end{array}$} & $290 \quad 83 \%$ & $03 \% \mathbf{I}$ & $03 \% \mathrm{I}_{0}$ & $24 \%$ & \\
\hline 74 & & $3.6801754 \% \mathbf{I}$ & $03 \% \mathbf{I}$ & _002.tagl & $43 \%$ & \\
\hline 75 & \multirow{2}{*}{$\begin{array}{l}\text { SENT. " " " Daniel NP Daniel Cousin NP Cousin 's POS 's goal NN goal for IN } \\
\text { ? SENT ? Carlton NP Carlton Cole NP Cole 's POS's goal NN goal }\end{array}$} & $2.099568 \%$ & $03 \%$ & $03 \% \mathrm{ljo}$ & $93 \%$ & \\
\hline 76 & & $1.121628 \% \mathbf{I}$ & $01 \% \mathbf{I}$ & $01 \%$ I & $51 \%$ & \\
\hline 77 & $\begin{array}{l}\text { ? SENT ? Carlton NP Carlton Cole NP Cole 's POS 's goal NN goal } \\
\text { NP Didier Drogba NP. SENT. Cole NP Cole 's POS's goal NN goal in IN in }\end{array}$ & $986 \quad 332 \%$ & $06 \% \mathbf{I}$ & $06 \%$ & $36 \%$ & \\
\hline 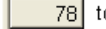 & \multirow{2}{*}{$\begin{array}{l}\text { to celebrate } W \text { celebrate. SENT. City NP City 's POS 's goal NN goal had } V H D \\
\text { to celebrate } W \text { celebrate. SENT. City NP City's POS 's goal NN goal had VHD }\end{array}$} & $748 \quad 183 \%$ & $06 \% \mathbf{I}$ & $06 \% \mid 0-i$ & $36 \%$ & \\
\hline 79 ts & & $772183 \%$ & $07 \% \mathbf{l}$ & $07 \% \mathrm{ljo}$ & $36 \%$ & \\
\hline 80 & JJ corner NN corner of IN of Cech NP Cech 's POS 's goal NN goal. SENT & $4.4031590 \% \mathbf{I}$ & $08 \% \mathbf{l}$ & $08 \% \ln$ & $37 \%$ & \\
\hline $81 \mathrm{w}$ & \multirow{2}{*}{$\begin{array}{l}\text { wide JJ wide of IN of Petr NP Petr Cech NP Cech 's POS 's goal NN goal! SENT } \\
\text { surprise lead NN lead. SENT. Carroll NP Carroll 's POS 's goal NN goal was }\end{array}$} & $3.7891100 \% \mathbf{I}$ & $00 \% \mathbf{I}$ & $00 \% \mathbf{l}-n$ & $79 \%$ & \\
\hline 82 & & $6.0001784 \%$ & $05 \%$ & $05 \%$ Ina & $55 \%$ & \\
\hline 83 & being VBG be told WN tell Cameroon NP Cameroon 's POS 's goal NN goal & $4.2471685 \% \mathbf{I}$ & $05 \% \mathbf{I}$ & $05 \%$ Ina & $35 \%$ & \\
\hline 84 & \multirow{2}{*}{$\begin{array}{l}\text { WG bear down RP down on IN on Butt NP Butt 's POS 's goal NN goal from IN } \\
\text { ball NN ball towards IN towards Burnley NP Burnley 's POS 's goal NN goal. }\end{array}$} & $1.596401 \% \mathbf{I}$ & $04 \%$ I & $04 \% \mathrm{jo}$ & $75 \%$ & \\
\hline 85 b & & $1.730391 \% \mathbf{I}$ & $07 \%$ & 5_012.tagl & $77 \%$ & \\
\hline 86 & the DT the face NN face of IN of Brazil NP Brazil 's POS 's goal NN goal , , , but & $4.7231439 \% \mathbf{I}$ & $05 \%$ & 0 5\%Inar-gua_012.tagl & $45 \%$ & \\
\hline 87 & \multirow{2}{*}{$\begin{array}{l}\text { 1. CD @ord@ But CC but Australia NP Australia 's POS 's goal NN goal } \\
\text { corner NN corner. SENT. Anderson NP Anderson 's POS's goal NN goal }\end{array}$} & $7.2162918 \%$ & $08 \%$ & $08 \%$ Inar- & $67 \%$ & \\
\hline 88 & & $1.665 \quad 46 \quad 1 \% \mathbf{I}$ & $00 \% \mathbf{l}$ & $00 \%$ lo-if & $71 \%$ & \\
\hline 89 & \multirow{2}{*}{$\begin{array}{l}\text { corner NN corner. SENT. Anderson NP Anderson 's POS 's goal NN goal } \\
\text { of IN of Carlos NP Carlos Alberto NP Alberto 's POS 's goal NN goal in IN }\end{array}$} & $1.728 \quad 461 \% \mathbf{I}$ & $01 \%$ & 0 1\%ljo- & $71 \%$ & \\
\hline 90 & & $8.8513713 \% \mathbf{I}$ & $00 \%$ & 0 0\%Inar-gua_014.tagl & $61 \%$ & \\
\hline 91 & RB particularly on IN on Adriano NP Adriano 's POS 's goal NN goal. & $2.171504 \% \mathbf{I}$ & $02 \%$ & 0 2\%l jo-if-wp_002.tag & $73 \%$ & \\
\hline 92 & WD resume when WRB when Adriano NP Adriano 's POS 's aoal NN aoal -. : -- & $2790 \quad 544 \%$ & $\Pi$ Ћ\% & $\Pi$ F\%l in-if-wn $\Pi \Pi 2$ tan & $77 \%$ & $\underline{v}$ \\
\hline concordance & \begin{tabular}{|l|l|l|l|l|l|l|l} 
patterns & clusters filenames follow up source text notes \\
\end{tabular} & & & & & \\
\hline
\end{tabular}

Figura 56 - Parte das linhas de concordância da busca "NP * 's POS 's goal”"

Ao observar as linhas, constatamos que o espaço designado ao nome próprio ora é preenchido com o nome de um jogador, ora é preenchido com o nome de um time. $\mathrm{Ou}$ seja, a estrutura é utilizada para designar um gol feito por um jogador ou por um time. Fato que nos intrigou quanto à equivalência das UFEs e nos incentivou a ler as linhas de concordância da fraseologia em português para verificar a situação em que ocorre: 


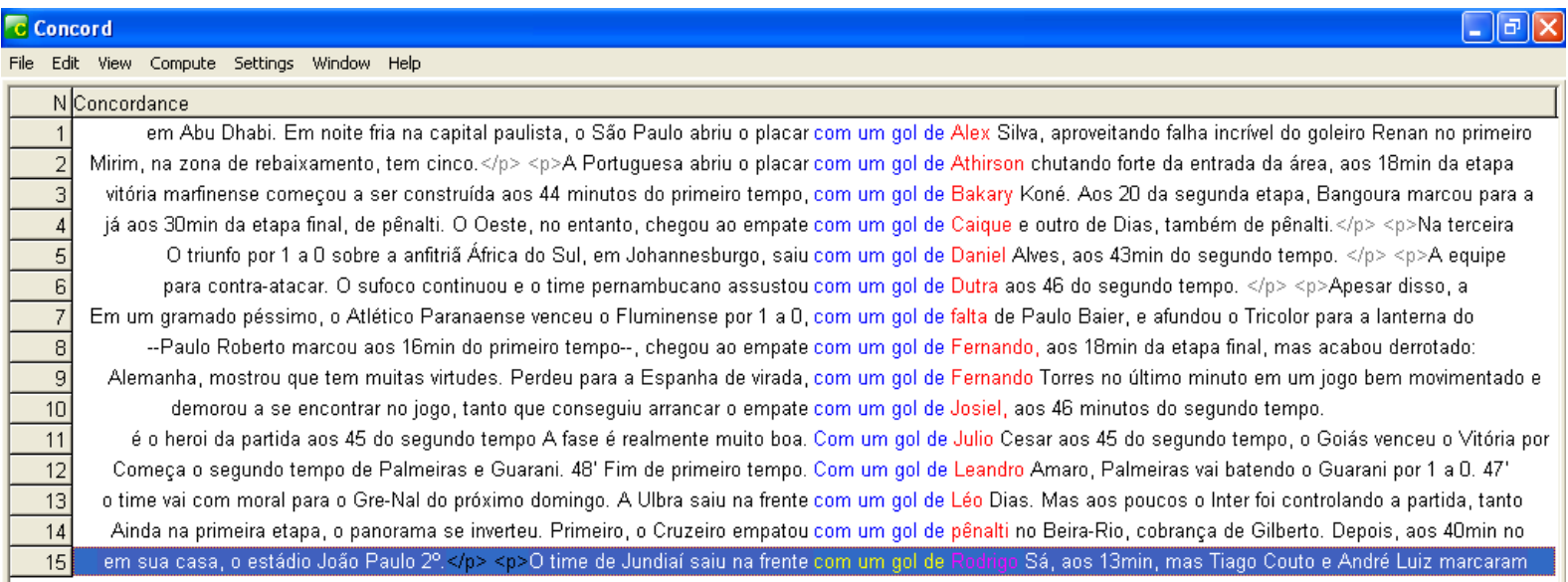

Figura 57 - Seleção de linhas de concordância da UFE com um gol de

As concordâncias revelaram que, no geral, a fraseologia ocorre para descrever uma mudança no jogo após o gol, ou seja, o foco não é o jogador, mas sim o efeito que o gol teve na partida. Tomemos os exemplos abaixo:

a) Em seu último amistoso antes da Copa do Mundo, a Croácia, o primeiro rival do Brasil na Alemanha, mostrou que tem muitas virtudes. Perdeu para a Espanha de virada, com um gol de Fernando Torres no último minuto em um jogo bem movimentado e com um bom toque de bola.

b) Pedrão, autor dos dois gols da estreia, abriu o placar no primeiro tempo e ampliou já aos 30min da etapa final, de pênalti. O Oeste, no entanto, chegou ao empate com um gol de Caique e outro de Dias, também de pênalti.

Tendo em vista a função da UFE, fizemos uma concordância para a expressão "when * scored" ordenada pelo nódulo e pela primeira palavra à direita e à esquerda: 


\begin{tabular}{|c|c|c|c|c|c|c|}
\hline \multicolumn{6}{|c|}{ C Concord } & \multirow[t]{2}{*}{ 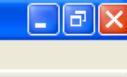 } \\
\hline File Edit & View Compute Settings Window Help & & & & & \\
\hline \multicolumn{2}{|c|}{$\mathrm{N}$ Concordance } & \begin{tabular}{|l|l|l|} 
Set & Tag & Word \# \\
\end{tabular} & t. \#| os. & An 0 . 1 | & H. os.||t. \#| os.|| & $\%$ \\
\hline 1 & game 14 minutes into the second half & 478 & $149 \%$ & $02 \%$ & $02 \%$ jo-iffoo_018.txt & $92 \%$ \\
\hline 2 & but went ahead eight minutes later when Donovan scored his & 225 & $65 \%$ & $35 \%$ & $08 \%$-if-espn_001.txt| & $36 \%$ \\
\hline 3 & content with his squad and only when Drogba scored a fortuitous winner & 250 & $60 \% \mathbf{l}$ & $04 \%$ | & $04 \%$ jo-if-tel_028.txt & $63 \%$ \\
\hline 4 & centre-halves in a worse position than when Germany scored their first goal, I & 2.076 & $824 \% \mathbf{I}$ & $02 \%$ & $02 \%$ tso-bbc_015.txt| & $23 \%$ \\
\hline 5 & German pressure early in the match when he scored in the fourth minute. & 231 & $95 \%$ I & $19 \% \mathbf{I}$ & $08 \% \mathbf{l}$ jo-if-wp_016.txt & $36 \%$ \\
\hline 6 & Royal Bafokeng Stadium than Parker when he scored South Africa's first goal & 188 & $35 \%$ & $33 \% \mathbf{l}$ & $07 \%$-if-espn_004.txtl & $37 \%$ \\
\hline 7 & Tevez was in an offside position when he scored. But despite mass & 326 & $96 \% \mathbf{l}$ & $00 \% \mathbf{l}$ & 0 0\%ljo-if-sun_003.txt & $55 \%$ \\
\hline 8 & out its second win of the tournament when he scored his first goal in the 73rd & 308 & $138 \% \mathbf{I}$ & $59 \%$ & 0 5\%ljo-if-cnn_002.txt & $51 \%$ \\
\hline 9 & thought he'd bagged the winner when he scored a first on 85 minutes. & 108 & $04 \%$ I & $06 \%$ & 0 6\%ljo-if-sun_023.txt & $40 \%$ \\
\hline 10 & in the process of making the change when Hearts scored and, ironically, Nade & 728 & $298 \%$ & $07 \%$ & 0 7\%ljo-if-day_033.txt & $70 \%$ \\
\hline 11 & during the Ireland v Italy match in 1994 , when Houghton scored," says Seamus & 1.349 & $492 \%$ & $03 \% \mathbf{I}$ & 0 3\% I nar-gua_021.txt| & $35 \%$ \\
\hline 12 & as an 11 year old. It was a great feeling when I scored. $\langle p\rangle\langle p\rangle$ "To start a & 583 & $258 \%$ & $172 \% \mathbf{l}$ & 0 6\%ljo-if-sun_002.txt & $88 \%$ \\
\hline 13 & These plans for the match went awry when Jamaica scored in the fourth & 401 & $201 \% \mathbf{l}$ & $02 \%$ & $02 \%$-nw-esp_010.txtl & $14 \%$ \\
\hline 14 & These plans for the match went awry when Jamaica scored in the fourth & 402 & $201 \%$ & $02 \%$ & $02 \% \mid$-nw-esp_012.txtl & $14 \%$ \\
\hline 15 & took the lead in the $23 \mathrm{rd}$ minute when Jaziri scored off a corner kick. & 351 & $128 \% \mathbf{l}$ & $73 \% \mathbf{I}$ & $04 \%$ l jo-if-wp_032.txt & $95 \%$ \\
\hline 16 & until ten minutes into the second half when Maicon scored a stunning goal & 123 & $14 \%$ & $08 \%$ & $08 \%$ jo-iffoo_009.txt & $29 \%$ \\
\hline 17 & have believed their eyes anyway, not when Rapid scored in under a minute. & 362 & $93 \%$ & $01 \%$ & 0 1\%l jo-if-tel_035.txt & $58 \%$ \\
\hline 18 & strike were swiftly snuffed out when Rooney scored England's fifth. & 611 & $150 \% \mathbf{l}$ & $09 \% \mathbf{l}$ & 0 9\%ljo-if-bbc_035.txt & $81 \%$ \\
\hline 19 & his failure to deliver a clean connection when Spain scored what proved to be the & 1.009 & $260 \%$ & $06 \% \mathbf{l}$ & $06 \%$ ljo-if-sky_006.txt & $78 \%$ \\
\hline 20 & rewarded five minutes before half-time when they scored from their fist & 320 & $77 \%$ & $64 \% \mathbf{I}$ & $04 \%$ ljo-if-bbc_004.txt & $69 \%$ \\
\hline 21 & was decided on the two set-pieces when they scored. "We knew which two & 432 & $198 \%$ & $05 \%$ & 0 5\%ljo-if-sun_009.txt & $96 \%$ \\
\hline 22 & Tottenham got off to a dream start when they scored in the opening 60 & 203 & $46 \%$ & $05 \%$ & 0 5\% jo-iffoo_010.txt & $46 \%$ \\
\hline 23 & $\langle p\rangle\langle p\rangle$ Green also stood no chance when Tuncay scored Middlesbrough's & 565 & $168 \%$ & $125 \% \mathbf{I}$ & $00 \%$ lio-if-day $007 . t x t$ & $73 \%$ \\
\hline
\end{tabular}

Figura 58 - Seleção de linhas para a expressão de busca "when * scored"

Ampliamos as 58 linhas para observar se o efeito da expressão era o mesmo. Após confirmar a hipótese, fizemos a busca na direção inversa, ou seja, geramos uma concordância para quando ordenada da mesma maneira que when e, para nossa surpresa, não encontramos nenhuma ocorrência de “quando * marcou” em nosso corpus. Esse tipo de busca nos evidenciou o seguinte: embora a expressão "quando * marcou” seja, gramaticalmente, possível, não é a expressão convencionada para descrever o efeito de um gol em uma partida.

A UFE em inglês ocorre em notícias de jornais, tabloides e periódicos esportivos.

\subsection{0 direita do gol, à (60)}

Utilizamos as expressões de busca "right * goal" e "right** goal" para tentar encontrar um possível equivalente da UFE à direita do gol e o programa nos retornou 20 ocorrências de right of goal e nove de right of the goal, as quais ordenamos pelas primeiras duas palavras à esquerda e chegamos a to the right of (the) goal, utilizada quase exclusivamente ( 27 ocorrências) em transmissões minuto a minuto de jornais e periódicos esportivos. 


\subsection{1 a bola \{PASSAR|SAIR $\}$ à direita do gol}

Como encontramos apenas 29 ocorrências da UFE to the right of (the) goal, aplicamos o dispositivo re-sort nas linhas de concordância e as ordenamos pelas três primeiras palavras à esquerda a fim de identificar os possíveis equivalentes de a bola $\{P A S S A R \mid S A I R\}$ à direita do gol:

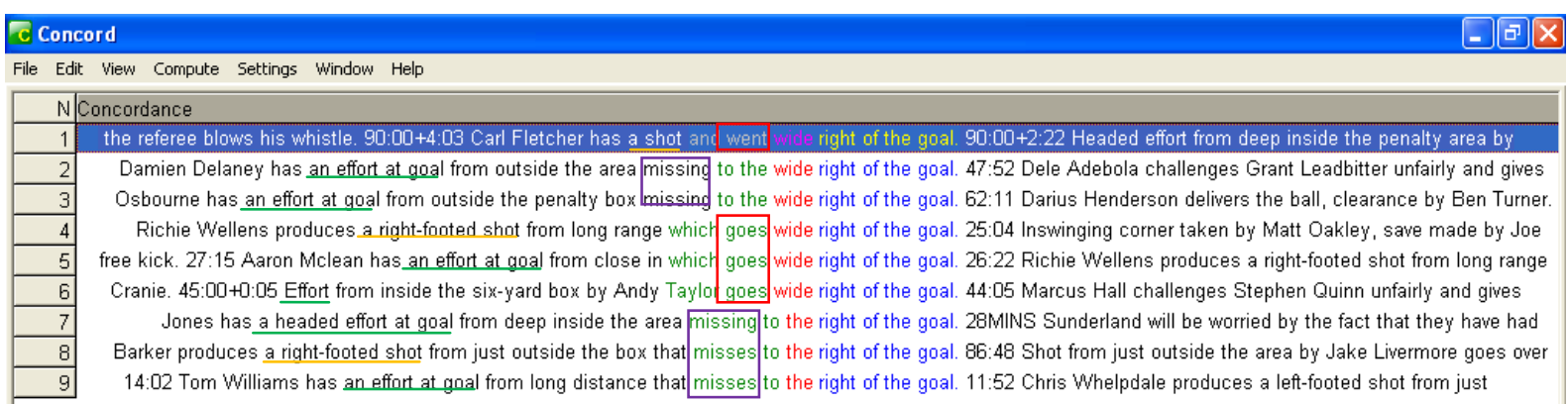

Figura 59 - Seleção das linhas de concordância de "to the right of the goal"

As concordâncias revelam que em inglês não é a bola que sai ou que passa à direita do gol, mas sim um shot (chute) ou um effort (tentativa), assim como os verbos utilizados são o go (ir) e o miss (errar). Outro achado interessante é que a palavra right é sempre antecedida do adjetivo wide. Desta forma, validamos as UFEs \{effort $\mid$ shot $\}$ goes wide right of the goal e [footballer] has an effort at goal \{missing |that misses\} to the wide right of the goal como equivalentes de a bola \{PASSAR|SAIR\} à direita do gol .

\subsection{1 esquerda do gol, à (75)}

O procedimento para estabelecer o equivalente de à esquerda do gol foi o mesmo adotado para a UFE à direita no gol. A única modificação que realizamos na busca foi substituir a palavra de busca right por left.

A UFE encontrada - to the left of (the) goal (25) - ocorre nos mesmos tipos de textos e periódicos que to the right of (the) goal.

4.11.1 a bola \{PASSAR | SAIR $\}$ à esquerda do gol 
Utilizamos o mesmo tipo de busca apresentado no item 4.10.1 e chegamos às UFEs \{effort | shot\} goes wide left of the goal (10) e \{footballer\} has an effort at goal goal \{missing | that misses\} the wide left of the goal (8).

\subsection{EVITAR o gol (32)}

Sem muitas alternativas de busca disponíveis, decidimos, antes de iniciar a identificação dos equivalentes, observar a situação em que a UFE é utilizada em português. Para tanto, geramos linhas de concordâncias para a expressão "evitar/evitou o gol ${ }^{113}$ ":

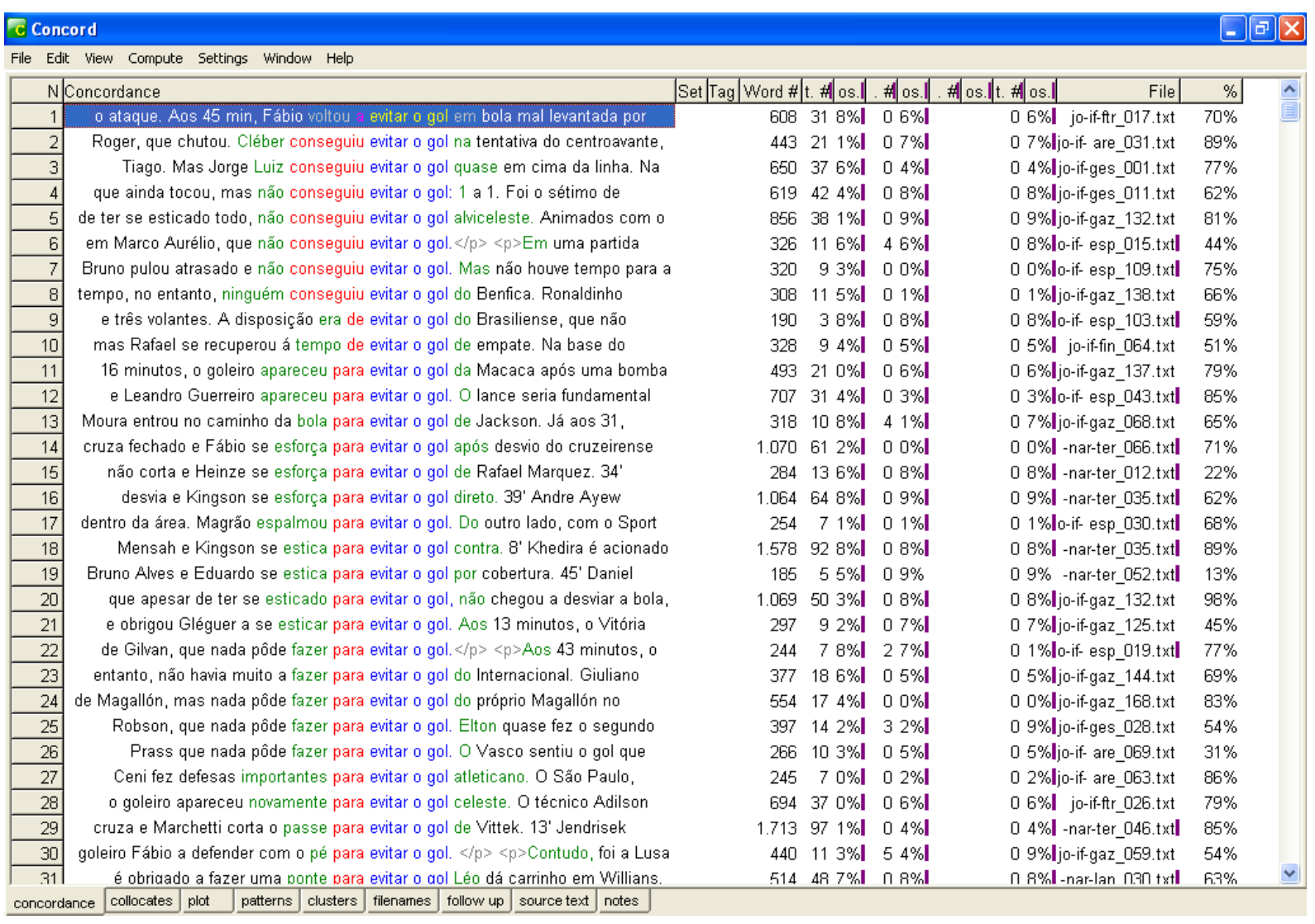

Figura 60 - Parte das linhas de concordância de evitar/evitou o gol

Por meio da observação das concordâncias, constatamos que tanto um goleiro quanto um jogador de linha podem evitar um gol. O próximo passo foi gerar linhas de

${ }^{113}$ A barra (/)permite que o programa retorne ocorrências de evitar e evitou. 
concordância para dois possíveis equivalentes de evitar em inglês: "block*” e "save*”, ambos presentes nas keywords do corpus em inglês ${ }^{114}$.

A busca retornou 526 ocorrências de blockblocked, sendo 32 seguidas de the shot, como podemos observar nas linhas abaixo:

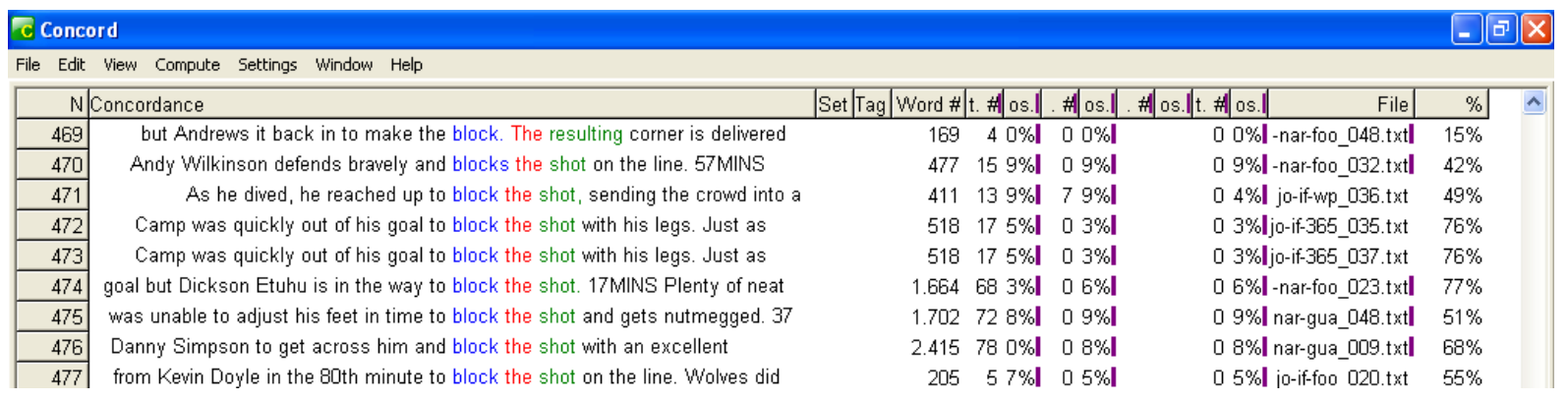

Figura 61 - Seleção de linhas de concordância de "block*”

Expandimos o contexto de todas as linhas para verificar quem é o responsável por evitar o gol nessas ocorrências e comprovamos que pode ser tanto um goleiro quanto um jogador de linha. Quando não sabíamos ao certo a posição de um jogador, conduzimos buscas com os nomes dos jogadores no Google.

Realizamos o mesmo procedimento para o verbo save, só que, desta vez, as 18 ocorrências revelaram que a UFE só ocorre antecedida por um goleiro como no exemplo abaixo:

a) Time almost stood still as he moved onto the ball in slow motion, but Friedel flew from the line to save the shot with his right hand.

Após a validação das UFEs, verificamos os periódicos em que ocorriam e, assim como a maior parte dos equivalentes encontrados nesta pesquisa, atestamos que estão presentes em jornais e periódicos esportivos. Quanto ao gênero, podemos afirmar que são mais comuns (44 ocorrências) em notícias do que em narrações (6).

\subsection{FAZER \{o | um\} gol (473) / MARCAR \{o|um\} gol (145)/ MARCAR o tento (40) / FINALIZAR (35) / EMPATAR (50)}

${ }^{114}$ Vide anexo F. 
Encontramos uma vasta gama de verbos e UFEs em inglês que funcionam como equivalentes de fazer \{o|um\} gol que, em português, tem como sinônimos, marcar $\{o \mid$ um\} gol, marcar o tento e, algumas vezes, finalizar e empatar.

Em um estudo piloto que realizamos para o relatório de qualificação, encontramos cinco equivalentes em inglês por meio da análise dos colocados de goal pelas linhas de concordância:

a) SCORE [\{a|the $\}$ goal $]$

Arjen Robben scored a delightful goal, but his teammates will have to up their game significantly when they play Brazil (probably) on Friday evening.

b) SNATCH [a goal]

But the early pressure soon dissipated and Celtic's task, already tough, grew even more difficult when Braga snatched an away goal in the 21st minute.

\section{c) DELIVER a goal}

The finest player in all of England delivered a goal to match the grandeur of his talent. And in that single, exhilarating instant, Manchester United declared that it will take a truly extraordinary football team to tear the title from their grasp.

d) ADD \{a|the\} ORDINAL (goal)

At Hanover, Andrea Pirlo scored in the 40th minute, and Vincenzo Iaquinta added a goal in the 83rd as Italy extended its unbeaten streak to 19 games.

e) BLAST in ([a goal])

Russia nearly made the points safe when Pavlyuchenko's dipping shot left the Wales crossbar quivering. But after a blocked Ledley shot had threatened a second Wales equaliser, Pavlyuchenko seized on a mistake by Collins deep in injury time to blast in a third goal and seal the result. 
Nos exemplos acima, o termo goal está presente em todas as UFEs. Entretanto, ao ler os textos que coletávamos para compilar o corpus, nos demos conta que a língua inglesa utiliza outros verbos que, muito frequentemente, não coocorrem com o termo gol, como sinônimos de score a goal.

Decidimos, então, conduzir buscas para todos os verbos do corpus utilizando as seguintes etiquetas: VV (verbo no infinitivo), VVD (verbo no passado simples), VVG (verbo no gerúndio), VVN (verbo no particípio passado) e VVZ (verbo no presente $-3^{\circ}$ pessoa do singular). A tabela 7 mostra o número de ocorrências de cada etiqueta no corpus:

\begin{tabular}{|l|l|}
\hline Etiqueta & Número de ocorrências \\
\hline VV & 25.283 \\
\hline VVD & 28.778 \\
\hline VVG & 19.406 \\
\hline VVN & 20.457 \\
\hline VVZ & 13.853 \\
\hline
\end{tabular}

Tabela 7 - Número de linhas de concordância para cada etiqueta gramatical

Aplicamos o dispositivo Re-sort e ordenamos as linhas de concordância pelo nódulo de busca, ou seja, pela etiqueta gramatical, e pela primeira palavra à direita e à esquerda. Deste modo, a visualização das etiquetas e dos verbos ficou mais clara: 


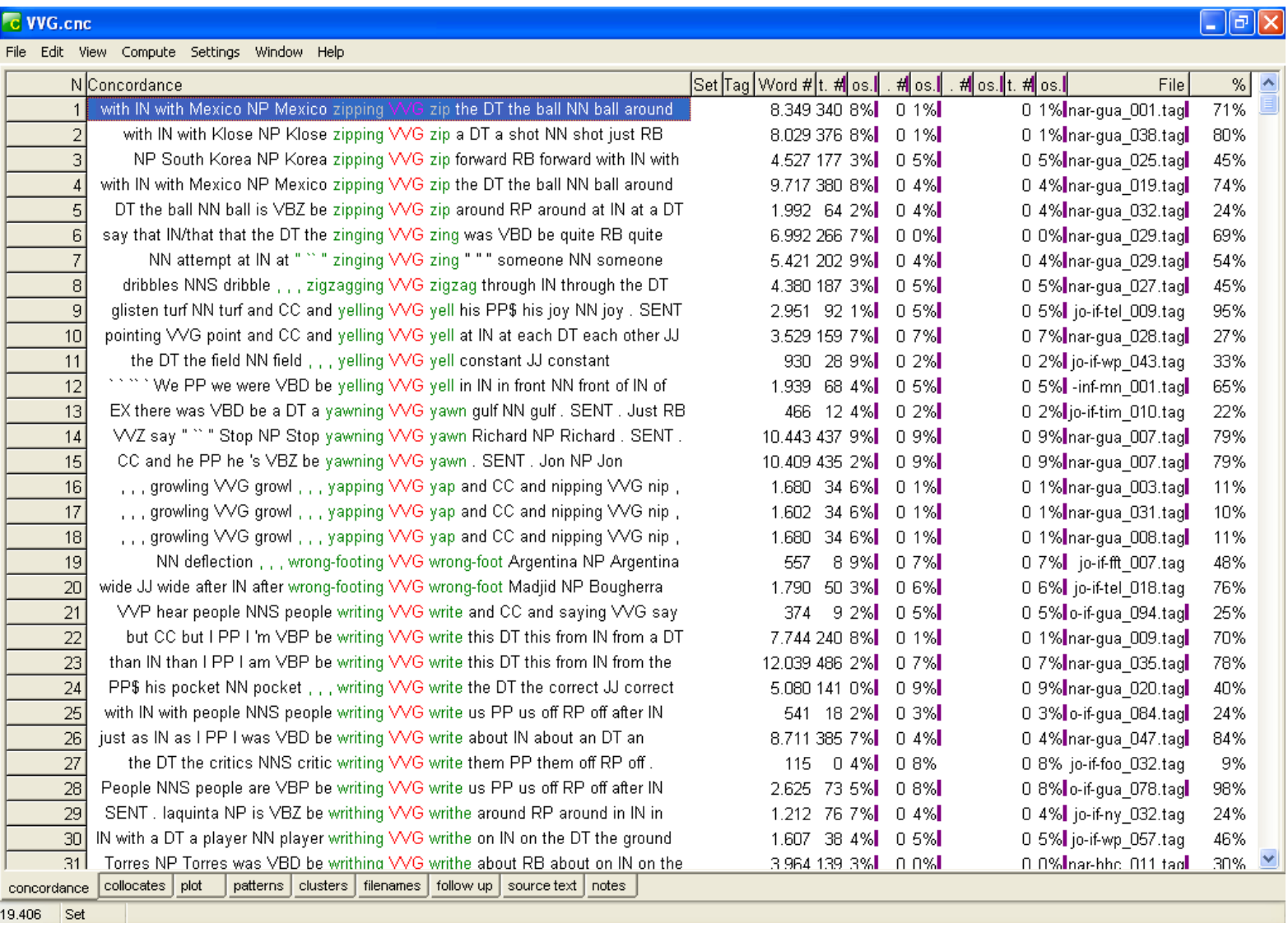

Figura 62 - Parte das linhas de concordância da etiqueta VVG

Observamos todas as linhas de concordância e identificamos 43 verbos que poderiam fazer parte de UFEs utilizadas para relatar um gol. Depois, geramos concordâncias no corpus sem etiquetas gramaticais para esses verbos a fim verificar como ocorrem nos textos, ou seja, os padrões em que ocorrem.

Nesta parte da análise, também eliminamos as estruturas que não funcionavam como equivalentes de fazer um gol. Observemos o exemplo, a seguir, da busca realizada para fire*: 


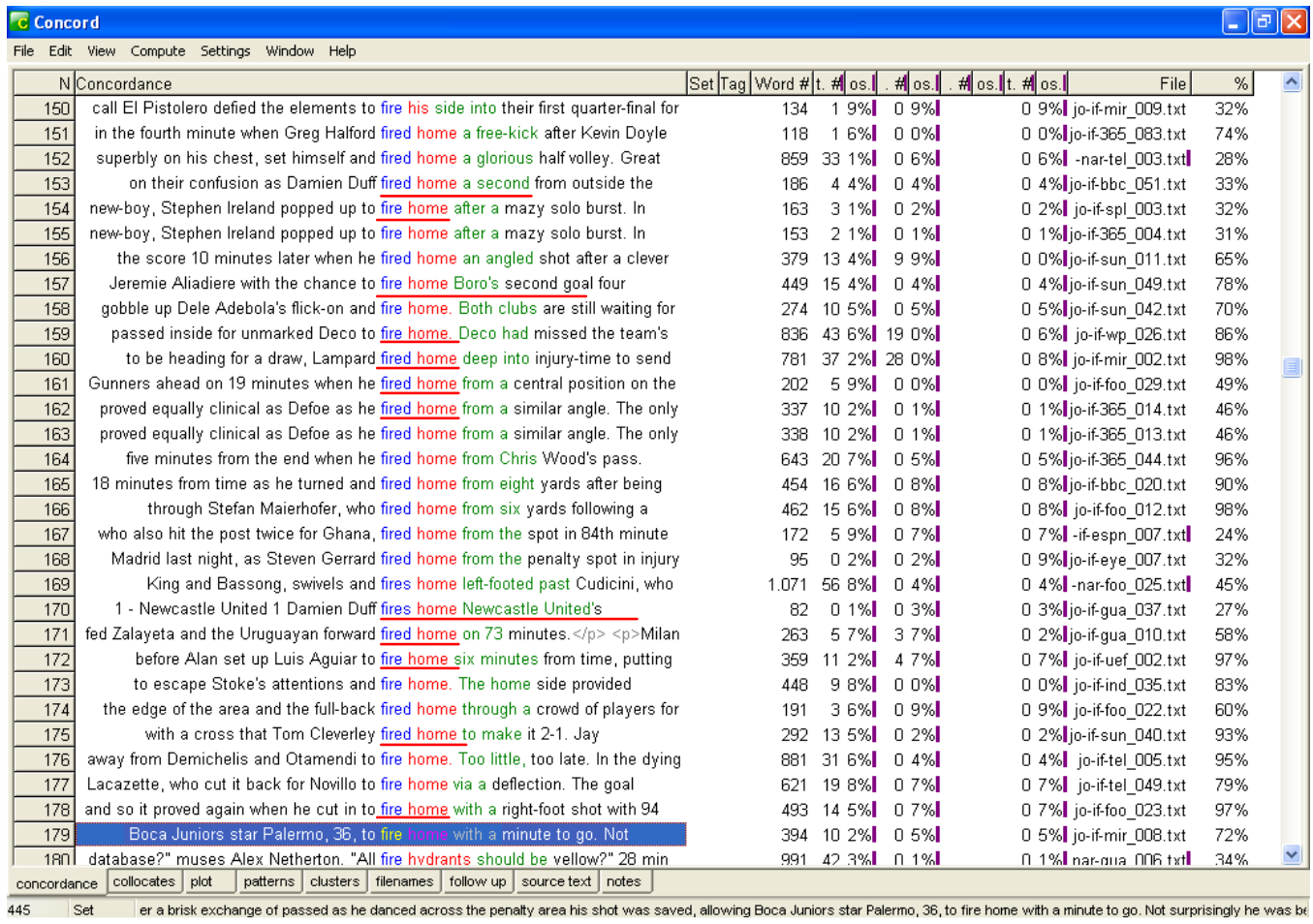

Figura 63 - Parte das linhas de concordância de "fire**"

O verbo fire ocorre 455 vezes no corpus. No entanto, em apenas 65 ocorrências ele é utilizado para narrar um gol. Ademais, muitas vezes, uma estrutura que é utilizada para descrever um gol, como fire home, pode ser utilizada em outras situações. Na figura 63, fire home só é equivalente de fazer um gol nas ocorrências sublinhadas. Em todas as outras, é utilizado para descrever uma tentativa que não resultou em gol.

O passo seguinte foi validar os candidatos a UFE por meio da análise das concordâncias e do contexto expandido. Ainda no caso de fire, ampliamos os contextos das linhas em que fire home era um possível equivalente de fazer um gol. Veja-se, por exemplo, a ocorrência número 153:

Fulham recovered from a poor first half display to claim an exciting victory over Everton at Craven Cottage $\langle$ omit>

<standfirst> Everton produced an assured performance to draw with Sigma Olomouc in the Czech Republic and confirm their place in the Europa League group stages. $</$ standfirst $>$

Fulham recovered from a poor first half display to claim an exciting victory over Everton at Craven Cottage

Tim Cahill's header gave Everton a deserved half-time lead but Paul Konchesky's deflected shot got Fulham back on terms after the restart.

Everton were rattled when Phil Neville was carried off and Fulham capitalised on their confusion as Damien Duffffired home a second from outside the box. Everton went all out for an equaliser but Fulham held on for a welcome win.

The early stages of the game were scrappy, with both teams' poor league positions being borne out by a reluctance to try and take charge of the game.

Figura 64 - Parte do contexto expandido da linha de concordância 153 de fire* 
Após a validação dos candidatos, agrupamos as 39 UFEs por categoria semântica tendo como base o Roget's International Thesaurus. Optamos por esse tipo de classificação porque, durante a análise, notamos que o significado de algumas UFEs é bastante similar e que este sentido que carregam está relacionado a uma determinada característica que o verbo expressa.

Nos itens que seguem, apresentaremos os equivalentes por categoria semântica. Embora intercambiáveis, todos apresentam características particulares que denotam categoria semântica, prosódia semântica e lexical priming ${ }^{115}$ distintos, causando, dessa forma, reações diferentes no leitor.

\subsubsection{Pontuação}

As UFEs que comportam os verbos score e notch compõem a categoria semântica de pontuação. Ambas são utilizadas para pontuar os gols e seus significados recaem sobre o ato de adicionar gols ao placar de uma partida.

SCORE (\{a|the\} goal) é a fraseologia equivalente a fazer um gol mais frequente em nosso corpus, com 1545 ocorrências. É também a mais ampla no que se refere ao sentido e é utilizada nas mais diversas situações. Está presente em notícias de resultados de partida, narrações minuto a minuto e nos comentários das "transmissões sociais". Além disso, ocorre em todos os tipos de veículos de informação com os quais trabalhamos (jornais, tabloides e periódicos esportivos) de forma bem distribuída. A gama de colocados com que coocorre é vasta e o verbo é, não raro, o colocado mais frequente dos seguintes tipos de gol: [number] goals, his [ordinal] goal, the sixth, hattrick ${ }^{116}$, the equaliser, the winner, the only goal, the winning goal, the equalizer, an own goal, a stunning goal e superb goal.

NOTCH \{his ORDINAL|CARDINAL\}(goal) é utilizada como sinônimo de SCORE (\{a|the\} goal); sua estrutura reflete a categoria semântica da qual faz parte, das 28 ocorrências de notch no corpus, somente duas não coocorrem com o número de gols

\footnotetext{
${ }^{115}$ Teoria linguística desenvolvida por Michael Hoey que parte do princípio de que à medida que temos contato com uma nova unidade lexical, seja verbo, substantivo, adjetivo etc., essa nova unidade é adquirida juntamente com os contextos linguísticos, sociais, culturais em que frequentemente ocorre. Dessa forma, ao reproduzir a unidade lexical tendemos a utilizá-la nos mesmos contextos em que a encontramos. Toda a informação adquirida por meio da unidade lexical em questão é considerada o lexical priming da palavra.

${ }^{116}$ Termo utilizado quando um jogador faz três gols no mesmo jogo.
} 
marcados por um jogador. Os exemplos abaixo ilustram o uso de notch seguido do número de gols:

a) Rooney notched his fifth goal of the season and showed that United are serious contenders to retain their Premier League crown despite the loss of Cristiano Ronaldo during the summer.

b) Former Crewe striker Maynard notched his sixth goal in his last seven games as the Robins continued their impressive start to the Championship season.

c) Mario Balotelli, who notched two goals against West Brom before being sent off at the weekend, might have been useful here if he had not been suspended but Roberto Mancini is not so naive a manager as to depend on a 20-year-old.

Fenômeno semelhante ocorre com o verbo score que, apesar da grande quantidade de colocados com os quais coocorre, apresenta 460 instâncias seguidas do número de gols. Tomemos os exemplos:

a) But Eduardo still had time to score the sixth, netting from close in after Andrey Arshavin's shot had come back off a post with two minutes to go.

b) Few clubs will now relish the chance of meeting the German side, who became the first team to score 12 goals over two legs in a Champions League knock-out tie.

c) Argentina were gifted their second goal on 33 minutes when Ricardo Osorio gave the ball away to Gonzalo Higuain and he scored his fourth goal of the tournament. 
Outra característica interessante de score é que o verbo é o único que ocorre com own goal $^{117}$. Ou seja, embora existam 39 UFEs frequentemente utilizadas como equivalentes de fazer um gol, apenas uma é comum para designar um gol contra:

a) Bolivia contributed to their downfall by missing a penalty and scoring an own goal in a disastrous first-half spell as their lingering hopes of qualify for South Africa effectively vanished.

Por fim, em razão do significado que evocam, as duas UFEs são utilizadas para narrar gols feitos tanto por jogadores, a exemplo das outras UFEs, quanto por times:

a) Henry Muggeridge's free kick was nodded home by Bobby Medjedoub to give City hope. However, Fulham notched a killer fourth at the death as the home side chased desperately to earn a point.

b) In the last match, Manchester United scored in the last minute.

\subsubsection{Ação Violenta}

Identificamos 12 UFEs que trans mi tem a idéia de uma ação violenta. São elas:

a) FIRE \{home | in (a goal)| (the ball) past [goalkeeper]| into the net\} (65);

b) HAMMER \{in | home\} (43);

c) SLAM \{(the ball) past [goalkeeper] | in | into the roof of the net\} (32);

d) BLAST IN (a goal)(29);

e) LASH home $\{($ a goal $) \mid$ into an empty net $\}$ (26);

f) SMASH home (26);

g) STAB the ball \{home | past [goalkeeper]\} (22);

h) POKE \{the ball home | home past [goalkeeper]\}(21);

i) KNOCK \{the ball \{into the net | in | home\}\} / NUMBER goals (17);

j) THUMP \{home | past [goalkeeper]\} (13);

${ }^{117}$ Gol gontra. 
k) CLIP the ball into the net (4);

l) SNATCH [a goal] (3);

Devido à alta incidência de verbos dessa categoria semântica em inglês, analisamos as concordâncias de cada uma das UFEs com o objetivo de estabelecer alguma diferença nos usos. Anotamos os veículos de comunicação em que as UFEs ocorrem bem como os gêneros textuais que estão contemplados. A análise, a qual contribuiu para um melhor entendimento das UFEs e para selecionar os exemplos do modelo de glossário, não foi muito útil no sentido de revelar peculiaridades sobre cada UFE.

Em um primeiro momento, pensamos que algumas UFEs poderiam ser mais comuns em, por exemplo, narrações do que em notícias de resultados de partida. No entanto, todas as UFEs apresentam frequência muito próxima nos dois gêneros, com exceção de FIRE \{home | in (a goal) | (the ball) past [goalkeeper]| into the net\}, que ocorre 65 vezes, sendo 57 em notícias e somente oito em narrações.

Outra característica das UFEs desse grupo é que nenhuma ocorre em tabloides com frequência semelhante ao que ocorre em jornais e sites e periódicos esportivos. Cada uma apresenta, em média, de duas a quatro ocorrências em tabloides, exceto as que não ocorrem nenhuma vez como STAB the ball \{home|past [goalkeeper]\} e POKE \{the ball home | home past [goalkeeper]\}, em comparação com uma média de 25 ocorrências em jornais e revistas.

O jornal The Guardian, a emissora BBC e os sites esportivos Football.co.uk e Football365 são os veículos de informação que apresentam maior riqueza lexical, pois possuem ocorrências de quase todas as UFEs utilizadas para narrar um gol.

Apesar de interessantes, os achados não nos revelaram muito sobre as UFEs que comportam verbos de ação violenta, o que suscitou duas dúvidas: 1) será que o uso de verbos dessa categoria semântica também é comum em português? 2) Por que esses verbos que são usados em contextos similares, sem preferências por gêneros textuais ou veículos de comunicação, são tão frequentes eminglês? 
Para responder a primeira pergunta, geramos linhas de concordância para a etiqueta gramatical $\mathrm{V}$, que indica um verbo ${ }^{118}$, no corpus de português. Assim, observamos as 92896 ocorrências.

As concordâncias confirmaram nossa hipótese: em português não utilizamos verbos de ação violenta com a mesma frequência que o inglês. Encontramos 222 ocorrências do verbo empurrar, sendo 87 sinônimas de fazer um gol. Os exemplos abaixo exemplificam as três situações em que a UFE é usada para narrar um gol:

a) EMPURRAR para o fundo da rede (60)

Aos 31 minutos, Juninho cobrou falta com violência e Eduardo espalmou como pôde. Na sobra, o atacante que entrara no segundo tempo empurrou para o fundo das redes, decretando números finais a partida.

b) EMPURRAR (a bola) para o gol (19)

Em desvantagem o Corinthians tentou pressionar, enquando o Santos tentava concluir os bons contra-ataques que estava conseguindo. Mas aos 34 minutos Bill aproveitou bola rebatida na trave e empurrou para o gol, empatando o jogo no Pacaembu.

Depois de cruzamento de Júlio César pela esquerda, Iarley antecipou-se a Welton Felipe e em uma ${ }^{119}$ lance plasticamente estranho, conseguiu empurrar a bola para o gol, sem chances para o goleiro Aranha.

c) EMPURRAR a bola para a(s) rede(s) (8)

O camisa sete invadiu a área e tocou para Carlos Alberto só ter o trabalho de empurrar a bola para as redes: Vasco 2 a 0.

Após a análise dos exemplos, constatamos que o verbo empurrar pertence à categoria de facilidade, e não de violência, pois em todas as ocorrências seu significado recai sobre a facilidade com que o jogador faz o toque para o gol.

\footnotetext{
118 A etiquetagem em português não faz distinção entre os tempos verbais, desse modo, na busca pela etiqueta $\mathrm{V}$, o programa retorna todas as formas verbais de cada verbo que ocorre no corpus.

119 Os exemplos são transcritos ipsis litteris.
} 
Também encontramos 6.000 ocorrências do verbo bater, das quais apenas 28 utilizadas para descrever um gol. Ao analisar as linhas de concordância, constatamos que das 28 UFEs com o verbo bater, somente 16 narram um gol feito. As outras representam tentativas que não deram certo, como os dois últimos exemplos de BATER para o gol:

a) BATER para o fundo \{do gol $\mid$ das redes $\}$ (2)

Aos 24 minutos, o zagueiro Emerson aproveitou a falha da zaga santista, após cobrança de falta, e bateu para o fundo do gol.

GOOOOOOOOOOOOOOOOOOOOOOOOOOL DO MÉXICO !!! Rafael Marquez encaixa belo lançamento para Hernandez, em posição legal. Atacante limpa o goleiro e bate para o fundo das redes

b) BATER para o gol (26)

Souza abriu o placar aos 17 minutos do primeiro tempo, de cabeça. Nove minutos depois, Jonas teve total liberdade dentro da área, dominou, ajeitou e bateu para o gol: 2 a 0 .

Jorge Wagner domina e bate para o gol. Mas a bola vai fraca e sem direção.

MUCHA SALVA!! Robben faz bela jogada pela esquerda e cruza rasteiro. Mathijsen bate para o gol e bola explode no rosto de Mucha.

Respondida a primeira pergunta, partimos em busca de uma resposta para nossa segunda dúvida: Por que esses verbos são tão frequentes em inglês?

Primeiramente pensamos na composição dos corpora, mas como mencionado no capítulo três, adotamos os mesmos procedimentos para a compilação nas duas línguas. Além disso, os corpora foram construídos para serem representativos da linguagem do futebol em português e inglês. Para tanto, selecionamos dois gêneros textuais, notícias e narrações, que englobam as transmissões minuto a minuto e a transmissão social, e seis tipos de veículos de comunicação: jornais, tabloides, periódicos esportivos, periódicos sobre futebol, revistas e agências. 
Após revisitar os critérios, concluímos que a diferença na frequência dos verbos de ação violenta não é resultado de um corpus não-balanceado, mas sim da própria forma de jogar futebol no Brasil e na Europa, mais especificamente na Inglaterra. Em outras palavras, se os corpora são realmente representativos, eles devem refletir, por meio do léxico, a forma como o futebol é jogado em diferentes culturas.

Se perguntarmos para qualquer pessoa que goste, acompanhe ou entenda, pelo menos um pouco, de futebol, sobre as diferenças entre o futebol brasileiro e o futebol inglês, as respostas serão muito parecidas: o futebol inglês é mais rápido e mais "pegado", mais “forte”. Observemos os depoimentos de jogadores, técnicos e jornalistas brasileiros sobre o futebol inglês:

a) Denílson, meia do Arsenal, em entrevista ${ }^{120}$ sobre a adaptação ao futebol inglês: "O futebol aqui é totalmente diferente. No Brasil, você tem mais tempo para dominar e pensar. O futebol inglês é muito forte, tem muito contato. Quem vê de fora acha fácil, mas é bastante complicado." ${ }^{\prime 21}$

b) Maurício Duarte, repórter do $R 7^{122}$, em agosto de 2010, sobre possível transferência do atacante Neymar para o Chelsea:

“O futebol inglês privilegia a força e há muito contato físico. Exatamente por isso, Robinho não se adaptou no Manchester City. Tanto que o atacante de mais sucesso atualmente no futebol inglês é Wayne Rooney, do Manchester United. $\mathrm{O}$ artilheiro pode não ter muita técnica, mas compensa de sobra na vitalidade e na força física." $" 123$

c) Ramirez, volante do Chelsea, em entrevista ao site da FIFA em outubro de 2010, sobre sua adaptação ao futebol inglês:

“O futebol inglês é muito físico e rápido. Aqui você não tem muito tempo para ficar com a bola no pé e tem que definir logo a jogada. Além de procurar as

\footnotetext{
${ }^{120}$ A data da entrevista não consta no site.

${ }^{121}$ Disponível em: <http://placar.abril.com.br/futebol-internacional/ingles/denilson/entrevistas/denilsonprimeiro-a-obrigacao.html?print=true\&post_id=2133>. Acesso em: 12 abr. 2011.

${ }^{122}$ Portal de notícias e entretenimento do conglomerado Record.

${ }^{123}$ Disponível em: <http://esportes.r7.com/futebol/times/santos/area-publica/noticias/estilo-do-futebolingles-desfavorece-talento-de-neymar-20100812.html>. Acesso em: 12 abr. 2011.
} 
jogadas quando tenho a bola, eu sempre marquei forte. Por isso, não estou encontrando muitas dificuldades. Já estou me acostumando ao ritmo das partidas aqui." $" 124$

d) Luis Filipe Scolari, ex-treinador do Chelsea, em entrevista à SKY Sports, em novembro de 2008, sobre o estilo do futebol inglês:

“... sometimes the games are more physical than I was expecting. Sometimes we need to adapt to sides that are much bigger than our players. Sometimes teams play with more physical contact, but not to injure someone." 125

e) Sandro, volante do Tottenham Hotspur, sobre o estilo do futebol inglês, em outubro de 2010:

“ Gosto do estilo do futebol inglês. É de pegada, rápido. O meio-campista tem que correr o tempo todo. No Inter [Sport Club Internacional] eu ficava mais focado na marcação. Aqui, posso apoiar sem problemas." 126

Características semelhantes são atribuídas ao futebol europeu:

a) Kaká, em entrevista ${ }^{127}$ a um grupo de estudo que objetiva tratar as diferenças entre o futebol brasileiro e o futebol europeu:

Kaká: "Existe uma diferença em relação a espaço, no futebol brasileiro, temos mais espaço para jogar, a marcação é feita mais de longe, em comparação ao italiano, no qual, os espaços são mais limitados, ou seja, a marcação é feita de perto. Em relação à violência, aqui na Itália eles jogam duro, mais não maldosos."

Entrevistador: "No livro Na Boca do Túnel (1968), Moreira relata o seguinte: “ $O$ europeu tem um jogo viril, com muitas faltas e muita violência, principalmente

\footnotetext{
${ }^{124}$ Disponível em: <http://www.guiame.com.br/v4/70368-1663-Destaque-no-site-da-Fifa-Ramires-dizestar-adaptado-ao-futebol-ingl-s.html>. Acesso em: 12 abr. 2011.

${ }^{125}$ Disponível em: <http://www.skysports.com/story/0,19528,12975_4467597,00.html>. Acesso em: 12 abr. 2011.

${ }^{126}$ Disponível em: <http://www.clicrbs.com.br/esportes/rs/noticias/futebol,3079647,Com-saudade-Sandrolembra-Jogar-Gre-Nal-e-bom-demais.html>. Acesso em: 12 abr. 2011.

${ }^{127}$ A data da entrevista não consta no site.
} 
dentro da área. O jogador brasileiro que vai jogar na Europa é o primeiro a sentir esta diferença." ${ }^{\prime 28}$

b) Luís Gustavo, meia-esquerda do juvenil do Barcelona em 2008, sobre a estréia do atacante Alípio no Real Madrid, em novembro de 2008:

"O futebol europeu é mais de força, mas ele tem que jogar o que ele sabe. Aproveitar a qualidade que o brasileiro tem. O Alípio tem que jogar o que sabe, não ficar nervoso porque está no Real."129

c) Ronaldinho Gaúcho, no bate-papo UOL, sobre a vida na Europa e o futebol europeu, em junho de 2005:

"Eu acho que o futebol europeu é mais de força e correria. O Futebol brasileiro é mais tecnico e mais bonito de se ver. ${ }^{130,}$

Se tomarmos os depoimentos acima, podemos caracterizar o futebol europeu, mas precisamente o inglês, já que $70 \%$ de nosso corpus é composto por textos de partidas do campeonato inglês, como um futebol que tem a força como um de seus elementos centrais. Por esse motivo, tratamos a discrepância da frequência de verbos de ação violenta em inglês e português por meio do conceito forma-representação de Toledo (2002).

Retomando Toledo (2002), o conjunto de regras não influencia nem determina as maneiras de jogar. Na verdade, a apropriação e a interpretação cultural que cada região faz das regras é que revelam as "formas de jogo". Justapostas, as regras e as formas de jogo dão origem a um terceiro aspecto que é identificado nas representações, ou seja, o ajustamento da observação empírica das "formas de jogo" em um plano simbólico que, por sua vez, consolidam "escolas", "jeitos" ou "estilos" próprios que se traduzem no código linguístico.

\footnotetext{
${ }^{128}$ Disponível em: <http://www.efdeportes.com/efd87/futebol.htm>. Acesso em: 12 abr. 2011.

${ }^{129}$ Disponível em: <http://globoesporte.globo.com/Esportes/Noticias/Futebol/0,„MUL880510-9842,00MEIOBRASILEIRINHO+DO+BARCELONA+SE+ESPELHA+NO+MEIA+DECO.html>. Acesso em: 12 abr. 2011.

${ }^{130}$ Disponível em: <http://tc.batepapo.uol.com.br/convidados/arquivo/esporte/ult1762u535.jhtm>. Acesso em: 12 abr. 2011.
} 
Investigar a apropriação cultural das regras na Inglaterra e no Brasil foge ao escopo de nossa pesquisa. Contudo, reconhecer que essa interpretação influencia o "estilo" de jogo e, por conseguinte, a terminologia utilizada nas duas culturas é essencial para entendermos algumas discrepâncias linguísticas. Assim, o fato de o futebol inglês ser mais "pegado" se revela na grande quantidade de verbos de ação violenta.

No caso dos verbos de ação violenta, nossa análise indica que se o futebol inglês é, realmente, mais "forte" e mais "pegado" do que o futebol brasileiro, tendo a força como elemento central, a variedade de verbos que carregam significado de ação violenta e, muitas vezes, de impulso e impacto, na língua inglesa, é reflexo do "futebol inglês".

Ressaltamos, entretanto, que a análise da forma-representação aqui conduzida mostra apenas alguns dos diversos aspectos que caracterizam o futebol inglês. Reconhecemos também que a análise do léxico é só uma das formas para a identificação de traços específicos de uma "escola".

Por fim, encerramos a análise das UFEs constituídas por esses verbos com um questionamento que, infelizmente, não será respondido nesta pesquisa: será que a frequência de verbos que denotam ação violenta tende a aumentar em português?

Levantamos a pergunta porque o "estilo" do futebol brasileiro, sempre caracterizado por jogadas de habilidade, está passando por um processo de transformação nos últimos anos, como podemos observar nas citações que seguem:

a) Resenha da professora Simoni Lahud Guedes do livro Lógicas do Futebol de Luís Henrique Toledo para a revista Scielo:

“... Copa do Mundo de 1994, por exemplo, que, segundo interpretações recorrentes, foi alcançada num "estilo" estranho às características valorizadas no futebol brasileiro, tendo sido privilegiadas a defesa, a disciplina tática e a marcação em vez do ataque e do drible, tem seu valor minimizado por muitos profissionais, especialistas e torcedores." $" 131$

b) Tiago Campos, jornalista, em artigo para o site Segue o Jogo:

\footnotetext{
${ }^{131}$ Disponível em: <http://www.scielo.br/pdf/rbcsoc/v18n51/15995.pdf>. Acesso em: 16 abr. 2011.
} 
"Acho que todos nós estamos presenciando uma mudança histórica na mentalidade do futebol brasileiro. A troca do futebol arte pelo futebol força, ou melhor, a junção dos dois fatores." 132

Se partirmos do pressuposto de que o futebol brasileiro está ficando mais "pegado", refletindo, dessa forma, um novo "estilo" de jogar, cuja dinâmica pode ser, aos poucos, traduzida no código linguístico, termos e UFEs que caracterizem ações violentas podem vir a se tornar mais frequentes no futebolês.

\subsubsection{Explosão}

Identificamos duas UFEs que transmitem a idéia de explosão:

a) BLAST in

But just as the visitors seemed set for a point, Hughes was left unmarked in the area to blast in the winner.

b) THUNDER a goal home

Barton thundered a goal home in injury time, setting pulses racing throughout the boisterous home support.

No corpus em português encontramos duas ocorrências do verbo bombardear, 18 do verbo explodir e 26 da UFE \{SOLTAR $\mid$ MANDAR\} \{a| uma\} bomba:

a) O gol no fim do primeiro tempo deu ânimo para o time da casa, que passou a bombardear o gol adversário na segunda etapa.

b) A bola explodiu na trave direita de Bruno.

\footnotetext{
${ }^{132}$ Disponível em: <http://www.odiariodemogi.inf.br/esporte/noticia_view.asp?mat=28755\&edit=> . Acesso em: 16 abr. 2011. 
c) A bola pegou Diego Tardelli entrando em velocidade na área, nas costas do zagueiro. $O$ artilheiro não deixou a bola quicar e soltou a bomba no alto. Um golaço, aos 28 minutos.

d) Aos 27 minutos, em jogada individual, Maikon Leite penetrou na defesa e mandou a bomba para o gol, deixando tudo igual.

Apesar da variedade terminológica, a ocorrência de verbos de explosão em português é relativamente inferior ao inglês, que apresenta 119 instâncias. Acreditamos que os verbos de explosão, que também são, de alguma forma, de violência, traduzem a força característica do futebol inglês.

\subsubsection{Facilidade}

Identificamos cinco UFEs que compõem a categoria de facilidade:

a) SLIDE \{home his ORDINAL (goal) | the ball home\} (10);

b) SWEEP \{home | the ball into the net\} (7);

c) DINK in [a goal] (3);

d) TUCK home (a goal)(2).

e) STROKE a shot past [goalkeeper](3).

Aqui, o sentido principal recai sobre a facilidade com que o gol foi feito. $\mathrm{Na}$ realidade, a facilidade não caracteriza o gol, mas sim a trajetória da bola, a posição do jogador ou o toque que o jogador dá na bola. Observemos os exemplos:

a) First skipper Rafael Marquez earned himself a needless booking for showing his frustration, then there was real calamity when Osorio scuffed a pass across the edge of his own box, Higuain seized onto the ball and kept his cool to round Perez neatly and slide home. 
b) It lacked depth and power but Jung Sung-Ryon added to the list of World Cup goalkeeping errors by making the most ineffective of attempts to stave off the danger.The ball ran through to an unmarked Suarez at the far post, who needed no second invitation to slide the ball home.

c) West Brom were booed off at half-time and within four minutes of the restart, after Jonas Olsson [West Brom] diverted the ball against Gianni Zuiverloon [West Brom], James Beattie [Stoke City] swept home his sixth goal in ten games since signing from Sheffield United.

d) Steven Gerrard bursts into the area and lays it across for FERNANDO TORRES to sweep the ball home, great start for Liverpool.

e) The World Player of the Year dinked in the winner in the 77th minute as Barca desperately poured forward after Andoni Iraola had cancelled out David Villa's early opener with a 49th-minute penalty.

f) The summer signing volleyed home after 14 minutes, crossed for Frazer Wright to head home before half-time, and tucked home a third from Danny Invincibile's low cross in the second half.

g) g) The striker controls, edges past Alex down the inside-right channel and into the box, and strokes a sure shot past Cech and into the bottom left-hand corner of the net.

O primeiro exemplo evidencia de maneira muito clara que a carga semântica de facilidade, da qual falamos antes, não recai sobre a ação de fazer o gol, mas sim sobre um jogada limpa. Higuain, o autor do gol, controla a bola, mantém a calma para limpar a jogada e mandar para o gol de forma precisa. No segundo exemplo, o gol é feito por um jogador que está bem colocado, sem marcação ${ }^{133}$ e que só precisa tocar para o gol. No exemplo "c", a oportunidade de gol do Stoke City surge como resultado de um erro

\footnotetext{
${ }^{133}$ Para confirmar a informação lemos a narração minuto a minuto.
} 
do West Brom, em que James Beattie, atacante do Stoke, se encontra na cara do gol para finalizar. No exemplo “d”, Steven Gerrard invade a área e praticamente coloca a bola nos pés de Fernando Torres, que faz o gol.

Em um primeiro momento, não entendemos o significado de DINK in [a goal], pois mesmo ampliando os contextos das concordâncias não conseguíamos classificar a UFE em nenhuma categoria semântica. Sabíamos que era usada para descrever um gol, no entanto, a situação, o tipo de gol e o contexto ainda estavam vagos. Consultamos quatro dicionários, três monolíngues e um bilíngue, à procura de uma definição que nos ajudasse a entender a UFE.

O Oxford Advanced Learner's Dicionary define o verbo dink como uma jogada que faz a bola aterrissar sem quicar muito. A definição, utilizada para o tênis, pode ser adaptada ao futebol para descrever um gol em que a trajetória da bola é limpa, ou seja, ela não quica e nem desvia em outro jogador, vai direto para o gol, como no exemplo "e".

A análise da quarta UFE, TUCK home (a goal), também demandou mais trabalho do que as demais. Após analisar o contexto expandido das oito ocorrências em nosso corpus e recorrer ao Google.uk em busca de mais exemplos, constatamos que TUCK home dá à UFE o sentido de terminar o movimento, quase sempre de um bom posicionamento. Em quatro das oito UFEs o jogador estava na cara do gol para finalizar, em duas o jogador estava perto, mas ainda sim bem posicionado, e nas outras duas não conseguimos identificar a posição do jogador.

O verbo stroke é definido pelo Oxford Advanced Learner's Dictionary como tocar ou mover algo de forma delicada. No exemplo g), o jogador controla a bola, passa "cuidadosamente" pelo zagueiro, entra na pequena área e chuta de maneira precisa no canto esquerdo do gol.

\subsubsection{Velocidade}

As UFEs TAP \{in|home\} e FIZZ the ball past [goalkeeper] com 101 e 22 ocorrências, respectivamente, compõem a categoria semântica de velocidade. Ambas enfatizam a velocidade do gol; não somente a velocidade com que o jogador recebe e chuta ao gol, mas também a rapidez dos toques até o momento do gol: 
a) The Zurich defence were expecting a shot but instead the Argentinian forward squared it for Raul to tap home from six yards.

b) Scott Carson, oh Scott Carson. Drogba lines up the shot, fizzes a sidefooter at goal, but it's straight at the keeper. Who proceeds to let the ball squirm from his grasp, drop to Mikel who dinks it square for Malouda to tap in.

c) Drogba was the provider this time, pinging the ball with pace to last season's top scorer Anelka, who responded by fizzing the ball past Schwarzer from inside the area.

Novamente, se tomarmos os depoimentos dos jogadores, jornalistas e técnicos sobre o futebol inglês, veremos que a alta ocorrência desses verbos de velocidade nos periódicos ingleses reflete o "estilo" do futebol inglês. Tomemos o depoimento de Ramirez: "O futebol inglês é muito físico e rápido. Aqui você não tem muito tempo para ficar com a bola no pé e tem que definir logo a jogada...".

Sabemos que o português, assim como o inglês, utiliza palavras de outras categorias gramaticais para indicar a rapidez e velocidade de uma jogada como, por exemplo, os termos rápido e de primeira. No entanto, chamamos atenção para o fato de que, pelo menos em nosso corpus, o jogo rápido se mostra tão comum no futebol inglês e europeu que existe uma necessidade de expressá-lo por meio de verbos específicos, diferentemente do português.

\subsection{6 "Movimento para dentro"}

Identificamos três UFEs que compõem a categoria de movimento para dentro:

a) SLOT \{home ([a goal)]| (the ball) into \{an | the\} empty net | past [goalkeeper]| in\} (47);

b) DRILL home (16);

c) BURY the ball past [goalkeeper] (12). 
O sentido das três UFEs expressa o movimento que a bola faz para dentro do gol:

a) The defender, 25 yesterday, settled a tight game and embarked on a celebration that would have looked more at home on Strictly Come Dancing than Match of the Day. He drilled home Swansea's 69th-minute winner after Leon Britton had rattled the home side's bar with a stunning overhead kick.

b) For good measure, Fabregas popped in a peach for his second and Arsenal's fifth as he ran up field, picked his spot and buried the ball past Howard.

c) Robinho, who was the game's outstanding player, then provided one of the assists of the championship so far as he threaded a delightful ball to Elano in the 72nd minute before the midfielder slotted home a second.

d) The home side extend their lead as Fellaini's shot is saved by Kirkland, only for OSMAN to be in the right place to slot the ball into the net.

e) Hamburg substitute Heung Min Son sealed the win with four minutes remaining when he beat Ricardo Carvalho in the box to coolly slot past goalkeeper Ross Turnbull.

f) COLE slots in Chelsea's third goal of the afternoon following a volley from Malouda which Fulop could only parry and unfortunately into the path of the Chelsea left back.

Sabemos que, muitas vezes, o sentido de uma palavra na língua geral e em uma língua de especialidade é diferente. Mas no caso desta categoria semântica, só entendemos o funcionamento das UFEs pelo signficado dos verbos drill, bury e slot na língua geral. Drill nos remete ao ato de perfurar, bury de enterrar e slot de preencher um espaço. Sentidos que se evidenciam nos exemplos acima. 


\subsubsection{Completude}

As UFEs FINISH (off) (78) e DELIVER a goal (37) carregam o sentido de completar, realizar uma tarefa, assim como o verbo finalizar em português:

a) O goleiro Felipe nem se mexeu. Novamente impaciente com o atacante Souza, a torcida do Corinthians passou a pedir a entrada de Dentinho. Só parou quando Elias, aos 42, finalizou de fora da área no ângulo: 2 a 1.

b) And 43 minutes into his full debut, Stanislas finished off a great end-to-end move by tapping in Luis Boa Morte's cross.

c) It's been 25 years since a match between these two teams delivered a goal and it doesn't look like we're going to get one tonight.

Esta é a única categoria semântica que funciona de forma semelhante e apresenta número aproximado de ocorrências nas duas línguas, 115 em inglês e 117 em português. A única diferença no uso das UFEs é que DELIVER a goal, assim como finalizar, pode ser antecedida por um jogador ou por um time, ao passo que FINISH (off) só coocorre com jogadores.

\subsubsection{Movimento da bola}

Detectamos a presença de duas UFEs que descrevem o movimento da bola ou seu controle por um jogador:

a) $\mathrm{HOOK}$ in ([a goal])

When defender Marius Zaliukas hooked in the second shortly after the break, belief they were capable of a sensational result coursed through the home ranks.

b) STEER the ball past [goalkeeper]

His pass picks out the run of Osman who steers the ball past Schwarzer. 
Analisamos as quatro ocorrências de HOOK in ([a goal]) no corpus e chegamos a duas possibilidades do uso. Primeiramente, pensamos que a UFE poderia descrever o tipo de jogada realizada para fazer o gol, já que hook in descreve uma jogada feita com o pé no ar, a meia altura, conhecida como voleio em português, fato que foi confirmado após a observação de outras ocorrências no Google.uk. Nossa segunda hipótese era que a UFE seria utilizada como o termo hook de uso corrente no cricket e no golfe, cujo significado indica um modo de bater na bola que faz com que ela desenhe uma curva em vez de ir reto. Confirmar essa segunda hipótese foi um pouco mais complicado do que a primeira, pois se o verbo hook designa, em seu significado, o movimento da bola, o texto, muito provavelmente, não usa nenhum outro recurso linguístico que possamos analisar para validar nossa hipótese. O detalhamento das notícias em inglês foi de grande valia para confirmar nossa idéia. Acessamos o site Football.co.uk, do qual um dos textos que contém a UFE foi coletado, vimos as fotos dos gols do jogo e clicamos em um link do YouTube que direcionava para um vídeo que mostrava os gols da partida: constatamos que a bola fez um movimento irregular no seu percurso para o gol.

A última UFE, STEER the ball past [goalkeeper], não descreve o movimento da bola, como a anterior. Seu significado recai sobre o controle da direção que a bola toma, como no exemplo "b", em que o jogador direciona a bola e chuta para o gol.

\subsubsection{Tipo de gol}

Identificamos três UFEs utilizadas para narrar gols de cabeça:

a) NOD \{home (into an empty goal) | in | into the net $\}$;

b) HEAD (the ball) \{home|past (goalkeeper)|into the (roof of the) net\};

c) $\{$ HAMMER $\mid$ POUND $\}$ a header into the net.

A alta frequência dos verbos que narram gols de cabeça em inglês nos chamou atenção quando comparada à frequência dos mesmos verbos em português, 1037 e 387 ocorrências em cada língua, respectivamente.

Recorremos ao conceito forma-representação de Toledo para entender essa discrepância. Tomemos os depoimentos abaixo: 
a) Robinho, em sua apresentação no Milan, sobre o futebol inglês:

"Não tive nenhum problema com o Roberto Mancini. O que acontece é que o futebol inglês não é muito bom pra jogador brasileiro, muito bola alta e a gente gosta de jogar com ela no chão."134

b) Guilherme Esteves, fanático por futebol, para o site Futebol no cotidiano:

"Hoje, tive a oportunidade de assistir a Chelsea x Blackburn, no estádio dos Blues, o Stamford Bridge, em Londres. O jogo em si, francamente... não foi bom. Aquele típico futebol inglês tomou conta do gramado. Muitas divididas, eficiência, objetividade e principalmente muitas jogadas aéreas."135

c) Mário André Monteiro, para o site IG sports, sobre as expectativas em relação à seleção da Inglaterra para a Copa de 2010

“O tradicional futebol inglês de jogadas aéreas se aliou à técnica e à velocidade que caracterizam alguns de seus principais atletas, o que transforma a Inglaterra em um dos times a serem batidos na Copa da África." ${ }^{136}$

Jogadas aéreas, principalmente de bola na área, definem um "estilo" bem europeu, sobretudo inglês, justamente porque envolvem a força, a impulsão e a altura características do futebol inglês.

Desse estilo, e também das condições climáticas da Inglaterra, pois devido à chuva constante as equipes eram forçadas a mandar a bola para o alto, já que era quase impossível fazê-la correr na grama encharcada ${ }^{137}$, surgiu a expressão "chuveirinho", para designar a grande quantidade de jogadas aéreas na área, que caracterizou por muitos anos a escola inglesa.

\footnotetext{
${ }^{134}$ Disponível em: <http://opiodopovo.wordpress.com/tag/chuveirinho/>. Acesso em: 21 mai. 2011.

${ }^{135}$ Disponível em: < http://futebolnocotidiano.com.br/?tag=futebol-ingles> Acesso em: 21 mai. 2011.

${ }^{136}$ Disponível em:

<http://esporte.ig.com.br/futebol/2009/12/04/especial+copa+2010+inglaterra+9197041.html > Acesso em: 21 mai. 2011.

${ }^{137}$ Disponível em: <http://veja.abril.com.br/090610/unidos-futebol-p-126.shtml>. Acesso em: 21 mai. 2011.
} 
O cabeceio, que definia o "estilo" inglês, era considerado como a melhor forma de atacar e de concluir uma jogada, levando a seleção da Inglaterra à conquista da Copa do Mundo de 1966, mas perdendo sua força nos anos seguintes.

Não nos cabe, aqui, discutir a origem e a eficácia do "estilo" inglês, mas sim reconhecer que o papel das jogadas aéreas no futebol inglês é fundamental para entender a divergência entre a frequência de UFEs que narram gols de cabeça em inglês e em português.

\subsubsection{Adição}

A estrutura de $A D D$ \{a|the\} ORDINAL (goal), que apresenta 111 ocorrências no corpus, nos leva a enquadrá-la na categoria semântica de adição, pois a referência ao número do gol que foi marcado é parte integrante da UFE.

a) Rumblings of discontent were just beginning to emerge as Arsenal took the lead through Abou Diaby in the 18th minute and the midfielder added a second three minutes later, prompting Wenger to compare his midfielder with a Highbury great.

b) Late substitute Franco Di Santo nearly added a third for the Londoners in stoppage time, taking a delicate Deco chip over the top on his chest and shooting right-footed over the bar.

c) Ordos added a fourth with an angled drive and Horova rounded off the scoring in the dying stages with a low drive after pouncing on a careless Duff mistake.

d) Ormerod almost added a fifth goal in the 84th minute only for Pollitt to take the ball off his feet as Blackpool secured their place in the third round with ease.

Como podemos observar, o foco está no número de gols adicionados ao placar de um time. A UFE é utilizada quase que exclusivamente em notícias de resultados de partidas: das 111 ocorrências, 109 são de notícias e apenas duas são de narrações. 
Os advérbios nearly e almost frequentemente se colocam com a UFE para descrever um gol que quase saiu: exemplos "b" e "d". Outra característica que nos chamou atenção é a referência ao tempo: 89 das 111 ocorrências da UFE são seguidas pelo momento em que o gol foi marcado, evidenciando, assim, seu lexical priming, já que é normalmente utilizada nos mesmos contextos.

\subsubsection{Igualar}

O verbo EQUALISE ocorre 234 vezes no corpus para narrar um gol de empate. Seu uso é comum tanto em notícias quanto em narrações e sempre aparece em jornais e periódicos esportivos, raramente em tabloides. Os trechos que seguem exemplificam seus principais usos:

a) The keeper keeps hold of the ball, then gets the trainer on to look at his trousers. Meanwhile in the other game, Nigeria have equalised!

b) Birmingham almost equalised three minutes later when Patrice Evra headed Franck Queudrue's header off the line, but Hart was called back into action early in the second-half when he saved well from another long-range Rooney effort.

c) Martinez's lads were 13 minutes from victory until Clint Dempsey equalised with a diving header and Zamora had the last word with his bonce on 81 minutes in this gripping fifth-round replay.

d) The South Americans took the lead for the first time early in the second half through the impressive Diego Forlan but Marcell Jansen equalised for Germany within five minutes.

O primeiro exemplo exemplifica o uso de equalise em uma narração. O segundo mostra o verbo seguido de uma referência ao tempo. O terceiro explicita o tipo de gol que foi feito e o último indica o time que empatou. 
Os verbos tie e draw, equivalentes do verbo empatar em português, também ocorrem no corpus. Entretanto, o primeiro ocorre majoritariamente em jornais e revistas americanos, 48 das 54 ocorrências, e o segundo ocorre para narrar um jogo que empatou, e não um gol de empate.

a) The Cottagers beat Arsenal 1-0 in August, drew 2-2 with Chelsea over Christmas and stunned United 2-0 last month.

\subsubsection{Posicionamento}

A UFE NESTLE \{in | into\} the (back of the) net, que ocorre 27 vezes no corpus, nos dá a idéia de acomodar a bola no gol:

a) A terrific Tuncay overhead kick just nestled in the net past Paul Robinson.

b) The Scotland striker crossed from the left and it went straight through without a touch and nestled into the net to give him just his sixth goal for the Baggies in more than two years at The Hawthorns.

c) Not a brilliant penalty - struck low and only a few feet to the left of the centre of the goal, but Julio Cesar went the other way and the ball nestled in the back of the net.

Como podemos observar, os três exemplos ilustram a posição da bola após o gol.

\subsubsection{Realização}

Identificamos 3 UFEs que pertencem à categoria de realização, entendida aqui como consecução, ou seja, o ato de alcançar um objetivo. Observemos os exemplos:

a) NET [a goal] (52) 
Liverpool's season is firmly back on track after Yossi Benayoun netted a hat-trick in Saturday's 4-0 Premier League home win over Burnley.

Substitute Stefan Maierhofer netted a late consolation for Wolves.

b) BAG [a goal](12)

Dave Kitson is finally beginning to find his feet at Stoke as he bagged the winner in a 1-0 victory over Sunderland at the Britannia Stadium.

Drogba was a real menace throughout, heading just over from a Jose Bosingwa cross before bagging the all-important goal.

c) NICK [a goal $](4)$

Birmingham City had the early Premier League leaders begging for the final whistle before Aaron Lennon nicked a winner for Tottenham deep into stoppage time.

Lions fans were already leaving the Den when Paul Shaw nicked a consolation goal on 79 minutes but the roar that went up when Tim Cahill (right) made it 3-2 within seconds brought many back.

Independentemente do significado de seus verbos na linguagem geral, as três UFEs descrevem um ato de realização. Quando utilizadas, enfatizam a conquista de um gol que é necessário ou importante. Se tomarmos como exemplos os colocados da UFE nos exemplos acima, hat-trick (três gols marcados por um jogador na mesma partida), consolation (gol de honra), the winner (gol da vitória) e the-all-important goal (gol importante, que pode ser decisivo para a vitória ou para a permanência de um time em um campeonato), veremos que além de descrever um gol feito, a UFE realça a importância do gol, tanto pela escolha de seus colocados como pelo seu uso em detrimento de algum outro equivalente. 


\subsection{4 gol da vitória, $0(84)$}

Geramos concordâncias para a expressão de busca "JJ * goal", em que JJ corresponde a um adjetivo, para verificar o possível equivalente de gol da vitória:

\begin{tabular}{|c|c|c|c|c|c|c|}
\hline \multicolumn{2}{|c|}{ C Concord } & & & & \multicolumn{2}{|c|}{ - $\mathrm{a} x$} \\
\hline \multicolumn{7}{|c|}{ File Edit View Compute Settings Window Help } \\
\hline \multicolumn{2}{|c|}{ N Concordance } & Set $\mid$ Tag $\mid$ Word \# $\mid$ t. \# os. $\mid$ & os. & \#| os.l|t. $\#|0 s|$. & $\%$ & $\hat{\underline{1}}$ \\
\hline 953 & IN towards the DT the unguarded $J J$ unguarded goal NN goal - : - but CC & $3.0851088 \%$ & $08 \%$ & $08 \%$ Inar-gua_003.tagl & $37 \%$ & \\
\hline 954 & IN towards the DT the Uruguayan JJ Uruguayan goal NN goal. SENT. He & $7.1203422 \% \mathbf{I}$ & $06 \%$ & 0 6\%Inar-gua_023.tagl & $56 \%$ & \\
\hline 955 & NP with IN with the DT the whole JJ whole goal NN goal to TO to aim W & $591109 \% \mathbf{I}$ & $02 \%$ ] & 0 2\%ljo-if-uef_007.tag & $61 \%$ & \\
\hline 956 & NP has VHZ have the DT the whole JJ whole goal NN goal to To to aim W & $6.4172415 \% \mathbf{I}$ & $08 \% \mid$ & 0 8\%Inar-bbc_009.tagl & $58 \%$ & \\
\hline 957 & NP with IN with the DT the whole JJ whole goal NN goal to TO to aim $W$ & $591109 \% \mathbf{I}$ & $02 \%$ l & 0 2\%ljo-if-uef_019.tag & $61 \%$ & \\
\hline 958 & NP got WD get the DT the winning JJ winning goal NN goal with $\mathbb{N}$ with & $18340 \% \mathbf{I}$ & $08 \%$ & $08 \%$ jo-ifffoo_010.tag & $9 \%$ & \\
\hline 959 & headed WD head the DT the winning JJ winning goal NN goal in IN in his PP\$ & $5803 \% \mathbf{I}$ & $04 \%$ & $04 \%$ jo-iff-foo_037.tag & $4 \%$ & \\
\hline 960 & chance. SENT. The DT the winning JJ winning goal NN goal , , , when WRB & $2.078566 \% \mathbf{I}$ & $06 \% \mathbf{l}$ & $06 \% \mathrm{ljo}-$ & $96 \%$ & \\
\hline 961 & Lennon NP Lennon 's POS 's winning JJ winning goal NN goal came WD & $2.124522 \%$ & $06 \% \mathbf{l}$ & 0 6\%lo-if-365_020.tagl & $96 \%$ & \\
\hline 962 & a stupendous $J J$ stupendous winning $J J$ winning goal NN goal against $\mathbb{I N}$ & $243 \quad 43 \% \mathbf{I}$ & $06 \% \mid$ & $06 \%$ & $15 \%$ & \\
\hline 963 & RB before, , , the DT the winning JJ winning goal NN goal contained $W D$ & $2.400 \quad 468 \% \mathbf{I}$ & $01 \%$ & $\left.01 \%\right|_{0}$ & $91 \%$ & \\
\hline 964. & June 5. CD@ord@ The DT the winning JJ winning goal NN goal unfolded WD & $1.825553 \% \mathbf{I}$ & $07 \%$ I & $07 \% \mathbf{~ j o}$ & $68 \%$ & \\
\hline 965 & Benayoun's NP late $J J$ late winning $J J$ winning goal NN goal against IN & $990160 \%$ & $03 \%$ & $03 \% \mathrm{ljo}$ & $33 \%$ & \\
\hline 966 & winner, , , but CC but a DT a winning JJ winning goal NN goal failed $W D$ fail to & $1.427 \quad 324 \% \mathbf{I}$ & $03 \% \mid$ & $03 \% \mathbf{I}$ & $93 \%$ & \\
\hline 967 & Lennon NP Lennon 's POS 's winning JJ winning goal NN goal came WD & $2.042502 \% \mathbf{I}$ & $06 \%$ & 0 6\% jo- & $96 \%$ & \\
\hline 968 & PP him. SENT. The DT the winning JJ winning goal NN goal was VBD be & $225 \quad 49 \%$ & $08 \%$ & $08 \% \mathrm{jo}-$ & $8 \%$ & \\
\hline 969 & After IN after his PP\$ his winning $J J$ winning goal NN goal from IN from the & $9.6423527 \%$ & $03 \% \mid$ & $03 \%$ Ina & $73 \%$ & \\
\hline 970 & \multirow{2}{*}{$\begin{array}{l}\text { an DT an excellent } J J \text { excellent winning } J J \text { winning goal NN goal. SENT. But CC } \\
\text { struck WD strike the DT the winning } J J \text { winning goal NN goal that WDT that }\end{array}$} & $46366 \%$ & $07 \%$ I & $07 \%$ & $17 \%$ & \\
\hline 971 & & $462168 \% \mathbf{l}$ & $07 \%$ & $07 \% \mathbf{l j o}$ & $17 \%$ & \\
\hline 972 & and score WP score a DT a winning JJ winning goal NN goal. SENT. They & $2.275 \quad 74 \quad 4 \% \mathbf{I}$ & $07 \%$ & 0 7\%Inar-sky_001.tagl & $16 \%$ & \\
\hline 973 & \multirow{2}{*}{$\begin{array}{l}\text { Whead a DT a vital JJ vital winning JJ winning goal NN goal into IN into an } \\
\text { celebrate } W \text { celebrate a DT a winning JJ winning goal NN goal SENT " " }\end{array}$} & $596141 \% \mathbf{l}$ & $01 \%$ l & $01 \% \mathbf{l j o - i f -}$ & $21 \%$ & \\
\hline 974 & & $950269 \% \mathbf{I}$ & $04 \%$ I & $04 \%$ jo & $33 \%$ & \\
\hline 975 & celebrate W celebrate a DT a winning JJ winning goal NN goal. SENT. " " " & $566 \quad 14 \quad 1 \% \mathbf{l}$ & $01 \%$ l & $01 \% \mathbf{I}_{0}$ & $22 \%$ & \\
\hline 976 & $\begin{array}{l}\text { Whead a DT a vital JJ vital winning } J J \text { winning goal NN goal into IN into an } \\
\text { headed WD head the DT the winning JJ winning goal NN goal as IN as }\end{array}$ & $2806 \%$ & $05 \%$ & $05 \%$ o-if-365_038.tagl & $6 \%$ & \\
\hline 977 & opening. SENT. The DT the winning JJ winning goal NN goal came WD & $31188 \%$ & $05 \% \mid$ & $05 \%$ lo-if-bbc_008.tagl & $16 \%$ & \\
\hline 978 & scored WD score the DT the winning JJ winning goal NN goal in IN in overtime & $3.7761176 \% \mathbf{l}$ & $07 \%$ & $07 \%$ jo-if-ny_024.tag & $78 \%$ & \\
\hline 979 & WZ celebrate his PP\& his winning JJ winning goal NN goal for IN for & $460126 \% \mathbf{l}$ & $06 \% \mid$ & $06 \% \mathrm{jo}-$ & $16 \%$ & \\
\hline 980 & created WD create the DT the winning JJ winning goal NN goal for IN for & $402106 \%$ & $04 \%$ | & $04 \%$ ljo-ifind_014.tag & $27 \%$ & \\
\hline 981 & NP Spanish , , , the DT the winning JJ winning goal NN goal ended WD end & $3.492595 \% \mathbf{I}$ & $07 \% \mathbf{I}$ & $07 \%$ lo-if-sky_006.tagl & $88 \%$ & \\
\hline 982 & Dempsey for IN for the DT the winning JJ winning goal NN goal on IN on a DT a & $2.9411009 \% \mathbf{I}$ & $08 \% \mid$ & 0 8\%ljo-if-nyt_005.tag & $88 \%$ & \\
\hline 98.3 & to TO to be VB be the DT the winnina JJ winnina aoal NN aoal ... so RB sol & $979>3 \%$ & ก $9 \%$ & ก $9 \%$ In-if-rav $n .30$ tanl & $49 \%$ & $\underline{\underline{v}}$ \\
\hline oncordanc & \begin{tabular}{|l|l|l|l|l|l} 
patterns & clusters & filenames & follow up & source text & notes \\
\end{tabular} & & & & & \\
\hline
\end{tabular}

Figura 65 - Linhas de concordância para a expressão " $J J$ * goal”

A busca retornou 988 ocorrências de adjetivos que antecedem a palavra goal, das quais 25 continham o adjetivo winning. Após analisar as concordâncias de winning 
goal na versão do corpus sem etiquetas gramaticais, validamos a UFE como equivalente de gol da vitória.

Apesar do equivalente encontrado, também analisamos as concordâncias de winner a fim de verificar se o termo também poderia ser considerado equivalente da UFE em português:

\begin{tabular}{|c|c|c|c|c|c|}
\hline C Conco & & & & & $\underline{\underline{X}}$ \\
\hline File Edit & View Compute Settings Window Help & & & & \\
\hline NO & Concordance & Set $\mid$ Tag $\mid$ Word \#|t. \# os.l|. \#| os.|| & . \#n os.||t. \#| os.|| & $\%$ & $\hat{\underline{1}}$ \\
\hline 188 & as predictable as their stoppage-time winner, it was impossible to doubt their & $144 \quad 05 \% \mathbf{I} \quad 01 \% \mathbf{I}$ & $01 \%$ jo-if-tim_036.txt & $30 \%$ & \\
\hline 189 & in a preposterous free-kick swerving winner from a mere 783 yards. Brazil & $331 \quad 130 \% \mathbf{I} 07 \%$ & $07 \%$ nar-gua_014.txtl & $9 \%$ & \\
\hline 190 & DAY AFTERNOON: In March 1966, the winner's prize -- the Jules Rimet Cup -- & $27585 \% \mathbf{I} \quad 58 \% \mathbf{I}$ & 0 7\%lo-inf-mn_001.txt| & $31 \%$ & \\
\hline 191 & he is most definitely not." $18: 46$ The winner of this game between Argentina & $3.6981643 \% \mathbf{I} \quad 08 \% \mathbf{I}$ & $08 \% \mid$ tso-bbc_016.txt| & $88 \%$ & \\
\hline 192 & 2-0 victory and into the final against the winner of Wednesday's France-Portugal & $317 \quad 77 \% \mathbf{I} \quad 45 \% \mathbf{I}$ & $04 \%$ jo-if-wp_041.txt & $39 \%$ & \\
\hline 193 & closed at halftime in the final and the winner announced soon after the match. & $352106 \% \mathbf{I} \quad 8 \% \mathbf{I}$ & $03 \% \mathbf{l}$ jo-if-ny_027.txt & $66 \%$ & \\
\hline 194 & Many pundits tipped Cannavaro as the winner, including 1986 winner Diego & $463 \quad 177 \% \mathbf{I} 130 \% \mathbf{I}$ & $03 \% \mathbf{l}$ jo-if-ny_027.txt & $84 \%$ & \\
\hline 195 & draw when Bruno Alves bagged the winner in the third minute of stoppage & $15427 \% \mathbf{I} \quad 16 \% \mathbf{I}$ & 0 9\% jo-if-fif_o09.txt & $52 \%$ & \\
\hline 196 & ace Arshavin thought he'd bagged the winner when he scored a first on 85 & $107 \quad 03 \% \mathbf{I} \quad 05 \% \mathbf{I}$ & 0 5\%ljo-if-sun_023.txt & $40 \%$ & \\
\hline 197 & find his feet at Stoke as he bagged the winner in a 1-0 victory over Sunderland at & $104 \quad 01 \% \mathbf{l} \quad 05 \% \mathbf{I}$ & 0 5\%ljo-if-365_033.txt & $25 \%$ & \\
\hline 198 & second-leg against Barcelona. The winner last night underlines what a & $349 \quad 140 \% \mathbf{I} \quad 02 \% \mathbf{I}$ & $02 \%$ ljo-if-sun_048.txt & $47 \%$ & \\
\hline 199 & and scored what turned out to be the winner. It was created when Steed & $28960 \% \mathbf{I} \quad 01 \% \mathbf{I}$ & 0 1\%ljo-if-bbc_027.txt & $38 \%$ & \\
\hline 200 & Spain scored what proved to be the winner in the $73 \mathrm{rd}$ minute. Xavi delivered & $1.017260 \% \mathbf{I} 06 \% \mathbf{I}$ & 0 6\%ljo-if-sky_006.txt & $79 \%$ & \\
\hline 201 & I don't think football would be the winner. 18:48 Commentary Any & $3.4431470 \% \mathbf{I} \quad 0 \quad 1 \% \mathbf{I}$ & 0 1\% tso-bbc_002.txtl & $82 \%$ & \\
\hline 202 & forward Luis Fabiano. It collected the winner in the 84th minute, when defender & $184 \quad 96 \% \mathbf{I} \quad 23 \% \mathbf{I}$ & 0 6\% jo-if-nyt_005.txt & $23 \%$ & \\
\hline 203 & What do punts mean? Crisis!" The winner of guardian.co.uk Crowbarred-In & $2.4921607 \% \quad 06 \% \mathbf{I}$ & 0 6\% Inar-gua_014.txt| & $58 \%$ & \\
\hline 204 & penalty kicks were used to decide the winner. Italy converted five to France's & $707310 \% 116 \% \mathbf{I}$ & $07 \%$ jo-if-wp_ $068 . t \times t$ & $39 \%$ & \\
\hline 205 & the far post. Then Doyle was denied the winner when Turner blocked his fierce & $659224 \% \mathbf{I} \quad 06 \% \mathbf{I}$ & 0 6\%ljo-if-365_034.txt & $96 \%$ & \\
\hline 206 & PROCEDURES TO DETERMINE THE WINNER OF A MATCH OR & $10.2131979 \% \mathbf{I} \quad 04 \% \mathbf{I}$ & $04 \%$ I & $44 \%$ & \\
\hline 207 & PROCEDURES TO DETERMINE THE WINNER OF A MATCH OR & $9.8911922 \% \mathbf{I} \quad 03 \% \mathbf{I}$ & $03 \%$ & $42 \%$ & \\
\hline 208 & 1 Only procedures to determine the winner of a match, which are approved & $5.2531400 \% \mathbf{I} \quad 03 \% \mathbf{I}$ & $03 \%$ & $23 \%$ & \\
\hline 209 & PROCEDURES TO DETERMINE THE WINNER OF A MATCH OR & $21.8064913 \% \mathbf{I} \quad 05 \% \mathbf{I}$ & $05 \%$ & $94 \%$ & \\
\hline 210 & Kick 52 Procedures to Determine the Winner of a Match or home-and-away 54 & $412103 \% \mathbf{I} \quad 02 \%$ & fifa.txt & $2 \%$ & \\
\hline 211 & showed superb technique to drive the winner into the top corner from 18 yards. & $722304 \% \mathbf{I} \quad 03 \% \mathbf{I}$ & 0 3\%ljo-if-gua_078.txt & $85 \%$ & \\
\hline 212 & Villar into a diving save. In the end, the winner was not forthcoming and a draw & $497 \quad 169 \% \mathbf{I} \quad 4 \% \mathbf{I}$ & $04 \%$ jo-if-tfa_009.txt & $95 \%$ & \\
\hline 213 & tournament. On Sunday, it will face the winner of Thursday's semifinal between & $39490 \% \mathbf{I} 51 \% \mathbf{I}$ & 0 5\% jo-if-nyt_006.txt & $41 \%$ & \\
\hline 214 & Chelsea to the FA Cup final. $\langle p>$ The winner, coming just six minutes from the & $161 \quad 23 \% \mathbf{I} \quad 02 \% \mathbf{I}$ & $07 \%$ jo-if-tel_001.txt & $25 \%$ & \\
\hline 215 & its own cute celebration. Following the winner, Rooney pretended to be trimming & $354 \quad 137 \% \mathbf{I} \quad 40 \% \mathbf{I}$ & 0 7\%ljo-if-gua_011.txt & $44 \%$ & \\
\hline 216 & precocious substitute Eljero Elia for the winner, deprived Scotland of the point & $203 \quad 47 \% \mathbf{I} \quad 05 \% \mathbf{I}$ & 0 5\%ljo-if-gua_093.txt & $34 \%$ & \\
\hline 217 & pull the trigger. Bulgaria looked for the winner they so desperately needed to & $403130 \% \mathbf{I} 08 \% \mathbf{I}$ & 0 8\%ljo-if-bbc_018.txt & $80 \%$ & \\
\hline 218 & ball over the advancina Murnhy for the winner. $\langle p\rangle\langle 0\rangle$ Scunnv boss Niael & 6ว1 $7.3 \mathrm{n \%} 1.9 \mathrm{~F} \% \mathbf{I}$ & ก.3\%lin-if-sun $n \cap 5$ txt & $85 \%$ & $\underline{\underline{v}}$ \\
\hline concordan & nce collocates plot patterns clusters filenames follow up source text notes & & & & \\
\hline
\end{tabular}

Figura 66 - Parte das linhas de concordância de winner ordenadas pelas três primeiras palavras à esquerda 
O corpus apresenta 278 ocorrências de winner, sendo que na maioria o termo é utilizado para descrever um time vencedor. Contudo, encontramos 26 ocorrências (algumas sublinhadas na Fig. 66) em que the winner refere-se ao gol da vitória de uma partida.

Uma diferença que notamos entre o uso de the winning goal e the winner é que, no primeiro, o gol foi marcado, ao passo que, no segundo, o time, muitas vezes, está à procura do gol. Observemos os exemplos:

a) Ronaldo's compatriot, Nani, had another ineffectual evening until he picked up possession on the left. He sent in a rasping shot which forced keeper Hakan Arikan to parry and Paul Scholes was there to head a vital winning goal into an empty net.

b) The visitors looked to be heading for their fourth successive draw when Bruno Alves bagged the winner in the third minute of stoppage time to rescue their South Africa 2010 dreams and deal a blow to the Albanians, in their first match under new Croatian coach Josip Kuze.

c) Bulgaria looked for the winner they so desperately needed to boost their qualification prospects.

Nos dois primeiros exemplos o gol já havia sido marcado, enquanto no último exemplo, embora o time tenha trabalhado pelo gol que lhe daria a vitória, a partida entre Bul gária e República da Irlanda terminou em empate.

Voltando às linhas de concordância, observamos que o verbo bag frequentemente coocorre com the winner, Decidimos, então, observar as concordâncias de "bag*" a fim de verificar outros possíveis colocados e descobrimos que bag normalmente é utilizado para relatar gols que tiveram importância em uma partida como, por exemplo, a memorable goal ou um gol que deu a vitória a um time: 
a) The full-time whistle goes. Brazil's campaign is up and running but they were made to work every step of the way by North Korea, who bagged a memorable goal at the death.

b) Ings bagged the second goal in Saturday's 2-0 win at Notts County with Robinson, 25, scoring the opener to help move the Cherries up to sixth in the table and end their winless run of eight league games.

A última busca que realizamos foi para decisive goal, que possui oito ocorrências no corpus. Em um primeiro momento, não realizaríamos tal busca, pois não cogitaríamos a hipótese de decisive funcionar como sinôni mo de winning. Entretanto, na busca que realizamos para a expressão "JJ * goal", deparamos com as ocorrências que chamaram nossa atenção. O passo seguinte foi gerar linhas de concordância para decisive goal no corpus sem etiqueta para observar a situação em que o gol ocorre:

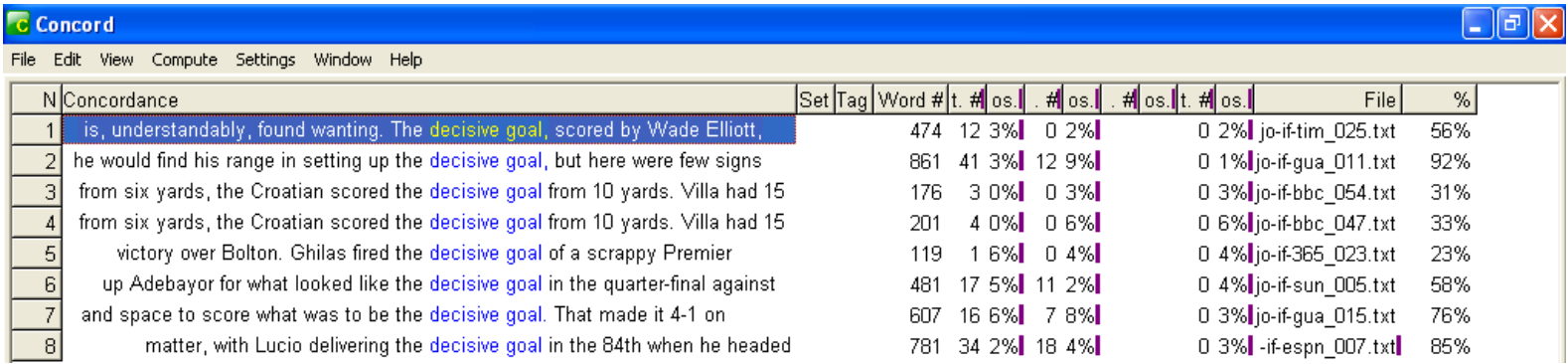

Figura 67 - Linhas de concordância para decisive goal

As concordâncias revelam que o the decisive goal ocorre como sinônimo de the winning goal e de the winner. A diferença está no sentido mais amplo que decisive goal possui. Tomemos como exemplo os dois exemplos abaixo:

a) The decisive goal, scored by Wade Elliott, was a case in point.

b) The disappointing part was the way City's defenders meekly allowed Guerrero the time and space to score what was to be the decisive goal. That made it 4-1 on aggregate and City were indebted to a generous penalty four minutes later to give them a fresh injection of hope. 
No primeiro exemplo, a UFE funciona como sinônimo de the winning goal e de the winner, pois foi utilizada para descrever o gol que deu a vitória ao Burnley em uma partida contra o Everton que terminou em 1 a 0.

No segundo exemplo, a UFE não é utilizada como sinônimo dos outros dois equivalentes, pois, se observarmos o parágrafo inteiro, veremos que, se fosse marcado o decisive goal, não seria o gol que daria a vitória para o Hamburgo, mesmo porque o time perdeu a partida por 2 a 1, mas sim o gol que, somado aos gols do jogo de ida, qualificaria o Hamburgo para a próxima fase da competição. Ou seja, nessa partida o Manchester City ganhou por 2 a 1 do Hamburgo; no entanto, na somatória de gols, o Hamburgo eliminou o Manchester City por 4 a 3, já que tinha ganhado o primeiro jogo das quartas de final por 3 a 1. Portanto, decisive goal pode ser sinônimo de "gol da vitória" dependendo do contexto.

Não diferente das outras UFEs encontradas, os equivalentes de o gol da vitória ocorrem com frequência aproximada em jornais e periódicos esportivos, com apenas seis ocorrências no tabloide Daily Mail e duas no The Sun. Quanto ao gênero textual, as ocorrências estão distribuídas uniformemente entre notícias e narrações.

\subsection{5 gol da virada, 0 (48)}

Em um estudo piloto que realizamos para o exame de qualificação, período em que o corpus ainda não estava fechado, deparamos com o termo go-ahead goal. Observamos as concordâncias de goal ordenadas pelas duas primeiras palavras à esquerda:

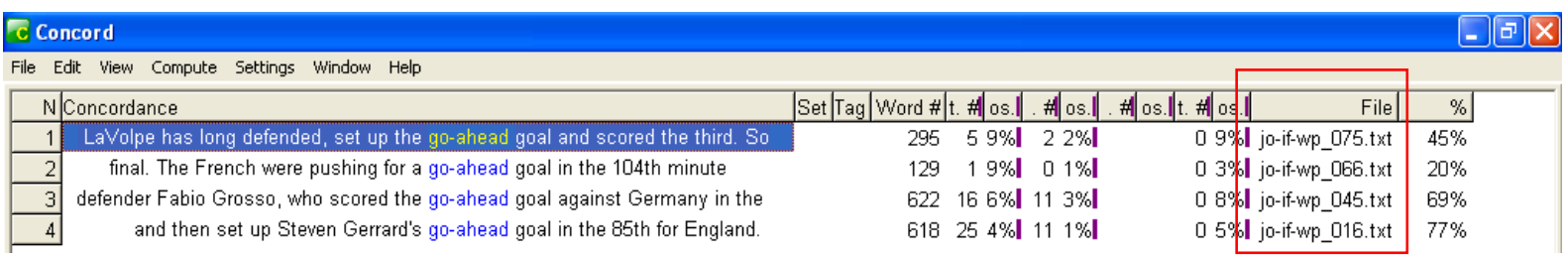

Figura 68 - Linhas de goal ordenadas pelas duas primeiras palavras à esquerda

Expandimos o contexto para melhor entender o funcionamento da UFE e verificamos que go-ahead goal ocorre para narrar um gol da virada. Todavia, uma 
questão nos intrigou: se gols de virada acontecem tanto no Brasil quanto na Inglaterra por que a grande diferença no número de ocorrências?

Não realizamos nenhuma análise mais detalhada para investigar a questão, bastou observamos os arquivos em que a UFE está presente para constatar que só ocorrem em um jornal americano (The Washington Post). Conduzimos uma busca com a expressão "go-ahead goal" seguida da palavra football no Google.uk e tivemos nossa hipótese confirmada. Na verdade, a UFE até ocorre em nosso contexto de busca, mas sempre em uma notícia sobre futebol americano. A mesma busca no Google.com retorna ocorrências em textos sobre futebol americano, hóquei e também sobre soccer. Não possuímos, em nosso corpus, um número relevante de ocorrências de go-ahead goal, mas levantamos a hipótese de que o termo é utilizado em textos sobre soccer por influência da terminologia utilizada no futebol americano e no hóquei.

Eliminado um possível equivalente e sem muitas idéias de busca, geramos linhas de concordância para a palavra ahead a fim de verificar se alguma das estruturas em que ocorre pode ser considerada um equivalente para gol da virada:

\begin{tabular}{|c|c|c|c|c|c|c|c|}
\hline \multicolumn{6}{|c|}{ C Concord } & \multicolumn{2}{|c|}{ - } \\
\hline \multicolumn{8}{|c|}{ File Edit View Compute Settings Window Help } \\
\hline \multicolumn{2}{|c|}{ N Concordance } & \begin{tabular}{|l|l|l|} 
Set & Tag & Word \#
\end{tabular} & t. $\# \mid$ os. $\mid$ & $\mathbb{H} \mid$ os.l| & \#n os. & $\%$ & $\hat{\Lambda}$ \\
\hline 1 & be flagged offside. Benfica almost ahead shortly before the break when & 143 & $25 \%$ & $07 \%$ & $07 \%$ ljo-if-365_082.txt & $77 \%$ & \\
\hline 2 & \multirow{2}{*}{$\begin{array}{l}\text { was unhappy about the call and went ahead and shot the ball into the goal } \\
\text { the Benfica winger that Argentina went ahead. Messi's free-kick was perfectly }\end{array}$} & 809 & $290 \% \mathbf{I}$ & $06 \% \mathbf{I}$ & $04 \%$ jo-if-wp_019.txt & $77 \%$ & \\
\hline 3 & & 241 & $50 \%$ & $01 \% \mathbf{l}$ & 0 1\% jo-if-fif_oog.txt & $49 \%$ & \\
\hline 4 & $<p>$ After the break, Argentina went ahead on a set piece. Juan Riquelme & 596 & $207 \% \mathbf{I}$ & $112 \% \mathbf{I}$ & $04 \%$ jo-if-wp_036.txt & $67 \%$ & \\
\hline 5 & the resulting corner Argentina went ahead, with five minutes played. Juan & 290 & $69 \% \mathbf{I}$ & $07 \% \mathbf{I}$ & $07 \%$ jo-if-mir_002.txt & $45 \%$ & \\
\hline 6 & the resulting corner Argentina went ahead, with five minutes played. Juan & 264 & $79 \%$ & $05 \% \mathbf{l}$ & 0 5\% -if-espn $005 . t x t \mid$ & $31 \%$ & \\
\hline 7 & after only nine minutes, Atletico went ahead shortly afterwards with a goal by & 350 & $127 \% \mathbf{I}$ & $03 \% \mathbf{l}$ & 0 3\% jo-if-fft_017.txt & $85 \%$ & \\
\hline 8 & It was no real surprise when Brazil went ahead after 37 minutes. $\langle p\rangle\langle p\rangle$ Luis & 334 & $90 \% \mathbf{I}$ & $73 \% \mathbf{l}$ & 0 3\% -if-espn $005 . t x t \mid$ & $69 \%$ & \\
\hline 9 & tackle on Gennaro Gattuso, but went ahead eight minutes later when Donovan & 221 & $66 \% \mathbf{l}$ & $37 \% \mathbf{l}$ & 0 8\% I-if-espn_001.txt| & $35 \%$ & \\
\hline 10 & \multirow{2}{*}{$\begin{array}{l}\text { shot from the left channel. Celtic went ahead in the 79th minute when Juarez's } \\
\text { of the match. Coventry went ahead in the 18th minute. Marcus Hall, }\end{array}$} & 628 & $220 \% \mathbf{l}$ & $03 \% \mathbf{I}$ & 0 3\%ljo-if-365_077.txt & $93 \%$ & \\
\hline 11 & & 1.064 & $380 \% \mathbf{l}$ & $00 \% \mathbf{I}$ & 0 0\%ljo-if-day_055.txt & $91 \%$ & \\
\hline 12 & a minute before halftime. Cruzeiro went ahead in the 66th when midfielder & 168 & $27 \%$ & $00 \% \mathbf{l}$ & 0 0\% jo-if-fft_015.txt & $51 \%$ & \\
\hline 13 & \multirow{2}{*}{$\begin{array}{l}\text { the back-post. The Super Eagles went ahead with Eneramo getting in front of } \\
\text { the Gunners and they eventually went ahead on } 18 \text { minutes. The ball was }\end{array}$} & 299 & $95 \% \mathbf{I}$ & $09 \% \mathbf{I}$ & 0 9\%ljo-if-bbc_019.txt & $66 \%$ & \\
\hline 14 & & 316 & $102 \% \mathbf{I}$ & $01 \% \mathbf{I}$ & 0 1\%ljo-if-365_021.txt & $48 \%$ & \\
\hline 15 & later. But Newcastle finally went ahead with seven minutes remaining & 552 & $154 \% \mathbf{l}$ & $06 \% \mathbf{I}$ & 0 6\%ljo-if-365_046.txt & $96 \%$ & \\
\hline 16 & final in Malmo. The Germans went ahead when Mesut Ozil went past Martin & 108 & $19 \% \mathbf{I}$ & $02 \%$ & $02 \%$ ljo-if-bbc_014.txt & $33 \%$ & \\
\hline 17 & final in Malmo. The Germans went ahead when Mesut Ozil went past Martin & 108 & $19 \% \mathbf{I}$ & $02 \%$ & $02 \%$ ljo-if-bbc $041 . t x t$ & $33 \%$ & \\
\hline 18 & was again creator when Hibs went ahead. His free-kick was met with a flick & 372 & $70 \%$ & $01 \% \mathbf{l}$ & 0 1\% Jo-iff-tel_039.txt & $67 \%$ & \\
\hline 19 & $\langle i p\rangle\langle p\rangle \ln$ the 72 nd minute, Italy went ahead, 2-1, on a 35-yard rocket from & 826 & $440 \% \mathbf{l}$ & $182 \%$ l & 0 0\% jo-if-nyt_002.txt & $81 \%$ & \\
\hline 20 & soon be forgotten. $\langle/ p\rangle\langle p\rangle \mid$ taly went ahead midway through the first half on & 432 & $121 \% \mathbf{I}$ & $74 \%$ l & $08 \%$ jo-if-wp_023.txt & $41 \%$ & \\
\hline 21 & \multirow{2}{*}{$\begin{array}{l}\text { period came early. United nearly went ahead on } 15 \text { minutes when Valencia } \\
\text { and, from the moment they went ahead, they were the better side. What }\end{array}$} & 773 & $254 \% \mathbf{I}$ & $02 \%$ & $02 \%$ jo-ifind_028.txt & $84 \%$ & \\
\hline 22 & & 514 & $274 \% \mathbf{I}$ & $07 \%$ & $07 \%$ ljo-if-day_001.txt & $81 \%$ & \\
\hline 23 & looked a real threat. And they went ahead when Castro, who also scored in & 274 & $109 \% \mathbf{I}$ & $05 \%$ & 0 5\%ljo-if-bbc_014.txt & $63 \%$ & \\
\hline 24 & looked a real threat. And they went ahead when Castro, who also scored in & 274 & $109 \% \mathbf{I}$ & $05 \% \mathbf{l}$ & $05 \%$ ljo-if-bbc_041.txt & $63 \%$ & \\
\hline 25 & desk league on Pick The Score. Well ahead of 'renowned' tipsters Ingle and & 622 & $363 \% \mathbf{l}$ & $05 \%$ & 0 5\% n nar-gua $007 . t x t$ & $17 \%$ & \\
\hline 26 & Chris Foy West Ham had gone ahead after 22 minutes through the & 468 & $149 \% \mathbf{I}$ & $06 \%$ & 0 6\% jo-if-foo_004.txt & $69 \%$ & \\
\hline 27 & \multirow{2}{*}{$\begin{array}{l}\text { slightly flattered Russia, who had gone ahead when Igor Shemshov dispatched } \\
\text { on and the Catalans could have gone ahead after } 20 \text { minutes but Iker Casillas }\end{array}$} & 223 & $47 \%$ & $00 \%$ & 0 0\%ljo-if-gua_095.txt & $70 \%$ & \\
\hline 28 & & 376 & $119 \% \mathbf{I}$ & $00 \% \mathbf{l}$ & 0 0\%ljo-if-day_042.txt & $57 \%$ & \\
\hline 29 & for both sides. Orient should have gone ahead just before half-time when a & 448 & $162 \% \mathbf{I}$ & $08 \% \mathbf{l}$ & $08 \%$ ljo-if-365_045.txt & $63 \%$ & \\
\hline 30 & Spurs then really should have gone ahead on 30 minutes. Wilson Palacios & 423 & $123 \% \mathbf{I}$ & $03 \% \mathbf{I}$ & 0 3\%l jo-if-spl_010.txt & $59 \%$ & \\
\hline 31 & Sours then reallv should have aone ahead on 30 minutes. Wilson Palacios & 427 & $11.3 \% \mathbf{I}$ & ก.3\% & $\Pi, 3 \%$ lin-if-3h5 $\Pi \Pi 2$ txt & $59 \%$ & $\underline{v}$ \\
\hline concordar & \begin{tabular}{|l|l|l|l|l} 
patterns & clusters & filenames & follow up & source text \\
notes
\end{tabular} & & & & & & \\
\hline
\end{tabular}

Figura 69 - Parte das linhas de concordância de ahead ordenadas pelas duas primeiras palavras à esquerda e pela primeira palavra à direita 
O programa nos retornou 374 ocorrências de ahead, das quais 42 eram precedidas pelo verbo go. Ao observar as linhas de concordância e ampliar os contextos, validamos a estrutura [club] went ahead when [footballer] VERB como uma possível tradução de gol da virada.

A descoberta da estrutura acima nos incentivou a fazer uma nova busca, dessa vez com a palavra lead que, quando substantivo, pode ser traduzida como liderança e, quando verbo, como liderar ou vencer. O objetivo era verificar se gol da virada poderia ter mais de um equivalente em inglês:

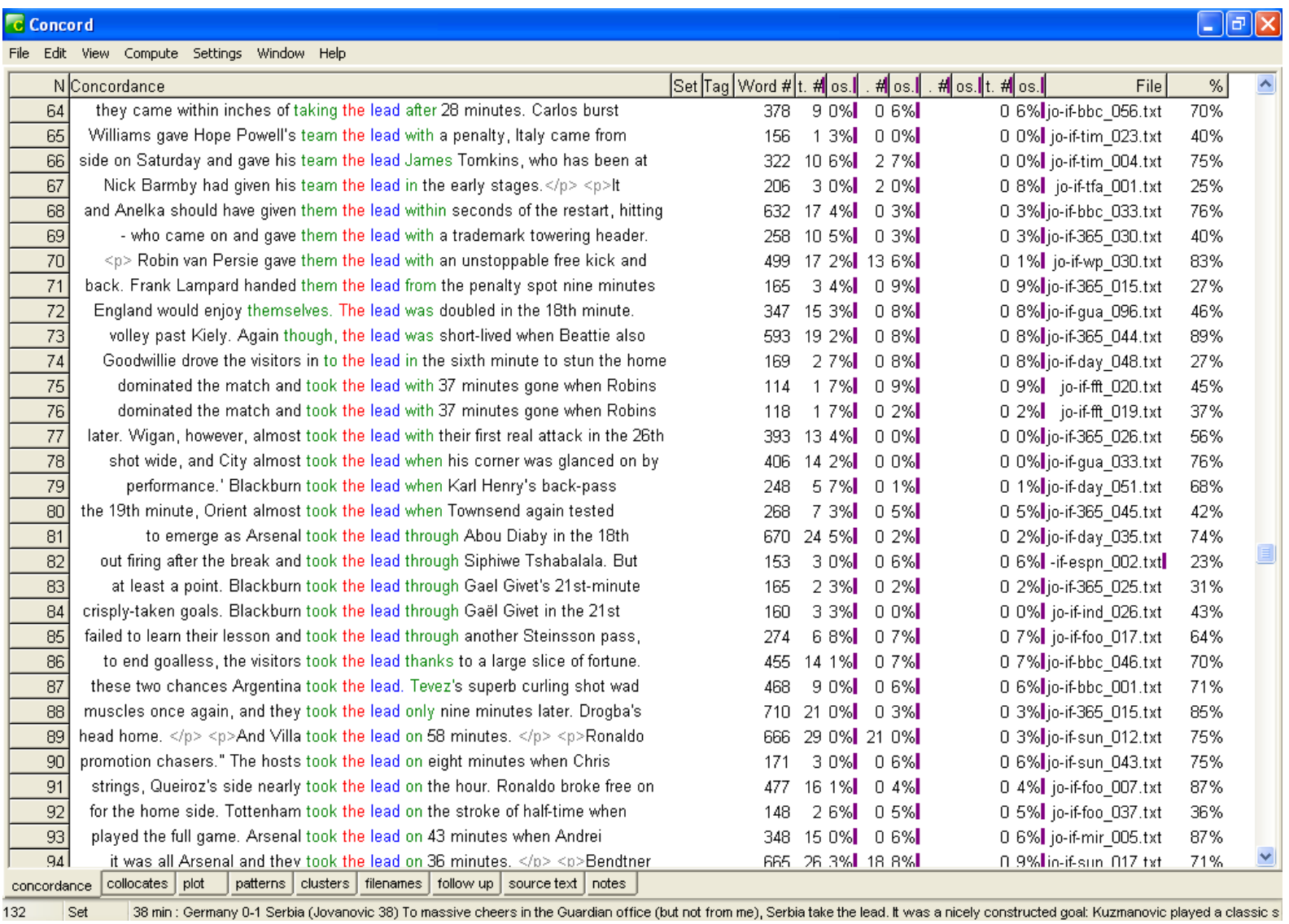

Figura 70 - Parte das linhas de concordância de lead ordenadas pelas duas primeiras palavras à esquerda e pela primeira palavra à direita 
A busca realizada encontrou 639 ocorrências de lead que, após aplicar o disposito re-sort e ordenar as linhas, reduzimos para 132, todas precedidas do verbo take. Ao observar as linhas, percebemos que take the lead ocorre muito frequentemente como parte de uma estrutura maior: [club] took the lead through [footballer] a qual também validamos como possível tradução de gol da virada.

a) Behind after six minutes through Kevin Davies, they equalised via DJ Campbell and took the lead through Jason Puncheon before Matt Taylor pulled the visitors level.

Os dois equivalentes em inglês ocorrem quase que exclusivamente em notícias de resultado de partidas de jornais, periódicos esportivos e tabloides.

\subsection{6 gol de empate, $0(85)$}

As concordâncias de " $J J *$ goal”, geradas para encontrar o equivalente de gol da vitória (vide Fig. 37), retornaram algumas ocorrências de tying goal, possível equivalente de gol de empate. Resolvemos, então, gerar concordâncias para tying goal no corpus sem etiquetas:

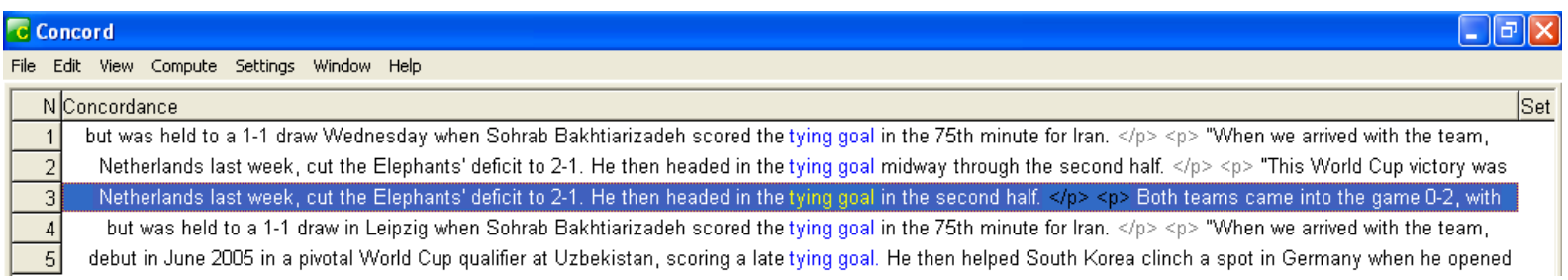

Figura 71 - Linhas de concordância de tying

Após observar as concordâncias, validamos a UFE como equivalente de gol de empate. 
Como já conhecíamos o verbo equalise, geramos linhas de concordância de "equalis*" para verificar se o corpus apresentava alguma ocorrência de equaliser ou equalising:

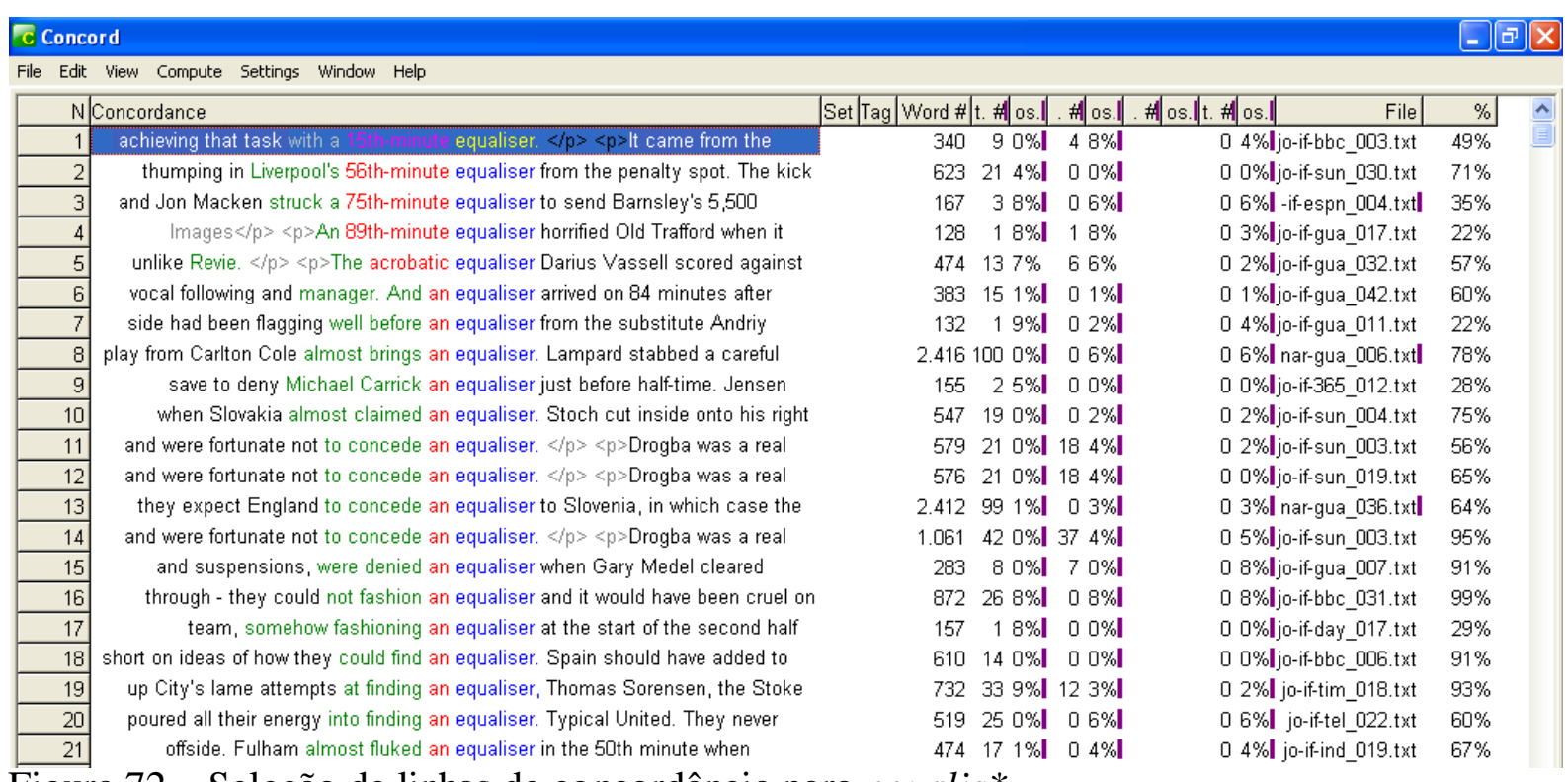

Figura 72 - Seleção de linhas de concordância para equalis*

A pesquisa retornou 201 ocorrências de equaliser como equivalente de gol de empate. Como podemos observar, o termo equaliser é bem mais frequente do que a UFE tying goal (5).

Não encontramos nenhuma característica específica no que se refere ao uso dos equivalentes. Ambos são utilizados em todos os gêneros textuais do nosso corpus e em todos os tipos de periódicos.

\subsection{7 gol de pênalti, um (32)}

O primeiro passo para encontrar o equivalente de um gol de pênalti foi gerar concordâncias para penalty no corpus de inglês. A busca retornou 1366 ocorrências, que ordenamos pela primeira palavra à direita e pelas duas primeiras palavras à esquerda.

Ao observar as ocorrências em busca do equivalente de gol de pênalti, identificamos várias UFEs, dentre elas: penalty appeal (pedido de pênalti), penalty area (área), penalty box (área), penalty claim (reclamar de penalty), penalty decision (decisão por pênalty), penalty kick (cobrança de pênalti), penalty mark (marca do pênalty), 
penalty shoot-out (pênaltis) e penalty spot (marca do pênalti). Contudo, não conseguimos identificar um possível equivalente para a UFE que procurávamos.

Sem mais alternativas de busca, decidimos observar mais atentamente as 104 concordâncias de penalty kick:

\begin{tabular}{|c|c|c|c|c|c|}
\hline \multicolumn{4}{|l|}{ Concord } & \multicolumn{2}{|c|}{ - } \\
\hline 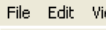 & Yiew Compute Settings Window Help & & & & \\
\hline \multicolumn{2}{|c|}{ N Concordance } & Set $|\operatorname{Tag}|$ Word \#|t. \#| os. || . \# os.|| & . & $\%$ & $\hat{\Lambda}$ \\
\hline \begin{tabular}{c|c}
74 & $w$ \\
$m$
\end{tabular} & \multirow{2}{*}{$\begin{array}{l}\text { with the now-retired Zidane, including a penalty kick against Portugal in the } \\
\text { championship game crawled into a penalty kick tiebreaker Sunday evening, }\end{array}$} & $790 \quad 347 \% \mathbf{|} 210 \% \mathbf{I}$ & 0 5\%l jo-if-wp_053.txt & \multicolumn{2}{|l|}{$86 \%$} \\
\hline 75 & & $112 \quad 03 \% \mathbf{I} \quad 03 \% \mathbf{I}$ & $02 \%$ l jo-if-wp_065.txt & $18 \%$ & \\
\hline 76 3) & 3) 45 LAW 14 - THE PENALTY KICK A penalty kick is awarded against a team & $7.4981735 \% \mathbf{I} \quad 03 \% \mathbf{I}$ & $03 \% \mathbf{I}$ & $32 \%$ & \\
\hline 77 & * (see page 3) Penalty Kick A penalty kick is awarded if any of the & $5.8391514 \% \mathbf{I} \quad 05 \% \mathbf{I}$ & & $25 \%$ & \\
\hline 78 & \multirow{2}{*}{$\begin{array}{l}\langle/ p\rangle\langle p\rangle \ln \text { the } 67 \text { th, Gyan missed a penalty kick given after Czech Republic } \\
\text { coming off a win and a draw, missed a penalty kick and played the last } 30\end{array}$} & $598328 \% \mathbf{|} 123 \% \mathbf{I}$ & $\begin{array}{l}05 \% \mathbf{l} \quad \text { fifa.txt } \\
01 \% \mathbf{l} \text { jo-if-wp_026.txt }\end{array}$ & $63 \%$ & \\
\hline 79 & & $185 \quad 58 \% \mathbf{I} \quad 25 \% \mathbf{I}$ & $04 \%$ jo-if-wp_009.txt & $32 \%$ & \\
\hline 80 & coming off a win and a draw, missed a penalty kick and played the last 30 & $18358 \% \mathbf{I} 35 \% \mathbf{I}$ & 0 5\% jo-if-wp_005.txt & $34 \%$ & \\
\hline 81 & coming off a win and a draw, missed a penalty kick and played the last 30 & $190 \quad 58 \% \mathbf{I} \quad 25 \% \mathbf{I}$ & $04 \%$ l jo-if-wp_013.txt & $32 \%$ & \\
\hline 82 & League play, even though he missed a penalty kick against Arsenal in the & $878 \quad 365 \%|183 \%|$ & 0 5\% jo-if-ny_030.txt & $95 \%$ & \\
\hline 83 & Not only had Zidane scored on a penalty kick earlier in Sunday's match, & $757 \quad 331 \% \mathbf{l} 114 \% \mathbf{l}$ & 0 7\% jo-if-ny_024.txt & $48 \%$ & \\
\hline 84 & \multirow{2}{*}{$\begin{array}{l}\text { European Championships, also on a penalty kick by Zidane. The memory of } \\
\text { as France defeated Portugal } 1-0 \text { on a penalty kick by Zinédine Zidane to reach }\end{array}$} & $150 \quad 16 \% \mathbf{I} \quad 05 \% \mathbf{I}$ & 0 5\%l-nw-esp_021.txt| & $21 \%$ & \\
\hline 85 & & $114 \quad 06 \% \mathbf{I} \quad 02 \% \mathbf{I}$ & $02 \%$ I-nw-esp_021.txtl & $18 \%$ & \\
\hline 86 & \multirow{2}{*}{$\begin{array}{l}\text { the lead in the seventh minute on a penalty kick, but his late-game nemesis, } \\
\text { Zidane put France ahead, } 1-0 \text {, on a penalty kick, becoming only the fourth }\end{array}$} & $430 \quad 146 \% \mathbf{I} 53 \% \mathbf{I}$ & \multirow{2}{*}{0 5\%l jo-if-wp_065.txt } & $51 \%$ & \\
\hline 87 & & $448 \quad 155 \% \mathbf{l} \quad 6 \quad 2 \% \mathbf{I}$ & & $30 \%$ & \\
\hline 88 & Zidane gave France an early lead on a penalty kick and seemed poise to leave & $299 \quad 59 \% \mathbf{I} \quad 27 \% \mathbf{I}$ & 0 1\%l jo-if-wp_066.txt & $36 \%$ & \\
\hline 89 th & The ollence occurred (see page s) or a penalty kick il the oflence occurred & 18.046406 1\%ा प प8\% & fifla.txt & $78 \%$ & \\
\hline 90 th & \multirow{2}{*}{$\begin{array}{l}\text { the offence occurred ( } \text { (see page } 3 \text { ) or a penalty kick (if the offence occurred } \\
\text { where the offence occurred * or a penalty kick. - against a team-mate, play }\end{array}$} & $19.8984471 \% \mathbf{l} \quad 06 \% \mathbf{l}$ & fifa.txt & $86 \%$ & \\
\hline 91 & & $20.2144552 \% \mathbf{I} \quad 08 \% \mathbf{I}$ & $08 \% \mathbf{l}$ & $87 \%$ & \\
\hline 92 & offence punishable by a free kick or a penalty kick 6 . uses offensive or insulting & $6.3491543 \% \mathbf{I} \quad 08 \% \mathbf{I}$ & $08 \% \mathbf{I}$ & $28 \%$ & \\
\hline 93 & KICK Procedure Feinting to take a penalty kick to confuse opponents is & $21.1104748 \% \mathbf{I} \quad 02 \% \mathbf{I}$ & $02 \%$ & $91 \%$ & \\
\hline 94 & and if you go all the way down to a penalty kick shootout, someone could & $913364 \% \mathbf{I} 17 \% \mathbf{I}$ & $09 \% \mathbf{l}$ jo-if-wp_036.txt & $98 \%$ & \\
\hline 95 & an Italian defender, the second was a penalty kick that put France up 1-0 & $149 \quad 22 \% \mathbf{I} \quad 23 \% \mathbf{I}$ & 0 1\%l jo-if-wp_056.txt & $53 \%$ & \\
\hline 96 & it is kicked and moves forward When a penalty kick is taken during the normal & $7.7271762 \% \mathbf{I} \quad 04 \% \mathbf{I}$ & $04 \% \mathbf{I}$ & $33 \%$ & \\
\hline 97 & with the Law - decides when a penalty kick has been completed 46 & $7.6791766 \% \mathbf{I} 03 \% \mathbf{I}$ & fifa.txt & $33 \%$ & \\
\hline 98 th & the referee, hoping to avoid a whistle. A penalty kick was called, and Zidane & $704 \quad 343 \% \mathbf{l} \quad 0 \quad 1 \% \mathbf{l}$ & 0 1\%l-nw-esp_021.txtl & $73 \%$ & \\
\hline 99 & Zidane, who put France ahead with a penalty kick in the opening minutes, was & $176 \quad 31 \% \mathbf{I} \quad 38 \% \mathbf{I}$ & 0 1\%l jo-if-ny_027.txt & $39 \%$ & \\
\hline 100 & area, the referee restarts play with a penalty kick. If a player standing inside & $20.4914587 \% \mathbf{I} \quad 09 \% \mathbf{I}$ & fifa.txt & $89 \%$ & \\
\hline 101 & have struck the opponent or with a penalty kick. If a substitute or & $20.5954599 \% \mathbf{I} \quad 09 \% \mathbf{I}$ & fifa.txt & $89 \%$ & \\
\hline 102 & Egypt 4-3 on a disputed 90 th-minute penalty kick by Kaka, his second goal of & $779333 \% \mathbf{l} 164 \% \mathbf{I}$ & $08 \%$-if-espn_001.txt| & $99 \%$ & \\
\hline 103 & which is a priority in any case. 845 . Penalty kick The assistant referee shall & $14.3892928 \% \mathbf{I} \quad 02 \% \mathbf{I}$ & $02 \%$ & $62 \%$ & \\
\hline $1 \cap 4$ & the offence occurred. * (see pace 3) Penalty Kick A nenalty kick is awarded if & $58.35151>\% \quad \cap 5 \% \mathbf{I}$ & $n 5 \%$ & $25 \%$ & \\
\hline oncordance & patterns clusters filenames follow up source text notes & & & & \\
\hline
\end{tabular}

Figura 73 - Linhas de concordância de penalty kick

Se analisarmos as ocorrências atentamente, veremos que penalty kick, além de caracterizar uma cobrança de pênalti, pode caracterizar um pênalti que foi convertido, ou seja, um gol de pênalti:

a) History uncannily repeated itself Wednesday, as France defeated Portugal, 1-0, on a penalty kick by Zinédine Zidane to reach the World Cup final for the second time in less than a decade. 
No exemplo acima, penalty kick faz referência a um gol de pênalti. Encontrado o equivalente, seguiríamos nossa análise verificando o gênero textual e os periódicos em que a UFE normalmente ocorre, mas foi exatamente nessa parte da análise que voltamos à estaca zero. Ao observar os periódicos em que penalty kick ocorre com o sentido de um gol convertido, constatamos ocorrências somente em periódicos americanos como os jornais The New York Times e The Washington Post e a revista Newsweek (vide Fig. 73).

Voltamos para as linhas de concordância de penalty e reparamos que muitas vezes o termo é precedido pelo caso genitivo ('s). Sendo assim, geramos linhas de concordância para a expressão de busca “POS * penalty”, em que a etiqueta POS indica o caso genitivo:

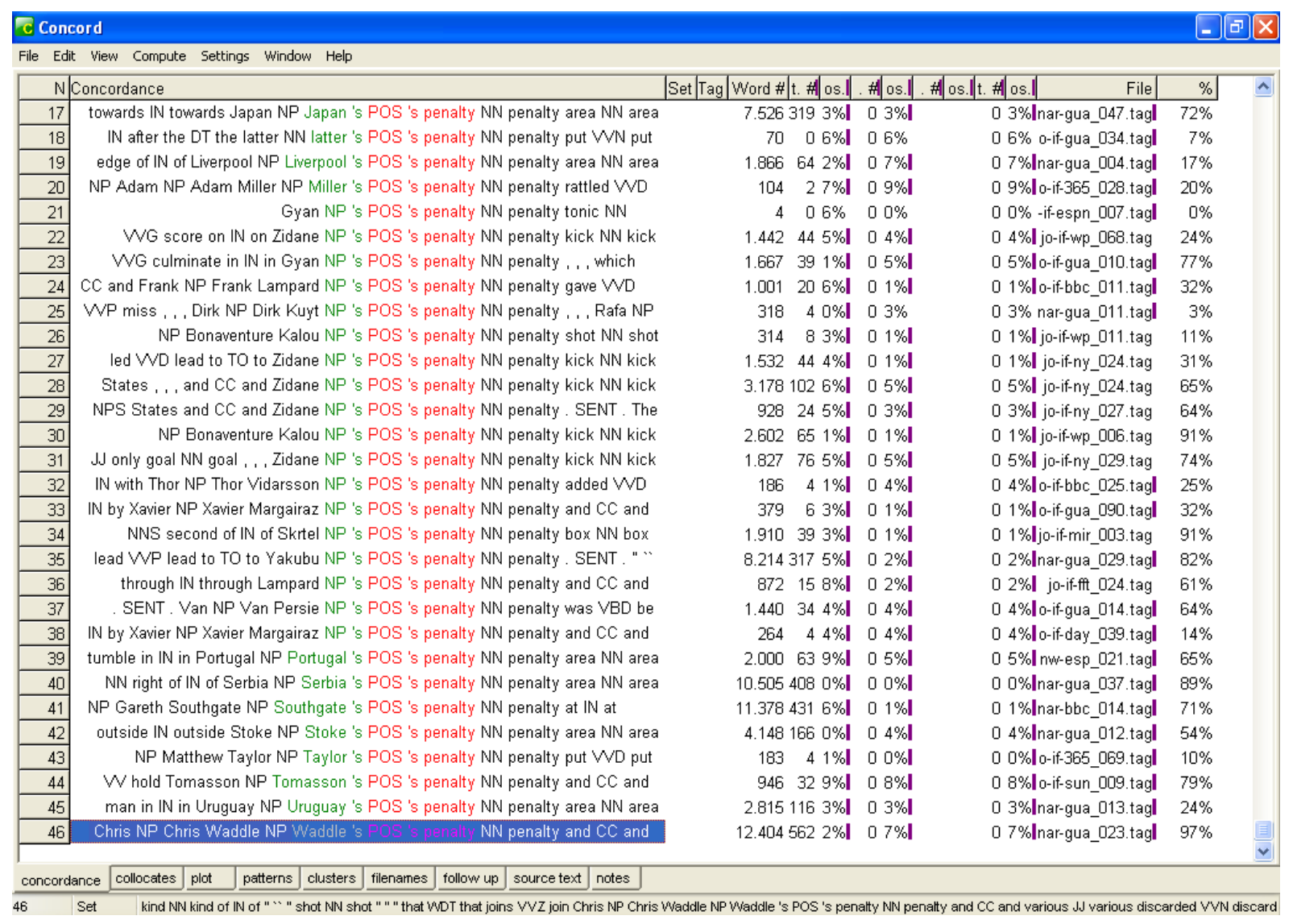

Figura 74 - Linhas de concordância da expressão "POS * penalty"

A expressão apresenta 46 ocorrências no corpus, sendo que em al gumas o caso genitivo refere-se a um time e em outras a um jogador. Foram os casos precedidos por jogadores que nos interessaram: 
a) The match was effectively settled through Lampard's penalty and Gerrard's first well-directed header.

b) Matthew Taylor's penalty put Bolton back in front four minutes before the break.

Nos exemplos, a estrutura [footballer]'s penalty indica que um jogador marcou um gol de pênalti, e não que um jogador sofreu um pênalti. Por esse motivo, consideramos a estrutura equivalente da UFE um gol de pênalti, em português.

4.17.1 com um gol de pênalti (5)

Quando validamos [footballer] 's penalty como equivalente de um gol de pênalti, nos perguntamos se a UFE em inglês também poderia funcionar como equivalente de com um gol de pênalti, dada a função da UFE em português: caracterizar uma mudança no placar. Observemos o exemplo:

a) O Palmeiras foi ao Couto Pereira nesta quarta-feira e perdeu por 1 a 0 para o Coritiba, com um gol de pênalti no final do segundo tempo.

Aqui, a UFE foi utilizada para explicar o efeito que o gol de pênalti teve no placar e, neste caso, no resultado da partida. Se observarmos algumas ocorrências da UFE em inglês, veremos que a situação de uso é a mesma:

a) Wayne Rooney, a subdued figure for the most part here, demonstrated his class with a stunning overhead kick 18 minutes from time. And Frank Lampard's penalty gave the scoreline a convincing appearance with a 78th minute penalty after Heskey has been hauled down by Renat Abdulin.

b) Scott McGleish's penalty gave NORTHAMPTON a 1-0 win at BARNET while WREXHAM snatched a point at home to NOTTS COUNTY with a 90th-minute equaliser from Robbie Foy. 
Dado o contexto de uso das UFEs, atestamos a UFE [footballer]'s penalty como equivalente de com um gol de pênalti.

\subsection{8 [goleiro] SAIR $\{$ mal | be m $\}$ (do gol) (51)}

Geramos concordâncias das palavras goalkeeper e keeper a fim de encontrar o equivalente de [goleiro] sair \{mal| bem\} (do gol). A busca retornou 1531 ocorrências, que foram reordenadas de diferentes maneiras. Após algumas tentativas, encontramos dois possíveis candidatos a equivalentes das UFEs em português:

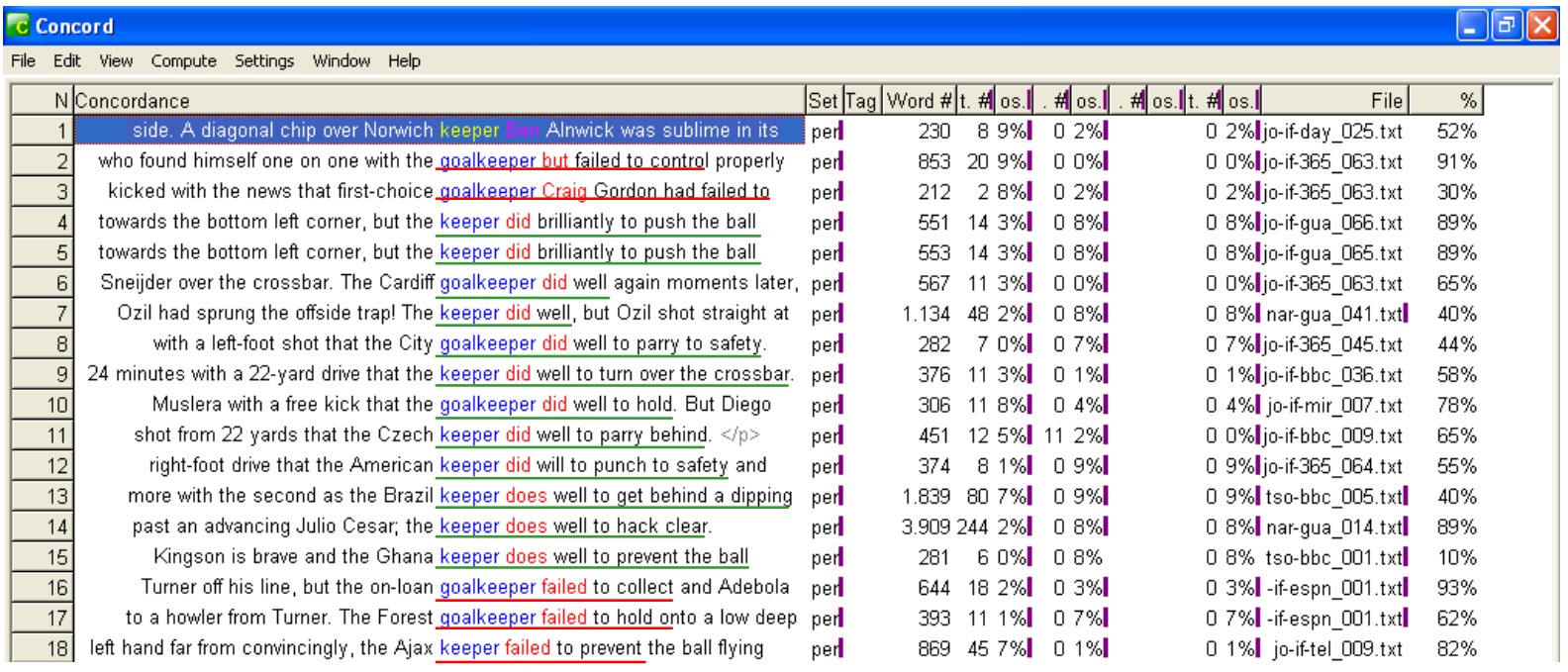

Figura 75 - Linhas de concordância de goalkeeper/keeper ordenadas pela primeira palavra à direita

Sublinhamos de vermelho e de verde dois padrões que atestamos como equivalentes da UFE em português. A figura 75 apresenta somente 18 ocorrências, pois a busca realizada não permite que os termos goalkeeper e keeper sejam substituídos por nomes de goleiros, tampouco permite que o nome de um goleiro seja inserido entre keeper $^{138}$ e a próxima palavra. Uma diferença que nos chamou atenção é que em português podemos preencher a estrutura da UFE com os advérbios bem e mal, ao passo que o inglês utiliza duas estruturas diferentes.

Analisaremos, primeiramente, a estrutura [goalkeeper] DO/DID well to VERB. Devido ao baixo número de ocorrências, realizamos buscas para "NP * * VVD * RB" e

${ }^{138}$ Uma busca no corpus revelou que é comum o nome de um goleiro ocorrer precedido da palavra keeper, mas raras vezes ocorre antecedido de goalkeeper. 
para "NP ** VVZ * RB", em que NP = substantivo próprio, $\mathrm{VVD}=$ verbo no passado, $\mathrm{VVZ}=$ verbo na terceira pessoa do singular do presente e $\mathrm{RB}=$ advérbio.

Com as buscas realizadas, o número de ocorrências subiu para 40. Como as linhas de concordância do corpus etiquetado são um tanto complicadas para se analisar, visto que não mostram o texto corrido, mas sim com as palavras intercaladas por uma etiqueta gramatical, tivemos que realizar buscas individuais para confirmar cada ocorrência. Após a análise, identificamos [goalkeeper] DO well to \{BEAT away|BEAT out $\mid$ PARRY $\mid$ BLOCK $|H O L D| S A V E \mid T I P$ the ball over the bar\} como equivalente para a UFE [goleiro] SAIR bem do gol.

Para confirmar se a estrutura [goalkeeper] FAIL to VERB poderia ser equivalente da UFE [goleiro] SAIR mal do gol, utilizamos as expressões de busca "NP * FAILED VVD FAIL" e "NP * FAILS VVZ FAIL" no corpus etiquetado. Desta vez, para centralizar a busca e não obter ocorrências de outros verbos, substituímos o símbolo (*), utilizado na expressão de busca anterior, por fail e suas formas no passado e na terceira pessoa do presente. O número de ocorrências subiu para 24 e validamos a estrutura [goalkeeper] FAIL to \{collect (a cross $\mid$ a header|the ball) | GRAB the ball | HOLD a shot\} como equivalente da UFE em português.

As UFEs encontradas são utilizadas em notícias e, com menos frequência, nove dentre 64 ocorrências, em narrações. Quanto ao tipo de veículo de comunicação, as UFEs ocorrem em jornais, periódicos esportivos e tabloides.

\subsection{ORDINAL gol \{do atacante | de [jogador]\} EM \{[torneio] | [competição] | [campeonato]\}, o (51)}

A princípio, para encontrar o equivalente para a UFE ORDINAL gol \{do atacante | de [jogador]\} EM \{torneio | competição | campeonato\} utilizaríamos a etiqueta de número ordinal e analisaríamos seus colocados. No entanto, ao procurar pela etiqueta no quadro 6, nos demos conta de que o Tree-Tagger não possui etiqueta para números ordinais. Ao utilizar os ordinais first, second e third como palavras de busca, verificamos que o etiquetador os classifica como adjetivos; classificação não muito útil para nossa pesquisa já que a quantidade de adjetivos que antecedem a palavra goal é 
muito grande. Por esse motivo, geramos linhas de concordância para first, second e third separadamente no corpus não etiquetado.

As concordâncias revelaram que, diferentemente do português, em inglês não é comum o uso dos termos forward, striker e attacker, equivalentes de atacante em inglês, em uma estrutura que descreva o primeiro, segundo ou terceiro gol de um jogador, pois não encontramos, em nenhuma das ocorrências, a presença dos termos citados. Todavia, encontramos 93 ocorrências em que \{first $\mid$ second $\mid$ third $\mid$ fourth $\}$ goal são precedidas do pronome his. Logo, validamos his ORDINAL goal como equivalente de ORDINAL gol do atacante.

Para encontrar o equivalente da outra parte da UFE, geramos concordâncias de first|second|third|fourth goal, separadamente, e as ordenamos pelas três primeiras palavras à direita:

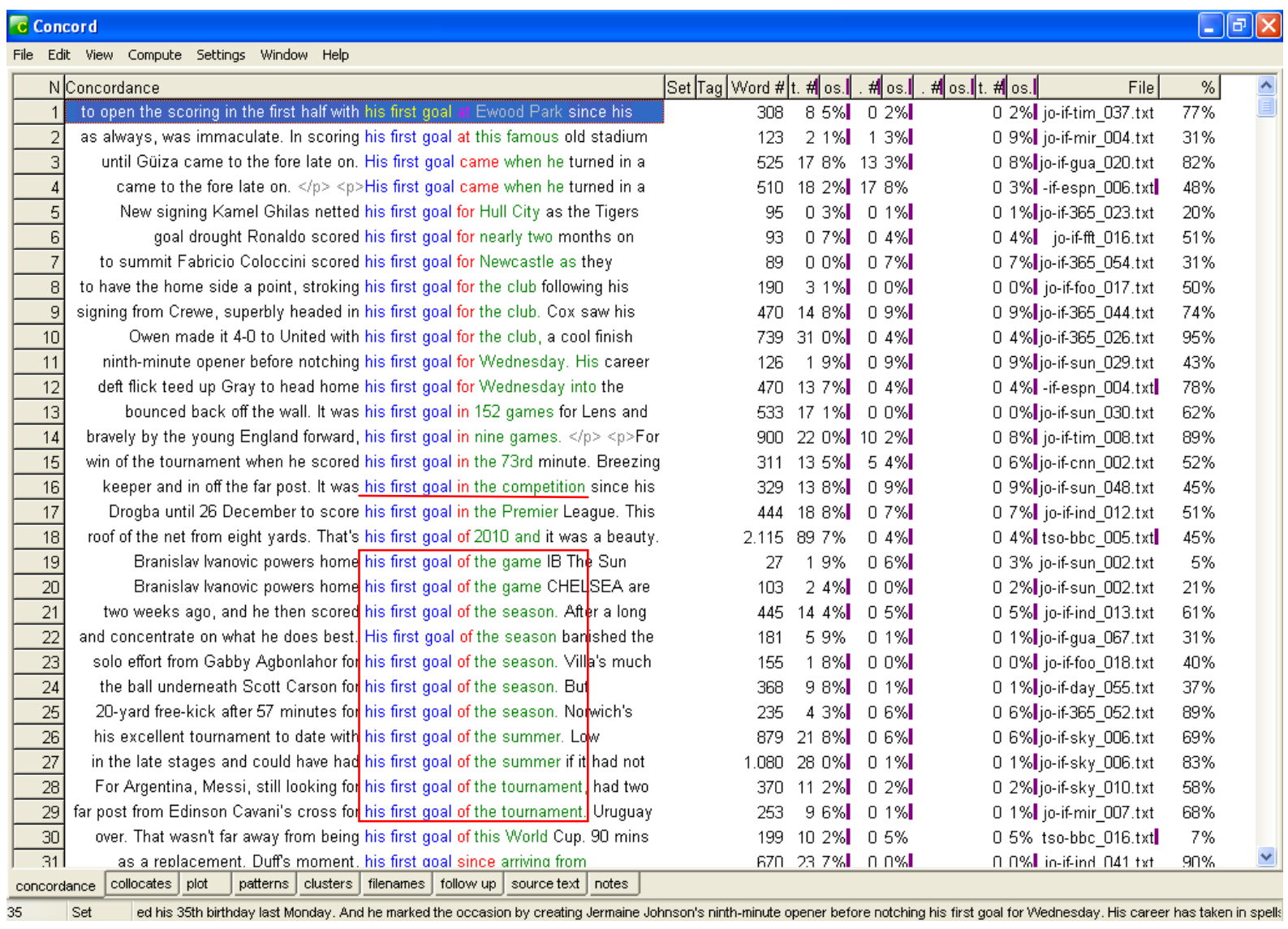

Figura 76 - Linhas de concordância de his first goal ordenadas pelas três primeiras palavras à direita 
As concordâncias indicam in the competition, of the game, of the season, of the summer e of the tournament como equivalentes de EM \{torneio | competição | campeonato ${ }^{139}$ \}. Após realizar o mesmo procedimento acima para as buscas com os outros ordinais, validamos a UFE his ORDINAL goal \{in the competition | of the season | of the tournament | of the summer\} como equivalente de o ORDINAL gol do atacante EM \{torneio $\mid$ competição | campeonato\}.

4.19.1 primeiro gol de [jogador] com a camisa ADJ ADN, o (10)

Primeiramente, realizamos buscas com os nódulos t-shirt e uniform a fim de verificar se a estrutura da UFE em inglês era parecida com a utilizada em português e, como esperávamos, o corpus não retornou nenhuma ocorrência que pudesse ser considerada equivalente. Analisamos, então, os colocados à direita de his ORDINAL goal e encontramos 21 ocorrências seguidas pela preposição for:

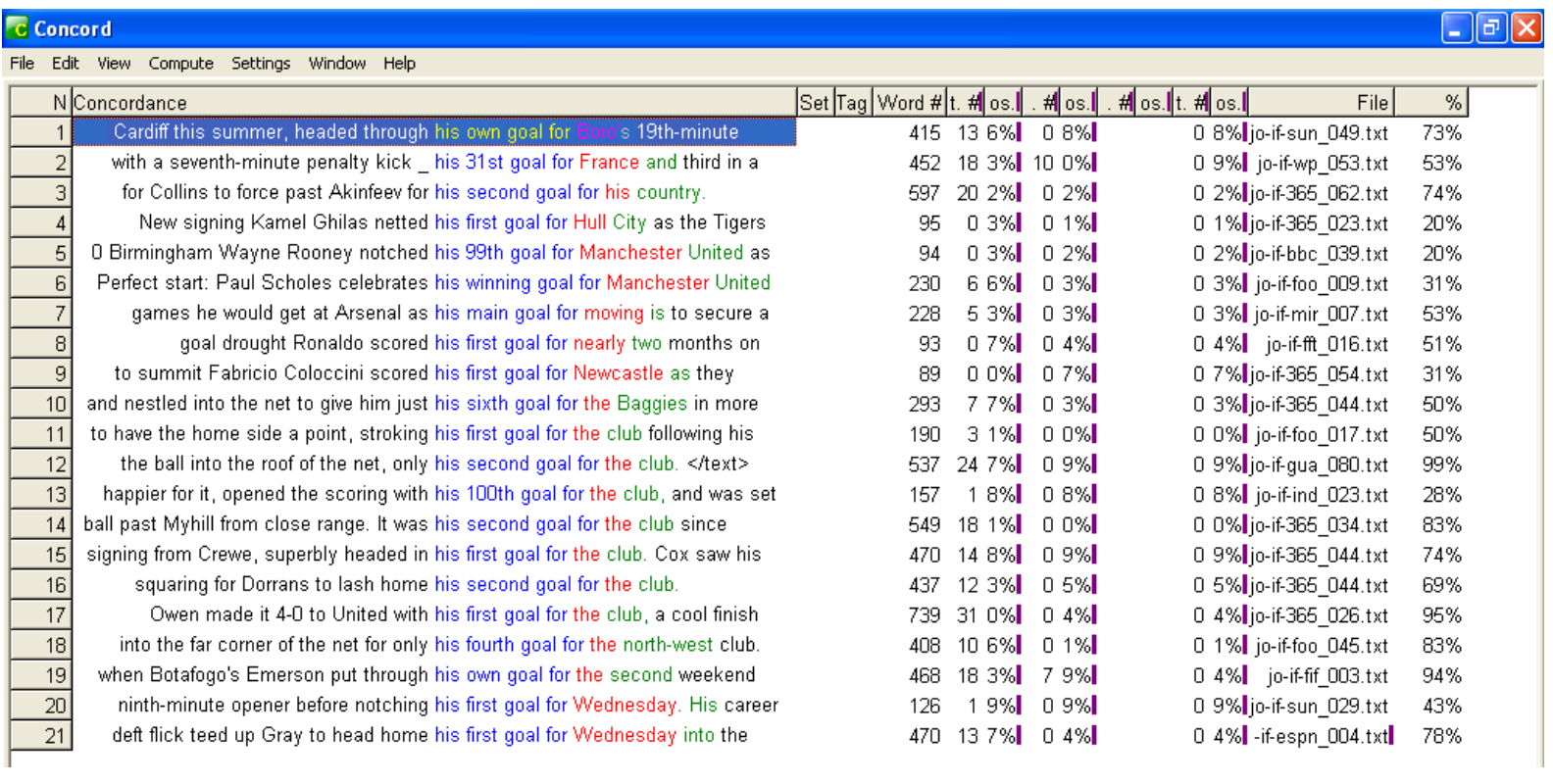

Figura 77 - Linhas de concordância para a expressão de busca "his * goal”

Das 21 ocorrências, 15 caracterizam o primeiro, segundo, terceiro ou quarto gol de um jogador para um time, fato que nos permitiu validar his first goal for [club] como

${ }^{139}$ Termos apresentados por ordem de frequência. 
UFE. Não obstante o achado, geramos concordâncias para a expressão de busca “*'s * goal for”, em que o símbolo (*) é substituído por uma palavra. Optamos por não utilizar "the club" uma vez que na maior parte das vezes o nome do clube substitui a expressão. A busca realizada apontou 26 ocorrências, sendo que oito caracterizavam o primeiro gol de um jogador para o clube, como podemos observar no exemplo:

a) It was Demontagnac's first goal for Blackpool since he arrived at Bloomfield Road eager to get his career back on track.

Analisamos as concordâncias e validamos [footballer]'s first goal for [club] como equivalente de primeiro gol do [jogador] com a camisa.

A análise aponta que as duas UFEs em inglês são utilizadas em notícias e narrações de jornais, periódicos esportivos e, menos frequentemente, em tabloides.

\subsection{0 longe do gol (108)}

Assim como na busca de equivalentes de grande parte das UFEs, iniciamos a busca com um possível colocado de goal em inglês. Dessa vez, o primeiro candidato que nos ocorreu foi o advérbio far, que eliminamos como equivalente durante a análise de suas ocorrências.

O próximo candidato foi o adjetivo wide, palavra-chave do corpus de inglês com 1300 ocorrências. Devido a esse grande número, em vez de ordenar as linhas pelos colocados à direita ou à esquerda, optamos por observar os clusters em que o termo ocorre: 


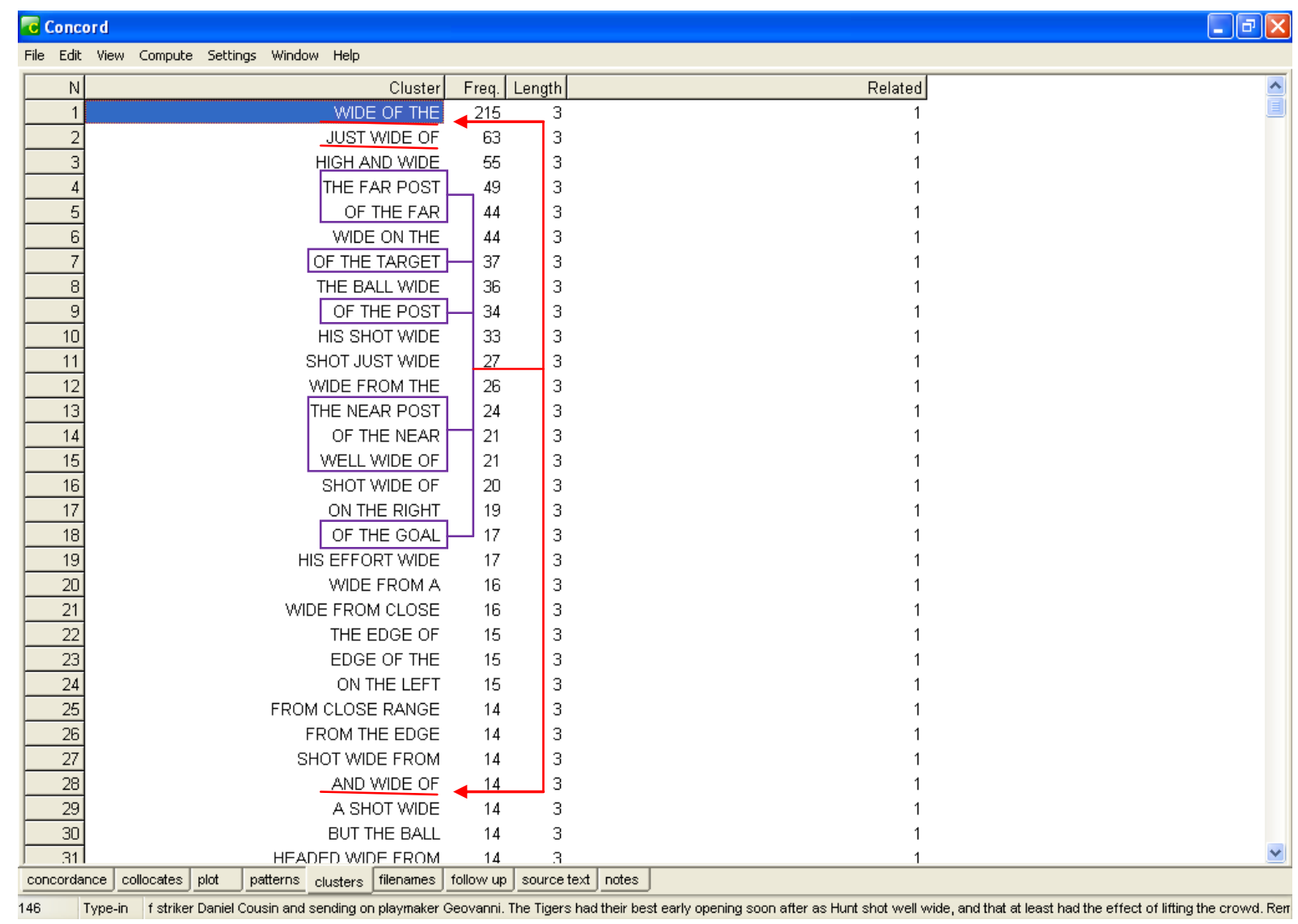

Figura 78 - Clusters de wide

Os clusters sublinhados indicam possíveis UFEs. Para validá-las, geramos linhas de concordância para wide of, agrupamento que parece estar presente em todos os clusters destacados: 


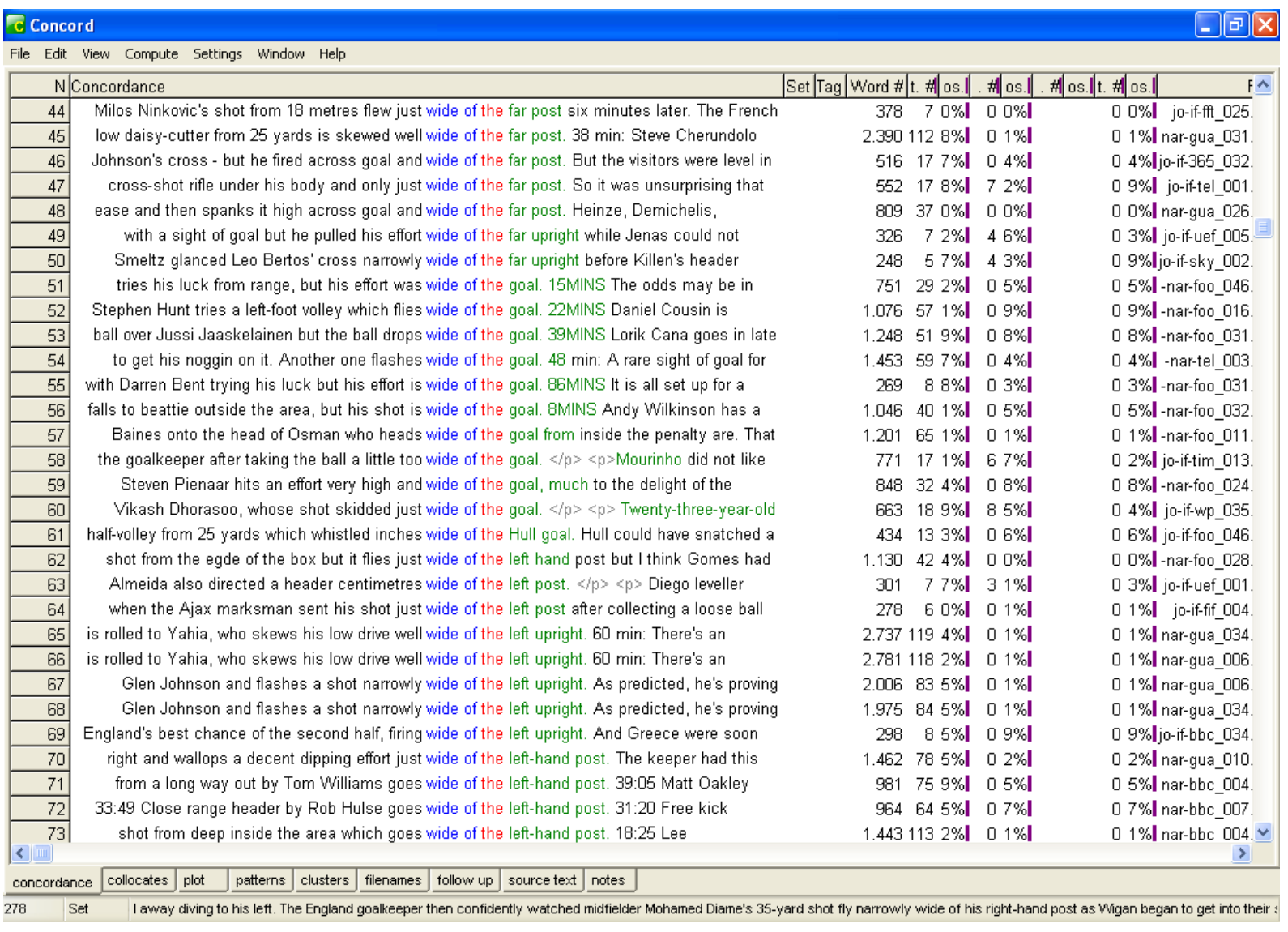

Figura 79 - Parte das linhas de concordância de wide of ordenadas pelas três primeiras palavras à direita

A busca por wide of reduziu o número de ocorrências de 1300 para 288 facilitando, assim, a análise em busca de padrões, que nos indicou a existência de seis UFEs:

a) wide of [goalkeeper]'s goal (32)

Deco shows some good touches to win the ball back from Villa but his shot is well wide of Brad Friedel's goal.

b) wide of the (far) post (29)

Altidore sticks out a leg to try to hook the ball past goalkeeper Kingson, but sends it wide of the far post. 
c) wide of (the) goal (22)

Sunderland clear quickly and break up the field with Darren Bent trying his luck but his effort is wide of the goal.

d) wide of the target (9)

Wright-Phillips flashes a shot wide of the target, after cutting inside from the left.

e) wide of the $\{$ right $\mid l e f t\}$-hand post (6)

Park Chu-Young cuts inside from the right and wallops a decent dipping effort just wide of the left-hand post.

f) wide of the $\{$ left|right $\}$ upright (4)

Barry loses the ball in midfield and the ball is lofted towards Ziani on the left wing. He cuts inside Glen Johnson and flashes a shot narrowly wide of the left upright.

As ocorrências nos indicam que, assim como em português, as UFEs em inglês ocorrem em notícias e em narrações de periódicos esportivos e jornais, sendo muito mais frequentes nas narrações. $\mathrm{O}$ uso das UFEs nas duas línguas difere quanto a variação terminológica: em português usamos o termo gol enquanto em inglês usamos os termos post (trave), goal (gol) e target (alvo); e também quanto à especificidade do lado que a bola passou: à direita (right) ou à esquerda (left).

4.20.1 a bola PASSAR longe do gol (13)

Para encontrar o equivalente de a bola PASSAR longe do gol, analisamos as palavras que ocorrem à esquerda de wide of the (far) post, wide of the target, wide of (the) goal, wide of [goalkeeper]'s goal, wide of the \{right|left\}-hand post, wide of the \{left|right\} upright e identificamos duas estruturas: 
1) $\{$ his effort $\mid$ his shot $\mid$ the ball $\}\{\mathrm{GO} \mid \mathrm{BE}\}$ \{wide of the (far) post $+\mid$ wide of the target $\mid$ wide of (the) goal | wide of [goalkeeper]'s goal | wide of the \{right|left $\}$ hand post | wide of the $\{$ left|right $\}$ upright $\}$ (14)

A primeira característica que nos chama atenção é que a língua inglesa utiliza outros dois termos, effort (tentativa) e shot (chute), além de ball (bola). Ademais, enquanto em português utilizamos apenas um verbo, passar, em inglês utilizamos outros três: go, be, sail. Os exemplos que seguem demostram os principais usos da UFE:

a) Half chance for Spurs as Lennon has a go from range but his effort goes wide of the right post.

b) Richard Eckersley shoots but the ball goes wide of the post.

c) Valencia tries to direct a diving header on goal but the ball goes wide of the target.

d) Clarke Carlisle manages to clear another Delep monster thrown from the sidelines, the ball falls to beattie outside the area, but his shot is wide of the goal.

e) Sunderland clear quickly and break up the field with Darren Bent trying his luck but his effort is wide of the goal.

2) the ball DROP wide of the [target $\mid$ goal] (8)

A estrutura desta UFE é parecida com a anterior, porém a apresentamos separadamente porque o verbo drop é sempre seguido de target e goal, não coocorrendo com effort, nem com shot. 
a) Gerrard tries his luck with a long range header but the ball drops wide of the target.

b) Kieran Richardson plays in Darren Bent who just tries to lob the ball over Jussi Jaaskelainen but the ball drops wide of the goal.

Em português a UFE é utilizada somente em transmissões minuto a minuto dos periódicos esportivos Globo Esporte, Terra Esporte, LanceNet e Gazeta Esportiva. Já em inglês, as UFEs equivalentes são utilizadas tanto em notícias quanto em transmissões minuto a minuto, apresentando maior número de ocorrências nas transmissões de jornais e periódicos esportivos. Acreditamos que o uso da UFE não seja frequente em notícias de resultados de partida porque, ao que nossa análise indica, o leitor brasileiro parece estar mais preocupado com o resultado geral da partida, e não com lances individuais.

\subsection{2 \{FINALIZAR|MANDAR\} para longe do gol (16)}

Uma vez que já conhecíamos os equivalentes de para longe do gol bem como os termos que coocorrem à sua esquerda, shot, effort e ball, analisamos as linhas de concordância em busca de verbos que os antecedem. Em um primeiro momento, geramos concordâncias para a expressão "shot/effort/the ball * wide of" a fim de obter resultados para os três termos em uma única busca. Entretanto, ao observar as primeiras linhas, notamos que os termos atraem verbos distintos. Assim sendo, realizamos três buscas, uma para cada termo: "shot * wide of", "effort * wide of" e "the ball * wide of".

Encontramos nove verbos que antecedem a expressão de busca "shot * wide of": slash, slice, squirt, hook, clip, scuff, screw, drag e hit. Dado o baixo número de ocorrências de cada verbo, devido à variedade terminológica, não conseguimos estabelecer nenhum padrão de ocorrência no que se refere a um determinado jornal ou gênero textual. Por essa razão, com o objetivo de facilitar a análise e estabelecer alguma diferença entre os usos dos verbos, os dividimos em categorias semânticas: 


\begin{tabular}{|l|l|}
\hline Categoria semântica & Verbos \\
\hline impulso / impacto & hit, clip \\
\hline trajetória & screw, hook \\
\hline lentidão & drag \\
\hline direção & slice (golf) \\
\hline ação violenta & scuff, slash \\
\hline movimento rápido & squirt \\
\hline
\end{tabular}

Quadro 12 - Verbos que antecedem a expressão de busca "shot * wide of" classificados por categoria semântica

A divisão proposta acima não tem pretensão alguma de ser absoluta. A principal razão da classificação é tentar estabelecer alguma diferença de uso entre os verbos. Tarefa, esta, que, para alguém que trabalhe com o inglês como segunda língua, seja traduzindo, lecionando ou escrevendo notícias, não é das coisas mais simples de se instituir.

Na busca realizada para a segunda expressão, "effort * wide of", identificamos cinco verbos, curl, hammer, poke, pull e slide, com os quais aplicamos o mesmo tipo de classificação:

\begin{tabular}{|l|l|}
\hline Categoria semântica & Verbos \\
\hline trajetória & curl \\
\hline ação violenta & hammer, poke \\
\hline impulso / impacto & poke \\
\hline facilidade & slide \\
\hline direção & pull \\
\hline
\end{tabular}

Quadro 13 - Verbos que ocorrem na estrutura "effort * wide of" classificados por categoria semântica

$\mathrm{Na}$ busca com o termo ball encontramos dois verbos, thunder e send. O Roget's International Thesaurus classifica o primeiro, thunder, como verbo de explosão e o segundo, send, como verbo de transporte.

Apesar da classificação realizada, no modelo de glossário apresentamos as UFEs por ordem de frequência, tanto na macro quanto na microestrutura do verbete. Assim, a UFE mais frequente será lista primeiro (macroestrutura), da mesma maneira que os verbos e expressões mais frequentes serão listados por ordem de frequência em sua microestrutura: 
1) \{ SLASH | SLICE |SQUIRT | HOOK | CLIP | SCUFF | SCREW | DRAG | HIT

\{his|a\} shot $\{$ wide of the (far) post $\mid$ wide of the target $\mid$ wide of (the) goal | wide of [goalkeeper]'s goal\} (12);

2) CURL | HAMMER | POKE | PULL | SLIDE\} his effort \{wide of the (far) post | wide of the target | wide of (the) goal | wide of [goalkeeper]'s goal $\}$ (5);

3) $\{$ THUNDER $\mid$ SEND $\}$ the ball (just) wide of (the) goal (3).

\subsection{1 meio do gol, no (77)}

Geramos concordâncias para a expressão "the middle/centre of" a fim de constatar se a UFE em inglês era formada por um dos possíveis equivalentes prima facie de meio em português. A busca retornou 22 ocorrências, que reordenamos pelas duas primeiras palavras à direita e pela primeira palavra à esquerda:

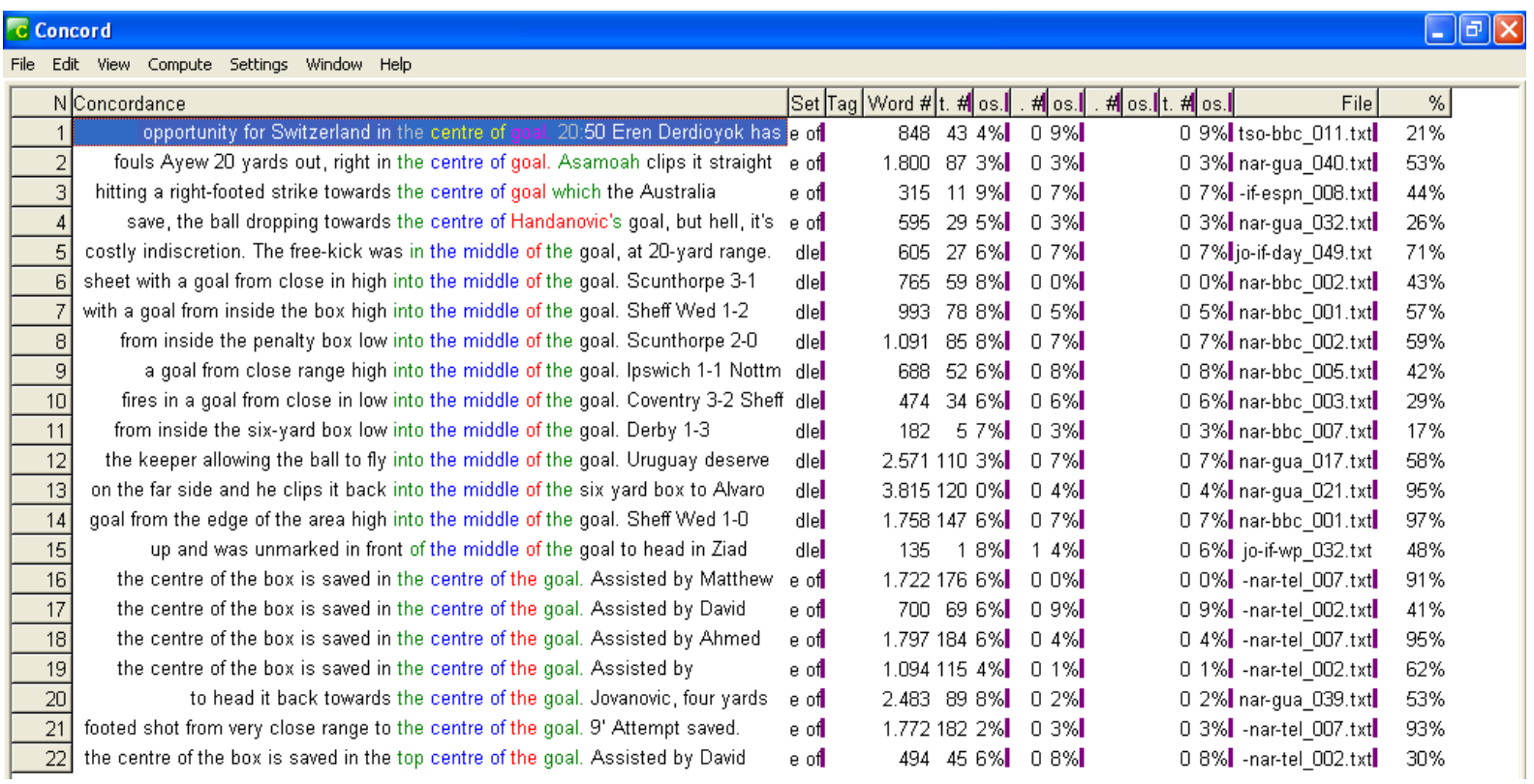

Figura 80 - Linhas de concordância para a expressão de busca "the middle/centre of"

Os resultados apontam os padrões \{into $\mid$ in\} the middle of the goal e in the centre of (the) goal como equivalentes para no meio do gol. 
Tanto em inglês quanto em português a UFE aparece quase que exclusivamente em transmissões minuto a minuto e transmissões sociais. A diferença de uso está no tipo de veículo informativo. Em português ocorre somente em periódicos esportivos e em inglês ocorre com mais frequência em jornais, mas também é encontrada em um tabloide (Daily Mail) e em um periódico esportivo (ESPN).

\subsection{1 [goleiro] segura no meio do gol (20)}

Expandimos o contexto das concordâncias de "the middle/centre of" e observamos o seguinte padrão: [shot | header] is saved in the centre of the goal.

Como podemos observar, a língua portuguesa utiliza a voz ativa para designar uma defesa que foi realizada no meio do gol, ao passo que a língua inglesa utiliza a voz passiva. Vejam-se os exemplos eminglês:

a) Kenwyne Jones right footed shot from the centre of the box is saved in the centre of the goal. Assisted by Matthew Etherington with a through ball.

b) Rafael Van der Vaart header from the centre of the box is saved in the centre of the goal.

Um fato a ser considerado é a diferença no número de ocorrências da UFE nas duas línguas. Em português o corpus apresenta 20 ocorrências e em inglês somente quatro, sendo que todas estas são de um mesmo jornal, The Telegraph. Acessamos o cabeçalho para examinar se os textos, todos narrações minuto a minuto, eram oriundos de um único autor e constatamos que não. As narrações foram feitas por três autores diferentes.

A diferença no número de ocorrências pode dever-se ao fato de que as notícias e narrações escritas em inglês, apesar de serem muito mais detalhadas, normalmente não enfatizam a posição do goleiro no momento da defesa. Tomemos como exemplo duas defesas realizadas em jogos da Copa do Mundo de 2010:

1) Defesa realizada pelo goleiro da Holanda em um jogo contra a Dinamarca 
Narração em português:

22' Agger avança ao ataque, chuta de longe e Stekelenburg segura no meio do gol, com facilidade.

Narração em inglês:

$22 \mathrm{~min}$ : He takes a couple of touches and then lets fly from just outside the box, but it's straight at Stekelenburg, who blocks comfortably.

2) Defesa realizada pelo goleiro da Argentina em um jogo contra o México

Narração em português:

43’ Rafael Marquez chuta de mui to longe e Romero segura no meio do gol.

Narração em inglês:

86 mins: Just looking at Hernandez's goal again: it is a real cracker. He is extremely nimble on his feet. Here's Salcido again having perhaps his 6th or 7th shot of the night but this is a real brick and it flies miles wide. David Keith is sceptical:" "Still not convinced by this argie side, their defense looks pretty rank, especially from set pieces and but for some culpable refereeing and daft mistakes, their frontline has generally been dealt with with ease." Hmm. Not sure about that. They have looked irresistible sparingly. Romero flumps down on another over-hit Mexican through pass, almost ruffling his immaculately sculpted beard.

Os dois casos acima representam algumas características de como a narração é realizada nas duas culturas. Neste caso, as ocorrências do corpus indicam que há uma tendência a mostrar o ângulo em que a defesa foi realizada nos jornais brasileiros. Não procedemos com tal afirmação tendo unicamente as ocorrências de no meio do gol como indício. Conduzimos buscas para expressões como no canto do, direito do, esquerdo do, para verificar se os outros ângulos também eram explicitados. Comprovamos que sim, embora com uma frequência menor. As narrações em inglês, 
por outro lado, demonstram preferir enfatizar o processo da defesa, daí a maior variedade de verbos utilizados para narrar uma defesa.

\subsection{VERBO para o fundo do gol (39)}

Geramos concordâncias de net e as ordenamos pelas três primeiras palavras à esquerda para encontrar um possível equivalente de VERBO para o fundo do gol:

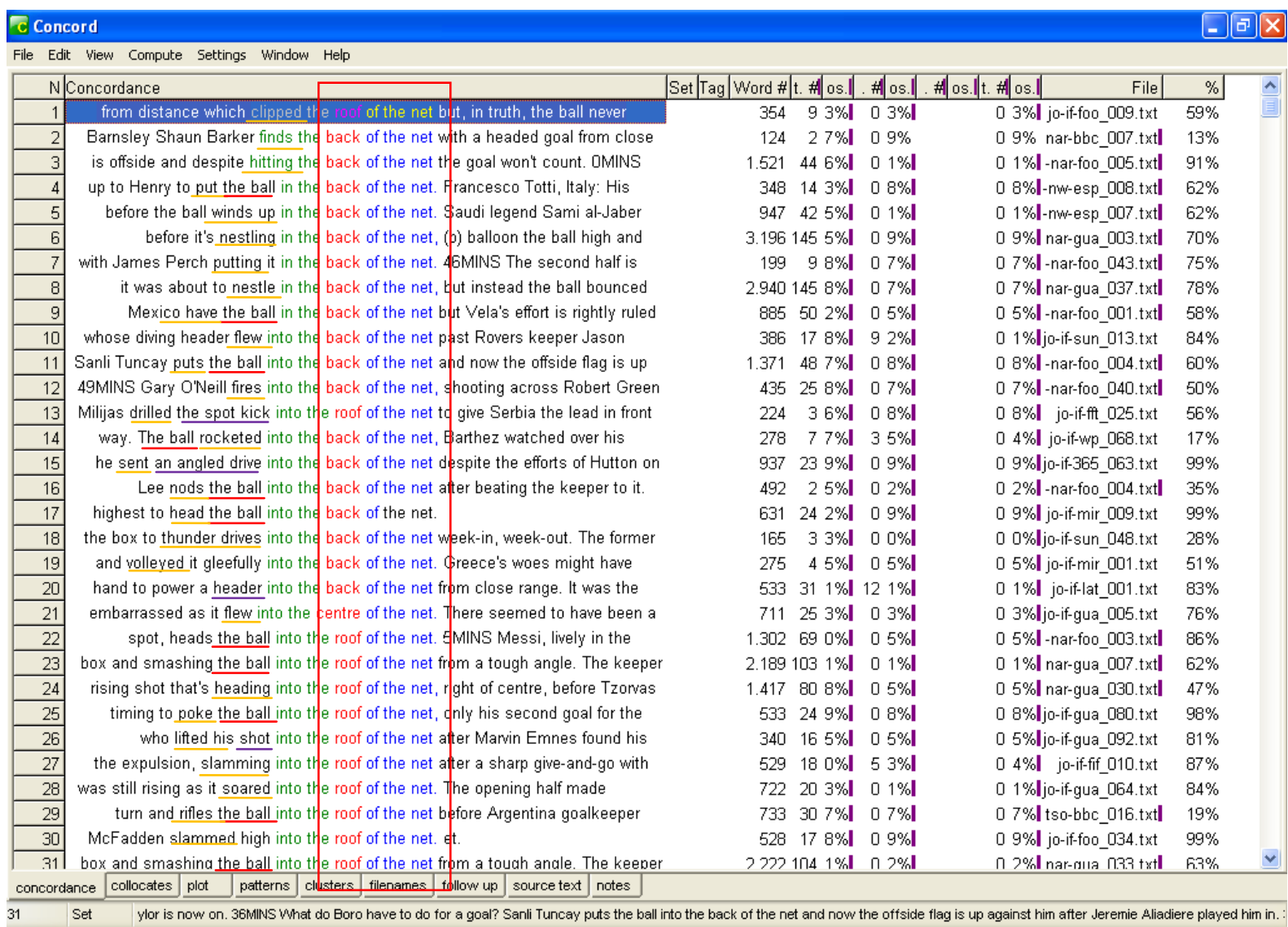

Figura 81 - Linhas de concordância de net ordenadas pelas três primeiras palavras à esquerda

Ao examinar as concordâncias percebemos que em inglês temos dois equivalentes para fundo do gol: back of the net e roof of the net. O primeiro, back of the net, pode vir antecedido por into the ou in the, o segundo, roof of the net, sempre vem antecedido de into the, formando a unidade into the roof of the net | (in|into) the back of the net . Essa unidade pode vir antecedida por the ball ou his shot e um verbo, como 
nas linhas 4, 9, 16, 22, 23, 26 e 31, ou simplesmente por um verbo para formar a UFE VERB (\{the ball | his shot $\})$ \{into the roof of the net | (in|into) the back of the net\}.

Nessa UFE, optamos por não analisar os verbos da UFE devido à grande variedade utilizada e ao índice de repetição nulo. Por mais que o índice de repetição em inglês seja sempre mais baixo do que em português, dada a diferença de construções formais com que a linguagem é utilizada, os verbos utilizados nas outras UFEs apresentam pelo menos duas ocorrências iguais.

Cremos poder afirmar que o uso das UFEs nas duas línguas é diferente no que se refere ao gênero textual. Em português, temos 36 ocorrências em notícias de resultados de partida e oito em narrações minuto a minuto e em inglês temos 39 em narrações e 13 em notícias. Em português, a UFE ocorre com frequência aproximada em jornais e periódicos esportivos e em inglês é mais comum em jornais.

\subsection{3 para o gol (318)}

A identificação de um equivalente para a UFE para o gol foi, ao contrário da maior parte da análise, um processo bastante simples, pois partimos do pressuposto de que o termo goalwards poderia funcionar como equivalente. Para averiguar a hipótese, geramos concordâncias para o termo e as ordenamos pelas três primeiras palavras à esquerda: 


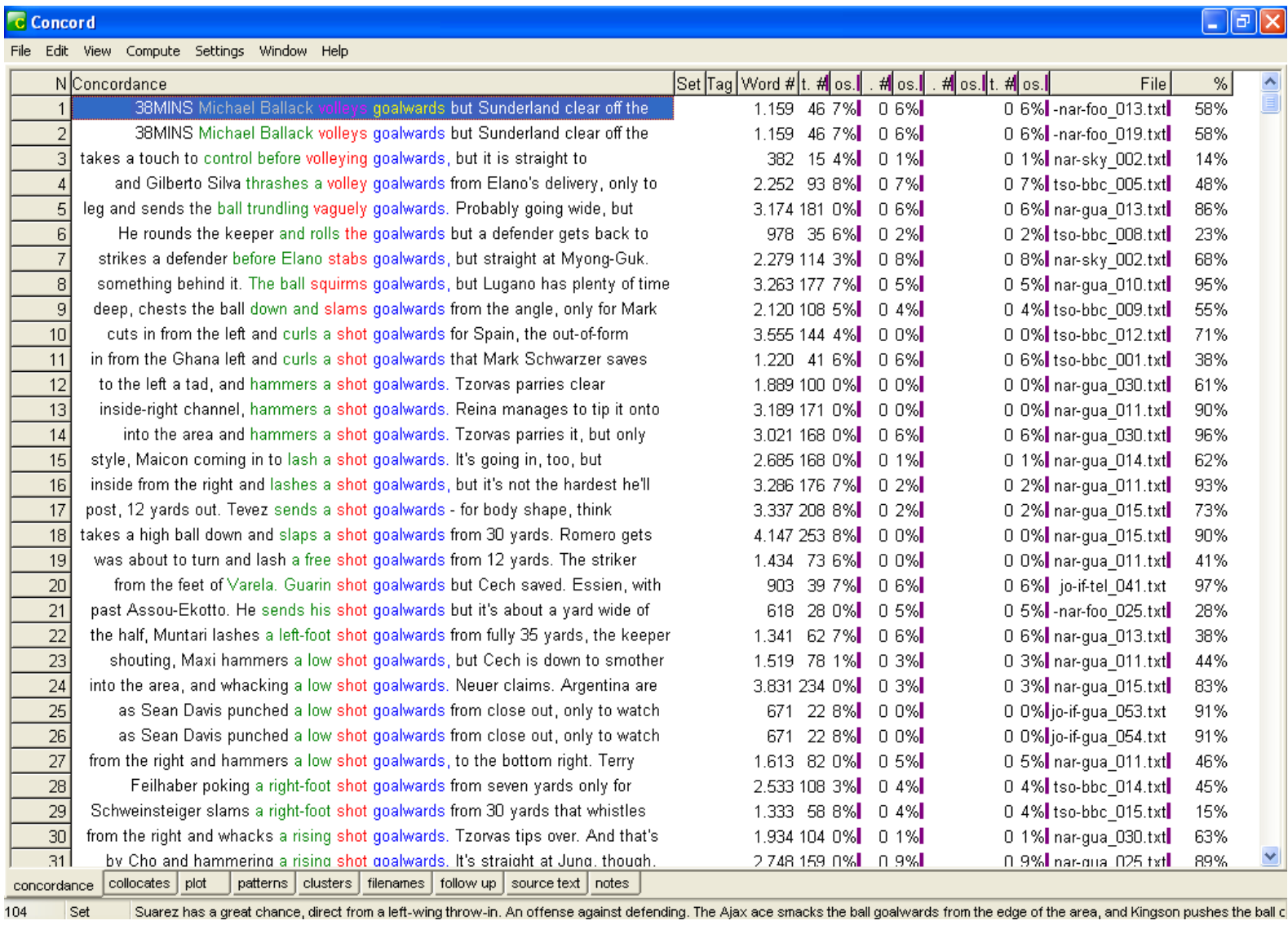

Figura 82- Parte das linhas de concordância de goalwards ordenadas pelas três primeiras palavras à esquerda

A pesquisa retornou 104 ocorrências que, depois de analisadas, confirmamos como equivalentes da UFE para o gol.

Das 104 ocorrências, apenas 12 ocorrem em notícias de resultados de partidas; a maior parte ocorre em narrações, tanto em transmissões minuto a minuto quanto na transmissão social. Em português, as ocorrências aparecem divididas de forma bastante equilibrada, metade em cada gênero textual. Tal característica pode ser explicada pela divisão detalhada que os sites ingleses apresentam. A UFE para o gol e sua equivalente em inglês, goalwards, são utililizadas para descrever uma ação em campo, que, em inglês, é sempre encontrada nas narrações minuto a minuto e não nas notícias. É esse o mesmo motivo pelo qual não encontramos ocorrências de goalwards nos tabloides, que não costumam realizar trans missões minuto a minto.

4.23.1 CABECEAR para o gol (15) 
Analisamos os colocados à esquerda de goalwards para encontrar o equivalente da UFE CABECEAR para o gol:

\begin{tabular}{|c|c|c|c|c|c|}
\hline \multicolumn{5}{|c|}{ C Concord } & \multirow{2}{*}{ - 0} \\
\hline File Edit & Wiew Compute Settings Window Help & & & & \\
\hline \multicolumn{2}{|c|}{$\mathrm{N}$ Concordance } & Set $\mid$ Tag $\mid$ Word \# t. \# & . & \#| os.||t. $\# \mid$ os.|| & $\%$ \\
\hline 1 & goalwards but it's headed off the line at & $1.503740 \%$ & $05 \%$ & $05 \% \mid$-nar-foo_029.txt| & $57 \%$ \\
\hline 2 & Taylor's inswinging corner was headed goalwards by Gary Cahill, but his & $690228 \%$ & $06 \% \mathbf{I}$ & 0 6\%ljo-if-365_005.txt & $87 \%$ \\
\hline 3 & Taylor's inswinging corner was headed goalwards by Gary Cahill, but his & $686238 \%$ & $06 \% \mathbf{l}$ & 0 6\% jo-if-spl_006.txt & $88 \%$ \\
\hline 4 & A cross from Van Persie was headed goalwards by Thomas Vermaelen into & $400 \quad 150 \%$ & $00 \% \mathbf{I}$ & 0 0\%l jo-iffoo_029.txt & $82 \%$ \\
\hline 5 & \multirow{2}{*}{$\begin{array}{l}\text { again - has a chance, flicking a header goalwards from a corner but it is cleared } \\
\text { penalty area. King glances a header goalwards but it comes back off the }\end{array}$} & $2.0241023 \%$ & $01 \% \mathbf{I}$ & 0 1\%Itso-bbc_009.txtl & $52 \%$ \\
\hline 6 & & $1.626875 \%$ & $07 \% \mathbf{I}$ & $07 \% \mathbf{I}$-nar-foo_025.txtl & $67 \%$ \\
\hline 7 & \multirow{2}{*}{$\begin{array}{l}\text { of Steven Taylor and powered a header goalwards. It took an excellent stop from } \\
\text { when Gael Givet powered a header goalwards from a Dunn corner and }\end{array}$} & $34180 \%$ & $04 \%$ & $04 \%$ ljo-if-gua_022.txt & $72 \%$ \\
\hline 8 & & $393127 \%$ & $03 \%$ & 0 3\%l jo-if-foo_012.txt & $87 \%$ \\
\hline 9 & of Steven Taylor and powered a header goalwards. It took an excellent stop from & $34280 \%$ & $04 \%$ ] & $04 \%$ ljo-if-gua_072.txt & $72 \%$ \\
\hline 10 & \multirow{3}{*}{$\begin{array}{l}\text { from deep and Jones thumps a header goalwards, which Friedel pushes away. } \\
\text { in. Cesar manages a flicked header goalwards, but James is well behind it. } \\
\text { of the ball and can't send his header goalwards. He'll probably feel he should }\end{array}$} & $1.598704 \%$ & $05 \%$ & 0 5\%I nar-gua_012.txtl & $66 \%$ \\
\hline 11 & & $2.2771374 \%$ & $06 \% \mathbf{l}$ & 0 6\% I nar-gua_035.txt| & $47 \%$ \\
\hline 12 & & $1.539810 \%$ & $03 \% \mathbf{I}$ & $03 \% \mid$-nar-foo_025.txt| & $64 \%$ \\
\hline 13 & \multirow{2}{*}{$\begin{array}{l}\text { Richards rose to send a looping header goalwards and Almunia, the penalty } \\
\text { of a kangaroo, rising high and heading goalwards only to be denied by a }\end{array}$} & $730 \quad 264 \%$ & $01 \% \mathbf{I}$ & 0 1\%ljo-if-day_054.txt & $83 \%$ \\
\hline 14 & & $530193 \%$ & $71 \% \mathbf{l}$ & 0 1\% jo-if-tel_009.txt & $55 \%$ \\
\hline 15 & arm and looks to be heading goalwards, but swerves wide. $62 \mathrm{~min}$ : & $2.499848 \%$ & $03 \% \mathbf{I}$ & 0 3\%I nar-gua_012.txt| & $74 \%$ \\
\hline 16 & Figueroa to the ground before heading goalwards. Foul, but the keeper saved it & $2.269900 \%$ & $00 \% \mathbf{I}$ & 0 0\%l tso-bbc_008.txtl & $51 \%$ \\
\hline
\end{tabular}

Figura 83 - Seleção de linhas de concordância de goalwards ordenadas pelas três primeiras palavras à direita

As linhas 5, 6, 7, 8, 9, 10, 12 e 13 nos direcionam para a seguinte estrutura:

\{POWER $\mid$ THUMP | GLANCE | FLICK | SEND\} a header goalwards (39)

O quadro 14 mostra a classificação que fizemos para os verbos por campo semântico:

\begin{tabular}{|l|l|}
\hline Categoria semântica & Verbos \\
\hline transporte & send \\
\hline movimento rápido & flick, glance \\
\hline impulso / impacto & thump, power \\
\hline
\end{tabular}

Quadro 14 - Verbos classificados por categoria semântica

\subsection{2 [jogador] DES VIAR para o gol (18)}

Realizamos o mesmo procedimento descrito no item anterior para encontrar o equivalente de [jogador] DESVIAR para o gol e o estudo das concordâncias nos direcionou à seguinte estrutura, que ocorreu cinco vezes no corpus:

[footballer] \{DIVERT | DEFLECT\} the ball goalwards 
Em razão do baixo número de ocorrências, achamos por bem entender melhor o uso da UFE em português para, assim, poder validar a estrutura em inglês como equivalente sem fazer generalizações infundadas. Tomemos os seguintes exemplos em português, ambos de transmissões minuto a minuto:

a) A bola sobrou para Denis Marques, que se esticou mas não conseguiu desviar para o gol.

b) MILAGREEEEEEE!!!!!!!!! Adriano aproveita cruzamento de escanteio e desvia para o gol. Felipe faz um verdadeiro milagre a queima-roupa.

No primeiro exemplo, a tentativa de desvio para o gol é feita a partir de uma bola que sobrou em uma jogada. No segundo, o desvio é feito a partir de um cruzamento, mas não resultou em gol, pois o goleiro Felipe fez a defesa. Observemos, agora, os exemplos em inglês:

a) Long range effort from Scholes. It's looking like it's well off target but Berbatov throws out a leg to deflect it goalwards, but it's wide.

b) Mark van Bommel sends over a cross from the right and Van Persie reaches the ball first at the near post, but cannot divert the ball goalwards.

No primeiro caso, o desvio é feito a partir de um effort, que pode ser traduzido para o português como uma tentativa ou mesmo como um lançamento, e passa longe do gol; no segundo, embora Van Persie chegue na bola após a inversão de Mark van Bommel, ele não consegue fazer o desvio.

A análise das concordâncias revelou que tanto em inglês quanto em português o desvio para o gol é feito a partir de uma inversão, de um cruzamento, de um lançamento ou de uma bola que sobra e raramente resulta em gol, com exceção de duas ocorrências no corpus de português. 
a) Porém, o Goiás acabou com a esperança do time alvinegro. Cinco minutos depois, Júlio César cobrou falta na cabeça de João Paulo, que desviou para o gol: 4 a 1 .

b) Aos 20, Maranhão cruzou e Henrique chegou antes de Fabão para desviar para o gol: 2 a 1 .

Após confirmar a situação e contexto de uso das UFEs nas duas línguas, validamos a UFE [footballer] \{DIVERT | DEFLECT\} the ball goalwards como equivalente de [jogador] DESVIAR para o gol.

\subsection{3 \{ARREMATAR | COMPLETAR | CONCLUIR | FINALIZAR $\}$ para o} gol (45)

Ao observar as concordâncias de goalwards em busca de possíveis equivalentes para os verbos arrematar, completar, concluir e finalizar, deparamos com os verbos drive, send, guide e direct.

Um achado interessante é que os verbos em português fazem parte da categoria semântica de "completude", pois todos sugerem a conclusão de uma ação. Já os verbos em inglês classificam-se na categoria de "transporte", já que todos indicam a condução de um objeto (the ball) de um ponto a outro. Outro possível equivalente em inglês seria o verbo finish (off), que, assim como a UFE em português, foca na conclusão da ação. Observemos os exemplos:

a) The attacker finished with a low and precise drive.

b) Germany had taken an early lead when Gonzalo Castro finished off Jerome Boateng's through ball from 12 yards.

Após ampliar o contexto das oito ocorrências com verbos de transporte e analisar as 58 ocorrências de FINISH (off), confirmamos a estrutura \{DRIVE | SEND | 
GUIDE | DIRECT\} it goalwards e o termo finish (off) como equivalentes da UFE em português.

\subsection{4 \{BATER | CHUTAR | EMPURRAR | MANDAR | TOCAR\} para o gol} (108)

Realizamos o mesmo procedimento empregado nos itens anteriores para identificar o(s) equivalente(s) da UFE $\{$ BATER $\mid$ CHUTAR $\mid$ EMPURRAR $\mid$ MANDAR $\mid$ TOCAR\} para o gol e chegamos a três estruturas:

1) $\{$ FIRE $\mid$ SLAM $\}$ goalwards (7)

a) Branislav Ivanovic bursts into the Australia area from deep, chests the ball down and slams goalwards from the angle, only for Mark Schwarzer to stick out a hand and somehow keep the ball out of his goal.

b) Etuhu makes a fantastic late run into the area from the left, bursting past Evans and $O^{\prime}$ Shea to take a pass and fire goalwards.

Encontramos sete ocorrências da estrutura no corpus, quatro com o verbo fire e três com o verbo slam, sendo que todas ocorrem em narrações de jornais e periódicos esportivos.

De acordo com a classificação de categoria semântica do Roget's International Thesaurus, o verbo fire pertence à categoria de ação violenta e o slam à categoria de verbos de impulso/impacto.

2) $\{$ BLAST $\mid$ BOOT $\mid$ FIRE $\mid$ HAMMER $\mid$ LASH | POKE | POWER $\mid$ PROD $\mid$ SEND | SMASH | SLAM |STAB | VOLLEY | CHIP | LOOP\} the ball goalwards (22)

O quadro abaixo mostra a classificação dos verbos por categoria semântica: 


\begin{tabular}{|l|l|}
\hline Categoria semântica & Verbos \\
\hline trajetória & loop, volley \\
\hline explosão & blast \\
\hline transporte & send \\
\hline ação violenta & fire, blast, hammer, chip, lash, smash, poke, stab, fire \\
\hline direção & boot \\
\hline impulso / impacto & slam, power, prod \\
\hline
\end{tabular}

Quadro 15 - Verbos classificados por categoria semântica

Como a tabela mostra, os verbos fire, blast, hammer, chip, lash, smash, poke, stab e fire indicam uma ação violenta. Observemos alguns exemplos:

a) Valencia gets the ball on the right and pulls it back for Scholes. He fires it goalwards first time from the edge of the area, but it's deflected wide for a corner.

b) Agger gets the ball in the penalty area and blasts it goalwards. It deflects off Yuki Abe's back and then Makoto Hasebe's hand before bouncing away to safety. No penalty.

c) Gerrard tries to hammer it goalwards, but Murphy is out quickly to block, then clear.

d) The ball comes back to Lionel Messi, who chips it goalwards but Tevez, who is miles offside, heads it in.

e) Downing crosses from the left and the ball flies about for a bit before falling to Collins, who lashes it goalwards from about eight yards, out to the left of goal, only for Sorensen to block.

Cabe uma curiosidade sobre esse grupo. Além de todos os verbos terem embutidos em seu significado um ato de violência, são sempre utilizados para caracterizar uma tentativa de gol que não deu certo, seja porque a bola foi desviada por outro jogador ou porque o "chute" foi para fora. Em nosso corpus, nenhum gol foi marcado nas 22 ocorrências da estrutura.

3) $\{$ HAMMER $\mid$ LASH $\mid$ SEND $\mid$ SLAP $\mid$ PUNCH $\mid$ SLAM $\mid$ POKE $\mid$ WHACK $\}$ a shot goalwards (14) 
Como podemos observar, os verbos que coocorrem com shot não são os mesmos que coocorrem com ball. Após a identificação dos colocados de shot, realizamos a mesma classificação semântica aplicada às outras estruturas:

\begin{tabular}{|l|l|}
\hline Categoria semântica & Verbos \\
\hline transporte & send \\
\hline ação violenta & hammer, lash, slap, whack, punch, poke, slam \\
\hline
\end{tabular}

Quadro 16 - Verbos classificados por categoria semântica

Embora os verbos sejam diferentes, esta estrutura, assim como as anteriores, é utilizada para descrever uma tentativa de gol que não foi concretizada:

a) Tevez sends a shot goalwards but Mertesacker is right next to him to take the shot in the face.

b) The increasingly impressive Gakas twists yet again on a sixpence, latching onto a poor defensive header by Cho and hammering a rising shot goalwards.

c) Sturridge nips inside from the right and lashes a shot goalwards, but it's not the hardest he'll ever hit, and Reina is fully behind it.

d) They break with pace down the right and a ball into the box is controlled and helped on by Jozy Altidore, with Benny Feilhaber poking a right-foot shot goalwards from seven yards only for Richard Kingson to stick out his left hand and make a top save.

e) Defoe is brilliantly tackled by Arne Friedrich on the edge of the Germany area, before Bastian Schweinsteiger slams a right-foot shot goalwards from 30 yards that whistles wide of the England goal.

f) Di Maria dances, shimmies, shakes and makes other disco-friendly movements down the right, before cutting inside, romping into the area, and whacking a low shot goalwards.

g) It arrived in the dying seconds as Sean Davis punched a low shot goalwards from close out, only to watch Fulop make another remarkable save. 
h) Kroos takes a high ball down and slaps a shot goalwards from 30 yards. Romero gets down to palm away.

A análise das UFEs revelou que o termo goalwards está relacionado à "não finalização" da jogada.

Em português, a estrutura $\{$ BATER $\mid$ CHUTAR $\mid$ EMPURRAR $\mid$ MANDAR $\mid$ TOCAR $\}$ para o gol é utilizada tanto com gols marcados quanto com tentativas que não deram certo, com exceção do verbo empurrar que, nessa UFE, tem prosódia semântica sempre positiva, pois só é utilizado para descrever gols marcados. Tomemos os exemplos:

a) O meia Lampard dominou na entrada da área, bateu para o gol e a bola acabou nas mãos do goleiro da Juventus, que segurou firme.

b) A redenção de Iarley veio aos 33 minutos do primeiro tempo, quando o centroavante recebeu bom passe de Vítor, desvencilhou-se de uma falta e bateu para o gol, abrindo o placar do clássico.

c) No segundo tempo, o Goiás entrou mais ligado. Aos 19 minutos, Vitor entrou dentro da grande área do Vila Nova, tabelou com Romerito, recebeu de volta e chutou para o gol, mas a bola não acertou a meta adversária.

d) Após lançamento de Salomon Kalou na área, o atacante Drogba dominou no meio da área, virou e chutou para o gol, marcando o primeiro tento da partida para o Chelsea.

e) Dois minutos mais tarde, o mesmo Neymar chutou da entrada da área, Fernando Henrique espalmou e Kléber Pereira apareceu para empurrar para o gol e definir o placar. 4 a 1.

f) Zagueiro Wellington aproveita rebote de cabeçada e, da pequena área, manda para o gol!! GOOOOOLLLL DO BOTAFOGOOOOOO!!

g) GRANDE CHANCE! Polsen manda para o gol, mas o goleiro japônes consegue mandar para escanteio. 
h) Maicon recebe na direita e chuta com a esquerda. Luis Fabiano, em posição le gal, domina e toca para o gol. GOOOOOOOOOOOLLL DO BRASIL!!!!

i) UUUUUUUHHH!!! Quase um golaço!!! Rooney recebe an frente, aplica um chapéu em Onyewu e toca para o gol. Em cima da linha, Demerit, salva os Estados Unidos.

\subsubsection{RECEBER de costas para o gol (10)}

Geramos concordâncias para a expressão "back * goal" a fim de encontrar o equivalente de RECEBER de costas para o gol. A busca retornou 40 ocorrências, sendo 30 da expressão "with his back to goal”.

Analisamos os colocados à esquerda da expressão e identificamos 13 ocorrências dos verbos pick up, gather e receive:

a) Pienaar picks up the ball with his back to goal 30 yards out and is tripped as he tries to turn.

b) Cole's goal in the 49th minute was from the Drogba back catalogue as he gathered a long ball with his back to goal, held it up, rolled his marker and unleashed a left-footer which screamed past Carlo Cudicini, standing in, a little shakily, for the injured Heurelho Gomes in the Spurs goal.

c) Wayne Rooney creates a chance out of nothing. He receives the ball with his back to goal, turns quickly and fires goalwards, but the ball drifts just wide.

Analisadas as linhas de concordância, que não foram apresentadas aqui, pois tivemos que ampliar o contexto de todas para observar a estrutura completa, validamos a estrutura \{PICK UP | GATHER | RECEIVE\} the ball with his back to goal como equivalente de RECEBER de costas para o gol.

Em português a UFE ocorre tanto em textos jornalísticos como em narrações de jornais e periódicos esportivos. Por outro lado, seu correspondente em inglês, ocorre quase 
exclusivamente em narrações, com apenas duas ocorrências em notícias de resultados de partida do tabloide The Sun.

\subsection{VERBO para o gol vazio (33)}

Estabelecer um equivalente em inglês para a UFE VERBO para o gol vazio não demandou tanto trabalho. Em nosso corpus, conduzimos uma busca para a palavra empty, um dos equivalentes prima facie de vazio em inglês, e obtivemos 75 ocorrências:

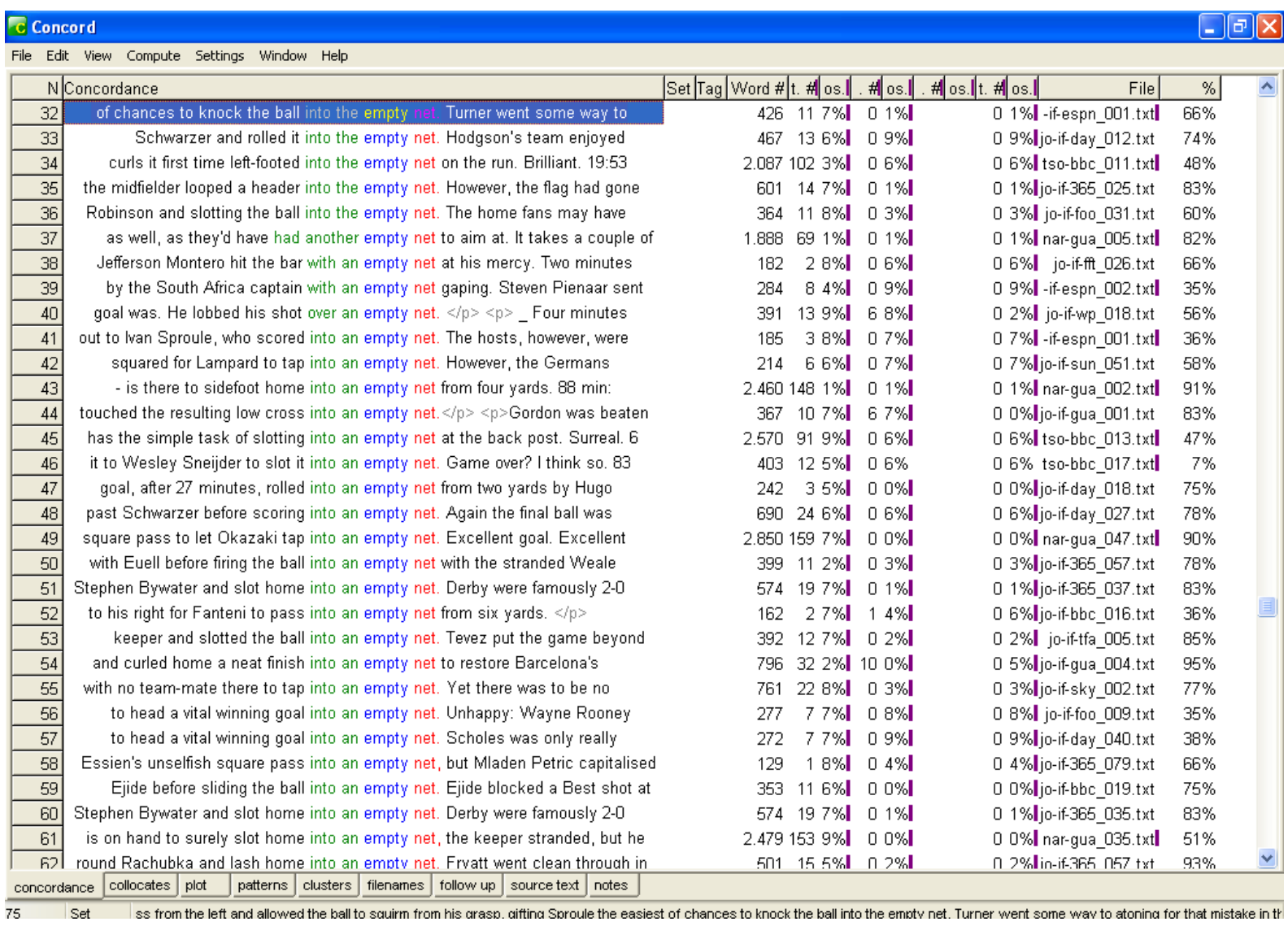

Figura 84 - Parte das linhas de concordância para empty ordenadas pela primeira palavra à direita e pelas duas primeiras palavras à esquerda

As concordâncias nos direcionam para o padrão into an empty net, que ocorre 40 vezes no corpus, sendo 30 vezes precedido de um verbo.

Assim como no item 4.22, optamos por não analisar os verbos da UFE devido à grande variedade utilizada e ao índice de repetição nulo. Portanto, validamos a estrutura VERB into an empty net como de VERBO para o gol vazio. 
Em português, a UFE ocorre 33 vezes no corpus. 14 em textos jornalísticos e 19 em narrações, sempre em periódicos esportivos, com exceção de uma ocorrência no jornal $O$ Globo. Seu equivalente em inglês ocorre com frequência aproximada nas notícias (14) e nas narrações (16) e está presente em jornais, periódicos esportivos e tabloides.

\subsection{5 perigo ao gol de [goleiro] (36)}

As primeiras buscas realizadas foram para as palavras danger e risk, possíveis equivalentes de perigo. O WordSmith Tools retornou 178 e 25 ocorrências, respectivamente. Todavia, nenhuma das ocorrências coocorria com goal ou tinha o mesmo sentido da UFE em português. Nossa próxima busca foi para a palavra threat, outro equivalente prima facie de perigo:

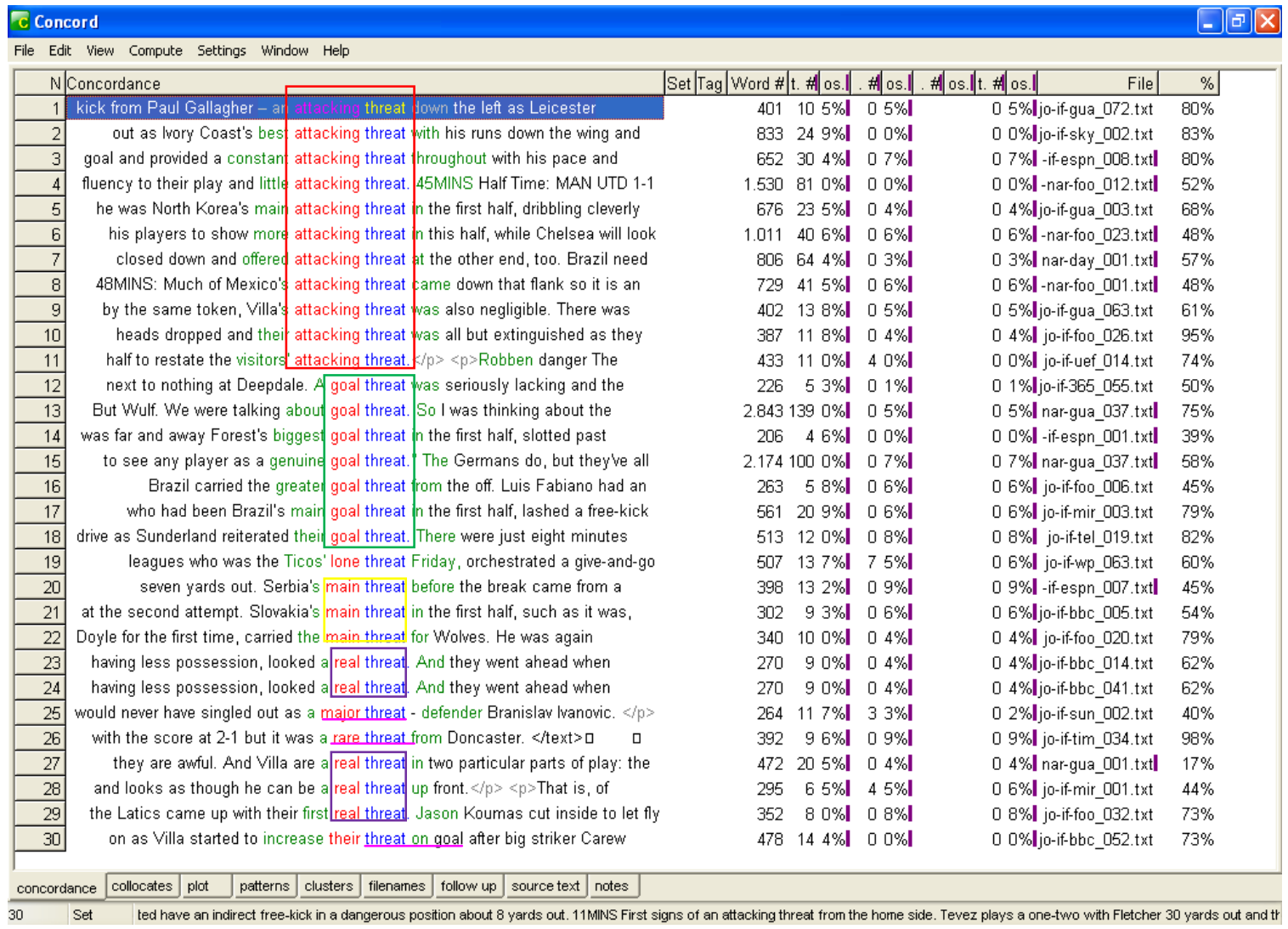

Figura 85 - Seleção das linhas de concordância de threat ordenadas pelas duas primeiras palavras à esquerda e pela primeira palavra à direita

Analisamos os 89 casos do substantivo threat e identificamos 30 ocorrências, que aparecem marcadas na figura 85, como equivalentes de perigo ao gol de [goleiro]. Assim como a maior parte dos equivalentes encontrados ao longo da pesquisa, a 
estrutura da UFE nas duas línguas é bem diferente. Ademais, o conteúdo e a informação também apresentam aspectos particulares em cada língua. Enquanto em português sempre mencionamos o nome do goleiro, em inglês, o goleiro é omitido e o foco da UFE recai sobre a intensidade da ameaça: real, major, rare, main, best, biggest, genuine e greater. Não encontramos nenhuma ocorrência de threat indicando perigo ao gol sem ser antecedido por um adjetivo, com exceção da última ocorrência: threat on goal.

Apesar da diferença na estrutura e no foco, confirmamos attacking threat / goal threat / real threat / main threat / rare threat / major threat / threat on goal como equivalentes de perigo ao gol de [goleiro], já que as duas UFEs são utilizadas na mesma situação. Ou seja, para indicar uma ameaça ao gol de um time, funcionando, portanto, da mesma maneira nas duas línguas.

\subsection{6 (muito) perto do gol (79)}

Geramos concordâncias para dois possíveis equivalentes de perto em inglês, near e close, e obtivemos 390 e 600 ocorrências, respectivamente. Entretanto, nenhuma colocava com goal ou exercia a mesma função da UFE (muito) perto do gol. Decidimos, então, buscar pela expressão "bar / post / crossbar", palavras equivalentes à estrutura física do gol eminglês:

Obtivemos 1914 ocorrências de bar, post e crossbar, 936 antecedidas do artigo definido the e 413 antecedidas das preposições over e past. A figura 86 exibe uma seleção das linhas de concordância da expressão de busca: 


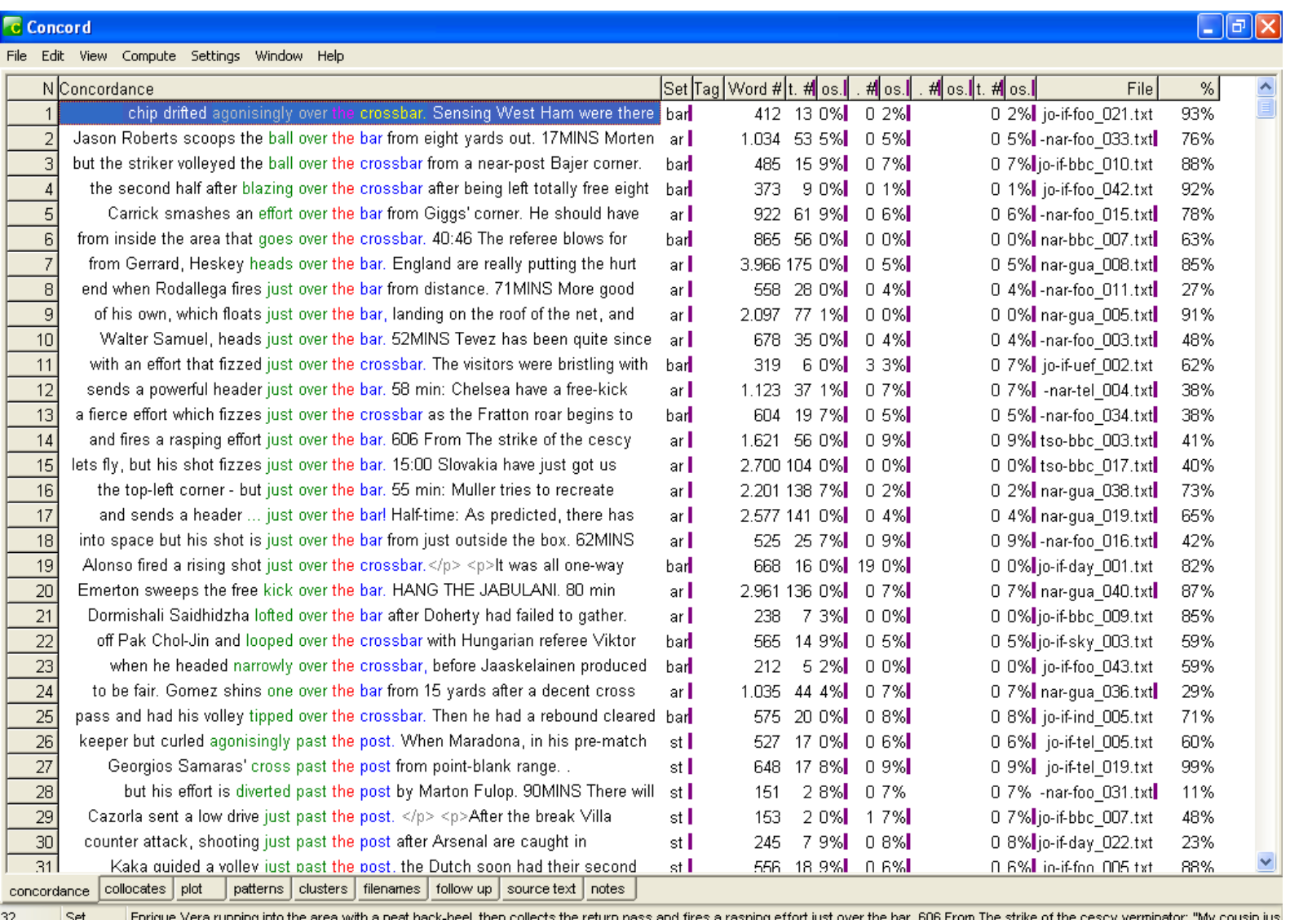

Figura 86 - Seleção das linhas de concordância da expressão de busca“"bar / post / crossbar"

As concordâncias apontam o padrão (just) \{over $\mid$ past $\mid$ narrowoly wide of\} the $\{$ bar $\mid$ post $\mid$ crossbar\} como UFE equivalente de (muito) perto do gol.

As UFEs são utilizadas de forma bastante semelhante nas duas línguas. Em português, ocorre em notícias de jornais e em narrações de periódicos esportivos, sendo muito mais frequente nas narrações. Em inglês, ocorre em notícias e narrações de jornais e periódicos esportivos, sendo mais frequente também nesta última, além de estar presente em algumas notícias de tabloides, apresentando somente dez das 413 ocorrências nesse último tipo de periódico.

\subsection{1 a bola PASSAR (muito) perto do gol (42)}

Para identificar o equivalente da UFE, observamos os colocados à esquerda de (just) \{over | past $\mid$ narrowly wide of\} the \{bar $\mid$ post $\mid$ crossbar\} e chegamos a duas estruturas: 
1) \{the ball $\mid$ the effort $\mid$ a shot $\mid$ a header\} \{GO $\mid$ FLASH\} (just)\{\{over $\mid$ past $\}$ the bar $\mid$ \{over|past\} the crossbar| over the post\}

2) \{the ball\} $\{B O U N C E|F L Y| B O B B L E\}$ narrowly wide of \{(goalkepper's) goal $\mid$ the (far) post\}

Depois de investigar os contextos, validamos as duas estruturas como UFEs. No entanto, não conseguimos estabelecer um padrão de uso, ou seja, identificar o tipo de periódico nem o gênero textual, pois o uso da UFE é bem amplo. Assim, a fim de proporcionar informações detalhadas, classificamos os verbos por categoria semântica:

\begin{tabular}{|l|l|}
\hline Categoria semântica & Verbos \\
\hline movimento & bounce, booble \\
\hline transporte & fly, go \\
\hline velocidade & flash \\
\hline
\end{tabular}

Quadro 17 - Verbos classificados por categoria semântica

\subsection{7 por cima do gol (230)}

Geramos concordâncias para a expressão de busca "bar / crossbar" e as ordenamos pelas três primeiras palavras à esquerda em busca do possível colocado over e chegamos à UFE over the \{bar|crossbar\}, que ocorre 395 vezes no corpus.

Em português, por cima do gol ocorre em notícias de jornais e narrações de periódicos esportivos, apresentando mais ocorrências neste último gênero. Em inglês, over the bar é utilizada de forma semelhante, em notícias e narrações, onde é mais frequente. A única diferença é que, ao contrário dos jornais brasileiros, os jornais ingleses disponibilizam transmissões minuto a minuto. Por este motivo, a ocorrência da UFE é bem mais comum em jornais do que em periódicos esportivos, já que nos primeiros ocorre tanto em notícias quanto em narrações.

4.27.1 a bola $\{$ IR |PASSAR | SAIR $\}$ por cima do gol (51) 
Analisamos as linhas de concordância de over the bar observando os verbos que ocorrem à esquerda e identificamos três estruturas:

1) the ball $\{F L Y \mid S O A R\}$ over the bar (19)

a) Shawcross nearly sells Sorensen short with a back-pass, which the keeper blasts at Nigel Reo-Coker, barely a yard away from him by then. The ball flies over the bar.

b) But credit to Chile - they did not give up and Jorge Valdivia's right foot volley had Julio Cesar concerned, before the Jabulani ball soared over the bar.

Ambos os verbos pertencem à categoria semântica de vôo, de acordo com o Roget's International Thesaurus.

2) \{the $\mid$ his\} shot $\{F L Y|G O| D I P\}$ over the bar (15)

a) Maxi attempts to volley a ball dropping by the left-hand edge of the Chelsea area into the top-right corner of Cech's goal. The shot flies over the bar, but given the difficulty of the shot, not by that much. A spectacular effort.

b) Shot from just outside the area by Jake Livermore goes over the bar.

c) Elliott had the first effort of the second half with a fierce long-range shot that dipped just over the bar.

Neste grupo, cada verbo pertence a uma categoria semântica. Fly faz parte da categoria de verbos de "voo"; go pertence à categoria de "transporte"; e dip de verbos de "movimento para dentro". 
3) \{the|his\} \{effort $\mid$ header\} GO over the bar (8)

a) Hermann Hreidarsson has a great chance from a Jermaine Pennant corner, but his header goes over the bar.

b) Clarke Carlisle meets the ball at the back post from a Burnley corner, but his effort goes over the bar, much to home fans delight.

4.27.2 CABECEAR por cima do gol (26)

Realizamos o mesmo procedimento descrito no item anterior para encontrar o equivalente de CABECEAR por cima do gol e deparamos com duas estruturas:

1) HEAD over the bar (31)

a) Gary $O^{\prime} N e i l$ puts a free kick into the middle from the right-hand side and Afonso Alves heads over the bar.

2) $\{P U T|S E N D| P L A C E \mid$ PLANT $\}$ his header over the bar (17)

a) Stephen Ward reaches the byline and stands a cross up for Ebanks-Blake who is wide open but he sends his header over the bar.

b) Jeremie Aliadiere comes in and puts his header over the bar after a great cross from Stewart Downing into the middle.

c) But the Frenchman placed his header over the bar and City were then allowed to test out the kind of football Arsenal "don't enjoy", as Hughes had put it. 
d) On 77 minutes a curling corner found a completely unmarked Ramos. Yet from just seven yards out the Real Madrid defender planted his header over the bar to mark an astonishing miss.

No que se refere à categorização semântica, o verbo send pertence à categoria de "transporte" e os verbos put, place e plant à categoria de verbos de "alocação". E, assim como as outras UFEs que relatam uma jogada aérea, as duas estruturas identificadas são mais comuns em inglês do que em português.

\subsection{3 \{CHUTAR | MANDAR\} (a bola) por cima do gol (64)}

Apresentamos, separadamente, as quatro UFEs confirmadas como equivalentes de \{CHUTAR | MANDAR\} (a bola) por cima do gol, seguidas da categorização semântica dos verbos que as compõem.

1) $\{B L A S T|S E N D| B L A Z E|F L I C K| S C O O P\}$ the ball over the bar (38)

\begin{tabular}{|l|l|}
\hline Categoria semântica & Verbo \\
\hline explosão & blast \\
\hline transporte & send \\
\hline movimento rápido & flick \\
\hline escavação & scoop \\
\hline queimar & blaze \\
\hline
\end{tabular}

Quadro 18 - Verbos classificados por categoria semântica

2) $\{$ BLAZE $\mid$ FIRE $\mid$ BLAST $\mid$ BOOM $\mid$ BOOT $\mid$ FINISH $\mid$ WHIP $\mid$ SLAM $\}$ over the bar (27)

\begin{tabular}{|l|l|}
\hline Categoria semântica & Verbo \\
\hline explosão & boom, blast \\
\hline completude & finish \\
\hline violência & whip, slam \\
\hline direção & boot \\
\hline queimar & blaze, fire \\
\hline
\end{tabular}

Quadro 19 - Verbos classificados por categoria semântica

3) $\{$ SMASH $\mid$ HIT $\mid$ FIRE\} \{an|his\} effort over the bar (16) 


\begin{tabular}{|l|l|}
\hline Categoria semântica & Verbo \\
\hline ação violenta & smash, hit, fire \\
\hline
\end{tabular}

Quadro 20 - Verbos classificados por categoria semântica

4) $\{$ SEND $\mid B A N G\}\{$ a his $\}$ shot over the bar (11)

\begin{tabular}{|l|l|}
\hline Categoria semântica & Verbo \\
\hline transporte & send \\
\hline ação violenta & bang \\
\hline
\end{tabular}

Quadro 21 - Verbos classificados por categoria semântica

\subsection{8 primeiro gol, o (173)}

A busca para a expressão " $J J *$ goal", em que a etiqueta $J J$ corresponde a um adjetivo, realizada para encontrar os equivalentes de belo gol, bonito gol e gol incrível, nos permitiu identificar the first goal e \{the|an\} opening goal como equivalentes de $o$ primeiro gol com 147 e 59 ocorrências no corpus, respectivamente.

Também geramos concordâncias para opener, termo que já conhecíamos, e, após observar as 156 linhas, identificamos 37 ocorrências em que the opener é utilizado como equivalente de o primeiro goal.

Em português, a UFE ocorre em notícias de jornais e narrações de periódicos esportivos, apresentando frequência muito maior no primeiro gênero. Em inglês, o uso da UFE é distribuído quase que uniformemente entre narrações e notícias e é característica de jornais e periódicos esportivos, com apenas 13 das 206 ocorrências em tabloides (sete no Daily Mail e seis no The Sun).

\subsection{1 o primeiro gol do [time] (29)}

Geramos concordâncias para a expressão de busca “'s POS 's first JJ first goal $N N$ goal”, em que "'s POS 's" corresponde ao caso genitivo e "first JJ first goal NN goal" a first goal: 


\begin{tabular}{|c|c|c|c|c|c|c|}
\hline \multicolumn{3}{|c|}{ C Concord } & & & & \multirow[t]{2}{*}{$-0 x$} \\
\hline File Edit & Yiew Compute Settings Window Help & & & & & \\
\hline $\mathrm{NC}$ & Concordance & & Set Tag $\mid$ Word \#|t. \#n os.| & Hillos.| & \#| os.||t. \#| os.|| & $\%$ \\
\hline 1 & score South NP South Africa NP Africa & of $\mathbb{I N}$ & $317 \quad 42 \%$ & $07 \%$ & $07 \%$-if-espn_004.tagl & $18 \%$ \\
\hline 2 & set WD set up RP up Brazil NP Brazil & 's POS 's first JJ first goal NN goal. & $2.524 \quad 640 \% \mathrm{I}$ & $08 \%$ & $08 \%$ l jo-if-wp_019.tag & $79 \%$ \\
\hline 3 & to do $W$ do. SENT Brazil NP Brazil & 's POS 's first JJ first goal NN goal & $1.618565 \% \mathrm{l}$ & $07 \%$ & $07 \%$ o-if-cnn_001.tagl & $47 \%$ \\
\hline 4 & DT the Arsenal NP captain NN captain & 's POS 's first JJ first goal NN goal on IN & $627 \quad 121 \%$ I & $06 \%$ & $06 \%$ |0-if-gua_046.tagl & $27 \%$ \\
\hline 5 & NP $\mid$ Manchester City NP City & 's POS 's first JJ first goal NN goal & $45 \quad 03 \%$ & $02 \%$ & $02 \%$ o-if-gua_015.tagl & $2 \%$ \\
\hline 6 & set up RP up England NP England & 's POS 's first JJ first goal NN goal of IN & $4.9421666 \% \mathrm{l}$ & $03 \% \mathbf{I}$ & $03 \%$ Inar-gua__o31.tagl & $33 \%$ \\
\hline 7 & set up RP up England NP England & 's POS 's first JJ first goal NN goal of IN & $5.0291666 \% \mathrm{l}$ & $04 \%$ ] & 0 4\%Inar-gua__003.tagl & $34 \%$ \\
\hline 8 & Trinidad. SENT . England NP England & 's POS 's first JJ first goal NN goal & $2.110746 \%$ & $05 \% \mathbf{I}$ & 0 5\%l jo-if-wp_014.tag & $75 \%$ \\
\hline 9 & set up RP up England NP England & 's POS 's first JJ first goal NN goal of IN & $5.0201666 \% \mathrm{l}$ & $04 \%$ ] & 0 4\%Inar-gua_008.tagl & $33 \%$ \\
\hline 10 & NP for IN for France NP France & 's POS 's first JJ first goal NN goal at IN & $661 \quad 141 \% \mathbf{I}$ & $09 \% \mathbf{I}$ & 0 9\%I jo-if-wp_021.tag & $39 \%$ \\
\hline 11 & WN result in $\mathbb{N}$ in Ghana NP Ghana & 's POS 's first JJ first goal NN goal ( ( ( & $1.070387 \% \mathrm{l}$ & $07 \%$ & $07 \%$ Inw-esp_006.tagl & $38 \%$ \\
\hline 12 & NP Davie $\$$ McGoldrick NP McGoldrick & 's POS 's first JJ first goal NN goal since & $6006 \%$ & $05 \%$ & $05 \%$ o-if-sun_042.tagl & $6 \%$ \\
\hline 13 & It PP it was VBD be Demontagnac NP & 's POS 's first JJ first goal NN goal for IN & $366 \quad 126 \% \mathbf{l}$ & $05 \% \mathbf{I}$ & 0 5\%|0-if-365_047.tagl & $27 \%$ \\
\hline 14 & It PP it whs VBD be Dementagnac ND & 's POS 's first JJ first goal NN goal for IN & $366 \quad 126 \% \mathbf{l}$ & $05 \% \mid$ & 0 5\%|0-if-365_047.tagl & $27 \%$ \\
\hline 15 & it was VBD be Serbia-Montenegro NP & 's POS 's first JJ first goal NN goal in IN & $2.110628 \% \mathrm{I}$ & $05 \%$ & 0 5\%l jo-if-wp_o 011. tag & $75 \%$ \\
\hline 16 & SENT Carlos NP Carlos Tevez NP & 's POS 's first JJ first goal NN goal & $6125 \%$ I & $01 \%$ & $01 \%$ nar-bbc_016.tagl & $1 \%$ \\
\hline 17 & Cesar - : - Korea NP Korea DPR NP & 's POS 's first JJ first goal NN goal at IN & $1.828351 \% \mathrm{I}$ & $08 \% \mathbf{I}$ & 0 8\%ljo-iff-foo_009.tag & $98 \%$ \\
\hline 18 & so RB so near $y$ RB nearly Messi NP & 's POS 's first JJ first goal NN goal of IN & $9.0773836 \% \mathrm{l}$ & $09 \% \mathbf{I}$ & 0 9\%Inar-gua_030.tagl & $90 \%$ \\
\hline 19 & so RB so near y RB nearly Messi NP & 's POS 's first JJ first goal NN goal of IN & $9.2383873 \% \mid$ & $01 \%$ & 0 1\%Inar-gua_030.tagl & $91 \%$ \\
\hline 20 & WG read 1.ch@ord@Smudgarnp & 's POS 's first JJ first goal NN goal for IN & $6.4112859 \%$ l & $04 \%$ & $04 \%$ Inar-gua__o08.tagl & $84 \%$ \\
\hline 21 & NP Czech Republic NP Republic & 's POS 's first JJ first goal NN goal and & $951324 \% \mathbf{I}$ & $09 \%$ & 0 9\%I jo-if-wp_071.tag & $30 \%$ \\
\hline 22 & WG score his PP\$ his side NN side & 's POS 's first JJ first goal NN goal of IN & $72 \quad 0 \quad 1 \%$ & $03 \%$ & $03 \%$ o-if-gua_067.tagl & $3 \%$ \\
\hline 23 & NP Manch \&ster United NP United & 's POS 's first JJ first goal NN goal from & $7.4163254 \% \mathrm{I}$ & $07 \%$ & $07 \%$ Inar-gua_008.tagl & $97 \%$ \\
\hline 24 & in $\mathbb{N}$ in Aston NP Aston Villa NP Villa & 's POS 's first JJ first goal NN goal & $475 \quad 86 \%$ & $07 \%$ & 0 7\%ljo-if-ind_011.tag & $17 \%$ \\
\hline
\end{tabular}

Figura 87 - Parte das linhas de concordância da expressão “'s POS 's first JJ first goal NN goal"

A busca retornou 163 ocorrências, das quais apresentamos 24 somente para demonstrar como a estrutura ocorre no corpus. As linhas revelam que a expressão pode ser antecedida por nomes de jogadores (identificados de roxo) ou por nomes de times (identificados de vermelho).

\subsection{2 o primeiro gol DE \{partida |jogo $\}$ (23)}

A análise das concordâncias de first goal of ordenadas pelas três primeiras palavras à direita nos direcionaram para quatro ocorrências the first goal of the game. Estrutura que validamos como equivalente da UFE em português.

A diferença entre o número de ocorrências das UFEs nas duas línguas pode ser explicada pelo uso dos termos \{the|an\} opening goal e the opener como sinônimos de $o$ primeiro gol da partida. Tomemos os exemplos: 
a) Fulham's seventh-place finish last season was largely built on defensive solidity, but they were torn apart on numerous occasions by Chelsea's intricate passing, with the game's opening goal summing up the visitors' qualities.

b) Soon after a long ball through the middle almost caught England out and a similar move led to the opening goal with 20 minutes played.

c) El-Hadji Diouf had celebrated his return to the starting line-up by giving his side a 19th-minute head-start when he raced clear and slotted the opener through Hennessey's legs.

Sendo assim, validamos the first goal of the game, the opening goal, the game's opening goal e the opener como equivalents da UFE em português.

Tanto em português como em inglês a UFE é normalmente utilizada em notícias de resultado de partidas de jornais e periódicos esportivos.

\subsection{9 sair do gol (35)}

Diferentemente da maioria das buscas, não sabíamos por onde começar a procurar pelo equivalente. Poderíamos tentar analisar todas as linhas de concordância de goal, mas tal tarefa demandaria muito tempo. Ademais, mesmo aplicando o dispositivo re-sort, seria quase impossível identificar padrões por meio da observação de mais de quatro mil concordâncias.

Decidimos, então, gerar linhas de concordância para a expressão de busca " $N P$ ** VVD”, em que NP corresponde a um substantivo próprio e VVD a um verbo no passado. O propósito foi encontrar o nome de um goleiro seguido de um verbo, visando facilitar a análise. Contudo, em vez de centralizar a análise em um número menor de linhas de concordâncias, a busca retornou 9739 ocorrências, mais que o dobro do número de ocorrências de goal. Resultado que, de certa forma, deveria ser esperado, já que a etiqueta NP indica, além de nomes de jogadores, nomes de técnicos, presidentes, membros da equipe técnica, países, estados etc. No entanto, apesar do alto número de 
ocorrências, decidimos observar as linhas em busca de algum padrão e, logo no início, identificamos duas ocorrências do verbo come que nos chamaram a atenção:

\begin{tabular}{|c|c|c|c|c|c|c|}
\hline \multicolumn{2}{|l|}{ C Concord } & & & & \multicolumn{2}{|c|}{ 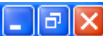 } \\
\hline \multicolumn{7}{|c|}{ File Edit Yiew Compute Settings Window Help } \\
\hline \multicolumn{2}{|c|}{$\mathrm{N}$ Concordance } & Set $\mid$ Tag $\mid$ Word \#|t. \# os.|| & \#| os.l| & \# os.||t. 粗 os.|| & $\%$ & $\widehat{\Lambda}$ \\
\hline 263 & Emmanuel NP Emmanuel Eboue NP <unknown> came WD come in IN in & $15646 \%$ & $02 \%$ & $02 \%$ jo-if-foo_029.tag & $12 \%$ & \\
\hline 264 & \multirow{3}{*}{$\begin{array}{l}\text { WRB where Van NP Van Bronckhorst NP <unknown> came WD come in IN in } \\
\text { back RB back Dennis NP Dennis Aogo NP <unknown> came WD come in IN in } \\
\text { IN while Yossi NP Yossi Benayoun NP <unknown> came WD come in IN in }\end{array}$} & $10.2143414 \% \mathbf{I}$ & $00 \% \mathbf{I}$ & 0 0\%Inar-gua_017.tagl & $70 \%$ & \\
\hline 265 & & $884 \quad 204 \%$ I & $01 \%$ & $01 \% \mathbf{j o}$ & $41 \%$ & \\
\hline 266 & & $316 \quad 60 \% \mathbf{I}$ & $03 \% \mathbf{I}$ & $03 \% \mathrm{lj}$ & $23 \%$ & \\
\hline 267 & \multirow{3}{*}{$\begin{array}{l}\text { far post NN post. SENT. Chipperfield NP <unknown> came WD come in IN in } \\
\text { SENT. Cristian NP Cristian Sapunaru NP <unknown> came WD come in IN in } \\
\text { campaigns NNS campaign. . . Posh NP <unknown> came WD come into IN }\end{array}$} & $8.4183455 \%$ & $09 \%$ & $09 \% \ln 2$ & $79 \%$ & \\
\hline 268 & & $45586 \%$ & $00 \% \mathbf{I}$ & $00 \% \mathrm{j}$ & $30 \%$ & \\
\hline 269 & & $460 \quad 129 \%$ & $03 \% \mathbf{I}$ & $03 \% 10$ & $33 \%$ & \\
\hline 270 & JJ late Friday NP Friday , , , Benayoun NP <unknown> came WD come into IN & $646 \quad 124 \% \mathbf{I}$ & $06 \% \mathbf{I}$ & $06 \%$ & $27 \%$ & \\
\hline 271 & \multirow{2}{*}{$\begin{array}{l}\text { JJ late Friday NP Friday , , , Benayoun NP <unknown }>\text { came } W D \text { come into IN } \\
\ldots \text {, goalkeeper NN goalkeeper Dida NP <unknown }>\text { came } W \text { come off RP }\end{array}$} & $646 \quad 124 \% \mathbf{I}$ & $06 \% \mathbf{I}$ & $06 \%$ & $27 \%$ & \\
\hline 272 & & $1.602361 \% \mathbf{l}$ & $00 \% \mid$ & $00 \% \mathbf{j}$ & $50 \%$ & \\
\hline 273 & \multirow{2}{*}{$\begin{array}{l}\text { Spaniard Andrey NP Andrey Arshavin NP <unknown> came WD come off RP } \\
\text { half NN half , , while IN while Yakubu NP <unknown> came WD come off RP }\end{array}$} & $4304 \%$ & $02 \%$ & $02 \% 0$ & $2 \%$ & \\
\hline 274 & & $1.144 \quad 245 \% \mathbf{I}$ & $08 \%$ & $08 \% 10$ & $88 \%$ & \\
\hline 275 & \multirow{2}{*}{$\begin{array}{l}\text { NN report Andrey NP Andrey Arshavin NP <unknown> came Wh come off RP } \\
\text { defender Jamie NP Jamie McCombe NP <unknown> came WL come off RP }\end{array}$} & $37 \quad 03 \%$ & $02 \%$ & $02 \% \mathrm{j}$ & $2 \%$ & \\
\hline 276 & & $1.007212 \% \mathbf{I}$ & $05 \%$ & $05 \% 10$ & $86 \%$ & \\
\hline 277 & \multirow{2}{*}{$\begin{array}{l}\text { as } \mathbb{N} \text { as Michael NP Michael Ballack NP <unknown> came WD come on IN } \\
\text { to TO to Brazil NP Brazil. SENT. Figo NP <unknown> came WD come on IN }\end{array}$} & $1.697320 \% \mathbf{I}$ & $08 \% \mathbf{I}$ & $08 \%$ & $68 \%$ & \\
\hline 278 & & $2.435817 \%$ & $06 \% \mathbf{I}$ & $06 \%$ & $86 \%$ & \\
\hline 279 & \multirow{2}{*}{$\begin{array}{l}\text { knee. SENT. John NP John Heitinga NP <unknown> came WD come on IN } \\
\text { winger NN winger Luis NP Luis Figo NP <unknown> came WD come on IN }\end{array}$} & $1.802449 \% \mathbf{I}$ & $06 \% \mathbf{I}$ & $06 \%$ & $86 \%$ & \\
\hline 280 & & $1.430 \quad 452 \%$ I & $08 \% \mathbf{I}$ & $08 \% \mathbf{l ~ j c}$ & $59 \%$ & \\
\hline 281 & and Roman NP Roman Pavlyuchenko NP <unknown> came WD come on IN & $2.382 \quad 46 \quad 1 \%$ & $06 \%$ & $06 \%$ & $76 \%$ & \\
\hline 282 & knee. SENT. John NP John Heitinga NP <unknown> came WD come on IN & $1.802449 \%$ & $06 \%$ & $06 \% 10$ & $86 \%$ & \\
\hline 283 & knee. SENT. John NP John Heitinga NP <unknown> came WD come on IN & $1.811449 \% \mathbf{I}$ & $06 \%$ & $06 \% \mathrm{jo}$ & $86 \%$ & \\
\hline 284 & \multirow{4}{*}{ 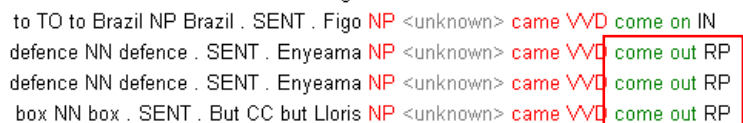 } & $2.426 \quad 817 \%$ & $05 \% \mathbf{l}$ & $05 \% \mathbf{j}$ & $85 \%$ & \\
\hline 285 & & $3.8291332 \%$ & $00 \%$ & $00 \% \ln a$ & $30 \%$ & \\
\hline 286 & & $3.8651332 \%$ & $00 \%$ & $00 \% \ln$ & $30 \%$ & \\
\hline 287 & & $8.2963627 \%$ & $03 \%$ & $03 \%$ Ina & $83 \%$ & \\
\hline 288 & and $\mathrm{CC}$ and then RB then Vermaelen NP <unknown> came W come to 10 & $1.063248 \% \mathbf{I}$ & $00 \% \mathbf{I}$ & $00 \% \mid 0-i$ & $90 \%$ & \\
\hline 289 & NN equaliser until IN until Guiza NP <unknown> came WD come to TO & $1.261303 \% \mathbf{I}$ & $08 \%$ & $08 \%$-if- & $40 \%$ & \\
\hline 290 & WN negate it PP it. SENT. Buffon NP <unknown> came WD come to TO & $2.273625 \%$ & $02 \% \mathbf{I}$ & $02 \% \mathrm{j}$ & $83 \%$ & \\
\hline 291 & NN equaliser until IN until Güiza NP <unknown> came WD come to TO & $1.340323 \% \mathbf{I}$ & $03 \%$ & 0 3\%|o-if-gua_020.tagl & $75 \%$ & \\
\hline 292 & soccer NN soccer. SENT. Riguelme NP sunknown> came WD come to TO & $2.210615 \%$ & $04 \%$ & $04 \% \mathbf{l}$ jo-if-ny_030.tag & $83 \%$ & \\
\hline 29.3 & NP hefore_IN hefore the DT the_Latics sunknown> & $8191 \% 7 \%$ & $\Pi \Pi \% \mathbf{I}$ & $\cap \Pi \%$ in-if-fnก $\Pi 33$ tar & БП\% & $\underline{\underline{v}}$ \\
\hline oncordance & \begin{tabular}{|l|l|l|l|l|l|} 
patterns & clusters & filenames & follow up & source text & notes \\
\end{tabular} & & & & & \\
\hline
\end{tabular}

Figura 88 - Seleção das linhas de concordância da expressão de busca "NP ** VVD”

Ampliamos o contexto das concordâncias e constatamos que come off ocorre sempre como parte de duas expressões maiores:

1) come off the bench

Utilizada quando um jogador que está no banco entra no time:

Campbell came off the bench to replace the injured Richardson in the 76th minute, but Bent and Jones continued to spearhead the attack.

2) come off his line

Utilizada quando um goleiro sai do gol para realizar uma defesa:

Schwarzer came off his line and got to Klose just as the striker headed home from Lahm's cross from the right. 
A segunda ocorrência que nos chamou atenção, come out, também é parte de uma estrutura maior: COME out of his goal. Observemos o exemplo:

a) Tomas Rosicky strokes the penalty low, hard and to David Seaman's right. Good penalty. Amazingly, it was won by Jan Koller, who made up a couple of yards to outrun Pascal Cygan. Seaman came out of his goal, and Koller poked the ball past him, inviting the inevitable trip. It's typical. I call him a giant lunk and he beats somebody in a sprint for the first time in his career.

A fim de visualizar melhor o contexto em que a UFE ocorre, confirmamos as duas estruturas como UFEs equivalentes a sair do gol depois de gerar concordâncias para comes/came off his line e para comes/came out of his goal no corpus sem etiqueta.

Acreditamos que a diferença no número de ocorrências das UFEs no corpus de português e no corpus de inglês, 35 e oito, respectivamente, pode ser explicada pela convencionalidade. Ou seja, embora as duas estruturas possam ser utilizadas para descrever a ação de um goleiro que sai do gol para tentar realizar uma defesa, na língua inglesa tal ação prefere se manifestar por meio de verbos específicos que denotam o ato de defender. Basta compararmos a variedade de verbos das UFEs $4.18 \mathrm{e}$ 4.21.1, em inglês e português.

4.29.1 [goleiro] SAIR do gol e ficar com a bola (20)

Ampliamos os contextos das oito linhas de concordância de COME OFF his line e COME out of his goal e encontramos duas ocorrências de [goalkeeper] COME OFF his line to grab the ball que, apesar da baixa frequência, foi validada como UFE, uma vez que funciona da mesma forma que a UFE em português.

\subsection{0 único gol da partida, o (22)}


A busca pela expressão " $J J *$ goal", realizada para encontrar os equivalentes de belo gol, bonito gol e gol incrível, nos retornou, também, os equivalentes da UFE $o$ único gol da partida:

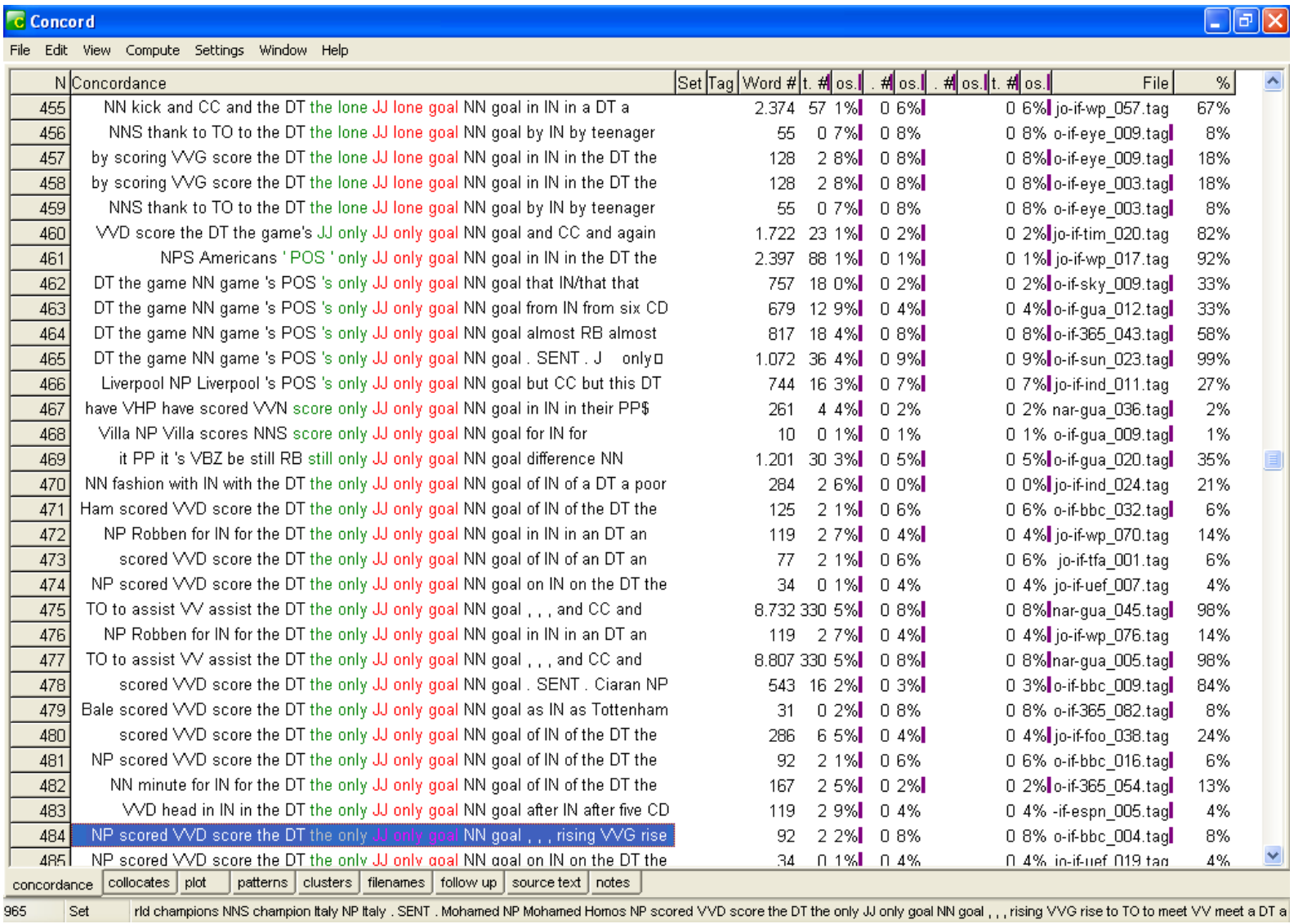

Figura 89 - Linhas de concordâncias da expressão de busca " $J J$ * goal”

Analisamos as 60 ocorrências de only goal e as cinco de lone goal e confirmamos as duas UFEs como equivalentes de o único gol da partida.

Tanto em português quanto em inglês as UFEs são utilizadas, sobretudo, em notícias de resultado de partidas de jornais, tabloides e periódicos esportivos. 


\section{Capítulo 5 - Modelo de Verbete}

Apresentamos, neste capítulo, o modelo de verbete que pretendemos construir para os demais termos que serão extraídos do corpus. Primeiramente, apresentamos uma introdução ao glossário, com explicações sobre as decisões tomadas e a metodologia utilizada; em seguida, mostramos a lista de símbolos utilizados e, ao fim, o modelo de glossário.

\section{INTRODUÇÃO}

Este glossário foi compilado de acordo com os princípios da Linguística de Corpus, ou seja, os termos, colocações e unidades fraseológicas foram ex traídos de um corpus eletrônico sobre futebol.

Seria impossível descrever toda a terminologia do futebol nesta obra, por isso optamos por focar a linguagem presente em notícias de resultados de partidas, em transmissões de jogos on-line e também nas regras do jogo. Por esse motivo, algumas expressões características da linguagem oral podem não ser encontradas.

Para que o corpus fosse representativo das variantes do futebolês, ou footie em inglês, compilamos um corpus de aproximadamente um milhão de palavras em cada língua composto por textos de português brasileiro e inglês britânico extraídos de jornais nacionais, revistas esportivas, jornais esportivos, revistas sobre futebol, sites sobre futebol e tabloides.

Ao contrário do que se imagina, as diferenças culturais representam um grande problema em qualquer língua de especialidade. No caso do futebol, as diferenças entre os modos de jogar e também a maneira como o esporte é tratado pela sociedade, influenciam de forma direta a terminologia utilizada nas duas línguas. Por esse motivo, muitas vezes o equivalente em inglês, embora reflita a forma convencionada, apresenta uma ocorrência relativamente inferior à da UF em português. Ou seja, os jornais, as revistas e os sites brasileiros e britânicos focam aspectos diferentes do futebol em suas notícias. 
A seleção dos termos foi feita por meio da análise da lista das palavras-chave do corpus, que resulta da comparação do corpus de estudo com um corpus de referência. Nessa comparação, as palavras que possuem frequência relativa estatisticamente mais relevante no corpus de estudo sobressaem revelando a temática do corpus. Sendo assim, em uma lista de palavras de um corpus de futebol, palavras como gol, bola e goleiro aparecerão como palavras-chave.

Trabalhar com as palavras-chave nos permite selecionar os termos mais recorrentes, fator de extrema importância para qualquer compilação terminológica. No entanto, isso não garante a utilidade da obra, já que uma das maiores preocupações dos tradutores e de qualquer pessoa que produz um texto em uma língua de especialidade é o comportamento do termo. Ou seja, muitas vezes o produtor do texto conhece o termo na língua-alvo, mas não sabe como utilizá-lo. Tomemos como exemplo a fraseologia FAZER \{o|um\} gol, que tem como sinônimos em português MARCAR \{o|um\} $\{$ gol|tento\}. O equivalente mais frequente em inglês, como o leitor deve imaginar, é SCORE (\{a|the\} goal). Contudo, a língua inglesa apresenta outras 40 formas equivalentes para fazer um gol.

Nosso principal objetivo é proporcionar ao usuário o máximo de informações possíveis para um melhor entendimento do texto especializado sobre futebol e, dessa forma, auxiliar na produção desses textos em língua inglesa. Partimos do pressuposto de que um termo raramente ocorre sozinho. Isto é, acreditamos que o termo está sempre acompanhado de um ou mais colocados e, muito frequentemente, é parte integrante de uma unidade de sentido maior, entendida aqui como Unidade Fraseológica Especializada (UFE).

Para cumprir o objetivo proposto, criamos três níveis para os verbetes. No primeiro nível, apresentamos o termo sozinho, por exemplo, gol. No segundo, apresentamos as UFEs como, por exemplo, à direita do gol. No terceiro nível, elencamos as UFEs que podem fazer parte da UFE apresentada no segundo nível: $a$ bola \{passar|sair\}, que pode anteceder à direita do gol resultando na UF a bola \{passar|sair\} à direita do gol.

Todos os verbetes e subverbetes possuem equivalentes em inglês e exemplos. Quando o equivalente em inglês pertence a uma classe gramatical distinta da UFE em português, usamos o símbolo $\square$. 
Sempre que possível, apresentamos expressões alternativas (/) e combinações possíveis $(\mid)$, que aparecem por ordem de frequência. Por exemplo, na UFE good | excellent\} scoring chances, good é mais frequente que excellent, por isso é apresentado primeiro.

Como trabalhamos com fraseologias, que são combinações semifixas, apresentamos, quando necessário, a categoria gramatical que integra a UFE. Por exemplo, a UFE para o fundo do gol, muito frequentemente, é precedida por um verbo. Sendo assim, no glossário, teremos um subverbete VERBO para o fundo do gol. Também identificamos as palavras que são opcionais na composição da UFE. Em inglês podemos dizer que um jogador scored \{the|a\} goal ou simplesmente que ele scored. No verbete, a parte opcional aparece entre parênteses: SCORE (\{a|the\} goal).

Utilizamos os hiperônimos para representar elementos que podem se realizar de diversas formas, como em: [footballer], who scored [the goal]. Nesse caso, substituímos [footballer] pelo nome de um jogador e [the goal] pelo gol que foi marcado, por exemplo: Striker Miroslav Klose, who scored a hat-trick in Germany's 2002 World Cup opener, put his country back on top with two goals from close range, where almost all of his damage is done.

Apresentamos formas sinônimas, remissivas e, sempre que preciso, inserimos um comentário sobre a UFE. Também chamamos a atenção do consulente para as formas que são significativamente mais frequentes por meio do símbolo $\star$. Quando necessário, mostramos ainda informação do gênero textual em que o termo ocorre.

\begin{tabular}{|c|c|}
\hline Símbolos & Symbols \\
\hline$\Leftrightarrow$ subverbete & $\Leftrightarrow$ derivative section of an entry \\
\hline$\partial$ vide & $\partial$ see also \\
\hline$\star$ significativamente mais frequente & $\star$ significantly more frequent \\
\hline$=\mathrm{o}$ mes mo que & $=$ same as \\
\hline$\checkmark$ comentário & $\sigma$ comment \\
\hline$\square$ estrutura correspondente em inglês & $\square$ equivalent structure in English \\
\hline \ só ocorre em jornais (newspapers) & $\boldsymbol{\Theta}$ appears only in newspapers \\
\hline IA mais comum em inglês americano & IA more common in American English \\
\hline (...) uso opcional & (...) optional use \\
\hline
\end{tabular}


\begin{tabular}{|l|l}
\hline$[\ldots]$ hiperônimo & {$[\ldots]$ hypernym } \\
$\{\ldots\}$ elenco de opções & $\{\ldots\}$ possible choices
\end{tabular}

LETRAS MAIÚSCULAS categoria gramatical

I expressões alternativas

| combinações possíveis

FAZER qualquer forma do verbo
CAPITAL LETTERS grammatical category

/ alternative expressions

I possible combinations

SCORE any form of a verb

\section{GOL}

\section{A}

após o gol

Após o gol, a seleção germânica foi para o ataque na base do desespero.

= depois do gol

\section{after the goal}

Brazil began to show their class after the goal and it was no surprise when they went further ahead in the 72 nd minute.

\section{autor do gol}

William fez pênalti bobo em Gilmar, autor do gol da vitória.

\section{[footballer], who scored [the goal] $\star /$ scorer $\square$}

The Poland international, who scored the first goal of his loan spell from Groclin against

Middlesbrough in midweek to set up a Carling Cup third round clash at home to Blackburn, crashed an unstoppable shot in off the underside of the crossbar after just 58 seconds.

The scorer of the opener and the leader of the comeback is still the greatest force in the team.

\section{B}

\section{belo gol, um}

Aos dez, Daniel Díaz desviou de primeira escanteio batido da direita e fez um belo gol.

= bonito gol, um

= gol incrível, um

\{great | stunning | superb | wonderful | lovely | outstanding | brilliant| excellent | dazzling\} goal, a 
Torres scores a great goal from inside the box after some good work by Insua.

The North Koreans kept Dunga's team scoreless until ten minutes into the second half when Maicon scored a stunning goal from an outrageous angle.

\section{bonito gol, um}

Com um bonito gol de falta de Bernardo, Goiás vence o Vitória por 1 a 0 , mas continua na décima nona colocação.

$\supset$ belo gol, um

C

\section{na cara do gol}

Renatinho faz boa jogada e deixa Bruno na cara do gol, mas o árbitro marca impedimento.

$=$ de frente para 0 gol

\section{in front of goal}

He rises to meet a cross from the right and is completely unmarked in front of goal but his header skids wide.

The expression goalmouth refers to the area immediately in front of the goal and in our corpus only occurs as part of the phraseology goalmouth scramble which means to maneuver about in the backfield while seeking an open receiver to whom to pass the ball; also, to run with the ball if unable to find a receiver.

\section{SAIR na cara do gol}

Com Apodi, a oportunidade foi melhor, o ala-direito recebeu lançamento nas costas de Richarlyson, saiu na cara dogol, mas Denis foi rápido e deu o bote certo para salvar o Sampa.

\section{$\leftrightarrow$ [footballer] FIND himself in front of goal}

Sweetman found himself in front of goal again and forced a good save from the keeper.

\section{chance(s) de gol}

Apesar de ter tido algumas chances de gol, o Timão viu o Santo André estar mais perto de balançar as redes.

$=$ oportunidade(s) de gol

\section{scoring opport unities / goal-scoring opportunity/ scoring chance(s) ${ }^{\text {IA }}$ /}


The 29-year-old squandered Newcastle's best goal-scoring opportunity against Portsmouth and that will have harmed his chances of forcing his way back into the England squad because he misfired in front of Fabio Capello's No 2 Franco Baldini.

Meanwhile, the Americans were relentless in their attack on a nervous-looking Brazil defense, with Donovan working hard to give his team several scoring chances.

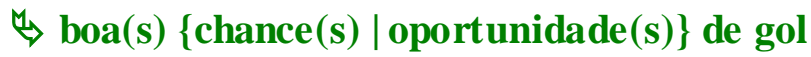

O primeiro tempo foi bastante movimentado, com boas chances de gol para os dois lados.

A primeira boa oportunidade de gol aconteceu apenas aos 23 minutos e foi para o time da casa.

$\rightarrow$ \{good | excellent $\}$ scoring opport unity(ies)

It was a good scoring opportunity for Zenit, who already look lightning quick on the break.

Ji-Sung Park blows another great scoring opportunity, with his touch and nerve deserting him as soon as the Milan goal hoves into view.

\section{$\rightarrow$ poucas chances de gol}

Em campo encharcado, a equipe não conseguiu se encontrar e teve poucas chances de gol.

\section{$\rightarrow$ few scoring \{opport unities $\mid$ chances $\left.{ }^{\mathrm{IA}}\right\}$}

The visitors closed down quickly, were well organized and restricted their opponents to relatively few scoring opportunities.

Although Barca pressed forward for much of the match, they created very few scoring chances.

\section{CHEGAR ao gol}

Austrália melhora no segundo tempo, mas ainda não consegue chegar ao gol alemão.

\section{GO close $\square$}

Just before Bendtner replaced Wilshere, Arsenal went close after Fabregas chested a pass between Newcastle's centre-halves and into the path of Theo Walcott, who was through on goal but also a foot or so offside.

\section{chute de \{direita|esquerda\} no gol feito por [jogador]}

Chute de direita no gol feito por Karim Matmour.

Belo chute de esquerda no gol feito por Lionel Messi.

[footballer] \{curl| produce | drive | smash | cannon | dispatch | fire | send | unleash | blast | boom | bury | drag | hit | hoick\} a \{right | left $\}$-footed shot (goalwards)

With choices left and right, he chose instead to curl a right-footed shot past Wayne Hennessey into the top left-hand corner. 
Dany N'Guessan produces a right-footed shot from deep inside the area which goes wide of the left-hand post.

From the left flank, Van Bronkhorst pings the ball into the path of Robin van Persie, who cannons a right-footed shot straight at the onrushing Hamidou Souleymanou.

[footballer] \{laze |drag |poke (in) | hit | send | slam | slide |lash | smash|

balloon | blast |, bend | hammer | fire (in) | slice | spank |curl | drive | unleash | scuff \slam | strike|direct | thump |blaze |drag |fizz | poke(in) | send |chip | drill (in) | crack in |dispatch | guide |leather\} a \{right |left\}-foot shot With the last kick of the half, Muntari lashes a left-foot shot goalwards from fully 35 yards, the keeper takes a telling half-step to his right and is beaten as the ball curls to his left.

A long ball from the back from Andre Ayew sees Gyan battling with Carlos Bocanegra and despite a little push from the defender, he keeps his composure to smash a left-foot shot past Tim Howard from 16 yards.

One such decent move for Germany ends with Sami Khedira ballooning a left-foot shot miles over from 25 yards.

\section{cobrar falta direto para o gol}

Schweinstger cobra falta direto para o gol, Kingston salva, Mertesacker chuta no rebote e carimba a zaga ganesa, que afasta na sequência.

\section{[TAKE | WHIP | DELIVER] a free-kick (towards goal)}

Steven Gerrard takes a free kick from the left but Friedel punches his effort away strongly

Van Persie whips a free-kick towards goal from the right corner of the box, and Mucha does really well to punch clear under pressure from Kuyt, who flew in knee-first at him.

\section{com um gol de [jogador]}

Em casa, equipe paulista conquista a vitória com um gol de Fernandinho aos 10 minutos do segundo tempo.

\section{when [footballer] scored}

The Tunisians took the lead in the 23rd minute when Jaziri scored off a corner kick.

D

de frente para o gol

O meia, de frente para o gol, encheu o pé e obrigou Diego a fazer grande defesa. 
depois do gol

Depois do gol, o Braga voltou para o jogo e começou a atacar novamente.

$\ni$ após o gol

direita do gol, à

Gekas sobe com Shittu e desvia cruzamento à direita do gol de Enyeama.

to the right of (the) goal

And now Garcia cuts across the ball with the outside of his right boot, just to the right of goal on the edge of the German area.

$\rightarrow$ a bola $\{$ PASSAR $\mid$ SAIR $\}$ à direita do gol

Cristiano Ronaldo arrisca de longe e a bola passa à direita do gol.

$\Leftrightarrow$ effort $\star \mid$ shot $\}$ goes wide right of the goal

Effort from inside the six-yard box by Andy Taylor goes wide right of the goal.

Richie Wellens produces a right-footed shot from long range which goes wide right of the goal.

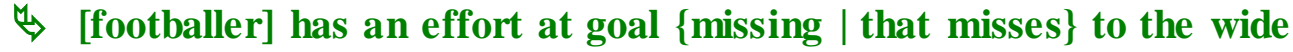
right of the goal $\square$

Damien Delaney has an effort at goal from outside the area missing to the wide right of the goal.

$\mathbf{E}$

esquerda do gol, à

Marcos Assunção manda falta para Danilo e o zagueiro desvia de cabeça à esquerda do gol.

to the left of (the) goal

Muller is booked for attempting to bring down a ball with his forearm, Gary Neville style, just outside his own area to the left of goal.

$\rightarrow$ a bola $\{$ PASSAR |SAIR $\}$ à esquerda do gol

Podolski avança e bate rasteiro, mas a bola passa à esquerda do gol de James.

$\leftrightarrow$ \{effort $\star \mid$ shot $\}$ goes wide left of the goal

Effort from outside the penalty area by Leighton Baines goes wide left of the goal.

Darius Henderson produces a left-footed shot from just outside the box that goes wide left of the goal. 
\{footballer\} has an effort at goal goal \{missing | that misses $\}$ the wide left of the goal $\square$

Lee Frecklington has an effort at goal from outside the penalty area missing to the wide left of the goal.

\section{EVITAR o gol}

Magrão espalmou para evitar o gol.

Em vantagem, a equipe da casa partiu para cima e quase fez o terceiro, em lance que Gilmar tocou por baixo do goleiro e Leandro Guerreiro apareceu para evitar o gol.

\section{BLOCK the shot}

Didier Drogba tries to create an opening for an effort at goal but (midfielder) Dickson Etuhu is in the way to block the shot.

Stephen Pearson then went on a wonderful mazy run and slipped in Hulse behind the Forest defence but (keeper) Lee Camp was quickly out of his goal to block the shot with his legs.

\section{[goalkeeper] save the shot}

Time almost stood still as he moved onto the ball in slow motion, but Friedel flew from the line to save the shot with his right hand.

$\mathbf{F}$

\section{FAZER $\{0 \star \mid$ um $\}$ gol}

Eguren emendou para a rede e fez o gol do alívio uruguaio.

Ainda não foi desta vez que a Grécia fez um gol em Mundiais.

$=$ MARCAR $\{0+\mid$ um $\}$ gol

= MARCAR o tento

= FINALIZAR

$=$ EMPATAR

\section{SCORE ([\{a|the $\}$ goal $])$}

The old warhorse, Pavel Nedved, equalised for Juve and scored again to give the Italian giants the lead they wanted.

South Korea must now do what no other side has managed in this World Cup so far and score a goal against Uruguay

FIRE \{home | in (a goal) |(the ball) past [goalkeeper]| into the net $\}$ 
The lapse allowed Maxi Rodríguez to latch on to a well-weighted ball from Sergio Aguero and fire in his third goal of the campaign.

Sheff Utd James Harper fires in a goal from close in low into the middle of the goal.

Ipswich's movement caught Coventry out most alarmingly in the 28th minute, when the home side's defence found itself wrenched apart and Walters cantered on to Jon Stead's through-ball to fire into the net from 20 yards.

Smith then turned provider on 63 minutes with a cross that Tom Cleverley fired home to make it 2-1.

Kahlenberg took advantage of a mistake from Sweden defender Mikael Nilsson midway through the first half to fire the ball past goalkeeper Andreas Isaksson.

\section{HAMMER \{ in | home $\}$}

The home side bossed the game from the off and Giuseppe Rossi hammered in a superb opening goal on 20 minutes.

Malouda's corner is met my Terry, whose header is kept out off the line by Mulumbu. He can't quite get it clear, though, and after a brief scramble Drogba is on hand to hammer home.

\section{SLOT \{home ([a goal]) | (the ball) into \{an | the empty net | past} [goalkeeper $\mid$ in]\}

On the second goal, captain Michael Ballack chipped a pass to the edge of the Ecuador box, Klose shook off two defenders while playing the ball off his thigh, went around Mora and coolly slotted home.

Cattermole's clearing header was picked up by Steed Malbranque, who lifted the ball over the top for Jones to leave Samba and Ryan Nelsen in his wake before rounding keeper Paul Robinson and slotting into the empty net.

Higuain could not believe his luck and made the most of it when he took the ball around the Mexico keeper and slotted the ball into an empty net.

The Scotland international robbed Milan Badelj 40 yards from goal and burst past Ivica Vrdoljak before slotting past Butina.

\section{NOD \{home (into an empty goal) | in | into the net}

Hull just couldn't withstand the pressure though and when Myhill failed to claim a Van Persie free-kick into the area, the ball looped up nicely for Gallas who nodded home into an empty goal although Hull looked to have a case in their claims for offside against the Frenchman.

Barry helps to calm England's early nerves and sloppiness to nod in the opener.

A free-kick floated into the Uruguay box is headed up in the air by Maurico Victorino and it lands about six yards out - where Bolton's Lee Chung-Yong is on hand to get there before Fernando Muslera and nod into the net, with Jorge Fucile failing to hack it off the line.

\section{SLAM \{(the ball) past [goalkeeper] | in | into the roof of the net $\}$}

Lukas Podolski celebrates after slamming the ball past David James for the Germans second.

Grosso slammed in the decisive kick. 
The Inter Milan wing-back roared through for Brazil's third goal seven minutes after the expulsion, slamming into the roof of the net after a sharp give-and-go with the incomparable Kaka to complete the rout.

\section{HEAD (the ball) \{home|past (goalkeeper)|into the (roof of the) net\}}

There was nothing the goalkeeper could do in the 63rd minute as Pekarik's cross found Jakubko who headed home from inside the box.

Torres' launched free-kick from deep was perfectly flighted and with Fabio Cannavaro and De Rossi flailing, Alcaraz headed past Buffon.

Crouch leapt over Brett Sancho and headed the ball past Shaka Hislop for England's first second-half goal in a World Cup since 1998.

From the corner, GABRIEL HEINZE, completely unmarked on the penalty spot, heads the ball into the roof of the net.

$\checkmark$ to hit a ball with your head

\section{M $>$ hamme r|pound $\}$ a header into the net}

A corner kick on the right was floated across to the far post, where Lucio, Brazil's captain, out-jumped Dempsey to hammer a header into the net, setting of a delirious Brazilian celebration.

The towering forward Jan Koller pounded a header into the net to start the scoring on a counterattack in the fifth minute.

\section{ADD \{a|the ORDINAL (goal)}

Ronaldo added $\boldsymbol{a}$ fourth with a free-kick which somehow found the net after a comical attempt to punch clear by Leoni and Guti chipped in a fifth right at the end.

By now Rovers were rampant and they added a third goal in the 64th minute.

\section{EQUALISE}

The keeper keeps hold of the ball, then gets the trainer on to look at his trousers. Meanwhile in the other game, Nigeria have equalised!

Birmingham almost equalised three minutes later when Patrice Evra headed Franck Queudrue's header off the line, but Hart was called back into action early in the second-half when he saved well from another long-range Rooney effort.

Martinez's lads were 13 minutes from victory until Clint Dempsey equalised with a diving header and Zamora had the last word with his bonce on 81 minutes in this gripping fifth-round replay.

The South Americans took the lead for the first time early in the second half through the impressive Diego Forlan but Marcell Jansen equalised for Germany within five minutes.

to score a goal that makes the score of both teams equal 


\section{KNOCK \{the ball \{into the net|in|home\}\} / NUMBER goals}

Ki Sung-young curled this one in from the left, and at the back post Lee Jung-soo met with his foot and knocked it into the net with more than a hint of fluke.

During extra time in the first half, defender Cafu flew down the right sideline and crossed the ball to Adriano, who knocked it in.

The substitute David Beckham delivered from the right, Steven Gerrard connected with a downward header and the captain, John Terry, knocked the ball home with his left foot.

Portugal much more than a one-man team, of course, what with six different players knocking seven goals past North Korea without reply.

\section{NET [a goal]}

Bolton snatched their first points of the season after Gary Cahill netted a controversial late winner in a 3-2 victory at Portsmouth.

He takes the ball through to the Sunderland box before squaring it to Eduardo netted the second via the post and then Wilshere grabbed the goal of the game with a clever half-volley 18 minutes from time.

\section{FINISH (off)}

The attacker finished with a low and precise drive.

Germany had taken an early lead when Gonzalo Castro finished off Jerome Boateng's through ball from 12 yards.

\section{TAP $\{$ in|home $\}$}

Eduardo, making his Premier League return after his lengthy absence through injury as a late substitute, got himself in on the act when he found himself in the right place to tap in a simple sixth for the Gunners.

Klose, who had scored the opener against England, then tapped home a 67th minute second.

\section{NOTCH \{his ORDINAL|CARDINAL\} (goal)}

Rooney notched his fifth goal of the season and showed that United are serious contenders to retain their Premier League crown despite the loss of Cristiano Ronaldo during the summer.

Mario Balotelli, who notched two goals against West Brom before being sent off at the weekend, might have been useful here if he had not been suspended but Roberto Mancini is not so naive a manager as to depend on a 20-year-old.

Forward David Villa, 24, scored two goals and could have easily notched a hat trick in just 55 minutes before being substituted, and on the bench were four young stars all worthy of a starting spot.

A hat-trick occurs when a player scores three goals in a single game. 


\section{SLAM (the ball) \{in | past [goalkeeper] | home \} SLAM \{in | home\} [a kick]}

Gerrard slammed in the third on 48 minutes before sub Andrea Dossena completed the rout a couple of minutes from time.

Lukas Podolski celebrates after slamming the ball past David James for the Germans second. Spurs' keeper Gomes needlessly hauled down Johnson as he dashed from his goal and Gerrard slammed home the spot-kick.

\section{STAB the ball \{home | past [goalkeeper]\}}

It was 3-0 after 78 minutes though as Kuyt stabbed the ball home from close range after being brilliantly set-up by Gerrard.

Altidore, who has been formidable in the second period, nodded a long diagonal ball down in the box and Bradley burst from deep to stab it past the keeper from 12 yards!

\section{SLIDE \{home his ORDINAL (goal) | the ball home\}}

Hungarian referee Viktor Kassai pointed to the spot and Los Angeles Galaxy's Donovan stepped up to slide home his third goal in four matches.

City were in front on 25 minutes when a quick free-kick from Richie Wellens allowed Fryatt to spring the offside trap and slide the ball home under keeper Paul Rachubka from 14 yards.

\section{THUNDER a goal home}

Barton thundered a goal home in injury time, setting pulses racing throughout the boisterous home support.

\section{SNATCH [a goal]}

But the early pressure soon dissipated and Celtic's task, already tough, grew even more difficult when Braga snatched an away goal in the 21st minute.

It took a while for them to regain their composure but slowly they began to create chances and then snatched their equaliser.

\section{SWEEP \{home | the ball into the net}

West Brom were booed off at half-time and within four minutes of the restart, after Jonas Olsson diverted the ball against Gianni Zuiverloon, James Beattie swept home his sixth goal in ten games since signing from Sheffield United.

The ball deflected off the ankle of defender Gerard Pique and fell to teammate Sergio Ramos, but before Ramos could control it, Dempsey came in from his blind side and swept the ball into the net.

\section{TUCK home ([a goal] $)$}

Eduardo tucked home a consolation for Croatia, who must now overhaul Ukraine in the battle to be runners-up.

NESTLE $\{$ in | into $\}$ the (back of the) net

A terrific Tuncay overhead kick just nestled in the net past Paul Robinson. 
The Scotland striker crossed from the left and it went straight through without a touch and nestled into the net to give him just his sixth goal for the Baggies in more than two years at The Hawthorns.

So close to a deserved opener for Ghana! John Pantsil's long throw was met by Asamoah Gyan whose downward header had Stojkovic beaten. I thought it was about to nestle in the back of the net, but instead the ball bounced inches wide of the near post.

\section{THUMP \{home | past [goalkeeper]\}}

Duda's low left-foot cross from the left should be cleared, but Ri Kwang-Chon makes a total mess of it and it falls for a gleeful Liedson to thump home on the volley from eight yards.

Celtic gave away a needless free-kick near the left corner of the area, which Bastos thumped past Zaluska high into the net.

\section{BURY the ball past [goalkeeper]}

For good measure, Fabregas popped in a peach for his second and Arsenal's fifth as he ran up field, picked his spot and buried the ball past Howard.

\section{POKE \{the ball home | home past [goalkeeper]\}}

Within 90 seconds of the re-start, Everton double thier lead as Fellaini gets on the end of a Hibbert cross and pokes the ball home.

England have the perfect start! A move from the right sees Emile Heskey slip a pass into the area and Gerrard was onto it in a flash to poke home past Tim Howard with the outside of his right foot.

\section{CLIP the ball into the net}

The French ace should have buried it first time. But, after Helton saved, he clipped it into the net at the second offering.

\section{DELIVER a goal}

The finest player in all of England delivered a goal to match the grandeur of his talent.

\section{STEER the ball past [goalkeeper]}

His pass picks out the run of Osman who steers the ball past Schwarzer.

the ball CORKSCREW towards the (empty) net

The ball corkscrewed back over the goalkeeper's body towards the empty net but Jarvie somehow contorted to claw the ball away from the line with his left.

STROKE a shot past [goalkeeper]

The striker controls, edges past Alex down the inside-right channel and into the box, and strokes a sure shot past Cech and into the bottom left-hand corner of the net.

\section{FIZZ the ball past [goalkeeper]}

Drogba was the provider this time, pinging the ball with pace to last season's top scorer Anelka, who responded by fizzing the ball past Schwarzer from inside the area.

\section{BLAST in ([a goal])}


But after a blocked Ledley shot had threatened a second Wales equaliser, Pavlyuchenko seized on a mistake by Collins deep in injury time to blast in a third goal and seal the result.

\section{LASH home $\{$ (a goal) | into an empty net $\}$}

The Slovakia full-back won the ball in his own half and burst down the flank before squaring for Dorrans to lash home his second goal for the club.

A mis-kick from Neal Eardley allowed Fryatt to pounce on the ball, round Rachubka and lash home into an empty net.

\section{SMASH home}

Cattermole fed Walcott down the left and he crossed for Milner to smash home from 12 yards.

\section{DRILL home}

It was Sigma's substitute Sultes who managed to drill home for the hosts with 10 minutes to go, but it was too little too late for the Czechs as Everton advanced to the group stages.

\section{HOOK in ([a goal] $)$}

When defender Marius Zaliukas hooked in the second shortly after the break, belief they were capable of a sensational result coursed through the home ranks.

\section{BAG [a goal]}

The full-time whistle goes. Brazil's campaign is up and running but they were made to work every step of the way by North Korea, who bagged a memorable goal at the death.

The visitors looked to be heading for their fourth successive draw when Bruno Alves bagged the winner in the third minute of stoppage time to rescue their South Africa 2010 dreams and deal a blow to the Albanians, in their first match under new Croatian coach Josip Kuze.

\section{NICK [a goal]}

Birmingham City had the early Premier League leaders begging for the final whistle before Aaron Lennon nicked a winner for Tottenham deep into stoppage time.

\section{DINK in [a goal]}

The 2004 European champions had almost got off a dream start when Vasileios Torosidis had a sniff - only to blaze over from inside the box. And he was made to pay when Lee dinked in the opener after seven minutes.

G

\section{gol da vitória, o}

Aos 33, Edno recebeu cruzamento preciso de Wilton Goiano e fez o gol da vitória.

\section{\{winning | decisive $\star$ \} goal, the / winner, the}

New signing Sebastien Bassong made a dream debut for Tottenham Hotspur as he headed the winning goal in his side's 2-1 victory at home to Liverpool. 
Ghilas fired the decisive goal of a scrappy Premier League encounter at the KC Stadium after being set up by fellow new signing Jozy Altidore's first touch with 61 minutes gone He scored the winner with just three minutes remaining in the extra time.

\section{gol da virada, $o$}

39 minutos, cruzamento de Elano, Lúcio foi no $5^{\circ}$ andar e fez o gol da virada: 3 a 2 para o Brasil.

\section{[club] took the lead through [footballer]}

Blackburn took the lead through Gaël Givet in the 21st minute and had two goals disallowed before a hectic finale when Benni McCarthy hit the bar and Nikola Kalinic wasted an opportunity a £6m striker should take.

\section{[club] went ahead when [footballer] VERB}

And they went ahead when Castro, who also scored in a 1-1 draw against England in the group stages, made no mistake after Ozil's fine pass.

\section{gol de empate, $o$}

O Botafogo pressiona, tentando o gol de empate, mas esbarra em seus próprios erros de afobação equaliser, $\{$ an $\mid$ the $\} \star$ / tying goal, the

After Giovanni van Bronckhorst's spectacular opener, Uruguay were gifted an equaliser when goalkeeper Maarten Stekelenburg failed to deal with Diego Forlan's long-range shot.

Needing a win to have any chance to advance, Angola scored its first goal of the tournament but was held to a 1-1 draw Wednesday when Sohrab Bakhtiarizadeh scored the tying goal in the 75th minute for Iran.

\section{gol de pênalti, um}

Com nova atuação brilhante de Petkovic, que fez um gol de pênalti,, o Mengão derrotou o atual tricampeão brasileiro por 2 a 1 .

\section{[footballer]'s penalty}

Matthew Taylor's penalty put Bolton back in front four minutes before the break.

\section{$\stackrel{7}{7}$ com um gol de pênalti}

Com um gol de pênalti de Kaká, aos 45 minutos do segundo tempo, a seleção brasileira venceu o Egito por 4 a 3, e evitou um tropeço em sua estreia na Copa das Confederações, em Bloemfontein.

\section{$\Leftrightarrow$ [footballer]'s penalty}

Wayne Rooney, a subdued figure for the most part here, demonstrated his class with a stunning overhead kick 18 minutes from time. And Frank Lampard's penalty gave the 
scoreline a convincing appearance with a 78th minute penalty after Heskey has been hauled down by Renat Abdulin.

\section{gol incrível, (um)}

Inzaghi entrou aos 15 do segundo tempo e sete minutos depois perdeu um gol incrível, após falha da zaga tcheca.

belo gol, um

$\checkmark$ A fraseologia é sempre utilizada para reportar que um gol foi perdido.

\section{[goleiro] sair $\{$ mal | bem\} (do gol)}

O goleiro palmeirense, inteiro no lance, saiu mal e não conseguiu segurar.

O camisa 25 do Tricolor entrou na área e chutou rasteiro, mas Harlei saiu bem do gol e evitou que o Sampa aumentasse a vantagem.

\section{$\square$ [goalkeeper] FAIL to \{collect (a cross|a header|the ball) | GRAB the ball | HOLD a shot $\}$}

The visitors' constant pressure finally told in the 77th minute when a long ball from McAllister brought Turner off his line, but the on-loan goalkeeper failed to collect and Adebola rose highest to head home.

Schwarzer failed to grab the ball when he crashed into a group of players.

Batata added the third almost immediately after the re-start and scored again just after the hour when Bruno failed to hold Renatinho's shot.

\section{$\square$ [goalkeeper] DO well to \{BEAT away | BEAT out | PARRY | BLOCK | HOLD |SAVE | TIP the ball over the bar\}}

Cudicini then did well to beat away a rasping shot from Victor Sanchez.

In the 19th minute, Orient almost took the lead when Townsend again tested Simonsen's reactions with a left-foot shot that the City goalkeeper did well to parry to safety.

Espanyol were also looking dangerous early on and the Catalans could have gone ahead after 20 minutes but Iker Casillas did well to save Moises Hurtado's right-foot effort after the midfielder was set up by Luis Garcia.

ORDINAL gol \{do atacante | de [jogador]\} EM \{[torneio] | [competição] | [campeonato]\}, o

É o nono gol do atacante no torneio.

Foi o quinto gol de Alecsandro no Brasileirão e o $16^{\circ}$ na temporada. 
his ORDINAL goal in the competition | of the season | of the tournament | of the summer\}

Jabo Ibehre and Stephen Gleeson went close for the home side before Puncheon curled in a stunning 20-yard free-kick after 57 minutes for his first goal of the season.

$\stackrel{4}{4}$ primeiro gol de [jogador] com a camisa ADJ ADN, o

A vitória em Belo Horizonte registrou o primeiro gol de Ronaldo com a camisa alvinegra fora do estado de São Paulo.

\section{$\rightarrow$ [footballer]'s first goal for [club]}

Although LDU won defeated Al-Ittihad 3-1 in their first game, they bowed out of the competition after losing 2-4 to Real Madrid, a match which saw Cristiano Ronaldo's first goalfor Real Madrid.

$\rightarrow$ his first goal for [club]

Fabricio Coloccini scored his first goal for Newcastle as they moved back to the top of the Championship after a 1-0 win at Cardiff on Sunday.

$\mathbf{L}$

\section{longe do gol}

Tshabalala aproveita levantamento na área adversária, mas cabeceia mal, longe do gol.

wide of the (far) post $\star \mid$ wide of the target $\mid$ wide of (the) goal | wide of [goalkeeper]'s goal | wide of the \{right|left\}-hand post | wide of the \{left|right\} upright

Valdivia pings the ball out wide of the six-yard box to Beausejour, who drags a half-decent effort wide of the far post.

Saha bursts into the box after riding the challenge of Sagna but loses his balance and slices his shot wide of the target.

Their first fell to Killen after 15 minutes but he failed to compose himself properly and blasted high and wide of Kassid's goal when it looked easier to score.

$\Leftrightarrow$ a bola PASSAR longe do gol

Bernardo cobra falta, mas a bola passa longe do gol de Marcos.

$\leftrightarrow$ hhis effort $\mid$ his shot $\mid$ the ball $\}\{$ GO | BE $\}$ \{wide of the (far) post $+\mid$ wide of the target | wide of (the) goal | wide of [goalkeeper]'s goal | wide of the \{right | left $\}$-hand post | wide of the \{left|right $\}$ upright $\}$

Sunderland clear quickly and break up the field with Darren Bent trying his luck but his

effort is wide of the goal.

Richard Eckersley shoots but the ball goes wide of the post.

$\rightarrow$ the ball DROP wide of the [target $\mid$ goal] 
Kieran Richardson plays in Darren Bent who just tries to lob the ball over Jussi Jaaskelainen but the ball drops wide of the goal.

4 $\{$ FINALIZAR|MANDAR $\}$ para longe do gol

Heskey faz boa jogada pela direita, mas finaliza para longe do gol, sem perigo.

Maximiliano Pereira (URU) chuta de direita e manda para longe do gol

↔ \{SLASH | SLICE | SQUIRT | HOOK | CLIP | SCUFF | SCREW |

DRAG | HIT $\}$ his|a\} shot $\{$ wide of the (far) post $\star \mid$ wide of the target $\mid$

wide of (the) goal | wide of [goalkeeper]'s goal\}

Saha bursts into the box after riding the challenge of Sagna but loses his balance and slices his shot wide of the target.

Nicolas Anelka should have scored when Drogba put him in on goal but he scuffed his shot wide of the far post.

$\leftrightarrow$ \{CURL | HAMMER | POKE | PULL | SLIDE $\}$ his effort \{wide of the (far) post $\star \mid$ wide of the target $\mid$ wide of (the) goal | wide of [goalkeeper]'s goal\}

The former Tottenham striker turned quickly, only to curl his effort wide of the post.

4 $\{$ THUNDER |SEND $\}$ the ball (just) wide of (the) goal

Well I can tell you that Ghana have a corner, and three men in Uruguay's penalty area ... but Isaac Vorsah makes a late run, wins the header and sends the ball just wide of goal.

M

MARCAR $\{0 \star \mid$ um $\}$ gol

Dentinho marcou o gol de honra do time alvinegro.

Após bom começo, o time da casa não furou a marcação rival, que marcou um gol de contra-ataque.

Dinei marcou o tento da Lusa.

$\ominus$ FAZER $\{0+\mid$ um $\}$ gol

$\rightarrow$ MARCAR o tento

meio do gol, no

Geraldo cobra no meio do gol e empata o jogo.

\{into $\star \mid$ in\} the middle of the goal

James Harper fires in a goal from close in low into the middle of the goal. 


\section{in the centre of (the) goal}

Honduras defender Osman Chavez goes in hard on Eren Derdiyok on the edge of the area - it's a yellow card and good free-kick opportunity for Switzerland in the centre of goal.

\section{[goleiro] segura no meio do gol}

Diego Maurício domina na área, gira o corpo, bate e Júlio César segura no meio do gol.

$\leftrightarrow[$ shot $\mid$ header $]$ is saved in the centre of the goal $\square$

Rafael Van der Vaart header from the centre of the box is saved in the centre of the goal.

Nedum Onuoha left footed shot from the centre of the box is saved in the centre of the goal.

$\mathbf{O}$

oportunidade(s) de gol

scoring chance(s) / scoring opport unities / goal-scoring opportunity $\bullet$

\section{chance(s) de gol}

$\mathbf{P}$

\section{VERBO para o fundo do gol}

Torrado cobra escanteio, Franco desvia e Vela empurra para ofundo do gol.

VERB (\{the ball | his shot\}) \{into the roof of the net | into the back of the net\}

Javier Hernandez makes space for himself in the box with a lightning-quick turn and rifles the ball into the roof of the net before Argentina goalkeeper Sergio Romero can blink.

Victorino heads straight up into the air from a free-kick and Chung-Yong Lee nods the ball into the back of the net after beating the keeper to it.

Ipswich have scored with Jon Walters putting it in the back of the net.

Gary O'Neill fires into the back of the net, shooting across Robert Green from Tuncay's pass to level terms.

\section{para o gol}

Zagueiro Wellington aproveita rebote de cabeçada e, da pequena área, manda para o gol!!!

goalwards 
Corner comes in and Jimenez gets to it to send it goalwards but it's cleared off the line by Modric.

$\checkmark$ commonly used when the goal is not scored.

\section{$\Leftrightarrow$ CABECEAR para o gol}

Time do Fla toca a bola no campo de ataque. Fierro cabeceia para o gol, mas a bola vai para fora e é tiro de meta para o Coxa.

$\stackrel{4}{4}$ HEAD (the ball) goalwards / \{POWER | THUMP | GLANCE\} a header goalwards

Leicester's Geordie striker Steve Howard did rather better at the other end when he muscled in front of Steven Taylor and powered a header goalwards.

\section{$\stackrel{4}{\rightarrow}$ [jogador] DESVIAR para o gol}

Depois de um arremesso lateral, Morel Rodríguez conseguiu cruzamento na área e Riveros desviou para o gol.

\section{$\Leftrightarrow$ [footballer] \{DIVERT | DEFLECT $\}$ the ball goalwards}

Right-back Hibbert almost set up Saha after Marouane Fellaini's clever reverse pass but the sliding French striker could not divert the ball goalwards.

It's looking like it's well off target but Berbatov throws out a leg to deflect it goalwards, but it's wide.

\section{naREMATAR | COMPLETAR | CONCLUIR | FINALISAR $\}$ para 0 gol}

Paulinho recebe passe na área e arremata para o gol.

Ceará apareceu livre na segunda trave e completou para o gol.

\section{$\stackrel{\leftrightarrow}{\rightarrow}\{$ DRIVE | SEND | PROD $\}$ it goalwards}

Gerrard will drive it goalwards but Danny Murphy races out of the wall to make the block. Corner comes in and Jimenez gets to it to send it goalwards but it's cleared off the line by Modric.

He's set in on goal against Cudicini, he prods it goalwards past Cudicini but King gets back to clear.

\section{$\stackrel{9}{\rightarrow}$ BATER | CHUTAR | EMPURRAR | MANDAR | TOCAR $\}$ para o gol}

Aos 41 minutos, Valdez dominou na área após cruzamento da direita e bateu para o gol, mas o árbitro, no entanto, paralisou alegando impedimento.

Aos cinco minutos Ananias driblou Pará e chutou para o gol. 
Lauro espalmou para o meio da área e Thiago Ribeiro apenas empurrou para o gol no rebote, dando números finais à vitória cruzeirense, e tirando do Internacional a chance de assumir a liderança do campeonato.

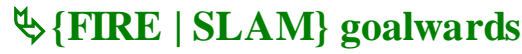

Etuhu makes a fantastic late run into the area from the left, bursting past Evans and O'Shea to take a pass and fire goalwards.

\section{$\stackrel{\leftrightarrow}{M}$ BLAST| BOOT | FIRE | HAMMER | LASH | POKE | POWER | PROD | SEND | SMASH | SLAM | STAB | VOLLEY | CHIP | LOOP\}} the ball goalwards

Agger gets the ball in the penalty area and blasts it goalwards.

Gerrard tries to hammer it goalwards, but Murphy is out quickly to block, then clear.

The delivery was perfect, hovering for what seemed like an eternity over the United penalty spot before Hangeland rose up to power it goalwards.

$\leftrightarrow\{$ HAMMER | LASH | SEND | SLAP | PUNCH | SLAM | POKE | WHACK\} a shot goalwards

Messi strides into the area and hammers a shot goalwards.

Kroos takes a high ball down and slaps a shot goalwards from 30 yards.

\section{$\leftrightarrow$ RECEBER de costas para o gol}

Aos 16 minutos, André Lima recebeu de costas para o gol e ajeitou de cabeça para Victor Simões, que entrou batendo de pé dieito e chutou por cima do travessão.

$\stackrel{\rightarrow}{\rightarrow}$ PICK UP | GATHER | RECEIVE $\}$ the ball with his back to goal Pienaar picks up the ball with his back to goal 30 yards out and is tripped as he tries to turn.

\section{VERBO para o gol vazio}

Aos 44 minutos, após tentativa pelo lado direito, a zaga do Atlético afastou errado e Misael completou para o gol vazio deixando os torcedores do time cearense eufóricos.

\section{VERB into an empty net}

The Ivorian finally got his reward for an impressive performance six minutes from time when he latched on to another high ball by Lampard, rounded the stranded Fabianski and slotted into an empty net.

\section{perigo ao gol de [goleiro]}

O São Paulo começou a partida marcando a saída de bola do Grêmio, que conseguiu levar perigo ao gol de Dênis em duas oportunidades. 


\section{attacking threat / goal threat / real threat / main threat / rare threat / major}

\section{threat / threat on goal $\square$}

First signs of an attacking threat from the home side. Tevez plays a one-two with Fletcher 30 yards out and the ball is worked between Giggs and Fletcher but he is crowded out on the right hand side and the danger is over.

Birmingham closed into their shell more the longer the game went on as Villa started to increase their threat on goal after big striker Carew entered the fray.

\section{(muito) perto do gol}

O Santo André incomoda a defesa tricolor e Wanderley chuta perto do gol de Ceni.

\section{(just) $\{$ over $\mid$ past $\}$ the $\{$ bar $\mid$ post $\mid$ crossbar $\}$}

Just two minutes after the re-start Howard produced a superb save to tip away Villa's effort, before Xabi Alonso fired a rising shot just over the crossbar.

$\rightarrow$ a bola PASSAR (muito) perto do gol

Kaká chuta da entrada da área e a bola passa perto do gol de Bravo, mas sem muita força.

$\leftrightarrow$ the ball | the effort $\mid$ a shot $\mid$ a header $\}$ GGO | FLASH $\}$ (just) \{over | past | narrowly wide of $\}$ the $\{$ bar | post | cross bar $\}$

Younes Kaboul has a header from inside the box, but his effort goes just over the bar.

A cross from the Cameroon right produces a glancing header from Pierre Webo that flashes past the far post.

$\rightarrow$ the ball $\} \quad\{$ BOUNCE $\mid$ FLY $\mid$ BOBBLE $\}$ narrowly wide of \{(goalkepper's) goal|the (far) post $\}$

Blake takes the free kick but the ball bounces narrowly wide of Foster's goal.

Villa almost level immediately after going behind. Ciaran Clark's cross deflects off Roger Johnson, but the ball bobbles narrowly wide of the far post.

\section{por cima do gol}

André Lima ajeitou com açúcar para Victor Simões, que chutou forte da entrada da área, por cima do gol de Galatto.

\section{over the $\{$ bar | cross bar $\}$}

The home crowd held their breath on the stroke of halftime after Yoann Gourcuff's 40-metre free kick almost caught Stojkovic napping, with the keeper making a last-gasp save to push the ball over the bar.

$\stackrel{\leftrightarrow}{\rightarrow}$ a bola $\{$ IR | PASSAR |SAIR $\}$ por cima do gol 
Longe!!! Washington arrisca novamente de fora da área, mas desta vez a bola foi por cima do gol de Rafael.

Krasic cruzou pela direita e Ninkovic pegou de primeira, mas a bola passou por cima do gol alemão. A Jabulani saiu por cima do gol de Jung Sung-Ryong, e os torcedores levaram as mãos às cabeças nas arquibancadas.

$\rightarrow$ the ball $\{$ FLY $\mid$ SOAR $\}$ over the bar

But credit to Chile - they did not give up and Jorge Valdivia's right foot volley had Julio Cesar concerned, before the Jabulani ball soared over the bar.

$\rightarrow\{$ the $\mid$ his $\}$ shot $\{$ FL Y | GO |DIP $\}$ over the bar

A free kick swung in from deep by Simao and the ball falls to Amorim but his shot flies over the bar from a way out.

James Beattie has a strike on goal after good play from Stoke, however the striker cant quite make a solid contact on it, and the shot goes over the bar.

Elliott had the first effort of the second half with a fierce long-range shot that dipped just over the bar.

\section{(5) $\{$ the $\mid$ his $\}$ \{effort | header $\}$ GO over the bar}

Hermann Hreidarsson has a great chance from a Jermaine Pennant corner, but his header goes over the bar.

Clarke Carlisle meets the ball at the back post from a Burnley corner, but his effort goes over the bar, much to home fans delight.

\section{$\Leftrightarrow$ CABECEAR por cima do gol}

Aos 33, após ótimo cruzamento de Emerson pela direita, o Imperador cabeceou por cima do gol, perdendo ótima chance.

\section{$\rightarrow$ HEAD over the bar}

Noble picked out Herita Ilunga with his delivery but he headed over the bar from a good position.

\section{$\stackrel{4}{\rightarrow}$ PUT | SEND | PLACE | PLANT $\}$ his header over the bar}

Jeremie Aliadiere comes in and puts his header over the bar after a great cross from Stewart Downing into the middle

Stephen Ward reaches the byline and stands a cross up for Ebanks-Blake who is wide open but he sends his header over the bar.

\section{$\Leftrightarrow$ CHUTAR | MANDAR $\}$ (a bola) por cima do gol}

Neymar faz a cobrança e manda a bola por cima do gol.

Zé Roberto recebe pela esquerda, invade a área e chuta por cima do gol, perdendo uma grande chance. 


\section{$\stackrel{\leftrightarrow}{\rightarrow}$ BLAST | SEND | BLAZE | FLICK | SCOOP $\}$ the ball over the bar}

Mido turns well and runs into some space, but Hibbert clears as far as Scharner who blasts the ball over the bar.

Nice move by Pompey after Piquionne did well to keep the ball in and pull it back to Mullins who lays it off for Kaboul on the edge of the area, the former Tottenham man opting to place it but only succeeds in sending it over the bar.

Muslera saved .... but the ball rebounds to Robben, who could score .... but instead blazes the ball over the bar!

\section{$\rightarrow$ BLAZE | FIRE | BLAST | BOOM | BOOT | FINISH | WHIP |}

\section{SLAM\} over the bar}

Luis Fabiano blazes over the bar from inside the box after being set up by Robinho.

Former Crystal Palace striker Morrison was presented with an opportunity to make it $2-0$ nine minutes before half-time but fired over the bar.

Fulham almost saw their hard work undone with the last kick of the game when substitute Zhilyaev blasted over the bar from eight yards.

\section{$\leftrightarrow\{$ SMASH | HIT | FIRE\} \{an|his $\}$ effort over the bar}

Carrick smashes an effort over the bar from Giggs' corner.

Tottenham should have taken the lead soon after when Defoe picked up the ball just outside the area, shrugged off the attention of Collins to forge a clear sight on goal but hit his effort over the bar.

Jose da Silva Bosingwa lays the ball in to Florent Malouda who fires an effort over the bar as Chelsea again go for a long-range attempt.

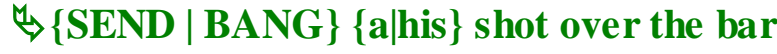

The Uruguayan keeper flapped at a Robben cross and the Liverpool dynamo pounced on the ball 14 yards out but, under pressure, banged his shot over the bar.

Cesc Fabregas sent a dipping shot over the bar and then the Arsenal captain threaded over a superb cross that Fernando Torres was just unable to convert at the far post.

\section{primeiro gol, o}

O primeiro gol do jogo saiu logo aos oito minutos.

\section{first goal, the $\star$ / opening goal, [an|the] / the opener}

He took just 18 minutes to mark his first start of the World Cup with the crucial first goal.

Delaney was still congratulating himself on checking Owen's first run when the striker deflected Frank Lampard's shot past Paul Jones for an opening goal in under four minutes.

Klose, who had scored the opener against England, then tapped home a 67th minute second.

o primeiro gol do [time] 
Aos 28 minutos do primeiro tempo, saiu o primeiro gol do Atlético Mineiro.

\section{$\leftrightarrow$ [club]'s first goal}

Rooney grabbed two goals, set up two and provided the assist that led to the penalty for United's first goal.

$\Leftrightarrow$ o primeiro gol DE $\{$ partida $\star$ |jogo $\}$

O primeiro gol da partida saiu logo aos dois minutos de jogo.

$\rightarrow$ the first goal of the \{game

Although Drogba is now unlikely to score the first goal of the game, there could be value backing him at 4/1 to score the last. His replacement, Aruna Dindane Dindane is $15 / 2$ to open the scoring although Cristiano Ronaldo unsurprisingly heads this market at 4/1.

$\mathbf{S}$

\section{SAIR do gol}

Mphela recebe longo lançamento pela esquerda, mas Óscar Pérez sai do gol e afasta o perigo com os pés.

\section{COME OFF his line / COME out of his goal}

Geovanni whips the ball in from wide but James comes off his line confidently to punch clear the danger.

Mark Schwarzer came out of his goal, but Drogba finished calmly inside the near post.

\section{4 [goleiro] SAIR do gol e ficar com a bola}

Ramon cruza em tiro de canto, Fábio sai do gol e fica com a bola.

$\leftrightarrow$ [goalkeeper] COME OFF his line to grab the ball

Minutes later, goalkeeper Dida came off his line to grab the ball, but fumbled it away as he ran into Viduka.

\section{único gol da partida, o}

O atacante David Villa fez o único gol da partida.

\{only $\star /$ lone $\}$ goal of the $\{$ game $\}$, the

Spencerport scored with 20 minutes remaining in the first half for the only goal of the game in a 1 - 0 win. 


\section{CONSIDERAÇÕES FINAIS}

O principal objetivo deste trabalho foi fazer um estudo aprofundado da terminologia do futebol por meio do estabelecimento de equivalentes fraseológicos. Para tanto, estabelecemos três objetivos específicos: a partir da compilação de um corpus comparável português-inglês de futebol, identificar as UFEs mais frequentes no corpus de português e seus equivalentes no corpus de inglês; criar um modelo de glossário bilíngue português-inglês de fraseologias do futebol e elaborar um verbete do glossário tendo como base o modelo proposto.

Para alcançar nossos objetivos, construímos um corpus de, aproximadamente, um milhão de palavras em cada língua: 917073 em português e 1002897 e m inglês. Coletamos textos de notícias de resultados de partida, narrações minuto a minuto, "transmissão social” e regras do jogo de 27 veículos de informação em inglês e 18 em português.

A compilação do corpus deu-se de forma simples. No entanto, seu balanceamento foi uma das tarefas mais laboriosas da pesquisa devido às diferenças culturais que influenciam o estilo do futebol jogado no Brasil e na Inglaterra e que regem a produção jornalística esportiva de cada país.

A diferença do número de palavras de um texto jornalístico de resultado de partidas em inglês e português foi explicada pelo conceito de high e low-context cultures, em que a quantidade de informação linguística necessária pra transmitir o significado varia de acordo com a cultura. O Brasil pertence à categoria de países highcontext, caracterizados por deixarem grande quantidade de elementos contextuais implícitos. Por esse motivo, informações que estão subentendidas na fala ou, em nosso caso, em um texto contribuem de forma efetiva para a transmissão do significado. A Inglaterra, por outro lado, pertence à categoria de países low-context, caracterizados por explicitar os elementos contextuais e debater exaustivamente os assuntos de modo que não restem dúvidas que dêem margem a uma interpretação equivocada. No caso das notícias e das transmissões minuto a minuto, observamos que os textos em português apresentam um relato sucinto, enfatizando os gols e dando pouco destaque para as jogadas, focando, dessa forma, o resultado em detrimento dos meios, até mesmo nas 
narrações minuto a minuto. Já os textos em inglês descrevem a partida com riqueza de detalhes e apresentam, quase sempre, além de um apanhado geral, a descrição dos lances mais importantes, enfatizando a importância dos meios e do resultado. Já os textos da "transmissão social" em inglês também são mais extensos do que os textos em português. Nesse caso, além das particularidades dos países de high e low-context, destacamos o interesse e o hábito do torcedor inglês de comentar a partida junto com o narrador, prática que não se mostrou popular no Brasil.

Ante as diferenças expostas, realizamos o balanceamento final do corpus pelo número de palavras em cada gênero textual e não pelo número de textos. Pretendemos, em breve, disponibilizar o corpus no site do $\operatorname{CorTec}^{140}$ para futuras pesquisas.

O primeiro objetivo, identificar as UFEs mais frequentes no corpus de português e seus equivalentes no corpus de inglês, foi alcançado parcialmente. No início da pesquisa, pretendíamos trabalhar com as fraseologias das keywords mais frequentes. No entanto, durante a análise, nos demos conta de que isso não seria possível devido ao grande número de UFEs para cada termo; sendo assim, analisamos somente as fraseologias de gol, termo mais frequente no corpus de português, e seus equivalentes em inglês.

Identificamos 58 UFEs no corpus de português e 102 possíveis equivalentes no corpus de inglês. Ao definir equivalência como "uma unidade fraseológica que funcione no texto de chegada como funciona no texto de partida" (TAGNIN, 2007, p. 1), identificamos, além de equivalentes no nível da palavra, da frase e do texto, equivalentes pragmáticos que, embora não reflitam uma tradução para a língua de chegada, são utilizados com o mes mo objetivo comunicativo.

A diferença no número de UFEs nas duas línguas e a maior variedade de verbos no corpus de inglês foram explicadas pelo conceito forma-representação, segundo o qual diferentes regiões se apropriam das regras de forma distinta, determinando, assim, 'estilos' próprios de jogar, que são traduzidos no código linguístico. O fato de o futebol inglês ser mais rápido e mais "pegado" do que o futebol brasileiro justifica a alta frequência de UFEs que indicam ação violenta, impulso, explosão e velocidade no corpus de inglês. As UFEs utilizadas para narrar gols de cabeça, também mais comuns nos periódicos britânicos, refletem a alta incidência de jogadas aéreas, características do

${ }^{140}$ Disponível em: <http://www.fflch.usp.br/dlm/comet/consulta_cortec.html>. 
futebol inglês. A maior variação de UFEs que descrevem a trajetória da bola, tanto em um gol quanto em uma tentativa, pode ser explicada pelo conceito de high e low-context culture. $\mathrm{O}$ torcedor brasileiro (high-context) espera um relato mais breve da partida e ênfase no produto final, o gol. Já o torcedor inglês (low-context) espera que os lances sejam narrados de forma precisa, com ênfase nos meios, ou seja, nas jogadas, que levaram ao gol.

O segundo objetivo, criar um modelo de glossário bilíngue português-inglês de fraseologias do futebol, foi alcançado. Elaboramos um modelo de glossário que reflete nossa visão de que além de conhecer um termo na língua $\mathrm{B}$, é necessário saber como utilizá-lo, ou seja, precisamos conhecer suas UFEs, contextos e situações. Para tanto, criamos três níveis para os verbetes. No primeiro nível, apresentamos o termo isolado, por exemplo, gol; no segundo, apresentamos as UFEs como, por exemplo, sair do gol; e no terceiro nível, elencamos as UFEs que podem fazer parte da UFE apresentada no segundo nível: [goleiro] SAIR do gol e ficar com a bola.

O terceiro e último objetivo, elaborar um verbete do glossário tendo como base o modelo proposto, também foi alcançado. Criamos um verbete para o termo gol com as 58 UFEs identificadas no corpus de português. Todas as entradas possuem equivalentes em inglês e exemplos; quando necessário, apresentamos formas sinônimas, remissivas e comentários.

As reflexões deste trabalho nos mostraram que a Terminologia não é uma atividade prescritiva, na qual os termos devem ser normatizados a fim de garantir a eficácia de uma comunicação especializada. Ao contrário, os fatores culturais, o contexto e a situação e a finalidade de uso influenciam de forma direta o funcionamento das terminologias; por esse motivo, o fazer terminológico, principalmente o bilíngue, deve considerar todos esses elementos na compilação de obras terminográficas.

Ainda há muito trabalho a ser feito sobre a terminologia bilíngue do futebol, principalmente entre o par de línguas português-inglês, como provou o levantamento das obras existentes no mercado. Fator, este, não muito positivo para um país que tem o futebol como paixão nacional e que será sede da próxima Copa do Mundo.

Por fim, acreditamos que o corpus compilado pode ser utilizado para a elaboração de um glossário bem mais abrangente do que os disponíveis on-line, que disponibilize os termos e UFEs mais comuns em português e seus equivalentes em 
inglês. Ademais, enfatizamos a importância de realizar o mesmo procedimento na direção inglês-português, de modo a identificar as UFEs mais comuns em inglês e estabelecer seus equivalentes em português, pois, como observamos, os tópicos abordados nem sempre são os mesmos nas duas línguas. Sendo assim, identificamos três próximos passos para o estudo: 1) realizar a extração das UFEs nas duas direções; 2) testar a recepção do modelo de glossário e realizar as modificações necessárias; 3) compilar, a partir das UFEs levantadas, um glossário bilíngue bidirecional português inglês de futebol. 


\section{RERERÊNCIAS BIBLIOGRÁFICAS}

AIJMER, K.; BENGT, A. English Corpus Linguistics. New York: Longman, 1991.

ALMEIDA, G. M. B. O percurso da Terminologia: de atividade prática à consolidação de uma disciplina autônoma. Tradterm, São Paulo, n. 9, p. 221-222, 2003.

ARNTZ, R.; PITCH, H. Einführung in die Terminologiearbeit. Heldesheim: Georg Olms Verlag, 1989.

ATKINS, S.; CLEAR, J. Corpus Design Criteria. Literary and Linguistic Computing, v. 7, n. 1, p. 1-16, 1992.

AZENHA JR., J. Tradução técnica e condicionantes culturais: primeiros passos para um estudo integrado. São Paulo: Humanitas/FFLCH-USP, 1999.

BAKER, M. Corpora in translation studies: An overview and some suggestions for future research. Target, Amsterdam, v. 7, n. 2, p. 223-243, 1995.

BAKHTIN, M. Marxismo e filosofia da linguagem. LAHUD, M.; FRATESCHI, F. Vieira São Paulo: Hucitec, 1986.

BERBER SARDINHA, T. Corpora eletrônicos na pesquisa em tradução. Cadernos de Tradução, Florianópolis, v. 9, n. 1, p. 15-60, 2002.

BERBER SARDINHA, T. Lingüística de Corpus. Barueri: Manole, 2004.

BERBER SARDINHA, T. Lingüística de Corpus: histórico e problemática. Revista D.E.L.T.A., São Paulo, v. 16, n. 2, p. 323-367, 2000.

BEVILACQUA, C. R. Unidades fraseológicas especializadas eventivas: descripción y reglas de formación en el ámbito de la energía solar. Tese (Doutorado em Linguística Aplicada) - Instituto Universitário de Linguística Aplicada, Universidad Pompeu Fabra, Barcelona, IULA/UPF, 2004. Disponível em: <http://tdx.cat/bitstream/handle/ 10803/7515/tcrb.pdf?sequence=1>. Acesso em: 10 jun. 2010.

BEVILACQUA, C. R. A fraseología jurídico-ambiental. Dissertação (Mestrado em Letras) - Universidade Federal do Rio Grande do Sul, Porto Alegre, 1996.

BLAIS, E. La phraséologie. une hypothèse de travail. In: Terminologies Nouvelles, Bruxelas, v. 10, p. 50-56, 1993. 
BOWKER, L.; PEARSON, J. Working with specialized language. A practical guide to using corpora. London: Routledge, 2002.

CABRÉ, M. T. La terminología, una disciplina en evolución: pasado, presente y algunos elementos de futuro. Revista Debate Terminológico, n. 1, mar. 2005. Disponível em: <http://riterm.net/revista/ojs/index.php/debateterminologico/ article/viewFile/23/45>. Acesso em: 08 abr. 2010.

CABRÉ, M. T.; LORENTE, M.; ESTOPÀ, R. Terminología y Fraseología. In: SIMPOSIO DE TERMINOLOGIA IBEROAMERICANA, 5., 1996, Cidade do México. Atas...Cidade do México: Colégio de México, 1996. p. 67 -81.

CABRÉ, M. T. Terminología: representación y comunicación. Una teoría de base comunicativa y otros artículos. Barcelona: Universitat Pompeu Fabra, Instituto Universitario de Lingüística Aplicada, 1999. [Serie Monografias, 3].

CAPINUSSÚ, J. M. A Linguagem popular do futebol. São Paulo: Ibrasa, 1998.

CRUZ, A. H. O. A nova economia do futebol: uma análise do processo de modernização de alguns estádios brasileiros. 2005. 114 f. Dissertação (Mestrado em Antropologia Social) - Universidade Federal do Rio de Janeiro, Rio de Janeiro, 2005.

D’AMBROSIO, O. Futebol na ponta da língua. Jornal Unesp, Araraquara, ano 10, n. 212, 2006.

DAMATTA, R. Esporte na sociedade: um ensaio sobre o futebol brasileiro. In: DAMATTA, R. (Org.). Universo do futebol: esporte e sociedade brasileira. Rio de Janeiro: Pinakotheke, 1982.

DAYRELL, C. Corpora no ensino de inglês acadêmico: padrões léxico-gramaticais em abstracts de pós-graduandos brasileiros. In: TAGNIN, S. E. O.; VIANA, V. Corpora no ensino de línguas estrangeiras. São Paulo: HUB Editorial, 2011.

DESMET, I. Pour une approche terminologique des sciences sociales et humaines. Les sciences sociales et humaines du travail en portugais et en français. Tese (Doutorado) - Université Paris-Nord (Paris XIII), Paris, v. 1, 1996.

FEIJÓ, L. C. S. A Linguagem do futebol no Brasil. Disponível em: <http://alinguagemdabola.com.br/fut_linguagem.html >. Acesso em: 23 mar. 2009.

FINATTO, M. J. B.; KRIEGER, M. da G. Introdução à Terminologia. Teoria \& prática. São Paulo: Contexto, 2004.

FRANCO JÚNIOR, H. A Dança dos deuses - futebol, sociedade, cultura. São Paulo: Companhia das Letras, 2007.

FRÉROT, C.; RIGOU, G.; LACOMBE, A. Phraseological approach to automatic terminology extraction from a bilingual aligned scientifc corpus. In: CORPUS 
LINGUISTICS CONFERENCE, 2001, Lancaster. Proceedings... Lancaster, Lancaster University, 2001.

GAUDIN, F. Pour une sociotermiologie. Dês prolemes semantiques aux pratiques institutionnelles. Rouen: Publications de l'Université de Rouen, 1993.

GIL, G. A copa da cultura no futebol. O Globo, Rio de Janeiro, 5. set. 2004. Disponível em: <http://www.suapesquisa.com/futebol/>. Acesso em: 16 nov. 2008.

GOUADEC, D. Nature et traitement des entités phraséologiques. In: Terminologie et phraséologie. Acteurs et amenageurs: actes de la deuxième Université d'Automne en Termi nologie. Paris: La Maison du Dictionnaire, 1994. p. 167-193.

GRÉCIANO G. Vers une modélisation phrasélogique: acquis et projets d'EUROPHRAS. Terminologies Nouvelles, Bélgica, v. 10, p. 16-22, 1993.

HALL, E. T. Beyond culture. New York: Anchor Press/Doubleday, 1976.

HALLIDAY, M. A. K. Corpus studies and probabilistic grammar. In: AIJMER, K.; ALTENBERG, B. English Corpus Linguistics. London: Longman, 1991.

HEID, U. Décrire las collocations: deux approches lexicographiques et leur application dans un outil informatisé. Terminologie et traduction. Bruxelas: Commission des Communautés Européennes, Service de Traduction, v. 2, n. 3, p. 523-548, 1992.

HEID, U. On ways words work together - topics in lexical combinatories. In: MARTIN, W. et al (Org.). Euralex'94 Proceedings... Amsterdam: Vrije University, 1994. p. 226257.

HEID, U. Towards a corpus-based dictionary of German noun-verb collocations". In: FONTENELLE, T. et al (Org.). Euralex'98 Proceedings... v. 2. Liège: Université de Liège, 1998. p. 513- 522.

HOFFMANN, L. Llenguatges d'especialitat. Selecció de textos. In: BRUMME, J. (Org.). Barcelona: IULA/UPF, 1998.

HUNSTON, S. Corpora in applied linguistics. Cambridge: Cambridge University Press, 2002.

KNOWLES, F.; THOMAS, P. Overview of phraseology in special language: synergy of collocation and valency. Moscou: Euralex, 1996.

L'HOMME, M. C. Understanding specialized lexical combinations. Terminology international journal of theoretical and applied issues in specialized communication, Amsterdam, v. 6, n. 1, p. 89-110, 2000.

L'HOMME, M-C. Caractérisation des combinaisons lexicales spécialisées par raport aux collocations de langue générale. In: FONTENELLE, T. et al (Org.). Euralex'98 Proceedings... v. 2. Liège: Université de Liège, 1998. p. 513- 522. 
LAINÉ, C.; PAVEL; S.; BOILEAU, M. La phrasélogie - nouvelle dimension de la recherche terminologique. Travaux du module canadien du RINT. L'Actualité terminologique, Canadá, v. 25, n. 3, p. 5-9, 1992.

LAVIOSA, S. Corpus-based translation studies: theory, findings, applications. Amsterdam: Rodopi, 2002.

LAVRICc, E. et al. The linguistics of football. Tübingen: Gunter Narr Verlag, 2008.

LEECH, G. The state of the art in corpus linguistics. In: SVARTVIK, J. English Corpus Linguistics. London: Longman, 1991.

LEITH, A. Over the moon, Brian - The football language. London: Boxtree, 1998.

LEONCINI, M. P.; SILVA, M. T. Entendendo o futebol como um negócio: um estudo exploratório. Gestão \& Produção, São Carlos, v. 12, n. 1, p. 11-23, jan. / abr. 2005.

MAIA, B. Making Corpora - a learning process. In: BERNARDINI, S.; ZANETTIN, F. I Corpora nella didattica della traduzione. Bologna: CLUEB, 2000. p. 74-61.

MANCA, E. From phraseology to culture: qualifying adjectives in the language of tourism. In: RÖMER, U.; RAINER, S. (Eds.). Patterns, meaningful units and specialized discourses. Philadelphia (USA): John Benjamins Publishing Company 2010. p. 105-122.

MARANHÃO, H. Dicionário de futebol. Rio de Janeiro: Record, 1998.

MARCO, M. J. L. Collocational frameworks in medical research papers: a genre-based study. English for specific purposes, v. 19, n. 1, p. 63-83, 2000.

MARTIN, W. Remarks on collocations in sublanguages. Terminologie et traduction, Bruxelas: Commission des Communautés Européennes, Service de Traduction, v. 2, n. 3, p. 157-164, 1992.

OLOHAN, M. Introducing corpora in translation studies. London: Routledge, 2004.

PALUMBO, G. The use of phraseology for training and research in the translation of LSP texts. In: MAIA, B.; JOHANN H.; MARGHERITA U. (Eds.). Training the Language Services Provider for the New Millenium - Proceedings of the III Encontros de Tradução de Astra-FLUP. Porto: Faculdade de Letras Universidade do Porto, 2003. p. 199-211.

PAVEL, S. La phraséologie en langue de spécialité. Méthodologie de consignation dans les vocabulaires terminologiques. Terminologies Nouvelles, Bélgica, v. 10, p. 67-82, 1993. Disponível em <http://www.termiumplus.gc.ca/didacticiel_tutorial/ francais/contributions_sp/1993_phraseologie_f.htm>. Acesso em: 18 maio 2010. 
PEARSON, J. Teaching terminology using electronic resources. In: BOTLEY, S.; MCENERY, A; WILSON, A. (Eds.). Multilingual Corpora in Teaching and Research. Amsterdam: Rodopi, 1998. p. 92-105.

PESANT, G.; THIBAULT, E. Terminologie et cooccurrence en langue du droit. Terminologies Nouvelles, Bélgica, v. 10, p. 23-35, 1993.

RAMOS, R. (Org.). A palavra é futebol. São Paulo: Scipione, 1990.

ROCHA, M. A. E. O uso de corpora computadorizados no ensino de língua portuguesa: metodologia e avaliação. In. GRIMM CABRAL, L. et al (Orgs.). Linguiística e ensino: novas tecnologias. Blumenal: Nova Letra, 2001. p. 137-55.

SANTORINI, B. Part-of-Speech tagging guidelines for the Penn Treebank Project. Disponível em: <http://www.ims.uni-stuttgart.de/projekte/corplex/TreeTagger/PennTreebank-Tagset.pdf $>$. Acesso em: 25 mar. 2011.

SANTOS, M. C. A.; VALE, O. A. Abordagem linguística no desenvolvimento de ontologias: proposta de construção de uma ontologia do domínio futebol. In: SEMINÁRIO DE PESQUIS A EM ONTOLOGIA NO BRASIL, 2008, Niterói. Anais... Niterói: UFF, 2008.

SCHAETZEN, C. de. Un accès rapide aux collocations. Terminologies Nouvelles, Bélgica, n. 10, p. 103-114, 1993.

SCHMIDT, T. The Kicktionary: Combining corpus linguistics and lexical semantics for a multilingual football dictionary. In: LAVRIC, E. et al. (Orgs.). The Linguistics of Football. Tübingen: Gunter Narr Verlag, 2008.

SINCLAIR, J. Corpus, concordance, collocation. Oxford: Oxford University Press, 1991.

SINCLAIR, J. Naturalness in language. In: AARTS, J; MEIJS, W. Corpus Linguistics: Recent developments in the use of computer corpora in English language research. Amsterdam: Rodopi, 1984.

SINCLAIR, J. Trust the text: language, corpus and discourse. London: Routledge, 2004.

STUBBS, M. Words and phrases. Corpus studies of lexical semantics. Oxford: Blackwell Publishers, 2001.

TAGNIN, S. E. O. A identificação de equivalentes tradutórios em corpora comparáveis. In: CONGRESSO INTERNACIONAL DA ABRAPUI, 1., 2007, Belo Horizonte. Anais... Belo Horizonte: Universidade Federal de Minas Gerais, 2007.

TAGNIN, S. E. O. O jeito que a gente diz: expressões convencionais e idiomáticas. São Paulo: Disal, 2005. 
TEMMERMAN, R. Towards a new way of terminology description. The sociocognitive approach. Amsterdam/Philadelphia: John Benjamins Publishing Company, 2000 .

TOGNINI-BONELLI, E. Between Phraseology and Terminology in the Language of Economics. In: NUCCORINI, S. (Ed.). Phrases and phraseology: data and descriptions. Bern: Peter Lang, 2002.

TOGNINI-BONELLI, E. Corpus Linguistics at Work. Amsterdam/Philadelphia: John Benjamins Publishing Company, 2001.

TOLEDO, L. H. de. Lógicas no Futebol. São Paulo: Hucitec/Fapesp, 2002.

TOLEDO, L. H. de. No país do Futebol. São Paulo: Zahar, 2000.

VARANTOLA, K. Disposable corpora as intelligent tools in translation. Cadernos de Tradução, Florianópolis, n. 9, p. 171-189, 2002.

WISNIK, J. M. Veneno remédio. São Paulo: Companhia das Letras, 2008.

WÜSTER, E. Introducción a la teoría eral de la terminología y a la lexicografía terminológica. Trad. Anne-Céceli Nokerman. Barcelona: Universidat Pompeu Fabra, 1998.

ZANATTA, R. Tradução técnica e fraseologia: por um estudo integrado. Dissertação (Mestrado em Letras) - Faculdade de Filosofia, Letras e Ciências Humanas, Universidade de São Paulo, São Paulo, 2004.

ZANETTIN, F. Corpora in translation practice. In: FIRST INTERNATIONAL WORKSHOP ON LANGUAGE RESOURCES FOR TRANSLATION WORK AND RESEARCH, 2002, Gran Canaria. Anais eletrônicos... Disponível em: <http://www.ifi.unizh.ch/cl/yuste/postworkshop/repository/fzanettin.pdf >. Acesso em: 12 mar. 2009.

ZILIO, L. Colocações especializadas e 'Komposita': um estudo constrastivo alemãoportuguês na área de cardiologia. Dissertação (Mestrado em Letras) - Instituto de Letras, Universidade Federal do Rio Grande do Sul, 2009.

Sites

Terra magazine

Disponível em: <http://terramagazine.terra.com.br/interna/0,,OI2056760-EI6608,00Uma+entrevista+parte+II.html >.

Futebol finance

Disponível em: <http://www.futebolfinance.com/real-madrid-barcelona-e-a-economiada-espanha>.

Glossário de futebol 
Disponível em: <http://br.geocities.com/helcio_englishteacher/soccer.html >.

Banco de Português

Disponível em: <http://www2.lael.pucsp.br/corpora/bp/conc/index.html >.

BNC

Disponível em: <http://www.natcorp.ox.ac.uk/>.

Etiquetas do Tree-Tagger - Português

Disponível em: <http://gramatica.usc.es/ gamallo/>.

Disponível em: <http://www.scielo.br/pdf/rbcsoc/v18n51/15995.pdf>.

\section{Dicionários}

Dicionário Houaiss eletrônico.

Dicionário Aurélio Eletrônico.

Oxford Advanced learner's dictionary of current English.

Roget's International Thesaurus. 


\section{ANEXOS}

\section{ANEXO A}

Palvras-chave do corpus de português

\begin{tabular}{rrrrrrr}
$\mathbf{N}$ & Key word & Freq. & \multicolumn{1}{c}{$\%$} & RC. Freq. & RC. $\%$ & Keyness \\
\hline 1 & BOLA & 6853 & 0,7473 & 180 & 54751 \\
2 & GOL & 6080 & 0,663 & 236 & 47837 \\
3 & FALTA & 6884 & 0,7506 & 1814 & 0,024 & 42138 \\
4 & DIREITA & 4810 & 0,5245 & 399 & 35906 \\
5 & BATIDO & 3955 & 0,4313 & 10 & 32517 \\
6 & MINUTOS & 4092 & 0,4462 & 518 & 29047 \\
7 & COBRANÇA & 3163 & 0,3449 & 157 & 24552 \\
8 & JOGO & 3859 & 0,4208 & 950 & 0,0126 & 24040 \\
9 & ÁREA & 5919 & 0,6454 & 4433 & 0,0586 & 23092 \\
10 & CHUTE & 2551 & 0,2782 & 23 & 20800 \\
11 & ESQERDA & 3099 & 0,3379 & 549 & 20787 \\
12 & GOLEIRO & 2360 & 0,2573 & 84 & 18627 \\
13 & PARTIDA & 2454 & 0,2676 & 471 & 16194 \\
14 & TIME & 2628 & 0,2866 & 688 & 16101 \\
15 & TIRO & 1924 & 0,2098 & 71 & 15159 \\
16 & COMETIDA & 1835 & 0,2001 & 23 & 14893 \\
17 & ESCANTEIO & 1674 & 0,1825 & 6 & 13736 \\
18 & META & 2011 & 0,2193 & 369 & 13391 \\
19 & ÁRBITRO & 1572 & 0,1714 & 33 & 12625 \\
20 & FORA & 2621 & 0,2858 & 1448 & 0,0191 & 12119 \\
21 & VITÓRIA & 1923 & 0,2097 & 496 & 11826 \\
22 & ATACANTE & 1541 & 0,168 & 106 & 11686 \\
23 & CRUZA & 1394 & 0,152 & 23 & 11256 \\
24 & SAI & 1635 & 0,1783 & 309 & 10820 \\
25 & JOGADA & 1353 & 0,1475 & 41 & 10742 \\
26 & AMARELO & 1376 & 0,15 & 73 & 10630 \\
27 & AOS & 5128 & 0,5592 & 8174 & 0,1081 & 10622 \\
28 & DEFESA & 2139 & 0,2332 & 1094 & 0,0145 & 10265 \\
29 & RECEBE & 1704 & 0,1858 & 504 & 10076 \\
30 & CHUTA & 1229 & 0,134 & 14 & 9985 \\
31 & O & 40135 & 4,3764 & 194044 & 2,5659 & 9982,4 \\
32 & CARTÃO & 1339 & 0,146 & 133 & 9796,8 \\
33 & GOLS & 1277 & 0,1392 & 81 & 9743,4 \\
34 & PLACAR & 1183 & 0,129 & 14 & 9605,7 \\
35 & CIMA & 1521 & 0,1659 & 373 & 9477
\end{tabular}


36

37

38

39

40

41

42

43

44

45

46

47

48

49

50

51

52

53

54

55

56

57

58

59

60

61

62

63

64

65

66

67

68

69

70

71

72

73

74

75

76

77

78

79

80

81

82

83

84

85

86
MEIA $1356 \quad 0,1479$

ATAQUE $1434 \quad 0,1564$

COPA $1488 \quad 0,1623$

PASSE $1201 \quad 0,131$

$\begin{array}{lll}\text { BATE } & 1141 & 0,1244\end{array}$

TENTA $1306 \quad 0,1424$

$\begin{array}{lll}\text { ENTRA } & 1428 & 0,1557\end{array}$

CAMPO $2216 \quad 0,2416$

EMPATE $\quad 1010 \quad 0,1101$

$\begin{array}{lll}\text { RODADA } & 997 & 0,1087\end{array}$

NA $14140 \quad 1,5419$

ZAGA $\quad 895 \quad 0,0976$

GRÊMIO $894 \quad 0,0975$

TRAVE

BATEU

CORINTHIANS

ZAGUEIRO

CHUTOU

DIEGO

IMPEDIMENTO

MAS

LANCE

CAMPEONATO

CRUZAMENTO

CHANCE

PERIGO

ENTRADA

FLAMENGO

LATERAL

PALMEIRAS

PÊNALTI

JOGADOR

ESTÁDIO

POR

BOTAFOGO

PONTOS

FLUMINENSE

NED

MARCOU

PASSES

FELIPE

RECEBEU

ADVERSÁRIO

DOMINGO

CABEÇA

TEMPO

FEZ

CRUZEIRO

TORCIDA

TRAVESSÃO $\begin{array}{ll}838 & 0,0914\end{array}$

$\begin{array}{lll}893 & 0,0974\end{array}$

$894 \quad 0,0975$

$861 \quad 0,0939$

$\begin{array}{lll}805 & 0,0878\end{array}$

8220,0896

8320,0907

$5897 \quad 0,643$

$\begin{array}{ll}795 & 0,0867\end{array}$

$872 \quad 0,0951$

$810 \quad 0,0883$

$970 \quad 0,1058$

$990 \quad 0,108$

15210,1659

$\begin{array}{lll}691 & 0,0753\end{array}$

$827 \quad 0,0902$

$871 \quad 0,095$

$\begin{array}{ll}658 & 0,0718\end{array}$

$\begin{array}{lll}894 & 0,0975\end{array}$

$\begin{array}{lll}731 & 0,0797\end{array}$

$11476 \quad 1,2514$

$\begin{array}{ll}683 & 0,0745\end{array}$

$1449 \quad 0,158$

$\begin{array}{ll}666 & 0,0726\end{array}$

$\begin{array}{ll}564 & 0,0615\end{array}$

$\begin{array}{ll}666 & 0,0726\end{array}$

$604 \quad 0,0659$

$\begin{array}{ll}611 & 0,0666\end{array}$

9930,1083

$\begin{array}{ll}659 & 0,0719\end{array}$

$802 \quad 0,0875$

$1126 \quad 0,1228$

$3081 \quad 0,336$

$1336 \quad 0,1457$

$\begin{array}{lll}647 & 0,0706\end{array}$

$\begin{array}{ll}602 & 0,0656\end{array}$

$535 \quad 0,0583$

NO $13418 \quad 1,4631$
229

322

390

95

52

239

385

1725

68

60

52450

9

37

13

67

69

49

11

57

69

15576

65

149

100

287

338

1299

31

177

231

17

292

104

45811

58

1402

88

0

94

35

46

566

107

284

8190,0108

6671

1314

119

76

15

$60126 \quad 0,7951$
9172,4

9132,4

9108,8

8995,3

8892

8697,9

8673,1

8425,9

7668,7

7634,2

7552,6

7280,6

7000,1

6770,7

6718

6708,6

6617,2

6518,5

6224,7

6200,8

6183,3

5932,7

5882,4

5761,2

5731,4

5586,6

5433,5

5385,9

5322,7

5311,2

5247,6

5119,5

5089,2

5079

5076,9

4728,7

4689,1

4641,9

4641,8

4633,6

4592,3

4514,8

4485,4

4467,5

4465,1

4367,8

4305,5

4300,4

4266

4253,5

4244,7 


\begin{tabular}{|c|c|c|c|c|c|c|}
\hline 87 & TRICOLOR & 515 & 0,0562 & 7 & & 4167,2 \\
\hline 88 & BRUNO & 572 & 0,0624 & 61 & & 4144,8 \\
\hline 89 & EQUIPE & 1664 & 0,1814 & 2220 & 0,0294 & 4128,9 \\
\hline 90 & ESP & 541 & 0,059 & 34 & & 4125,3 \\
\hline 91 & CRUZOU & 528 & 0,0576 & 24 & & 4110,3 \\
\hline 92 & COBRA & 587 & 0,064 & 81 & & 4104,7 \\
\hline 93 & ANDRÉ & 795 & 0,0867 & 349 & & 4078,1 \\
\hline 94 & JOGADORES & 790 & 0,0861 & 342 & & 4075,9 \\
\hline 95 & GOIÁS & 612 & 0,0667 & 116 & & 4042,5 \\
\hline 96 & CAMISA & 539 & 0,0588 & 60 & & 3884,3 \\
\hline 97 & GER & 491 & 0,0535 & 17 & & 3871,9 \\
\hline 98 & AVAí & 468 & 0,051 & 0 & & 3850,2 \\
\hline 99 & SANTOS & 1091 & 0,119 & 964 & 0,0127 & 3804,1 \\
\hline 100 & AFASTA & 504 & 0,055 & 38 & & 3786 \\
\hline 101 & LONGE & 819 & 0,0893 & 455 & & 3771,3 \\
\hline 102 & URU & 452 & 0,0493 & 2 & & 3697,9 \\
\hline 103 & PRIMEIRO & 2309 & 0,2518 & 4590 & 0,0607 & 3671,1 \\
\hline 104 & BRA & 447 & 0,0487 & 6 & & 3616,5 \\
\hline 105 & VASCO & 475 & 0,0518 & 32 & & 3601,6 \\
\hline 106 & ESQUERDO & 521 & 0,0568 & 78 & & 3594,7 \\
\hline 107 & MANDA & 497 & 0,0542 & 54 & & 3591,9 \\
\hline 108 & CHANCES & 626 & 0,0683 & 204 & & 3585,3 \\
\hline 109 & DEFENDIDO & 472 & 0,0515 & 35 & & 3550,3 \\
\hline 110 & MARCAÇÃO & 747 & 0,0815 & 397 & & 3515,3 \\
\hline 111 & RAFAEL & 500 & 0,0545 & 68 & & 3503 \\
\hline 112 & CABECEIA & 427 & 0,0466 & 3 & & 3481,6 \\
\hline 113 & DOMINA & 545 & 0,0594 & 121 & & 3475,2 \\
\hline 114 & PELA & 4721 & 0,5148 & 15149 & 0,2003 & 3458,3 \\
\hline 115 & CANTO & 601 & 0,0655 & 204 & & 3395,4 \\
\hline 116 & $\mathrm{GHA}$ & 410 & 0,0447 & 0 & & 3371,8 \\
\hline 117 & VENCE & 461 & 0,0503 & 46 & & 3365,3 \\
\hline 118 & REBOTE & 406 & 0,0443 & 5 & & 3288,4 \\
\hline 119 & GANA & 409 & 0,0446 & 9 & & 3273,6 \\
\hline 120 & ARRISCA & 428 & 0,0467 & 28 & & 3251,8 \\
\hline 121 & ERRA & 407 & 0,0444 & 11 & & 3237,7 \\
\hline 122 & DESVIA & 404 & 0,0441 & 12 & & 3203,3 \\
\hline 123 & CRUZADO & 456 & 0,0497 & 61 & & 3202 \\
\hline 124 & CONTRA-ATAQUE & 415 & 0,0453 & 23 & & 3190,5 \\
\hline 125 & FORTE & 973 & 0,1061 & 936 & 0,0124 & 3187,6 \\
\hline 126 & CORITIBA & 387 & 0,0422 & 0 & & 3182,2 \\
\hline 127 & GRAMADO & 404 & 0,0441 & 17 & & 3155,7 \\
\hline 128 & ATLÉTICO & 429 & 0,0468 & 40 & & 3154,9 \\
\hline 129 & TOCA & 453 & 0,0494 & 65 & & 3146,3 \\
\hline 130 & TOCOU & 420 & 0,0458 & 33 & & 3141,9 \\
\hline 131 & BARUERI & 392 & 0,0427 & 9 & & 3133,5 \\
\hline 132 & VAN & 600 & 0,0654 & 253 & & 3127,5 \\
\hline 133 & APÓS & 1595 & 0,1739 & 2669 & 0,0353 & 3124,5 \\
\hline 134 & ETAPA & 998 & 0,1088 & 1026 & 0,0136 & 3105,9 \\
\hline 135 & RASTEIRO & 380 & 0,0414 & 5 & & 3074 \\
\hline 136 & COBROU & 388 & 0,0423 & 15 & & 3042 \\
\hline 137 & JOGADAS & 404 & 0,0441 & 37 & & 2976,3 \\
\hline
\end{tabular}


138

139

140

141

142

143

144

145

146

147

148

149

150

151

152

153

154

155

156

157

158

159

160

161

162

163

164

165

166

167

168

169

170

171

172

173

174

175

176

177

178

179

180

181

182

183

184

185

186

187

188

\begin{tabular}{|c|c|c|}
\hline CORTA & 389 & 0,0424 \\
\hline PEGA & 440 & 0,048 \\
\hline ROBINHO & 358 & 0,039 \\
\hline CÉSAR & 525 & 0,0572 \\
\hline TÉCNICO & 877 & 0,0956 \\
\hline CONSEGUIU & 749 & 0,0817 \\
\hline HOLANDA & 492 & 0,0536 \\
\hline VAGA & 545 & 0,0594 \\
\hline BOA & 1091 & 0,119 \\
\hline VENCEU & 448 & 0,0489 \\
\hline PERDE & 557 & 0,0607 \\
\hline RONALDO & 465 & 0,0507 \\
\hline ACERTA & 349 & 0,0381 \\
\hline VOLANTE & 388 & 0,0423 \\
\hline FUNDO & 850 & 0,0927 \\
\hline FINALIZA & 342 & 0,0373 \\
\hline SAIU & 567 & 0,0618 \\
\hline MINUTO & 412 & 0,0449 \\
\hline LINHA & 984 & 0,1073 \\
\hline JPN & 324 & 0,0353 \\
\hline FABIANO & 324 & 0,0353 \\
\hline CABEÇADA & 326 & 0,0355 \\
\hline SÁBADO & 487 & 0,0531 \\
\hline $\mathrm{CHI}$ & 321 & 0,035 \\
\hline MARCAR & 449 & 0,049 \\
\hline VOLTOU & 501 & 0,0546 \\
\hline RIVAL & 333 & 0,0363 \\
\hline FAZ & 1475 & 0,1608 \\
\hline LUGAR & 1425 & 0,1554 \\
\hline URUGUAI & 400 & 0,0436 \\
\hline KAKÁ & 307 & 0,0335 \\
\hline THIAGO & 376 & 0,041 \\
\hline MEX & 306 & 0,0334 \\
\hline ANDAMENTO & 545 & 0,0594 \\
\hline ADRIANO & 333 & 0,0363 \\
\hline CHEGOU & 718 & 0,0783 \\
\hline CASA & 1184 & 0,1291 \\
\hline SOBRA & 344 & 0,0375 \\
\hline QUARTA-FEIRA & 428 & 0,0467 \\
\hline ACERTOU & 335 & 0,0365 \\
\hline ATLÉTICO-MG & 294 & 0,0321 \\
\hline ACRÉSCIMO & 406 & 0,0443 \\
\hline ATLÉTICO-PR & 283 & 0,0309 \\
\hline JÚLIO & 341 & 0,0372 \\
\hline MARCADOR & 380 & 0,0414 \\
\hline ARG & 291 & 0,0317 \\
\hline LUIS & 410 & 0,0447 \\
\hline LEVANTA & 324 & 0,0353 \\
\hline INTER & 311 & 0,0339 \\
\hline MANDOU & 334 & 0,0364 \\
\hline RENAN & 281 & 0,0306 \\
\hline
\end{tabular}

$\begin{array}{rrr}24 & & 2967,8 \\ 78 & & 2943,4 \\ 0 & & 2943 \\ 189 & & 2905,1 \\ 834 & 0,011 & 2897,5 \\ 567 & & 2895,1 \\ 155 & & 2847,4 \\ 229 & & 2844,3 \\ 1381 & 0,0183 & 2842,5 \\ 102 & & 2838,1 \\ 250 & & 2828,7 \\ 131 & & 2784 \\ 13 & & 2740,8 \\ 54 & & 2706,8 \\ 852 & 0,0113 & 2697,7 \\ 14 & & 2673,7 \\ 301 & & 2668,2 \\ 86 & & 2662,9 \\ 1199 & 0,0159 & 2653,6 \\ 1 & & 2652,4 \\ 5 & & 2612,3 \\ 7 & & 2609,1 \\ 195 & & 2589,8 \\ 5 & & 2587,6 \\ 145 & & 2577,3 \\ 218 & 2577 \\ 18 & 2562,5 \\ 2750 & 0,0364 & 2542 \\ 2586 & 0,0342 & 2538,1 \\ 92 & & 2527 \\ 0 & 2522,4 \\ 66 & 2518,9 \\ 2 & 2493,9 \\ 320 & 2437,5 \\ 34 & & 2422,1 \\ 667 & & 2412,9 \\ 1921 & 0,0254 & 2400,1 \\ 53 & & 2359,2 \\ 156 & & 2356,7 \\ 45 & 2348,7 \\ 7 & 2345,4 \\ 132 & 2324,7 \\ 0 & & 2324,5 \\ 55 & & 2319,9 \\ 101 & & 2311,6 \\ 9 & & 2301,4 \\ 146 & & 2276,1 \\ 33 & & 2251,5 \\ 57 & & 2248,7 \\ 6 & & \end{array}$


202

203

204

205

206

207

208

209

210

211

212

213

214

215

216

217

218

219

220

221

222

223

224

225

226

227

228

229

230

231

232

233

234

235

236

237

238

239

\begin{tabular}{|c|c|c|}
\hline TENTOU & 376 & 0,041 \\
\hline EXPULSO & 312 & 0,034 \\
\hline AVANÇA & 328 & 0,0358 \\
\hline COMPETIÇÃ̃O & 546 & 0,0595 \\
\hline FRENTE & 877 & 0,0956 \\
\hline CABECEOU & 277 & 0,0302 \\
\hline JOGOS & 578 & 0,063 \\
\hline MESSI & 267 & 0,0291 \\
\hline APROVEITOU & 314 & 0,0342 \\
\hline SPORT & 312 & 0,034 \\
\hline DERROTA & 440 & 0,048 \\
\hline ERMEDIÁRIA & 370 & 0,0403 \\
\hline LEANDRO & 306 & 0,0334 \\
\hline EMPATOU & 285 & 0,0311 \\
\hline LÚCIO & 323 & 0,0352 \\
\hline EQUIPES & 537 & 0,0586 \\
\hline NÁUTICO & 261 & 0,0285 \\
\hline FÁBIO & 377 & 0,0411 \\
\hline ESTREIA & 257 & 0,028 \\
\hline SELEÇÃO & 860 & 0,0938 \\
\hline SAIIDA & 695 & 0,0758 \\
\hline KLÉBER & 264 & 0,0288 \\
\hline VILLA & 268 & 0,0292 \\
\hline PRK & 252 & 0,0275 \\
\hline COREIA & 250 & 0,0273 \\
\hline LEEO & 258 & 0,0281 \\
\hline DERRUBADO & 260 & 0,0284 \\
\hline ENTROU & 439 & 0,0479 \\
\hline SNEIJDER & 247 & 0,0269 \\
\hline PERDEU & 458 & 0,0499 \\
\hline JOGA & 322 & 0,0351 \\
\hline BAIXAMENTO & 285 & 0,0311 \\
\hline GUARANI & 306 & 0,0334 \\
\hline PARAGUAI & 322 & 0,0351 \\
\hline PERSIE & 240 & 0,0262 \\
\hline SEGURA & 335 & 0,0365 \\
\hline MUSLERA & 238 & 0,026 \\
\hline PRIMEIRA & 1517 & 0,1654 \\
\hline MAICON & 234 & 0,0255 \\
\hline ALEMANHA & 643 & 0,0701 \\
\hline MARCA & 611 & 0,0666 \\
\hline JOGANDO & 306 & 0,0334 \\
\hline ESPANHA & 468 & 0,051 \\
\hline CMR & 233 & 0,0254 \\
\hline AUS & 239 & 0,0261 \\
\hline TIMES & 351 & 0,0383 \\
\hline SRB & 231 & 0,0252 \\
\hline SUI & 270 & 0,0294 \\
\hline DAGOBERTO & 239 & 0,0261 \\
\hline SVK & 228 & 0,0249 \\
\hline ARGENTINA & 506 & 0,0552 \\
\hline
\end{tabular}

\begin{tabular}{|c|c|c|}
\hline 107 & & 2243,1 \\
\hline 35 & & 2242,7 \\
\hline 52 & & 2238 \\
\hline 378 & & 2227,8 \\
\hline 1152 & 0,0152 & 2206,5 \\
\hline 7 & & 2205,3 \\
\hline 448 & & 2199,6 \\
\hline 0 & & 2192,5 \\
\hline 44 & & 2186 \\
\hline 42 & & 2186, \\
\hline 209 & & 2178, \\
\hline 110 & & 2178,6 \\
\hline 37 & & 2177,6 \\
\hline 17 & & 2177,3 \\
\hline 55 & & 2175 \\
\hline 381 & & 2159 \\
\hline 2 & & $2122, \varepsilon$ \\
\hline 130 & & 2115, \\
\hline 0 & & 2110 \\
\hline 1165 & 0,0154 & 2100 \\
\hline 743 & & 2094, \\
\hline 9 & & 207 \\
\hline 13 & & 2074 \\
\hline 0 & & 2068 \\
\hline 0 & & 2052 \\
\hline 7 & & 2048 \\
\hline 10 & & 2036 \\
\hline 241 & & 2030 \\
\hline 0 & & 2027 \\
\hline 281 & & 2000 \\
\hline 79 & & 2000 , \\
\hline 38 & & 1999,2 \\
\hline 63 & & $1981, \mathrm{~s}$ \\
\hline 83 & & 1974, \\
\hline 0 & & 1969 \\
\hline 101 & & 1963, \\
\hline 0 & & 1953 \\
\hline 3515 & 0,0465 & $1948, \varepsilon$ \\
\hline 0 & & 1920, \\
\hline 696 & & 1918, \\
\hline 621 & & 191 \\
\hline 73 & & 191 \\
\hline 323 & & 1912 \\
\hline 0 & & 1912 \\
\hline 5 & & 1911, \\
\hline 132 & & 1909, \\
\hline 0 & & 1895, \\
\hline 36 & & 1893 , \\
\hline 9 & & 1873 , \\
\hline 0 & & 1870, \\
\hline 410 & & 1869, \\
\hline
\end{tabular}




\begin{tabular}{|c|c|c|c|}
\hline 240 & ARRISCOU & 238 & 0,026 \\
\hline 241 & MARCELINHO & 250 & 0,0273 \\
\hline 242 & FORLÁN & 227 & 0,0248 \\
\hline 243 & PARA & 14468 & 1,5776 \\
\hline 244 & DESVIOU & 235 & 0,0256 \\
\hline 245 & ESLOVÁQUIA & 224 & 0,0244 \\
\hline 246 & BRASILEIRÃO & 224 & 0,0244 \\
\hline 247 & ABRIU & 394 & 0,043 \\
\hline 248 & RESULTADO & 1120 & 0,1221 \\
\hline 249 & DEU & 682 & 0,0744 \\
\hline 250 & STEKELENBURG & 217 & 0,0237 \\
\hline 251 & ADVERSÁRIA & 231 & 0,0252 \\
\hline 252 & $\mathrm{HON}$ & 216 & 0,0236 \\
\hline 253 & COMETE & 244 & 0,0266 \\
\hline 254 & FEITO & 1054 & 0,1149 \\
\hline 255 & DESARMADO & 212 & 0,0231 \\
\hline 256 & KINGSON & 210 & 0,0229 \\
\hline 257 & ATLÉTICO-GO & 210 & 0,0229 \\
\hline 258 & COLOCAÇÃO & 376 & 0,041 \\
\hline 259 & CONTRA & 1330 & 0,145 \\
\hline 260 & ZÉ & 270 & 0,0294 \\
\hline 261 & COM & 11315 & 1,2338 \\
\hline 262 & NEYMAR & 206 & 0,0225 \\
\hline 263 & CONSEGUE & 537 & 0,0586 \\
\hline 264 & XAVI & 205 & 0,0224 \\
\hline 265 & DEN & 219 & 0,0239 \\
\hline 266 & VIRADA & 282 & 0,0308 \\
\hline 267 & TRAVADO & 208 & 0,0227 \\
\hline 268 & VANTAGEM & 477 & 0,052 \\
\hline 269 & ROBBEN & 203 & 0,0221 \\
\hline 270 & CIV & 203 & 0,0221 \\
\hline 271 & LOGO & 713 & 0,0777 \\
\hline 272 & COXA & 221 & 0,0241 \\
\hline 273 & CHEGA & 524 & 0,0571 \\
\hline 274 & TEVE & 855 & 0,0932 \\
\hline 275 & MARCADO & 362 & 0,0395 \\
\hline 276 & CARIOCA & 299 & 0,0326 \\
\hline 277 & NGA & 200 & 0,0218 \\
\hline 278 & PONTA & 410 & 0,0447 \\
\hline 279 & LIBERTADORES & 228 & 0,0249 \\
\hline 280 & DUELO & 217 & 0,0237 \\
\hline 281 & SVN & 197 & 0,0215 \\
\hline 282 & GRE & 197 & 0,0215 \\
\hline 283 & PASSOU & 715 & 0,078 \\
\hline 284 & MEIO-CAMPO & 262 & 0,0286 \\
\hline 285 & VENCER & 343 & 0,0374 \\
\hline 286 & VOLTA & 652 & 0,0711 \\
\hline 287 & KOR & 192 & 0,0209 \\
\hline 288 & POSSE & 469 & 0,0511 \\
\hline 289 & ENG & 217 & 0,0237 \\
\hline 290 & ESTICA & 197 & 0,0215 \\
\hline
\end{tabular}

$\begin{array}{rrr} & & \\ 9 & & 1865 \\ 20 & & 1863,6 \\ 0 & & 1862,7 \\ 81199 & 1,0737 & 1861,2 \\ 7 & & 1859,3 \\ 0 & & 1837,9 \\ 0 & & 1837,9 \\ 213 & & 1836 \\ 2188 & 0,0289 & 1819,2 \\ 858 & 0,0113 & 1785,4 \\ 0 & & 1780,2 \\ 12 & & 1779,4 \\ 1 & & 1761,8 \\ 29 & & 1738,8 \\ 2040 & 0,027 & 1732,3 \\ 1 & & 1728,8 \\ 0 & & 1722,5 \\ 0 & & 1722,5 \\ 212 & & 1715,4 \\ 3095 & 0,0409 & 1697,3 \\ 64 & & 1690,7 \\ 61563 & 0,8141 & 1690,6 \\ 0 & & 1689,5 \\ 545 & & 1686,2 \\ 0 & & 1681,3 \\ 12 & & 1680,8 \\ 81 & & 1676 \\ 3 & & 1675,9 \\ 419 & & 1667,4 \\ 0 & & 1664,8 \\ 0 & & 1664,8 \\ 1019 & 0,0135 & 1651,3 \\ 18 & & 1643,6 \\ 533 & & 1642,4 \\ 1459 & 0,0193 & 1636,2 \\ 208 & & 1635,5 \\ 111 & & 1633,5 \\ 1 & & 1629,9 \\ 297 & & 1626,6 \\ 27 & & 1625 \\ 17 & & 1619,6 \\ 0 & & 1615,3 \\ 0 & & 1615,3 \\ 1058 & 0,014 & 1598,2 \\ 69 & & 1595,6 \\ 188 & & 1586,7 \\ 891 & 0,0118 & 1578,3 \\ 0 & & 1574,1 \\ 53 & & 1568,4 \\ 5 & & 1568,4 \\ & & 1565,6 \\ & & \end{array}$




\begin{tabular}{|c|c|c|c|c|c|c|}
\hline 291 & DEIXA & 512 & 0,0558 & 540 & & 1559,1 \\
\hline 292 & CHILE & 319 & 0,0348 & 157 & & 1553 \\
\hline 293 & ÁFRICA & 433 & 0,0472 & 367 & & 1551,4 \\
\hline 294 & ALEX & 207 & 0,0226 & 16 & & 1546,5 \\
\hline 295 & WELLINGTON & 192 & 0,0209 & 3 & & 1544 \\
\hline 296 & SANTO & 380 & 0,0414 & 269 & & 1528,4 \\
\hline 297 & ESPALMA & 185 & 0,0202 & 0 & & 1516,3 \\
\hline 298 & SEGUNDA & 898 & 0,0979 & 1709 & 0,0226 & 1507,2 \\
\hline 299 & ALESSANDRO & 206 & 0,0225 & 20 & & 1503,9 \\
\hline 300 & NEUER & 183 & 0,02 & 0 & & 1499,8 \\
\hline 301 & ALVINEGRO & 186 & 0,0203 & 3 & & 1494,5 \\
\hline 302 & TORCEDORES & 223 & 0,0243 & 40 & & 1484,5 \\
\hline 303 & AJEITA & 190 & 0,0207 & 8 & & 1479,4 \\
\hline 304 & BASTOS & 232 & 0,0253 & 51 & & 1478,5 \\
\hline 305 & DEPOIS & 1488 & 0,1623 & 4066 & 0,0538 & 1469 \\
\hline 306 & GYAN & 179 & 0,0195 & 0 & & 1466,9 \\
\hline 307 & MÉXICO & 356 & 0,0388 & 242 & & 1466,4 \\
\hline 308 & DOUGLAS & 239 & 0,0261 & 63 & & 1454,5 \\
\hline 309 & ITÁLIA & 433 & 0,0472 & 404 & & 1448,7 \\
\hline 310 & JONG & 178 & 0,0194 & 1 & & 1448,5 \\
\hline 311 & JUAN & 230 & 0,0251 & 54 & & 1442,5 \\
\hline 312 & ACIONADO & 211 & 0,023 & 35 & & 1425,2 \\
\hline 313 & FUTEBOL & 418 & 0,0456 & 380 & & 1425,2 \\
\hline 314 & HOWARD & 205 & 0,0224 & 30 & & 1414,9 \\
\hline 315 & LANÇAMENTO & 434 & 0,0473 & 420 & & 1412,9 \\
\hline 316 & MARK & 220 & 0,024 & 47 & & 1411 \\
\hline 317 & EMPATAR & 181 & 0,0197 & 8 & & 1405,3 \\
\hline 318 & CONTRA-ATAQUES & 182 & 0,0198 & 9 & & 1404,3 \\
\hline 319 & MÁRCIO & 274 & 0,0299 & 120 & & 1402,8 \\
\hline 320 & CONCA & 171 & 0,0186 & 0 & & 1400,9 \\
\hline 321 & ALÇA & 178 & 0,0194 & 6 & & 1399,5 \\
\hline 322 & DAVID & 279 & 0,0304 & 132 & & 1381,9 \\
\hline 323 & JONAS & 193 & 0,021 & 22 & & 1381,3 \\
\hline 324 & HENRIQUE & 443 & 0,0483 & 455 & & 1377,3 \\
\hline 325 & MARACANÃ & 183 & 0,02 & 13 & & 1376,3 \\
\hline 326 & HARLEI & 167 & 0,0182 & 0 & & 1367,9 \\
\hline 327 & PODOLSKI & 167 & 0,0182 & 0 & & 1367,9 \\
\hline 328 & CHUTAR & 168 & 0,0183 & 2 & & 1356 \\
\hline 329 & FRA & 177 & 0,0193 & 10 & & 1354 \\
\hline 330 & ARTILHEIRO & 180 & 0,0196 & 13 & & 1351,7 \\
\hline 331 & CASILLAS & 165 & 0,018 & 0 & & 1351,4 \\
\hline 332 & LIVRE & 503 & 0,0548 & 619 & & 1342,6 \\
\hline 333 & DANIEL & 271 & 0,0296 & 130 & & 1333,8 \\
\hline 334 & ZAGUEIROS & 175 & 0,0191 & 11 & & 1328,5 \\
\hline 335 & CENI & 162 & 0,0177 & 0 & & 1326,7 \\
\hline 336 & JORGE & 361 & 0,0394 & 295 & & 1325,1 \\
\hline 337 & GOLEADA & 174 & 0,019 & 11 & & 1320,3 \\
\hline 338 & CRISTIANO & 191 & 0,0208 & 28 & & 1317,4 \\
\hline 339 & TIMÃO & 163 & 0,0178 & 2 & & 1314,8 \\
\hline 340 & SÉRVIA & 176 & 0,0192 & 14 & & 1310,1 \\
\hline 341 & RICARDO & 384 & 0,0419 & 352 & & 1301 \\
\hline
\end{tabular}




\begin{tabular}{|c|c|c|c|c|c|c|}
\hline 342 & KLOSE & 158 & 0,0172 & 0 & & 1293,7 \\
\hline 343 & SELEÇÕES & 191 & 0,0208 & 32 & & 1287 \\
\hline 344 & MAL & 505 & 0,0551 & 654 & & 1286,1 \\
\hline 345 & SCHWEINSTEIGER & 157 & 0,0171 & 0 & & 1285,4 \\
\hline 346 & KUYT & 157 & 0,0171 & 0 & & 1285,4 \\
\hline 347 & ASAMOAH & 157 & 0,0171 & 0 & & 1285,4 \\
\hline 348 & TORNEIO & 208 & 0,0227 & 52 & & 1283,1 \\
\hline 349 & CEARÁ & 236 & 0,0257 & 90 & & 1275,2 \\
\hline 350 & KAWASHIMA & 157 & 0,0171 & 2 & & 1265,3 \\
\hline 351 & MINEIRÃO & 160 & 0,0174 & 5 & & 1260,8 \\
\hline 352 & DOMINOU & 174 & 0,019 & 18 & & 1259,7 \\
\hline 353 & ROONEY & 163 & 0,0178 & 8 & & 1257,3 \\
\hline 354 & WESLEY & 163 & 0,0178 & 8 & & 1257,3 \\
\hline 355 & SUAREZ & 156 & 0,017 & 2 & & 1257,1 \\
\hline 356 & PERTO & 401 & 0,0437 & 408 & & 1255,6 \\
\hline 357 & MARQUINHOS & 157 & 0,0171 & 3 & & 1255,5 \\
\hline 358 & $\mathrm{RI}$ & 188 & 0,0205 & 34 & & 1248,3 \\
\hline 359 & CLEITON & 154 & 0,0168 & 2 & & 1240,6 \\
\hline 360 & LADO & 1048 & 0,1143 & 2564 & 0,0339 & 1238,9 \\
\hline 361 & BAIER & 151 & 0,0165 & 0 & & 1236 \\
\hline 362 & GUK & 151 & 0,0165 & 0 & & 1236 \\
\hline 363 & SOBROU & 174 & 0,019 & 21 & & 1235 \\
\hline 364 & FRACO & 209 & 0,0228 & 61 & & 1234,5 \\
\hline 365 & OITAVAS & 158 & 0,0172 & 7 & & 1225,5 \\
\hline 366 & ALVES & 338 & 0,0369 & 283 & & 1220,2 \\
\hline 367 & RUBRO-NEGRO & 149 & 0,0162 & 0 & & 1219,5 \\
\hline 368 & FERNANDO & 515 & 0,0562 & 722 & & 1215 \\
\hline 369 & OBINA & 148 & 0,0161 & 0 & & 1211,2 \\
\hline 370 & ALG & 150 & 0,0164 & 2 & & 1207,6 \\
\hline 371 & MAXI & 152 & 0,0166 & 4 & & 1204,5 \\
\hline 372 & DENTINHO & 152 & 0,0166 & 4 & & 1204,5 \\
\hline 373 & $x$ & 934 & 0,1018 & 2159 & 0,0285 & 1203 \\
\hline 374 & FINAL & 1102 & 0,1202 & 2841 & 0,0376 & 1198,7 \\
\hline 375 & DEIXOU & 405 & 0,0442 & 443 & & 1196,2 \\
\hline 376 & BOATENG & 146 & 0,0159 & 0 & & 1194,7 \\
\hline 377 & MARCELO & 303 & 0,033 & 222 & & 1192,4 \\
\hline 378 & TREINADOR & 217 & 0,0237 & 79 & & 1192,1 \\
\hline 379 & ENFRENTA & 253 & 0,0276 & 134 & & 1188,7 \\
\hline 380 & ELANO & 145 & 0,0158 & 0 & & 1186,5 \\
\hline 381 & CONFRONTO & 259 & 0,0282 & 145 & & 1184,1 \\
\hline 382 & TOQUE & 225 & 0,0245 & 92 & & 1183,4 \\
\hline 383 & ACABOU & 403 & 0,0439 & 446 & & 1178,8 \\
\hline 384 & TARDELLI & 144 & 0,0157 & 0 & & 1178,2 \\
\hline 385 & PARTIDAS & 201 & 0,0219 & 61 & & 1172,9 \\
\hline 386 & RODRIGO & 196 & 0,0214 & 55 & & 1170,7 \\
\hline 387 & OFENSIVO & 161 & 0,0176 & 16 & & 1170,4 \\
\hline 388 & ASSISTENTE & 254 & 0,0277 & 142 & & 1162 \\
\hline 389 & LAMPARD & 142 & 0,0155 & 0 & & 1161,7 \\
\hline 390 & PRUDENTE & 237 & 0,0258 & 117 & & 1150,7 \\
\hline 391 & SUBSTITUIÇÃO & 444 & 0,0484 & 568 & & 1143,3 \\
\hline 392 & COMEÇA & 504 & 0,055 & 735 & & 1142,6 \\
\hline
\end{tabular}




\begin{tabular}{|c|c|c|c|c|c|c|}
\hline 393 & JUNINHO & 171 & 0,0186 & 30 & & 1141,5 \\
\hline 394 & GOLAÇO & 139 & 0,0152 & 0 & & 1137 \\
\hline 395 & ROLA & 150 & 0,0164 & 10 & & 1132,4 \\
\hline 396 & MARFIM & 151 & 0,0165 & 11 & & 1131,7 \\
\hline 397 & VERDÃO & 138 & 0,015 & 0 & & 1128,8 \\
\hline 398 & RAMIRES & 145 & 0,0158 & 6 & & 1127,9 \\
\hline 399 & VICTOR & 238 & 0,026 & 124 & & 1126,8 \\
\hline 400 & PARK & 191 & 0,0208 & 57 & & 1120 \\
\hline 401 & PÉREZ & 141 & 0,0154 & 4 & & 1113,9 \\
\hline 402 & JOGAR & 300 & 0,0327 & 241 & & 1113 \\
\hline 403 & EDUARDO & 386 & 0,0421 & 436 & & 1109,6 \\
\hline 404 & GALO & 145 & 0,0158 & 8 & & 1109,4 \\
\hline 405 & DINAMARCA & 177 & 0,0193 & 42 & & 1105,5 \\
\hline 406 & MARCOS & 370 & 0,0403 & 399 & & 1105,4 \\
\hline 407 & PUNIDO & 158 & 0,0172 & 21 & & 1105,3 \\
\hline 408 & LIDERANCA & 320 & 0,0349 & 286 & & 1103,5 \\
\hline 409 & DONOVÁN & 136 & 0,0148 & 1 & & 1102,2 \\
\hline 410 & MUCHA & 139 & 0,0152 & 4 & & 1097,5 \\
\hline 411 & GAÚCHO & 188 & 0.0205 & 57 & & 1096.9 \\
\hline 412 & PEGOU & 184 & 0,0201 & 52 & & 1096,4 \\
\hline 413 & INTERVALO & 335 & 0,0365 & 325 & & 1087,6 \\
\hline 414 & MICHEL & 205 & 0,0224 & 82 & & 1086,9 \\
\hline 415 & CHUTES & 141 & 0,0154 & 7 & & 1085,7 \\
\hline 416 & FICA & 676 & 0,0737 & 1333 & 0,0176 & 1083,8 \\
\hline 417 & ROGÉRIO & 203 & 0,0221 & 80 & & 1082,5 \\
\hline 418 & LANÇADO & 346 & 0,0377 & 353 & & 1080,5 \\
\hline 419 & VITÓRIAS & 204 & 0,0222 & 82 & & 1079,5 \\
\hline 420 & POSIÇÃO & 638 & 0,0696 & 1208 & 0,016 & 1076,9 \\
\hline 421 & BAIANO & 193 & 0,021 & 68 & & 1071,9 \\
\hline 422 & INFRAÇÃO & 208 & 0,0227 & 90 & & 1068,8 \\
\hline 423 & PARANAENSE & 158 & 0,0172 & 26 & & 1066,8 \\
\hline 424 & LUCAS & 176 & 0,0192 & 47 & & 1065,4 \\
\hline 425 & MARCÃO & 130 & 0,0142 & 0 & & 1062,8 \\
\hline 426 & $E$ & 28810 & 3,1415 & 193999 & 2,5653 & 1061 \\
\hline 427 & HONDA & 132 & 0,0144 & 2 & & 1059,3 \\
\hline 428 & INGLATERRA & 341 & 0,0372 & 352 & & 1055 \\
\hline 429 & EMPATA & 132 & 0,0144 & 3 & & 1049,5 \\
\hline 430 & INVADIU & 163 & 0,0178 & 34 & & 1049,2 \\
\hline 431 & NOVAMENTE & 375 & 0,0409 & 439 & & 1045,3 \\
\hline 432 & BRASILEIRO & 868 & 0,0946 & 2103 & 0,0278 & 1041,3 \\
\hline 433 & BENAGLIO & 127 & 0,0138 & 0 & & 1038 \\
\hline 434 & MYONG & 127 & 0,0138 & 0 & & 1038 \\
\hline 435 & NZL & 128 & 0,014 & 1 & & 1036,2 \\
\hline 436 & SEGUE & 361 & 0,0394 & 411 & & 1030,6 \\
\hline 437 & MAGRÃO & 126 & 0,0137 & 0 & & 1029,8 \\
\hline 438 & CARREGA & 197 & 0,0215 & 82 & & 1028 \\
\hline 439 & FICOU & 572 & 0,0624 & 1029 & 0,0136 & 1027 \\
\hline 440 & MURICY & 128 & 0,014 & 2 & & 1026,3 \\
\hline 441 & INIESTA & 125 & 0,0136 & 0 & & 1021,6 \\
\hline 442 & ADVERTIDO & 132 & 0,0144 & 6 & & 102 \\
\hline 443 & SOBE & 216 & 0,0236 & 113 & & 1020,1 \\
\hline
\end{tabular}




\begin{tabular}{|c|c|c|c|c|c|c|}
\hline 444 & VILLAR & 136 & 0,0148 & 10 & & 1017,6 \\
\hline 445 & CARRINHO & 143 & 0,0156 & 17 & & 1015,6 \\
\hline 446 & TIROU & 166 & 0,0181 & 43 & & 1012,9 \\
\hline 447 & PASSA & 560 & 0,0611 & 1006 & 0,0133 & 1007,8 \\
\hline 448 & QUARTAS & 141 & 0,0154 & 16 & & 1007,5 \\
\hline 449 & DONOS & 191 & 0,0208 & 78 & & 1004,1 \\
\hline 450 & SOZINHO & 222 & 0,0242 & 128 & & 999,04 \\
\hline 451 & DERRUBA & 131 & 0,0143 & 8 & & 994,43 \\
\hline 452 & LANTERNA & 161 & 0,0176 & 41 & & 986,71 \\
\hline 453 & FIM & 864 & 0,0942 & 2164 & 0,0286 & 984,05 \\
\hline 454 & ENCARA & 150 & 0,0164 & 29 & & 980,96 \\
\hline 455 & RENTE & 126 & 0,0137 & 5 & & 980,94 \\
\hline 456 & CLUBE & 249 & 0,0272 & 183 & & 977,14 \\
\hline 457 & COLOCOU & 250 & 0,0273 & 185 & & 976,91 \\
\hline 458 & ESPALMOU & 123 & 0,0134 & 3 & & 975,31 \\
\hline 459 & BELMIRO & 136 & 0,0148 & 15 & & 975,05 \\
\hline 460 & BATER & 180 & 0,0196 & 68 & & 974,5 \\
\hline 461 & RAMON & 124 & 0,0135 & 4 & & 973,94 \\
\hline 462 & GERRARD & 119 & 0,013 & 0 & & 972,08 \\
\hline 463 & DERROTOU & 146 & 0,0159 & 26 & & 970,64 \\
\hline 464 & AMPLIOU & 158 & 0,0172 & 40 & & 969,7 \\
\hline 465 & PRÓXIMA & 494 & 0,0539 & 828 & 0,0109 & 963,68 \\
\hline 466 & JONATHAN & 130 & 0,0142 & 11 & & 959,78 \\
\hline 467 & JAPÃO & 310 & 0,0338 & 320 & & 958,75 \\
\hline 468 & SUL & 660 & 0,072 & 1402 & 0,0185 & 958,14 \\
\hline 469 & SEQUÊNCIA & 190 & 0,0207 & 86 & & 957,44 \\
\hline 470 & ARRANCA & 123 & 0,0134 & 5 & & 956,26 \\
\hline 471 & VALLADARES & 123 & 0,0134 & 5 & & 956,26 \\
\hline 472 & PACAEMBU & 130 & 0,0142 & 12 & & 951,22 \\
\hline 473 & MADSON & 116 & 0,0126 & 0 & & 947,34 \\
\hline 474 & ENYEAMA & 116 & 0,0126 & 0 & & 947,34 \\
\hline 475 & BELO & 288 & 0,0314 & 276 & & 943,11 \\
\hline 476 & GANHA & 308 & 0,0336 & 323 & & 940,58 \\
\hline 477 & TEVEZ & 115 & 0,0125 & 0 & & 939,09 \\
\hline 478 & HUGO & 165 & 0,018 & 54 & & 938,71 \\
\hline 479 & DIOGO & 132 & 0,0144 & 16 & & 934,39 \\
\hline 480 & DANILO & 143 & 0,0156 & 28 & & 932,32 \\
\hline 481 & ZELÂNDIA & 137 & 0,0149 & 22 & & 928,09 \\
\hline 482 & CARLINHOS & 132 & 0,0144 & 17 & & 926,38 \\
\hline 483 & XABI & 113 & 0,0123 & 0 & & 922,6 \\
\hline 484 & ALECSANDRO & 113 & 0,0123 & 0 & & 922,6 \\
\hline 485 & ÉDER & 121 & 0,0132 & 7 & & 921,38 \\
\hline 486 & WAGNER & 185 & 0,0202 & 87 & & 916,73 \\
\hline 487 & IARLEY & 112 & 0,0122 & 0 & & 914,36 \\
\hline 488 & DRIBLE & 114 & 0,0124 & 2 & & 910,89 \\
\hline 489 & ARBITRAGEM & 131 & 0,0143 & 18 & & 910,4 \\
\hline 490 & COMEÇOU & 521 & 0,0568 & 961 & 0,0127 & 907,87 \\
\hline 491 & BOMMEL & 111 & 0,0121 & 0 & & 906,11 \\
\hline 492 & CHICÃO & 118 & 0,0129 & 6 & & 905,87 \\
\hline 493 & EMERSON & 159 & 0,0173 & 52 & & 904,54 \\
\hline 494 & PARAÍBA & 205 & 0,0224 & 123 & & 903,06 \\
\hline
\end{tabular}




\begin{tabular}{|c|c|c|c|c|c|c|}
\hline 495 & SEMIFINAL & 125 & 0,0136 & 13 & & 902,03 \\
\hline 496 & ARREMATA & 115 & 0,0125 & 4 & & 899,85 \\
\hline 497 & CHELSEA & 110 & 0,012 & 0 & & 897,86 \\
\hline 498 & MAARTEN & 110 & 0,012 & 0 & & 897,86 \\
\hline 499 & MORUMBI & 164 & 0,0179 & 60 & & 897,78 \\
\hline 500 & DESPERDIÇOU & 111 & 0,0121 & 1 & $1 E-05$ & 896,05 \\
\hline
\end{tabular}


ANEXO B

Linhas de concordância de por cima do gol

\section{Concord}

File Edit View Compute Settings Window Help

\begin{tabular}{|r|l} 
N & Concordance \\
\hline 1 & leve toque, o atacante deixou para Kaká, que chutou forte, da entrada da por cima do gol de Pletikosa. O Brasil continuava a tocar, mas nåo conseguia
\end{tabular}

ajeitou com açúcar para Victor Simốes, que chutou forte da entrada da área, por cima do gol de Galatto 9 Por enquanto nenhum lance de perigo para

jogo aos $11 \mathrm{~min}$. Após passe de Kaká, o atacante chutou forte de fora da área, por cima do gol adversário. Somente aos $17 \mathrm{~min}$, a seleção voltou a ameaçar

de alçar bola na área. 14' Adriano dispara pela direita, corta Juan e arremata por cima do gol. 13' Flamengo chega ao ataque com facilidade, mas nẫo

da meta. 3' Rafael Cruz avança pela esquerda, corta para o meio e arremata por cima do gol. 2' Nino Paraíba alça bola da direita, Adaílton nẵo consegue o

chegam com facilidade ao ataque. 21' Suarez pega sobra da zaga e arremata por cima do gol. 20' Muller estica passe para Khedira, mas Fucile aparece bem e cima de Rafael Cruz. 16' Obina faz o passe da meia-lua e Fernandinho arremata por cima do gol. 15' Rafael Cruza alça bola na área e Émerson tira de cabeça.

também de cabeça, tirou tinta da trave. Depois, aos nove, Rodrigo arriscou, por cima do gol. $\langle$ p $\rangle\langle p\rangle$ A melhor chance saiu dos pés de Arouca. Aos 15

primeira derrota 45' Perez pega sobra na intermediária, domina no peito e bate por cima do gol 44' Resultado: Em andamento, pelo Grupo A: França 1 $\times 2$ África

10 ataca, mas a zaga coritibana corta e parte para o contra-ataque Marcelinho bate por cima do gol de Fabio. Tiro de meta para o Cruzeiro Henrique recebe o terceiro fora da área, mas a bola explodiu no travessăo. No rebote, Junior Cesar bateu por cima do gol. O Grêmio acordou e antes de diminuir assustou Dênis, que teve à frente no placar aos $37 \mathrm{~min}$, quando Ricardo Xavier invadiu a área e bateu por cima do gol de Rogério Ceni. $\langle p\rangle\langle p\rangle$ Mesmo levando todo o time ao ataque pela direita e cruzou na área, 0 atacante dominou a bola na área, girou e bateu por cima do gol. Com um jogador a mais, o treinador gremista, Paulo Autuori. a acordar. Aos 25, Léo Lima tabelou com larley, recebeu na área, mas bateu por cima do gol. 0 time esmeraldino insistiu e, aos 26, o próprio Léo Lima viu recebeu passe dentro da área aos 18 , driblou o zagueiro e finalizou de bico por cima do gol. Quatro minutos depois, Felipe Azevedo bateu na saída do jogada, dribla Osório e arrisca da entrada da área, mas Pérez espalma a bola por cima do gol. $45^{\prime} 2^{\circ}$ tempo Argentina prende a bola no campo de ataque. $44^{\prime} 2^{\circ}$ gol adversário 28 Rafa Márquez bate falta da intermediária, mas manda a bola por cima do gol 27 Dikgacoi faz falta dura em Giovanni dos Santos e recebe e é punido com cartẫo amarelo. 31'> Neymar faz a cobrança e manda a bola por cima do gol. 30' > Em andamento: Cruzeiro $0 \times 3$ Atlético-MG 29' > Alan da entrada da área. A bola sai 6 Elano arrisca de fora da área e manda a bola por cima do gol 5 Lúcio sai com a bola dominada e passa para Elano, que toca

afastou, mas a bola sobrou para Chu-young que, sozinho, soltou a bomba por cima do gol de Muslera. Os asiáticos exploravam as jogadas aéreas e a para fora. Depois, voltou a ficar cara a cara com Reina, mas soltou uma bomba por cima do gol. O Chelsea acabou por empatar a partida aos 39. Após

aos 35, quando Léo pegou rebote na entrada da área e soltou uma bomba por cima do gol. Nos minutos finais, o Santo André passou a pressionar. Aos 46 , Aos 33, novamente o Imperador protagonizou ótima oportunidade, de cabeça, por cima do gol de Felipe. Em seguida, deu os tradicionais murros na própria boa chance ao receber um grande cruzamento de Elias e, sozinho, cabecear por cima do gol. Quatro minutos depois, Douglas achou Dentinho sozinho na × 2 Japão, gol de Hendo. 30' Geremi cruza da ponta direita e Chedjou cabeceia por cima do gol. 29' Van Persie disputa no alto com Nkoulou e o árbitro marca por Onyewu na hora de concluir. 37 Rooney cruza da direita e Crouch cabeceia por cima do gol. A Inglaterra tenta, mas nẫo consegue marcar. Substituição34 por Onyewu na hora de concluir. 37 Rooney cruza da direita e Crouch cabeceia por cima do gol. A Inglaterra tenta, mas nẫo consegue marcar. Mudança na 44 UUUUHHHI Jonatanh sobre mais alto que a defesa adversária e cabeceia por cima do gol 42 Terceira substituiçấo em Gana. Amoah entra no lugar de indica três minutos de acréscimo. 43' Schwenck recebe na área e cabeceia por cima do gol. 42' Egídio cobra escanteio por baixo e Gabriel tira. 41' Em 30 tempo Por pouco - Xavi alça a bola no segundo pau, Ramos cheqa e cabeceia por cima do gol, mas por pouco. Na queda, Valladares acaba acertando o rosto 
ataque pela direita e Chipperfield, que acabou de entrar, chega e cabeceia por cima do goll $19^{\prime} 2^{\circ}$ tempo Asamoah tenta o chute pelo meio do campo, a bola $>$ Marquinhos bate escanteio da direita, Edu Dracena sobe sozinho e cabeceia por cima do gol. 42'>11.075 pessoas, pagantes, assistem a esta partida na Vila alcançar a bola. $43^{\prime} 1^{\circ}$ tempo Maicon cruza da direta e Luis Fabiano cabeceia por cima do gol de Bravo. $41^{\prime \prime} 1^{\circ}$ tempo Com o gol, Luis Fabiano chega a três gols 34 amarelo por cometer falta em Matsui. $32 \mathrm{Em}$ cobrança de falta, Honda cabeceia por cima do gol holandês. 28 Van der Vaart tenta passe em profundidade pelo 35 amarelo por cometer falta em Matsui. $32 \mathrm{Em}$ cobrança de falta, Honda cabeceia por cima do gol holandês. 28 Van der Vaart tenta passe em profundidade pelo 36 tempo Dinamarca $40^{\prime} 2^{\circ}$ tempo Emana cruza, Eto'o desvia e Idrissou cabeceia por cima do gol de Sorensen $38^{\prime} 2^{\circ}$ tempo Camarốes pressiona a Dinamarca. $36^{\prime}$ 37 há um minuto. $24^{\prime} 2^{\circ}$ tempo RESPOSTA! Sneijder cobra falta e Kuyt cabeceia por cima do gol. 23' $2^{\circ}$ tempo ESTATíTISCAS: Foram as duas primeiras 30' Karagounis bate escanteio aberto na segunda trave e Kyrgiakos cabeceia por cima do gol 28' A Grécia mantém a posse de bola, mas nẫo mostra de Leo Fortunato, chuta e Fábio salva o Cruzeiro. O zagueiro Marcẫo cabeceia por cima do gol de Fábio. ábio.

40 da trave direita de Casillas. $33^{\prime} 1^{\circ}$ tempo Xavi cobra escanteio e Piqué cabeceia por cima do gol de Bravo. $32^{\prime} 1^{\circ}$ tempo Em contra-ataque, Villa toca para Torres, 41 chega na área carioca. 37' Juan cobra a falta para a área e Renato cabeceia por cima do gol. 36' Marcâo recebe cartẫo amarelo. 35' Willians faz jogada pela $3^{\prime} 1^{\circ}$ tempo Em cobrança de falta, Xavi cruza e Fernando Torres cabeceia por cima do gol de Bravo. $3^{\prime} 1^{\circ}$ tempo Beausejour é lançado, mas Casillas sai do 30 Geremi cruza na área e Chedjou chaga antes do goleiro, mas cabeceiaa por cima do gol Cartẫo Amarelo29 0 primeiro cartẫo amarelo da partida é

Santos recebeu na área, deu de bicicleta para o meio e Conca cabeceou por cima do gol. $\langle p\rangle\langle p\rangle 0$ Flu errava muito no seu próprio campo e a prova

e saiu para escanteio. Na cobrança, Sérgio Ramos subiu livre e cabeceou por cima do gol, perdendo grande oportunidade. Robben perdeu mais uma grande Aos 33, após ótimo cruzamento de Emerson pela direita, o Imperador cabeceou por cima do gol, perdendo ótima chance (veja foto abaixo). E deu cascudos na

47 quem levou a advertência. Ronaldo mandou para a área mas Jean cabeceou por cima do Gol de Harlei. Falta em cima de Dentinho. Vem bola na área do quem levou a advertência. Ronaldo mandou para a área mas Jean cabeceou por cima do Gol de Harlei. Falta em cima de Dentinho. Vem bola na área do 49 Vasco, Rodrigo Pimpẫo cruzou pela direita para Níton, mas o volante cabeceou por cima do gol. $\langle p\rangle\langle p\rangle$ Com mais objetividade, o Vasco criou mais uma 50 errado e entrega de graça para Muller. Meia rola para Klose e o artilheiro chuta por cima do gol 21' Belo passe de Messi na área para Tevez. Neuer faz saída 51 defesa. No rebote, Batista e Reinaldo se enrolam com a bola e o atacante chuta por cima do gol. Quase! Após cobrança de falta pela direita, Victor Simổes nas arquibancadas. $29^{\prime}$ Zé Roberto recebe pela esquerda, invade a área e chuta por cima do gol, perdendo uma grande chance. 27' Fagner cruza da direita, diret 54 Ceará 1 × 0 Internacional 1' Maikon Leite recebe na área, gira o corpo e chuta por cima do gol. Começa o segundo tempo de Atlético-PR e Vasco. 48' Fim de 55 0. 44' Kláberson consegue recuperar a bola na direita, corta para o meio e chuta por cima do gol. 43' 0 Vasco acalma o jogo neste final de primeiro tempo e só 56 recebe passe de Valdivia, chega à linha de fundo e cruza, mas González chuta por cima do gol de Casillas. $9^{\prime} 1^{\circ}$ tempo Puyol dá um carrinho em Valdivia e 0 57 Tomasson. O camisa 9 chuta e acerta o marcador. No rebote, Gronkjaer chuta por cima do gol. 40' $1^{\circ}$ tempo Geremi cruza da direita, mas Sorensen sai do gol Carvalho. 19' Na entrada da área, Hong Yong Jo ajeita e Kim Yong Jun chuta por cima do gol. 18' Cristiano Ronaldo acelera pela direita, cruza e Raul Meireles, o lançamento na área Athirson toca para Fabricio na entrada da área, que chuta por cima do gol de Édson Bastos Bola para fora. Lateral para o Coritiba $\mathrm{O}$ time 60 mal feito do qoleiro Muslera. Kuyt ficou com a bola, e livre, acabou chutando por cima do qol. Bem fechado atrás, o time uruquaio via a seleçâo européia 

Numa delas, Daniel Alves deu dois cortes pela ponta e cruzou para Juan chutar por cima do gol. Na mais bonita, Robinho deixou para trás dois marcadores, Luis da baliza. $4^{\prime} 1^{\circ}$ tempo Sneijder recebe na intermediária e arrisca. Outro chute por cima do gol. $3^{\prime} 1^{\circ}$ tempo Robben năo domina, após cruzamento de Van 64 as duas equipes, que desperdiçavam todas as boas oportunidades com chutổes por cima do gol. 0 único lance polêmico de toda a partida aconteceu aos 39

dar um tapa e jogá-la para o travessẩo. No rebote, André Alves chutou por cima do gol aberto. $\langle p\rangle\langle p\rangle 0$ Atlético parecia apático em campo e 0 Rio

do jogo foi de "El Cabezón", logo com quatro minutos. 0 argentino chutou por cima do gol de Andújar. A0s 22, a arbitragem poderia ter marcado pênalti

desperdiçadas continuaram após o gol. Aos dez minutos, Douglas chutou por cima do gol. Aos 14, mais uma carimbada, desta vez de Jorge Henrique, que pés de quase todos os jogadores, chegou em Paulinho, que arriscou e chutou por cima do gol de Lopes. O Figueira seguiu dominando enquanto o Ceará

o Coxa assustou também aos 15 e aos 18. Primeiro, Marcio Gabriel chutou por cima do gol de fora da área. Em seguida, foi a vez de Pedro Ken e Marcelinho

e a bola ainda pegou na trave. No rebote, 0 atacante Evando, livre, chutou por cima do gol. Preocupado com a pressão, o time goiano tentou se soltar aos jogadas de contra-ataque. Matou no peito, driblou um adversário, mas chutou por cima do gol. Da intermediária, Robinho acertou outro passe, espetacular,

até o fim veio com Marcinho, aos 26 . Liwre na grande área, o meia chutou por cima do gol após cruzamento de Wallyson. Àquela altura, pouco importava o

e arrematou de esquerda. Muslera defendeu, e no rebote, Robben chutou por cima do gol, perdendo gol feito. $O$ lance de perigo animou a Laranja, que 2 a 2 . O Brasil voltou a ser o Brasil e seguiu insistindo. A0s 36 , Robinho chutou por cima do gol. 〈p $\langle p\rangle$ LÚClO, O CAMISA 9 Com o jogo nas măos, o gol era

de Dossena passa por Toni. Luisẫo tira da área André Santos cobra por cima do gol de Buffon Cartâo para Chiellini Felipe Melo arranca com a bola aciona larley na meia-lua, o atacante finta o marcador e, desequilibrado, conclui por cima do gol. 10' Danilo levanta da esquerda e a defesa adversária recupera a 27 ' Kléber é acionado no ataque, disputa a bola com dois adversários e conclui por cima do gol. 26' Fabrício finaliza da entrada da área e manda à direita de Zé e é punido com o cartẫo amarelo. 40' Boiadeiro arranca pela direita e conclui por cima do gol. 39' Magno Alves arrisca de longe e nẫo oferece perigo à meta afasta. 22' Ailson erra o tempo de bola, Marcelo Nicácio domina e conclui por cima do gol. 21' Bola alçada na área do Guarani, 0 ataque do time cearense o árbitro e recebe cartẫo amarelo. 40' Vicente avança pela esquerda e conclui por cima do gol. 39' Apodi recebe passe na entrada da área e Vicente afasta. $38^{\prime}$

do goleiro adversário. 13' Reinaldo toca da direita e Paulo Roberto conclui por cima do gol. 12' Diego Souza recebe passe no meio de campo, domina com para Alecsandro. 0 jogador é bloqueado na hora do chute e, na sobra, conclui por cima do gol, perdendo ótima oportunidade. 15' Serginho arremata da meia

83 31' Jobson penetra pela linha de fundo, rola para Loco Abreu e o uruguaio desvia por cima do gol 30' Bruno pega firme de fora da área e exige outra boa defesa de 84 e tocou para Boquita na direita. Ele cruzou na cabeça de Henrique, que desviou por cima do gol. Aos 21 minutos, uma baixa no clube paulista. Edu, machucado, o cruzamento para González. O chileno passou da bola e o chute saiu errado, por cima do gol. 0 lance, porém, mostrou que o Chile poderia ser bem mais Emerson. $\mathrm{O}$ atacante, contudo, perdeu um gol feito, ao bater de perna esquerda por cima do gol. Até o final do jogo, o panorama pouco se alterou. $\mathrm{O}$ time da 87 recebe cartão amarelo e está fora da próxima partida. 31' Rogério cobra a falta por cima do gol mineiro. 30' Lucas é derrubado por Léo nas proximidades da 88 22' Em andamento: Santos 2 x 0 Atlético-PR. 21' Adriano Pimenta cobra a falta por cima do gol. 20' Falta perigosa para o Grêmio Prudente. 19' Willian cobra a falta logo em seguida. 6' Rithelly recebe cartẫo amarelo. 5' Felipe cobra falta por cima do gol, sem perigo algum. 4' Dedé faz falta dura em Felipe e Simon 90 Henrque faz cera e recebe qratuitamente o cartão amarelo. Ramom cobra falta por cima do qol. Tartá deixa o campo lesionado. Diquinho entra. Falta periqosa 
na defesa e ganha o reconhecimento do público. $17 \mathrm{~m} 49 \mathrm{~s}$ : Ronaldo cobra falta por cima do gol. A torcida aplaude. 16m49s: Para Leandro Euzébio, do Goiás, Após cruzamento da esquerda, em bela jogada de Marcelo Oliveira, Bill finaliza por cima do goll 00m28s: Alessandro solta o pé de fora da área e erra 0 alvo. como $2^{a}$ colocada do grupo F. 1' Jendrisek domina na entrada da área e finaliza por cima do gol. Começa o jogo. Clique aqui e simule os resultados do Mundial desarmado. 26' Em contra-ataque rápido, Allan domina na meia-lua e finaliza por cima do gol. 25' Marquinhos cobra infração em cima da barreira. 24' Pela falta Em andamento: Santos $0 \times 0$ Palmeiras. 11' Ramon avança pelo meio e finaliza por cima do gol. 10' Egídio tenta jogada pela esquerda e erra o passe para

alça bola na área, Emerson espalma, Fernandinho domina e, livre, finaliza por cima do gol, perdendo boa chance de marcar. 41' Fernandinho arrisca de fora

na cobrança, o ex-cruzeirense Marcelo Moreno bateu muito mal e a bola foi por cima do gol. $\langle p\rangle\langle p\rangle 0$ desperdício da penalidade desanimou os bolivianos,

bola do lado direito e o atacante André Lima testou firme, mas a bola foi por cima do gol de Rafael. Do outro lado do campo, Jefferson também tinha Longe!!! Washington arrisca novamente de fora da área, mas desta vez a bola foi por cima do gol de Rafael. Washington chuta de fora da área para a defesa de

e chutou cruzado O zagueiro Luiz Albento entrou para contar e a bola foi por cima do gol. < $><>0$ Flu respondeu a0s 12. Após uma roubada de bola , falta pela esquerda e Luiz Alberto, de cabeça, assustou Rogério Ceni. A bola foi por cima do gol. Aos nove, o técnico Renato Gaúcho modificou o esquema tático

de Edmar da esquerda que encontrou Jandson, porém a cabeçada foi por cima do gol. No lance seguinte, após cruzamento da direita, Jandson ajeitou

Zé Roberto recebeu de Fabrício e arriscou, mas a bola subiu demais e foi por cima do gol. Apesar da pressão rubro-negra, quem balançou as redes foi o

em cabeçada de Barrios e conclusões de Valdez e Barreto. A última foi por cima do gol e as duas primeiras foram defendidas por Kawashima. Do outro

em cabeçada de Barrios e conclusốes de Valdez e Barreto. A última foi por cima do gol e as duas primeiras foram defendidas por Kawashima. Do outro de Conca, Marquinho recebe bem na ala esquerda, domina e bate com força, por cima do gol de Vitor. Conca tem oportunidade em cobrança de falta. 0 perigosa para o Grêmio, Souza corre para a bola e manda com muita força, por cima do gol. Sai Adeílson, entra Fábio Neves. Que defesa! Jonas faz bela 108 mais um aos 15 minutos. $\mathrm{O}$ atacante dominou na entrada da área e bateu forte, por cima do gol. Com Petkovic inspirado, o rubro-negro carioca chegava com 109 tempo Giovani dos Santos cobra fechado no primeiro pau, Franco cabeceia forte por cima do gol. $13^{\prime} 1^{\circ}$ tempo Tshabala tira de carrinho bola para escanteio.

110 do pênalti, após jogada de Arouca. O jogador se precipitou e chutou forte, por cima do gol. DECLínIO O bom jogo da primeira etapa sumiu na segunda para 111 com Luciano Henrique, aos 13. Ele completou cruzamento de Élder Granja por cima do gol. Aos 23, o lance polêmico do jogo. Ramon deu passe na medida

112 de fora da área. Dessa vez Fábio Bahia foi quem arriscou. Cebeçada de larley por cima do gol. Mais uma chegada do Goiás. Dessa vez Vitor chutou e Felipe de fora da área. Dessa vez Fábio Bahia foi quem arriscou. Cebeçada de larley por cima do gol. Mais uma chegada do Goiás. Dessa vez Vitor chutou e Felipe terem pressa nenhuma para atacar 11' Cardozo cobra falta perto da área e joga por cima do gol 10' Nelsen recebe cartăo amarelo 9' Esse empate vai

115 inverte jogada para Thiago Ribeiro, que ajeita atrás. Pablo chega batendo e joga por cima do gol 34' Henrique é pressionado por Marcelo Costa e passa errado

116 a bola no meio campo e Danilo recebe na direita. Santista bate forte e joga por cima do gol 32' Conca cobra falta da frente da área e Rafael encaixa no meio

117 e Richarlyson tira. 6' Ricardo Oliveira fica frente-a-frente com Giovanni e joga por cima do gol. $5^{\prime} \mathrm{O}$ Grêmio Prudente vai para o ataque nesses primeiros

118 na área e bate forte. Mbolhi dá rebote. Ná sobra, Altidore pega mal e isola por cima do gol 33' Quase os EUA abrem o placar. Donovan rola na medida para

119 acréscimo 43' Valbuena pega de primeira cruzamento na segunda trave e isola por cima do gol 42' Blanco bate falta rápida para Hernandez e o goleiro francês 
ma descida chilena. Beausejour, pela esquerda, cruza e Suazo cabeceia mal, por cima do gol adversário 37 A expulsẫo do suíço faz o Chile retomar o domínio gol foi do Cienciano, novamente com Vassallo, que livre na área cabeceou mal, por cima do gol. Aos 29, outra boa chance para Vassallo, que fez grande jogada, recebe boa bola de Diego Tardelli na grande área do Botafogo, mas chuta mal, por cima do gol. Entra Marcos Rocha, sai Renan. Sai Renato, entra Tony. Lucio da área e zagueiro australiano afasta o perigo. $34^{\prime} 2^{\circ}$ tempo Emerton cobra mal, por cima do gol. $33^{\prime} 2^{\circ}$ tempo Cartẫo amarelo para Jonathan Mensah Jonathan à esquerda de Felipe 24 Willians faz boa jogada no meio mas chuta muito mal, por cima do gol 20 Bruno defende duas vezes! Primeiro, em chute de Dentinho e e cruza em cima de Ashley Cole. 43' Donovan chuta de fora da área e manda por cima do gol inglês. 42' Inglaterra troca passes no campo defensivo. 41' Clark Atlético-PR $2 \times 1$ Goiás. 40' Renato Abreu bate de fora da área e manda por cima do gol. 38' Público total no estádio do Engenhăo: 13.423 torcedores. 37

e Ricardo Berna encaixa. 3' Felipe arrisca da entrada da área e manda por cima do gol. 2' Conca lança Tartá, mas Max chega bem e recupera o lance. primeira, perde um chance incrivel! Fernandão mete a cabeça na bola e manda por cima do gol alvinegro. POR CIMA!! Leandro Euzébio chuta longe, após pegar falta, mas a bola fica na barreira 23 Quase!!! Samuel sobe de cabeça e manda por cima do gol! 22 Higuain perde mais um gol na cara do goleiro! Ele recebeu falta, mas a bola fica na barreira 23 Quase!!! Samuel sobe de cabeça e manda por cima do gol! 22 Higuain perde mais um gol na cara do goleiro! Ele recebeu Beausejour cruza forte da esquerda, Suazo pega mal com a cabeça e manda por cima do gol. $37^{\prime} 1^{\circ}$ tempo Vidal bate de longe à esquerda do gol. $35^{\prime} 1^{\circ}$ tempo cobra falta da direita, na pequena área. Lincoln desvia de coxa e manda por cima do gol 1' Resultado: Final, pela Série A: Guarani Dx0 Corinthians, amarelo 16 Pienaar cobra falta da intermediária, mas bate muito forte e manda por cima do gol 14 PERIGO! Franco sobe sozinho em cobrança de escanteio de perto do gol defendido por Green. 37 Wright-Phillips arrisca de longe e manda por cima do gol de Howard. 34 Ashley Cole recebe na esquerda e cruza para perto do gol defendido por Green. 37 Wright-Phillips arrisca de longe e manda por cima do gol de Howard. 34Ashley Cole recebe na esquerda e cruza para trás. por cima. Partida muito disputada. 24 Lampard cobra falta de longe e manda por cima do gol de Howard. Cartẫo Amarelo22 Carragher comete falta e recebe livre para Perez fazer a defesa. 27 Rafa Marquez cobra falta de longe e manda por cima do gol sul-africano. Cartẫo Amarelo26 Dikgacoi faz falta em Giovani dos na França: sai Diarra e entra Govou. 34 Tshabalala arrisca de longe e manda por cima do gol de Lloris. Substituiçẩo32 Última mudança na África do Sul: sai 10' Júnior domina na área e ajeita para trás. Ramon pega de primeira e manda por cima do gol. 9' Ramon cobra infraçẫo da entrada da área, Jefferson espalma e entra Buddle. 32 Cruzamento da esquerda de Cole. Heskey sobe e manda por cima do gol de Howard. 31 Rooney recebe na frente e finaliza em cima de e entra Buddle. 32 Cruzamento da esquerda de Cole, Heskey sobe e manda por cima do gol de Howard. 31 Rooney recebe na frente e finaliza em cima de invade a área pela direita e cruza. Barboza divide com o zagueiro e manda por cima do gol. 12' Barboza cobra falta para a área e ninguém consegue 0 México pressiona. Blanco levanta para dentro da área e Hernandez manda por cima do gol. 41 Blanco cobra falta para dentro da área e Letshonloyane

atrasa saída e recebe amarelo 43 Lúcio Flávio arrisca o chute mas manda por cima do gol de Galatto $37 \mathrm{~A}$ torcida do Botafogo vaia o time no Engenhẵo 32 e cabeceia por cima da meta de Lloris. $33 \mathrm{Na}$ cobrança, Tshabalala manda por cima do gol de Lloris. 32 Mphela é derrubado na entrada da área. Boa chance para bater, Mathijsen chega na marcaçẫo. Quando finaliza, Vittek manda por cima do gol. 40' $2^{\circ}$ tempo Após cruzamento de Heitinga, Elia fica com a

para bater, Mathijsen chega na marcaçẩo. Quando finaliza, Vittek manda por cima do gol. 30' $2^{\circ}$ tempo Elia recebe de Sneijder e cruza outra para a área. scanteios. Aos sete minutos, André Lima perdeu nova oportunidade ao mandar por cima do gol. Em seguida, foi a vez de Reinaldo errar após grande jogada. A comnanheiro. A bola volta nara o camisa 20. aue toca nara Rodriauinho mandar nor cima do aol de Fábio 22' Pablo tenta roubar a bola de Conca e derruba 0 
181 8' Obradovic desvia cruzamento de cabeça, na marca do pênalti e a bola passa por cima do gol 7' lvanovic busca o centro do lado direito. A bola desvia no de acréscimo. 43' Elkeson bate infraçẫo da entrada da área e a bola passa por cima do gol. 42' Renato Cajá faz a cobrança, Leandro Guerreiro ajeita para o na defesa do Japão 21' Banitez finaliza da lateral esquerda e a bola passa por cima do gol 20' 0 Japão responde. Matsui pega de primeira, de fora da área,

Camoranesi fica com o rebote e arrisca da entrada da área. Bola passa por cima do gol de Júlio César, com perigo Kaká arrisca de longe. Sem perigo no Fluminense. Entra Adeílson e sai Kieza Marquinho cobra longe!!! Bola passa por cima do gol de Ceni Amarelo. Hernanes é punido por causa do tumulto com o com facilidade. Tony dribla um zagueiro e chuta com força, a bola sobe e passa por cima do gol do Santos. o Santos tenta chegar nos contra-ataques. Molina mais liberdade e arriscou bons chutes de fora da área. Se três deles passaram por cima do gol e já levaram perigo ao goleiro Fred, 0 chute tentado aos 27

à trave esquerda. Em seguida, Obina arriscou um voleio, mas a bola passou por cima do gol de Edinho. $\langle p\rangle\langle p\rangle$ Com problemas para criar jogadas, Cuca mas a bola fica com Felipe Douglas bateu de fora da área mas a bola passou por cima do gol Obina bate para o gol, mas a bola passa ao lado da meta de

a bola na área do Náutico, livrou-se de Nilson e chutou forte. A bola passou por cima do gol, dando perigo ao goleiro Gledson. Aos 22 minutos, Madson fez ainda teve boa chance de ampliar, após a falha do zagueiro, mas a bola passou por cima do gol. $\langle i p\rangle$

192 de fora da área. Aos 37, Gabriel cobrou falta de longa distância e a bola passou por cima do gol. Os donos da casa cresceram e Alex Afonso perdeu grande

Após uma rebatida da zaga, Ramon acertou uma bomba, mas a bola passou por cima do gol de Robson. $\langle p\rangle\langle p\rangle 0$ jogo ficou tenso logo nos primeiros
Krasic cruzou pela direita e Ninkovic pegou de primeira, mas a bola passou por cima do gol alemão. $8^{\prime} 1^{\circ}$ tempo Uma vitória deixará a seleçẫo alemâ muito à trave esquerda. Em seguida, Obina arriscou um voleio, mas a bola passou por cima do gol de Edinho. $\langle p\rangle\langle p\rangle$ Com problemas para criar jogadas, Cuca ângulo, chutou para fora. Depois Davi chutou de fora da área e a bola passou por cima do gol, perto do travessẫo. Aos 11, Alex Afonso recebeu na área, girou chutou de fora da área, aos 22, porem a bola subiu demais e passou por cima do gol. Embora a maior posse de bola fosse da Holanda, eram os a bola vem fácil para Gléguer. Wlington chute de longe, mas a bola se perde por cima do gol. Fernando Henrique faz cera tentando esfriar a pressão do defesa de Victor Ganso faz bela jogada na entrada da área e bate com perigo, por cima do gol de Victor Paulo Henrique bate falta e a zaga do Grêmio antecipa da direita e Handanovic afasta de soco. No rebote, Lampard bate com perigo, por cima do gol. o, por cima do gol.

201 a bola no meio-de-campo e carregou até a meia-lua, de onde bateu com perigo por cima do gol. Passado o susto, a África do Sul equilibrou novamente o jogo. logo a um minuto, com o lateral-direito Léo Moura, que mandou com perigo por cima do gol. O Atlético-MG mostrou porque vive uma grande fase. O meia o perigo e puxa contraataque. Gonzalez fica com a bola e chuta perigosamente por cima do gol de Valladares 45 Gonzalez ajeita e pega forte de fora da área 204 direita do ataque goiano, invadiu a área e bateu forte, mandando perigosamente por cima do gol. Enquanto o Campinense enfrentava dificuldades para passar 205 empatam em 0 a 0. 46' Washington bate falta da entrada da área e Neto resvala por cima do gol. 45' Marquinho cobra escanteio da esquerda, Leandro Euzébio 206 × 1 Atlético-MG 8' > Adriano Pimenta experimenta da intermediária e a bola sai por cima do gol. 7' > Zé Eduardo domina na risca da área e arremata longe da 207 Cole entra no lugar de Rooney. 25' Birsa cobra falta de muito longe e a bola sai por cima do gol. 24' Por enquanto, Inglaterra e Eslovênia vẫo se classificando

208 gramado e a partida é paralisada. 5' Asamoah bate de fora da área e a bola sai por cima do gol. 4' Adiyiah recebe pela esquerda e é desarmado por Maximiliano 209 gramado e a partida é paralisada. 5' Asamoah bate de fora da área e a bola sai por cima do gol. 4' Adiyiah recebe pela esquerda e é desarmado por Maximiliano com o cartẫo amarelo. 31' Wanderley chuta da entrada da área e a bola sai por cima do qol, sem preocupar a torcida local. 30' André Lima tenta recuperar 
meia esquerda e é parado com falta. 2' Killen chuta de fora da área e a bola sai por cima do gol. 1' Na outra partida do grupo F, Itália e Paraguai empataram em 1 afasta o perigo com a mẫo. $40^{\prime}$ Careca cruza fechado da direita e a bola sai por cima do gol. 39' Fábio Rochemback faz o lançamento e Fabrício tira de grande jogada pela direita e cruza. Éder Luís pega de primeira, mas a bola sai por cima do gol. 30' Éder Luís cruza rasteiro da direita, Marcão se atrapalha todo COM PERIGO! Jendrisek recebe de Weiss e chuta de fora da área. Bola sai por cima do gol. 0' $1^{\circ}$ tempo Começa a partida! Pré-Jogo Após sorteio, a

$\mathrm{O}$ atacante, que entrou no segundo tempo, chuta de fora da área e bola sai por cima do gol de Bravo $43 \mathrm{Na}$ cobrança de falta, Ponce solta a bomba de longe Fogão! Neymar cobra falta, Fabăo cabeceia para baixo, a bola toma efeito e sai por cima do gol de Jefferson Pará faz o cruzamento pela direita, mas Emerson

de fora da área, mas a bola explode na cabeça de Christian Poulsen e sai por cima do gol. Na sequência da jogada, 0 camisa 2 dinarmaguês é atendido

de fora da área, mas a bola explode na cabeça de Christian Poulsen e sai por cima do gol. Na sequência da jogada, o camisa 2 dinarmaquês é atendido Gonzalez ajeita e pega forte de fora da área pelo Chile. Mas a bola também sai por cima do gol 44 Welcome tenta a sorte para Honduras no final do jogo. 0 tempo. Aos 38 Wlaker tentou arriscar de fora da área, mas viu seu chute sair por cima do gol. $\langle p\rangle\langle p\rangle$ Nos últimos minutos 0 Juventude ainda teve duas

foi lançado, avançou em velocidade, entrou na área, mas a conclusăo saiu por cima do gol. $\langle p\rangle\langle p\rangle 0$ jogo continuou animado, com o Fla se mandando a conclusẫo de Kapetanos, que tinha substituído Charisteas. A Jabulani saiu por cima do gol de Jung Sung-Ryong, e os torcedores levaram as mẫos às único chute do time de Parreira foi numa cobrança de falta de Pienaar que saiu por cima do gol de Perez. Bola na trave no final frustrou torcedores sul-africanos Hamsik passa para Stoch, que bate para o gol. Stekelenburg se estica e toca por cima do gol. 20' $2^{\circ}$ tempo ESTATISTICAS: Holanda tem 11 finalizaçốes,

mas a bola vai com muita força para fora Hassan chuta forte mas a bola vai por cima do gol Até o momento Robinho só apareceu para fazer faltas Falta em equipes se arriscam pouco. 4' Jucilei faz o levantamento na área e a bola vai por cima do gol após desvio de cabeça. 3' Corinthians troca passes e tenta 25 Escanteio para Camarổes. Mbia se antecipa a defesa e desvia. A bola vai por cima do gol holandês 23 Mais uma vez Van der Vaart. Ele cobra falta pela os landos Săo Paulo responde com chute de fora da área de Arouca. Bola vai por cima do gol de Rafael Conca cobra e Luiz Alberto, livre, cabeceia para fora. Rossi chega e corta Dossena rola para De Rossi, que solta a bomba. Chute vai por cima do gol de Júlio César Zambrotta cruza e Júlio César afasta de soco e entrega para Acleisson, que tenta mais um chute de fora da área. Outra vez por cima do gol <minute $27 \mathrm{~m} 35 \mathrm{~s}$ : UHHHH! Acleisson arrisca de novo e, desta 


\section{ANEXO C}

Linhas de concordância de right-footed shot

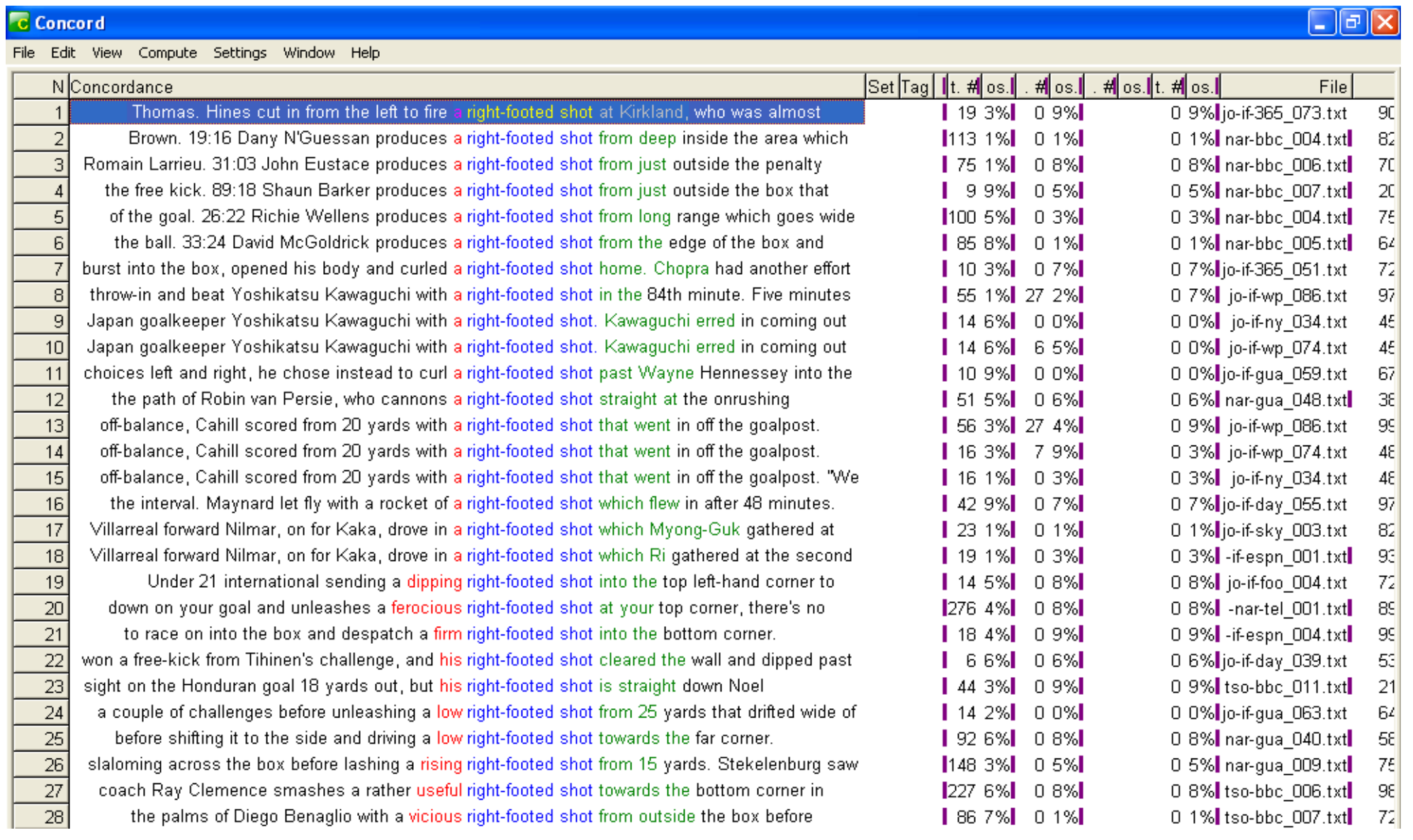




\section{ANEXO D}

Linhas de concordância de right-foot shot

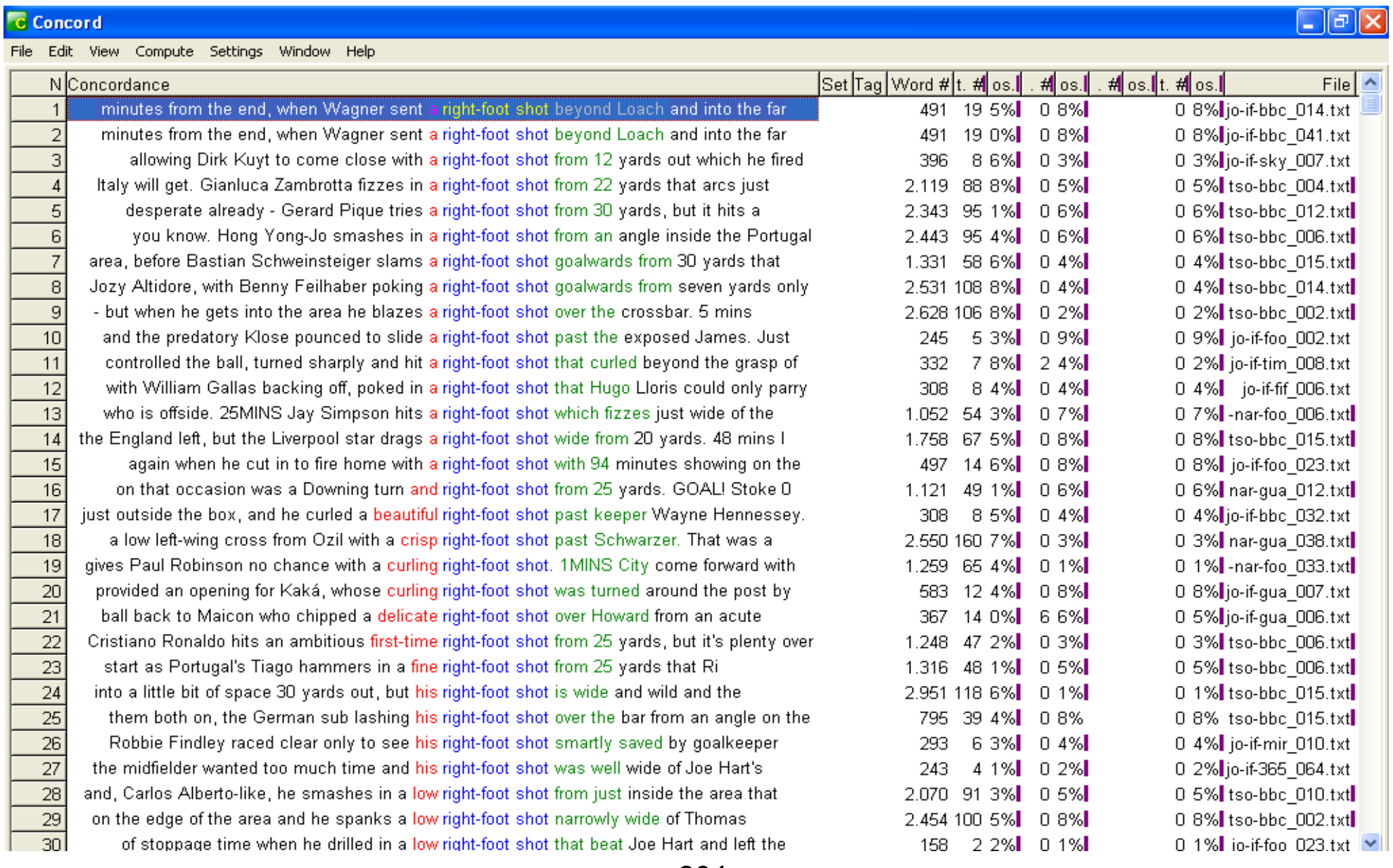


provide one worthwhile effort with a powerful right-foot shot that flashed across goal. Mexico

given time and space to crack in a powerful right-foot shot. With Mexico struggling to

only as far as Garry O'Connor, whose rushed right-foot shot was well wide. Niko Kranjcar

only as far as Garry O'Connor, whose rushed right-foot shot was well wide. Niko Kranjcar

another goalkeeping howler. Mark Bresciano's right-foot shot bounces in front of Richard

of the game by miles, but Jesper Gronkjaer's right-foot shot is deflected behind. From the

the edge of the box, but his toe-poked right-foot shot drifts wide of David James's

Luke Young and guiding an unreachable right-foot shot past goalkeeper Brad Friedel,

for Adebayor, who dispatched an unstoppable right-foot shot past Paul Robinson with great
$337 \quad 91 \% \quad 00 \%$

$424 \quad 118 \% \mathbf{I} \quad 05 \% \mathbf{I}$

$38999 \% \quad 02 \% \mathbf{I}$

$391 \quad 99 \%$ l $02 \%$

$2.398 \quad 877 \% \quad 01 \% \mathbf{I}$

$2.310943 \% \mathbf{I} \quad 4 \% \mathbf{I}$

$1.450 \quad 593 \% \mathbf{l} \quad 05 \% \mathbf{I}$

$280 \quad 20 \% \mathbf{I} 31 \% \mathbf{I}$

$30070 \% \mathbf{I} \quad 07 \% \mathbf{I}$
0 0\% jo-if-fif_006.txt $05 \%$ jo-if-fif_006.txt

0 2\%ljo-if-gua_066.txt

0 $2 \%$ ljo-if-gua 065 .txt

$01 \%$ tso-bbc_001.txt

$04 \%$ tso-bbc_002.txt

0 5\% Iso-bbc 015.txt

0 1\% lo-if-tel_002.txt

0 7\%l jo-if-foo_040.txt 


\section{ANEXO E}

Linhas de concordância de left-foot shot

\begin{tabular}{|c|c|c|c|}
\hline \multicolumn{2}{|c|}{ c Concord } & \multicolumn{2}{|r|}{ 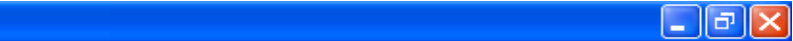 } \\
\hline ille Edit & View Compute Settings Window Help & & \\
\hline \multicolumn{2}{|c|}{ N Concorda } & \multicolumn{2}{|c|}{ 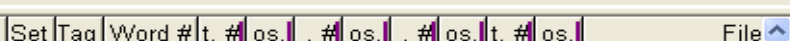 } \\
\hline 1 & 17) Keisuke Honda, 30 yards out, sends left-foot shot arcing perfectly into the far corner. & $968527 \%$ & $01 \%$ Inar-gua_047.txt_ \\
\hline 2 & in the box and from eight yards he bends a left-foot shot around Hamidou Souleymanou and & $1.173455 \% \mathbf{l}$ & $08 \% \mid$ tso-bbc_002.txt \\
\hline 3 & Park cuts inside but slightly slices a left-foot shot from 20 yards wide of the mark. & $98885 \% \mathbf{I}$ & $04 \%$ I-nar-foo_004.txt \\
\hline 4 & Hamburg left-winger, had got in the way of a left-foot shot from Elano, the ball ricocheting off & $646 \quad 183 \% \mathbf{I}$ & 0 8\%ljo-if-gua_015.txt \\
\hline 5 & eluded two Hamburg defenders to score with a left-foot shot from just inside the penalty & $775243 \% \mathbf{I}$ & 0 4\%ljo-if-gua_015.txt \\
\hline 6 & is that he's been wasteful again, spanking a left-foot shot from the left-hand angle of the & $2.9411278 \% \mathbf{l}$ & 0 1\%Itso-bbc_014.txt \\
\hline 7 & elsewhere. $45 \mathrm{MINS}$ Nicky Barmby has a left-foot shot from the edge of the area but & $784 \quad 408 \% \mathbf{I}$ & $02 \%$ I-nar-foo_0 $038 . t \times t$ \\
\hline 8 & Better from Ghana as Andre Ayew fires in a left-foot shot from the edge of the Australian & $2.205833 \% \mathbf{I}$ & bbc_001.txt \\
\hline 9 & With the last kick of the half, Muntari lashes a left-foot shot goalwards from fully 35 yards, the & $1.339623 \% \mathbf{I}$ & 0 6\%I nar-gua_013.txt \\
\hline 10 & mistake to turn Javi Garcia and hammer a left-foot shot in from 18 yards. Milner wrapped it & $125 \quad 06 \% \mathbf{I}$ & bc_043.txt \\
\hline 11 & Kitson feeding Ricardo Fuller, who leathered a left-foot shot just over the top. Bardsley had a & $467 \quad 14 \quad 1 \% \mathbf{I}$ & 10_024.txt \\
\hline 12 & Germany ends with Sami Khedira ballooning a left-foot shot miles over from 25 yards. SMS & $3.1691260 \% \mathbf{l}$ & 0 3\%l tso-bbc_015.txt \\
\hline 13 & ball fell to Assou-Ekotto, wholet fly with a left-foot shot of exceptionalferocity past Jose & $841321 \% \mathbf{I}$ & $00 \_003 . t \times t$ \\
\hline 14 & forced a fine one-handed save from Jung with a left-foot shot on the turn with nine minutes & $563 \quad 157 \% \mathbf{I}$ & in_004.txt \\
\hline 15 & forced a fine one-handed save from Jung with a left-foot shot on the turn with nine minutes & $584 \quad 147 \% \mathbf{I}$ & ir_001.txt \\
\hline 16 & minutes, when Christoph Metzelder blasted a left-foot shot over the bar from close range. & $355107 \% \mathbf{I}$ & ay_-042.txt \\
\hline 17 & just nine minutes, striker Thierry Henry slid a left-foot shot past Korean goalkeeper Lee & $29572 \% \mathbf{I}$ & p_021.txt \\
\hline 18 & defender, he keeps his composure to smash a left-foot shot past Tim Howard from 16 yards. & $1.243512 \% \mathbf{l}$ & c_014.txt \\
\hline 19 & Michael Carrick teeing up Ronaldo for a left-foot shot that sneaked inside the far post & $937230 \% \mathbf{I}$ & C_008.txt \\
\hline 20 & again tested Simonsen's reactions with a left-foot shot that the City goalkeeper did well to & $277 \quad 73 \% \mathbf{I}$ & 0 6\%ljo-if-365_045.txt \\
\hline 21 & Podolski at the far post and he smashed a left-foot shot through the legs of the advancing & $31871 \% \mathbf{I}$ & -002.txt \\
\hline 22 & past two defenders, cuts inside and sends a left-foot shot towards the near post which Myhill & $1.651 \quad 618 \% \mathbf{l}$ & a_005.txt \\
\hline 23 & player on a sub-standard pitch, pulled a left-foot shot wide, and City almost took the & $398 \quad 148 \% \mathbf{l}$ & 0 9\%ljo-if-gua_033.txt \\
\hline 24 & Villa, lurking on the wing, curled a beautiful left-foot shot over the keeper and into the net. & $300101 \% \mathbf{l}$ & n_006.txt \\
\hline 25 & Gareth Barry 30 yards out - he hits a decent left-foot shot, but it's comfortable low down for & $2.7931122 \% \mathbf{I}$ & c_015.txt \\
\hline 26 & - and Mesut Ozil, with a delicious, dipping left-foot shot from the edge of the area provides & $1.111531 \% \mathbf{I}$ & 0 8\%I tso-bbc_009.txt \\
\hline 27 & Malouda added the third with a driven left-foot shot eight minutes from time and & $32 \% \mathbf{I}$ & bc_013.txt \\
\hline 28 & past three defenders and drove an early left-foot shot past Howard. Th & $27251 \% \mathbf{I}$ & 0 9\% jo-if-mir_010.txt \\
\hline 29 & who spun past Faye before unleashing a fierce left-foot shot which ripped into the top left-hand & $410116 \%$ & $07 \%$ jo-if-foo_011.txt \\
\hline 30 & is in on the left of the USA penalty area, his left-foot shot drawing a br & $3.0231288 \% \mathbf{l}$ & $03 \%$ lso-bbc $014 . t \times t ²$ \\
\hline
\end{tabular}


the centre-back cannot adjust his feet and his left-foot shot flies away for a throw in the end leads the charge, but he is selfish and his left-foot shot from 22 yards is blocked - he had having raced clean through, ballooned his left-foot shot high over the crossbar. Mexico himself in space 10 yards out, but scuffed his left-foot shot horribly. Ryan Nelsen, who had Asamoah lets fly from about 30 yards and his left-foot shot sails wide. Not afraid to shoot

in the wet conditions. He slams a hopeful left-foot shot in from 25 yards that takes a

far post and he swivelled before driving a low left-foot shot inches wide of the far post with far post and he swivelled before driving a low left-foot shot inches wide of the far post with to the edge of the box where he slams a low left-foot shot into the bottom corner, What a of space just outside the box and struck a low, left-foot shot on target. Green appeared to be

pass and cut inside before firing a low left-foot shot past Smithies. However, the lead 35 yards out before turning and curling a neat left-foot shot straight at Stekelenburg, who swivelled and somehow directed a precise left-foot shot just inside the far post. $\langle p\rangle$

raced off his line to parry the midfielder's left-foot shot from 14 yards. Sunderland pressed raced off his line to parry the midfielder's left-foot shot from 14 yards. Sunderland pressed complete calamity engulfed Green. Dempsey's left-foot shot from 25 yards barely merited the 51 st minute. Nine minutes later Livermore's left-foot shot from the edge of the box found its 51 st minute. Nine minutes later Livermore's left-foot shot from the edge of the box found its half in charge, with Boruc turning Eduardo's left-foot shot to safety and Bendtner heading the half in charge, with Boruc turning Eduardo's left-foot shot to safety and Bendtner heading the a save from Jung Sung-Ryong with a smart left-foot shot on the turn from 15 yards out. Park, was at full stretch as a perfectly struck left-foot shot sneaked in under the bar. $\langle/ p\rangle$

back-heel from Torres and a thumping left-foot shot from Gerrard, unleashed when Garry O'Connor managed to fire off a vicious left-foot shot only to see his effort deflected in free-kick saw the ball fall to Boateng, whose left-foot shot deflected off John Obi Mikel into
$2201900 \% \quad 07 \%$

$3.318131 \%$ | $05 \%$ I

$231 \quad 55 \% \mathbf{I} \quad 01 \% \mathbf{I}$

$480 \quad 101 \%$ I $05 \%$ I

$1.283425 \% \mathbf{I} \quad 08 \% \mathbf{I}$

$2.8101085 \%$ | $02 \%$ I

$568 \quad 193 \%$ I $02 \%$ I

$\begin{array}{lllll}572 & 18 & 3 \% & 0 & 2 \%\end{array}$

$3.8601546 \% \mathbf{l} \quad 07 \%$ I

$19456 \%$ | $6 \%$

$335 \quad 63 \%$ I $08 \%$

$721 \quad 16 \quad 1 \% \mathbf{l} \quad 09 \% \mathbf{I}$

$488 \quad 114 \% \mathbf{l} 50 \%$ I

$538 \quad 187 \%$ | $08 \%$

$542 \quad 17 \quad 7 \%$ | $08 \%$ |

$551 \quad 179 \% \quad 0 \quad 3 \%$ |

$657 \quad 234 \%$ | $03 \%$ I

$657234 \% \quad 03 \%$

$423 \quad 128 \%$ | $02 \%$ I

$425 \quad 128 \%$ | $02 \%$ I

$231 \quad 87 \%$ l $\quad 7 \%$ I

$452 \quad 94 \%$ | $82 \%$ |

$908367 \% \mathbf{I} 315 \% \mathbf{I}$

$290 \quad 93 \%$ | $06 \%$ |

269 6 $1 \%$ । $4 \%$ I
- $7 \%$ tso-bbc 0 5\% tso-bbc_015.txt [ 1\% jo-if-fif_006.txt 5\%ljo-if-365 025.txt 0\%I tso-bbc_001.txt 0 2\%l tso-bbc_006.txt $2 \%$ jo-if-spl 006.txt 2\%ljo-if-365 005.txt 0 7\% tso-bbc_014.txt $6 \%$ jo-if-tfa 002.txt 8\%ljo-if-365 046 .txt 0 9\%ljo-if-sky_007.txt 9\% jo-if-fif 005.txt 8\% jo-if-spl 006.txt 8\%ljo-if-365_005.txt 0 3\%ljo-if-bbc_002.txt 3\%ljo-if-365 037.tx $3 \%$ ljo-if-365 035 .txt 0 $2 \%$ ljo-if-bbc_053.txt $2 \%$ ljo-if-bbc 045.txt $7 \%$-nar-foo $002 . t x t$ 6\%ljo-if-day_007.txt 0 9\%ljo-if-day_002.txt $6 \%$ jo-iff-foo 007 .tx 0 4\% jo-if-foo_046.txt 


\section{ANEXO F}

Palvras-chave do corpus de inglês

\begin{tabular}{|c|c|c|c|c|c|c|}
\hline $\mathbf{N}$ & Key word & Freq. & $\%$ & RC. Freq. & RC. $\%$ & Keyness \\
\hline 1 & BALL & 4543 & 0,4536 & 7366 & & 166514,6 \\
\hline 2 & GOAL & 4052 & 0,4046 & 5928 & & 158576,1 \\
\hline 3 & KICK & 2511 & 0,2507 & 2269 & & 128575,3 \\
\hline 4 & HEADER & 922 & 0,0921 & 715 & & 50712,9 \\
\hline 5 & SHOT & 2377 & 0,2373 & 7960 & & 50665,24 \\
\hline 6 & DROGBA & 454 & 0,0453 & 0 & & 44986,1 \\
\hline 7 & PENALTY & 1369 & 0,1367 & 2665 & & 44315,27 \\
\hline 8 & CHELSEA & 1050 & 0,1048 & 1421 & & 43068,72 \\
\hline 9 & GAME & 2764 & 0,276 & 14344 & 0,0144 & 39824,62 \\
\hline 10 & ROONEY & 488 & 0,0487 & 104 & & 39695,43 \\
\hline 11 & REFEREE & 899 & 0,0898 & 1085 & & 39432,91 \\
\hline 12 & TORRES & 426 & 0.0425 & 63 & & 36658.38 \\
\hline 13 & CORNER & 1874 & 0.1871 & 7091 & & 35977.36 \\
\hline 14 & RONALDO & 362 & 0,0361 & 1 & & 35748,88 \\
\hline 15 & GERRARD & 455 & 0,0454 & 118 & & 35613,89 \\
\hline 16 & GHANA & 568 & 0,0567 & 334 & & 35038,51 \\
\hline 17 & LAMPARD & 357 & 0,0356 & 5 & & 34854,94 \\
\hline 18 & GOALKEEPER & 711 & 0,071 & 757 & & 33421,07 \\
\hline 19 & FOOTED & 353 & 0,0352 & 41 & & 31245,01 \\
\hline 20 & STRIKER & 818 & 0,0817 & 1293 & & 30446,21 \\
\hline 21 & BRAZIL & 851 & 0,085 & 1474 & & 29828,1 \\
\hline 22 & PERSIE & 287 & 0,0287 & 0 & & 28401,45 \\
\hline 23 & CUP & 2109 & 0,2106 & 11944 & 0,012 & 27938,9 \\
\hline 24 & YARDS & 1170 & 0,1168 & 3500 & & 27359,56 \\
\hline 25 & MESSI & 275 & 0,0275 & 0 & & 27209,75 \\
\hline 26 & MIDFIELDER & 539 & 0,0538 & 521 & & 26640,69 \\
\hline 27 & OFFSIDE & 431 & 0,043 & 252 & & 26629,97 \\
\hline 28 & ARSENAL & 736 & 0,0735 & 1229 & & 26427,33 \\
\hline 29 & FULHAM & 458 & 0,0457 & 381 & & 24360,54 \\
\hline 30 & ANELKA & 243 & 0,0243 & 0 & & 24031,86 \\
\hline 31 & KUYT & 239 & 0,0239 & 0 & & 23634,63 \\
\hline 32 & MINUTES & 2307 & 0,2303 & 17662 & 0,0178 & 22538,45 \\
\hline 33 & URUGUAY & 431 & 0,043 & 378 & & 22349,32 \\
\hline 34 & PLAYERS & 1521 & 0,1519 & 8115 & & 21336,39 \\
\hline 35 & TEAM & 2282 & 0,2278 & 18307 & 0,0184 & 21217,79 \\
\hline 36 & ARGENTINA & 562 & 0,0561 & 893 & & 20835,29 \\
\hline 37 & HESKEY & 210 & 0,021 & 0 & & 20754,68 \\
\hline 38 & CROSS & 1428 & 0,1426 & 7430 & & 20515,33 \\
\hline 39 & FABIO & 214 & 0,0214 & 9 & & 20281,02 \\
\hline 40 & $\mathrm{ROBINHO}$ & 200 & 0,02 & 0 & & 19761,59 \\
\hline 41 & VILLA & 752 & 0,0751 & 1941 & & 19757,19 \\
\hline 42 & ROBBEN & 222 & 0,0222 & 26 & & 19599,14 \\
\hline 43 & CAPELLO & 199 & 0,0199 & 2 & & 19462,69 \\
\hline 44 & DEFENDER & 598 & 0,0597 & 1160 & & 19386,34 \\
\hline 45 & MINUTE & 1490 & 0,1488 & 8609 & & 19352,97 \\
\hline 46 & WENGER & 210 & 0,021 & 18 & & 19083,09 \\
\hline
\end{tabular}




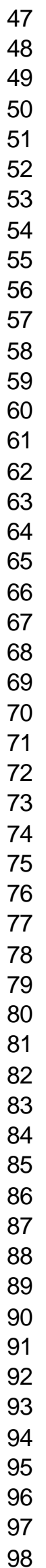

CROSSBA

MATCH

EVERTON

STOKE

$\mathrm{CECH}$

HALF

TEVEZ

KEEPER

SUNDERLAND

MIDFIELD

BENAYOUN

ADEBAYOR

SCORED

BALLACK

FABREGAS

BENITEZ

SCHWARZER

FREE

ZIDANE

STADIUM

MALOUDA

LEAGUE

PARAGUAY

ANCELOTTI

CARRAGHER

GOALS

ALONSO

ALTIDORE

FIFA

FORLAN

BURNLEY

SNEIJDER

GYAN

WIN

DEMPSEY

TOTTENHAM

BOX

DEFOE

FOUL

TOURNAMENT

KALOU

FANS

BENDTNER

KAKA

AGBONLAHOR

BOATENG

KLOSE

LIVERPOOL

PLAYER

COLE

CRISTIANO

VOLLEY $\begin{array}{rr}241 & 0,0241 \\ 1478 & 0,1476\end{array}$

$452 \quad 0,0451$

$\begin{array}{lll}430 & 0,0429\end{array}$

$\begin{array}{ll}175 & 0,0175\end{array}$

$2648 \quad 0,2644$

$\begin{array}{ll}168 & 0,0168\end{array}$

$\begin{array}{lll}579 & 0,0578\end{array}$

$562 \quad 0,0561$

$471 \quad 0,047$

$\begin{array}{ll}160 & 0,016\end{array}$

$\begin{array}{ll}158 & 0,0158\end{array}$

$\begin{array}{lll}779 & 0,0778\end{array}$

$\begin{array}{ll}153 & 0,0153\end{array}$

$152 \quad 0,0152$

$\begin{array}{ll}150 & 0,015\end{array}$

$\begin{array}{lll}147 & 0,0147\end{array}$

$2010 \quad 0,2007$

$143 \quad 0,0143$

$455 \quad 0,0454$

$140 \quad 0,014$

12180,1216

2140,0214

$141 \quad 0,0141$

1390,0139

$\begin{array}{ll}930 & 0,0929\end{array}$

$148 \quad 0,0148$

$\begin{array}{ll}137 & 0,0137\end{array}$

2030,0203

$134 \quad 0,0134$

2230,0223

$131 \quad 0,0131$

$132 \quad 0,0132$

$1341 \quad 0,1339$

$192 \quad 0,0192$

$355 \quad 0,0354$

12110,1209

$\begin{array}{ll}190 & 0,019\end{array}$

$436 \quad 0,0435$

$\begin{array}{ll}536 & 0,0535\end{array}$

$\begin{array}{ll}126 & 0,0126\end{array}$

$752 \quad 0,0751$

$123 \quad 0,0123$

$123 \quad 0,0123$

$123 \quad 0,0123$

$138 \quad 0,0138$

$124 \quad 0,0124$

$900 \quad 0,0899$

$927 \quad 0,0926$

3120,0312

$\begin{array}{ll}131 & 0,0131\end{array}$

$246 \quad 0,0246$ $\begin{array}{rr}84 & 17549,19 \\ 9368 & 17519,08 \\ 692 & 17153,87 \\ 612 & 17079,96 \\ 2 & 17079,7\end{array}$

$296260,0298 \quad 16986,5$

16583,73

$1341 \quad 16511,19$

$1283 \quad 16198,39$

$841 \quad 16158,19$

15789,26

15590,65

15507,03

15094,11

14994,8

14500,2

14299,72

$20566 \quad 0,0207 \quad 14293,61$

$0 \quad 14101,03$

$949 \quad 14003,19$

$0 \quad 13803,11$

$8074 \quad 13798,2$

$111 \quad 13782,28$

$2 \quad 13704,05$

$0 \quad 13703,8$

$4724 \quad 13662,19$

$11 \quad 13567,28$

$0 \quad 13505,18$

$100 \quad 13305,9$

$0 \quad 13207,26$

$150 \quad 13001,81$

$0 \quad 12909,34$

$1 \quad 12908,86$

$104850,0105 \quad 12807,8$

$90 \quad 12791,86$

$589 \quad 12781,57$

$8647 \quad 12715,33$

$91 \quad 12568,03$

$1005 \quad 12470,2$

$1616 \quad 12441,17$

$1 \quad 12313,09$

$3432 \quad 12200,41$

12114,88

12114,88

12114,88

12082,25

11919,83

11897,79

11861,6

11531,24

11396,55

11366,59 
99

100

101

102

103

104

105

106

107

108

109

110

111

112

113

114

115

116

117

118

119

120

121

122

123

124

125

126

127

128

129

130

131

132

133

134

135

136

137

138

139

140

141

142

143

144

145

146

147

148

149

150
CASILLAS $\quad 116 \quad 0,0116$

BERBATOV $113 \quad 0,0113$

PLAY $1810 \quad 0,1807$

MOYES $\quad 117 \quad 0,0117$

FRIEDEL $\quad 1190,0119$

DEFLECTED $211 \quad 0,0211$

CHAMPIONS 4790,0478

PORTUGAL $407 \quad 0,0406$

SUAREZ $118 \quad 0,0118$

ASAMOAH $\quad 109 \quad 0,0109$

POST $1150 \quad 0,1148$

OZIL $106 \quad 0,0106$

ARSHAVIN $106 \quad 0,0106$

$\begin{array}{lll}\text { WIDE } & 1291 & 0,1289\end{array}$

MILNER $\quad 170 \quad 0,017$

SORENSEN $\quad 111 \quad 0,0111$

SPURS $\quad 337 \quad 0,0336$

ASSOU

KEANE

GOALWARDS

FABIANO

ESSIEN

HIGUAIN

SKRTEL

MYHILL

MODRIC

KOREA

GALLAS

MAICON

CAHILL

REINA

PODOLSKI

EKOTTO

MARADONA

BOOKED

STEKELENBURG

PREMIER

NANI

MEXICO

TEAMS

ARJEN

BOLTON

DIDIER

INIESTA

ENYEAMA

SPAIN

SCHWEINSTEIGER

CAMEROON

REDKNAPP

SOCCER

HIDDINK

EVRA
100

$192 \quad 0,0192$

$105 \quad 0,0105$

99

97

97

97

97

97

$487 \quad 0,0486$

99

96

1320,0132

$\begin{array}{lll}133 & 0,0133\end{array}$

95

92

1530,0153

$\begin{array}{ll}399 & 0,0398\end{array}$

91

$\begin{array}{ll}540 & 0,0539\end{array}$

89

$426 \quad 0,0425$

$\begin{array}{ll}667 & 0,0666\end{array}$

86

$\begin{array}{ll}270 & 0,027\end{array}$

$\begin{array}{ll}171 & 0,0171\end{array}$

85

85

$680 \quad 0,0679$

84

$174 \quad 0,0174$

1180,0118

$\begin{array}{ll}380 & 0,0379\end{array}$

86

83 $\begin{array}{rr}1 & 11320,15 \\ 0 & 11121,81\end{array}$

$21038 \quad 0,0212 \quad 11096,89$

11037,4

10964,61

10944,5

10919,33

10836,11

10778,35

10625,11

10444,07

10426,66

10426,66

$118490,0119 \quad 10368,03$

$108 \quad 10131,32$

$10 \quad 10002,2$

$744 \quad 9944,12$

$0 \quad 9830,823$

$177 \quad 9686,234$

$7 \quad 9668,839$

19632,231

$0 \quad 9532,903$

$0 \quad 9532,903$

$0 \quad 9532,903$

$0 \quad 9532,903$

$0 \quad 9532,903$

$1799 \quad 9530,53$

9439,503

9433,598

9310,141

9195,823

9137,936

9036,374

9007,915

8957,141

8937,068

8819,806

8738,456

8543,294

8450,891

8440,54

8427,133

8398,934

8341,234

8341,234

8310,248

8241,93

8220,318

8191,018

8152,955

8150,265

8142,625 


\begin{tabular}{|c|c|c|c|c|c|c|}
\hline 151 & MASCHERANO & 83 & & 0 & & 8142,625 \\
\hline 152 & DONOVAN & 207 & 0,0207 & 301 & & 8092,839 \\
\hline 153 & DIEGO & 221 & 0,0221 & 358 & & 8068,456 \\
\hline 154 & LESCOTT & 82 & & 0 & & 8043,319 \\
\hline 155 & ENGLAND & 1582 & 0,158 & 21461 & 0,0216 & 8036,407 \\
\hline 156 & SEASON & 1066 & 0,1064 & 10418 & 0,0105 & 7980,307 \\
\hline 157 & DOMENECH & 82 & & 1 & & 7944,448 \\
\hline 158 & RODALLEGA & 81 & & 0 & & 7944,014 \\
\hline 159 & LUIS & 192 & 0,0192 & 259 & & 7856,272 \\
\hline 160 & FULOP & 80 & & 0 & & 7844,709 \\
\hline 161 & LEFT & 2387 & 0,2383 & 45180 & 0,0454 & 7792,898 \\
\hline 162 & $S$ & 1633 & 0,163 & 23425 & 0,0236 & 7732,183 \\
\hline 163 & JONG & 116 & 0,0116 & 55 & & 7672,604 \\
\hline 164 & KENWYNE & 78 & & 0 & & 7646,1 \\
\hline 165 & VUVUZELAS & 78 & & 0 & & 7646,1 \\
\hline 166 & BECKHAM & 81 & & 4 & & 7562,604 \\
\hline 167 & CESC & 77 & & 0 & & 7546,795 \\
\hline 168 & SCORING & 391 & 0,039 & 1467 & & 7545,443 \\
\hline 169 & EQUALISER & 195 & 0,0195 & 295 & & 7434,327 \\
\hline 170 & UPSON & 91 & & 18 & & 7431,365 \\
\hline 171 & CHANCES & 542 & 0,0541 & 2971 & & 7398,578 \\
\hline 172 & EFFORT & 869 & 0,0868 & 7573 & & 7383,963 \\
\hline 173 & XAVI & 75 & & 0 & & 7348,186 \\
\hline 174 & MOURINHO & 75 & & 0 & & 7348,186 \\
\hline 175 & ELANO & 75 & & 0 & & 7348,186 \\
\hline 176 & CESAR & 104 & 0,0104 & 40 & & 7329,542 \\
\hline 177 & KLINSMANN & 82 & & 10 & & 7151,34 \\
\hline 178 & KINGSON & 73 & & 0 & & 7149,578 \\
\hline 179 & LANDON & 88 & & 19 & & 7074,059 \\
\hline 180 & WIGAN & 251 & 0,0251 & 594 & & 7026,52 \\
\hline 181 & LENNON & 152 & 0,0152 & 167 & & 6987,131 \\
\hline 182 & FREEKICK & 76 & & 5 & & 6978,452 \\
\hline 183 & FOOTBALL & 781 & 0,078 & 6560 & & 6905,47 \\
\hline 184 & CATTERMOLE & 73 & & 3 & & 6861,636 \\
\hline 185 & VIDIC & 70 & & 0 & & 6851,666 \\
\hline 186 & SCHOLES & 103 & 0,0103 & 48 & & 6844,004 \\
\hline 187 & XABI & 69 & & 0 & & 6752,36 \\
\hline 188 & CARLOS & 250 & 0,025 & 627 & & 6696,56 \\
\hline 189 & VAN & 605 & 0,0604 & 4119 & & 6664,118 \\
\hline 190 & SLOVAKIA & 161 & 0,0161 & 214 & & 6639,559 \\
\hline 191 & HEADED & 493 & 0,0492 & 2742 & & 6634,62 \\
\hline 192 & TWITTER & 77 & & 11 & & 6584,336 \\
\hline 193 & SCOLARI & 67 & & 0 & & 6553,756 \\
\hline 194 & BASSONG & 67 & & 0 & & 6553,75 \\
\hline 195 & DIABY & 67 & & 0 & & 6553,75 \\
\hline 196 & TOURE & 76 & & 11 & & 6486,777 \\
\hline 197 & CUDICINI & 66 & & 0 & & 6454,453 \\
\hline 198 & SECOND & 2076 & 0,2073 & 40763 & 0,041 & 6429,481 \\
\hline 199 & ETO'O & 65 & & 0 & & 6355,149 \\
\hline 200 & MIKEL & 69 & & 5 & & 6286,869 \\
\hline 201 & RICARDO & 135 & 0,0135 & 145 & & 6277,134 \\
\hline 202 & HULL & 342 & 0,0341 & 1374 & & 6213,301 \\
\hline
\end{tabular}




\begin{tabular}{|c|c|c|c|c|c|c|}
\hline 203 & NEUER & 66 & & 3 & & 6168,13 \\
\hline 204 & HAM & 341 & 0,034 & 1378 & & 6163,136 \\
\hline 205 & BROM & 117 & 0,0117 & 98 & & 6162,755 \\
\hline 206 & LEDLEY & 65 & & 2 & & 6161,594 \\
\hline 207 & JOZY & 63 & & 0 & & 6156,544 \\
\hline 208 & BAFANA & 63 & & 0 & & 6156,544 \\
\hline 209 & GEOVANNI & 63 & & 0 & & 6156,544 \\
\hline 210 & WALCOTT & 85 & & 30 & & 6121,256 \\
\hline 211 & UNMARKED & 174 & 0,0174 & 299 & & 6102,337 \\
\hline 212 & DEFENDERS & 241 & 0,0241 & 651 & & 6093,038 \\
\hline 213 & FINALS & 270 & 0,027 & 843 & & 6078,533 \\
\hline 214 & ONYEWU & 62 & & 0 & & 6057,242 \\
\hline 215 & KHUNE & 62 & & 0 & & 6057,242 \\
\hline 216 & BENÍTEZ & 62 & & 0 & & 6057,242 \\
\hline 217 & UNITED & 1305 & 0,1303 & 19030 & 0,0191 & 6049,508 \\
\hline 218 & GERMANY & 885 & 0,0884 & 9399 & & 6025,035 \\
\hline 219 & OPENER & 170 & 0,017 & 289 & & 6004,095 \\
\hline 220 & IVANOVIC & 63 & & 2 & & 5963,268 \\
\hline 221 & JERMAIN & 61 & & 0 & & 5957,94 \\
\hline 222 & RIBERY & 61 & & 0 & & 5957,94 \\
\hline 223 & MUSLERA & 61 & & 0 & & 5957,94 \\
\hline 224 & WHISTLE & 249 & 0,0249 & 722 & & 5951,354 \\
\hline 225 & OFF & 2741 & 0,2737 & 68195 & 0,0686 & 5909,39 \\
\hline 226 & HERNANDEZ & 75 & & 18 & & 5897,156 \\
\hline 227 & $\mathrm{COACH}$ & 516 & 0,0515 & 3396 & & 5880,773 \\
\hline 228 & ARSENE & 63 & & 3 & & 5871,021 \\
\hline 229 & SEMI & 176 & 0,0176 & 326 & & 5866,97 \\
\hline 230 & DELAP & 62 & & 2 & & 5864,111 \\
\hline 231 & EBOUE & 60 & & 0 & & 5858,638 \\
\hline 232 & $\mathrm{CROUCH}$ & 146 & 0,0146 & 206 & & 5803,224 \\
\hline 233 & PALACIOS & 63 & & 4 & & 5781,53 \\
\hline 234 & MANCHESTER & 608 & 0,0607 & 4831 & & 5702,694 \\
\hline 235 & FOULS & 81 & & 31 & & 5700,753 \\
\hline 236 & SAHA & 63 & & 5 & & 5694,67 \\
\hline 237 & HEINZE & 59 & & 1 & & 5661,39 \\
\hline 238 & ETUHU & 58 & & 0 & & 5660,035 \\
\hline 239 & MELO & 65 & & 8 & & 5644,568 \\
\hline 240 & SIDE & 1709 & 0,1706 & 32155 & 0,0323 & 5624,8 \\
\hline 241 & ZAMORA & 101 & 0,0101 & 75 & & 5613,21 \\
\hline 242 & ال ال & 75 & & 23 & & 5588 , \\
\hline 243 & GAMES & 679 & 0,0678 & 6094 & & 5584,57 \\
\hline 244 & STOPPAGE & 123 & 0,0123 & 139 & & 5558,29 \\
\hline 245 & BUFFON & 72 & & 19 & & 5548,42 \\
\hline 246 & FLORENT & 66 & & 11 & & 5513,692 \\
\hline 247 & PIENAAR & 80 & & 33 & & 5507,444 \\
\hline 248 & HUDDLESTONE & 61 & & 5 & & 5497,419 \\
\hline 249 & ALGERIA & 198 & 0,0198 & 475 & & 5480,146 \\
\hline 250 & NICOLAS & 129 & 0,0129 & 163 & & 5472,822 \\
\hline 251 & SUBSTITUTION & 233 & 0,0233 & 691 & & 5467,066 \\
\hline 252 & MPHELA & 56 & & 0 & & 5461,433 \\
\hline 253 & PASS & 741 & 0,074 & 7372 & & 5434,138 \\
\hline 254 & ATTACKING & 294 & 0,0294 & 1161 & & 5420,325 \\
\hline
\end{tabular}




\begin{tabular}{|c|c|c|c|c|c|c|}
\hline 255 & BOSINGWA & 55 & & 0 & & 5362,132 \\
\hline 256 & CARVALHO & 65 & & 12 & & 5344,654 \\
\hline 257 & ALBION & 161 & 0,0161 & 300 & & 5342,032 \\
\hline 258 & VILLA'S & 96 & & 74 & & 5244,4 \\
\hline 259 & ALVES & 81 & & 41 & & 5220,342 \\
\hline 260 & MENSAH & 58 & & 5 & & 5201,704 \\
\hline 261 & HOLLAND & 322 & 0,0321 & 1476 & & 5193,27 \\
\hline 262 & YAKUBU & 56 & & 3 & & 5178,091 \\
\hline 263 & INSWINGING & 56 & & 3 & & 5178,091 \\
\hline 264 & FELLAINI & 53 & & 0 & & 5163,533 \\
\hline 265 & TOUCHLINE & 119 & 0,0119 & 145 & & 5152,464 \\
\hline 266 & ROONEY'S & 59 & & 7 & & 5136,098 \\
\hline 267 & GOMES & 82 & & 45 & & 5135,734 \\
\hline 268 & CHILE & 201 & 0,0201 & 543 & & 5077,006 \\
\hline 269 & BLOCKED & 309 & 0,0309 & 1389 & & 5072,849 \\
\hline 270 & NASRI & 54 & & 2 & & 5071,054 \\
\hline 271 & VERON & 53 & & 1 & & 5065,968 \\
\hline 272 & JAASKELAINEN & 52 & & 0 & & 5064,232 \\
\hline 273 & SERBIA & 205 & 0,0205 & 571 & & 5055,012 \\
\hline 274 & STEVEN & 265 & 0,0265 & 1007 & & 5051,097 \\
\hline 275 & PETR & 90 & & 66 & & 5023,267 \\
\hline 276 & AARON & 151 & 0,0151 & 282 & & 5000,339 \\
\hline 277 & TSHABALALA & 54 & & 3 & & 4980,212 \\
\hline 278 & PUYOL & 51 & & 0 & & 4964,934 \\
\hline 279 & VAART & 51 & & 0 & & 4964,934 \\
\hline 280 & EMAILS & 51 & & 0 & & 4964,934 \\
\hline 281 & VICTORY & 610 & 0,0609 & 5547 & & 4944,22 \\
\hline 282 & AFTER & 3561 & 0,3555 & 114062 & 0,1147 & 4917,393 \\
\hline 283 & WORLD & 2204 & 0,2201 & 53806 & 0,0541 & 4898,505 \\
\hline 284 & RAMIRES & 50 & & 0 & & 4865,634 \\
\hline 285 & ERIKSSON & 62 & & 15 & & 4853,331 \\
\hline 286 & HART & 201 & 0,0201 & 577 & & 4838,103 \\
\hline 287 & CONFEDERATIONS & 77 & & 42 & & 4829,375 \\
\hline 288 & GIGGS & 116 & 0,0116 & 152 & & 4812,734 \\
\hline 289 & JENSEN & 100 & & 101 & & 4791,482 \\
\hline 290 & IKER & 49 & & 0 & & 4766,336 \\
\hline 291 & DIRK & 103 & 0,0103 & 112 & & 4746,181 \\
\hline 292 & FLANK & 168 & 0,0168 & 393 & & 4734,369 \\
\hline 293 & SERGIO & 78 & & 47 & & 4713,07 \\
\hline 294 & ROSICKY & 48 & & 0 & & 4667,039 \\
\hline 295 & BOMMEL & 48 & & 0 & & 4667,039 \\
\hline 296 & AYEW & 48 & & 0 & & 4667,039 \\
\hline 297 & DROGBA'S & 48 & & 0 & & 4667,039 \\
\hline 298 & REBOUND & 116 & 0,0116 & 160 & & 4666,631 \\
\hline 299 & HOTSPUR & 119 & 0,0119 & 172 & & 4652,709 \\
\hline 300 & STANISLAS & 53 & & 6 & & 4627,757 \\
\hline 301 & MAXI & 80 & & 54 & & 4619,559 \\
\hline 302 & DEFENSE & 126 & 0,0126 & 203 & & 4600,244 \\
\hline 303 & SAVE & 683 & 0,0682 & 7330 & & 4592,102 \\
\hline 304 & GUK & 48 & & 1 & & 4569,854 \\
\hline 305 & TUNCAY & 48 & & 1 & & 4569,854 \\
\hline 306 & ALMUNIA & 48 & & 1 & & 4569,854 \\
\hline
\end{tabular}




\begin{tabular}{|c|c|c|c|c|c|c|}
\hline 307 & CHANCE & 923 & 0,0922 & 12821 & 0,0129 & 4548,935 \\
\hline 308 & PETROV & 53 & & 7 & & 4548,88 \\
\hline 309 & PLAYMAKER & 60 & & 17 & & 4538,94 \\
\hline 310 & YARD & 431 & 0,043 & 3079 & & 4515,527 \\
\hline 311 & YOSSI & 51 & & 5 & & 4512,624 \\
\hline 312 & MADRID & 230 & 0,023 & 846 & & 4506,819 \\
\hline 313 & HANDBALL & 68 & & 32 & & 4480,988 \\
\hline 314 & CHELSEA'S & 87 & & 76 & & 4477,78 \\
\hline 315 & CAVANI & 48 & & 2 & & 4476,558 \\
\hline 316 & KOLO & 48 & & 2 & & 4476,558 \\
\hline 317 & MALBRANQUE & 46 & & 0 & & 4468,443 \\
\hline 318 & CAPELLO'S & 46 & & 0 & & 4468,443 \\
\hline 319 & ELMANDER & 46 & & 0 & & 4468,443 \\
\hline 320 & WOLVES & 202 & 0,0202 & 649 & & 4435,591 \\
\hline 321 & NIGERIA & 207 & 0,0207 & 687 & & 4424,612 \\
\hline 322 & SAMBA & 71 & & 40 & & 4395,456 \\
\hline 323 & PULIS & 46 & & 1 & & 4371,434 \\
\hline 324 & HEITINGA & 45 & & 0 & & 4369,147 \\
\hline 325 & KABOUL & 45 & & 0 & & 4369,147 \\
\hline 326 & ZIGIC & 45 & & 0 & & 4369,147 \\
\hline 327 & MACHEDA & 45 & & 0 & & 4369,147 \\
\hline 328 & LIPPI & 48 & & 4 & & 4300,732 \\
\hline 329 & HALFTIME & 58 & & 18 & & 4292,31 \\
\hline 330 & MILIJAS & 44 & & 0 & & 4269,851 \\
\hline 331 & LAHM & 44 & & 0 & & 4269,851 \\
\hline 332 & CHERUNDOLO & 44 & & 0 & & 4269,851 \\
\hline 333 & SAGNA & 50 & & 7 & & 4255,953 \\
\hline 334 & FINAL & 993 & 0,0991 & 15406 & 0,0155 & 4246,859 \\
\hline 335 & ZOLA & 72 & & 46 & & 4246,303 \\
\hline 336 & BRAZILIAN & 187 & 0,0187 & 580 & & 4225,646 \\
\hline 337 & FERNANDO & 187 & 0,0187 & 581 & & 4219,674 \\
\hline 338 & REFEREE'S & 87 & & 86 & & 4209,043 \\
\hline 339 & BEASLEY & 62 & & 27 & & 4182,424 \\
\hline 340 & DENILSON & 43 & & 0 & & 4170,556 \\
\hline 341 & SUBSTITUTE & 318 & 0,0317 & 1826 & & 4144,073 \\
\hline 342 & BASTOS & 48 & & 6 & & 4137,931 \\
\hline 343 & WILSHERE & 46 & & 4 & & 4103,69 \\
\hline 344 & BRAZILIANS & 74 & & 55 & & 4095,841 \\
\hline 345 & ATLETICO & 52 & & 12 & & 4095,40 \\
\hline 346 & DEMERIT & 45 & & 3 & & 4090,516 \\
\hline 347 & HENNESSEY & 49 & & 8 & & 4083,776 \\
\hline 348 & DIMITAR & 44 & & 2 & & 4080,424 \\
\hline 349 & KRANJCAR & 42 & & 0 & & 4071,261 \\
\hline 350 & HOSTS & 200 & 0,02 & 706 & & 4057,038 \\
\hline 351 & SLOVENIA & 146 & 0,0146 & 349 & & 4044,293 \\
\hline 352 & FROM & 8474 & 0,8461 & 425987 & 0,4283 & 4018,796 \\
\hline 353 & SPECTOR & 54 & & 17 & & 3977,142 \\
\hline 354 & SHOREY & 42 & & 1 & & 3974,651 \\
\hline 355 & N'ZOGBIA & 41 & & 0 & & 3971,967 \\
\hline 356 & WINS & 287 & 0,0287 & 1553 & & 3959,652 \\
\hline 357 & EMILE & 83 & & 85 & & 3939,803 \\
\hline 358 & EDUARDO & 102 & 0,0102 & 150 & & 3939,61 \\
\hline
\end{tabular}




359
360
361
362
363
364
365
366
367
368
369
370
371
372
373
374
375
376
377
378
379
380
381
382
383
384
385
386
387
388
389
390
391
392
393
394
395
396
397
398
399
400
401
402
403
404
405
406
407
410

$\begin{array}{rrr}\text { EDGE } & 635 & 0,0634 \\ \text { EMMANUEL } & 99 & \\ \text { GUUS } & 42 & \\ \text { NICKLAS } & 41 & \\ \text { SCORE } & 460 & 0,0459 \\ \text { MYONG } & 40 & \\ \text { MATERAZZI } & 40 & \\ \text { JOLEON } & 40 & \\ \text { PITCH } & 380 & 0,0379 \\ \text { ASTON } & 186 & 0,0186 \\ \text { SEMIFINALS } & 44 & \\ \text { DUNGA } & 44 & \end{array}$

$\begin{array}{rr}7305 & 3935,758 \\ 141 & 3899,359 \\ 2 & 3882,432 \\ 1 & 3875,468\end{array}$

$4037 \quad 3874,255$

3872,673

3872,673

3872,673

$\begin{array}{rr}2811 & 3838,457 \\ 644 & 3834,14\end{array}$

JULIO 84

MEIRELES $\quad 40$

LAMPARD'S $\quad 40$

MOKOENA 39

KRASIC $\quad 39$

COLOCCINI 39

PRE $\quad 155 \quad 0,0155$

PLAYED $\quad 776 \quad 0,0775$

DUTCH $343 \quad 0,0342$

WINGER $165 \quad 0,0165$

BELHADJ

51

WAYNE $\quad 190 \quad 0,019$

RONALDINHO 38

OBASI $\quad 38$

GERVINHO 38

PORTSMOUTH $206 \quad 0,0206$

ITALY $482 \quad 0,0481$

POMPEY 85

HUTH $\quad 37$

CANNAVARO 37

KOUMAS $\quad 37$

BROMWICH 96

FINDLEY 42

KICKS $\quad 164 \quad 0,0164$

LUKA 49

BRANISLAV 39

CLEARANCE $204 \quad 0,0204$

RAFAEL $\quad 88$

MAROUANE 36

VERMAELEN 36

LLORIS $\quad 36$

RANIERI $\quad 36$

NEWCASTLE

FOULED

3440,0343

81

INJURY

$\begin{array}{ll}468 & 0,0467\end{array}$

BURNLEY'S

41

50

1010,0101

VALENCIA

RESTARTS

47

VORONIN 43

281
644

5

3825,281

3825,281

3801,767

3776,292

3776,292

3773,381

3773,381

3773,381

$\begin{array}{rrr}441 & 3751,805 \\ 1000 & 0,0111 & 3726,747\end{array}$

$2366 \quad 3722,828$

$515 \quad 3706,487$

$17 \quad 3698,496$

$708 \quad 3677,909$

$0 \quad 3674,09$

$0 \quad 3674,09$

$0 \quad 3674,09$

$855 \quad 3628,304$

4702

3610,934

3579,649

3574,799

3574,799

3574,799

3565,873

3551,988

3524,091

3513,706

3498,357

3488,44

3484,445

3475,509

3475,509

3475,509

3475,509

3471,902

3466,671

3462,55

3454,576

3447,229

3441,611

3440,182

3434,035 


\begin{tabular}{|c|c|c|c|c|c|}
\hline BREAK & 675 & 0,0674 & 9138 & & 3433,904 \\
\hline WENGER'S & 39 & & 4 & & 3415,211 \\
\hline RAMOS & 84 & & 114 & & 3401,095 \\
\hline JABULANI & 35 & & 0 & & 3376,22 \\
\hline AMEOBI & 35 & & 0 & & 3376,22 \\
\hline HANGELAND & 35 & & 0 & & 3376,22 \\
\hline BRONCKHORST & 35 & & 0 & & 3376,22 \\
\hline REYNA & 35 & & 0 & & 3376,22 \\
\hline RONALDO'S & 35 & & 0 & & 3376,22 \\
\hline BEAT & 511 & 0,051 & 5572 & & 3370,914 \\
\hline IVORY & 200 & 0,02 & 873 & & 3365,989 \\
\hline DEFENDING & 232 & 0,0232 & 1191 & & 3362,526 \\
\hline SENDS & 172 & 0,0172 & 635 & & 3354,404 \\
\hline BLOEMFONTEIN & 47 & & 17 & & 3329,78 \\
\hline YONG & 64 & & 55 & & 3306,054 \\
\hline DARREN & 166 & 0,0166 & 599 & & 3301,037 \\
\hline $\mathrm{OBI}$ & 36 & & 2 & & 3288,852 \\
\hline ROSSI & 72 & & 79 & & 3287,329 \\
\hline PEREIRA & 63 & & 53 & & 3286,779 \\
\hline AZZURRI & 34 & & 0 & & 3276,933 \\
\hline KONCHESKY & 34 & & 0 & & 3276,933 \\
\hline VITTEK & 34 & & 0 & & 3276,933 \\
\hline FUCILE & 34 & & 0 & & 3276,933 \\
\hline PIRLO & 34 & & 0 & & 3276,933 \\
\hline PEREZ & 79 & & 103 & & 3273,76 \\
\hline BUT & 8363 & 0,835 & 446783 & 0,4492 & 3271,783 \\
\hline OPENING & 596 & 0,0595 & 7602 & & 3262,562 \\
\hline FORWARD & 860 & 0,0859 & 14678 & 0,0148 & 3237,762 \\
\hline GIOVANI & 37 & & 4 & & 3218,921 \\
\hline ARGENTINA'S & 69 & & 73 & & 3211,033 \\
\hline CARRICK & 96 & & 176 & & 3207,075 \\
\hline POULSEN & 36 & & 3 & & 3202,704 \\
\hline POSSESSION & 368 & 0,0367 & 3135 & & 3199,273 \\
\hline CRISTIAN & 34 & & 1 & & 3181,392 \\
\hline NET & 548 & 0,0547 & 6660 & & 3180,287 \\
\hline MUAMBA & 33 & & 0 & & 3177,646 \\
\hline KOREANS & 92 & & 162 & & 3157,353 \\
\hline AGGER & 40 & & 9 & & 3146,875 \\
\hline ADRIANO & 40 & & 9 & & 3146,875 \\
\hline JIMENEZ & 49 & & 25 & & 3123,406 \\
\hline HIS & 7743 & 0,7731 & 410294 & 0,4125 & 3110,547 \\
\hline NEMANJA & 35 & & 3 & & 3104,232 \\
\hline TRIES & 286 & 0,0286 & 1979 & & 3092,272 \\
\hline QUARTERFINALS & 34 & & 2 & & 3091,16 \\
\hline ALLARDYCE & 38 & & 7 & & 3090,91 \\
\hline DECO & 73 & & 92 & & 3082,823 \\
\hline ZIANI & 33 & & 1 & & 3082,275 \\
\hline FAUBERT & 33 & & 1 & & 3082,275 \\
\hline MBM & 33 & & 1 & & 3082,275 \\
\hline UNSPORTING & 48 & & 24 & & 3079,777 \\
\hline DOSSENA & 32 & & 0 & & 3078,362 \\
\hline EBANKS & 32 & & 0 & & 3078,362 \\
\hline
\end{tabular}




\begin{tabular}{|c|c|c|c|c|c|c|}
\hline 463 & FORLÁN & 32 & & 0 & & 3078,362 \\
\hline 464 & SHAKITY & 32 & & 0 & & 3078,362 \\
\hline 465 & TZORVAS & 32 & & 0 & & 3078,362 \\
\hline 466 & KARAGOUNIS & 32 & & 0 & & 3078,362 \\
\hline 467 & ANDRIY & 32 & & 0 & & 3078,362 \\
\hline 468 & GEKAS & 32 & & 0 & & 3078,362 \\
\hline 469 & HEURELHO & 32 & & 0 & & 3078,362 \\
\hline 470 & FERGUSON & 193 & 0,0193 & 904 & & 3044,712 \\
\hline 471 & GERA & 36 & & 5 & & 3043,015 \\
\hline 472 & DESERVED & 200 & 0,02 & 978 & & 3032,065 \\
\hline 473 & SUAZO & 32 & & 1 & & 2983,17 \\
\hline 474 & SCHARNER & 31 & & 0 & & 2979,079 \\
\hline 475 & GHILAS & 31 & & 0 & & 2979,079 \\
\hline 476 & MUNTARI & 31 & & 0 & & 2979,079 \\
\hline 477 & $\mathrm{CHU}$ & 64 & & 68 & & 2968,073 \\
\hline 478 & LOFTED & 43 & & 17 & & 2964,867 \\
\hline 479 & JAVIER & 82 & & 134 & & 2953,209 \\
\hline 480 & ASHLEY & 197 & 0,0197 & 981 & & 2935,945 \\
\hline 481 & HUGHTON & 33 & & 3 & & 2907,429 \\
\hline 482 & RUSTENBURG & 46 & & 24 & & 2905,293 \\
\hline 483 & DANNY & 179 & 0,0179 & 814 & & 2900,433 \\
\hline 484 & GUTIERREZ & 36 & & 7 & & 2898,183 \\
\hline 485 & DEFENSIVE & 219 & 0,0219 & 1242 & & 2884,226 \\
\hline 486 & VILLARREAL & 30 & & 0 & & 2879,797 \\
\hline 487 & VUVUZELA & 30 & & 0 & & 2879,79 \\
\hline 488 & PIQUIONNE & 30 & & 0 & & 2879,79 \\
\hline 489 & FAHIM & 30 & & 0 & & 2879,79 \\
\hline 490 & ZIDANE'S & 30 & & 0 & & 2879,797 \\
\hline 491 & INSIDE & 784 & 0,0783 & 13627 & 0,0137 & 2878,67 \\
\hline 492 & RESTART & 101 & 0,0101 & 233 & & 2864,255 \\
\hline 493 & GOALLESS & 68 & & 86 & & 2862,816 \\
\hline 494 & KEOGH & 40 & & 14 & & 2848,205 \\
\hline 495 & ETHERINGTON & 40 & & 14 & & 2848,205 \\
\hline 496 & JERMAINE & 32 & & 3 & & 2809,106 \\
\hline 497 & MATCHES & 334 & 0,0333 & 2934 & & 2807,538 \\
\hline 498 & COLLISON & 35 & & 7 & & 2802,031 \\
\hline 499 & SHOOTOUT & 40 & & 15 & & 2794,98 \\
\hline 50 & RIERA & 31 & 0,0031 & 2 & $2 \mathrm{E}-06$ & 2794 \\
\hline
\end{tabular}

